CIHM

Microfiche Series (Monographs)
ICMH

Collection de microfiches (monographies)

Canadian Institute for Historical Microreproductions / Institut canadien de microreproductions historiques
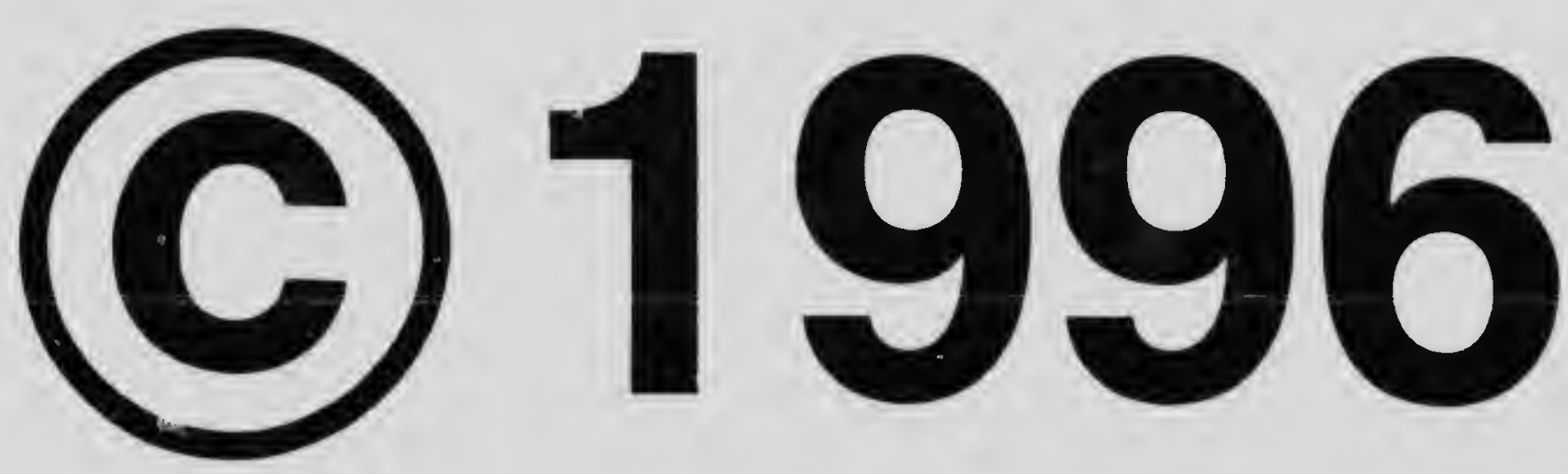


\section{Technical and Bibliographic Notes / Notes techniques et bibliographiques}

The Institute has attempted to obtain the best original copy available for filming. Features of this copy which may be bibliographically unique, which may alter any of the images in the reproduction, or which may significantly change the usual method of filming are checked below.

\section{Coloured covers /}

Couverture de couleur

Covers damaged /

Couverture endommagée

Covers restored and/or laminated /

Couverture restaurée et/ou pelliculée

Cover title missing / Le titre de couverture manque

Coloured maps / Cartes géographiques en couleur

Coloured ink (i.e. other than blue or black) /

Encre de couleur (i.e. autre que bleue ou noire)

Coloured plates and/or illustrations /

Planches et/ou illustrations en couleur

Bound with other material /

Relié avec d'autres documents

Only edition available /

Seule édition disponible

Tight binding may cause shadows or distortion along interior margin / La reliure serrée peut causer de l'ombre ou de la distorsion le long de la marge intérieure.

Blank leaves added during restorations may appear within the text. Whenever possible, these have been omitted from filming / II se peut que certaines pages blanches ajoutées lors d'une restauration apparaissent dans le texte, mais, lorsque cela était possible, ces pages n'ont pas été filmées.

\section{A Jditional comments /}

C:ommentaires supplémentaires:
L'Institut a microfilmé le meilleur exemplaire qu'il lui a été possible de se procurer. Les détails de cet exemplaire qui sont peut-être uniques du point de vue bibliographique, qui peuvent modifier une image reproduite, ou qui peuvent exiger une modification dans la méthode normale de filmage sont indiqués ci-dessous.

Coloured pages / Pages de couleur

Pages damaged / Pages endommagées

Pages restored and/or laminated /

Pages restaurées et/ou pelliculées

Pages discolsured, stained or foxed /

Pages décolorées, tachetées ou piquées

Pages detached / Pages détachées

Showthrough / Transparence

Quality of print varies /

Qualité inégale de l'impression

Includes supplementary material /

Comprend du matériel supplémentaire

Pages wholly or partially obscured by errata slips, tissues, etc., have been refilmed to ensure the best possible image / Les pages totalement ou partiellement obscurcies par un feuillet d'errata, une pelure, etc., ont été filmées à nouveau de façon à obtenir la meilleure image possible.

Opposing pages with varying colouration or discolourations are filmed twice to ensure the best possible image / Les pages s'opposant ayant des colorations variables ou des décolorations sont filmées deux fois afin d'obtenir la meilleure image possible.

This item is filmed at the reduction ratio checked beiow I Ce document est filmó su taux de réduction indiqué ci-dessous.

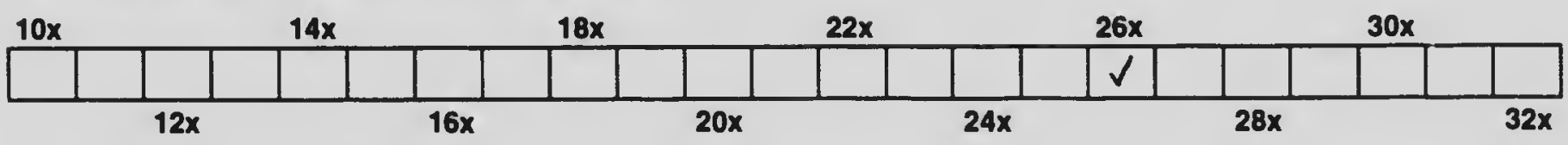


The copy filmed here hes been reproduced thanks to the generosity of:

$$
\text { National Library of Canada }
$$

The imeges appeering here are the best quality possible considering the condition and legibillty of the original copy and in keoping with the filming contract specificotions.

Original copies in printed paper covers are fllmed beginning with the front cover and ending on the last pege with a prlnted or illustrated impres. sion. or the back cover when appropriete. All other original copies are filmed beginning on the first pege with e printed or illustreted impression. and ending on the last page wlth printed or illustretod improssion.

The last recorded frame on each microfiche shall contain the symbol $\rightarrow$ Imeening "CON. TINUED"), or the symbol $\nabla$ (meening "END"). whichover epplies.

Maps. plates, cherts, etc.. may be filmed at different reduction ratios. Those too lerge to be entirely included in one exposure are filmed beginning in the upper latt hend corner, loft to right and top to bottom, as many frames os required. The following dlagrams illustrate the method:
L'exempleire filmo fut reproduit grâce la góndrosito da:

Bibliothèque nationale du Canada

Les images suiventes ont bth reproduites evec lo plus grand soin. compte senu de le condition ot de le nottete de l'exempleire filmo, at on conformith avec los conditions du contrat de fllmege.

Les exemplaires origineux dons le couverture en pepier ast Imprimbe sont filmbe en commencant par le premior plat et en torminant soit par la dernitre pege qui comporte une empreinse d'impression ou d'illustretion. soit per le second plat, selon le cas. Tous las eutres exemplaires orlginaux sont filmbe en commencent par la premidre pege qui comporte une empreine d'impression ou d'illustrstion et en terminant fer le dernidre page qui comporte une tsble empreines.

Un des symboles suivants apparaitre sur la durnidre image de chaque microfiche, selon le ces: le symbole $\longrightarrow$ signifie "A SUIVAE". Io symbole $\nabla$ signifie "FIN".

Les cartes. planches, tableeux, etc.. peuvent àtre filmbs des taux de roduction differents.

Lorsque le document est trop grand pour etre reproduit on un soul cliche. il est filme a partip de l'angle supórieur gauche, de gauche d droite. et de haut en bas. en prenent le nombre d'imeges ndcesseire. Les diegremmes suivants iliustrent la mothode.
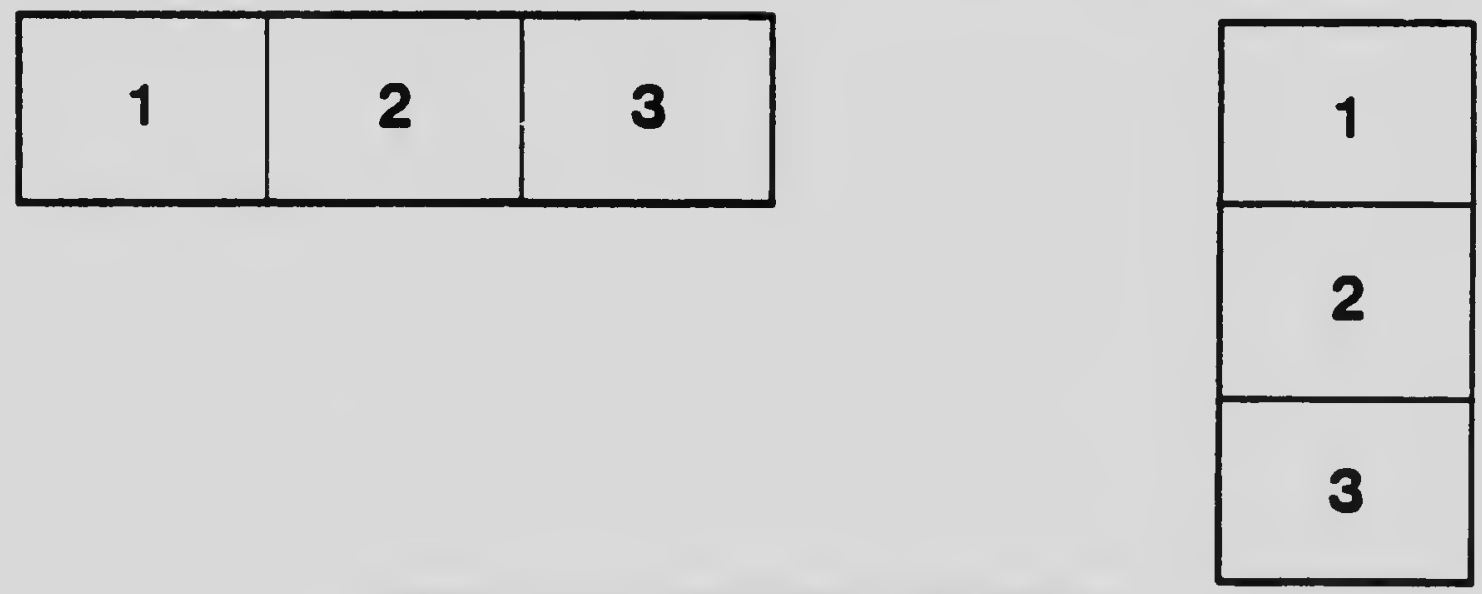

\begin{tabular}{|l|l|l|}
\hline 1 & 2 & 3 \\
\hline 4 & 5 & 6 \\
\hline
\end{tabular}


MICROCOPY RESOUTION TEST CHART

(ANSI and ISO TEST CMART No 2 \}
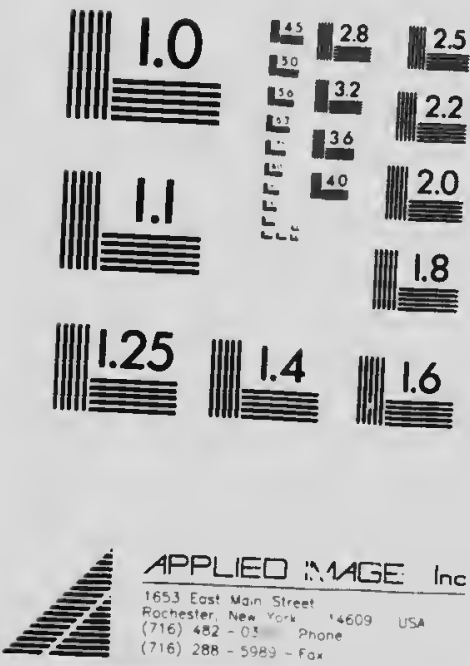


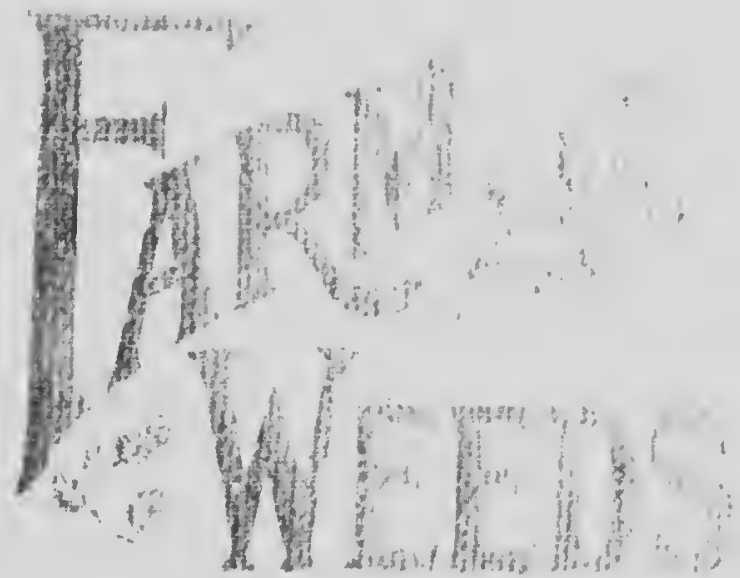

$$
\text { Departmenganda }
$$


$\cdot$ 


\title{
Farm Weeds of Canada
}

\author{
BY \\ GEORGE H. CLARK, B.S.A., \\ AND \\ JAMES FLETCHER, LL.D., F.R.S.C., F.L.S.,
}

With Iltustrations by Norman Criddle

SECOND EDITION

Revised and Enlarged by George H. Clark

Published by Direction of

The Hon. Sydney A. Fisher, Minister of Agriculture, Ottawa, 1909

FOR SALE, BY SINGLE OOP ES OXLY,

AT THE OFFICE OF

THE SUPERIXTENDENT OF STATIONFRY,

GOVERAMENT PRINTING BEREAV, OTTAWA.

Price \$1.00. 


\section{TABLI OF CONTENTS}

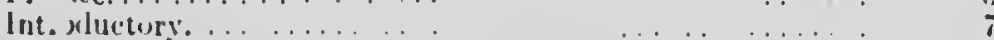

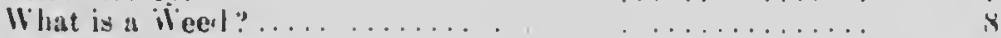

Losses llue to Weerls . . . . . . . . . . . . . . . . . .

llow Weeds spreal . . . . . . . . . . . . . . . $\quad$ 10

('lassification if Weerls. . . . . . . . . . . . . . . . . . .

Weel seerls in the sioil. . . . . . . . . . . . . . . .

Control and kixtermination of Weets. . ........... 1:3

lieneral l'rineiples ........ . . . . . . . . 15

S'unmer Fallowing. . . . . . . . . . . . . . . . . . .

Short Rotatiun of ('rops. .................... 17

s'heep l lestroy lieerl........................ Is

Seeding to (irus. ......................... 1s

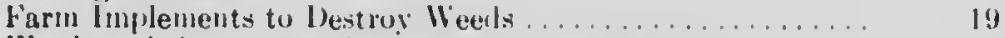

Weerl recels in (ommercial Seeds aml lieeding stuff. . . . . . . 21

Cirass Funily . . . . . . . . . . . .

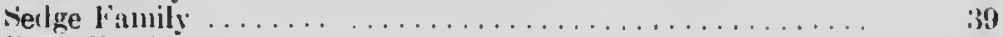

Rush Fimily. . . . . . . . . . . . . . . . . . . . . .

Burekwhent family ........................ 10

Spinach or Goosefoot Family................... 50

ligweed family ........................... 5

l'ink limily............................ 59

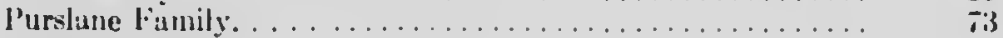

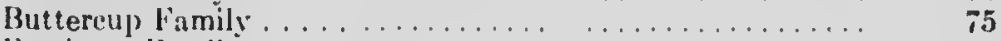

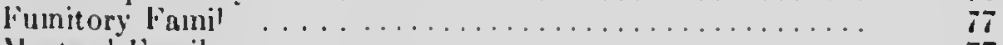

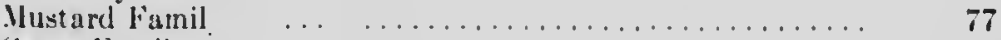

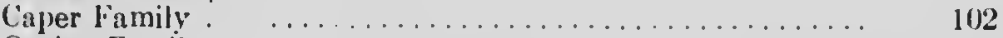

Orpine Fumily . ....................... 103

Rose Fanily ............................. 1033

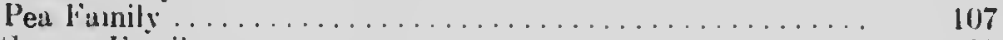

Spurge Family .......................... 110

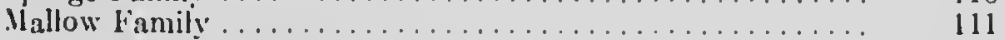

St. John's-wort lamìy . . . . . . . . . . . . . . . . . 112

Evening l'rimrose Fanily..................... 113

l'arsley lamily. ... ....................... 115

Milkweed lianily ........................ 119

IIorning Glory or Convolvulus Family. . . . . . . . . . . 120

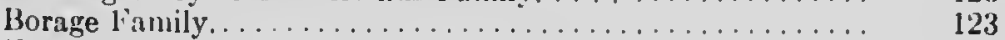

Vervain lanily . . . . . . . . . . . . . . . . . . . . . 128

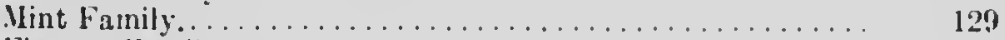

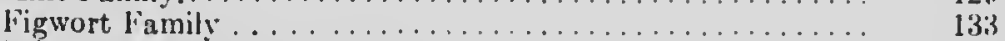

Ribwort or Plantain Family. ................ $1: 35$

Iladder or liedstraw Fanily. .................... 140

Sunflower Family. ....................... 141

Explanation of Botanical Ternis.................. 181

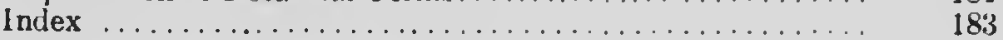




\section{PREF A C E}

The first edition of "larm Weels of canada" was llistributed thee

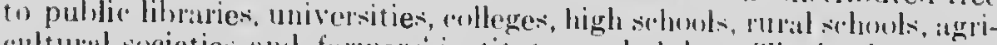

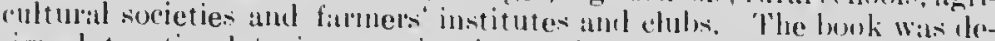
signed to stimulate interest in the sturly of farm weels in gencral. their habits of growth and the hest methuls of ambating them. It was distributerl with a view to make it anveniently an:ailable for the purpose of reference, to all who are interested in agricultulal pursuits but partieularly to farmers and pupils of solhools in farming hlistricts.

The second edition has heen prepared and publisherl to llwet the urgent requests from indiviluals who desire the lomk for their personal une. The information presented in the test is useful her:anse the illustrations of weets aml weed seenls milke it intelligible to falmers and others who are not expert in the momenchatme of phants. The expense entailed in the preparation, printing and limling of sevontssix coloured plates as contained in this volume precludes it from the list of those publications of the lepartment of . Igridulture that ale listributed generall! ant free of change. The mominal price fised for its sale will restrict its distibution to those who will preserve ant make proper use of it, anul will meet a patt of the lmustual pxpense incurrell in its issue.

The death of 1)r. James Fletrher. "on-rolitor of the tirst ellition, caused a temporary suspension of the plans for the publication of the second edition. With his co-operation ant supervisun, a lange number of water colour sketches of weenls were male hy Norman cridclle, while employed hy the seed Bramb, luring the eaty summer of lons From these sketches selections were manle of the illist rations of weels

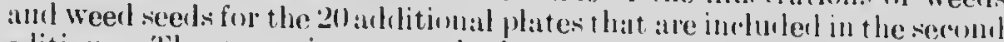
edition. The tentative general plans fol the enlargonent, lotanical re-arrangement and revision of text for a new ellition of " " had been discussed with $\mathrm{H}_{\mathrm{r}}$. Fother in a general way ull several oceasions during 190\% and the winter and eanly spring of lons. It is believed that the nature of the revision is in aroord with the vicus: which he held and with the spirit of prongessiveness that is rearly evillent in all his life work.

Considerable re-amangement of the mattro was mald neressiny in the second erlition in order that the varjuts plant tamilies, goneri

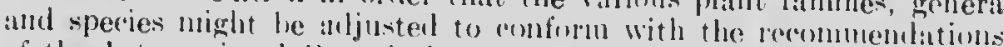
of the International Butanical Comgress at Vionna and now generally arlopted by hotanists. Some alulitions to the sulject matter have been made to indude new and inportant information that has resulted from recent research work. In revising the descriptions of plants and seerls technical terms have been avoiled whenever prsible.

T!e hank is not intended for ase as a text luoh of imalu. Inasmuch as the primary objert of its issue is to present information por- 
taining only to those plants that are commonly characterized as weeds, it will be obvious that several plant families of importance in the study of the science of botany, are not treated with in this publication. Nor has it seemed practicable to illustrate, descrile or even mention more than those species that are known to he quite widely distributed and generally troublesoine weeds in Canada.

Some of the weeds herein illustrated and described have been introduced witlun recent years, and it is to be expected that many others and equally troublesome weeds may be introduced from time to time and distributed in future years. Additional information concerning weeds and methods of combating them will doubtless also accrue from further research work. It is thought reasnnable to expect that later revised editions of "Farm Weeds" niay be necessary to bring it up to date for future years.

"Farin Weeds of Canada" was one of the last of the many contributions to agriculture from the late Dr. Janles Fletcher. It is desired that this second edition of the hook will further perpetuate to his memory that large measure of appreciation of his unselfish personality and zeal for useful service which he so richly deserved.

Recognition for much arduous detail work in the compilation and revision of the descriptions of weeds and weed seeds as contained in this volume is due to Mr. George Michaud, Botanist in charge of the Seed Laboratory. Valuable assistance was rendered by I'rof. John Hacoun, who was frequently consulted in connection with the work of re-classification and botanical nonienclature. Information as to the lest methods that may he employel in the control and extermination of particular weels was provided by nany experts in the practice of agriculture, annong then being T. (i. Raynor, W. C. Mchillican, J. II. Grisdale. Henry Glendenning, T. N. Willing, T. B. R. Henderson, Angus Hachay, s. A. Bedford, James Vurrny, W. H. Fairfield and Archibald Nitchel.

The illustratious of farm implements to destroy weeds were selected witl a view to show the type of implements referred to in the text. There are numerous implements of approximately the sane general type, but of somewhat different design, which are equally desirable and effective as weed destroyers.

Numerous quotations from old writings which treat with farm ueeds and other plants are inserted in space not required for the principal text. The quotations fron Tusser, Grahame, Jethro Tull, Sinclair, Jickson, Worlirlge, Fitzherberts, Ilale and IBlith were contributed ly I'1incipal IR. I'atrick Wright, Glasgow, Scotland, and R. B. Greig, llarischal ('ollege, Aberdeen, scotland. The subject matter as well as the text itself of many of the oldest of the quotations will doubtless prove interesting and some of them even instructive when studied in relation to tho subject matter of this volume. They nay. convey to the mind of the rearler a fairly clear idea of the general knowledge of plants that was possessed by the stuclents of the llatural sciences in past centuries.

\section{S. A. F.}

G. H. C. 


\section{FARM WEEIS OF CANADA.}

\section{INTRODUCTORY.}

The annual losses due to the occurrence of pernicious weeds upon farm lands, although acknowledged in a general way, are far greater than is realized. These losses can be appreciably lessened, however, by treatment based upon an accurate knowledge of the nature of each weed.

Most farmer' give little critical attention to the wceds growing among their crops. Some think that, because many of these plants are unfamiliar, the exact recognition of all of them is impossible. This, howcver, is not the case, and, as the different kinds vary greatly in their power of robbing the farmer, it is certainly advisable that more attention should be given to wced pests. Although several hundred kinds of plants grow wild in alınost every locality, and many of these may appear among cultivated crops, comparatively few give serious trouble -not $\mathrm{m}$ re than there are different kinds of crops grownand every cultivator of the soil knows the difference between wheat, barley, oats, rye, peas, turnips, beets, etc. It is no more difficult to learn the names, nature and appearance of Stinkweed, Hare's-ear Mustard, False Flax, Canada Thistle, Field Sow Thistle, Sweet Grass, Quack, etc., than to recognize the familiar cultivated plants.

In the official bulletins which have been widely distributed during recent years, the weeds have been named uniformly, though many of them have other local names. It is therefore clearly important that those for whose benefit the bulletins have been prepared should know the plants by the names officially recongnized, so that they may be able to make the fullest use of the information. 
The prevalence of some speeies of weeds in certain parts of the Dominion must be viewerl with the gravest alarm, for they have taken such possession of the land as to seriously affect profitable farming. Such aggressive enemies are: Wild Ilustard, Quack or Couch Grass and Canada Thistle in parts of almost covery province; Ux-eye Datisy in the Maritime Provinces; Field sow Thistle in the Maritine Provinees, Quebec, Ontario, and the Red River Valley in Manitoba; and stinkweed or Penuy Cress, Ball Mustard and Hare's-ear Mustard in all the
Prairie Provinces.

The incrase of weels is frequently due to the fact that through iguorance of their noxious nature and power to spread,
farmers have negleced them.

"Many of our farnors hitve only a limited knowlerlge of werds, and in many eases do not recognize those that are dingerous on their first appearance. Hence we have 'One year's needing, seven years' weeding.' There are some weeds so nized the plants on thers knew their real character and recogall other business until they appearance, they would postpone should be a sufficient incertive destroyed. . . Self-interest if it is clearly shown that it wive to farmers to destroy weeds hellar.

\section{WHAT IS A WEHD?}

There are many definitions of the word, but perhaps from a farmer's standpoint the best one is, "Any injurious, toublosome or unsightly plant that is at the same time useless or comparatively so." As a general statement, it may be sairt introduecd into tronblesonce and aggressive weeds have been true that, under special con other countries; but it is also wild plants may increase aurelintanees, some of our native

\section{L.OSSES DUE: TO WrEDS.}

It is imposibible to determine accurately the losses to the individual farmer, or to an agricultural district or conutry 
ats a volole, from woreds growing mpon coultivated land. In various

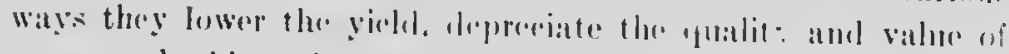
cropse and atel to the rost of productiont.

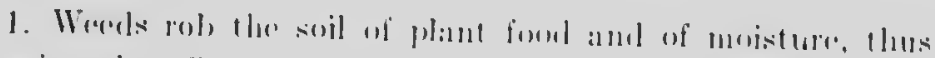

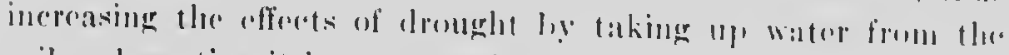
suil and wastiug it lọ "vaporation.

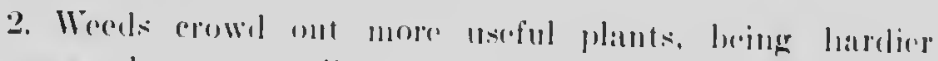
and, as a rule, morre prolifie.

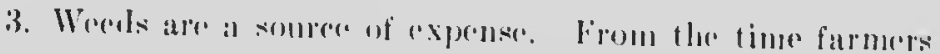

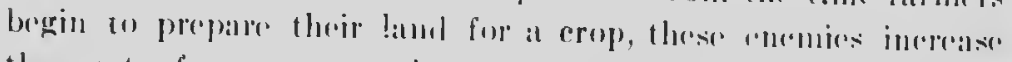
the cost of crery operation - of plowing. harrowing. seroling

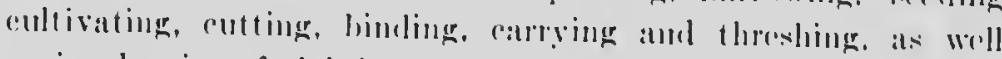

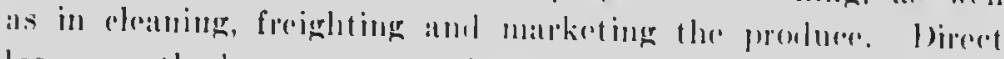

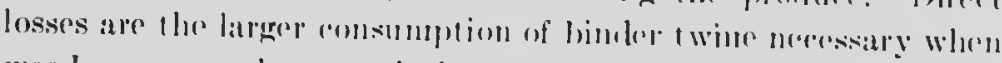

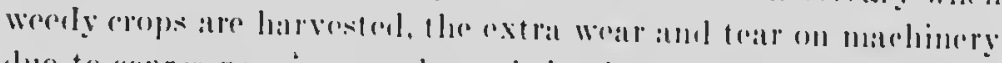

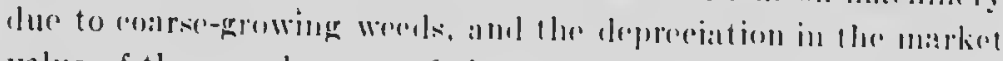

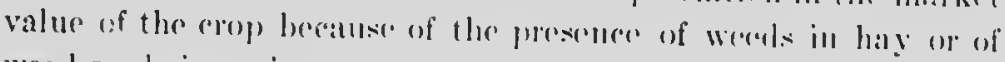
weed serels in grain.

4. The eradication of the worst worels is costly in lithour, time and machinery, and frecpumely provents a farmor from

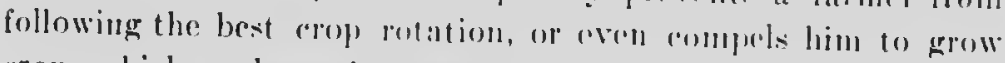
rrops which are less allvantageous.

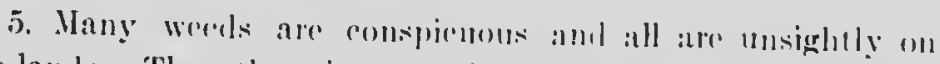
farm lands. They thus. in a varying degere. alerending to thein several natures. deprereiate the value of lamel.

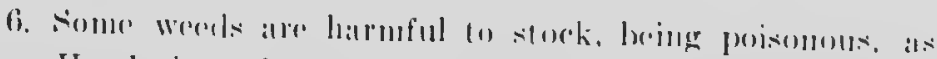
Water Homloch: whers are injurious to thoir proluets, ats burs in wool, or Will Garlice and sialkworel. Which taint milk.

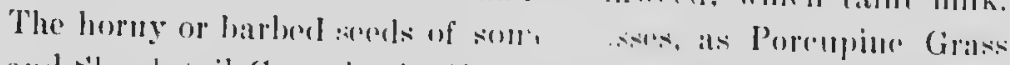
and skunk-tail Grass in the Sortla . callse irritation or painful wounds by pencetrating the flesh, patrtionlanly the month parts.

7. Worels attract injurious inserets ambl lampour fumgus

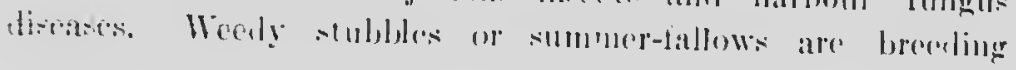


grounds tor cut-worms, and the rust of small grains may pass the winter on several kinds of grasses.

\section{HOW WEEDS SPREAD.}

In the present age of rasy crinuunication with all parts of the country, and inderd with the whole world, there are frefuent opportunities for the introduction of weed secds into previously uninfes:cel distriets.

1. By natural agencies. The wind rarries sceds long distanees, not only in summer, but with dititing soil and over the surface of the snow in winter. Strcans distribute them along their courses. 'They are alse distributed by secl-cating birds and lierbivorous animals, through the stomachs of which the seeds pass undigested; or they attach themselves by special contrivanees, such as hooked and barbed hairs, spines, gummy exerctions, etc., to passing animals.

2. By human agencie:. New weeds are introluced on farms with grass, elover or otlicr commicreial seeds, and commereial feeding stuffs usually contain some vital weed seeds. They are spread from district to district ilirough rarious transportation facrlities, such as railways, and become disseminated within a locality in stable manure fron towns and eities, and through threshing machines and farm implements. The illustrations of weed seeds on the last five plates of this volume will aid in the identification of impuritics eorninon in commercial seeds and feeding stuffs.

\section{CLASSIFICATION OF WFEDS.}

Werds, like all other plants, may be classificd, according to the length time they live, as anuuals, or one-yen plants; biennials, or two-year plants; and perenuials, or many-year plants. In cradicating weeds, it is of the greatest imporiance to aseertain under which of these heads they come, because the treatment is usually to prevent annuals and bicnnials fron: secding and perennials from forming new leaves, roots and underground stems. 
Ann als complete their growth 111 a geal. As a rule, they hatre smull fibrous rowts and jereluer a large guantity of seed. Examples of this class arr II Hild Mustarl, lamb's Quarters,

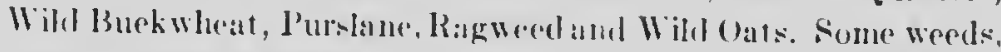
"illed Winter Annuals, are tru" anumits wi:en the soeds germintere in the spring. but they anr also hiemial in habit: that is.

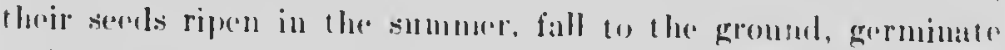
and produer a rertain growh before winter sets in, and then eomplete their development the next spring. of these may bo mentioned shepherd's l'urese, P'operergrass, stiuhwerl. Worm-

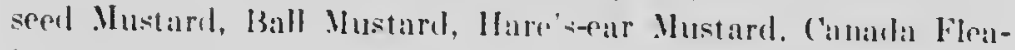
batne aud Bhe Bur.

Biennials repuire two sousons to complete their growth, the first being spent in colloeting and storing up a supply of nourishment, which is used the serond solson in producing flowers and secels. Examples of these are Burdect, False Tansy, 'ommon Evening Primrose and Vipere's Bugloss or Blueweed.

Perennials are those phuts which continar to grow for many years. Preenuial wereds are propagated in soreal ways, but all produee serels as well. They have two distinct modes of growth: some reot deeply, while with others the root system is mear the surfiee. The unost troublesome are those which extent long undergrouml stems ol rootstueks beneath the surface of the ground, as Camula Thistle, Peremuinl or Field sow Thistle, Find Bindwerd, Bladiler Campion, White-stemmed Evening Prinrose, Blue lettuere and some will sunflowers. representatives of the seeond alass or shallow-rooted perennials are Pasture Sage, Yarrow a Coueh Grass. Some perennitils extend but showly from the ot hy short stems or offects, but proluee a large quantity of seel. Of these, ()x-eye Daisy, Dandelion. Goldenrod and Yarrow are examples.

Weeds might also be gromperl, aecorling to their manuer ol distribution, into two general elasses:-

a. Weeds distributed in time are those which, when maturs. diseharge their seed elose to the mother plant. The seeds of 


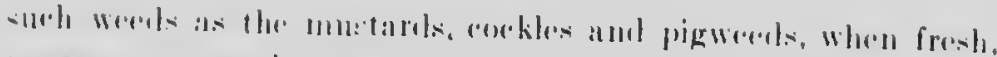

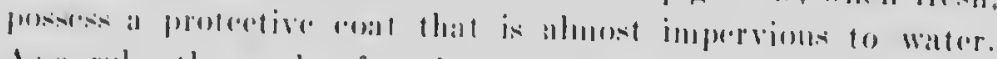

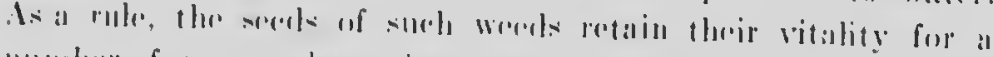

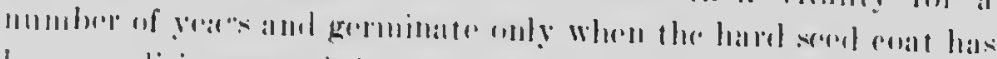

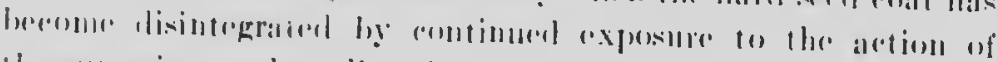

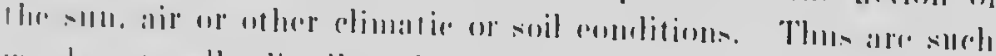
werels lattorall! listribntorl in tinte.

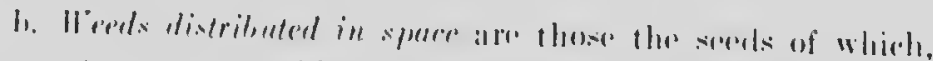

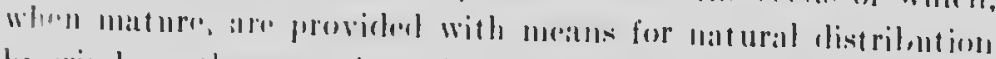

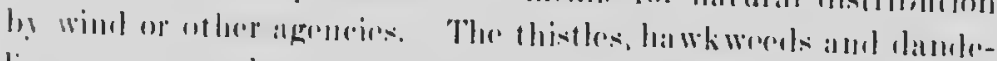

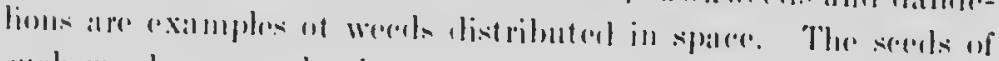

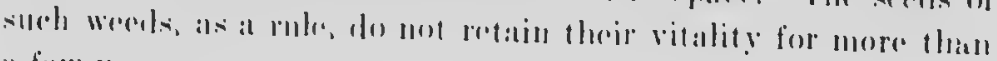
a fow grats.

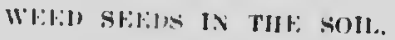

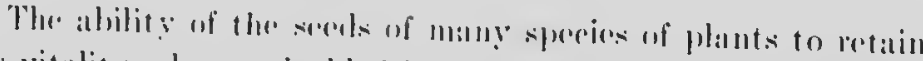

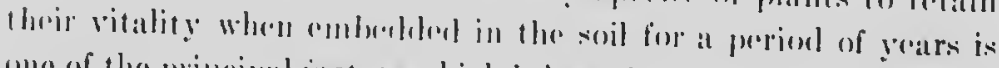

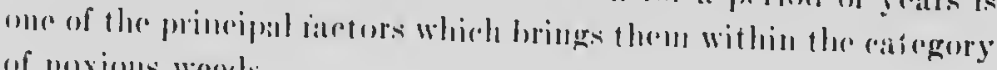
of mxims werels.

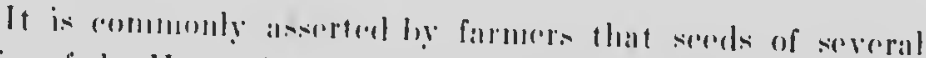

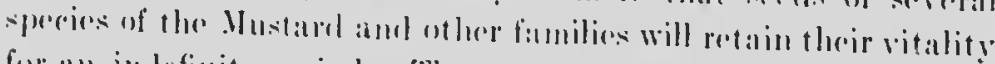

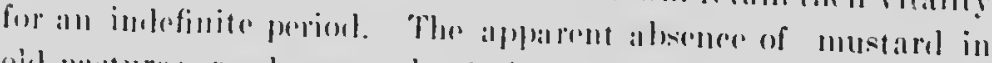

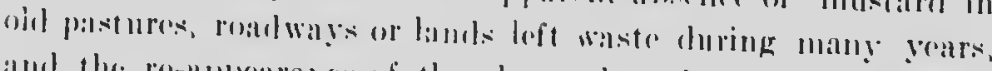

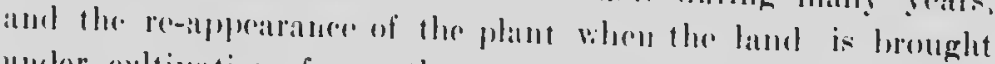

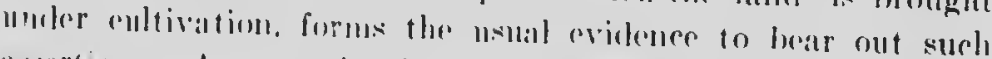
atsorertions. In examination of permaturnt pasture or watste

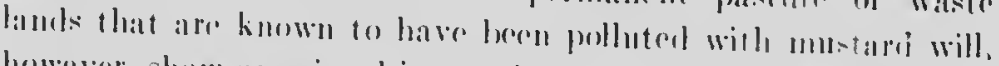
howrore, show oreatsional inconspicuons plants that give promiso of ripening a fo wherls.

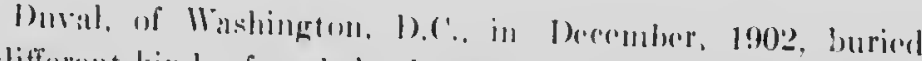
112 different kinds of secels in elay soil in airthen pots, fo depths of six, rightren amel thrty-six inches, and compared their vitality with eomteol simples kept in proper storage. When deg up in Norrmber, 1903. practically all the sorols of cultivated plants were decayed, mamy of them having first germinated, cren at 


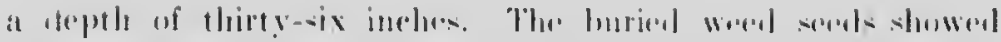

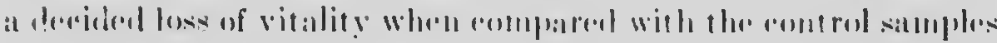
that were kept in storage. The latter germinaterl tifty-theres

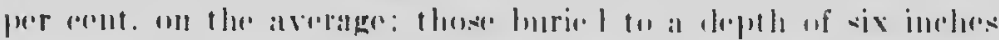

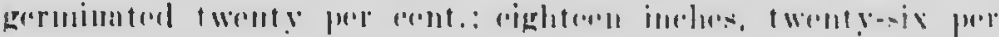

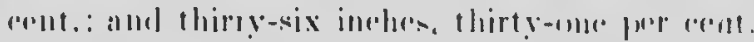

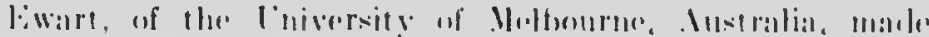

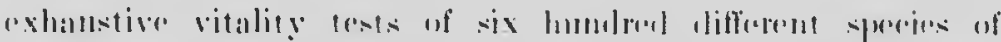

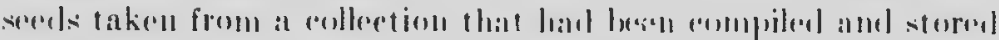

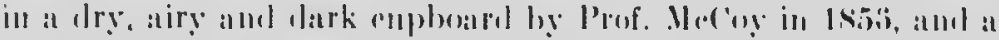
large number of spereimenes of serels, of villying aleses, from the

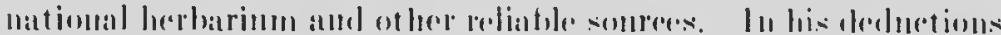

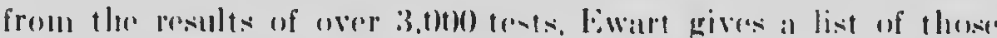

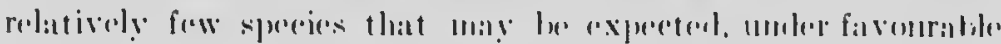

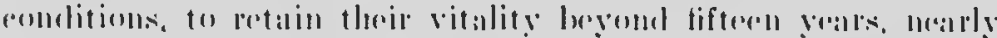

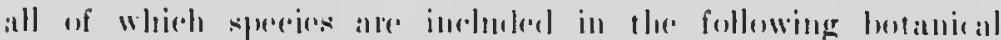

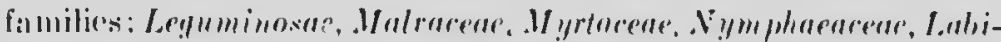

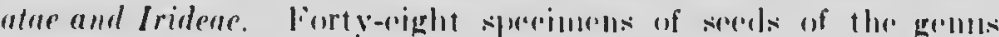

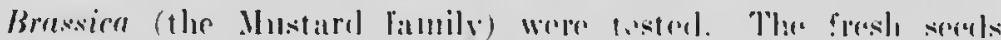
gatre a germination as high as aighty-six jele enthe and one lot

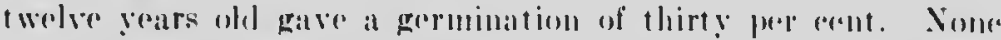

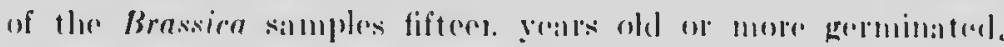

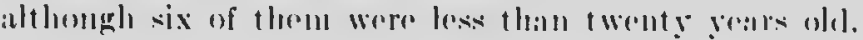

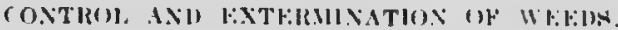

In ahlopting : Inethoul of estermination, the matme of the

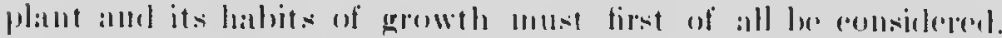

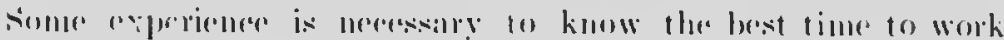

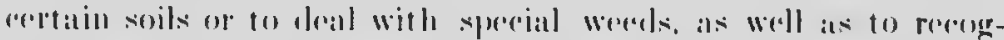
nize them in all therir stages. Somme worels, Russian Thistle amel

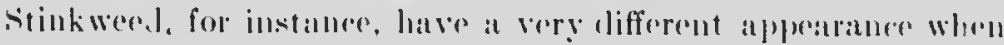
young and when unture. So general rule ean 1, given, as the treatment must valy witle different distriets, hlffoment soils. and different climatic conditions. What mas be steressful in one place maty fail in anothere. 
Annuals may be erialieaterel from laud, lowever bally infosterl it aly ine throngh any undlend by which geroumation

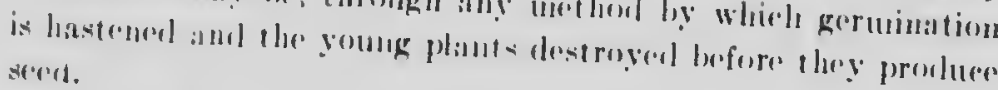

Biennials mast be abler plowerl or eut lown luefore they

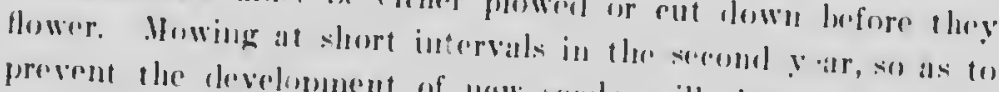

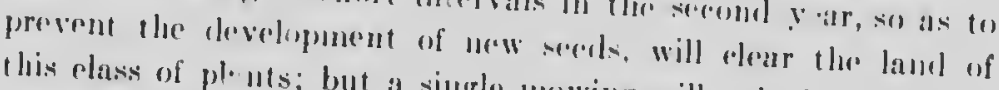
this elass of plents; but a siugle unowing will ouly induee them to send out lator brauches, which, if not cut, will mature many serels. Where plowing is impracticable, such plants should
be cut off below the crown of the root.

Perennials are by far the most tromblesome of all weeds and respuire thoromgh treatment, ir sme instaneres the cultivatical ol special erops, to insure their reruliention. Inperfeet treatment, such as a single plowing, of fon does morr harm than good, lyg breaking up the rootstorts and stimulatink growtl.

For shallow-rooted peremuals, infostod lamel shoulel bu plowed so lightly that the roots are expeseol to the sull to dry up. For tecp-rooted freremials, on the other hamd, plowiug should he as derol as eomverolemely possible. Tler nature of the famel must determine the elepth of plowiug. In light ar glatrelly soils shallow plowing maty lo proforable as derep plowing might interfere with the meehanical texture of the soil, which is so important in the storing of moisture.

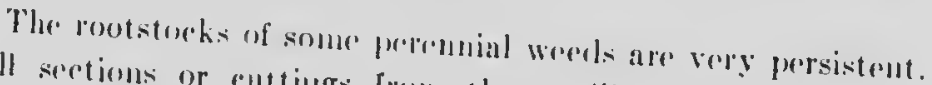
suall sections or enttings from llem will quickly take root when they are distrubuted by fluwng or entlivation. Where

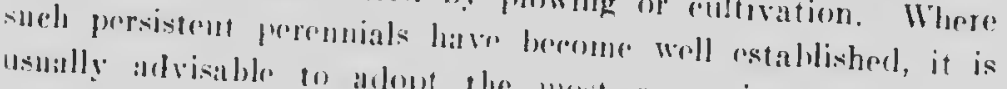
usually advisablo on alopt the most convenizut method of rultivation that will bring the metestoeks to the surfare. They Host perennial werests will, hownt or otherwise destrogerd.

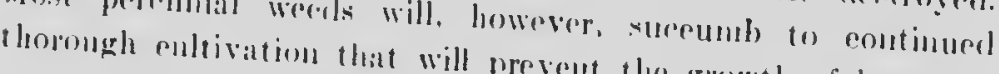

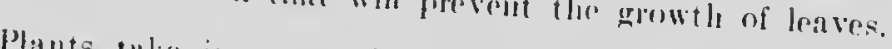

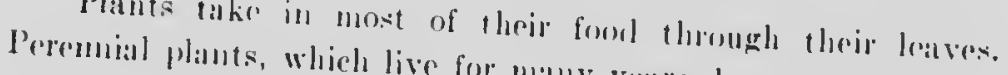

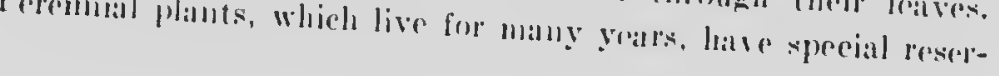




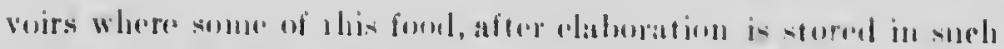

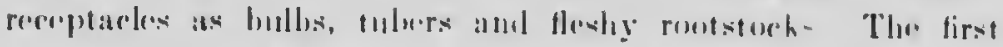
growtle in springe, partionlarly flowering stoms, is prouluenel mainly by trawing on this speeial store of nourse!ntent. Plants

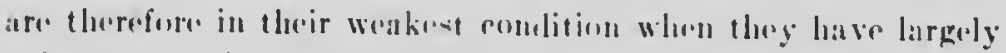
"xhausted their reserve supply of focel and lase not had time to replenish it. The stage of growth, then, when plowing will be most effective is when their flowring slems lanve mate full growth but before the secels, which would be n source of elanger, hate had time to mature.

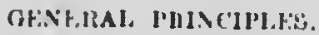

1. There is no weed known which eal t be cracieated lyy constant attention, if the nature of its growtio be understomi.

2. Siver allow weerls to ripen seeds.

3. Cultivite frequently, particularly carly in the suson, so as to destroy seedlings.

4. Many weel seredic can be induecel to germinate in autumn by cultivating stmbbles immerliatcly after harvest. Mlost of these serellings will bo winter-killod or can bo rasily disposed of by plowing or cultivation in spring.

5. All weeds bearing mature seeds slould he burnt. Linfer no circumstances should they le plowed mmler.

i. All weeds ean lo destroyed hy the use of crelimary implements of the farm, the plow, the altivator, the larrow, 1 t. spud and the hoe.

7. He constantly us: the alort to prevent new werels from becoming establisherl.

\section{SIMMFR FALIOWING,}

The practice of summer-fallowing lambl, to the cxclusion of all arops throughout the season, whatever may be said against it, affords the best opportunity to suppress noxioms weeds, for 
Iii

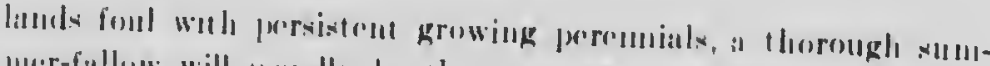

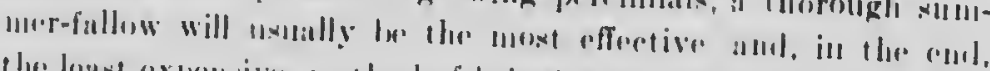

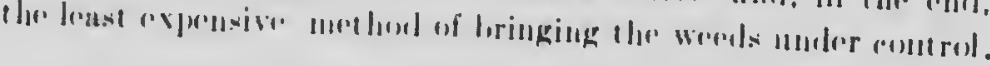

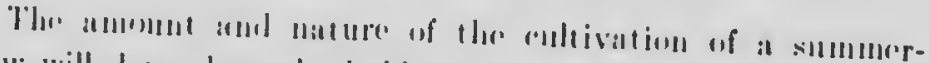

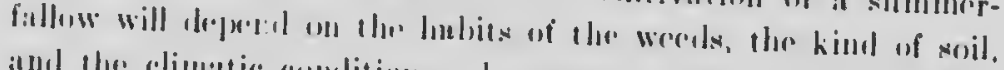

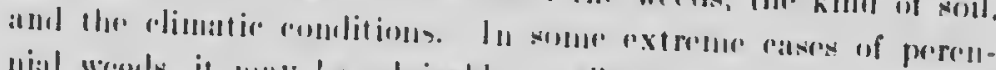

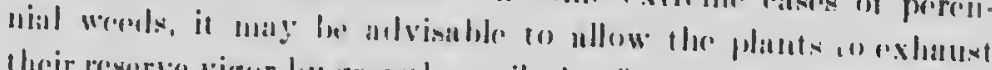
lheir ereserso vigur lug growth antil the flowers aro formenl, them

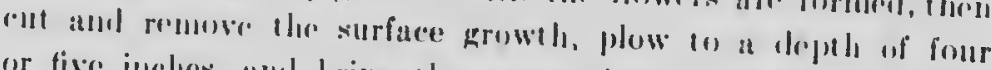

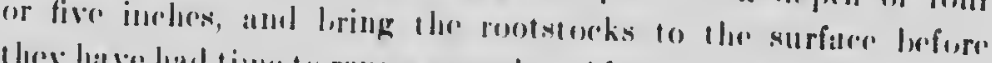

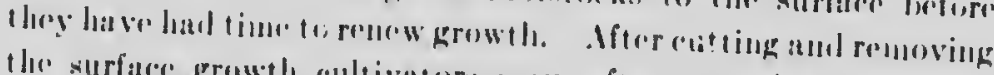
the surface growth rultivators may, afere several applientems,

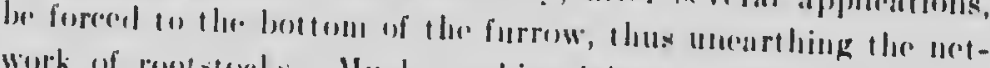

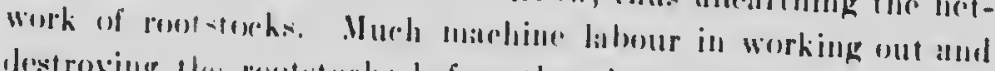

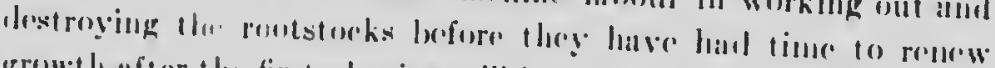

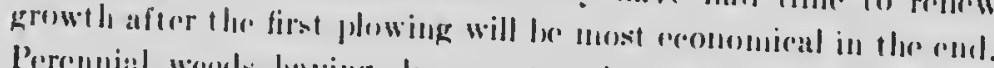

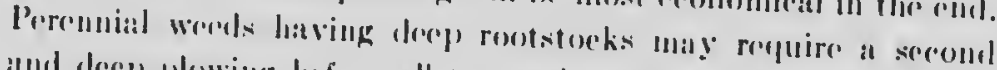
and decep plowing before all the molerground "egertation ram be

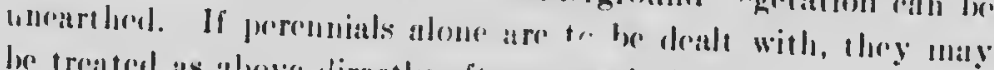

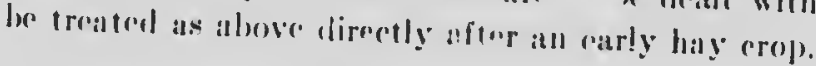

Perionlieal cultivation of the st:mmer-fallow throughout the

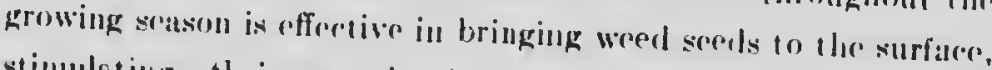
stimulating their germination allal destroying the acolling plants. When the destruetion of anumal weeds is the chief purpose of cultivation, deep plowing two or three timses luring the summer, with surfaer eultivation each work dluring June

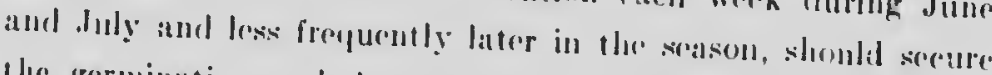
lle germination and destruction of the naximum number of seeds. ()n alerount of the soil and relimatre, oure plowing of summer-fallow is fatrourel in the Pratrie Proviness. In moin: soasons a second decep plowing is apt to stimulate too rank a growth of straw and delay the ripening of the grain. The germimution of weol soeds is stimulated most by cultivation during the rerly growing seatson, and sumuncr-fa!lows intronded primarily 
for that purperse should le: loroughe moder rulcuvatun early in the season.

\section{giont iotation of cliols.}

To keep farms free from weeds, few metlosls give such gooml results as a systematic short rotation of erops, with regular secding down to grass or chover at slont intervils.

Weecls are most in evidenee in clistriets where tlee production of cereal grains, lominates and where the systrinatie alternation of crops is not geuerally practiend. Iany weeds ripen their soeds with ecreal grans and the sechls are seatterend during harvest. When a cereal crop is followed hy early chover, the weeds in the clover may lo eut before they are nuture. The hay crop of the second year ufter seceling is not infested with weels becastese a fresh supply of the secols has not herent brought to the surfuce ly cultivation. The remusal of tha hay crop of the secend gear affords alt opportmity for a summerfallow, preparatory to the production of a lesel or solne wher cleaning crup.

The following short rotation is reommendent for the castepn provinces by J. II. Cirisdale, Aglienilturist of the Contral Experimental fiarus:-

"Te destro": weeds, probably the best rotation possible is one of three yals duration including chover and mixed hay, followed by root: " corn, the land shallow-plowed in fall aul sown to gra" 11 the mext spring with ten ponuts of rell clover and twelve poumls of timothy per ace. (Whan the land is heave

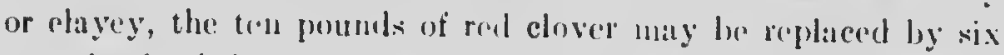
pounds of real clover and two of alsike.) If a portion of the arable land must be used for pasture, then the land might be allowel to remain under grass or hay for two years instead of one year. the secont being used for pasture, thus extenting the threeyear into a four-year rotation. The pasture land in the fouryear rutation, or the hay land in the threreyear rotation, slould be broken up early in Angust and ("ultivared at intervals to destroy the sucessive growths of werils as they appear. The 
land -hould bre agatin plowed or proforably riglged in the fall. These motations maty be cexpectorl to give gool results anywhere in ("antulat "ilst of . Nanitoba."

\section{SHEF:l' DFSTROY WFEIIS.}

When all abundance of sueculent pasture of the finer grasses is provicied, wreds can scarerly be said io be favoured by sheep as it staple part of their diot. Sheep will, however, even when good pisture is provided them, vary their diet by mipping off serdling phats or the fresh growing parts, and the bloom with its content of swects, from older plants of many of our eommon weeds. When their pastum is dopleted, shecp feed readily on Wild Hustard, Ux-eye Daisy, Yarrow, Pantain, Perennial and Annual siow Thistle, IFild Votrh or Tare, Docks, Sorres, anb's Quartors, Milkwerd, Ragwort, Burdoek and shepherd's P'urse. In fact. there are fow wreds that sheep will not eat, to the extent of proventing them from sording, if there is not rnough of their favorite grasses to sittisfy them. It is only when the supply of food is unususlly short that shrep will feed on plants having loaldes and struns rovered with bristly lialirs or spines, or with al flisour that is ohmoxions to them. When the plants are young allel tomeler. hewover, sherep have beren observed to eat such

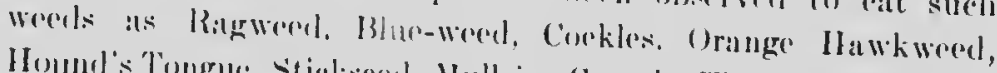
Homel's Tongue, Stiekserel, Mullrin, Canada Thistle, stinkweed, Toatflax, and others that are bristly or hatre pungent flaventr. Thoromgh cultivation with a sietematio rotation of cropse, rom-

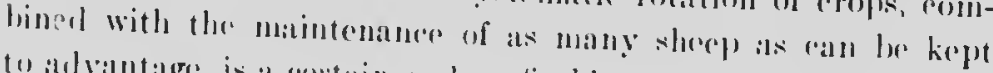

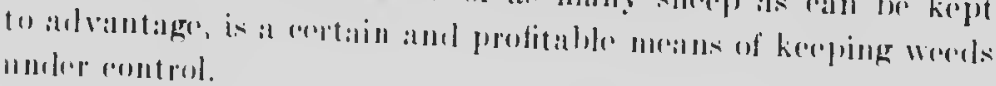

\section{SFFIMING TU GILASS.}

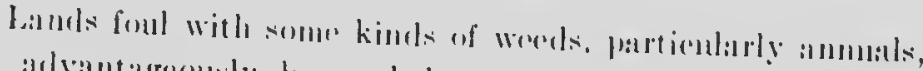

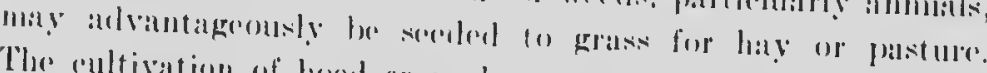

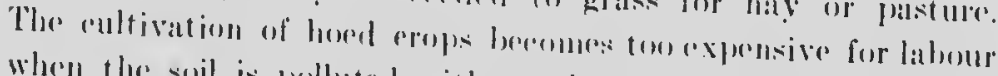

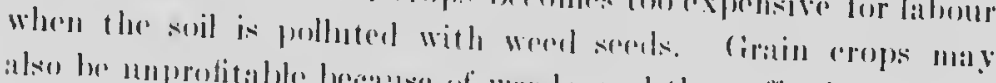

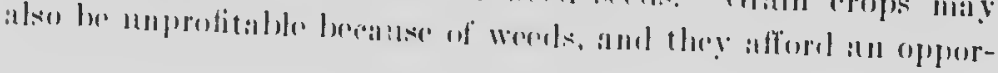




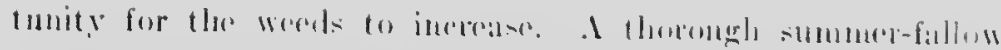

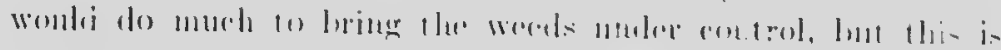

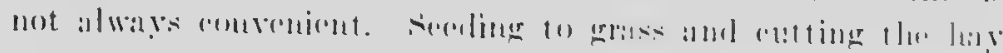

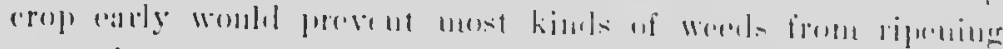

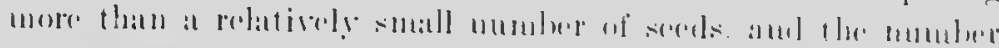

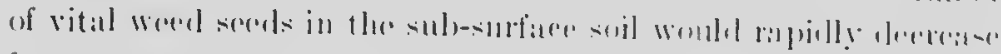

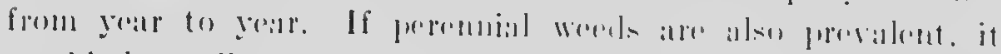

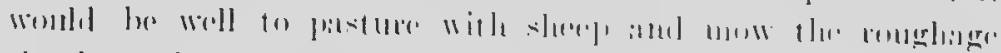

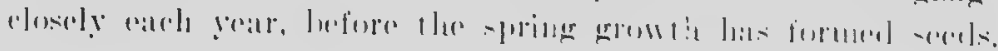

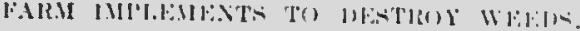

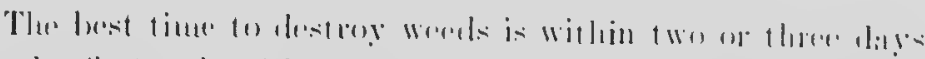

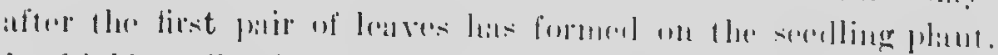

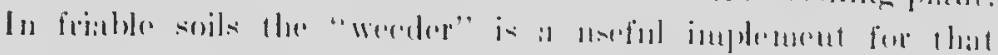

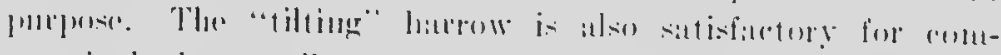

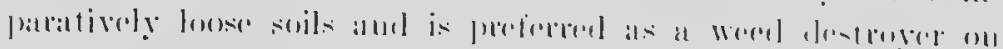

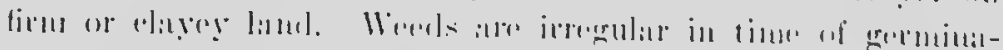

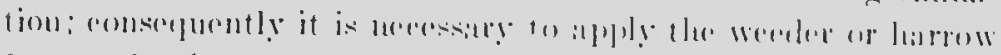

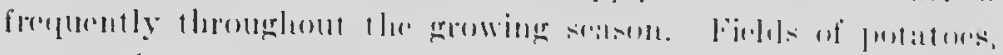

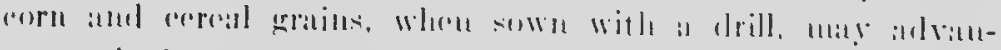

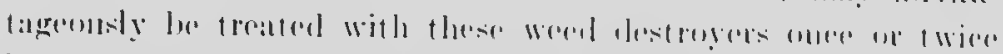

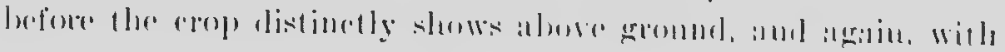

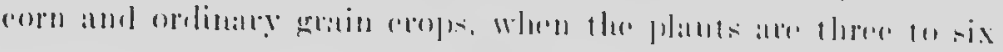

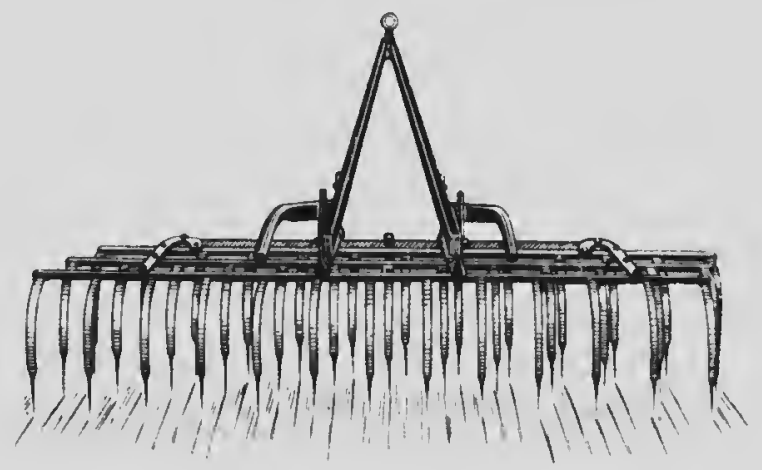

T11. M1.1.11\%.1 


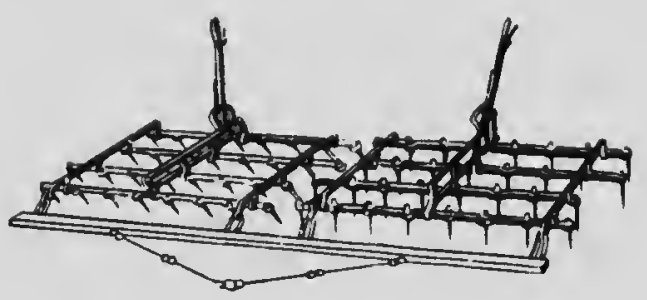

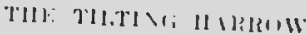

inelues high. Even relatively hang hamens orlinarily in use will do little dantage to the pentateres. corn on gratu plants if the latul is not wot, and the forsenting of the surfater soil benefits the erop in aldition to the destruetion of the wered.

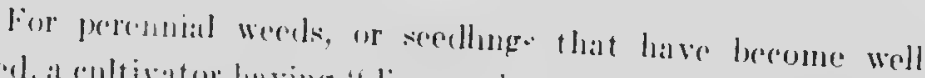
rooted, al coltivator having "diamona" almed or other relatively broal shares is needed fon hoed crops. The "dise" is a fatoured implement for destroving worels in summer-fallow or in prepatring a seed bed. When, howerene, it is desined to unearth and remote the motstoress of perembia.' werels such as couch cirass. a natrow-tonthed cultivator, that will loesen the sril and bring

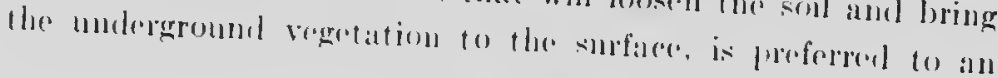

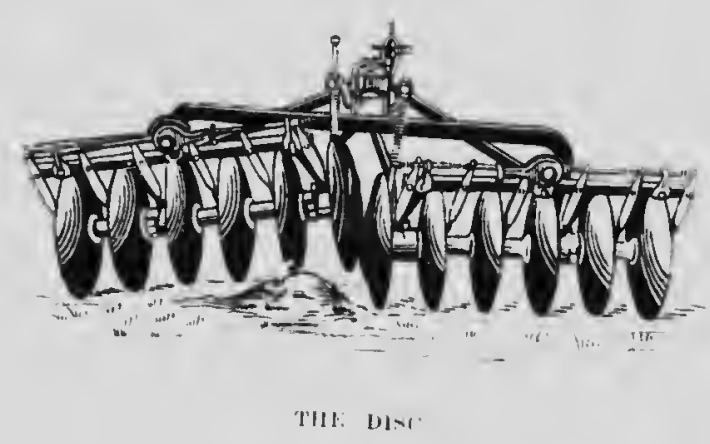




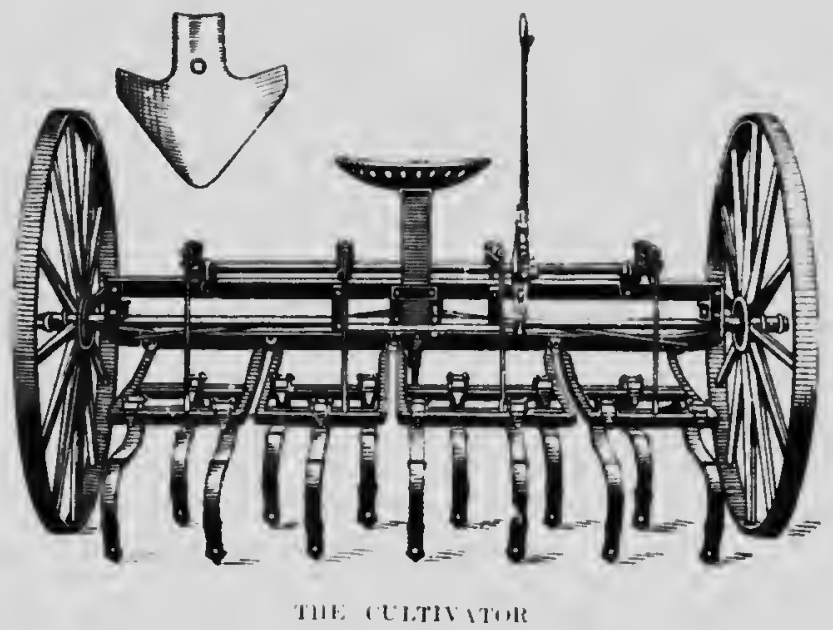

implentent that will ent the rootstochs, the -mall ruttings of

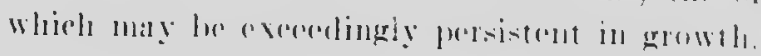

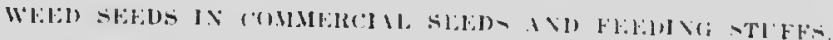

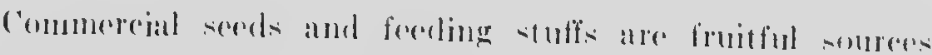
of weed introtuction and distribution. Stable mamme from citios and towns is often polluterl with wered serels; but its

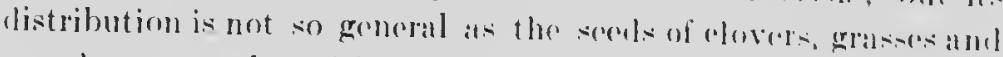
cereats or germund meal for forerling.

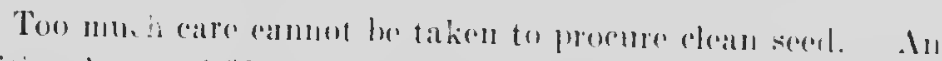

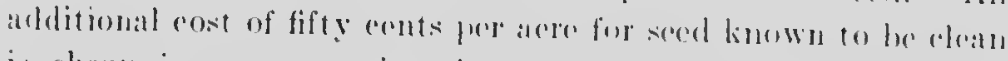

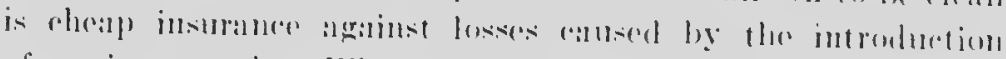

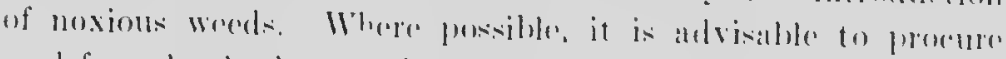
seed from lands that are known to be free from nevions werels.

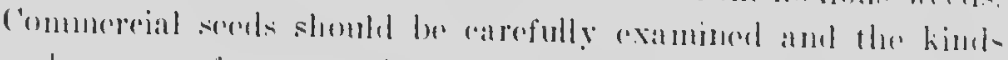

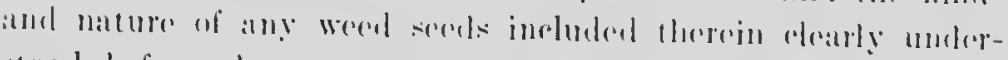
stoot before they are sown. Absolutely fure serels aro not obtainalide in quantity for emmeres and mang samples that splpear to bo cleatn contain serels of the most objectionable werds. Clovere secels foul with foxtail are often less harmfil 


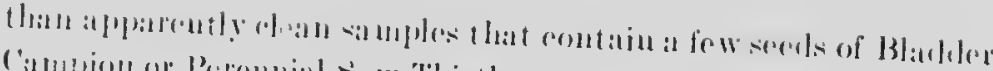
(ilmpion or [romnial sow Thistle.

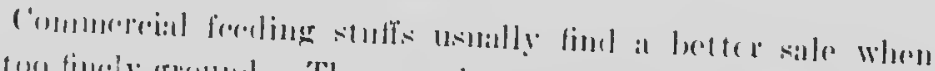

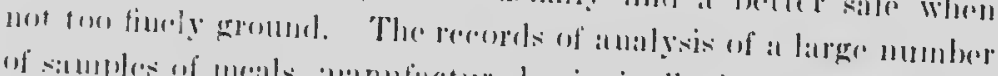

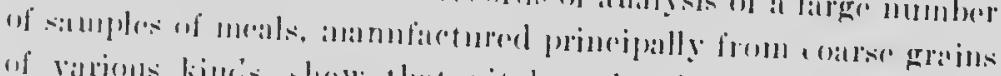

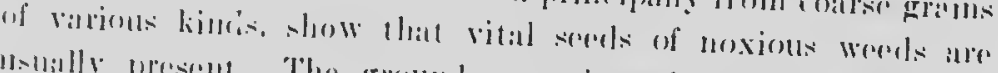

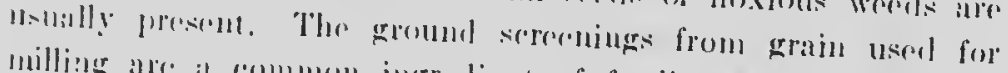

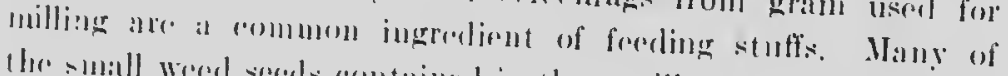

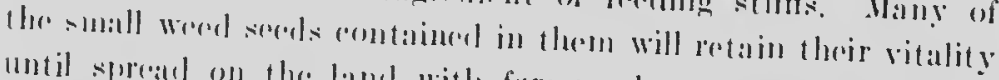
until spreat on the land with farmyart manure. such small

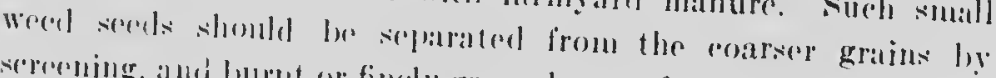

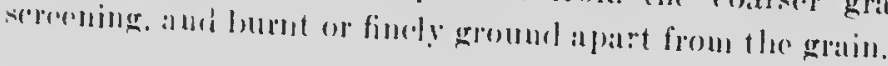

\section{THE GRASS FAMILY (Gramincae).}

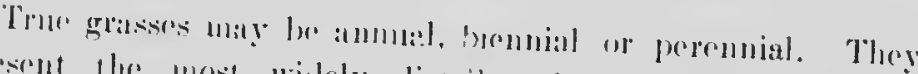

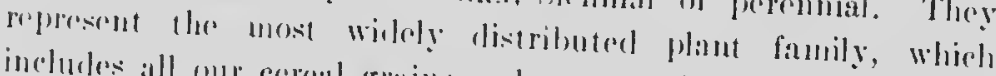

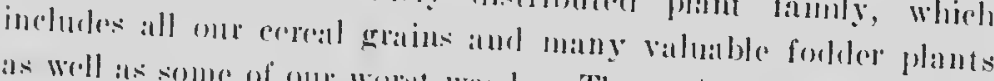
as wedl as somere of ond worst werels. The native grassess indicate

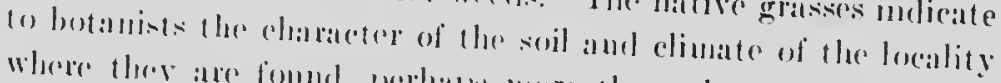
where they and fomml. perhalps more than plants of any other

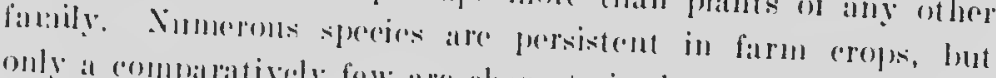

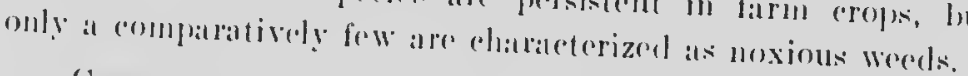

Crasses aro tulted or "hmoluel" when numerous stems risit from at single base or from short rootstocks, and creoping when the reotstorelis ale long. Floweriug stems and fibrous

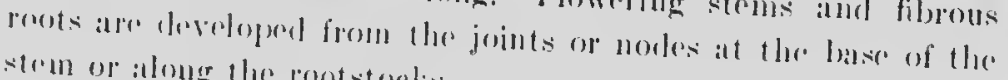
stron of along the rootstorks:

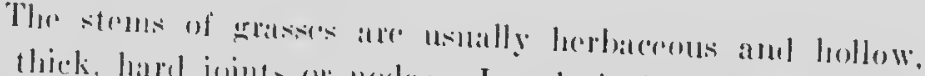

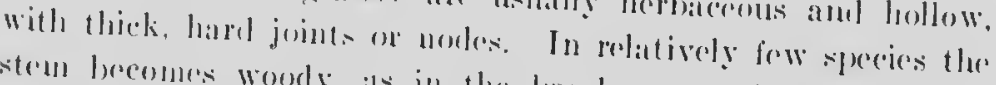

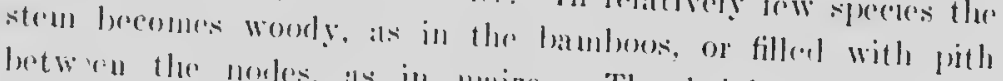

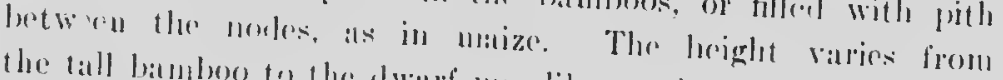

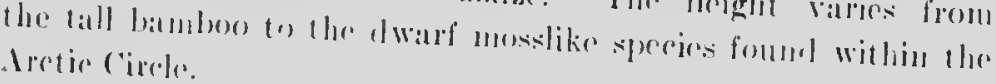




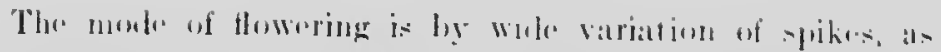

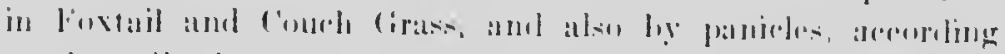

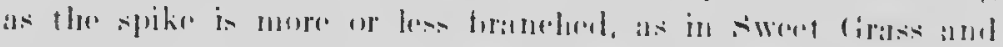

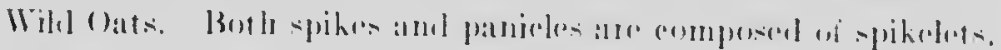

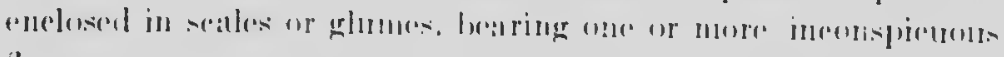
flowers.

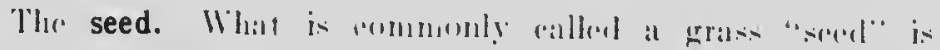

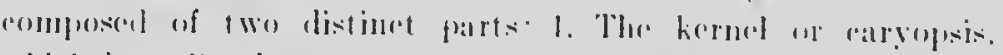

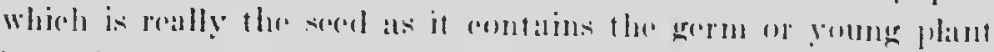

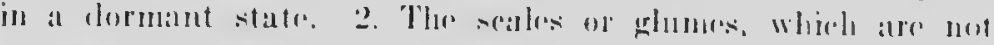

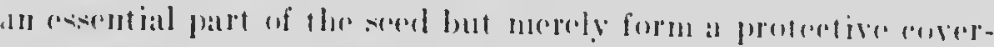

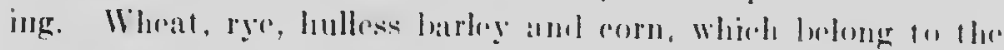

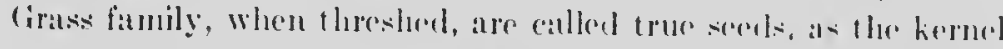

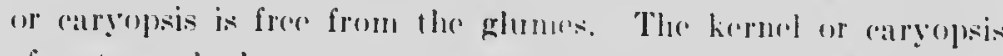

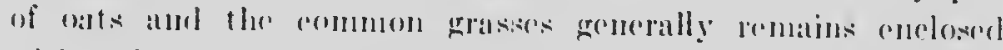
within the glumes. Ocrasioniliy both forms are found together as in timothy, which almos always rontalins both hulled and unhullow secols.

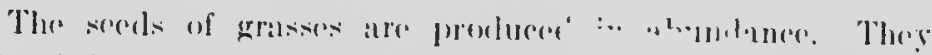
relain their vitalisy for a relativoly short, . The Tarious

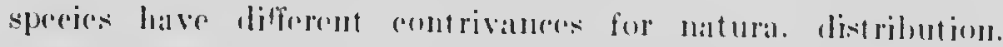
Those which give tromble as nexious wereds atre distributed

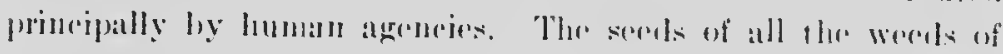

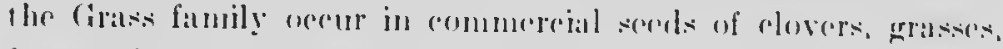
forage plants and eereal grains.

The annual and biemial grations are propagated hy serols

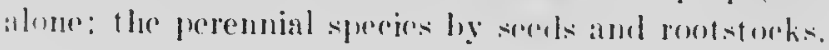

$$
\text { (1) } 1,1: 11
$$

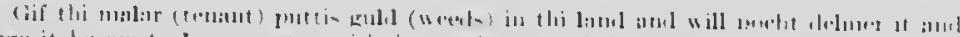

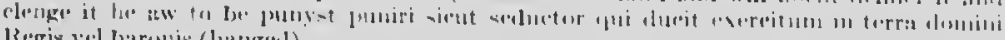
Regis vel baronis (liangral).

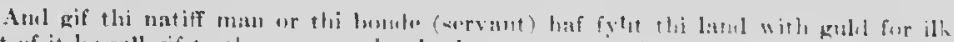

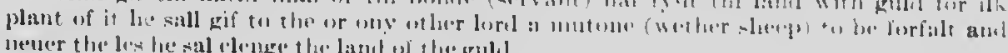

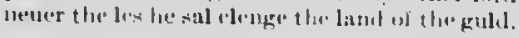




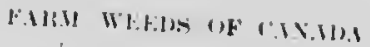

GREEN FOXTAIL (Neturin virili.:

(I.) Beaur.)

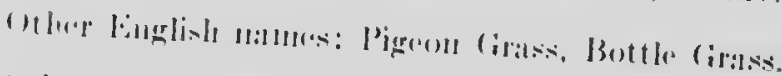

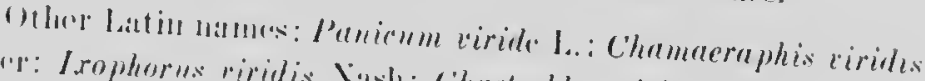

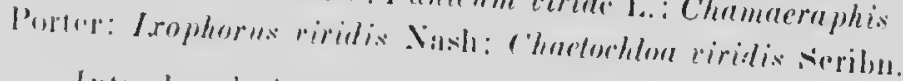

Intruluered from liurspe. Intual, tufted, stroms ereet,

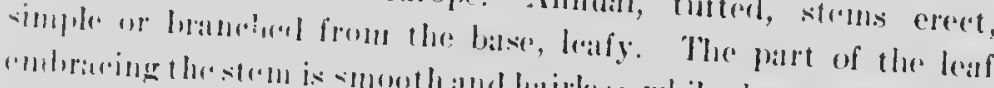

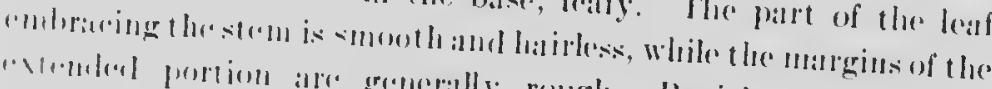

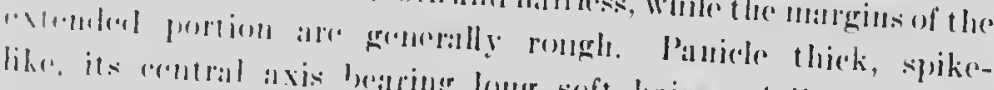

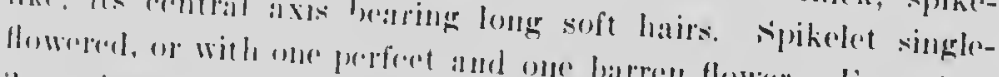

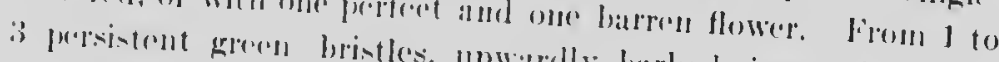
shert fontstilks just betow, upwardly harbed, insertod on the

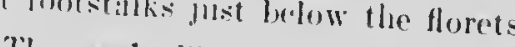

The seed (Platr i2. fig. 2) is gemerally found enclosed in it lough hind husk. 1/12 of an inch long, oval, with the outer thake roumber and folked over the polished rounded edges of the inter soaldr. Which is flattened in the midnlle. Both seales of the husk are moughened erosswise with milrow ridges. The

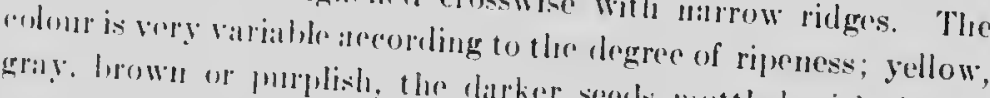

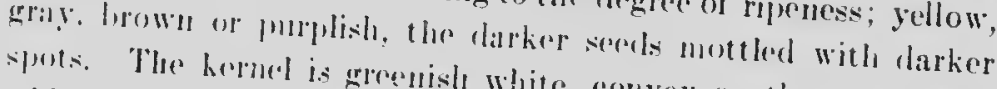

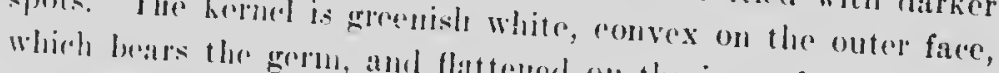

Time of flowering.

Propagation: 13y. Jume to septemlere; secels ripe by July.

Occur

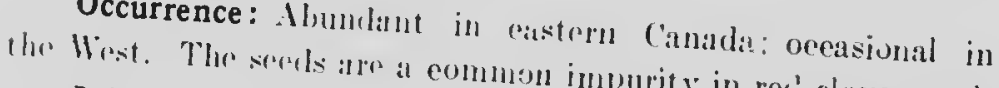

Injury: I tronblesome pervistent werly in rea clover seed. not workel under a short arop motent weed in all erops on land

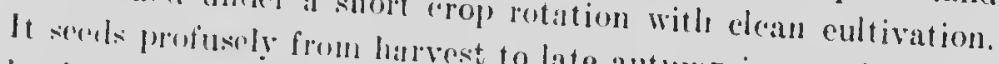

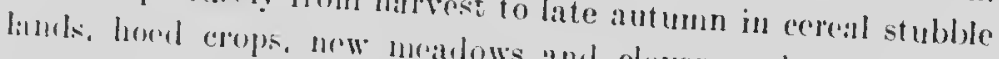
presenere of this serel as an in and elover socel crops. The value of real clover send for conpurity materially reduess the

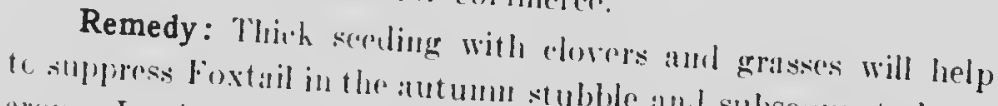
repp. In eforer serel crops, the stubble and subsepment elover killod shouk be mown whilde patches that have been winter- 


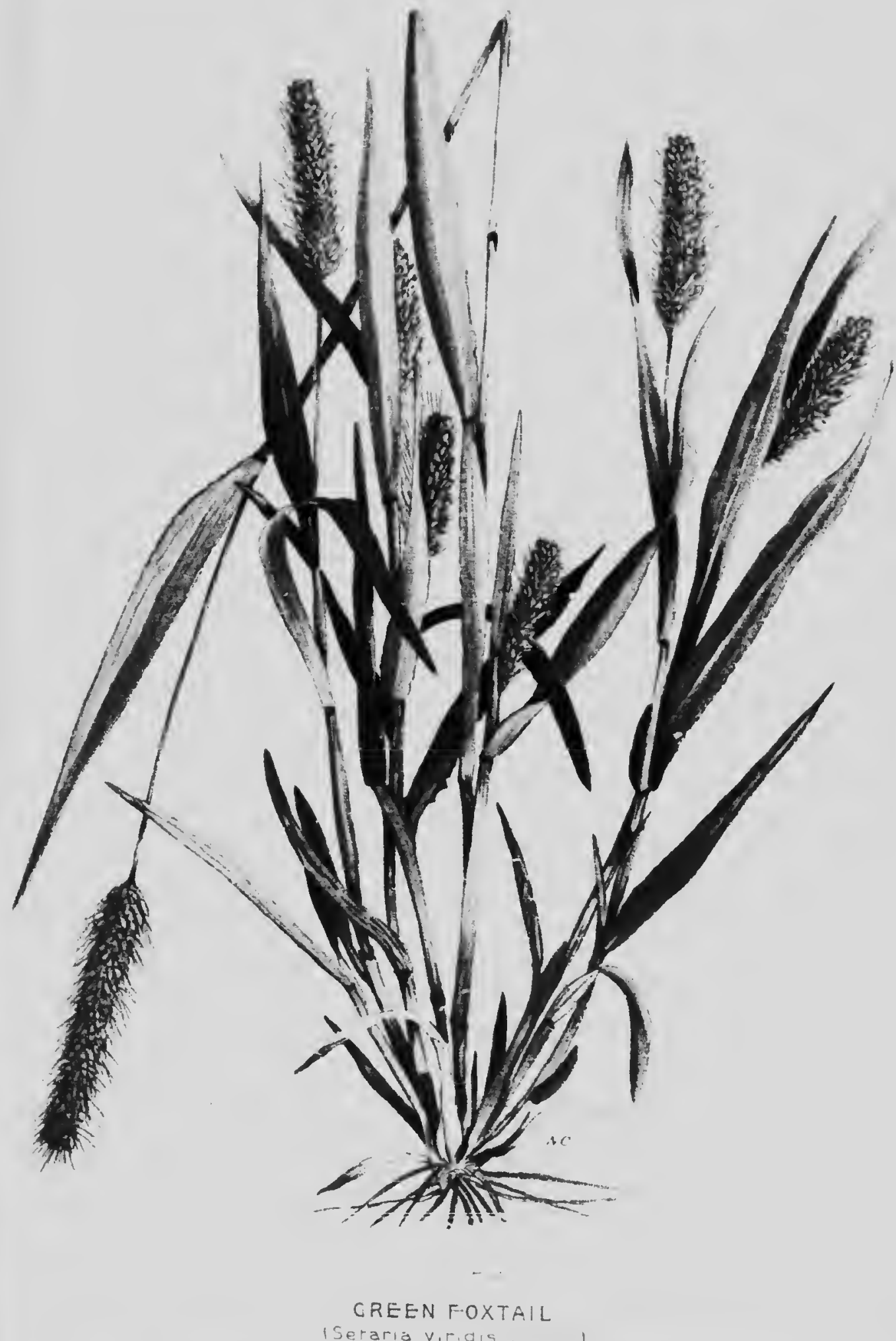




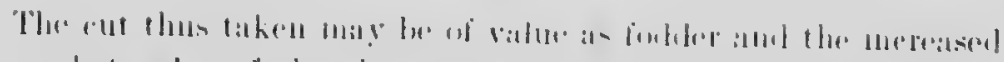

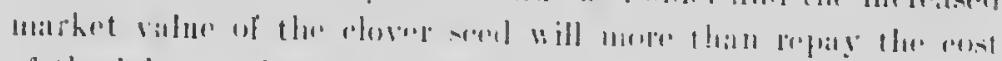

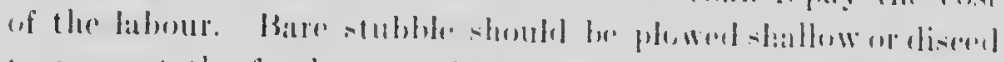

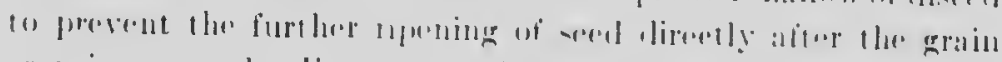

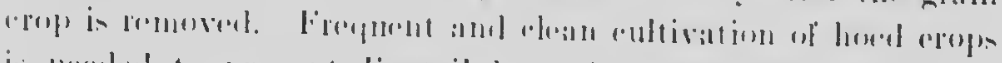

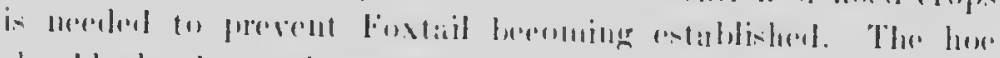

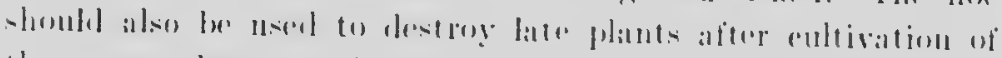

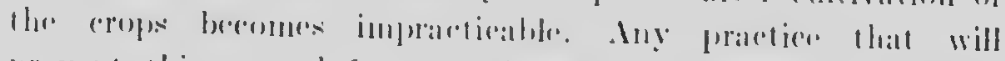

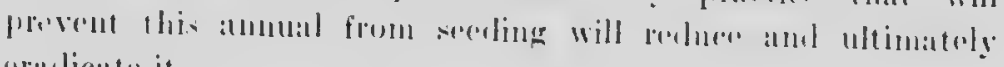
rratlicats it.

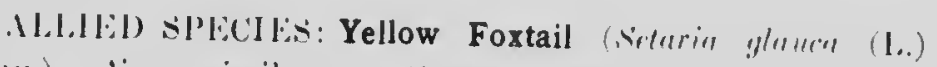

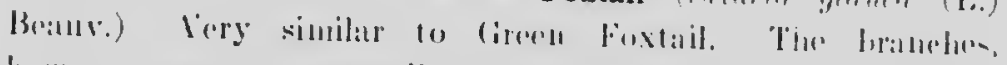

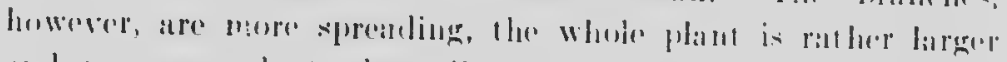

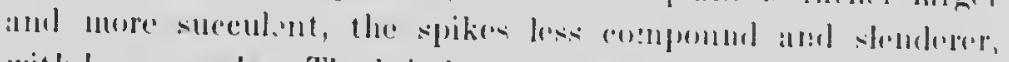
with hatgereseds. The bristles of the -pike alre dhetinetly geflow.

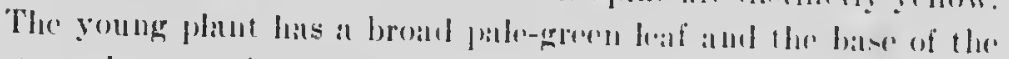
stru shows a chatrateristic grollow colour.

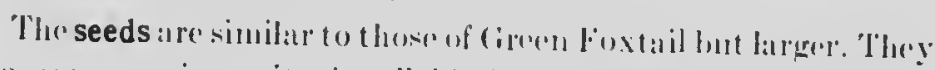

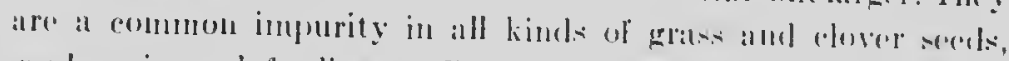
serel gratin and foreding stuff- l.ite mont of the millets, they

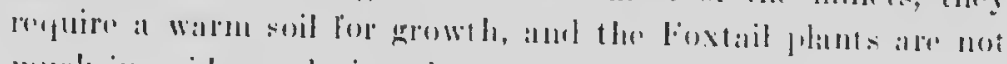

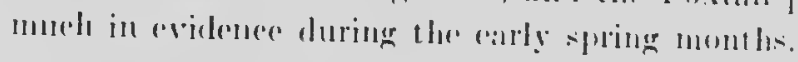

('losely allied to the foxtalis atre the widely distributed Panic grasses (lanicum). While they alre of valums habits of

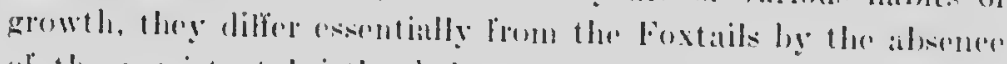
of the persistent bristles holus the Horets.

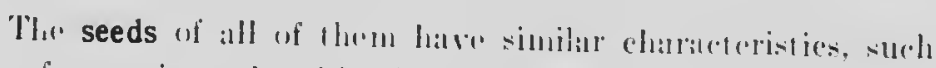

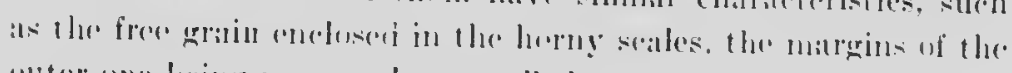

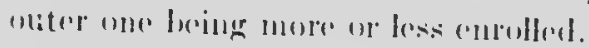

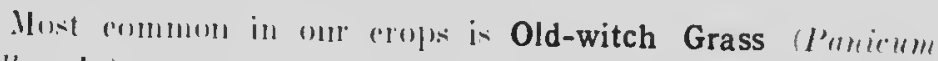

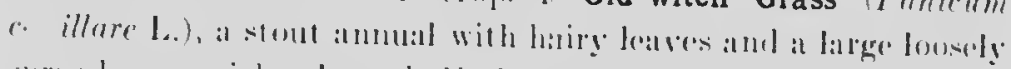

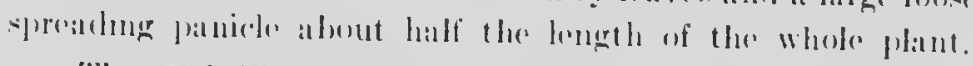

The seed (Ptite i:2, fig. 1) is abont $1 / 16$ of an inch long, spindle-shaped in outher, highly shing, olive grecon, with white

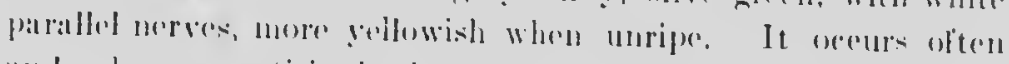

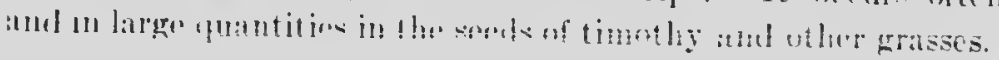


SWEET GRASS (Iticrorhloe mlormen (L.) Wahlonb.)

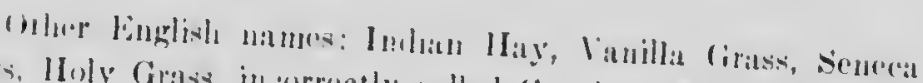

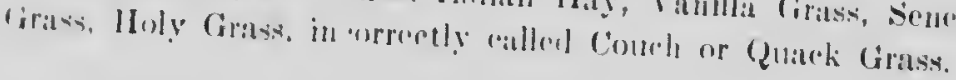

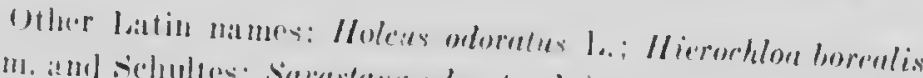

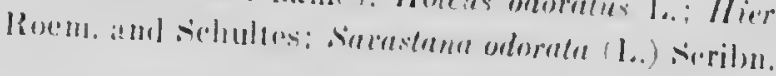

I native grass, sweelly aromatire with llu fragrant prillrephle of the Tonka Brin mel sweret Clever (commarin).

l'eremnial, decep-rosted, with wirle-sprealing white rootstreks, ritich produce in summer many batren sloots with long, flat, shining leatves of a derpgreon, over a foot in lengll. Flowering stens allo florown up early in spring, the first flowers opening when the stems alre only a frw inches out of the groumd. Paniele pyramilal, 1 to 3 inches ligh, lonse during flowering, with spreading branches, contracting and becoming dark golden-brown as the seeds ripen, when the strus are 12 to 18 inehes high. spikeluets drooping, with shining papery outer seales, which are yellowish tinged with purple, l-sociled but 3-flowered, two mald flowers bes weren seales, the margins of whirh aro fringed with hairs, and one frmale flower in the rentre inside two smooth
cailes.

The secd ('late 72 , fig. 3) is anclosed in the imner smooth

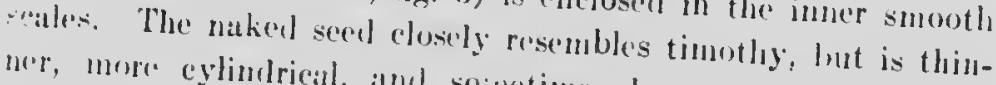
ner, more cylimbrical, and seinetimes bears at its apex tlor remaindere of the dried-off style (the alonguted part of the pistil). The miniature root of the germ is more prominent.

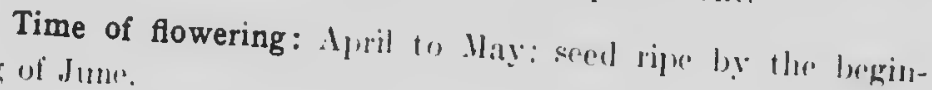
uing of Jinle.

Propagation: By seorls an:l running rontsterels.

Occurrence: Ratre in the atitemn provinees, growing most! in lamp places lig stroms atml rivers. Umler-ripe strms of this grass aro gatherol, curcol and sometimes stained ly Indian women for weaving haskets, mats and other ornaments. In 


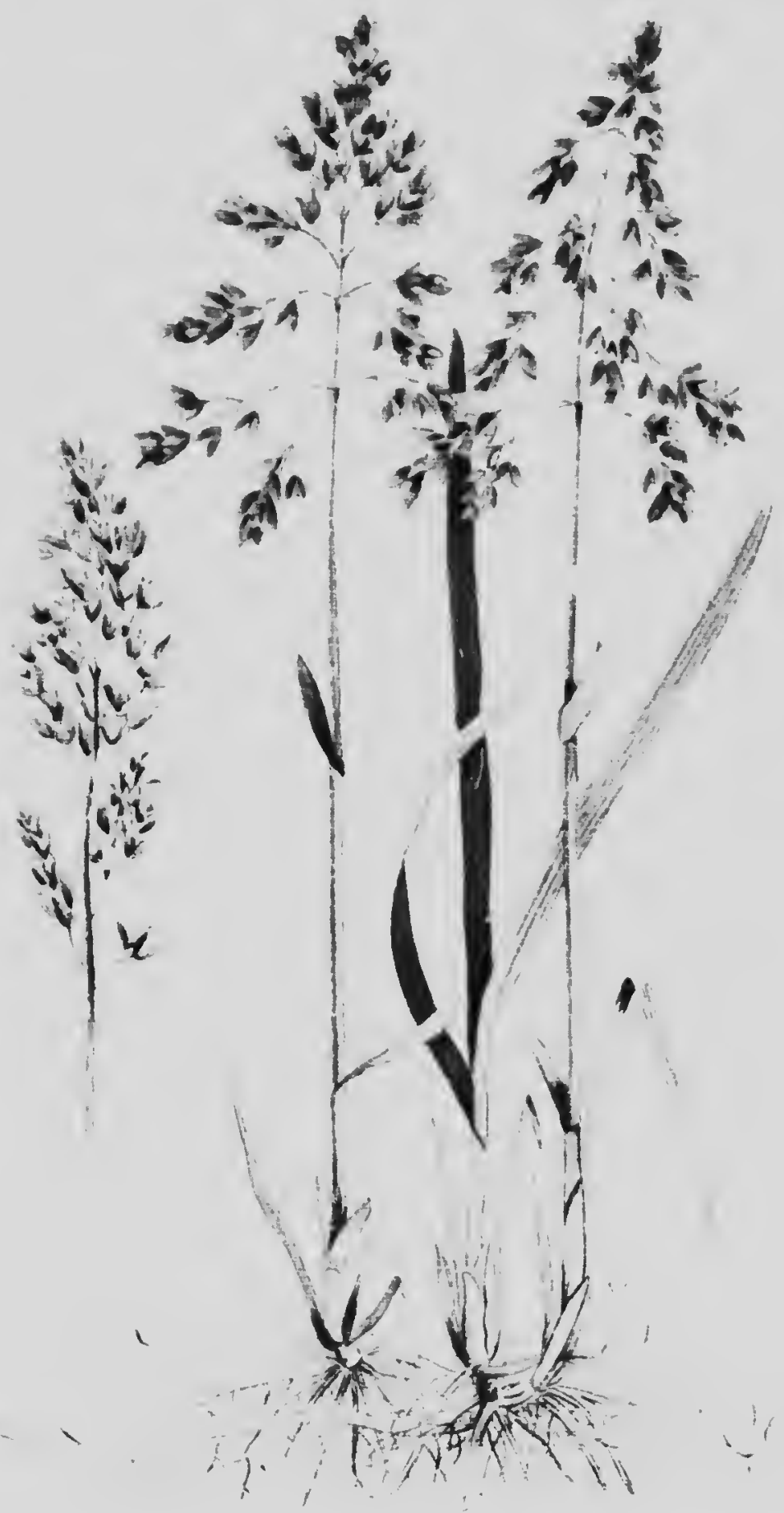




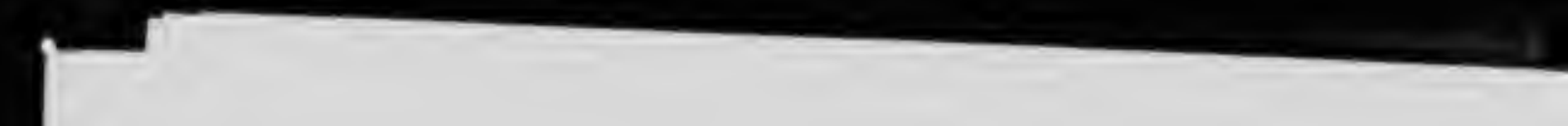

, 


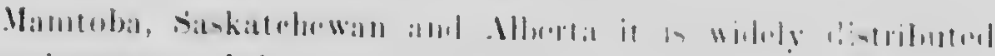
all worms to thrive an all himle of -rill.

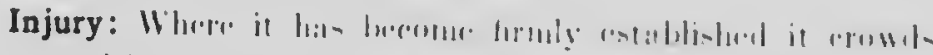

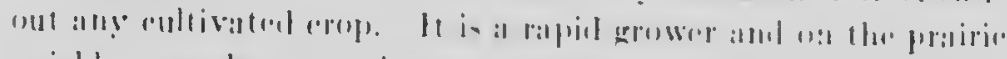

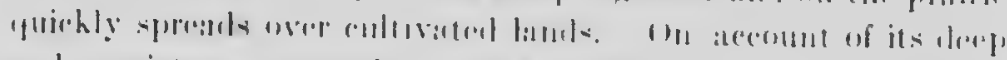

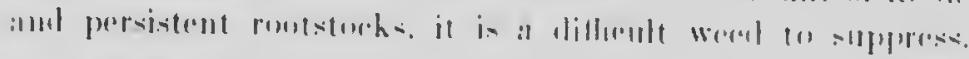

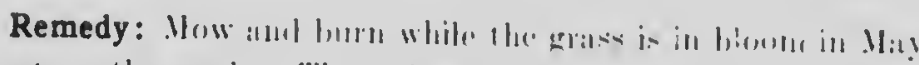

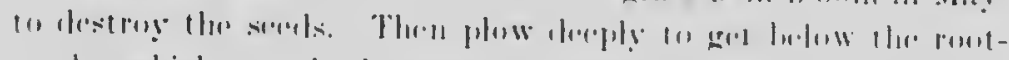

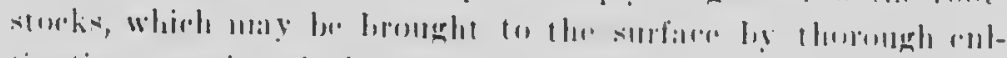

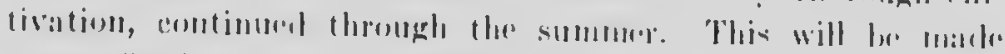

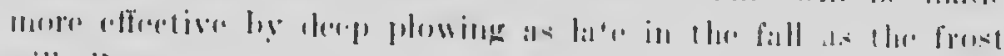
will :illuw.

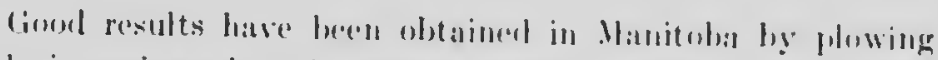
reeply in spring when the sweret (irass is in flower and at unce sereling lown heavily to barle!y.

Fur siskatchewan, Angus . Mackạ recommends as follows: "The first plowing shoukl be lone when the ground is dry andel the weather hot: early in .lugnst gives llue best results. Phow

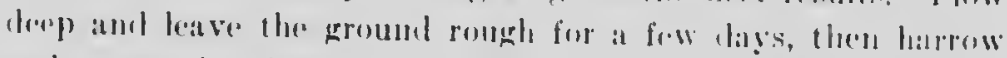
ant repeat the plowing in andher woek if the weather is warm and ily: Plowing when the grouml is wet only spreats the werel."

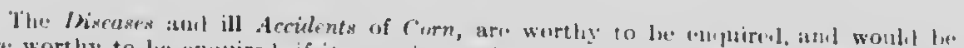

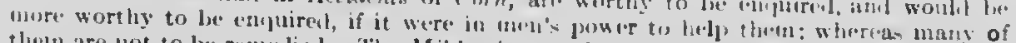

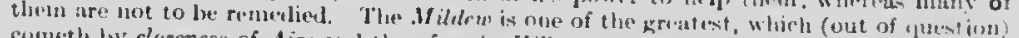

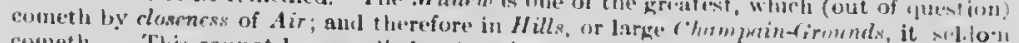

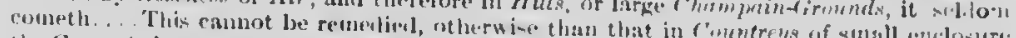

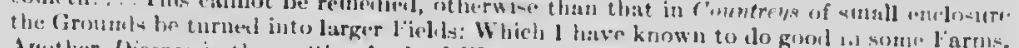

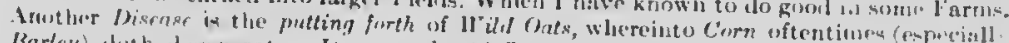

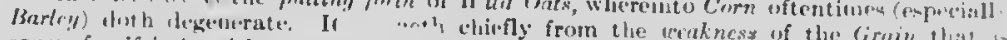
sown: for if it be eifler too.

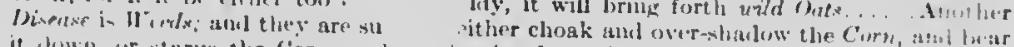

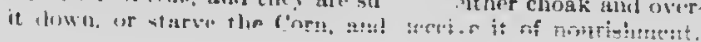


24

FIRU Wrils (JF (IXI).

\section{WILD OATS (.1 men! julu! L.)}

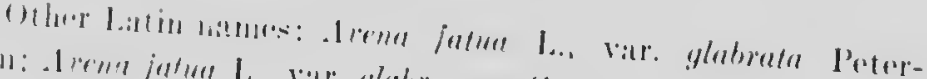

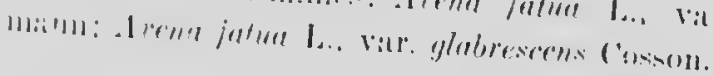

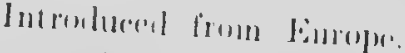

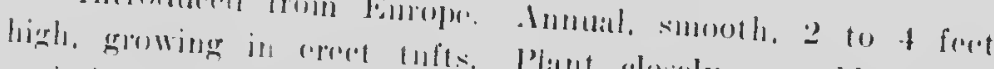

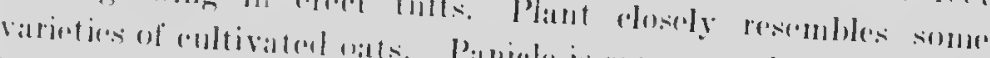

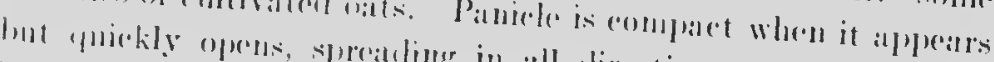
InII)

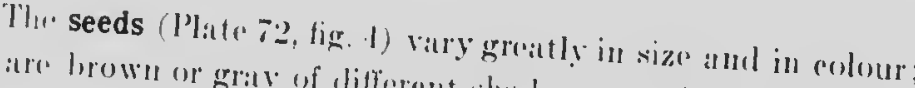

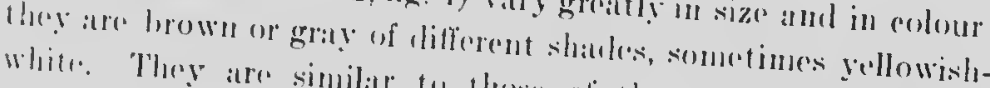
white. Thary are similar to those of the commen cultivatere varietion ef oats, lant grenerally slimmor, hatrder, of a horny

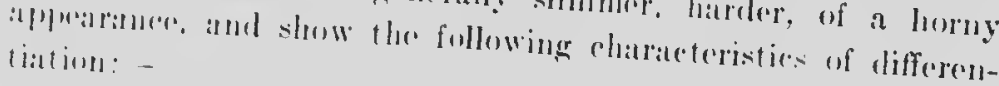

1. The strong. twistod, right-ilnglod ann, fropuently broken wif be throwhing

2. The stiff bristos surromeling the hasal satr, which,

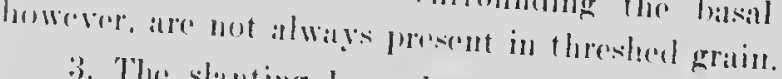

3. The stanting horseshom-shapeed sear at the base of the sered. which is somedimes broken off by the thresher or other
matehine.

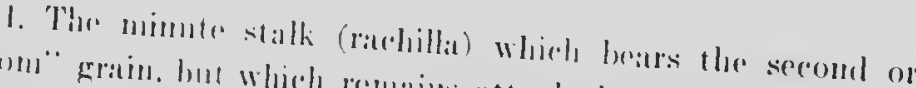

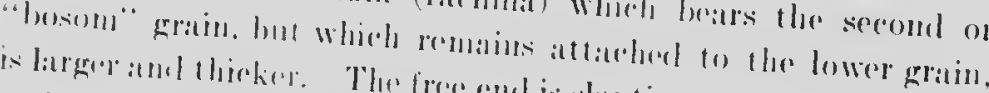

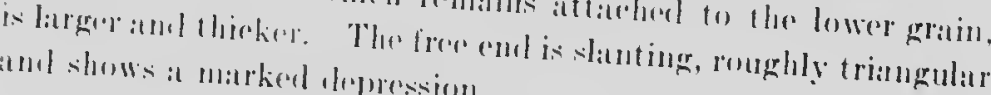
atmil shows a matrked deperesions. kirmel

5. The abumblatere and rougheness of the hatrs eovering the

Time of flowering:

Inur: : sumer sorests ripu

Propagation:

minly. Plants ant off when in flower

a strme very quickly.

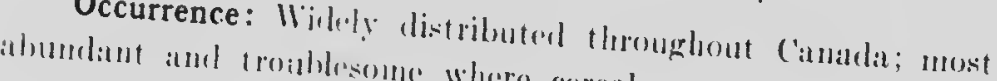

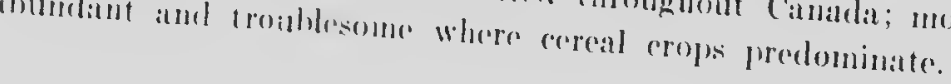




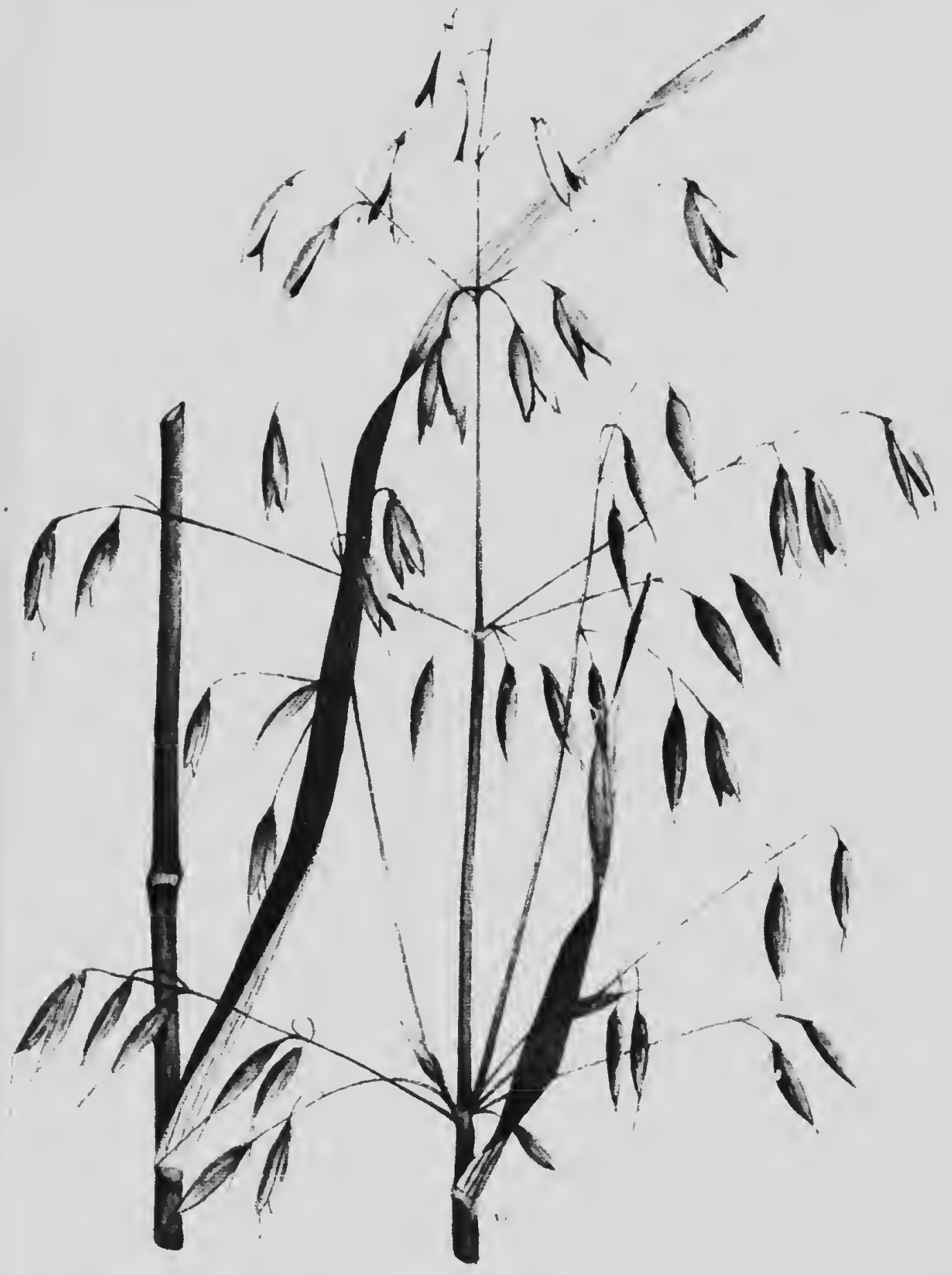




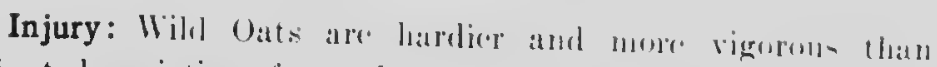

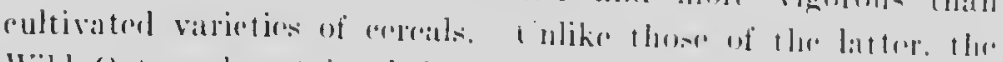

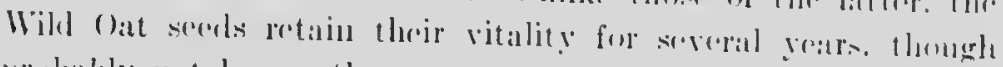

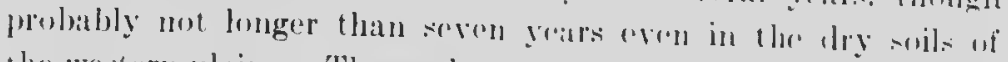

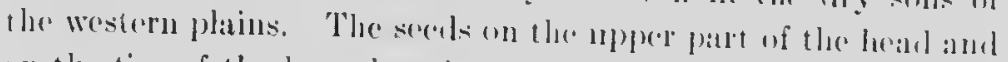

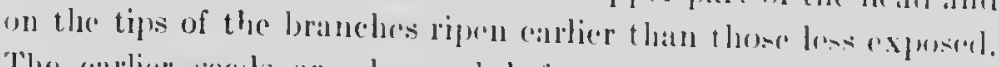

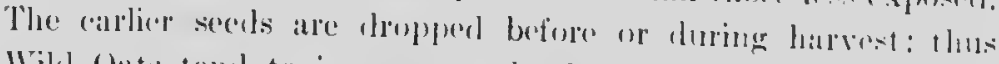
Will Oats tend to incerase on lamels where the proulatetion of careal grains predominates. The later maturing ecels atro latrrested with the rop and remain in commereial whent, calts and barley. They are the most frevelent impurity in wostorngrown gratin and the anmual loss antailed thorrhy is anommomi.

Remedy: Sow elean seod gratin. In the castern provinues

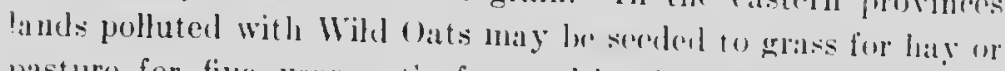
pasture for five years. Surface cultivation after harrest will start germination of the seeds seattered during hatrost. In! method of cultivation or arrangenent of (mols- that will indure the seeds in the soil to geminate and fremit the destruction

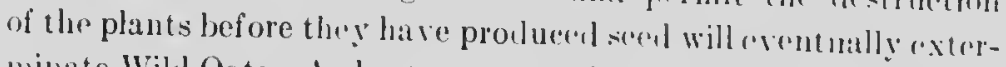
minate Wild Oats. A short crop rotation, with "lan cultivation of the beel crop and sereling to clover or gratseses. with at soriling or other crop in which Wild Oats ran not 1uature and lrop their seerls, will do mueh to chean the land of this pest.

To eralieate Wikl ()ats in the Pranie J'revinees, the lan:l should be plowed shallow or disered inmordiately atfor an infestrod crop is harvested; the best methorl is to batre the dise follow behind the binder. The purpose of this is to mored the soreds of Wikd Oats. Some of them will greminate in the atutumn: the reminder will start in the spring. As som as they appear in the spring, the ground should be plowed shallow te dretroy. them and to start as:other growth. This shomlel be followed in about two weeks by deep plowing, to bring up the sefols lying at at groater depth. Harrow after cach plowing, fo start growth. During the remainder of the smmmel Wiht liats should be licpet down by the use of the dise or broad-sharesl entivitur Tlan 
iif

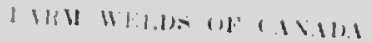

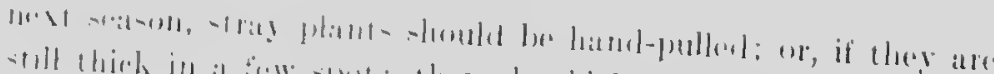

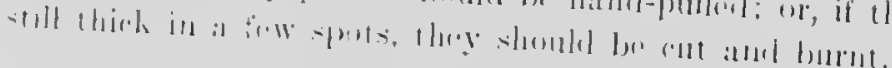

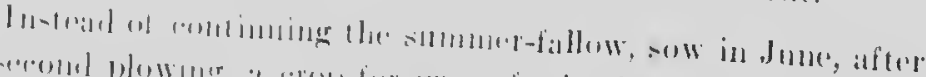

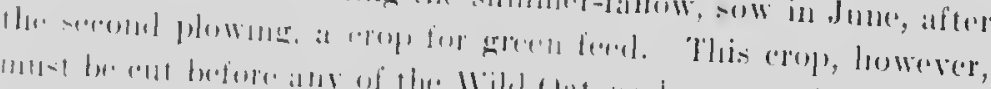
mats lwe

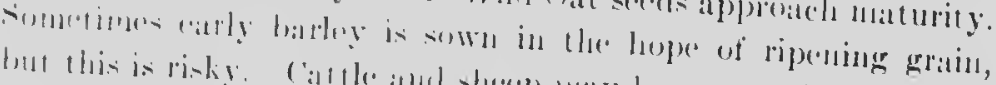

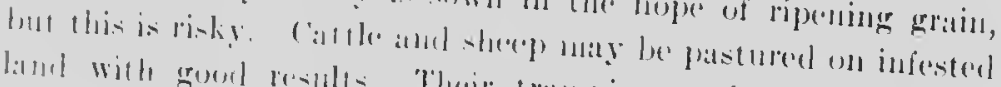

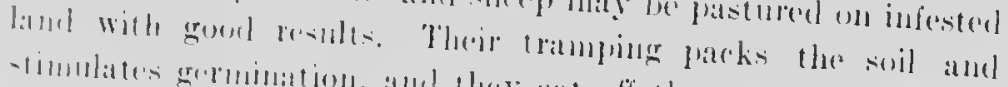
-limmlater eremimation, almel they rat off the young plants.

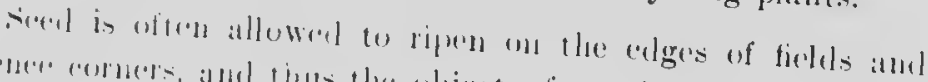

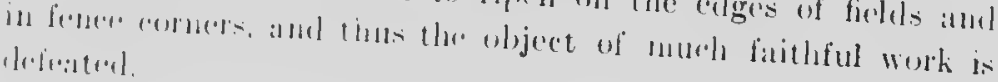

CHESS (Brumus veculinus I..)

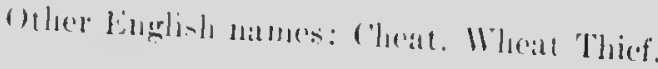

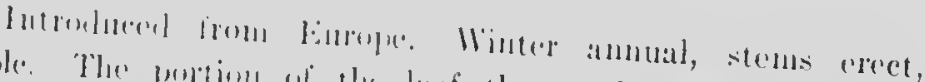

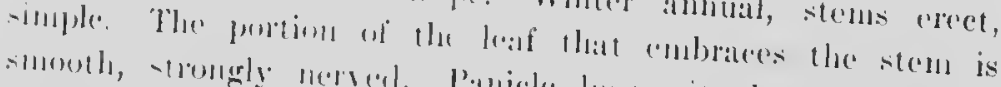

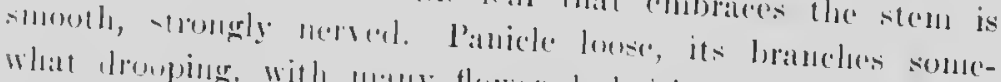

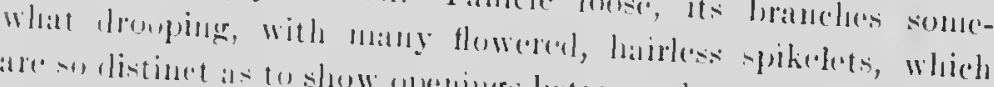

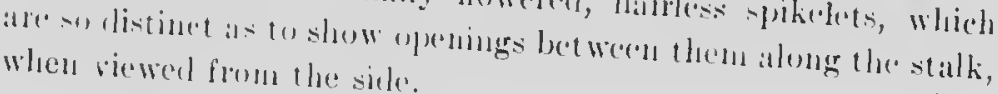

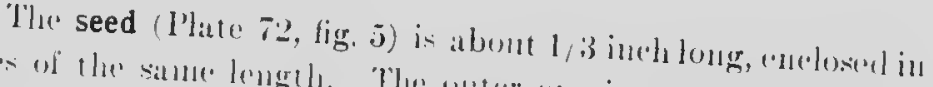

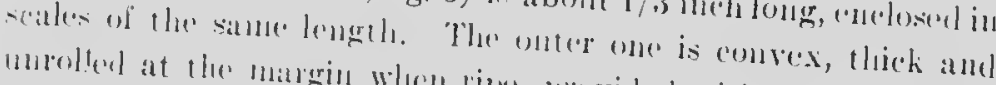

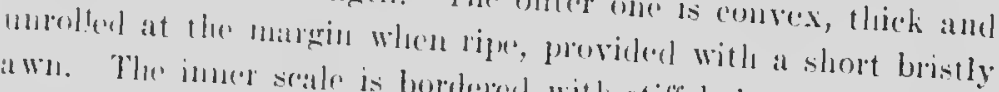

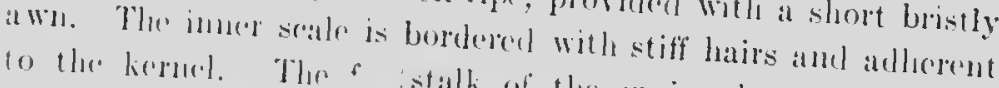

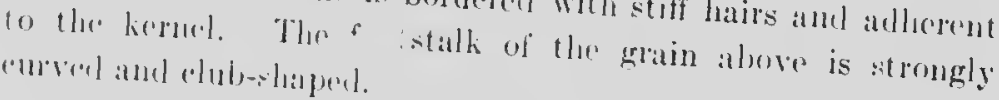

Time of flowering: hum, surls ripull in July.

Propagation: By stris.

Occurrence: 11 idlely di-tributed wherewer winter wheat or wher fill or winter crops an grown. 


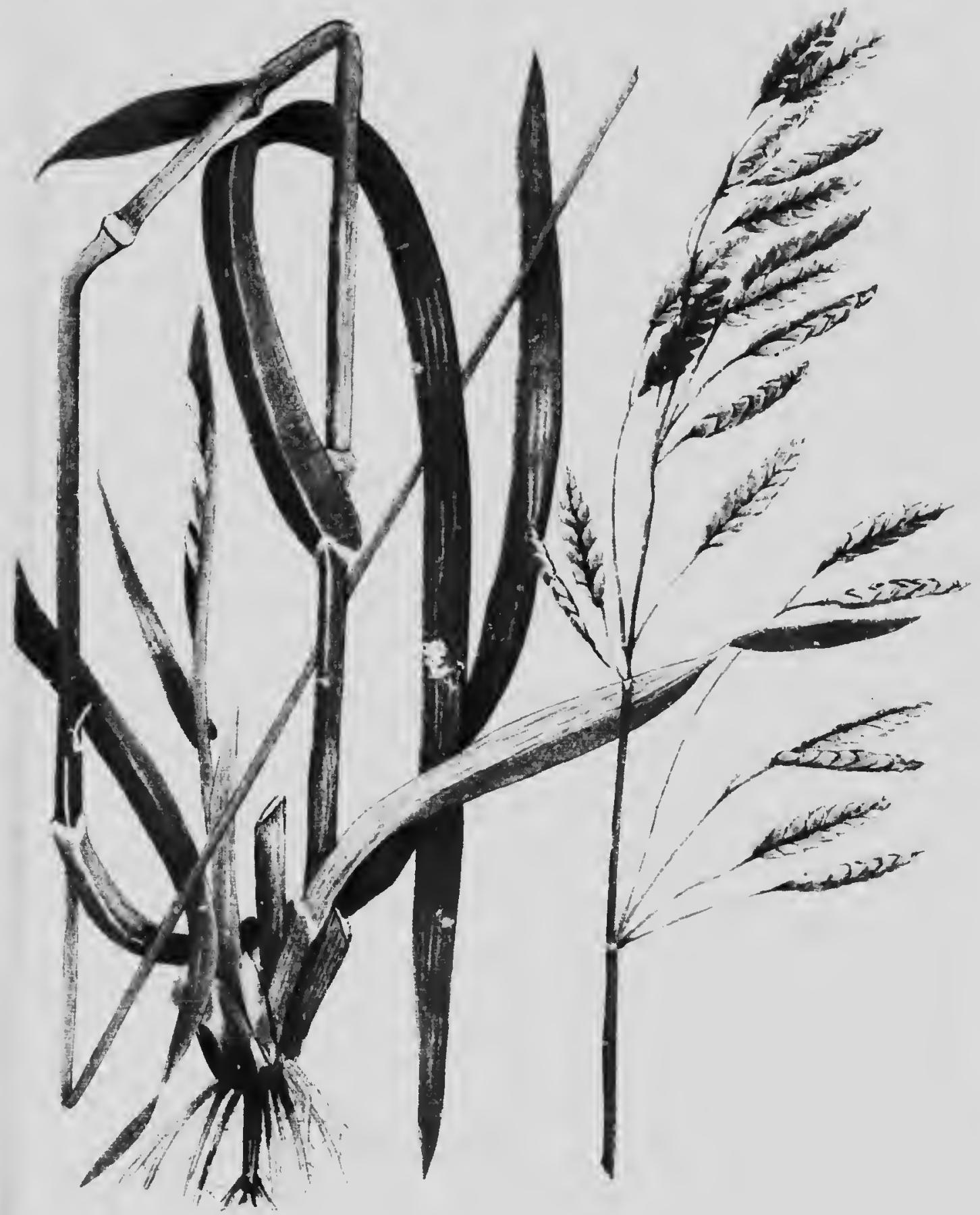


Injury: chess is harelior than wheat, and where the young,

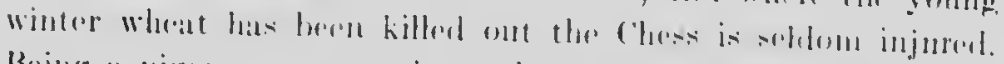

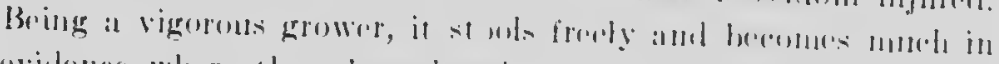

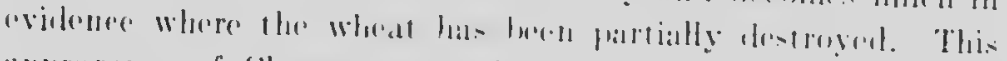

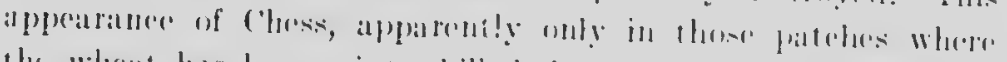

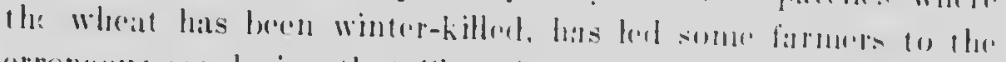

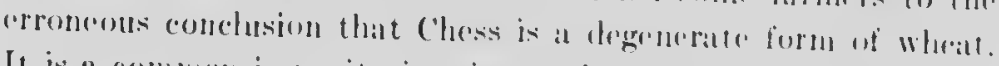
It is a comben impraty in winter wheat, aml, to a less extemt,

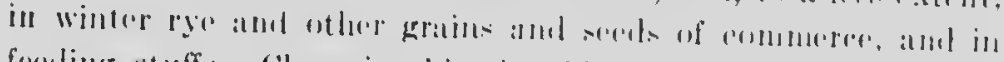

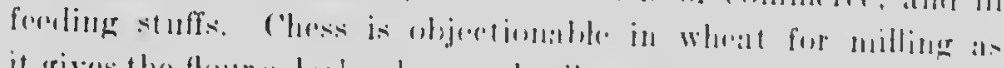

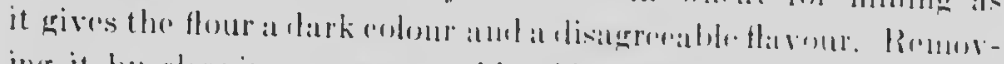

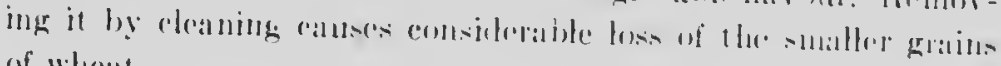
of wheist.

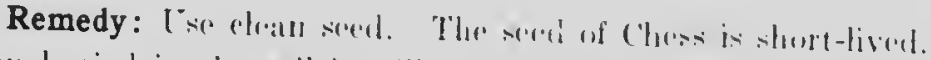
When burien in the soil it will not motan its vititity for nowe

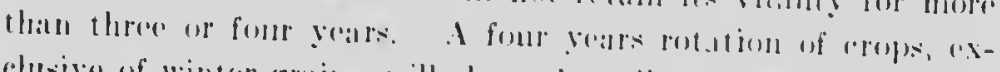

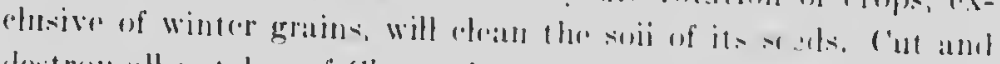

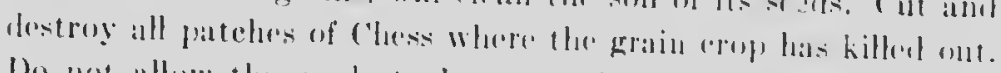

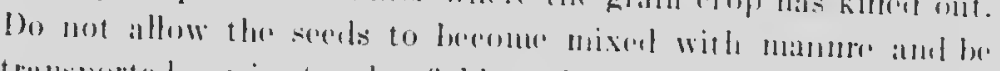
tramsported agrain to the firlids. Farme stock or birets, when

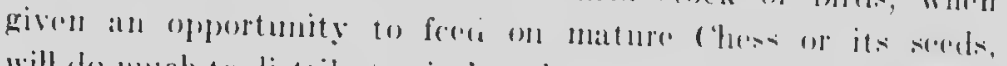
will do much to distribute vital soreds. fror a firld bidly inforted,

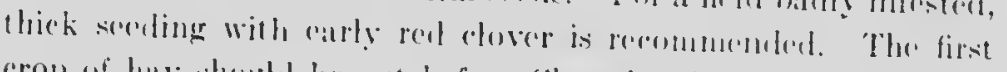

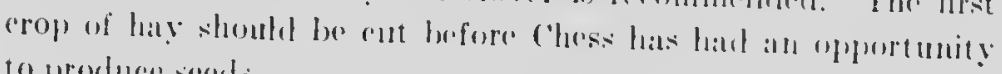
to prosherer serolis.

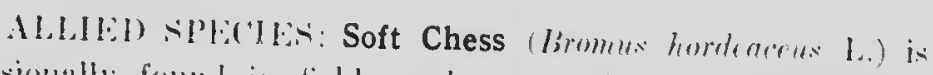

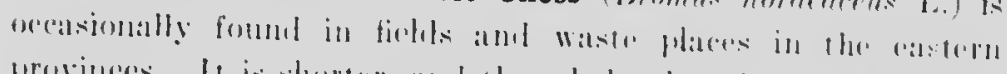
provineses. It is shorter, and the whole plant is of al soft harig chatracter. It seldom grives trouble als a morol.

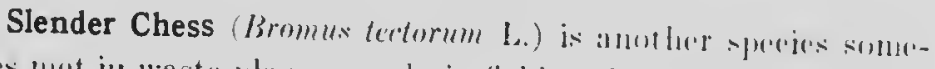

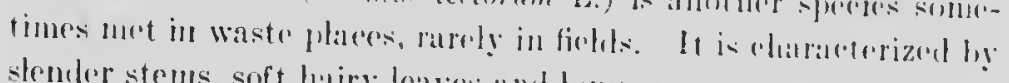
stendor stems, soft hairy leaves and long awns.

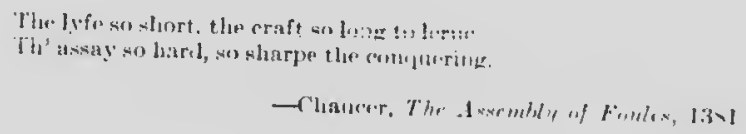




\section{COMMON DARNEL (Lolium lemulerilum L..)}

(Hhrer Finglish natmes: Poison Da m, White Darnel Irray, Peoison Rge (irass, Bearrfel batrudel.

Other Latin name: Lolium areense With.

Introlnced from Europer. Annual, sumoth, stomis $210+$ feet himh, simple. Leares suooth heneath, rough abuve, the portion embracing the stem is purple when the plant is young. spike 6 to 10 inches long; sonewhint resembling tlat of couch Grass, hut having the efleres of the sprikelets resting against the stalk insteal of the broalsides, ats in Couch Grass. spikelets 3 to F-flowerel, solitary, stalhless and altermate, with theje eclges fitting tightly inte greores on rithere silde of the stalk; "ach spikelet in $1 / 10$ axil of a long, rigid, strongly-nerved, per-

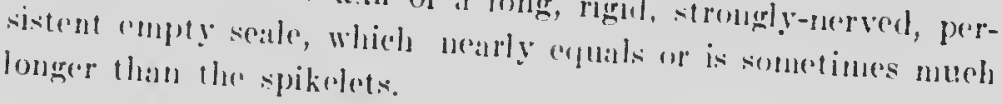

The seed, somewhat swollen, resembles small barley, with bunt rmb and a stallow wile groove on the inner surface. The inner seale is minutely bristly on the edges but not coarsely bristly along the margins, as in Chess: the outer soale is hurd and flinty, as in the elaff of wheat, and cither with or without is loug awn. The footstalk of the grain abore on the spiketer is long, Hat, smooth, stritigit-cut on the top. The kerned, after whe husks hal we bern removed, is greenish-brown, often tinged with deep muphe. Harmel seerls arr found in vestern wheat.

Time of flowering: July: sereds ripe in August.

Propagation: By. sirels.

Occurrence: Mlumelant in parts of the Red River Valley,

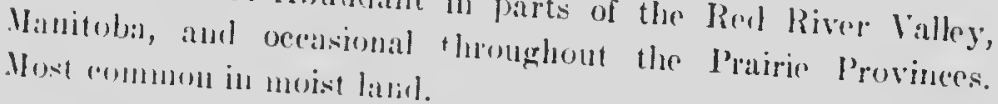

Injury: The secales eover the sees! very tightly. the inner one being atherent trit: in that condition it is nearly the same diflieult to separate by machinery. Darmel has bereonce at 


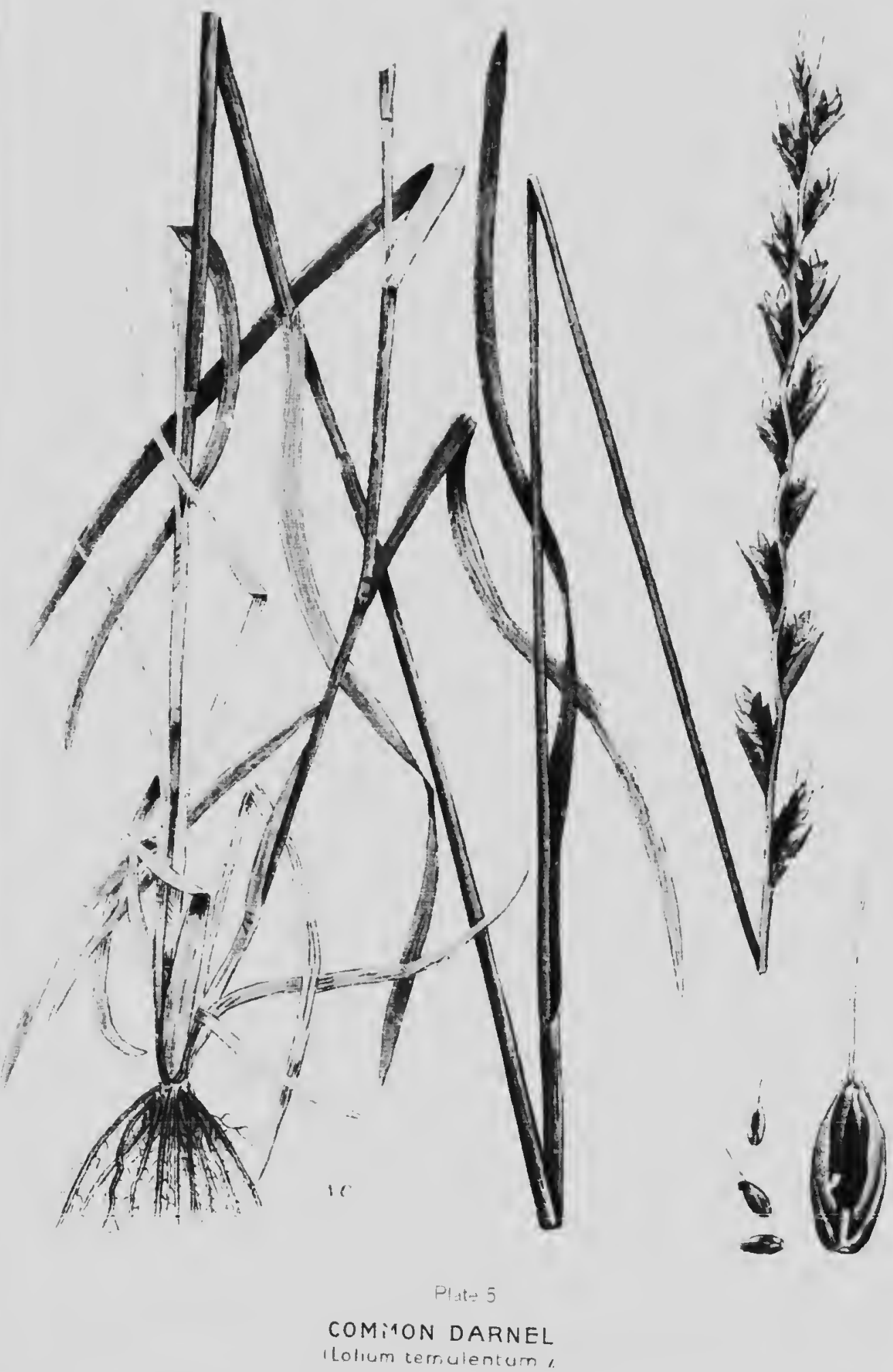




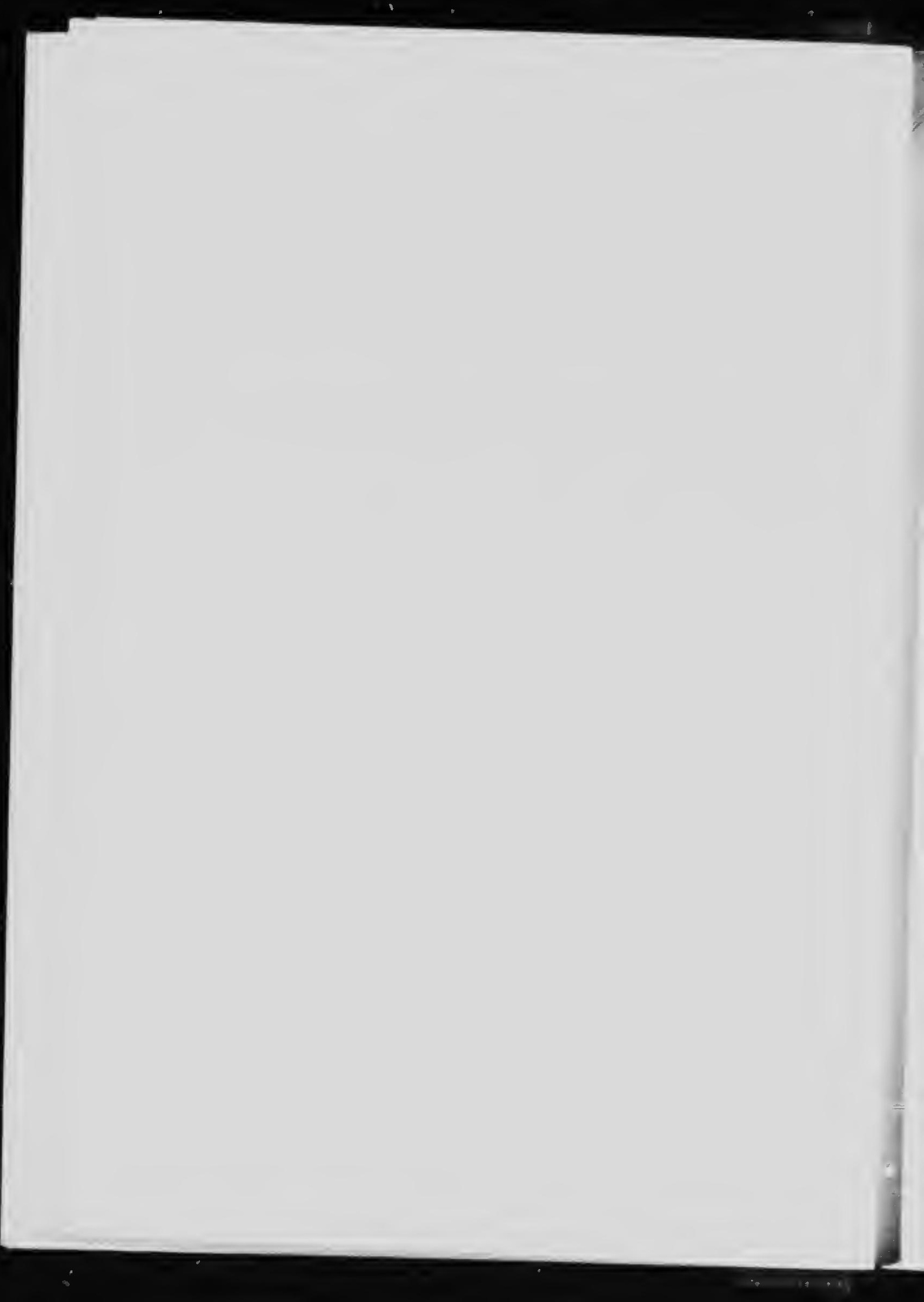




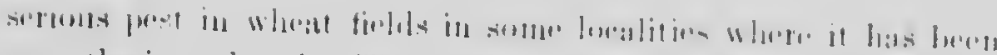

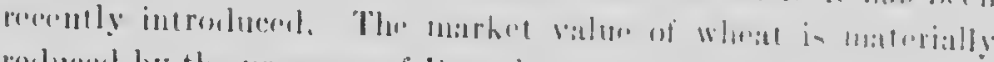

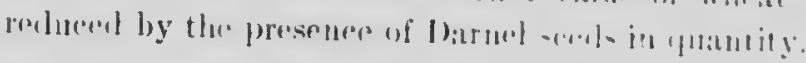

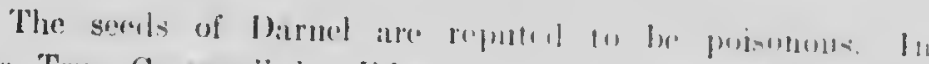

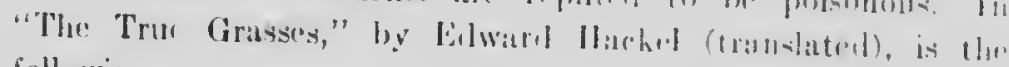
folluwing:-

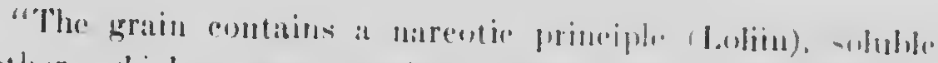
in ether, which eauses cruptions, tronshling and confusion of sighte in man and llesh-eating animals, antel rerge strongly in rabbits; but it loes not atfect swinc, hermed catthe or lueks."

Dr. Li. I. Freeman, of the liniversty of .linnestla, has shown, however, that there are two racese of the plant. one with

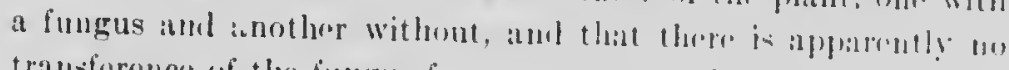
transforence of the fimgus from one race to the othere In refierring to the results of his investigntions, he silgs: "If the serels are really poisonons, it may be that these with the fumerus ane poisonous, while tlose without fungus atro mol. I halle attomptrel recentiy to determine this, hut have faildel to gro any andelusive
results."

Remedy: Sow clean seed. It i .ut drefinitoly hmown how long the seeds will retain their vitulity. Latmls bindly infested witl Darnel may be seeded to grass to advatutage. That will prevent it from sprealing in serel grain amel will ultimituly destroy the vitality of the seeds in the snil. Ferol gran enutaining Darmel should be finely ground. It is distributer! principill!? in serel grain, teeding stuffs ant hy othel human ingencios. The met! od of eradication outlined for Wild ()at - will bereffective for Darnel. 


\section{COUCH or QUACK GRASS}

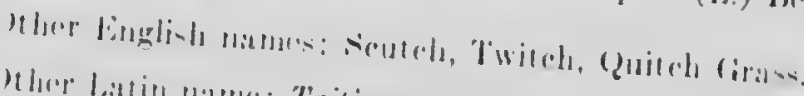

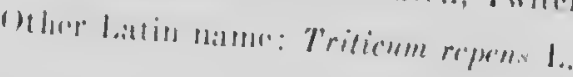

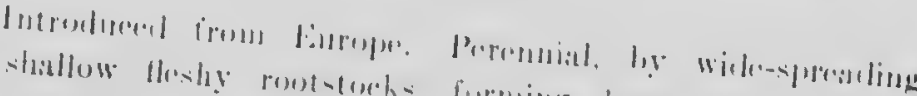

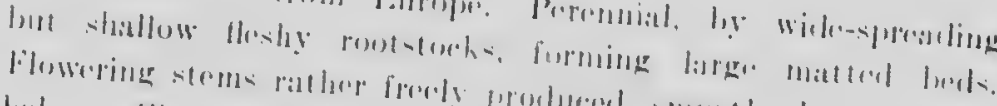

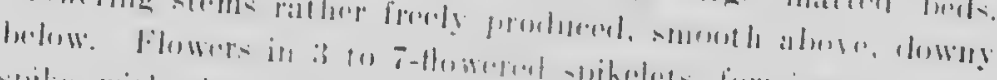

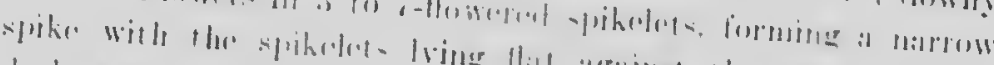

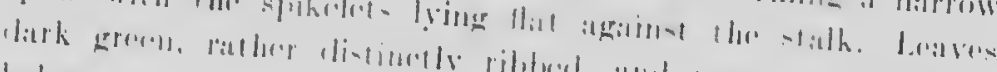
linlin.

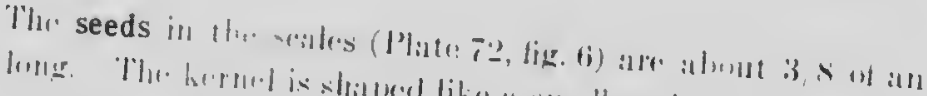

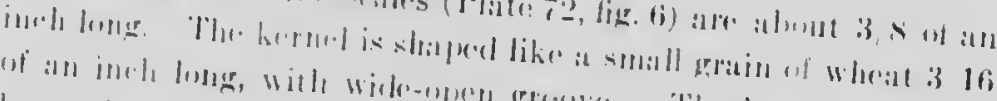

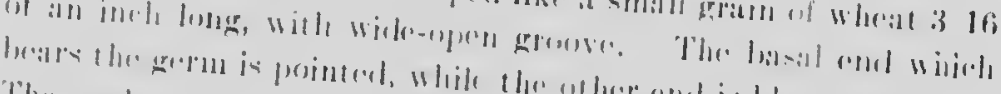

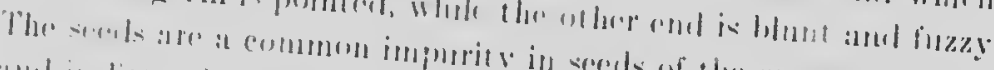

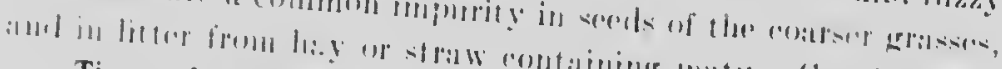
InI

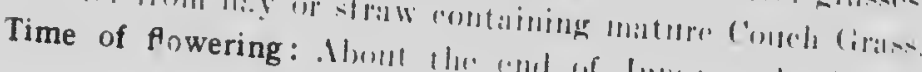

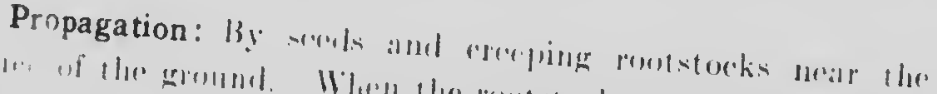

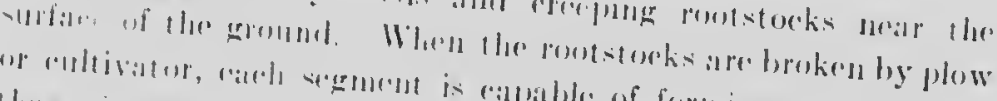

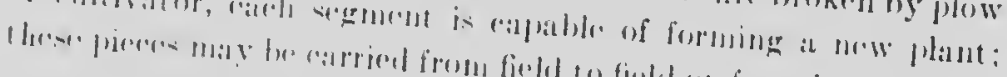

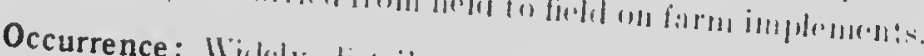

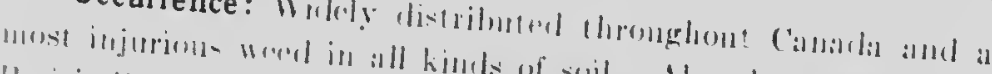

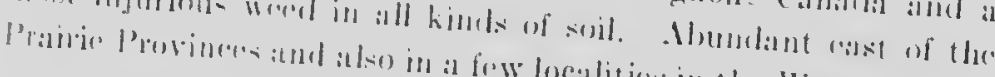

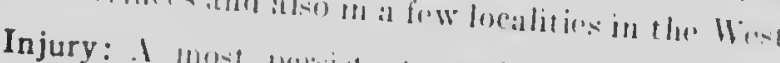

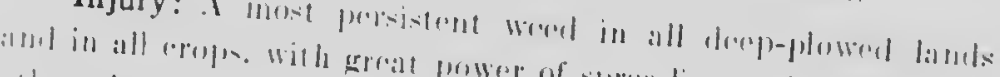
11) here plants.

Remedy: lon the plint "xhatest its substance ist the prom

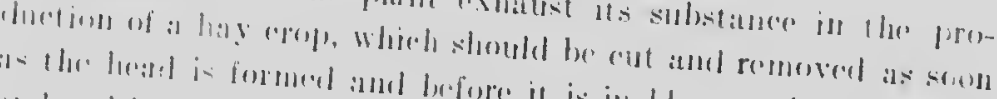

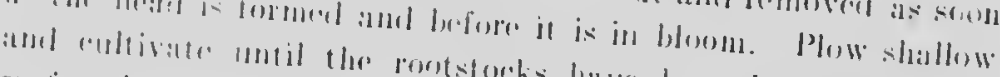

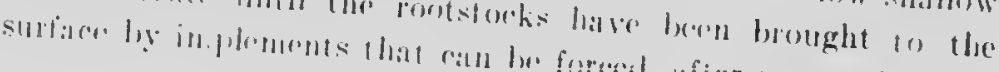

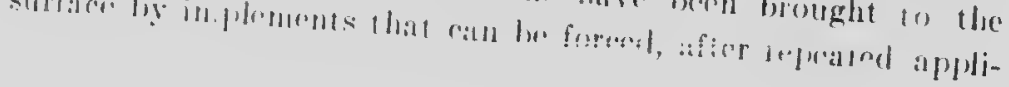




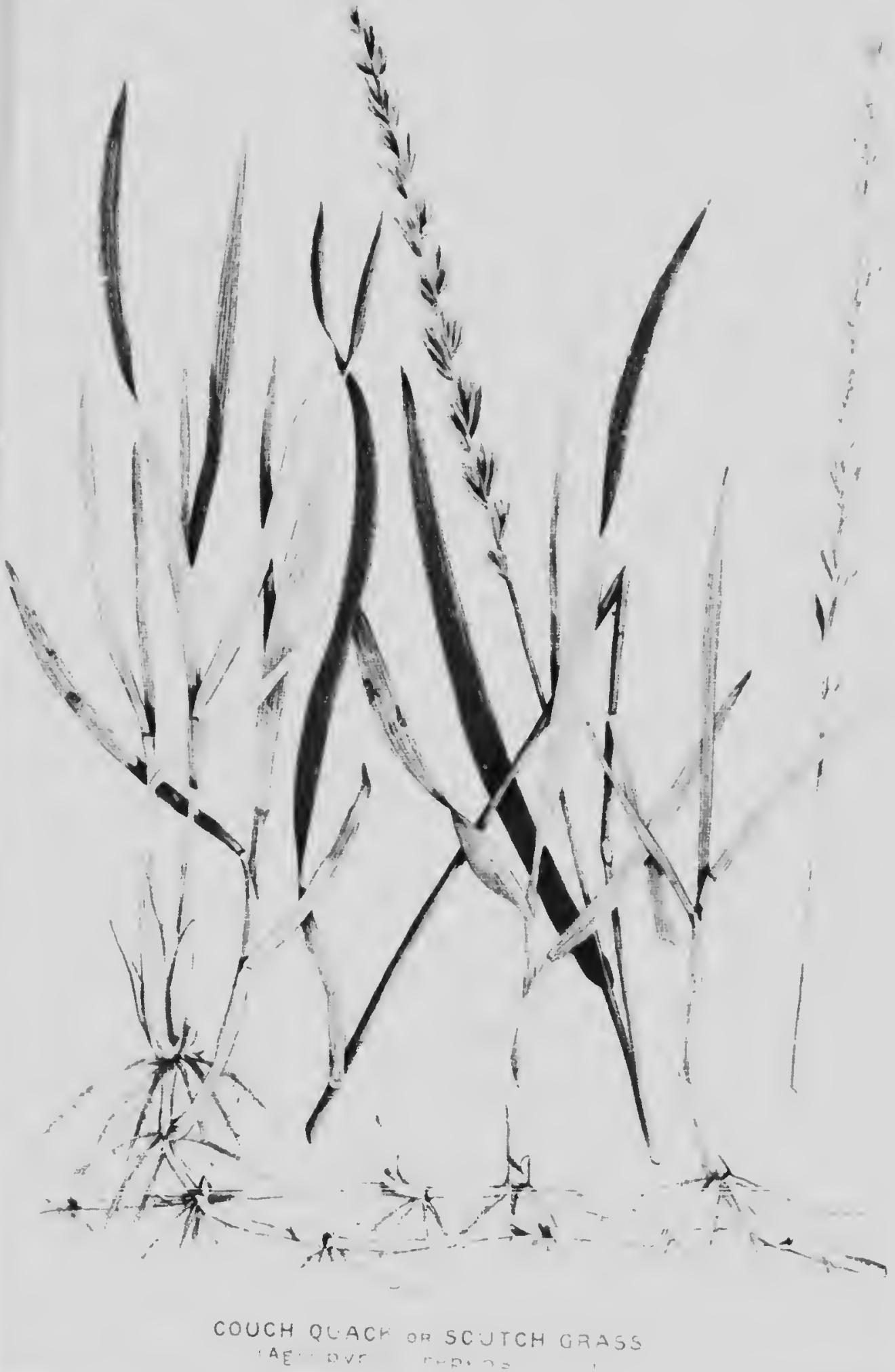


$\checkmark$ 
cations, to the full depth of the furrow. A dise is not satisfactory beeause the euttings from the rootstocks are diflinle to gather and they perpetuate the growth, wherever transplantert. II:ari: brought to the surface the rootstocks shouhl lo gathered and burnt or removed. This should be done at unee before the plant has had an opportunity to renew its growth. For Nanitoba, s. A. Bedford recommenels plowing up the Conch firass late in the spring and seceling at once to barley, three buhnls to the arere.

Rape, buekwheat or nillet, sown aftor the lant hax buen well cultivated and the rootstocks removed, is a goond cleaning crop for late sowing. The land may be pul muler homb rerop. eorn, potatoes or roots the following year.

\section{ALIIED SPECIES: Blue Joint or Western Couch Grass

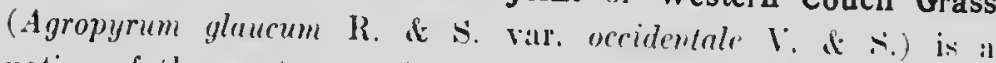
native of the western prairies, where it is harly and persistent and prevalent everywhere. It is differentiated firom the common Couch Grass by the decided grayish-green eolour of its foliage. It is often troublesome when breaking is done carcessly, but eontinued thornugh eultivation of the land with fexterminate it in a few years. It gives trouble on the prairics among trems and shrubbery and should be thormenty subduert before such plantations are laid out.

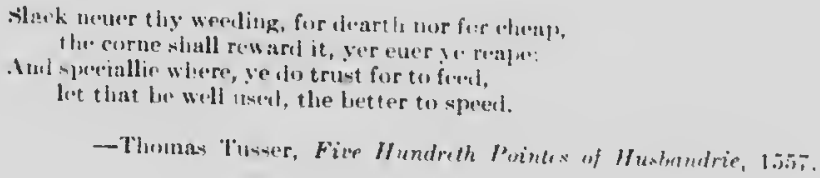

There is an opinion in the Coumey, That if the same Ground be oft somen with the firmi. that grew upon it, it will, in the end, grow to be of a barme hind. It is cert ain, fliat it very Sterile Years, Corn smun will grow to an other kind. Anil generally it is a Rul. that Plants that are brought forth by rulture, as Corn, will wouner chatigr into ather speeies, than those that come of thenselves: For that Culure giveth bint ant ailventitious. Nature, which is more easily put off. 
330

FARM WRYUS OF CANADA

\section{SKUNK-TAIL GRASS (IIordeum jubatum L.)}

(Wher Finglish manes: skunk Grass, squuirrel-tail Grass, llild Batrley, Tickle Girass, and, inacementely called lioxtail.

Sative, Poremial, nut flowering the first year, forming tufts \& to 12 inches high. I.'ares grayish-green. Flowers in hoiltiful, silky, hristly luatuls, 3 to 4 inches long, pale yellowishgreen often tinged with red. Whon ripe, the spikes break up into F-awned clusters of three flowers. The entral long-awned tlower is the fertile formale one: on wach side of it and attached to its hase are two barren flowers, anch with three shorter awns.

'The seed probluced by the female flower is slonder, sharp)

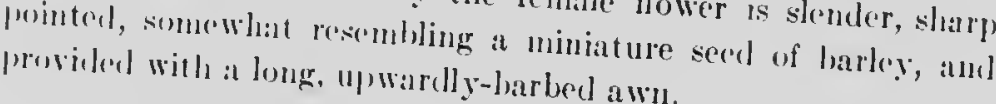

Time of flowering: July: secels ripe July to August.

Propagation: By secels. This gratss is frequently silid to be an anmual or bicnnial: but all the plants grown in Ottawa front western soesl during the past twenty years are eertainly premial, forming large tufts but sending out no ruming root-

Occurrence: From lake Supwrior westward. partieularly in alkalime suil where lotter grasses can not thrive. Occasional
in rastern (anallat.

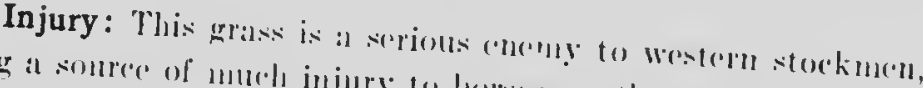

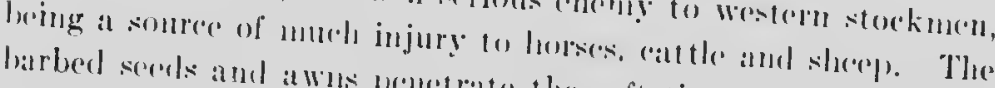
barbed sorels and atwis penetrate the soft tissues of the mouth, rallsing irritation amel inflinterl ulders: they work down heside

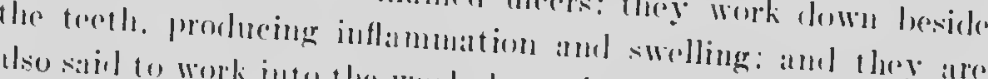

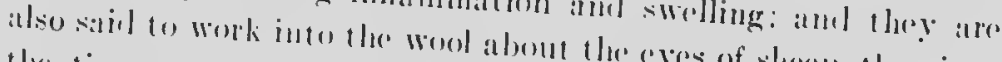

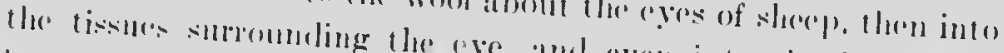

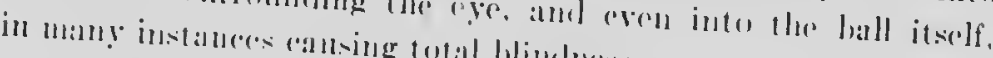

Remedy: T. ․ Ililling. of Rogin:1, sisk. smms up the

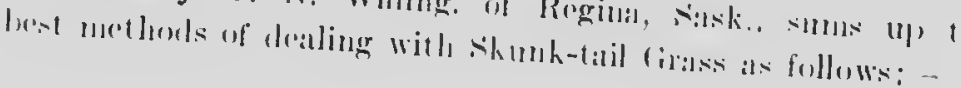



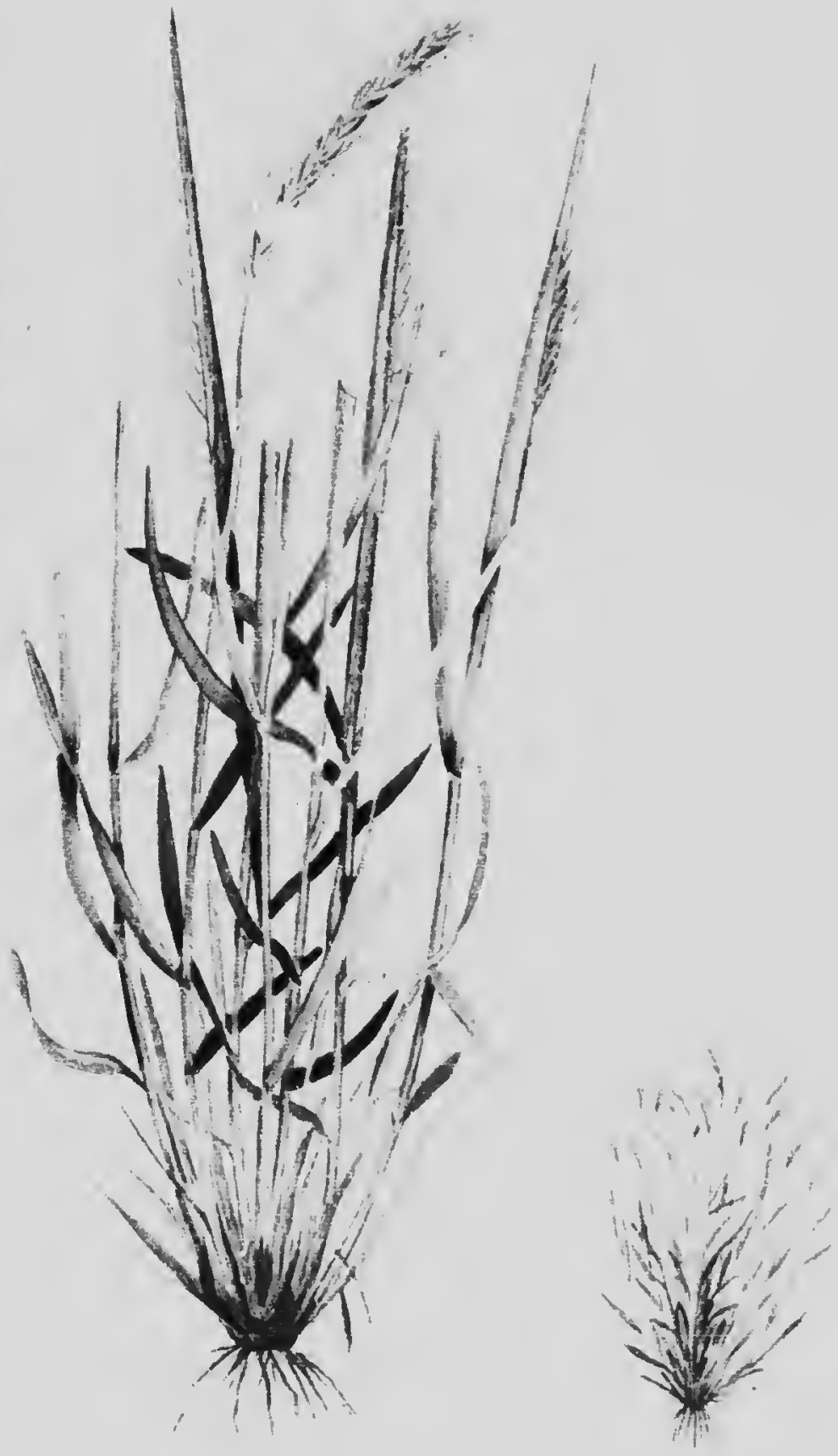

SRUNK GRASS AID BARLEY OR SOURRE TA LGRASS 

"There is no diflienlty in oruldeating this grass from any land which can be plowerl, as the testal methot of hreaking in

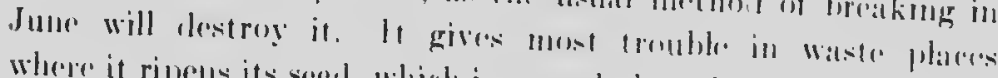

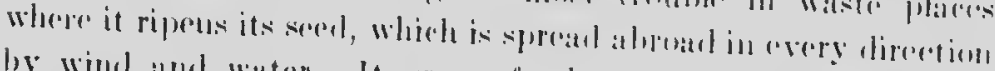

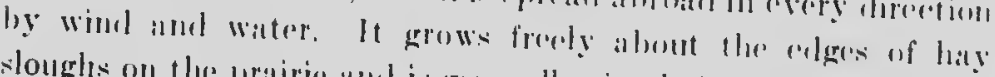

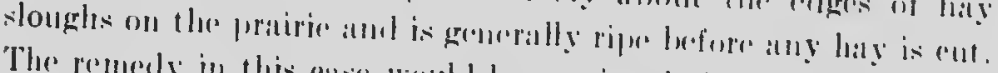

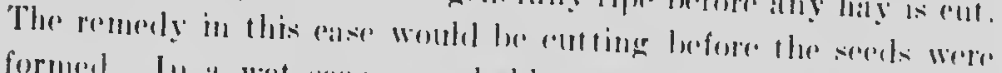

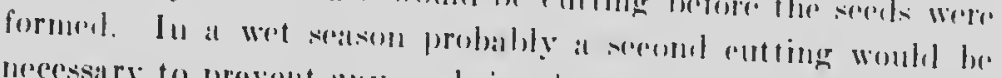

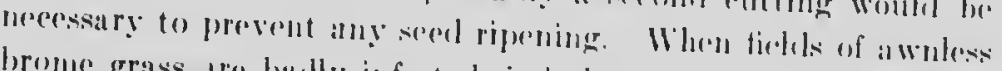

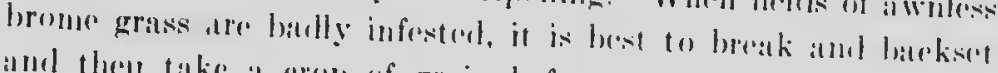
and then take a crepe of grain before re-sereling: of the fields

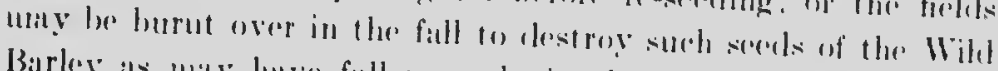
Barley as may hatre fallen; early in the following spring plew the sod shallow and then harrow and roll. In this way the

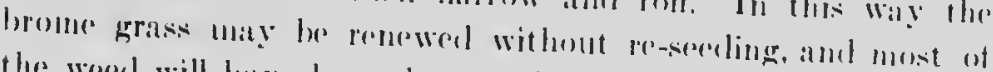
the wered will hatre !nen destrogerd."

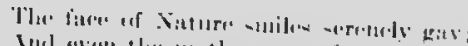

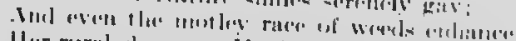

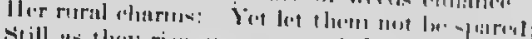

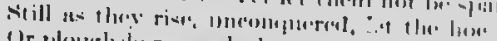

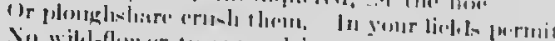

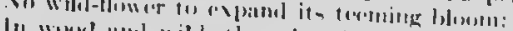

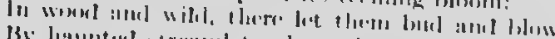

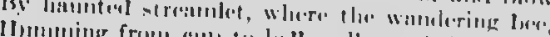

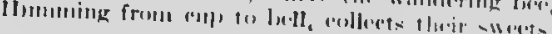

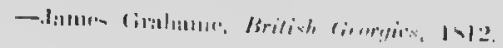

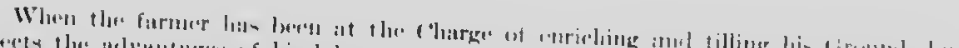

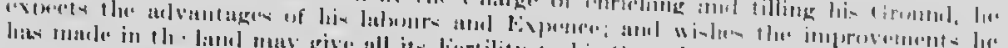

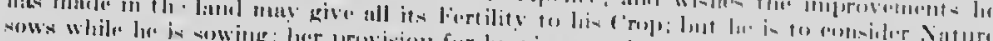

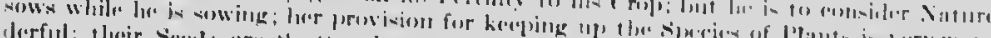

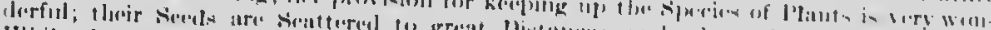

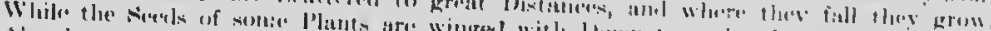

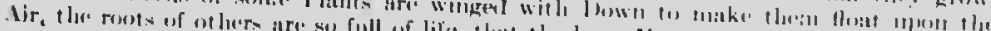

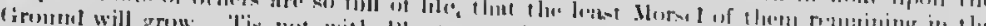

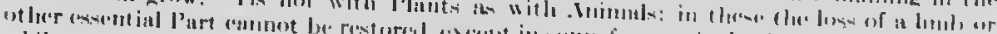

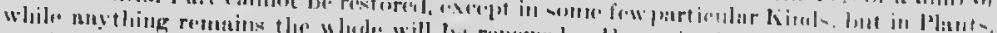

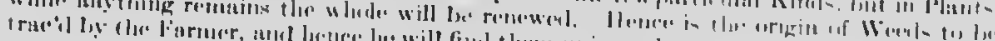




\section{ERGOT on COUCH, RYE and TIMOTHY (Clariegs: purpuren (Fr.) Tul.)}

Fhere are often found allong grains of rye, larely allong those of wheat, and abundantly anong the secels of some grasses. blackish or purplish solicl bodies, rommonly called ergot. Fresh specincus are of a waxy ol oily consisteney, purplish white inside. They are the storage organs or resting stage of a parasitic fungus belonging to the genus claviceps. Ergot grails vary in size and form, aecording to the spreics of grain or other grasses on which they develop. Each of these solid bodies is called a selerotium (plural selerotia), derived from a Circok word shlerom, hard or dry, in allusion to their mature thicy the vegetative systeut, the "sliry are a part of condition, but "apable of growth in" of the fungus, in a resting able conditions of waruth ant in the spring under such favourwith erop seed, or when lying moisture as they get when sown stems on whieh they were for on the ground at the bases of the spring small toadstool-like boline the previous summer. In the orange-eolourenl heads, about thes, on violet stalks, with lound, duced from the selerotia the size of mustard sed, are proenormous numbers of lying on the ground. These develop analogous to the secels of higher plants), small spores (organs and grains are in flower. of air or by inserets, forlge in the flowte spores, carried ly eurents in a short time they eompletely flowers of the grasses and grow: them the horn-like selerotia. Jestroy the soed and form from formed oll these holns. at the same the summer spores are secetion, veryattractive to insects, same time appears a sugary many of the summer spores to the thoweh earry off on their bodices and thus spread the infeetion. duetion of spores stops, and the in the summer the probegin to lay up a kind of statele founclerotia or storage organs as fungus starch, an woll as oils, to whe only in fungi and known 


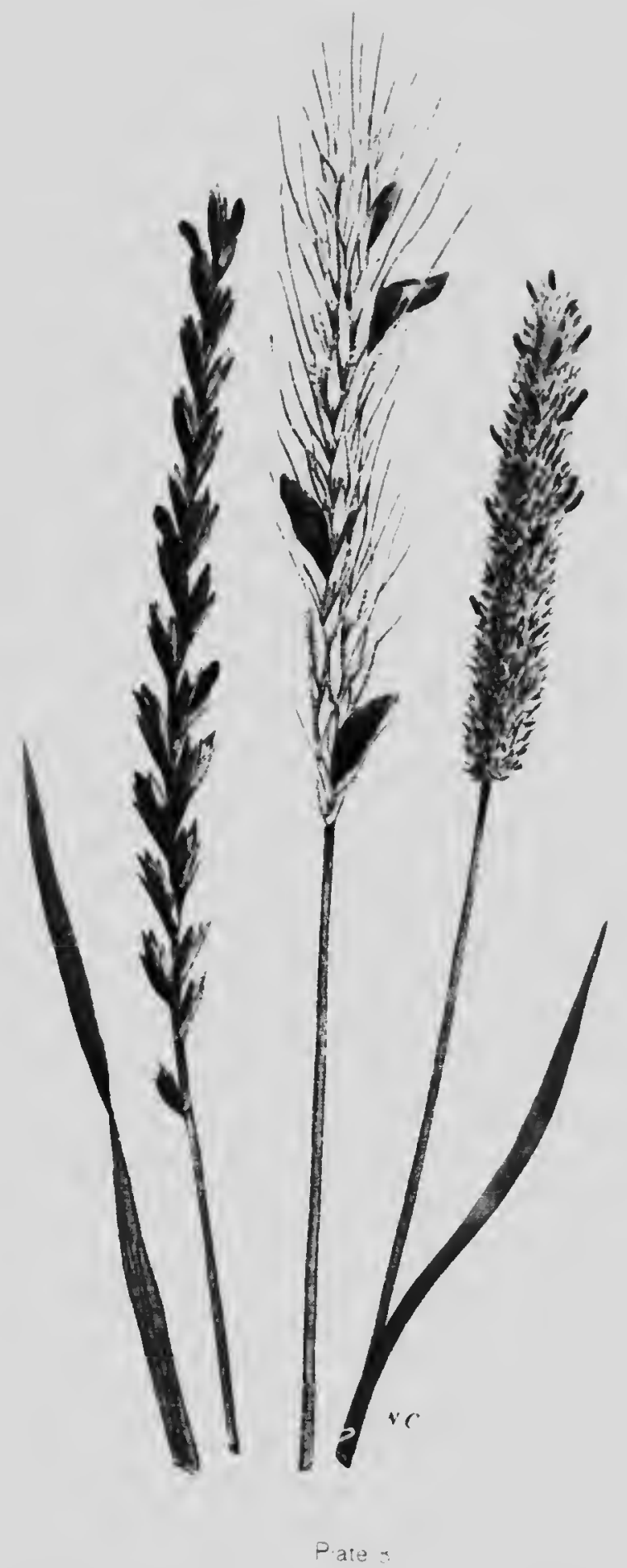

COUCH OR QUACK GRASS, RYE AND TIMOTHY attacked oy Ergot 


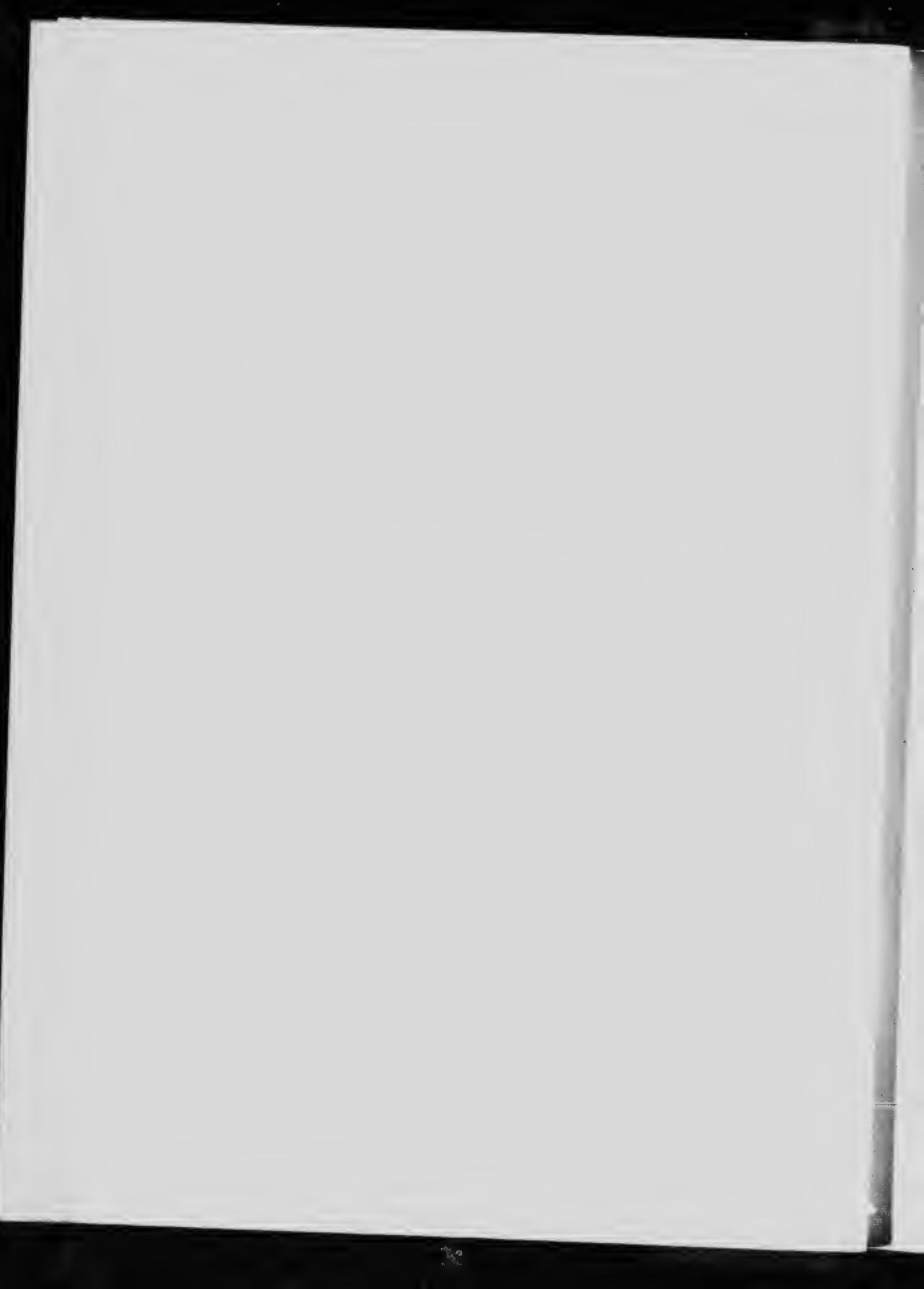


of the fruiting organs to be solt out the following spring. Thery

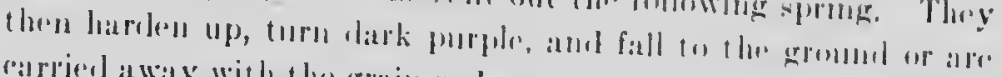

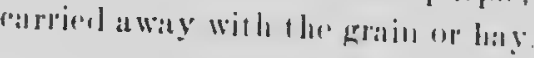

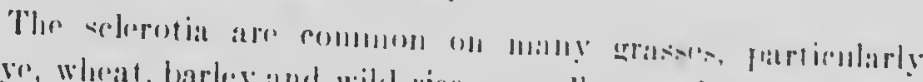

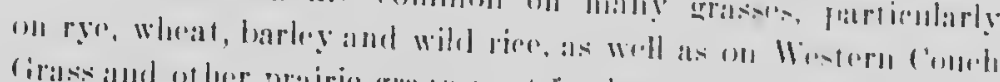

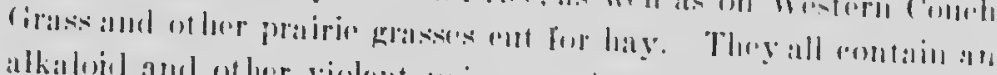

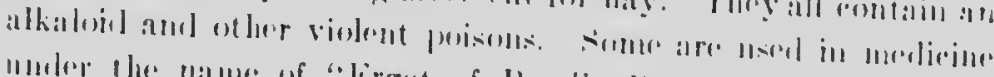

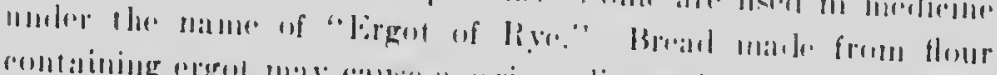

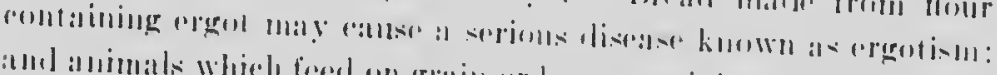

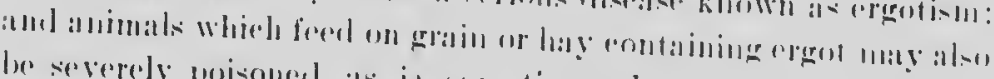

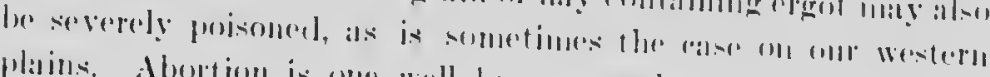

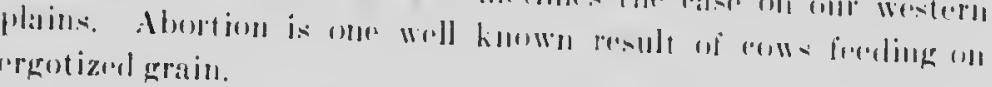

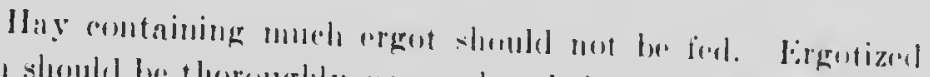

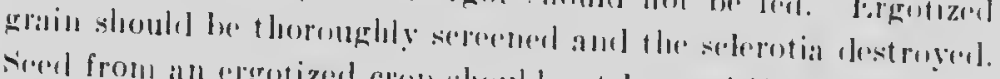

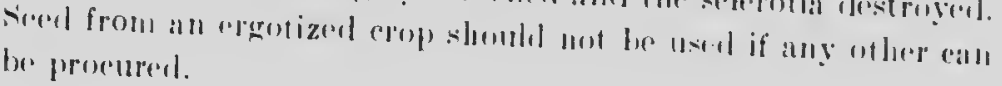

\section{THE SEDGE FAMILY (r'mprncem).}

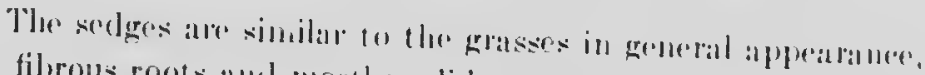

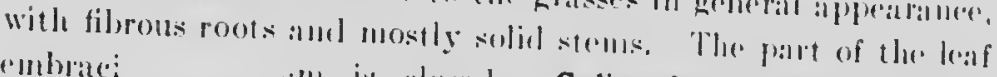

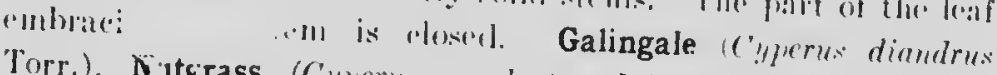

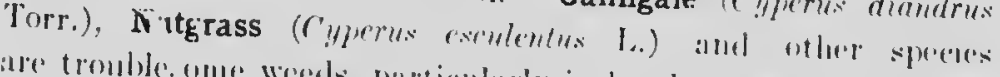

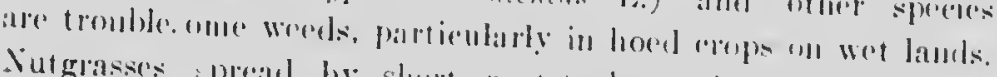

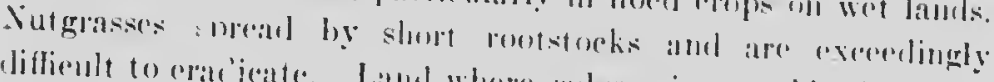

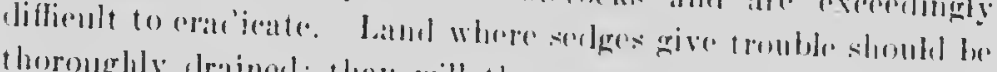

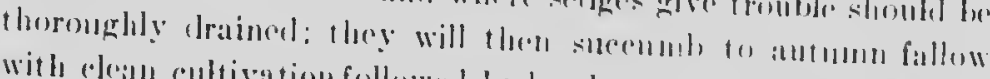

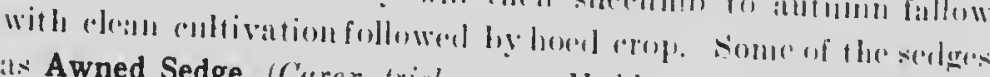

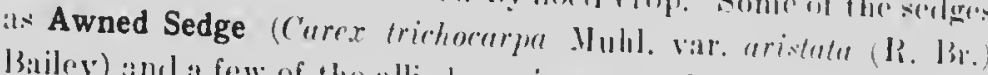
bailey) and a few of the allied speceses are valuable follor flams.

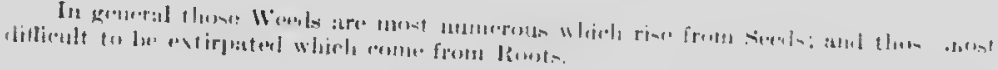

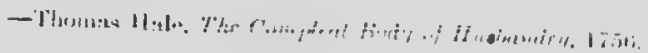




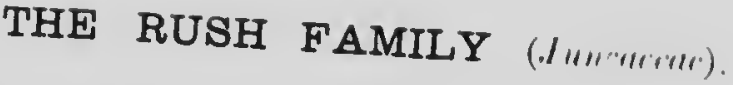

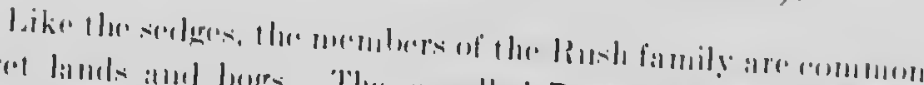

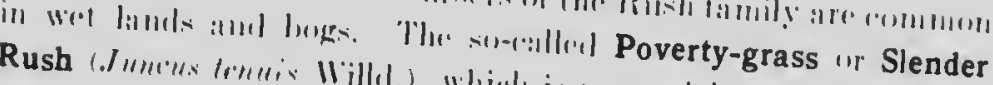

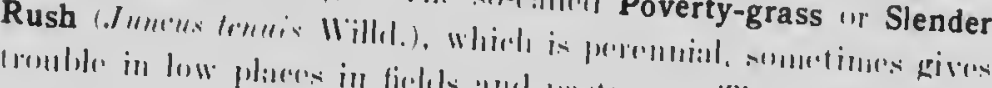

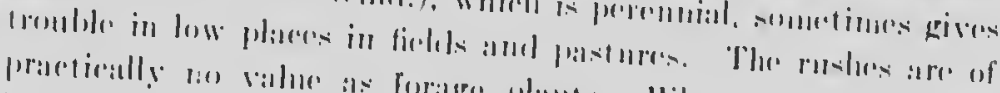

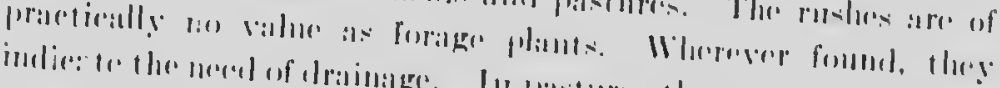

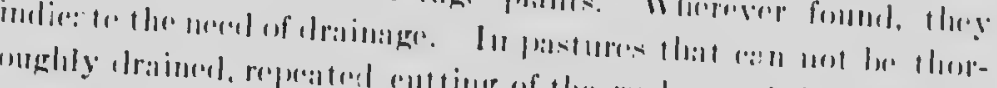

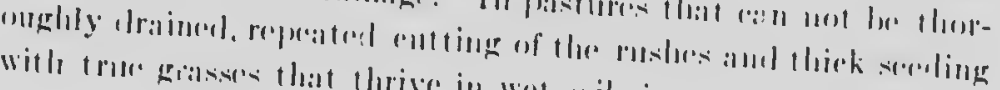

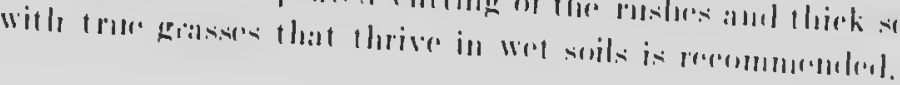

\section{THE BUCKWHEAT FAMILY (I'm!!ymuncere).}

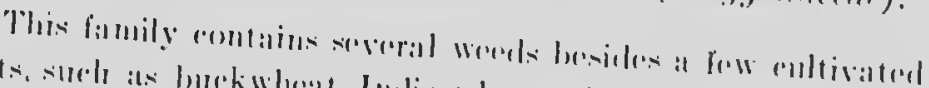

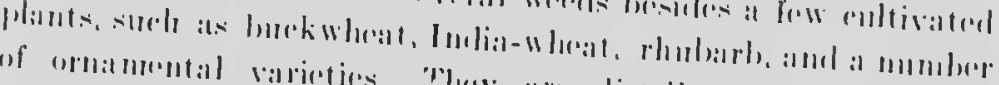

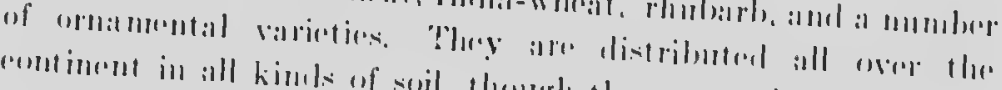

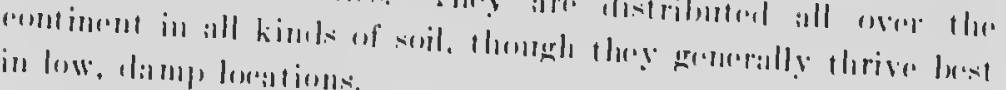
in low, linmpl lonations.

Therie hashit of gres.

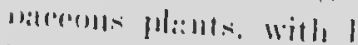
latrese atre aldermatre.

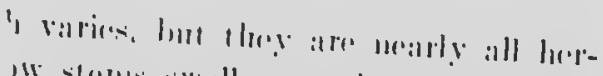

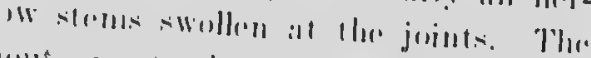

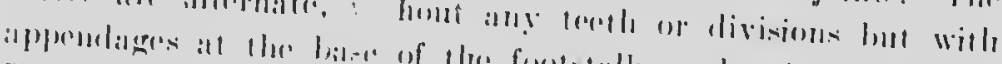

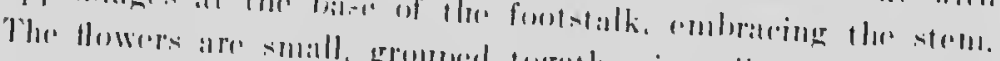

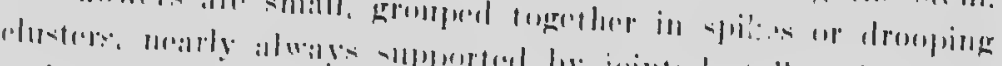

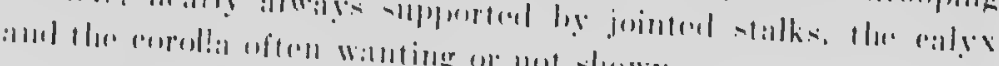

.

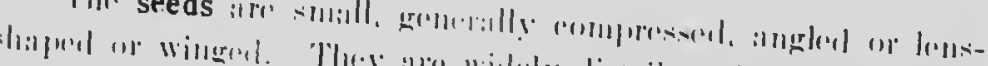

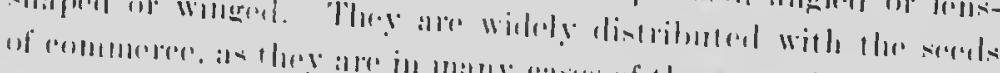

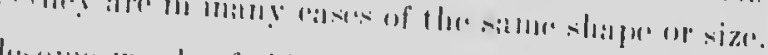

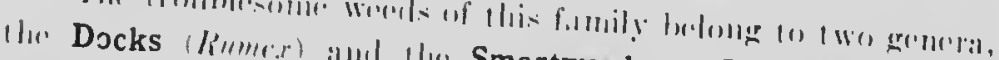
(gomulim).

Docks arre tiall-stemmund wereds

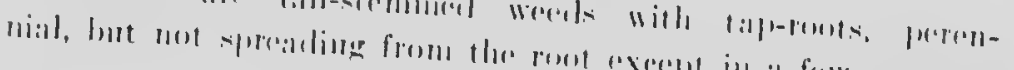




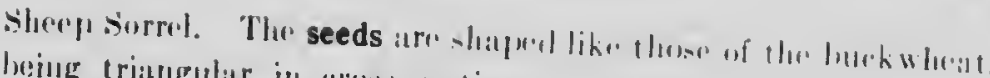

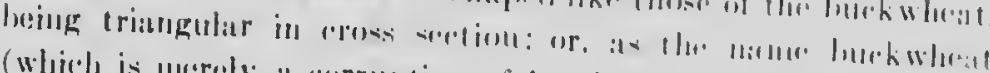

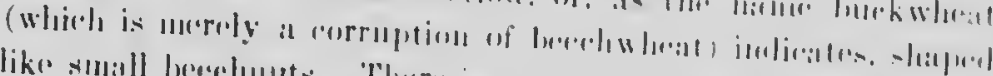

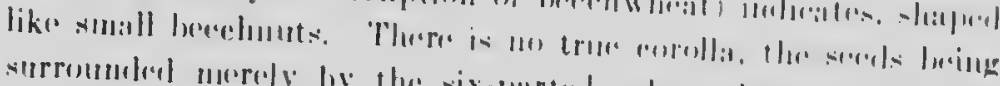

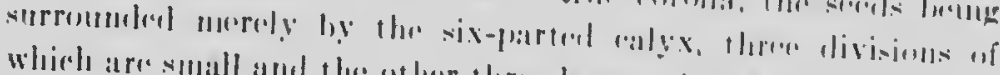

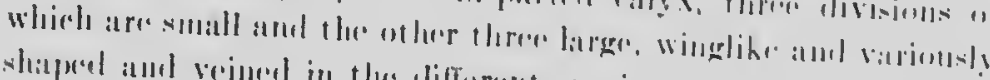

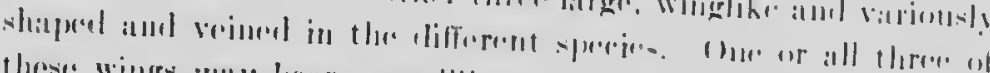

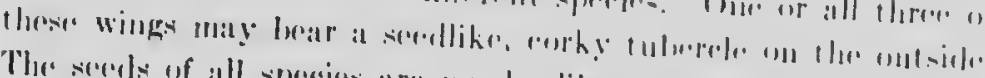

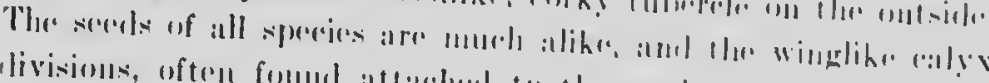

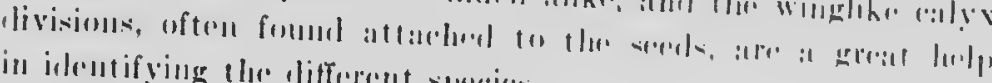

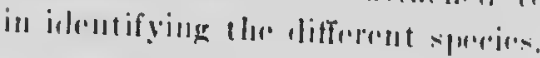

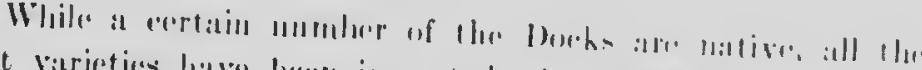

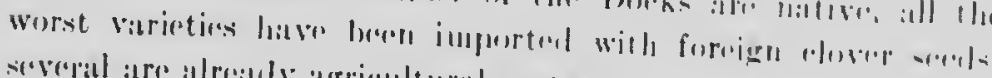

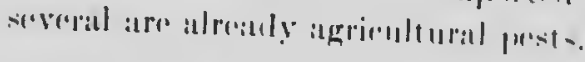

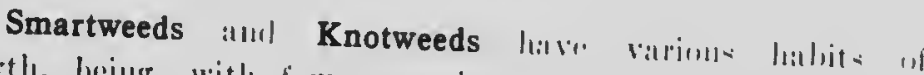

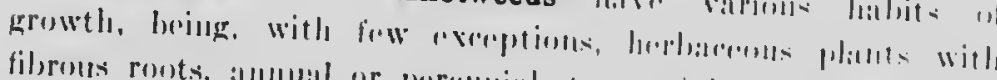

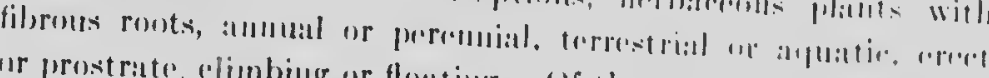

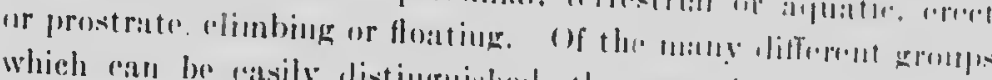

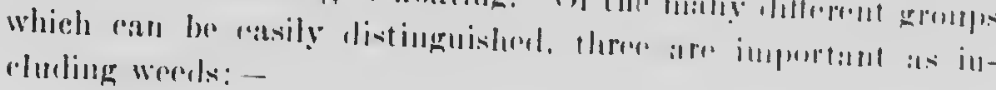

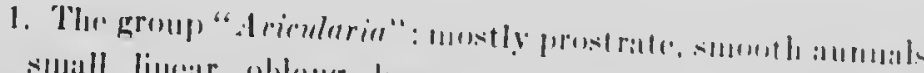

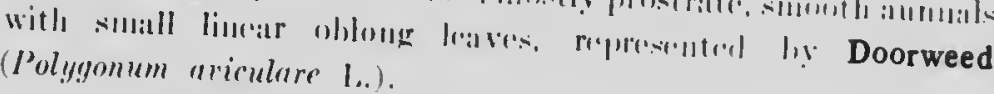

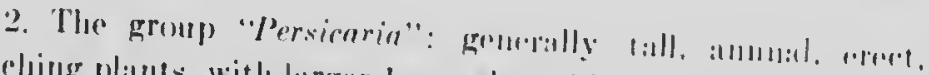

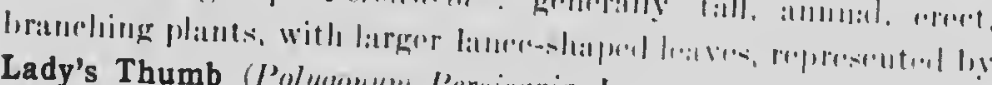
Lady's Thumb (Polygumum P'ervirurin l..).

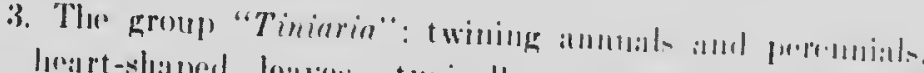

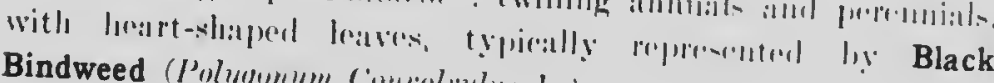

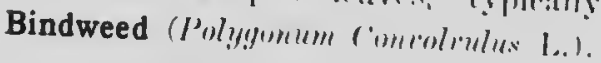

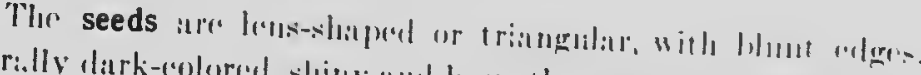

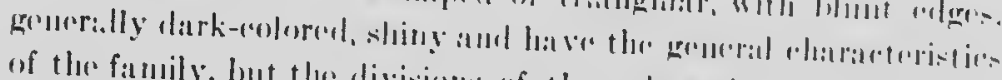

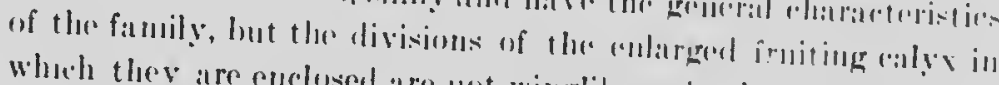
wheh they are endesed are not wingliter as in the loweks. There

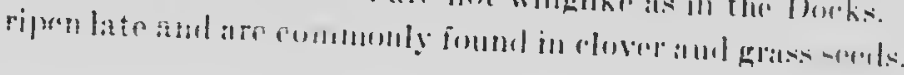


42

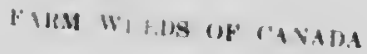

\section{CURLED DOCK (limmex , rixpus l..)}

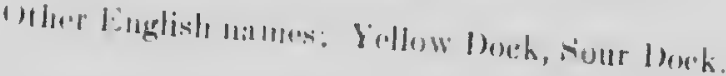

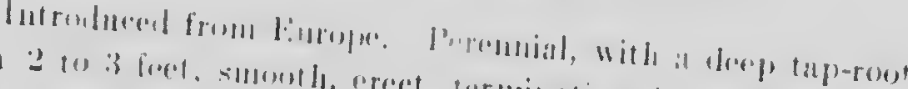

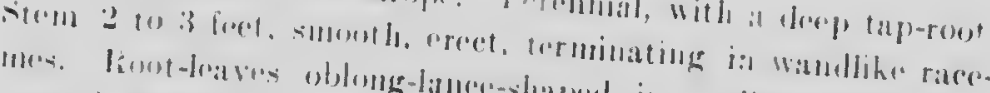

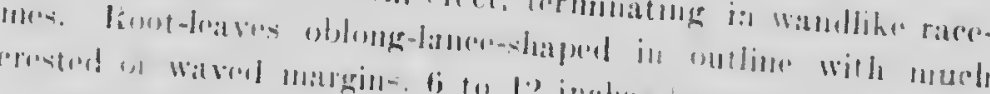

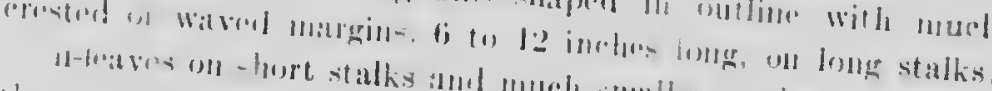

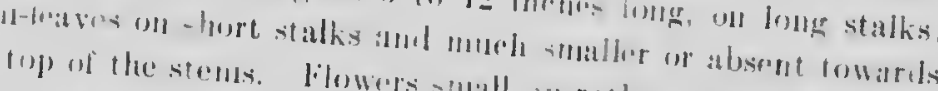

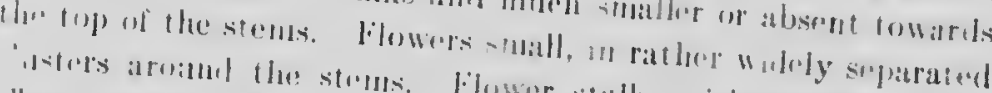

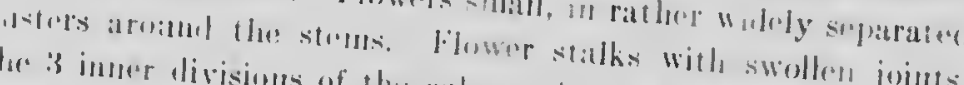

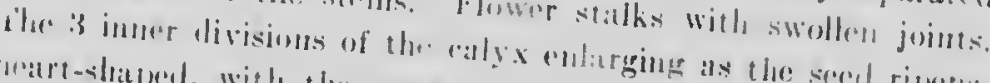

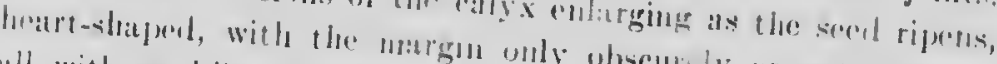

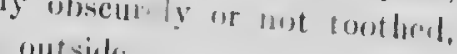

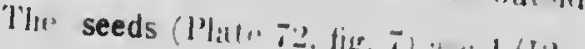

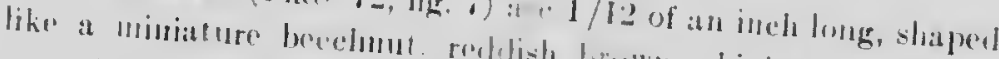

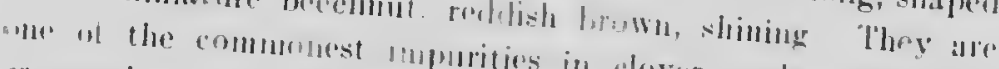

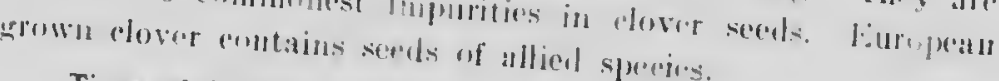

Time of flowering: Jusse sorels ripe by duly.

Propagation: by xerek. The chumpe herease sowly hy sheots

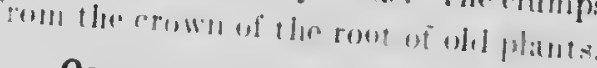

Occurrence: In ficlsk and waste palces, Naturalizod from

Injury: 1 r

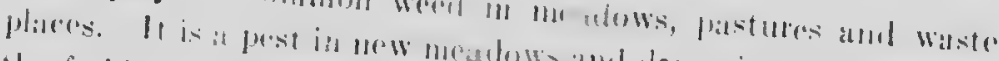

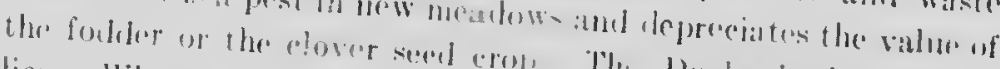

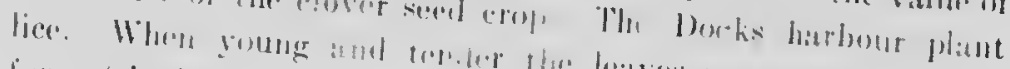
lon put hertes.

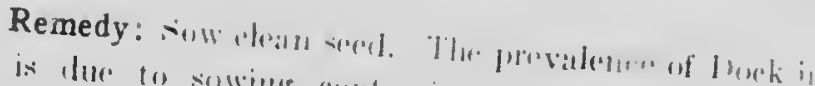

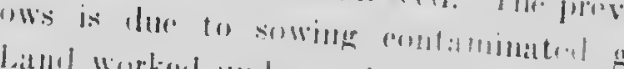

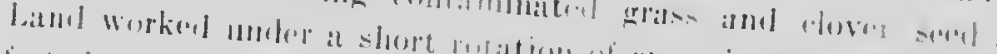

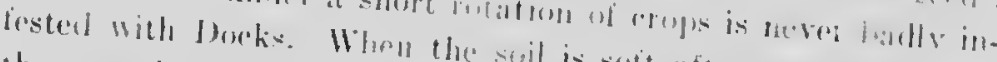

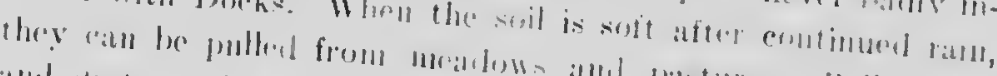

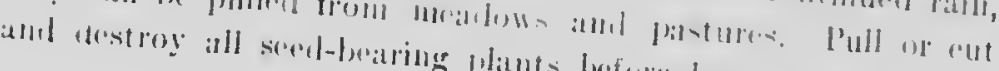




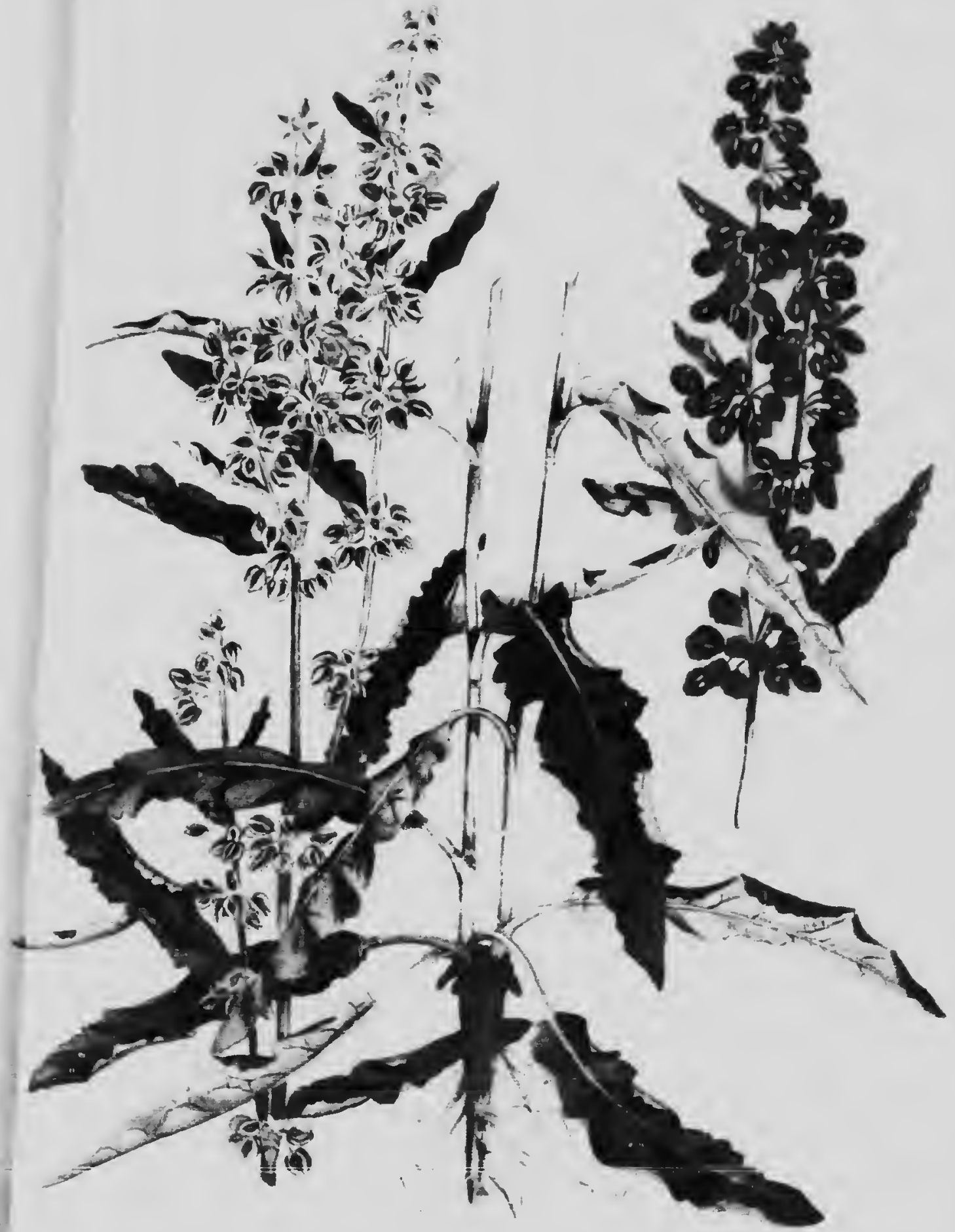




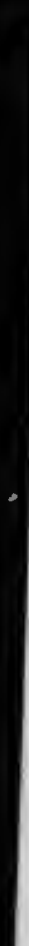

4 


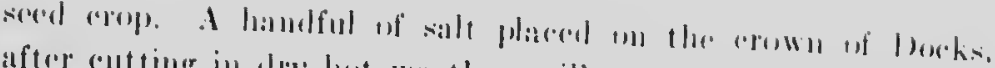

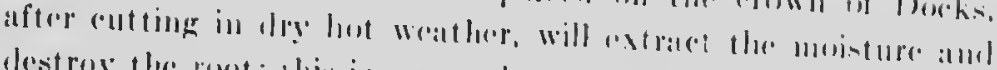

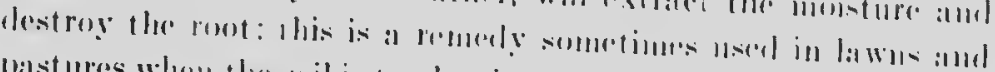

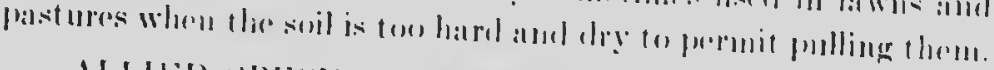

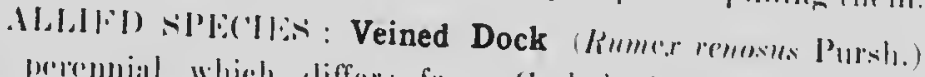

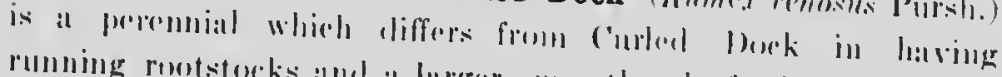

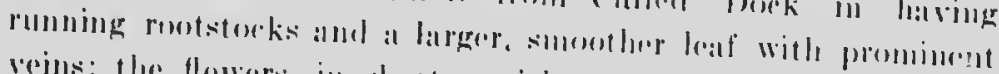

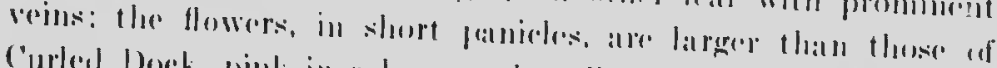

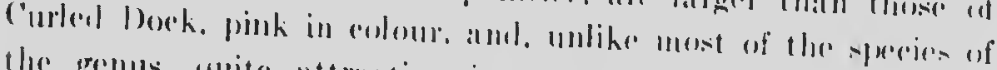

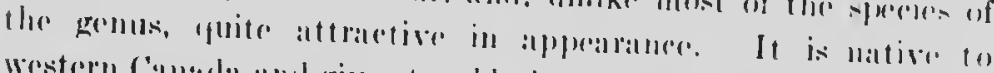

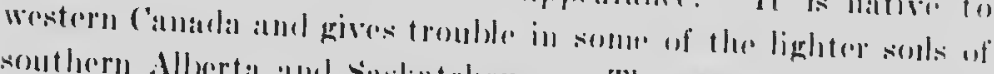

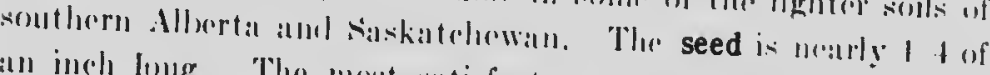

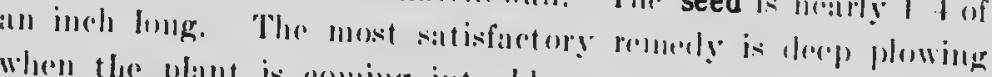
when the phant is roming intu hlmom.

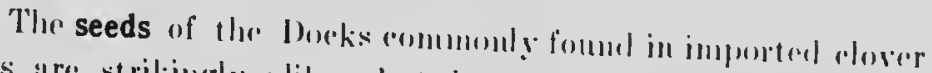
sowes are strikingl! alike. hut hase the following puints of difierentiation.

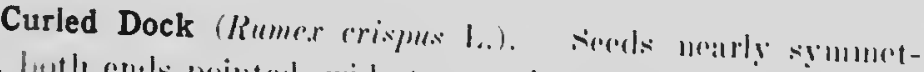

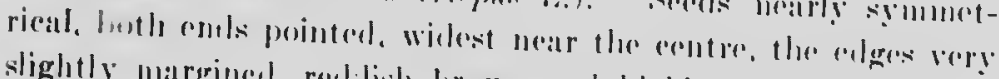
slightly marginnl, rolilish hrwwn and highly shims.

Clustered Dock (Rumex conglomeratus. Murr.). Ifwex of the

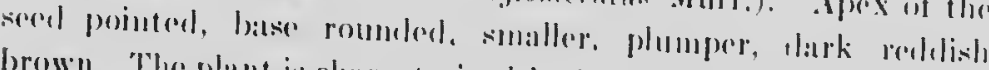

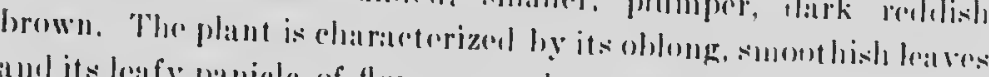
alul its loufy panicle of flowers ons short stalks.

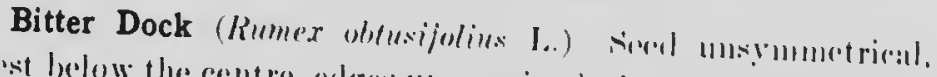

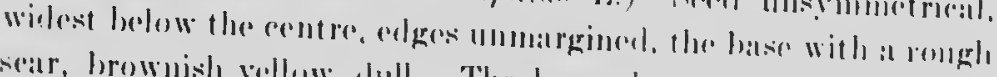

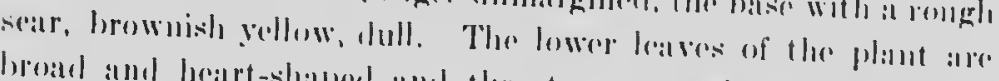

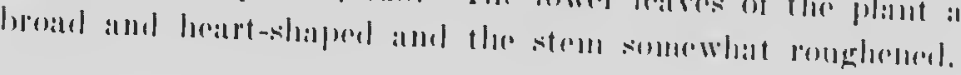

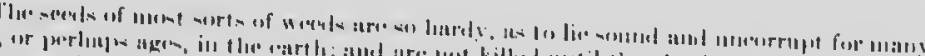

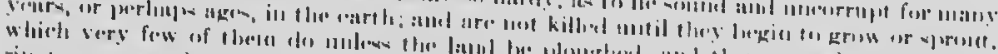

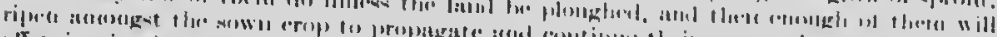

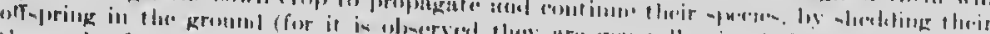

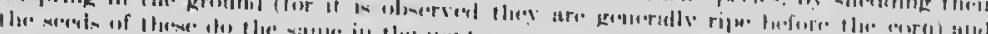

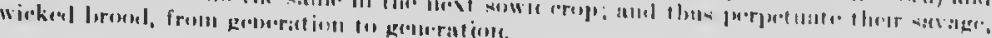

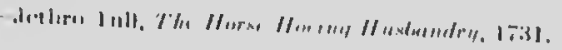




\section{SHEEP SORREL (Rumex Aletonella l..)}

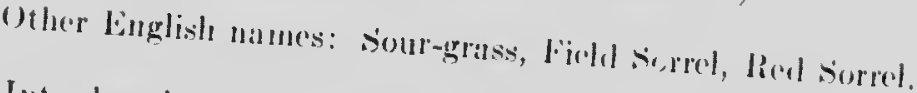

Introlueed from liurope. P'rrminial, very persistent by

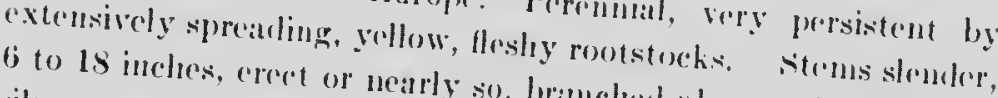
6 to 18 inches, croet or nearly so. branched athove. Lecaves with narrowly arrow-lowendages, spreatling outward from the hase,

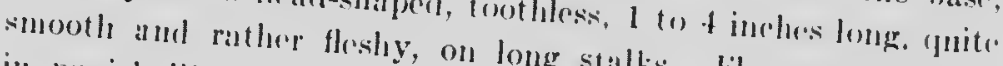
in pancle-like racemes, of two long stalks. linerers mumerous male flowers have conspicuouse kinds on separate phants: the showy and are tipped with stamens: the female are much less organs (the stigmas) milh three ting, erimson, fouther-like

The seeds (Plate 72, fige. s), as lhey occur anong clorer and grass secels, arr generally covered by the three hagere conspicuously veined ealyx divisions which fit closely over the serel. The three small divisions, which alternate with there, fit seed.

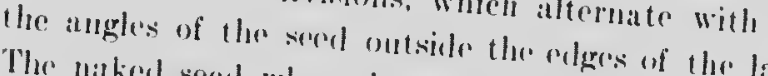

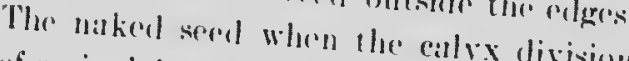
of an inch long and nearly as brent, triangen and removent, is $1 / 20$ shining. tember.

Time of flowering: May to Angust; scerls ripe July to sip)-

Propagation: lis sorels and shallow mming rootstorelss.

Occurrence: Nalturalizorl in all palts of the conntry.

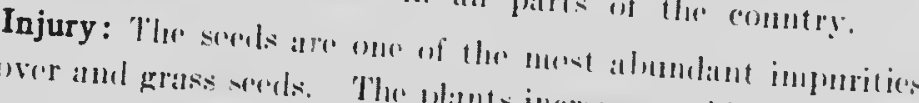

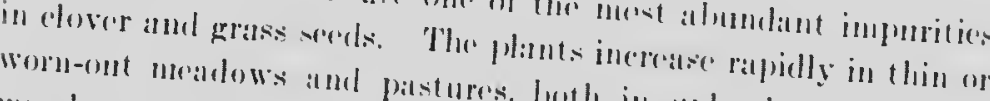
worm-ont meatows and patstures, loth in mplatuls and in lialy

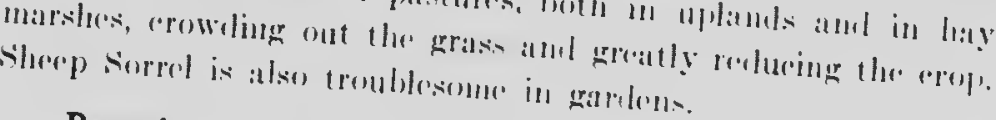

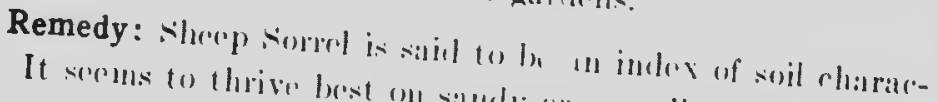

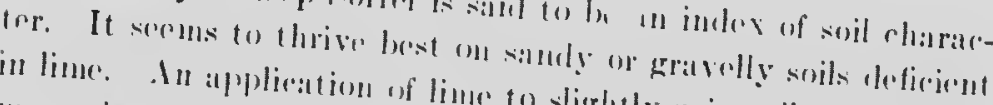

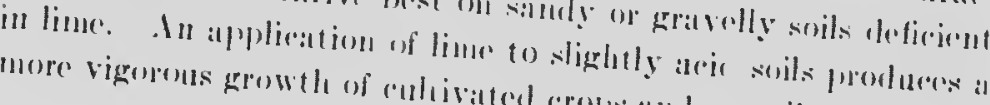

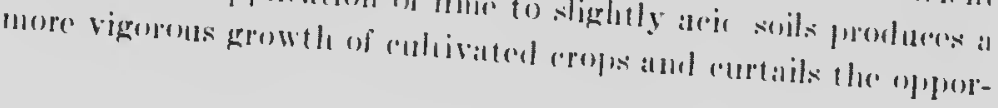




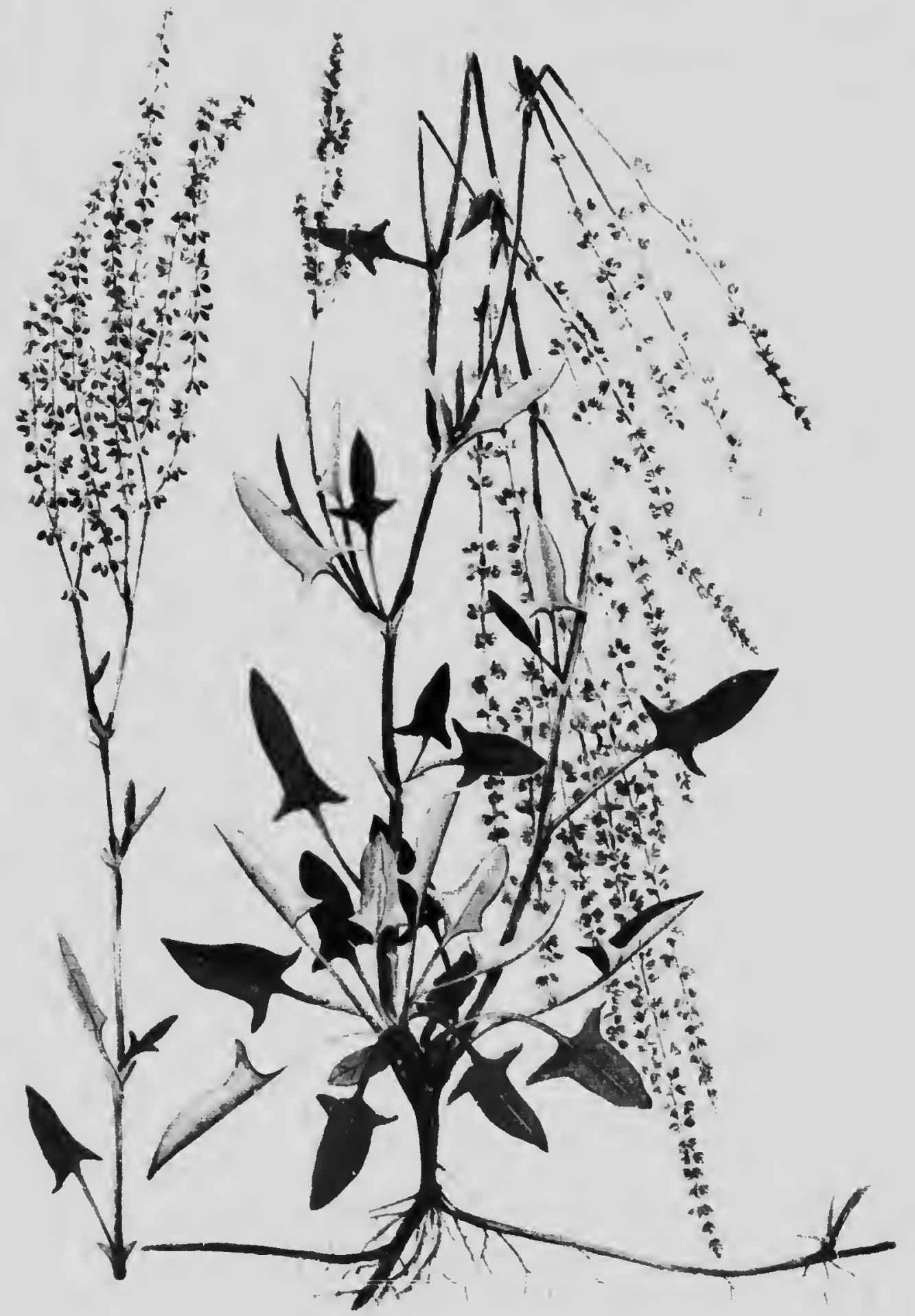



tunities of the sorrel to grow and spread. Ohd me:afows and pas-

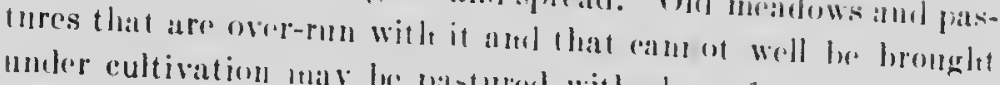

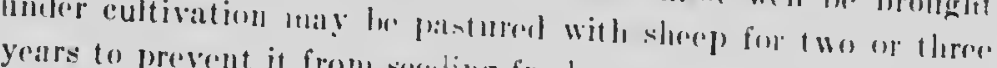
years to prevent it from sineting frenly.

The seed is exeefelingly ditlieult to sepallate from alsihe sred, and lands foul with sorrel should mot le used for the pro-
luetion of this crop.

A three-year rotation of aropse with goml entivation, ineluling shallow plowing direcely after hay arop and frepluent cultivation motil atumn to prepare for hoed rops, will keep

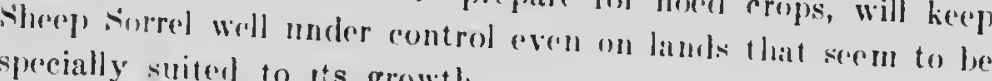
spercially suited to its growth.

In adstition to the applieation of lime and good cultivation, the liberal use of farmyard manure, flowing lown elover or other green crops, or any other means of enriching the soil, will stimulate field crops to a more vigoroms growth alud thus do nonch to smother out and suppress this prest.

MllIEI) SPE('IEs: Garden Sorrel (Rumer .lreto:n I..) is

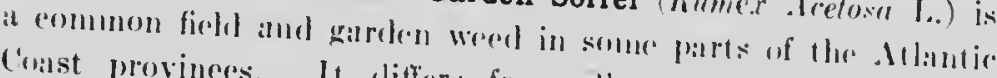
Const provinees. It liffers from sheepe soreel in its more creet habit of growth and its lorouler, arrow-shapmed, oblong leaf, with the ear-like appendages directed downwarl.

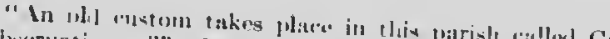

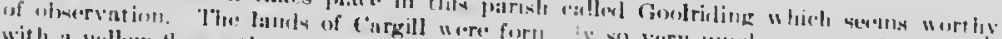

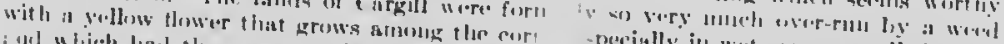

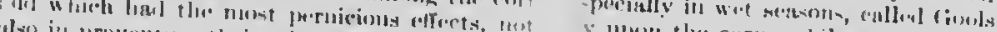

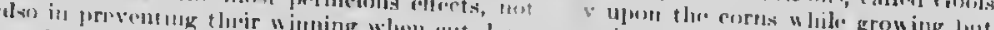

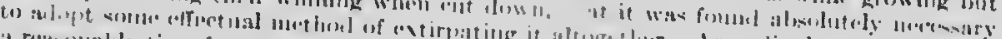

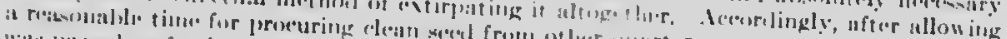

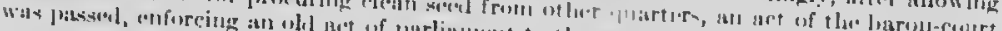

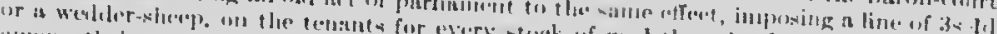

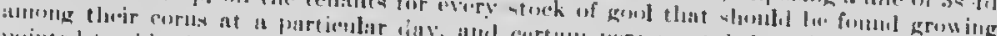

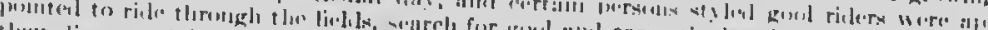

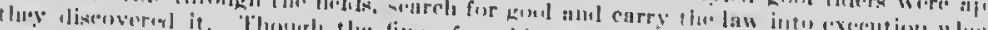

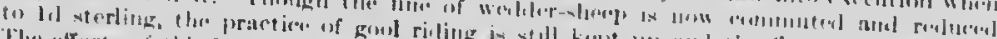

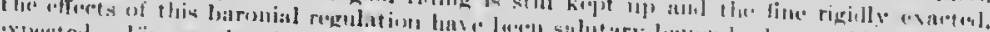

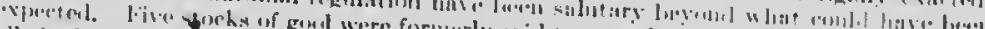

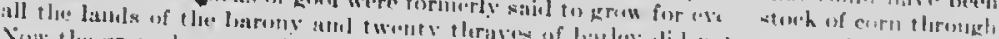

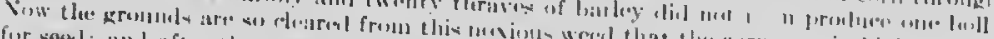

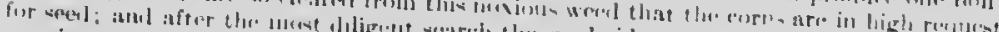

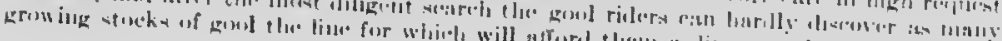

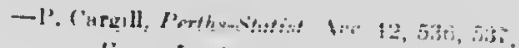

$$
\begin{aligned}
& \text { from Jumirson's Scollich Difumar }
\end{aligned}
$$




\section{* LADY'S THUMB ( /"ul!!!mmm!' J'enicurin L.)}

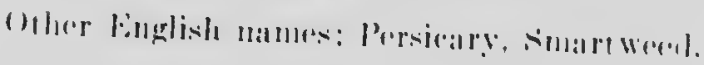

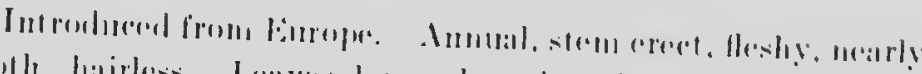

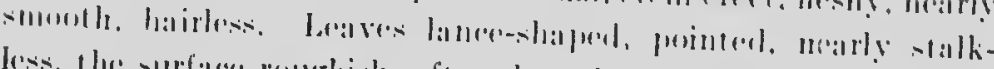

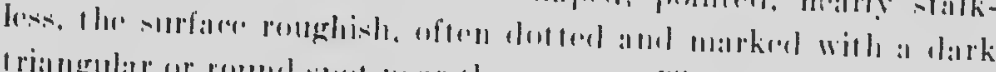

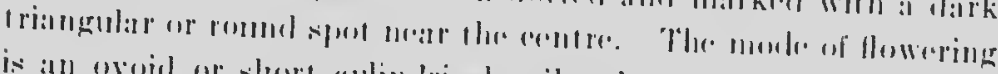

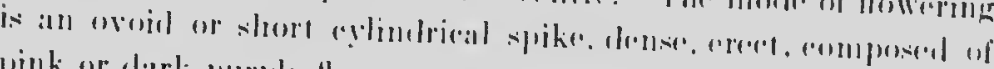
jink or dark purple Hewers.

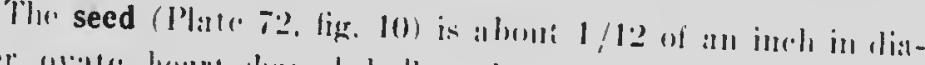

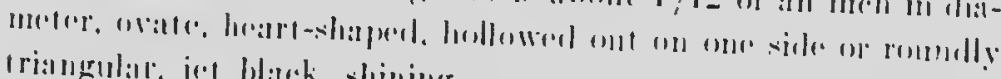
triangulall. jel Warck, shining.

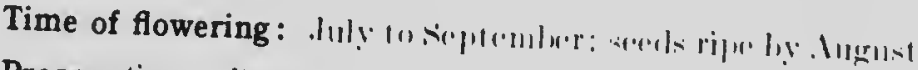

Propagation: By surels.

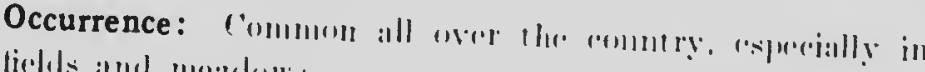
low ticlds and morirlows.

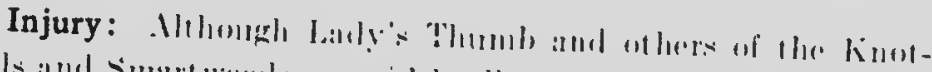

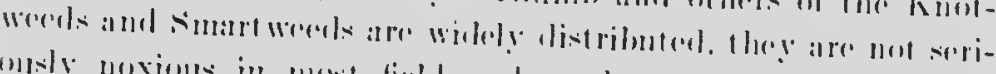

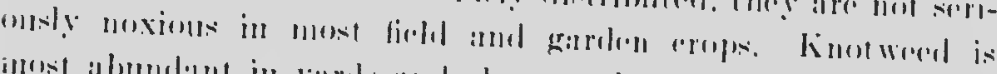

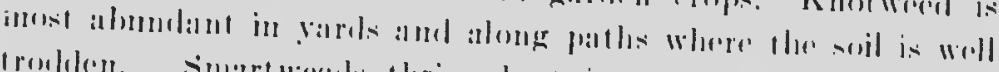

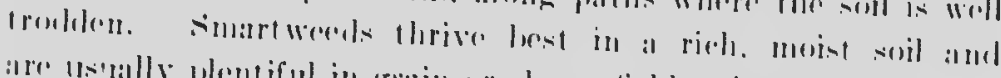

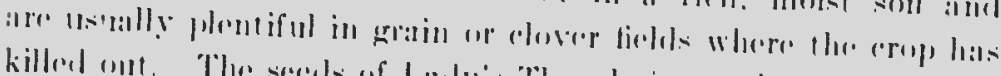

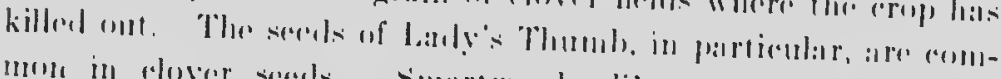

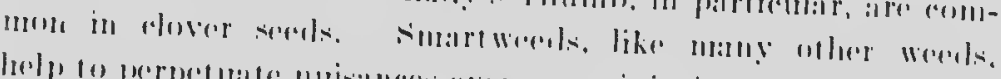

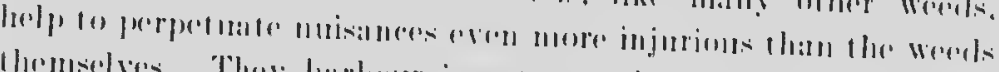

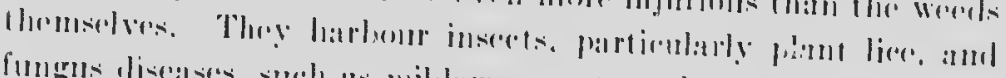

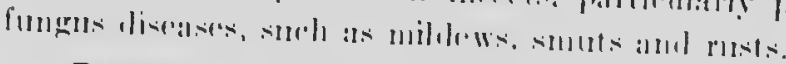

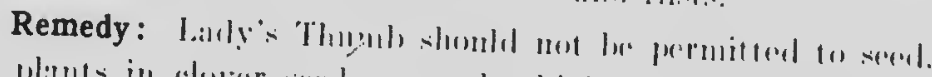

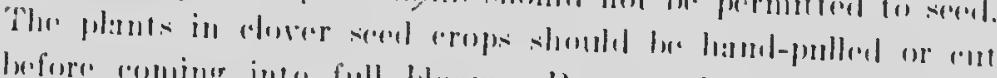

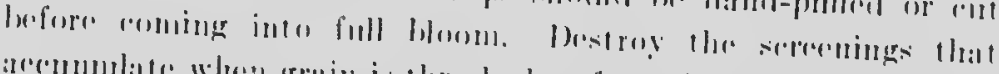

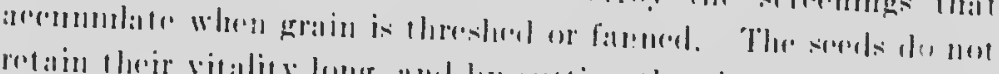

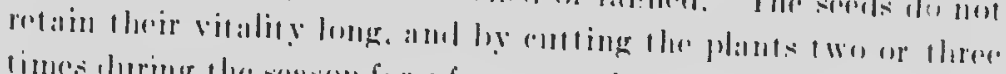

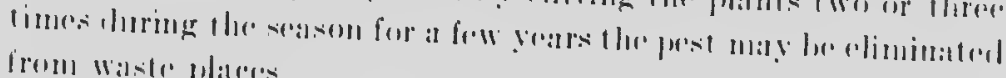

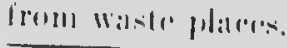

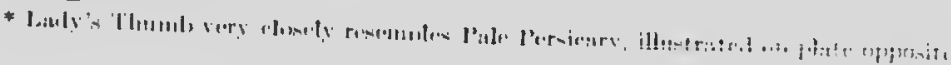




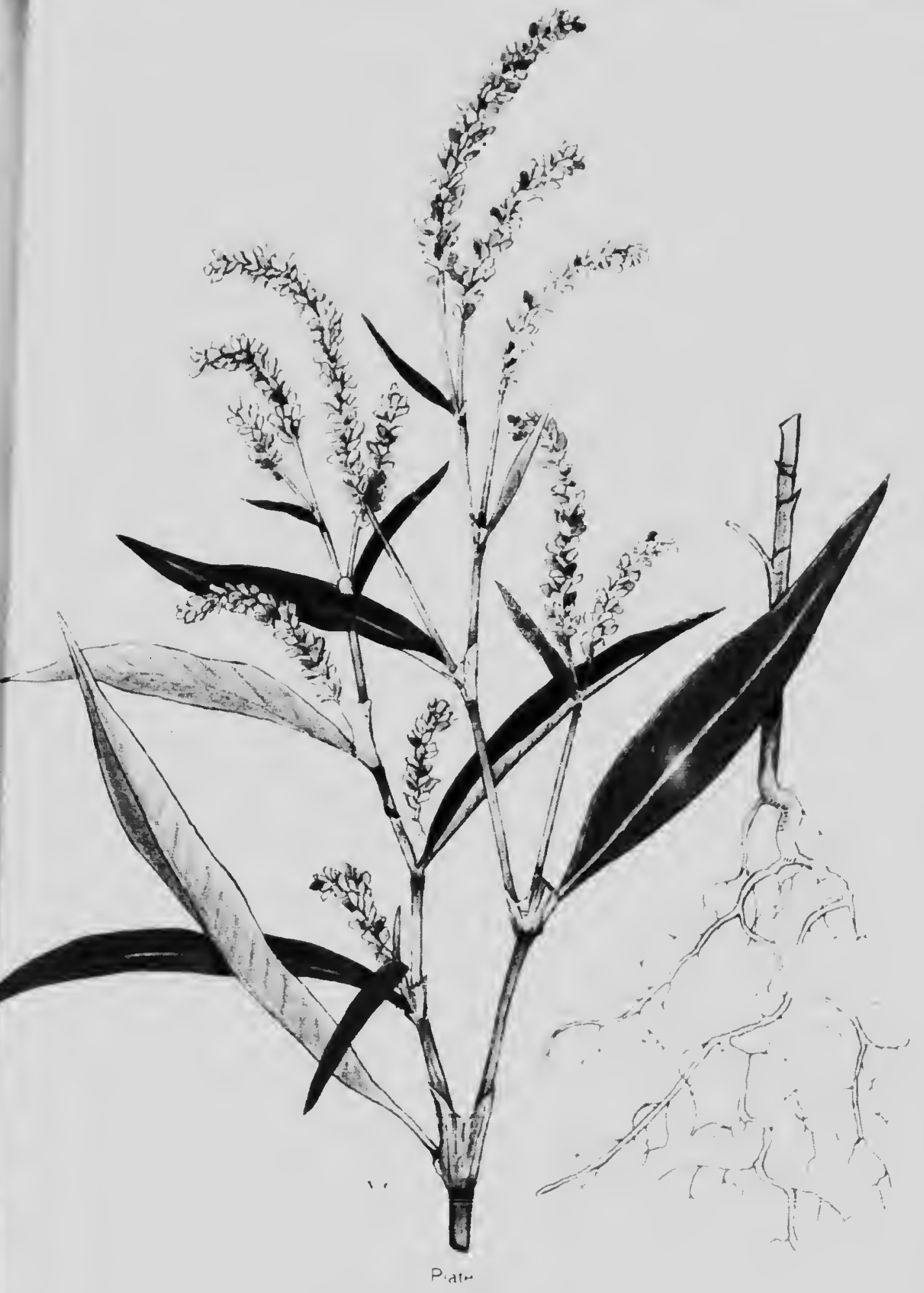





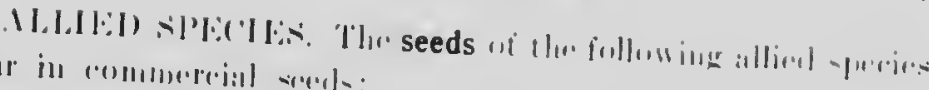

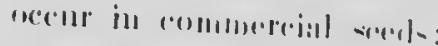

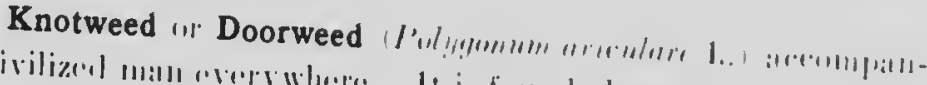

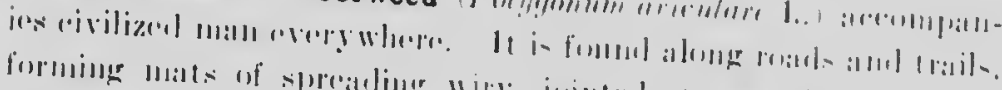

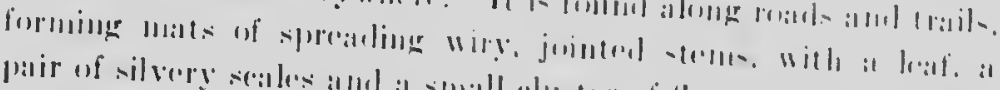

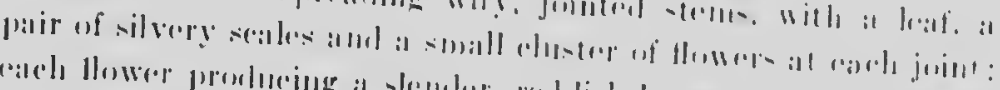

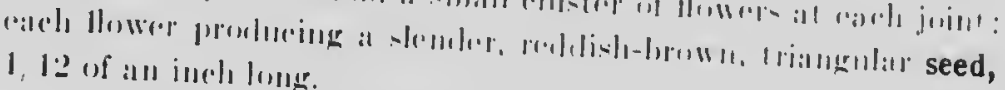

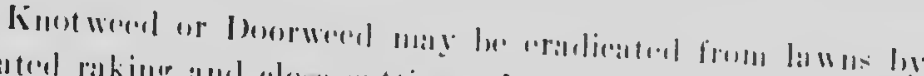

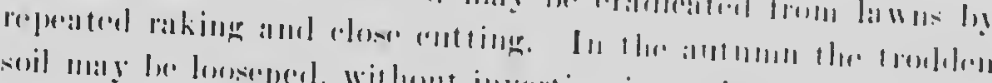

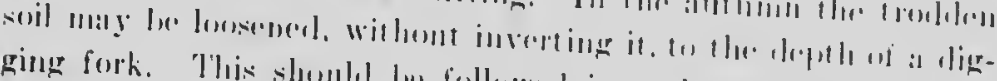

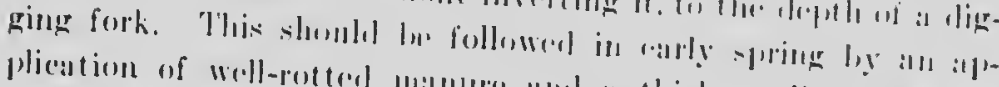

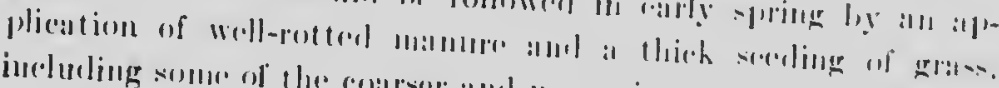

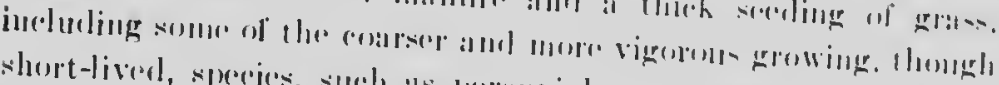

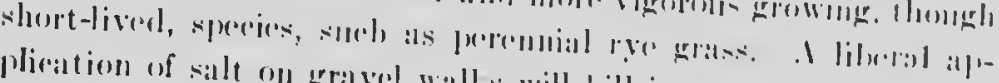
plimation of salt onl gravel walhs will hill it.

Pale or Dockleaved Persicary (I"oly!gmmm! lupmthijolimm 1..)

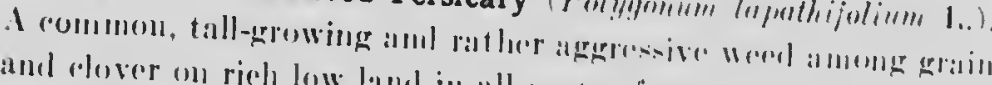

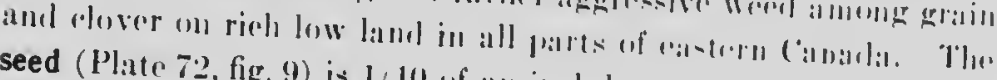

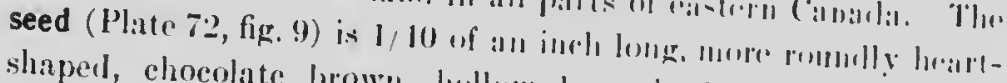

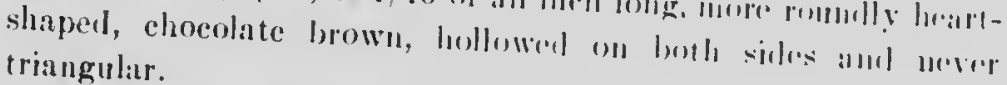

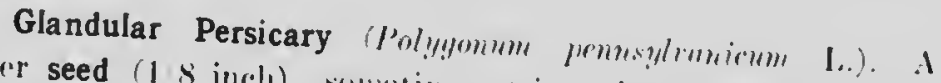

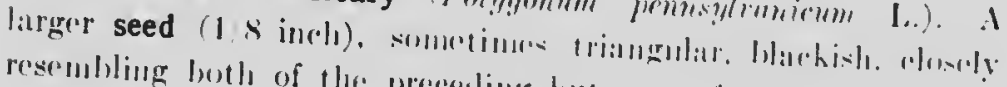

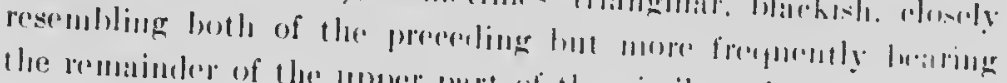
the remaindere of the mplerer part of the pistil at the tip.

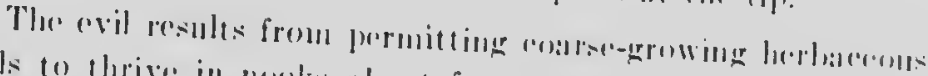

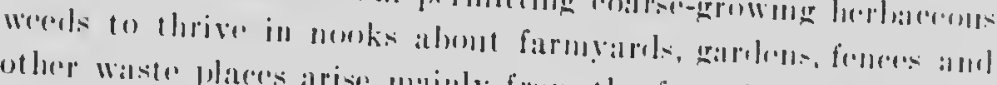

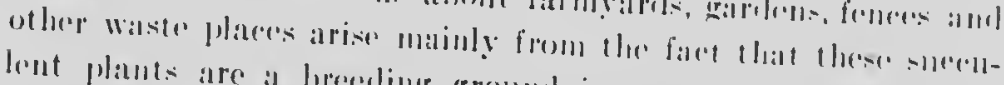

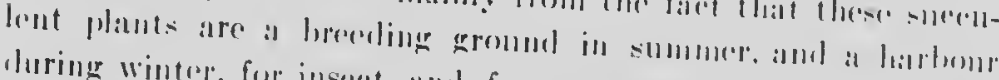
luring wintore for inseret and fomgus pests. finders atml waste.

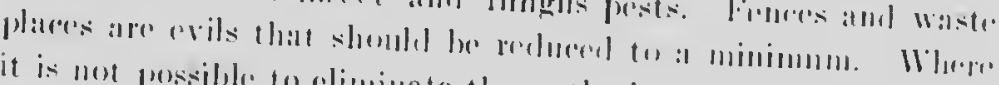

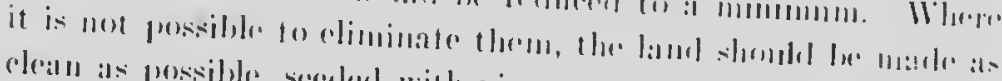

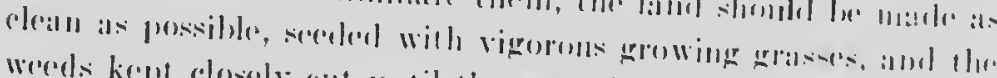

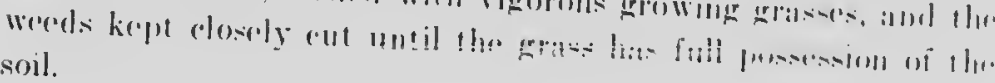


in

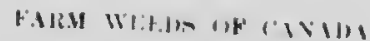

WILD BUCKWHEAT ("olugomm! ('merolrulu: l.)

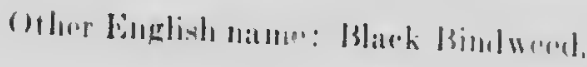

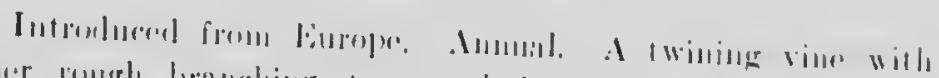

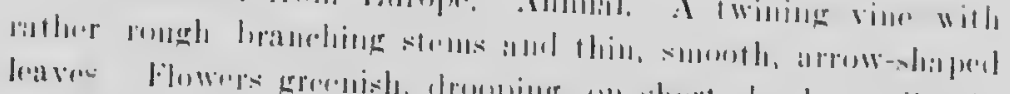

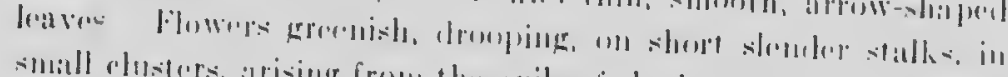

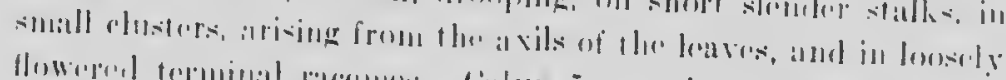

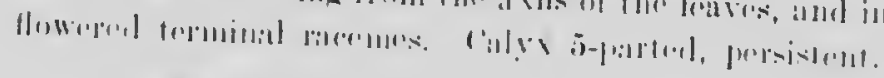

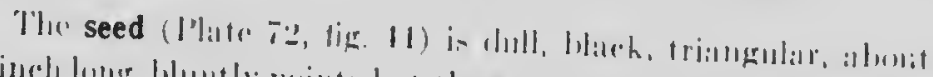

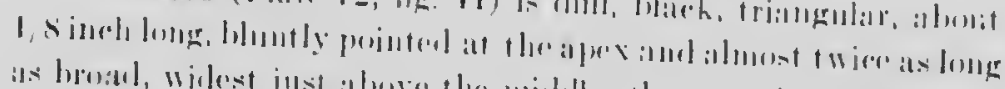

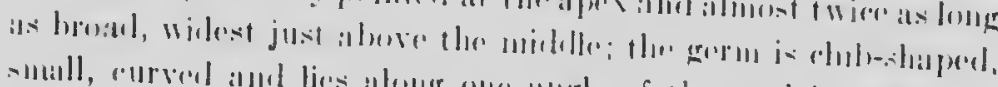

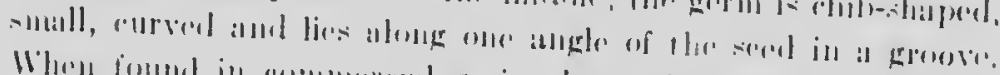

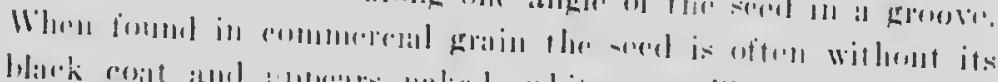

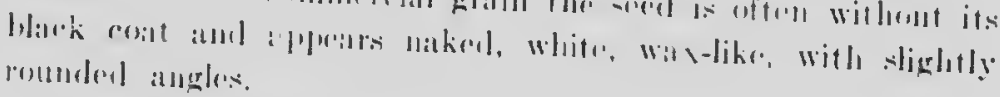

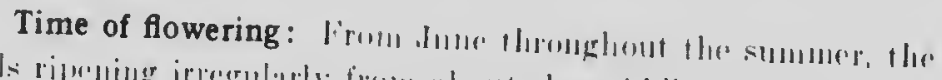

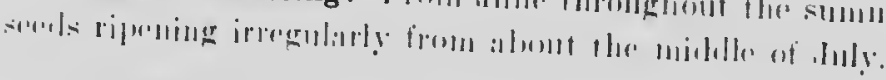

Propagation: 13y sfecls.

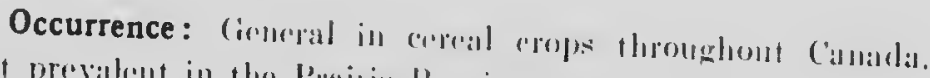

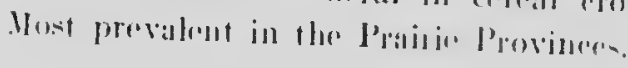

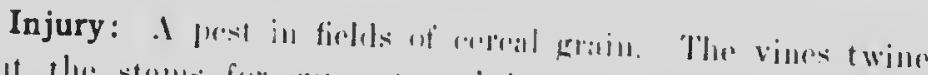
shout the stroms for steperert and intorfore with the reaping

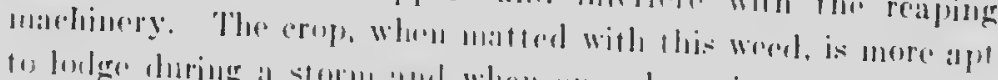

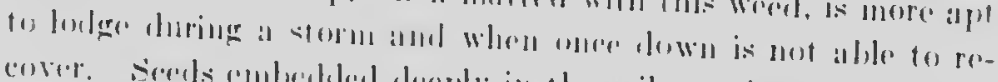

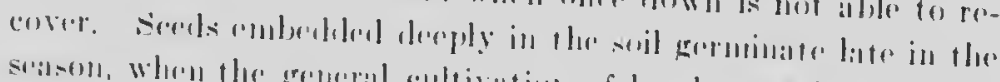

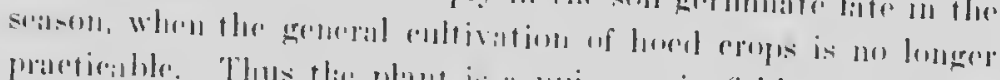

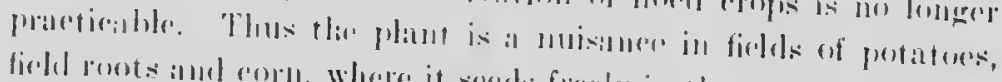

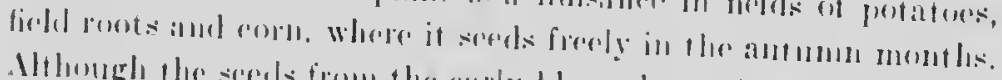

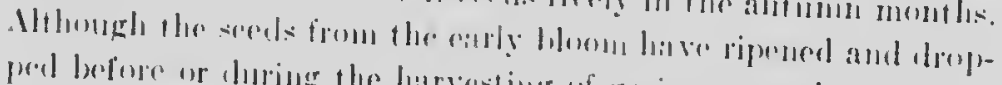

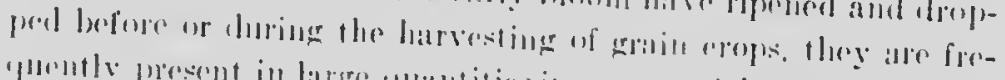

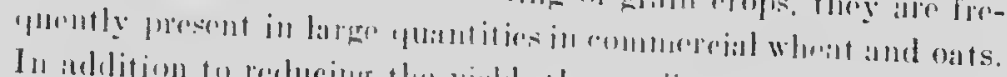
In aldition to reducing the giold, the grading and marhot value of the grain is elepreciated by their presenese. 


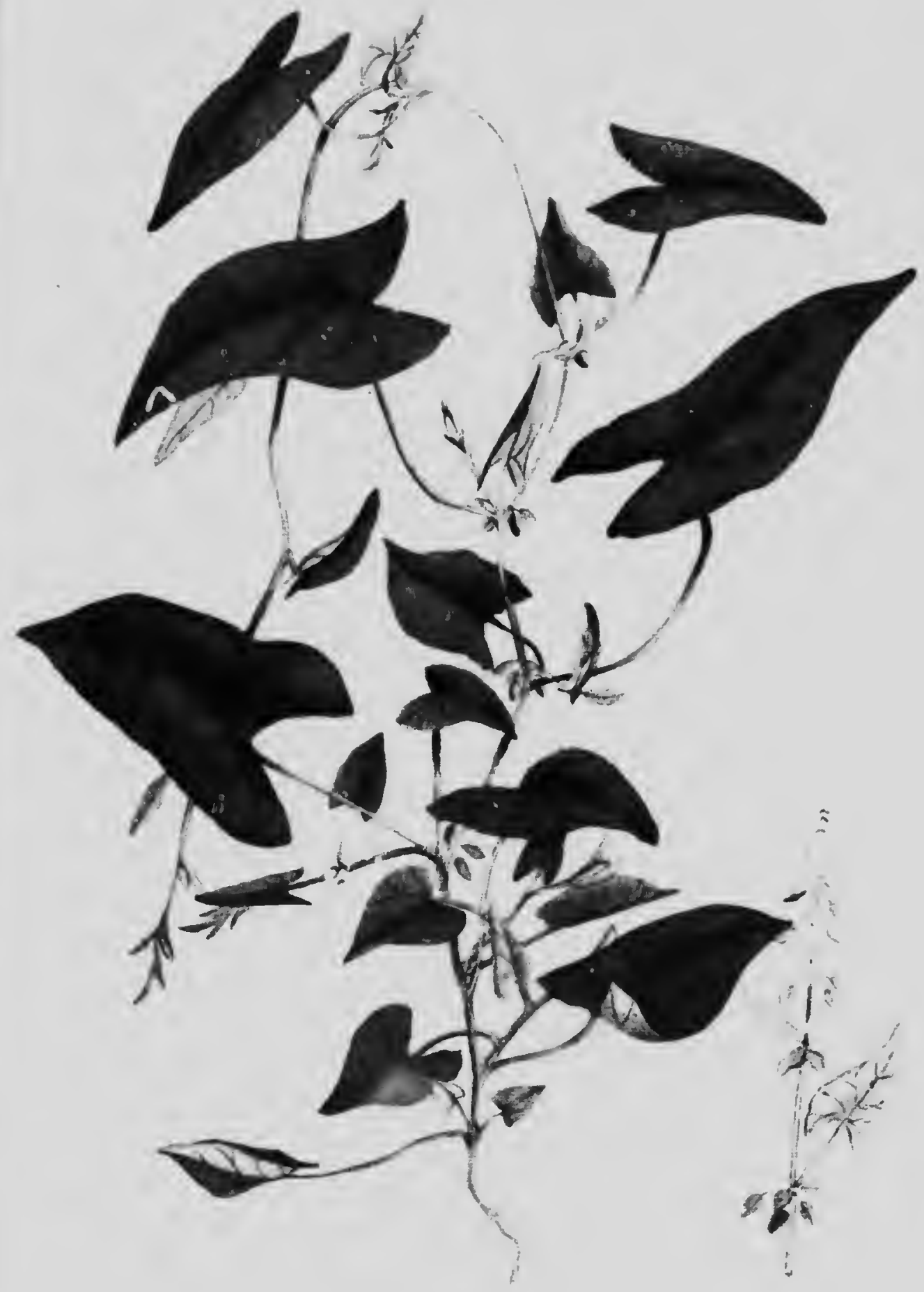



Renuedy

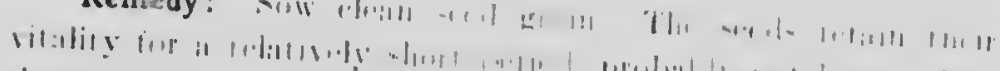

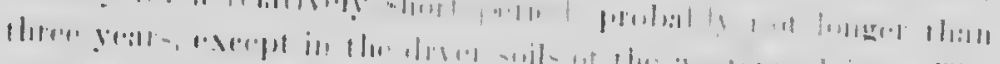

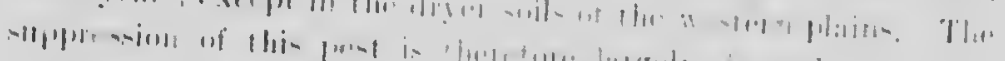

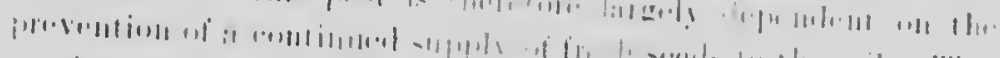

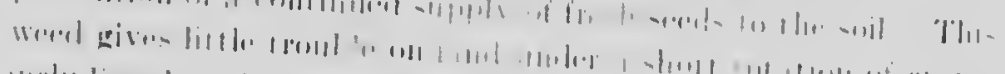

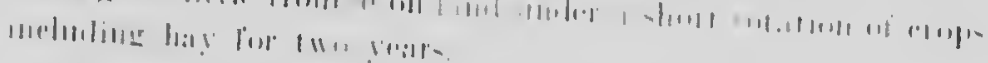

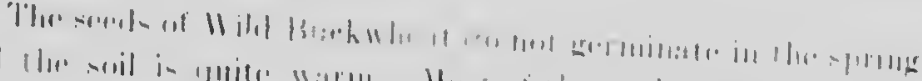

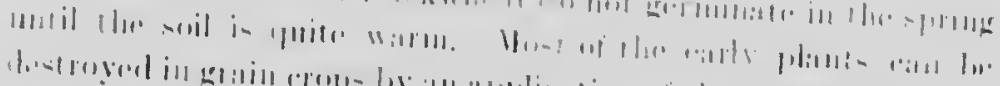

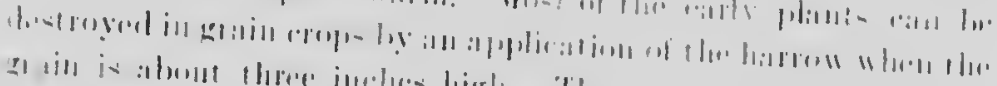

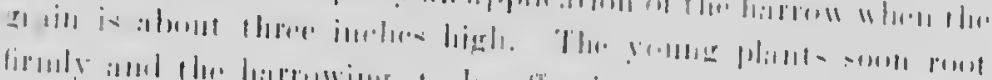

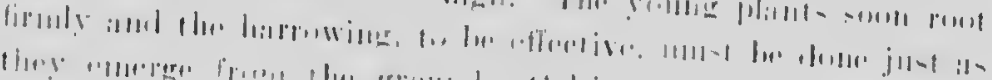

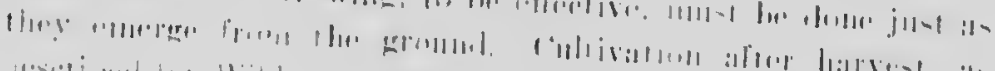

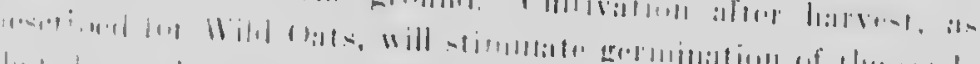

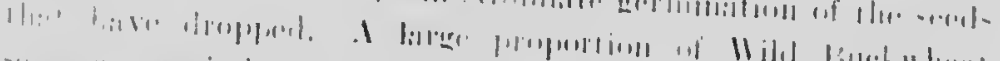

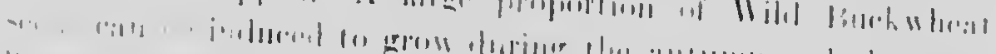

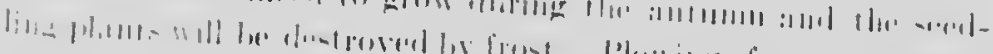

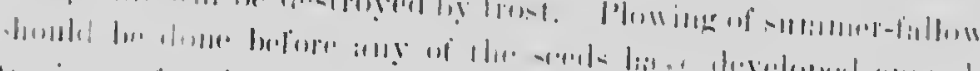

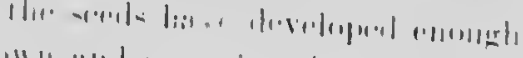

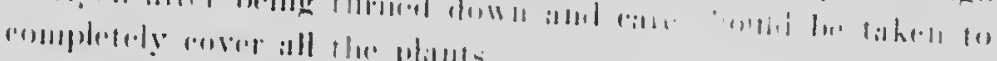

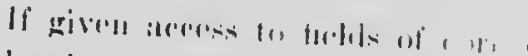

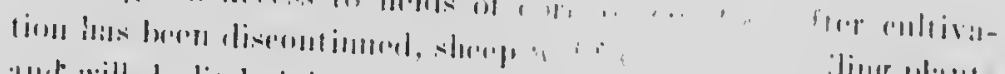
alut will do lintw injury to the are

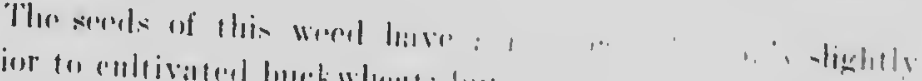

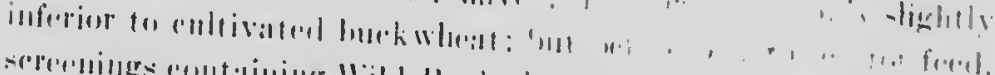

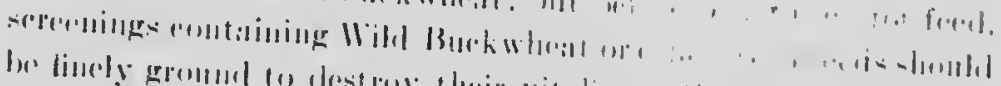

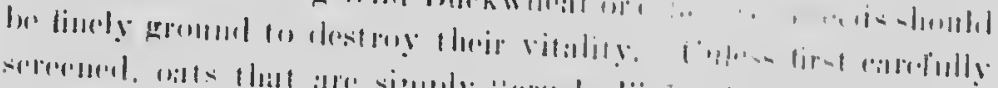

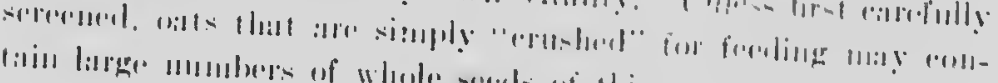

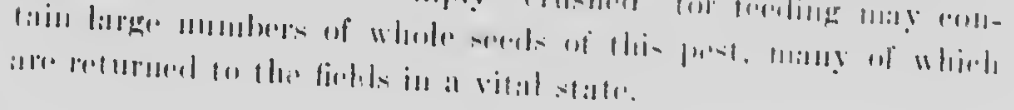

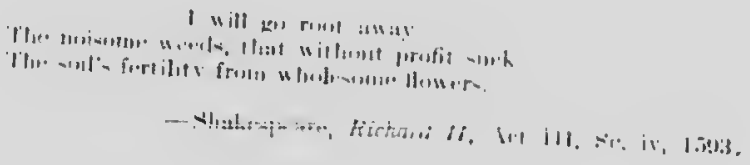


(x)

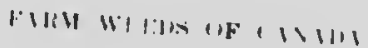

\section{THE SPINACH OR GOOSEFOOT FAMILY ('hemenerlincerne).}

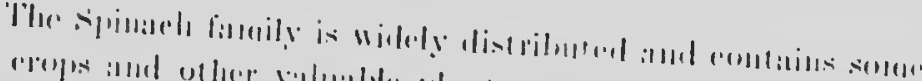

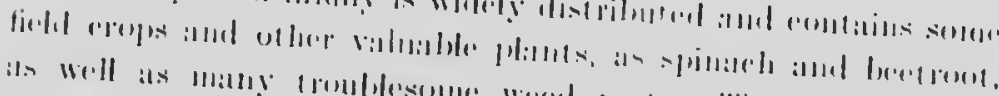

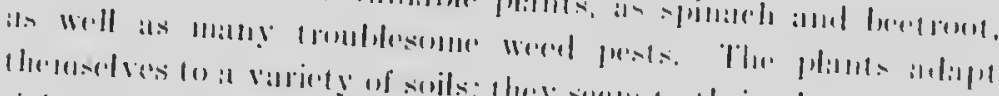

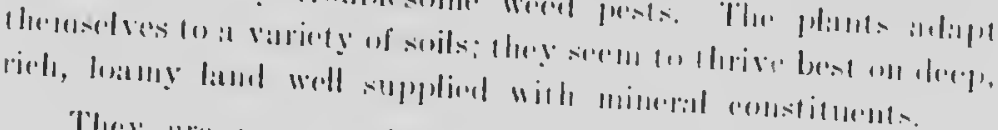

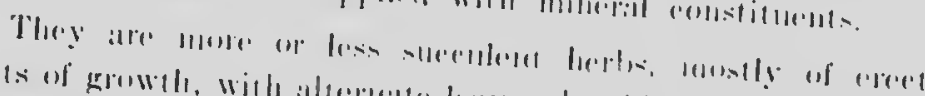

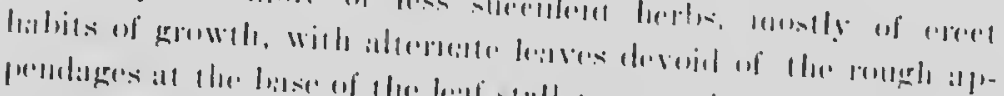

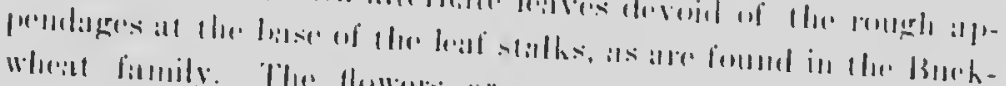

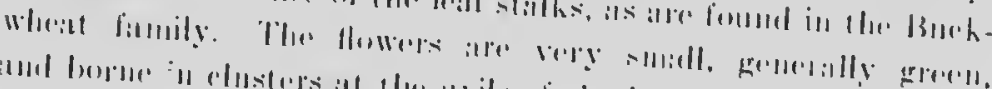

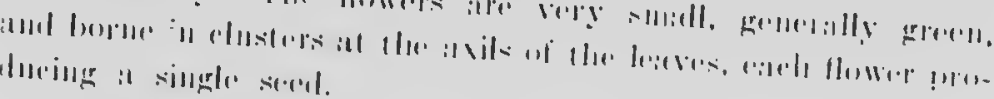

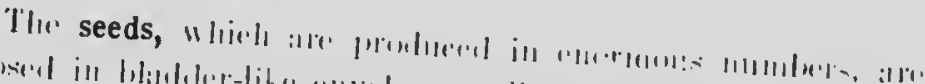
imporetast

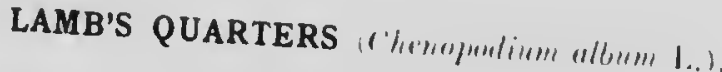

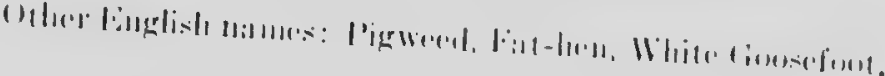

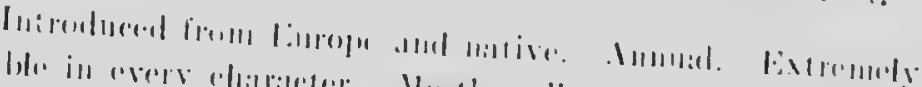

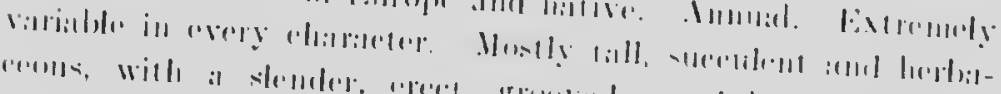

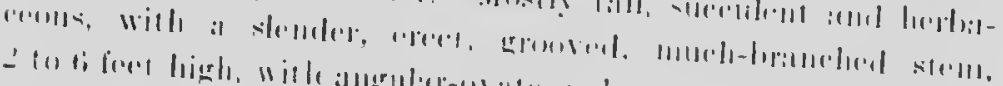

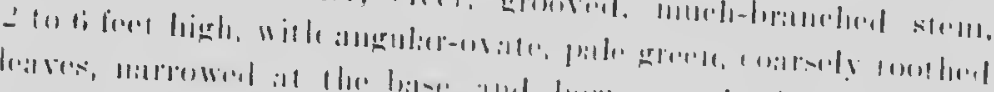

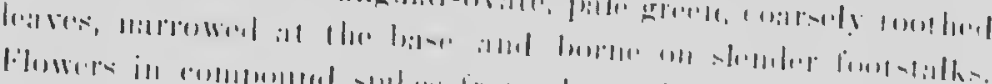

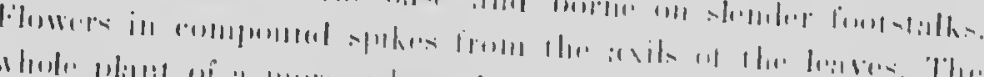

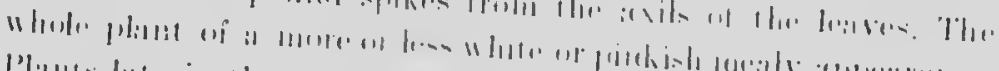

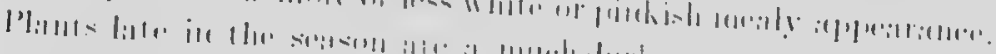
allelorl landres.

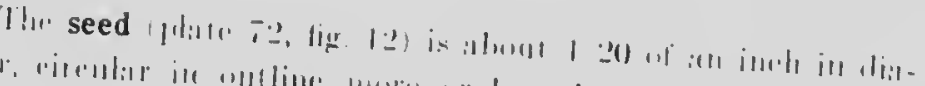

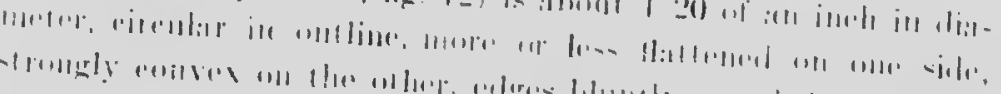

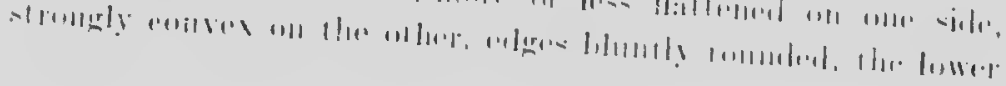




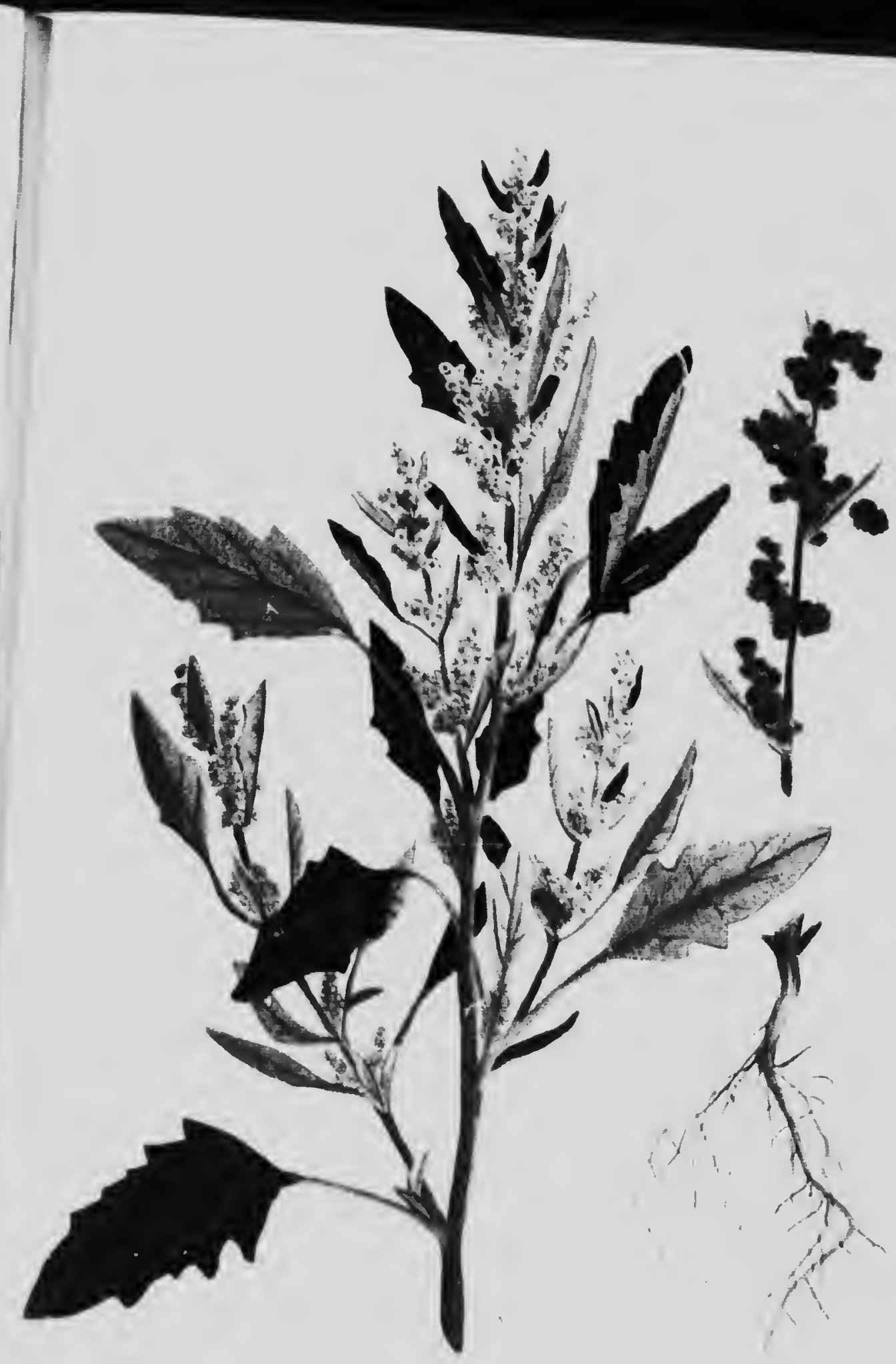




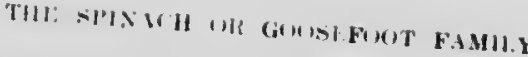

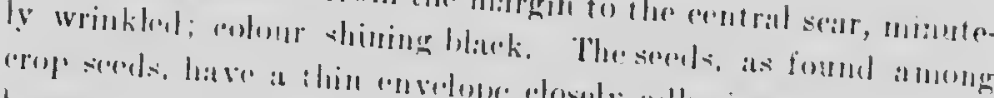

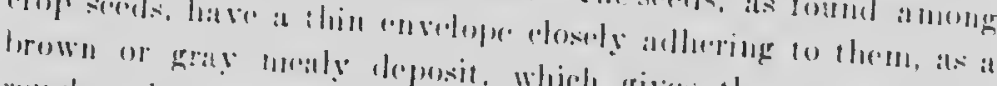

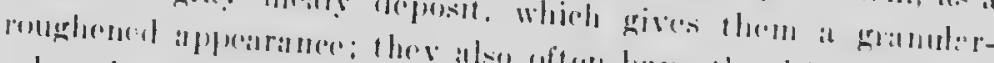

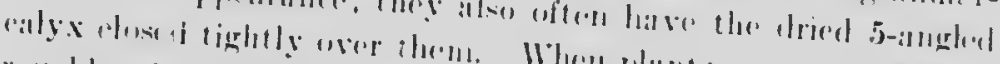

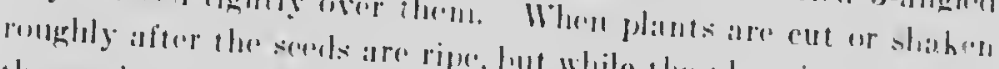

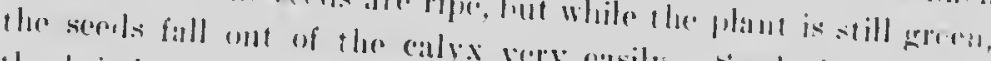

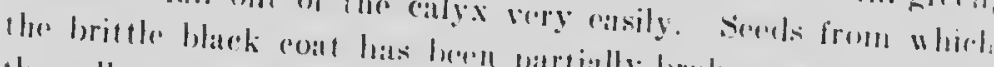

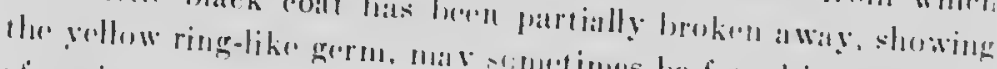
111 grain.

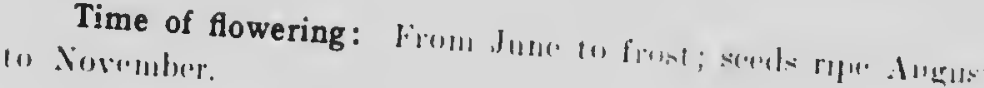

Propagation: 13y sivel.

Occurrence: liverywhere in rivli land.

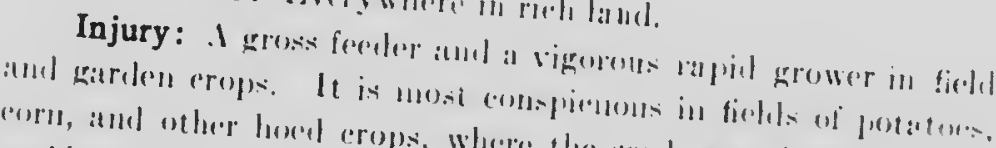

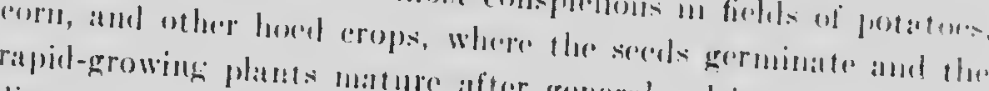

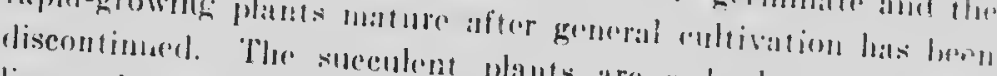

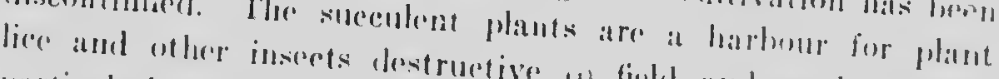
particularly on matugels.

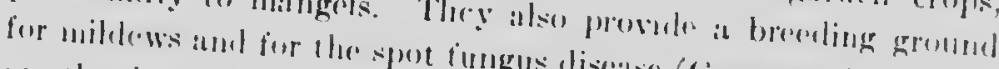

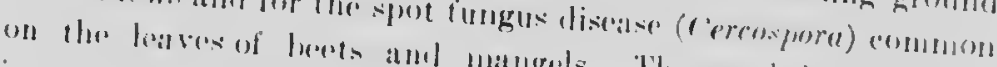

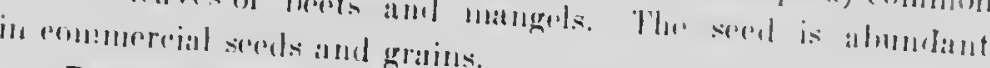

Remedy: The rechs grails.

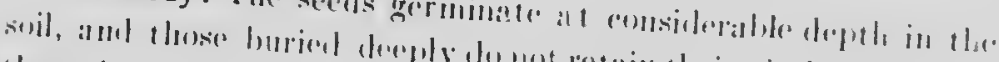

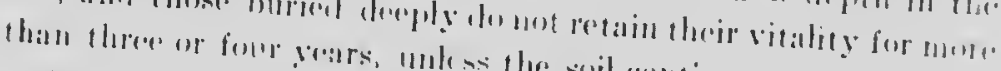

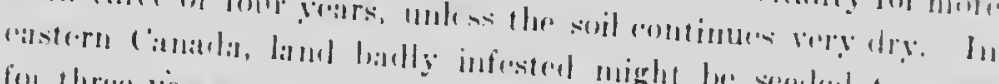

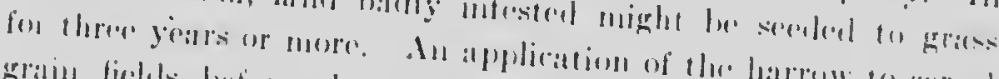

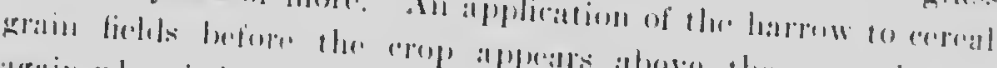

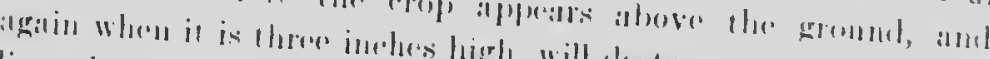

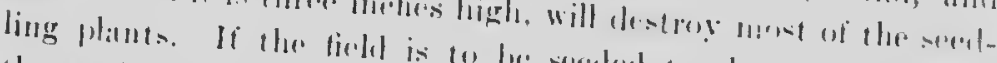

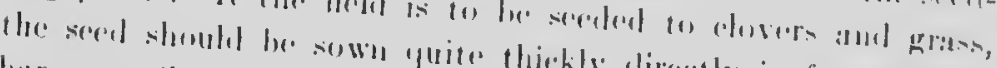

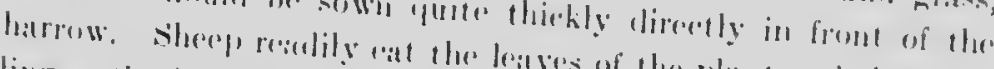

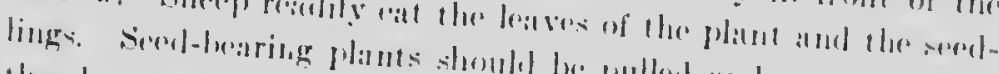

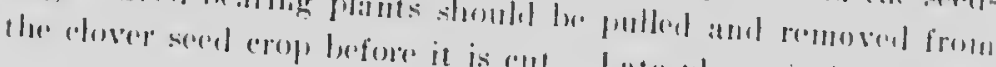


iI

$1111111+1110+111$

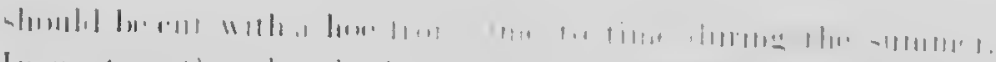

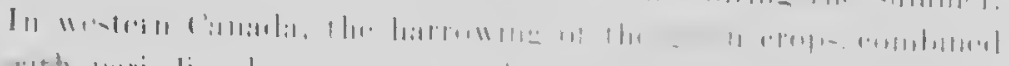

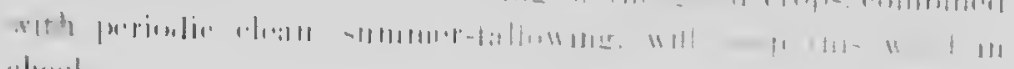
$1 \cdot 1, \cdots k$.

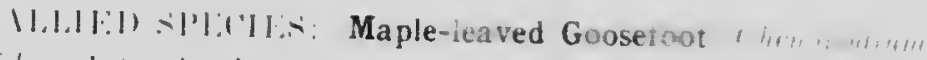

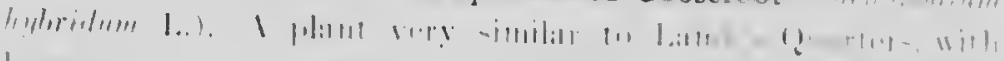

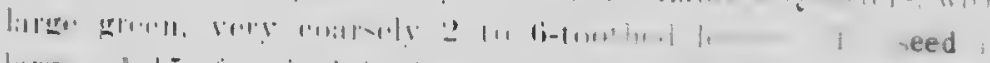

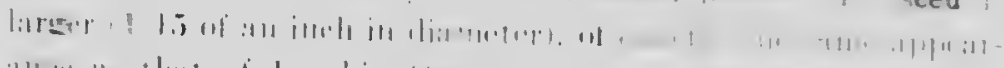

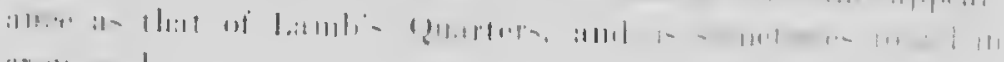

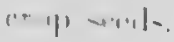

RUSSIAN PIGREED 1: mmonmmil 1

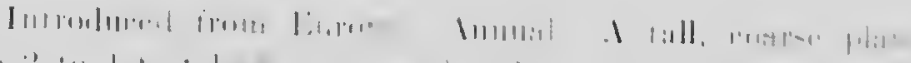

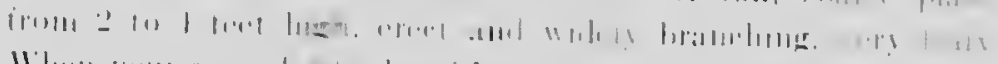

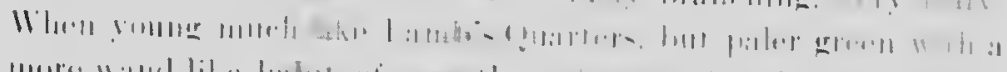

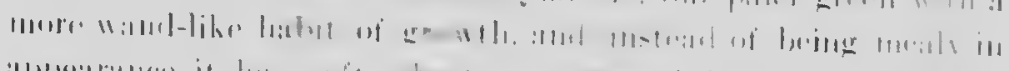

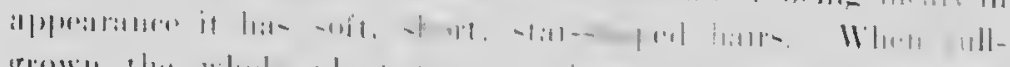

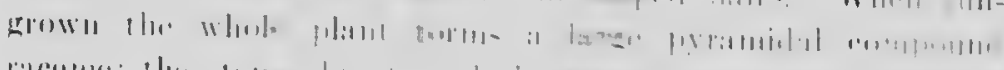

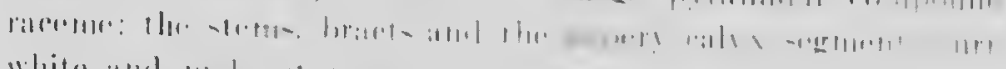
whitr and |alish.

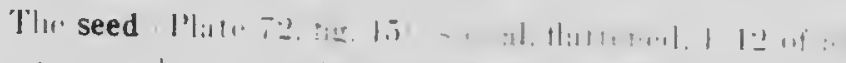

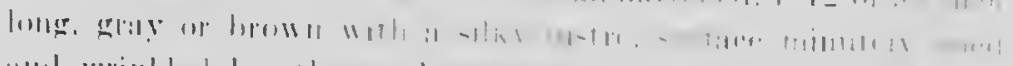

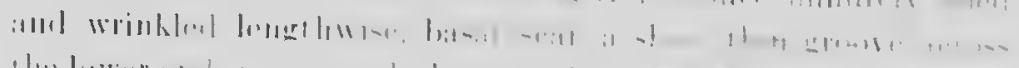

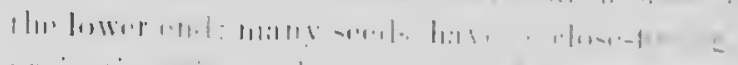

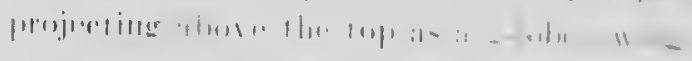

Time of flowering: 1.,

Propagation: 13!-1,1-

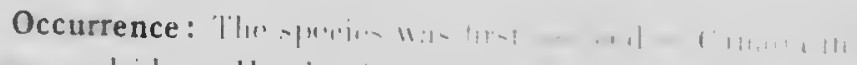

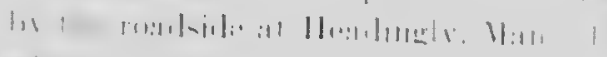

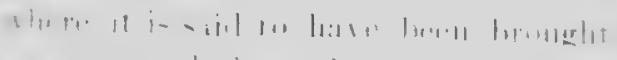

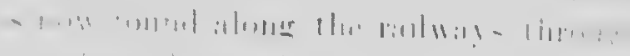

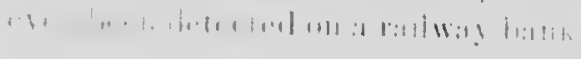




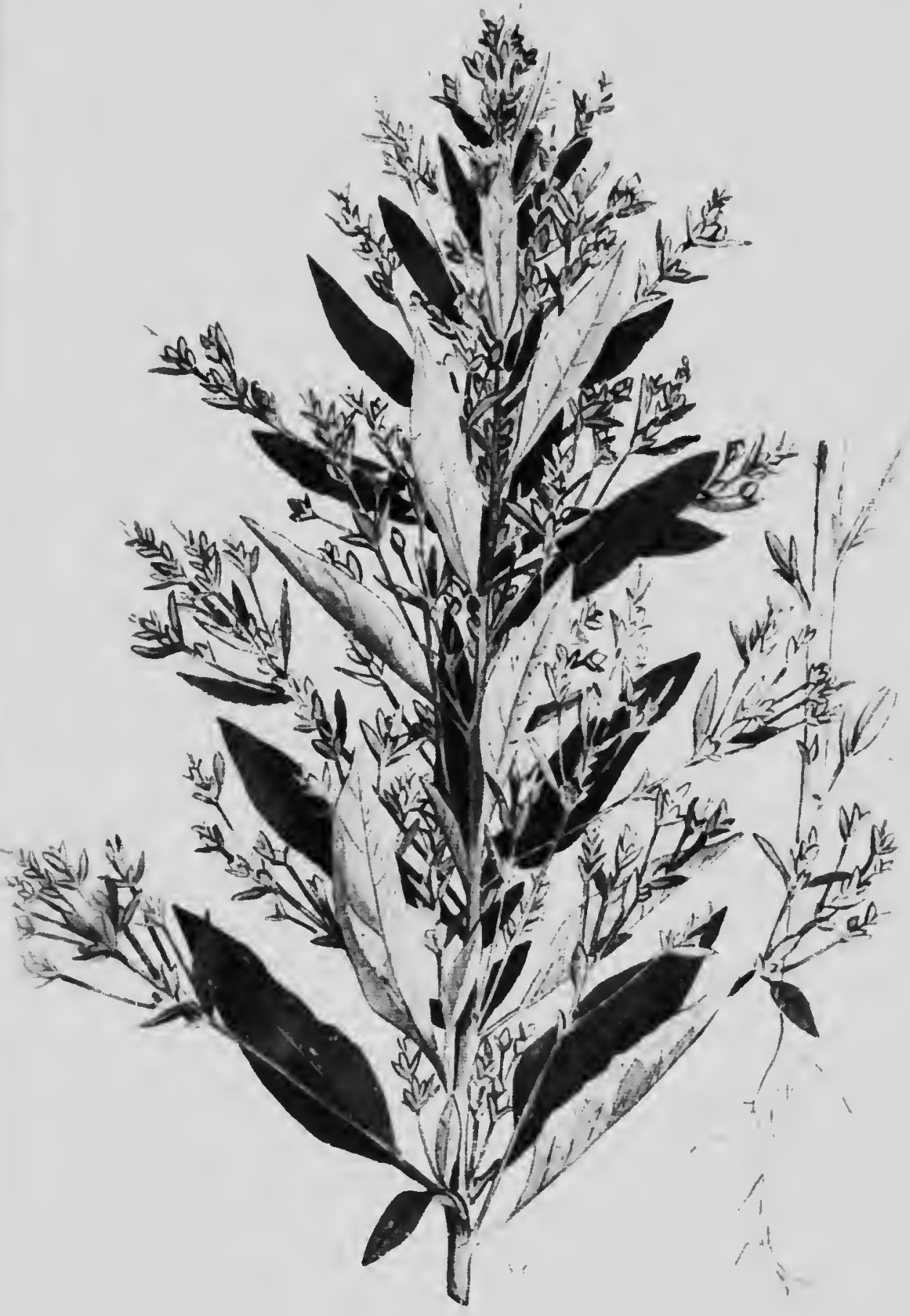




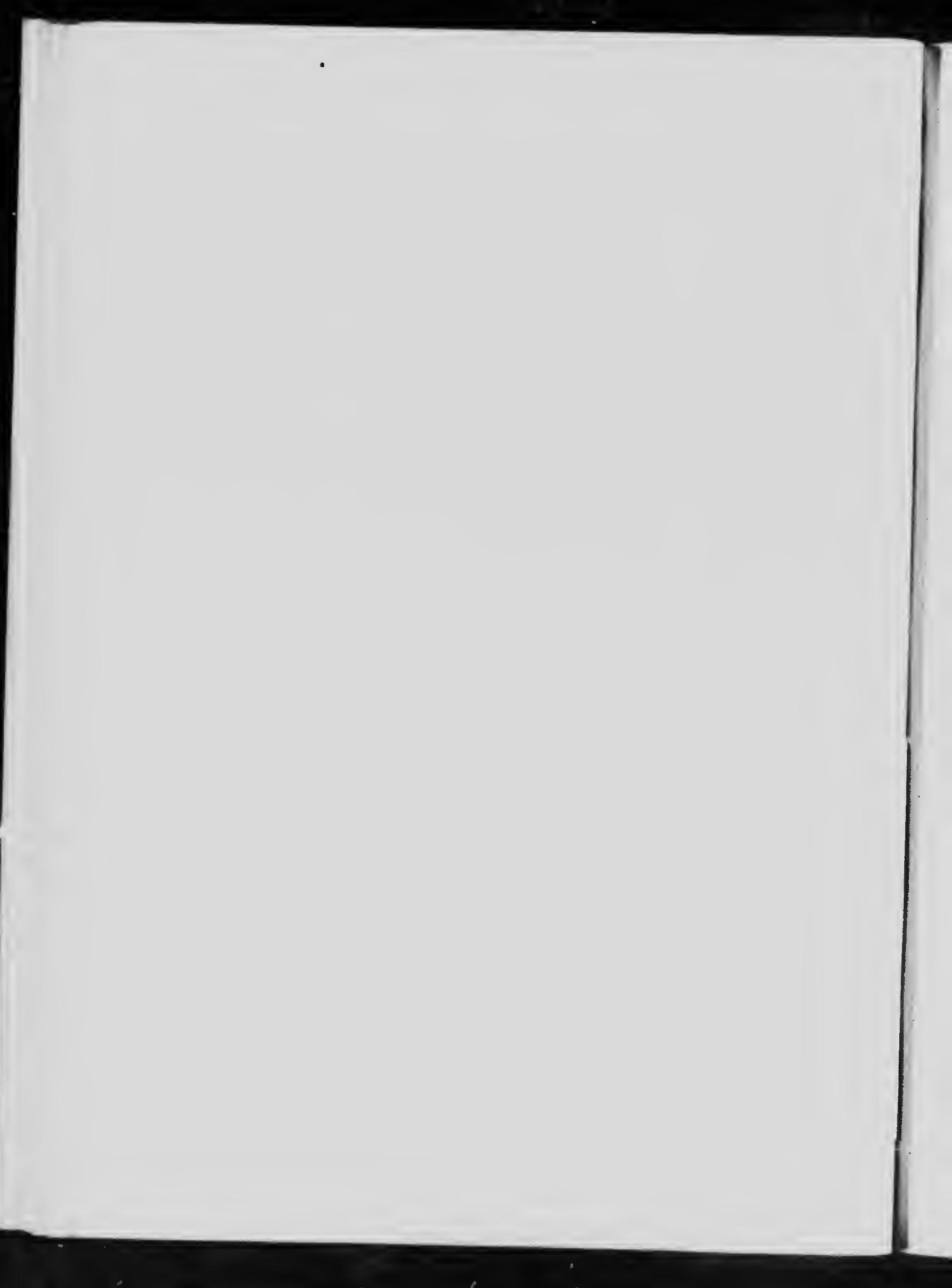




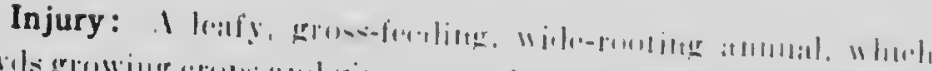

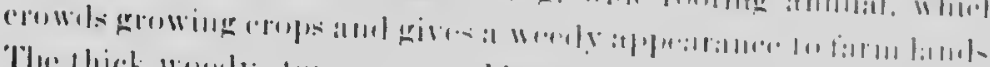

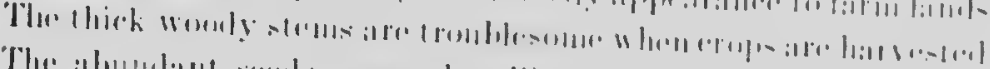

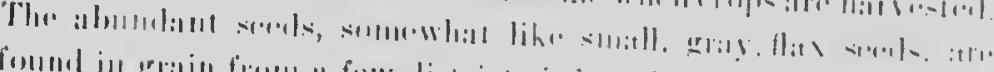

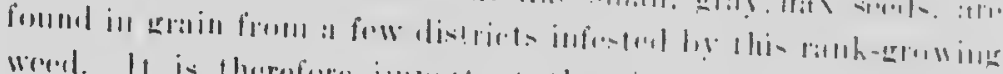

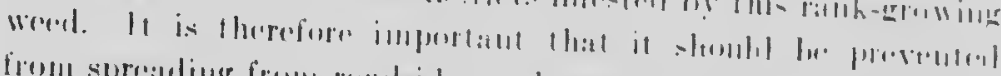

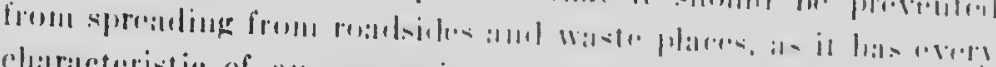

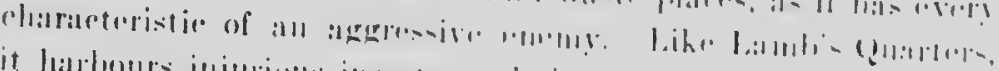

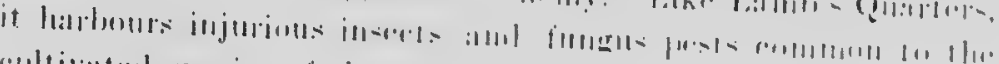

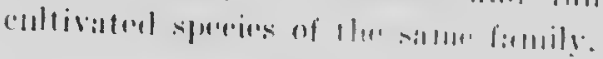

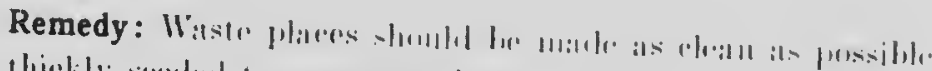

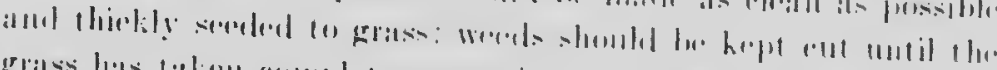

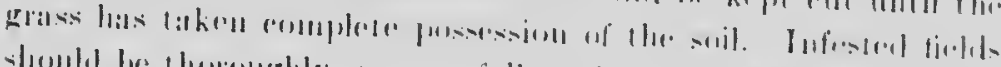

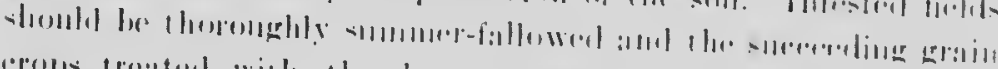

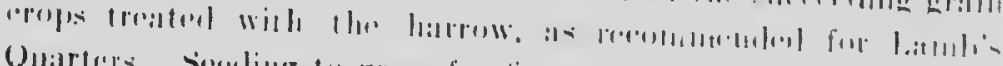

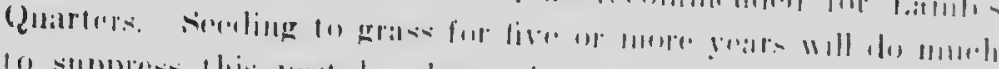

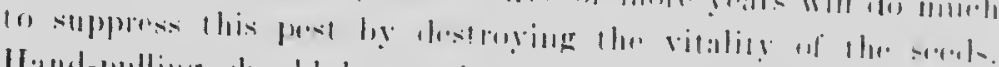

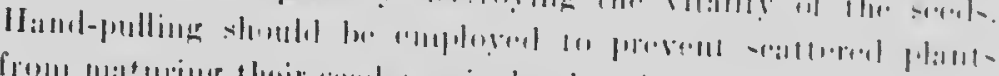

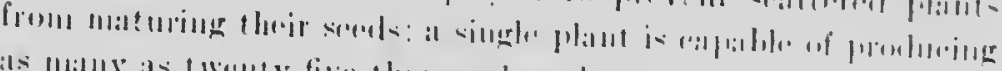

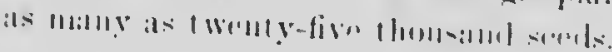

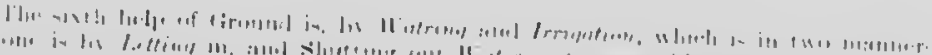

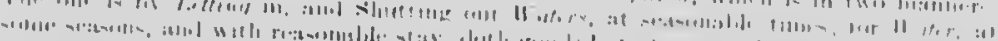

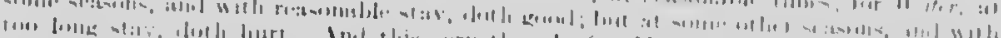

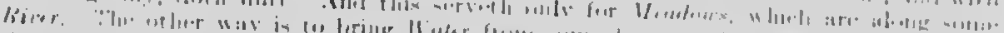

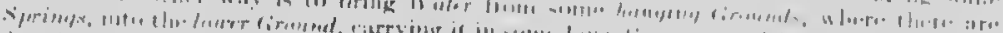

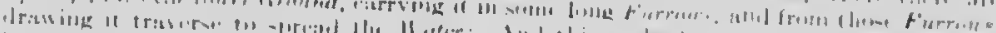

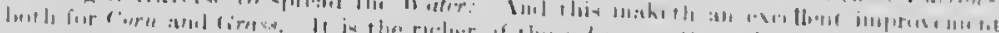

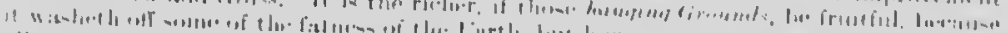

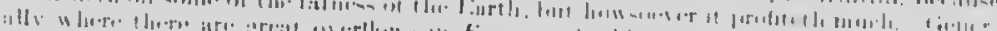

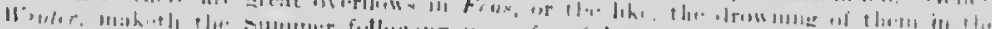

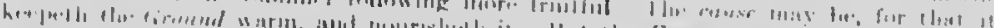

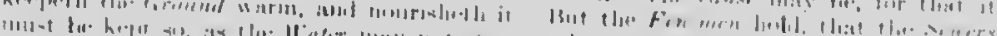

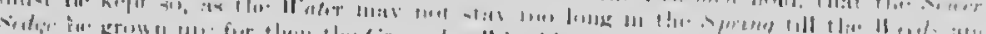
low! -14 …ent

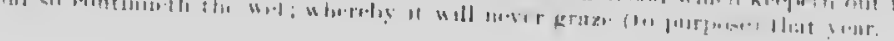




\section{RUSSIAN THISTLE (Salsola Kali I., var. tenuifolia G.F. W. M(y.).} Mog.

()ther English names: Russian Tumbleweed, Russian Cactus. ()ther Iatin nauses: Salsola Tragnes L., Salsola Kisli var. Tragnes

Introducel from Asia. Ansual. Bushy, of a prickly apfrarance, the to the long, thin, threal-like, prickle-tipped leave which eharacterize the young plant, and the short, triple, spiny bracts on the flowering branches of the older plants. It varies in appesance at different stages of growth. The young plant is dark green; the slemler laaves, about two inches long, drop off sori after the seed is formed. The somewhat spherical brauched top of the mature plant, when broken away froin the root, is blowll about by the wind and scatters its seeds widely. It is not a thistle and coull be more appropriately called a tminbleweel. Flowers solitary, borme in the axils of the l'aves.

The seed (Ilate 72 , fig. 13) is about $1 / 16$ ol an inch in diameter, cone-shaped, the large end concave with a well marked protuberance in the centre of the eavity. The coat is thin and trausparent, showing the grayish-brown, coiled germ. It is geuerally enclosed iu a papery envelope, the divisions of which are winglike and help to disseminate the seed.

Time of flowering: July to September; secels ripe by August.

Propagation: By seeds. The scels are distributed by the tumbling plants, which ar atrian by the wind. As the serels (b) not shell reallity, they ane arried long distanees.

Occurrence: Abumbant in several localities in the dryer parts of southern Aborta and Saskatehewan, chiefly along roadsicks, fire-guards and in unglected fields. Frequently foumd, though not seriously trouhlesorue, in the eastern provinces.

Injury : Russian 'Thistlo is a large, succulent weed and thrives where the laud is too dry for other plants. It thus usess up moisture where it is scareest and most neoled. Owing to 


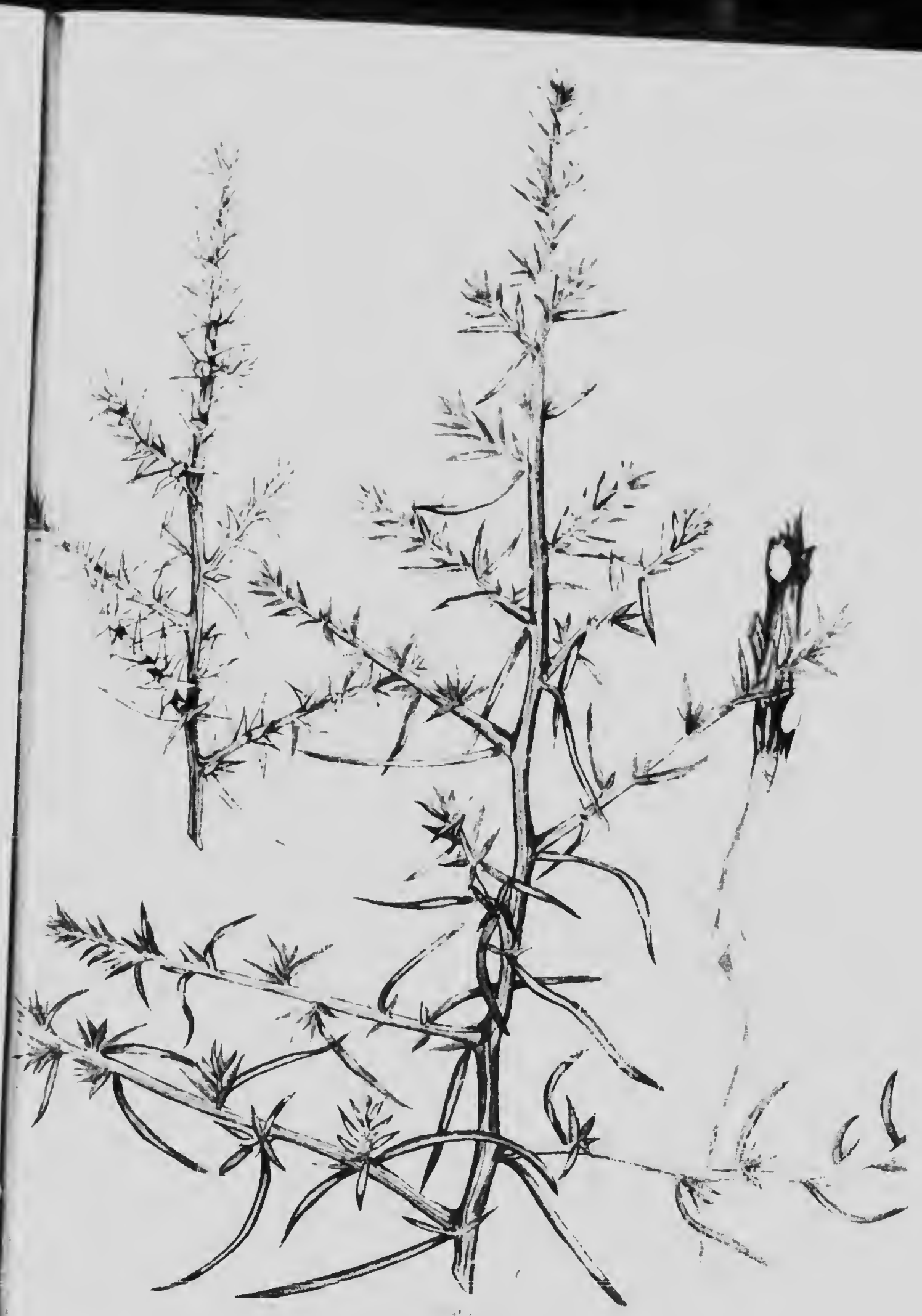




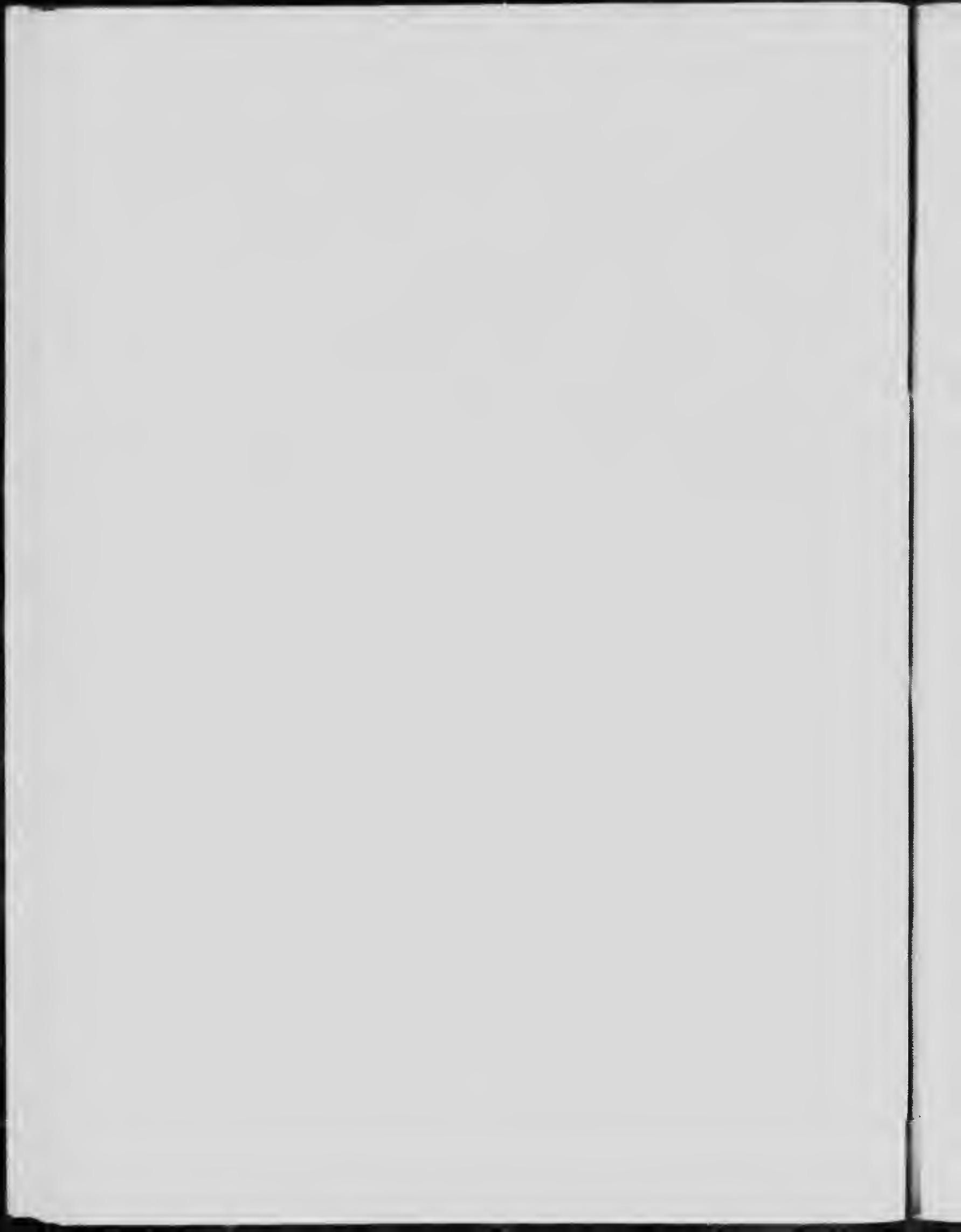




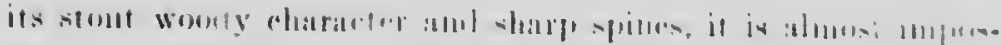

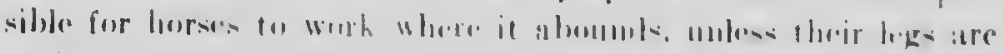

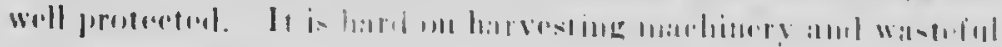
of himlar twim.

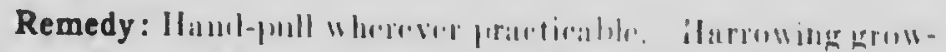

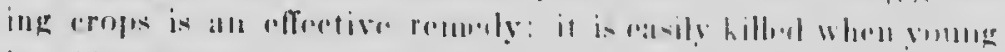

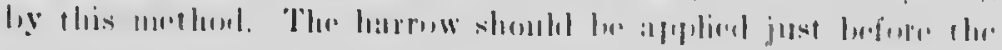

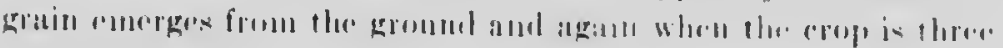
imehess high.

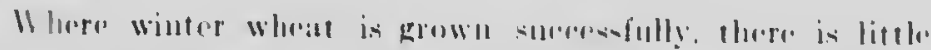

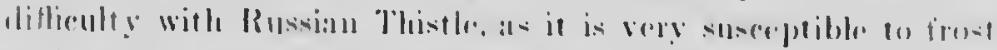

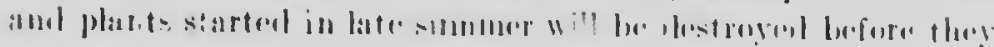

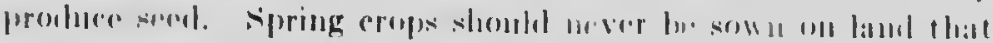

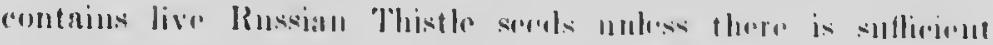

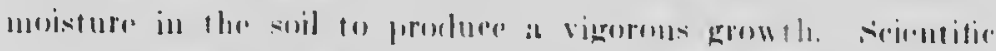

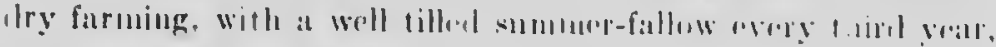

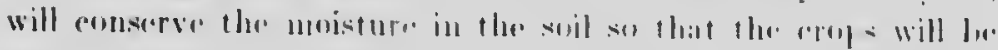

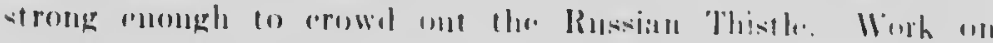

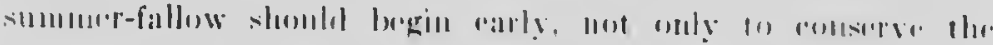

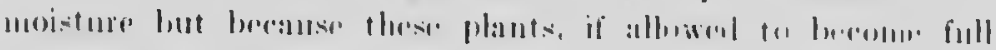

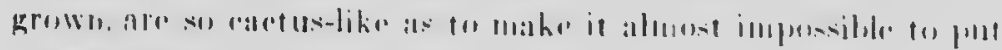
hurstes alluolug thentl.

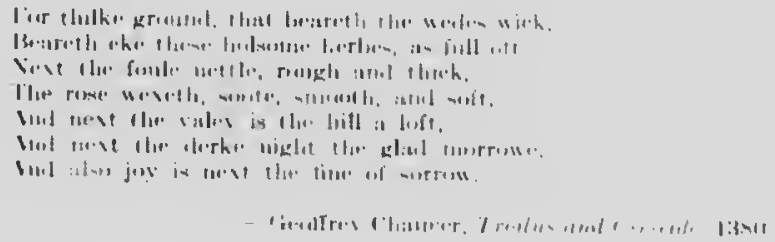

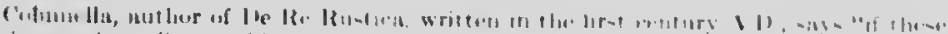

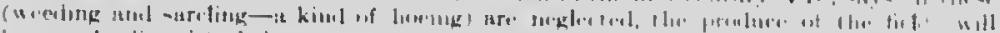

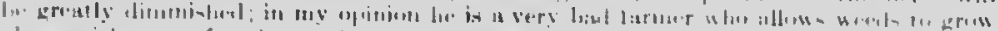

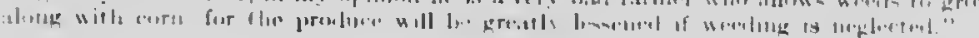




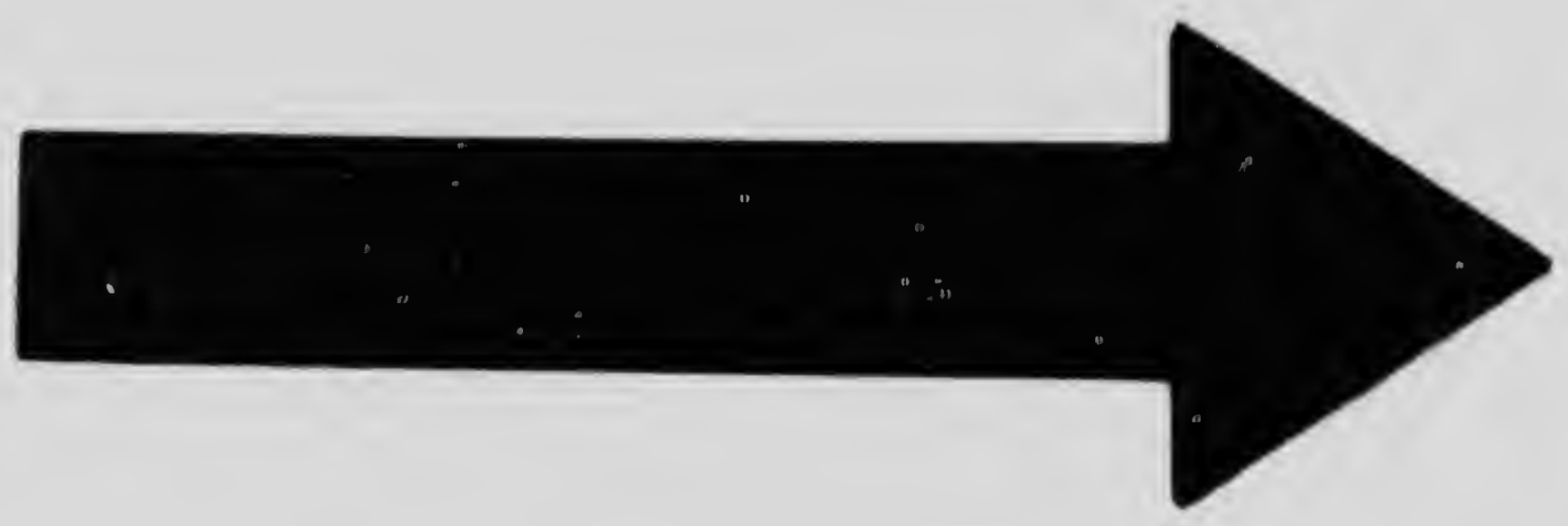


MICROCOPY RESOLUTION TEST CHART

'ANSI and ISO IEST CHART No 2;
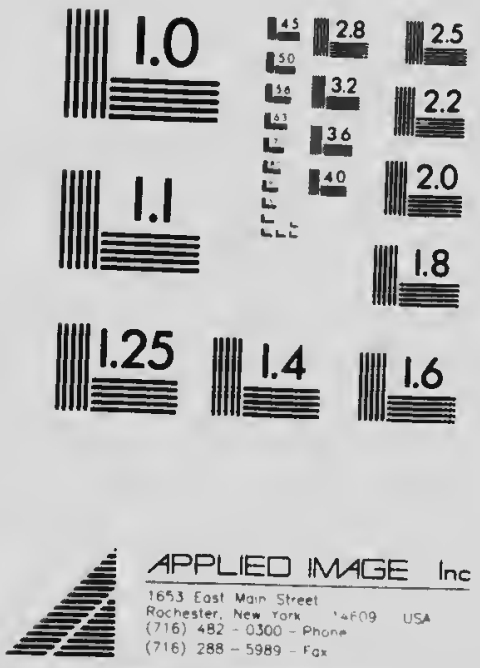


\section{THE PIGWEED FAMILY (imminthacou).}

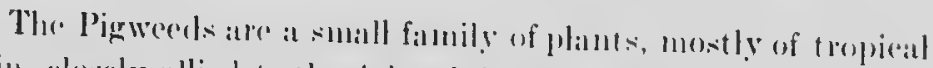
origin, closely allied to the spinateh fantyly. Lateh plant prochnes ('normous quantities of small, highly-polisherl, lons-shapued, more or less margined secels. The flowers aresmall and inconspiemens: leaves simple and berme on a stalk. Some of lle exotie nerm-

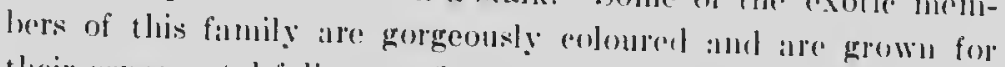
their on'manental folliage or flowers, as the Cockscombs (Celonin), Rainbow Amaranth (Amarmthus trivol, l..) and the well-hulowil Love-lies-bleeding (.Imararthus raudutus: L.).

The seeds alre borne singly, as in the spinileh fanily, onelosed in a thin, antilaginous covering known botanically as " "utricle." Lnless colosely cximnimed, they maly sometimes be confused with rubbed serels of Lamb s (Quarters. The surface of the Pigweed secerls is al ways more highly polished and smootloe?. The sear is the asjest point for distinguishing them: thise is a central print, with a long groore on one sidle, in Lambis Quarters ant at notwh in the maldegin in the Pigwerels.

\section{REDROOT PIGWEED (Amaranthus retrofterus L.).}

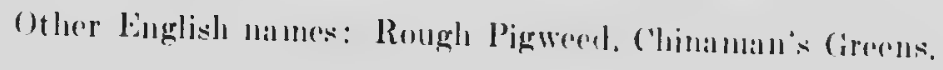

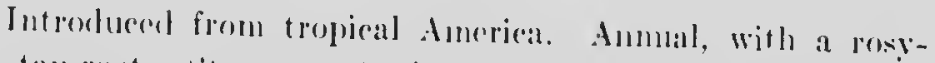
pink tap-poot. Strme ereet, simple or brallehed, romglh hairy. latives on long stalks, ovate, bristle-poninterl. Flowers inconsplenous, mmmerous, apowed into thick rompommel spikes at the chels of the loranelaes and in the axile of the leavere dracts

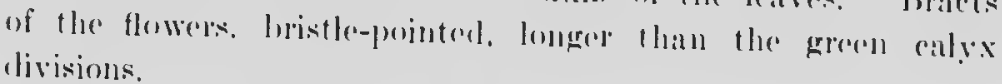

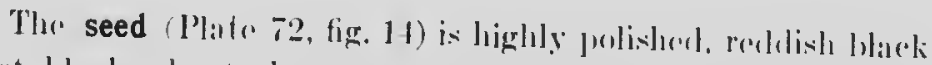

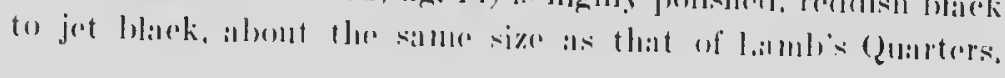



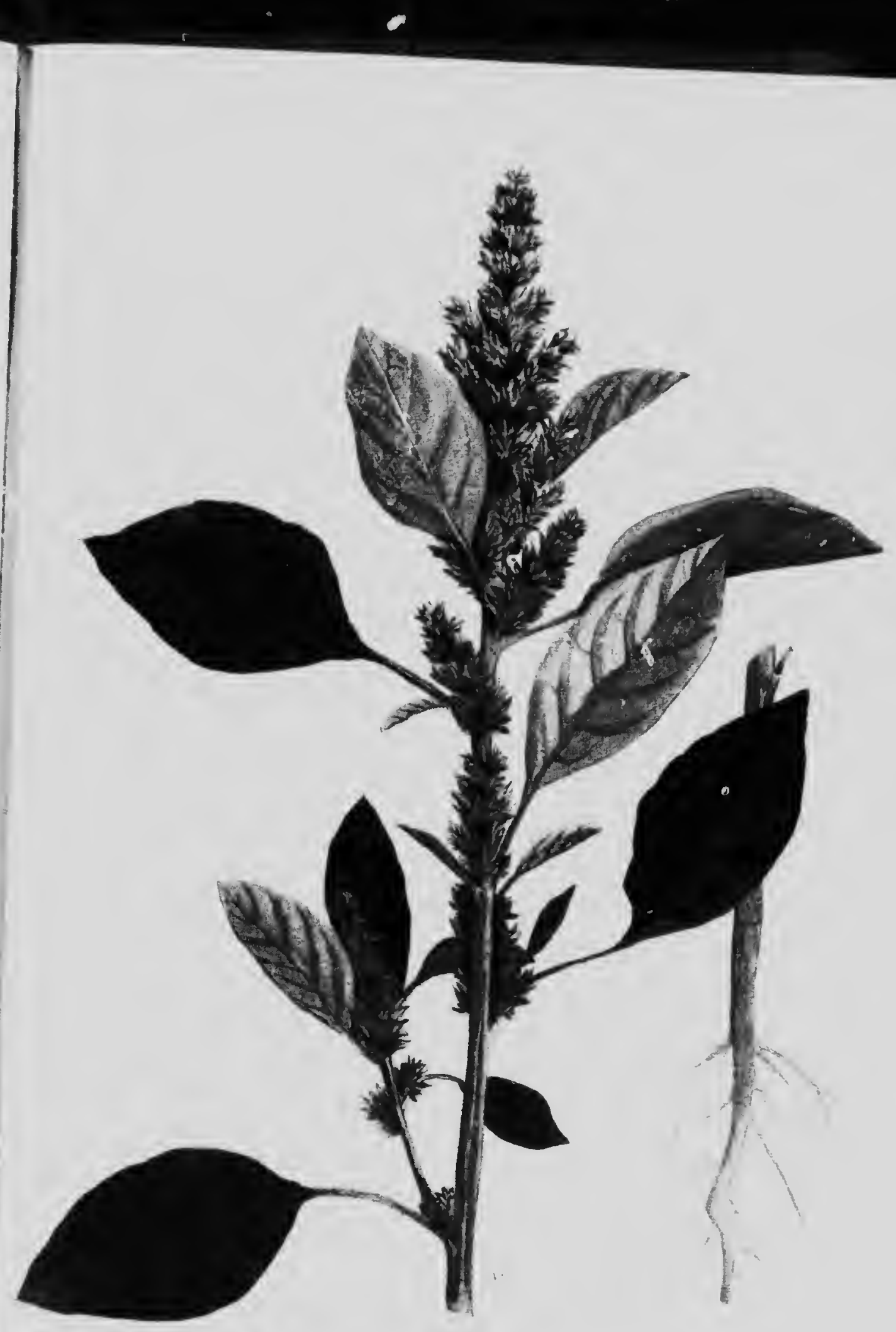

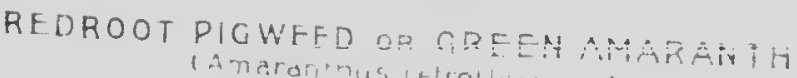


cireular or eggeshaped in outline, muteh flattencel mol erpually conslightly. the ring-like germe. Thereal band, which marks the location of The basal scar alperalse, ats a light point on the erlye of the secel separating the combs of the germ.

Tine of flowering: July to siptember; serel ripe ly dugust.

Propagation: I3y seeds.

Occurrence: In all crops. Thonoughly establishol in all the solted portions of the Doninion. Abunclant in waste placess around farm buildings and in gardens. Widely spreal by the sorels, which vecur eommonly in all commercial seeds.

Injury: A pestiferous weed in gardens and ficlds; especially troublesome in potato and ficld root crops. It is a eoarse, vigorous growor, and when it has attained to full sizc, is lifficult to lestroy by pulling or eutting. A medium-sized plant will produce fully twelve thousand serds.

Remedy: When embedded in the soil, the secels retain their vitality for several years, though probably not more than five in a inoist soil, and produer seedling plants only when brought by enltivation within about two inehes of the surface. Late cultivation in hoel erops should be malle as shallow as practicable; ufter goneral cultivation is diseontinued, plants of this and other weeds that have eseaped siould be cut with the hoe from time to time during the late smmmer months. Like other anmual weeds, it ean rapilly be suppressed by preventing the pronluction of a fresli supply of seerls.

Al.LIFI) SPECIES: Green Amaranth (Amaranthus hybrdu. I.) is quite similar to Redroot l'igweed, but smoother and deeper green in eolour. with spikes more slentler-cylindrical, and bracts with rather long awns. The seed is mueh like that of Redroot Pigweed and, although areraging rather smaller, about $1 / 32$ of an inch in dianeter, can not always be distinguished foun it when fomd among crop scels. 


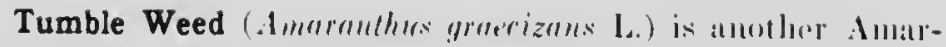

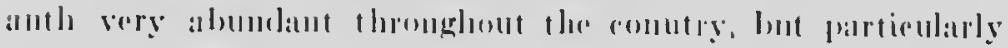

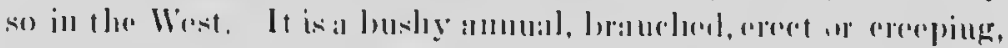

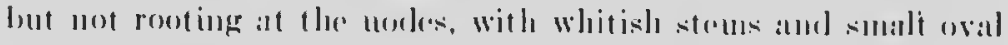

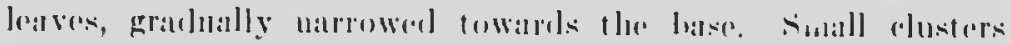

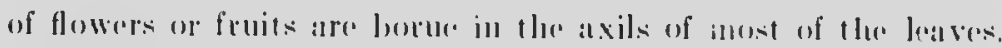

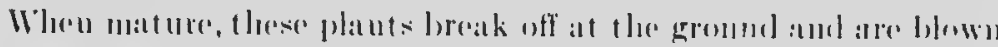

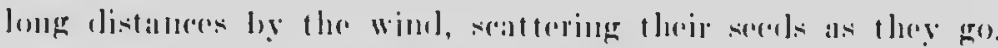

Spreading "1' Low Amaranth (Amrormthus Mitoidex. Witsou).

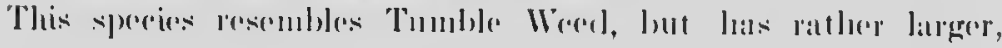

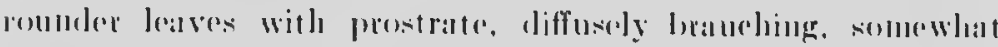

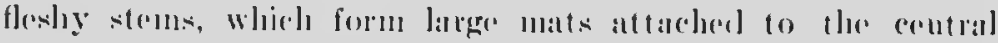
ront. This is a mative of the western pratries lont is freptuent

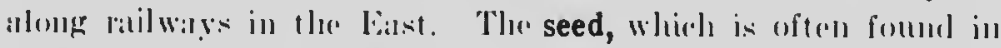

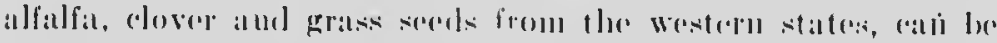

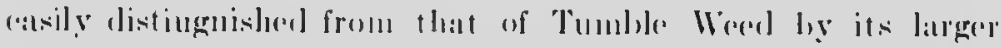

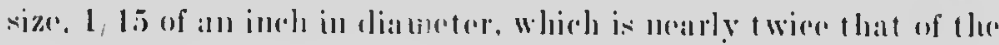

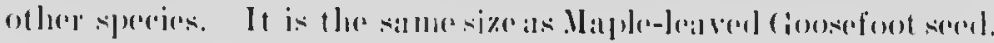

\footnotetext{
II.r fallow lo:its

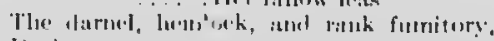

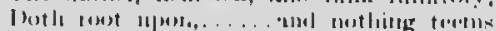

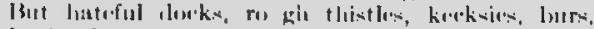

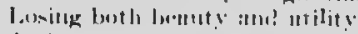

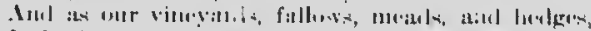

1).fortive in their 1:atures, grow te wildares

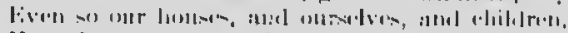

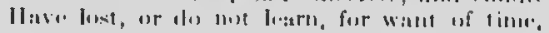

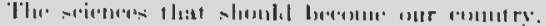

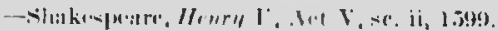

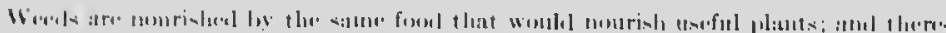

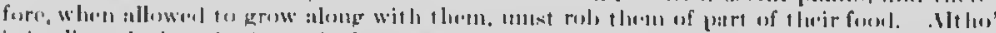

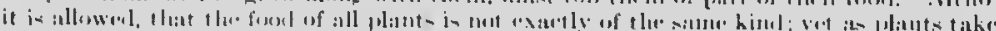

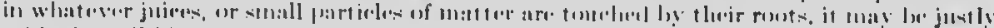

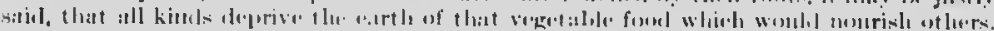

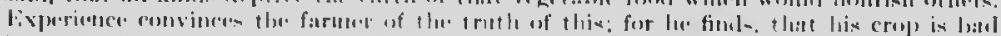

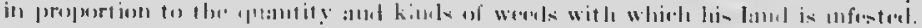




\section{THE PINR FAMILY (Car!m) h!lllucenc)}

Thr Pink family is withly distributed all arer the world, most

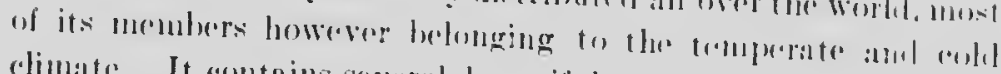

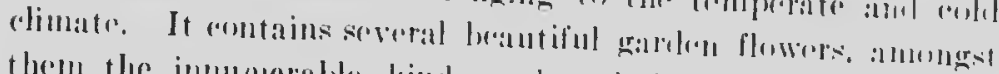

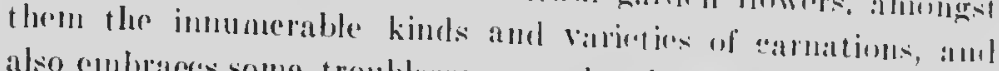
also embracess some tromblesome wereds, the sorels of which alre frequently foumd in clover and grass serols. Ther chatracters of all the weeds bolonging to the l'ink family ane woll unaterel. They are horbs with britte stems, articulated and thickencel at the joints, frequently forked. Laraces withont teether or divixions. generally opposite and joined round the stem at the base. The flowers are regular. The ralyx is always persistont and the

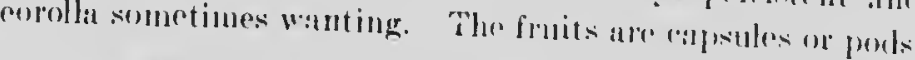

The seeds, usually many, alle attachecl to the hase or to al

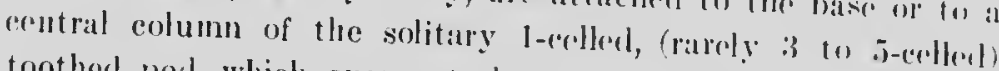
tootherl pod, which opens at the top. They aro often kidueyshaped and embossed with tubereles. The germe in most of the seeds is murverl so that the apex and base come close togerther. The soeds do not develop mueilage when sobked in water.

They are eovered with a harel protective cout, throngh which the water will penetrate slowly, thus kerping the vitality of the sered and delaying its germintion for many yoars when rmbeblont in the soil.

They are two tribes of these plints: tiar Chickweeds (Alsineae), low horbs in which the calys divisjons atre distinel of nearly so, and the erorolla divisions provided sith short clinus; and the Cockles (rilenene) with latge and showy fhowers, with the corollat divisions muitod in a tube and proverlonl with long claws.

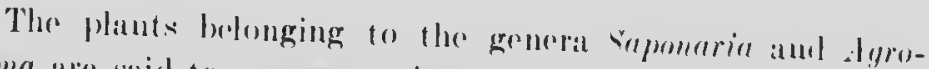
sfemma are said to possess a poisonous principle (sapotoxin) to al greater costent than the other members of the Pink family. It is 
a matter of common observation that all the members of this large family possess a pungert flavour objectionable to all classes of live stook, and the presenee of the plants, either in pastures or in cured forkler, entails considerable waste. Infinite information as to the buneful offects, if any, resulting from the consumption of the plants or tle secels is not avaliblje, altlongh it is known that wheat sereenings, eomposed langely of cockle serels, are ground with coarser grains and solel ats foreding stuffs.

\section{SPURREY (Spergula arrensi.s L.).}

()ther Linglish nanes: Corn spurrey, Sandweed, Pickpurse.

Introduced from kurope. Annual. stems curving upward, branching from the base, 6 to 18 inches high, almost smooth, *jaringly hairy above. Laraves narrowly lincar, 1 to 2 inclies long, apparently in a circle around the joints of the stem but rally in two opposite sets of 6 to 8 together, with scalc-like, enodifiel leaves betwern theus. Flowers white, opening in sunshine, $1 / 4$ inch across, in terminal forked cymes; the fruit hanging ubruptly dewnward.

The seed (I'late 72, fig. 16) is dull black, leus-shaped or round and compresserl, with the margin extenderl into a narrow pale wing. The surface is more or less roughenel with small, palecoloured, clongated protuberanees, like gland-tipperl hairs. l3oth the small protuberaness and the wing are sometimes absent when the seeds oceur among commereial secds.

Time of flowering: July; serd ripe July-August.

Propagation: By secrls.

Occurrence: Frequent in grain ficlss in the eastern provinres and in parts of British Columbia and occisional in fields and 


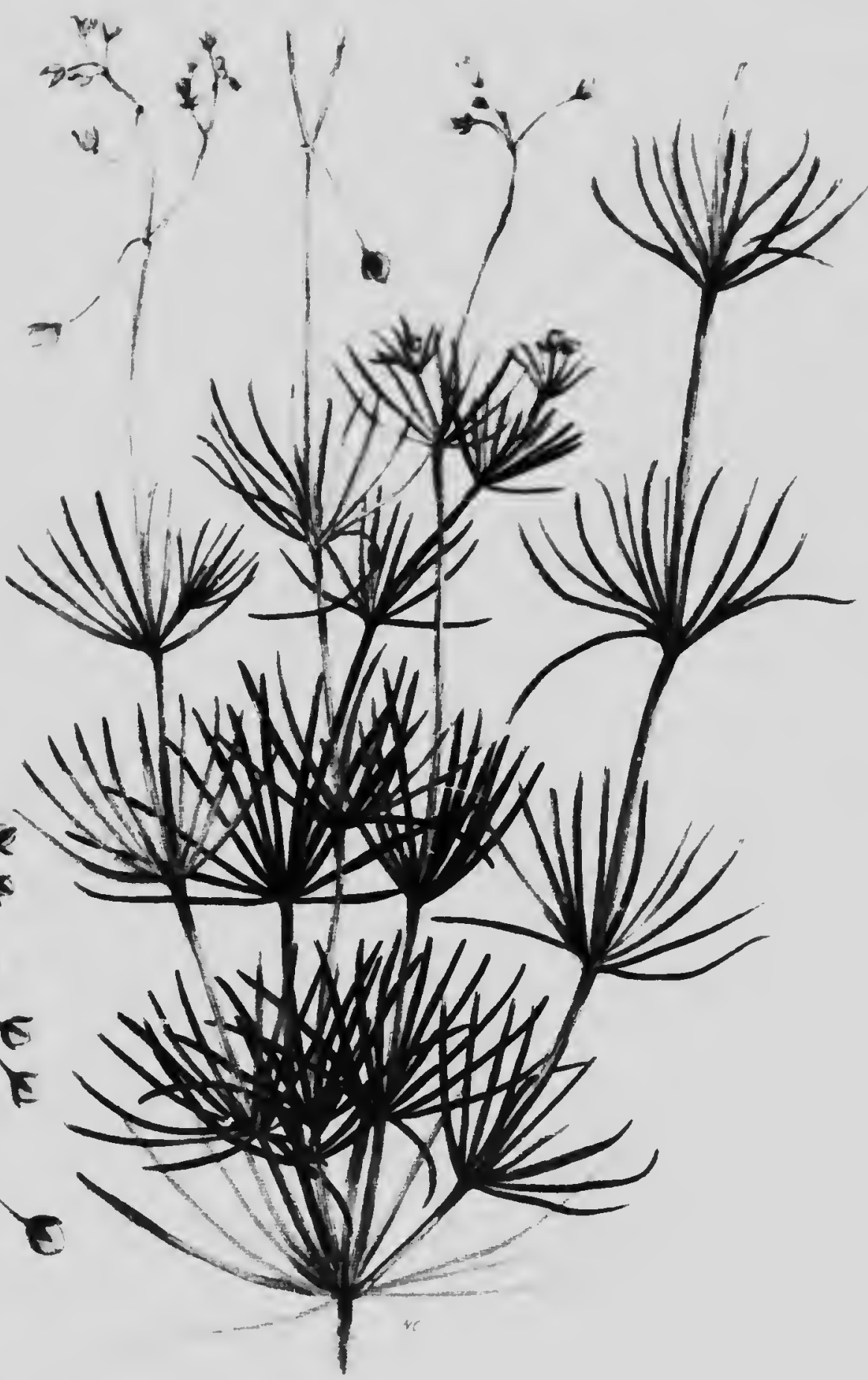

CORN SPURREY

ISpergula arvensis. 


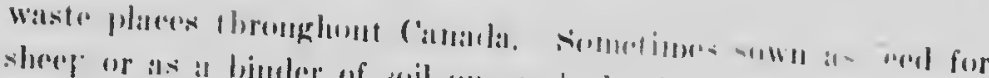
sheref or as a bimeler of soil on silumly lambl.

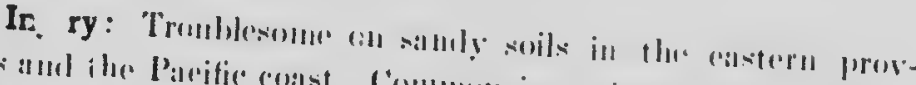

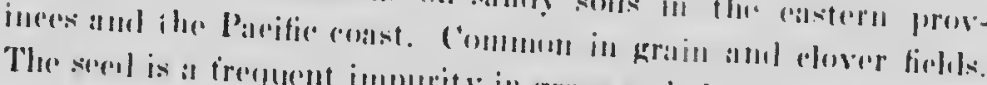

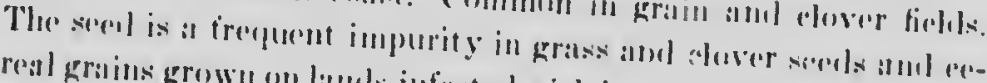

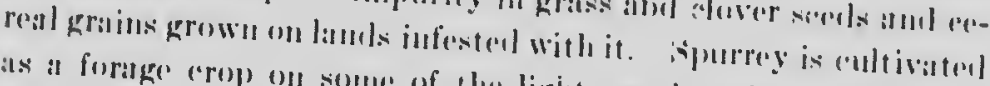

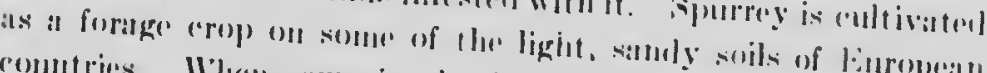

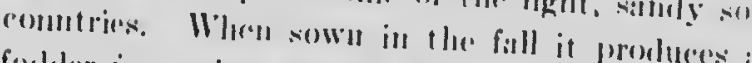
forloler bor spring foending.

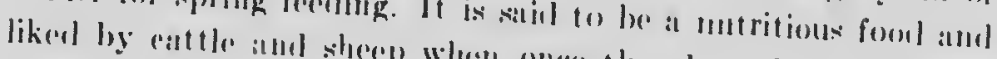
tomerel to it.

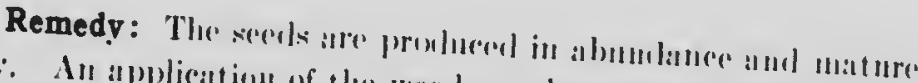

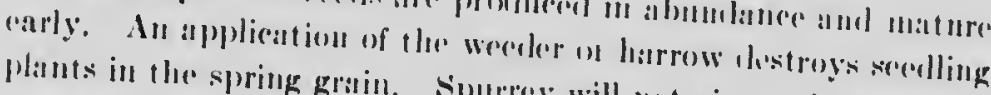
plants in the spring grain. Spurrey will not give sorions tronbla on Jamels worked mmler a systomatic arope robiation. Silatlow

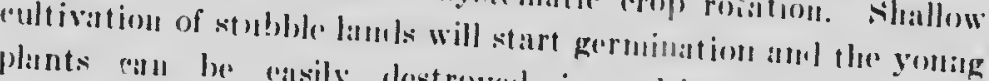
plants ent be casily destroyerel in eultivatiog for spring

Which seme the hene prefer,

The elhilitimale hamts, ar, if of lighter make.

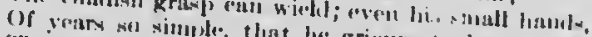

Mice pretes thewery that he grieves to hurt

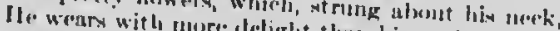

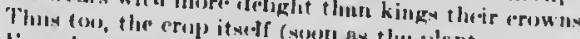

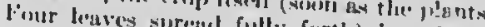

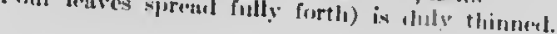

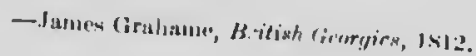

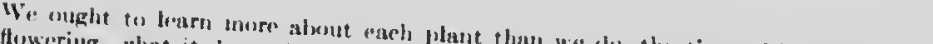

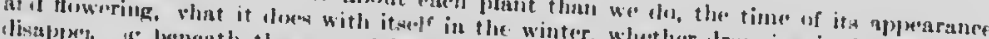

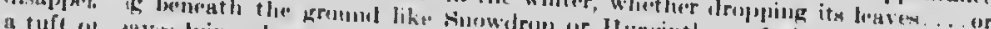

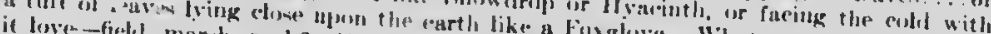

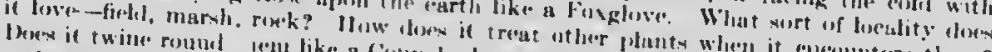

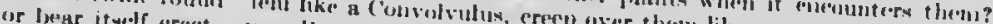

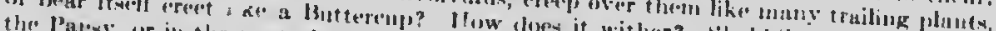

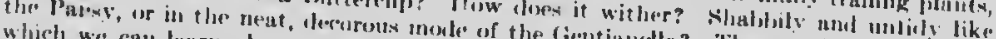

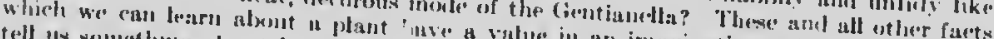

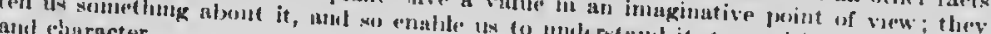

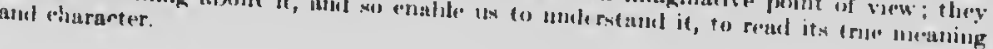


COMMON CHICKWEED (Nivllurin medin (b.) ('yrill.).

(1) leer linglish nume: Chickweenl.

()her latin name: Alsine media l..

lutroluced from Europer. Annual, sinceulent, stens diffusely braneling, rurving upwarel with a tendeney to lin down. linots, hair-like anul rxeeedingly tough. Heaves ovate, the foot-talks of the lower ones hairy on the margin. Stems bearing a conspicuous -tripe of artieulated hairs down one silde. Flowers 1. I inch in thancter, star-shaped, numerous, solitary from the axils of the leaves, in old plants in terminal leafy eymes; corollat white, about the length of the thin-margined ealyx. Fruit capsules, cone-shaped, spreading or langing down, longer than the ealyx.

The seed (Plate 72, tig. 17) is small, 1/24 of an inch in diameter, yellowish brown te dark brown, welge-kidney-shaped, llattened and covered with coarse tubereles arranged in regular ('urved rows, about 5 on cuels side and 4 on the edge.

Time of flowering: At all times of thr year execpt during frust; seed ripening eontinuon

Propagation: By secels.

Occurrence: This well-known little veed oceurs in all parts of Canada where the soil is moirt and richl.

Injury: A persistent grower, most troublesome in garden anl ficld hora rops. Its hiabit of seeding (arly and throughout

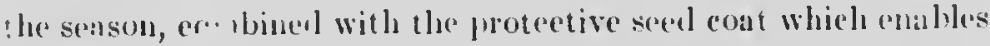
the seed to a...in its vitality for several year. makes it an execedingly diflieult pest to extorminate. The serels are frepuently present in grass and elover seeds. Chickweed larbours plant liee.

Remedy: This wool can bo suppressed by elean eultivation of hoel erops-the last general cultivation should be shallow, so as not to bring a fresh supply of seeds to the surface-aud discing of bare stubble lands direetly after larvest, to aluech 

further seceling. Good hainage of infested areas is also helpful. Thiek sereling with clovers and grassess is offective in smothering
it out.

\section{MLLIED SIECIES: Grass-leaved or Lesser Stitchwort (Stel-} laria gruminea 1.) is a weed fonnd oesasionally in the Maritime Provines. It is a wide-hranching plant, 1 to ? feet high, with miny grassy laures in pairs along the slender stems and bearing namy starry white flowers nearly $1 / 2$ inch across.

The seed is offen fouml in elover and grass serel; it is the same size as Common Chickweed serel but more nearly eireular in outline. The surface markings are quite difforent; instead of bearing tubereles, the surface is thiekly covered with short corved ridges in more or less legular rows.

The Mouse-ear Chickweeds (Cerastium), two or throe of which oesur in Canala as weols, are somewhat similar to Common Chickweed but rasily distinguished from it. Theres plants have muele the sane habit of growth as Common Chickweed but are eovered all orer with downy hairs, which in sone speeies are glandular, giving a dirty appearanee to the plants by reason of the dust which allheres to them.

Field Mouse-ear Chickweed (Cerastium arven.e L.) in some places is a troublesome and persistent weed. A native form oecurs abuuflantly throughout the westorn prairies but gives little trouble. In some parts of Ontario, Quebee and the Maritime Provines there is a kind with smoother leaves, and copious rootstock: which conble the plant to becone a persistent enemy. Pastures or meadows invaded by it must be bohen up and elemed by a short rotation of crops. The flowers of Field Chick-

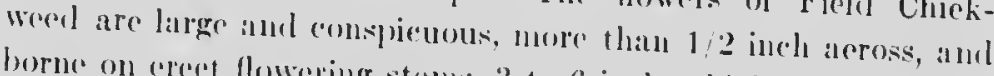
borne on creet flowering stems, 3 to fo inches high. In the llost the plant is sometimes grown for its beanty.

The seed is largere than that of the other chickwords here

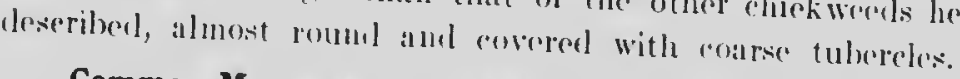

Common Mouse-ear Chickweed (Cerastium rulgntum L.) is a perennial plant which occurs in cultivated land, pastures and 
lawns thromghout camalat. The poeks atre much elomgated and

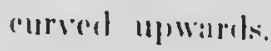

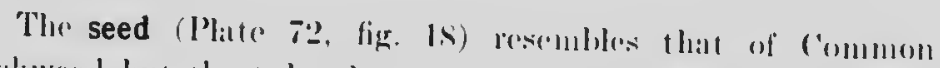

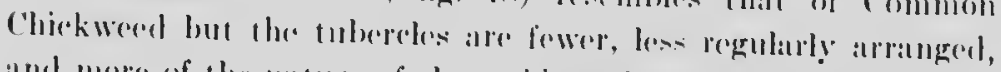
and more of the natture of short ridges: thath of low prominemeses, as in the formere spereses. It is rather more angular amel ant much mere than hatf the size.

\section{PURPLE COCKLE (.lyrostemmma (itlla!g! L.).}

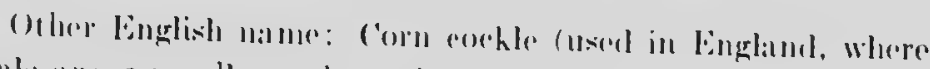

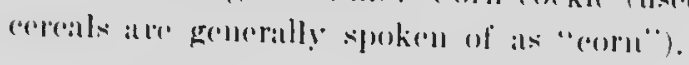

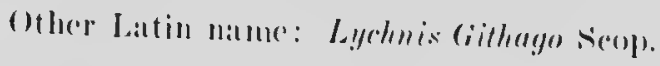

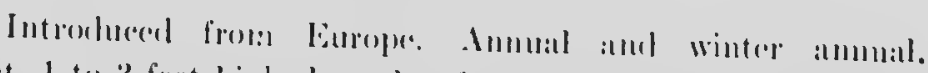

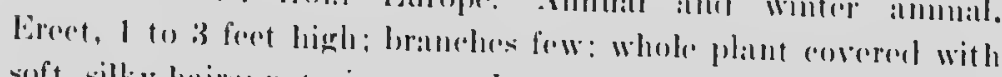

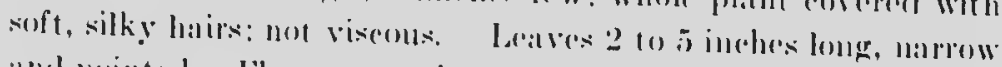
and pointed. Flowers purple, horde at the tips of the stems and branches, 11 inchess across: the eorollat divisions notehed at the

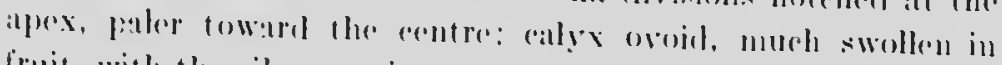
fruit, with the ribs prominent and the teenh long and anspien-

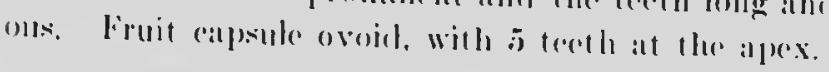

The seed (Plate 72, fig. 19) is pitchy black, from l 12 to

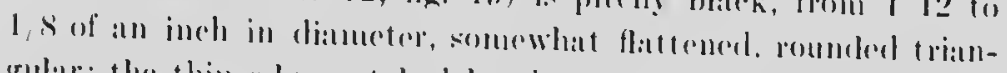

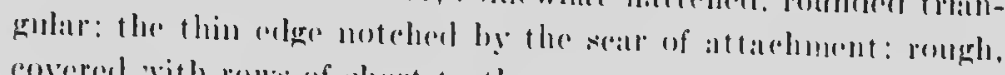
coverent rith rows of short troth.

Time of flowering: July: sirel ripe in .lugust.

Propagation: By socils.

Occurrence: In gratiu thronghomt ('allaliı.

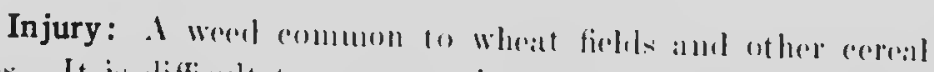

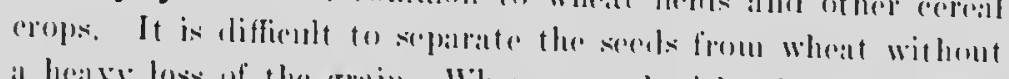
a healy lose of the grain. When groment with wheat, the sorols give the flour a dauk rolour amel a batel flarour. Breal matele

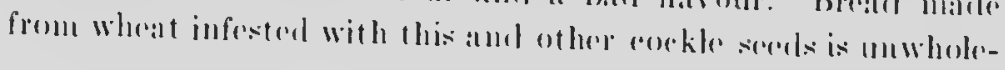




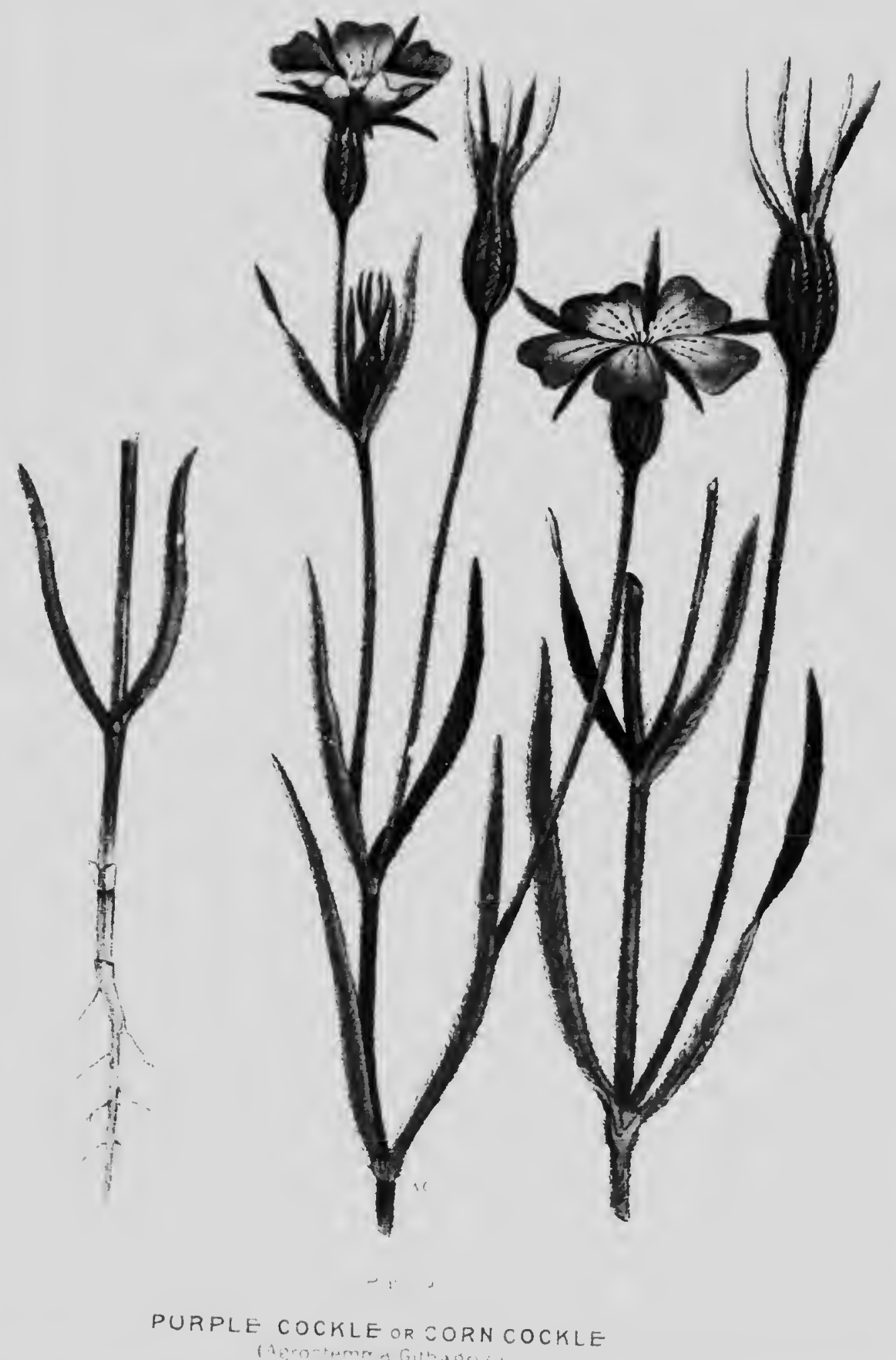




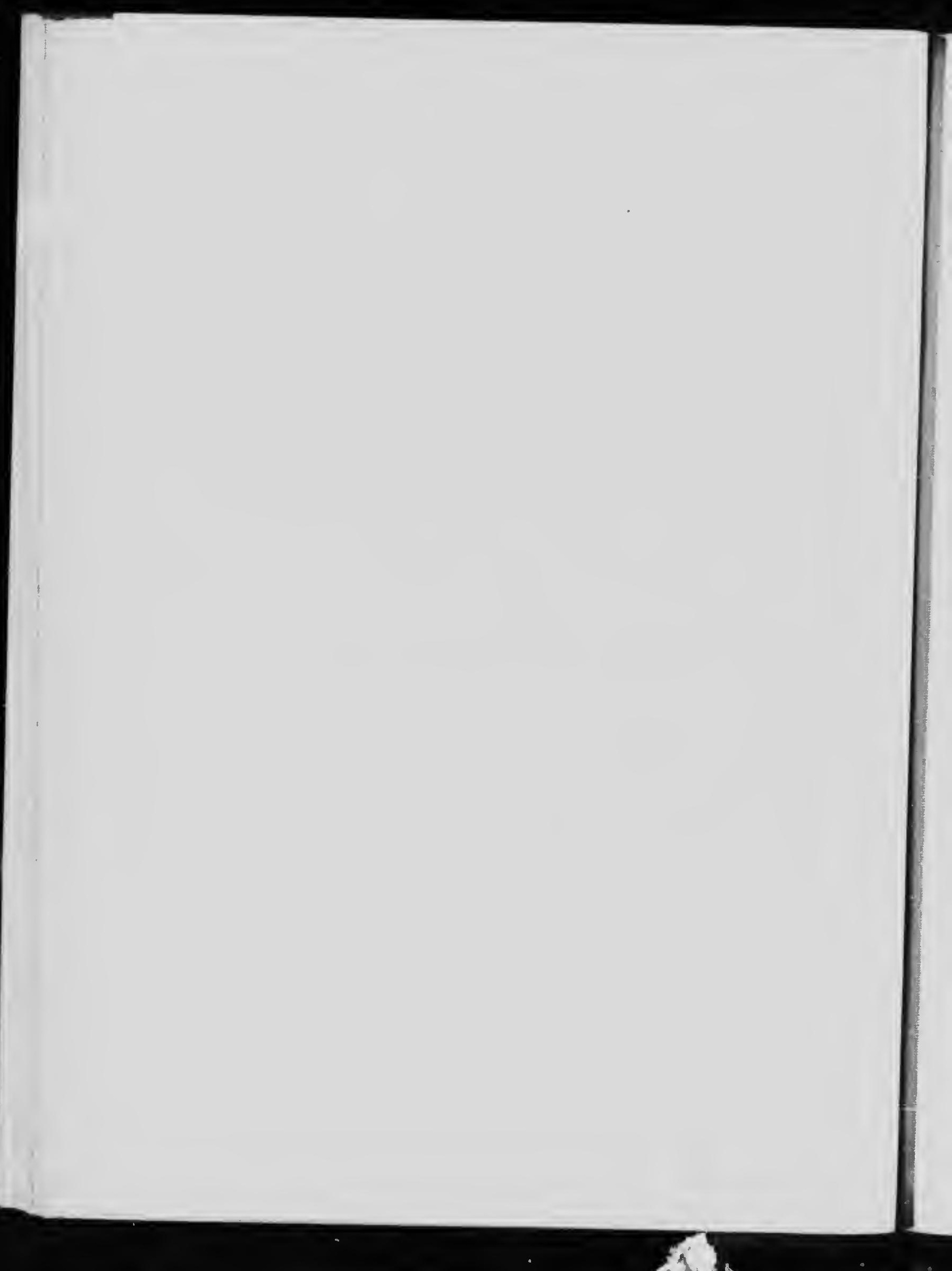


some owing to a poisonoms prineiple in the shant and sorels.

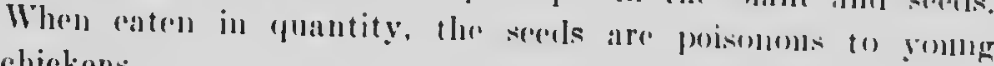
chickens.

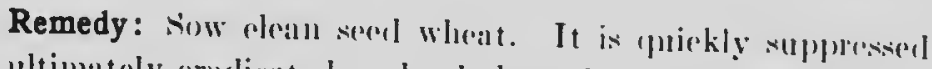
and ultimately araflicated on lamels bromght muler a shont potation of erops. In eastern ('moldat, when this werefl is abundant, wheat should be omited from the rotation for foul years.

In the Prairie Provinees, Latrowing the grain (crop) just before it emerges from the grommel and again when it is threse inches high keeps down this werel. Where the land is infesterl with Purple Coekle, a thorongle sumumer-fatlow is the best method of getting ris of it. Preparation for a summer-fallow shoull start in the fall, by coltivating the land immeliately aftor hatrest. This ean be aceomplished by having the dise follow immeliately behinel the binder and thes enttivate the open strip between the standing grain and the shestres. Fatry in the sp-.ug the land should again be cliserel or harrowed, to start the wrects as early as possible. The plowing should be deep amd should be begun as soon as sereling is eompleterl and finished not later than the end of June. Harrow immediately after plowing and repeat from time to time dmring the summer. Hand-pull any Purple Cockle that may be fommel in the crop after the summer-fallowing. Hand-pulling is also practiouble when this weerl first makes its appearanee.

\footnotetext{
13ewilew the plongh and how, the swepping sosthe Will mueh avail to wage the westing wat, If o'er your lens the yellow ragwort sjeresul A gamaly forest ; or the secels cloek "iurear its atalk prolific; or the trile

1) thistles fencel with prickly arme,-spure not

The moblem rear, but rutleless lay it low:

With all its lirether cululeneres of the eround:

For, if allowed to stand, the dowa-wingod seerl

lies far, a pastime to your playful elves,

To you a eame of axpiklo loss aurl bale.

Let noise of ell the intrusiow race "velu form

Their serel; for kuow-the fructifying stuge

() regetation most exhaust the soil.

And, though cut town before they shet their fruit,

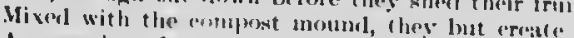

A magazine of prosols for your firlels.
} 


\section{WHITE COCKLE (Lychnis albo Mill).}

Other linglish nanes. Evening Iychnis, White Canpion.

()ther latin nimes: Lychenis respertimusibul, : silene pratensi. liokle \& Gren.

Introlueed from Europe: sparingly distributed in Ontario. Birnnial or short-livel permnial. Ruotstuck thick, sending up af f'w short barren shoots and long branching flowering stems, 1 to 21 feet high. Whole plant rather vistous hairy but not so much so as Night-flowering Catchfly. It resembles the latter somewhat, but is wider branching, has many stems, the leaves : ro larger, the flowers more numbrous, pure white, and witl it nore conspicuous crown of short white seales around the centie; the male and female flowers are on separate plants. The fruit "apsule has 10 teeth at the top instead of 6 , as in Night-tlowering Catrhfly, and is much larger and more swollen.

The seed (Plate 72, fig. 20) is pale gray, about as large as that of Bladeler Campion aud Night-flowering Catchfly. It is rough"ucel by regular concentric rows of tubereles, which are farther spart than those characteristic of allied species. The point of attuchment of the secel is usually depressed.

"ime of flowering: June; secrls ri in July.

Propagation: By sceds only.

Occurrence: Grain erops and mealows. White Cockle is not a eommon weed in Canada but has heen introdueed occasionilly with seeds imported from Europe. In the vicinity of Guelph it is abumelant and troublesome.

Injury: A persistent weed that is exceedingly difficult to raticate, once it is established; a nuisance in all ficld crops. The seeds are common in grass and clover seed from land where the weed is plentiful. 


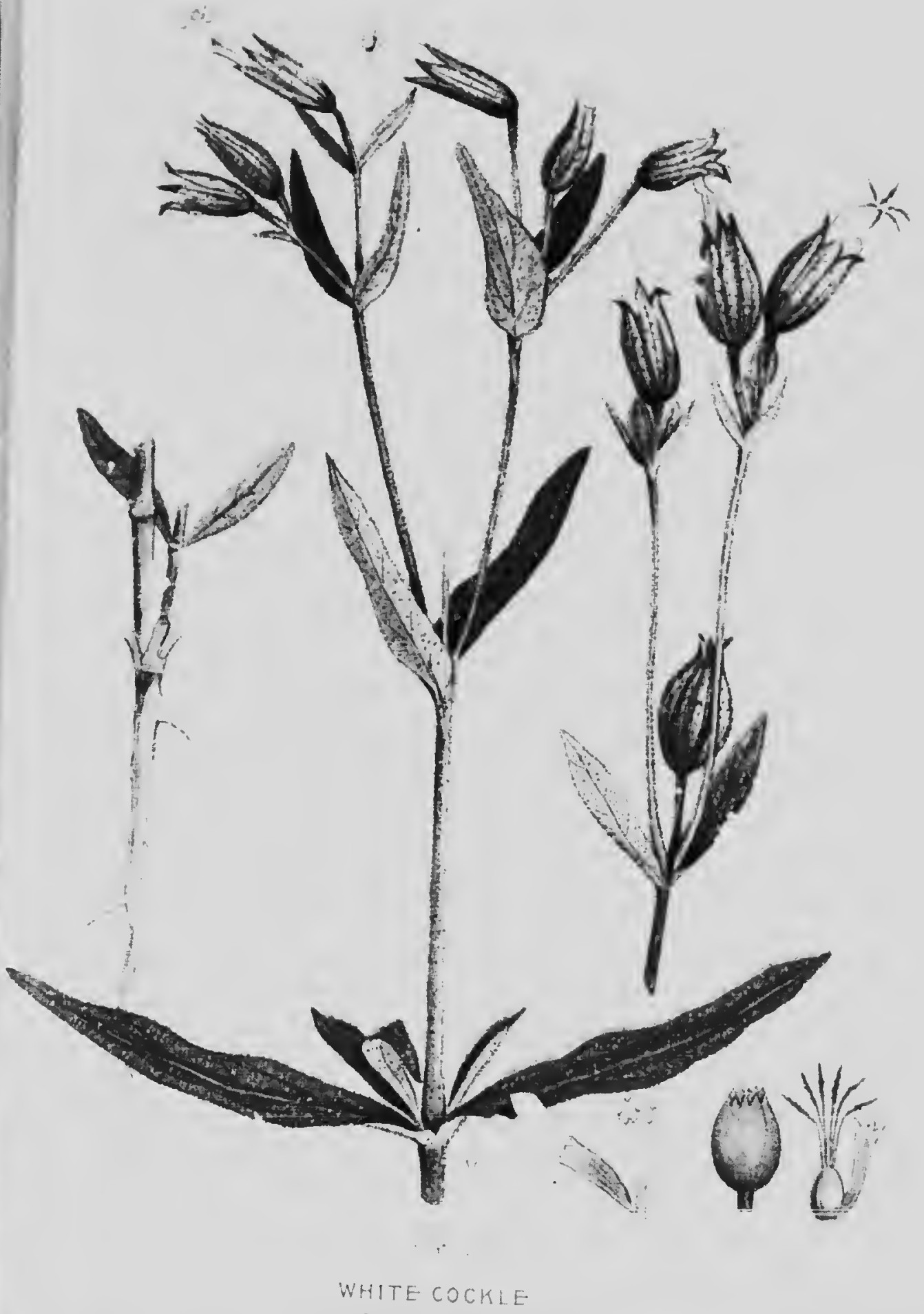




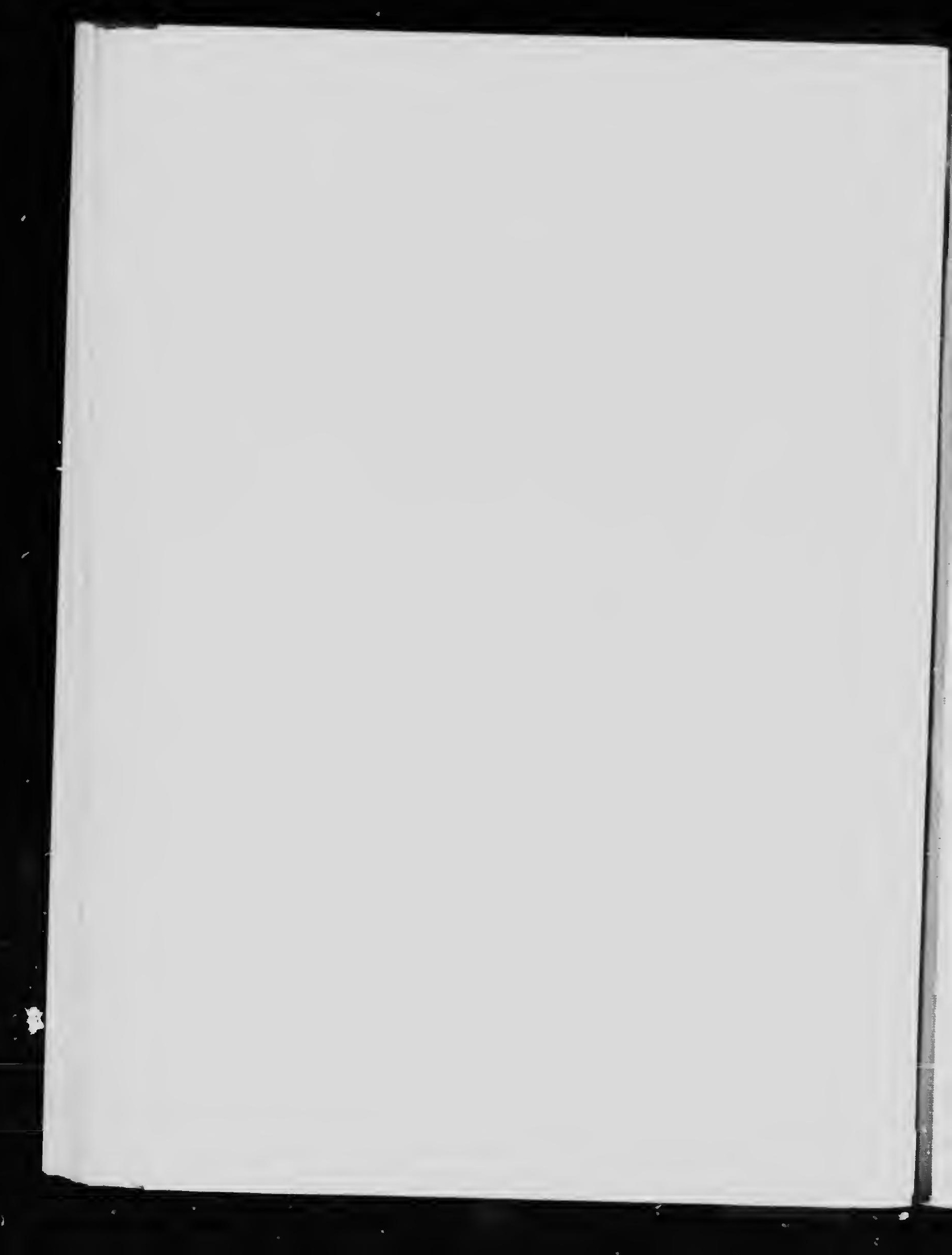


Remedy: A bitre summorefalluw, with thorumgh cultivition,

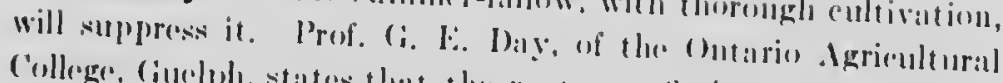

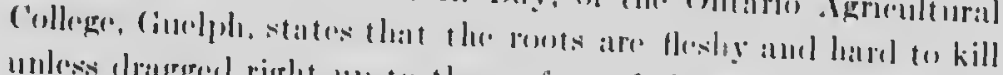
unless draggerl right up to the surface of the sib. If there is :

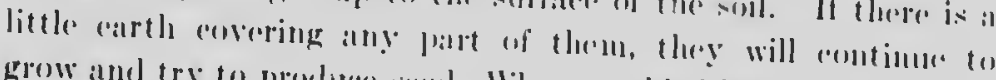

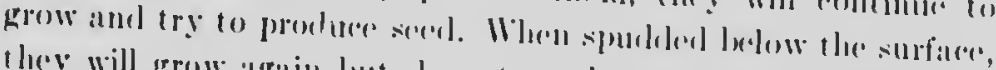

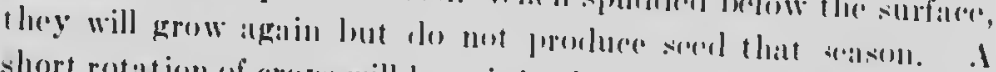

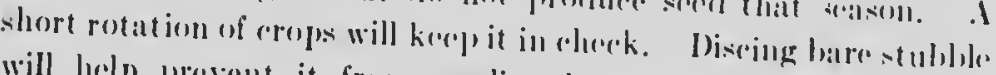
will help provent it froul sereding late in the season. Thick

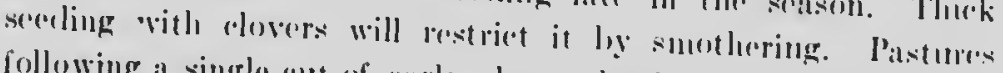

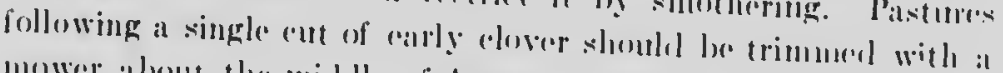

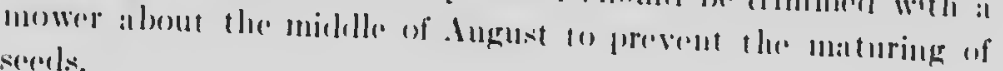
scoels.

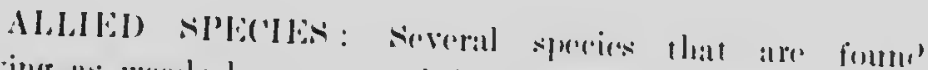

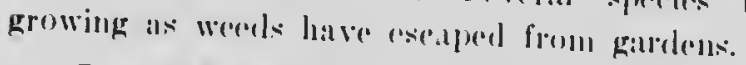

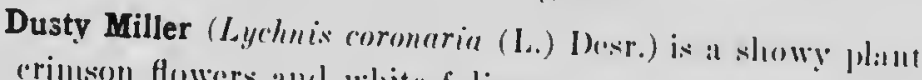
with crimson flumers and white foliage.

Ragged Robin (Lychnix Flos-ruculi L.j is ocecasionlally met about old gardens in the Maritime Provinces. It has a slemlede stom ansl rose or pink flowers, the corollat divisions f-eloft.

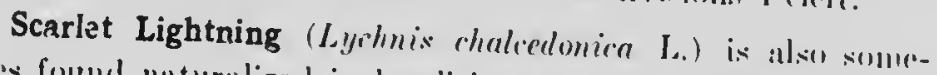
times found naturalized in localities where it has exeaperel frem cultivation.

Red Campion (Lyehnis dinime !..) is a coarso, hairy, somucwhat viscous plant, quite common in soune localities in tlue

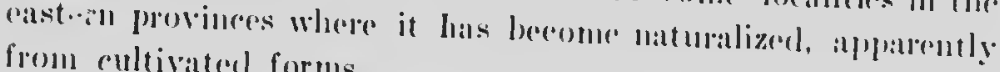
froun cultivated forms.

Drummond's Pink (L.yglinis Drummondii Itouk. II:Its.) is chatracterizel hy larrow leares, small piuk flowers, and a stoul almost leafless above; quite common in Manitobal.

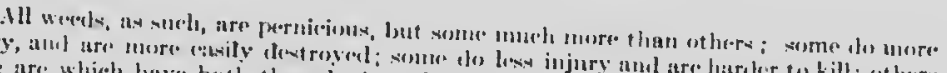

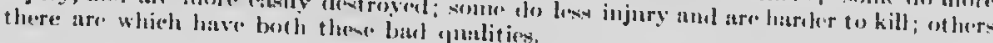


is

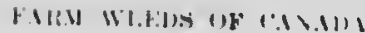

NIGHT-FLOWERING CATCHFLY (Nile me untiflor" I..)

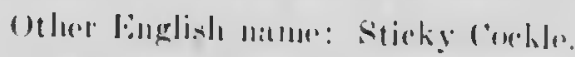

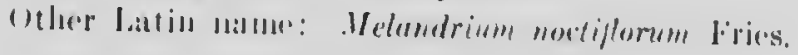

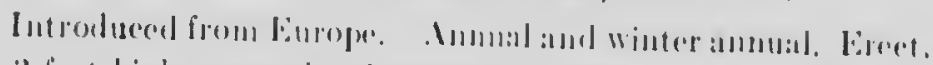

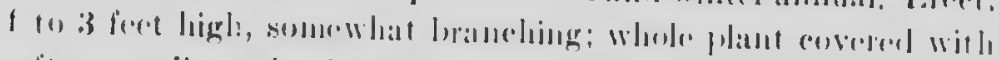

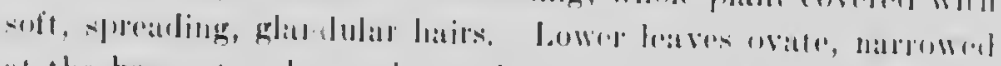

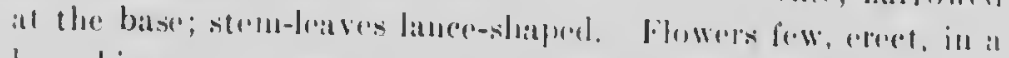

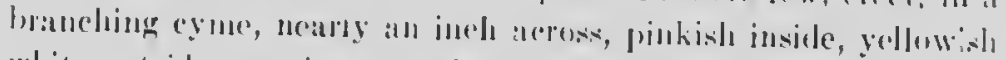
White outside, opening at night, corollat divivions doeply dividede

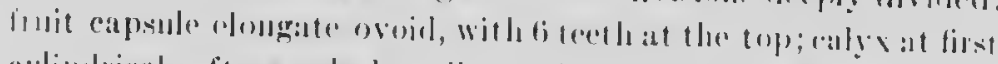

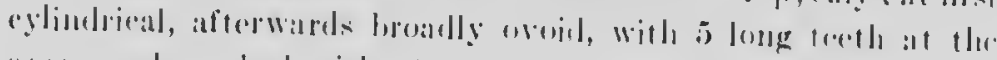

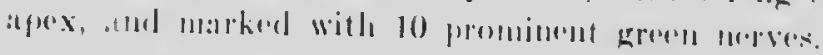

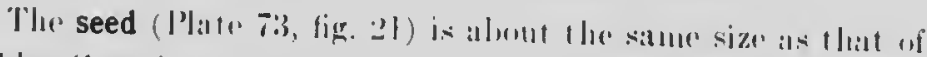

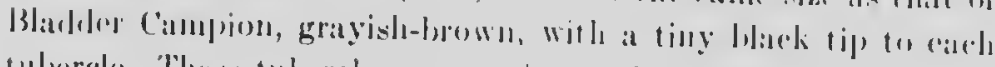

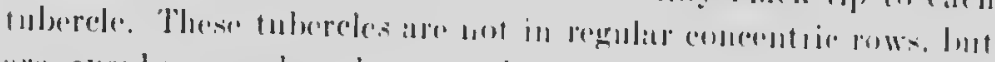

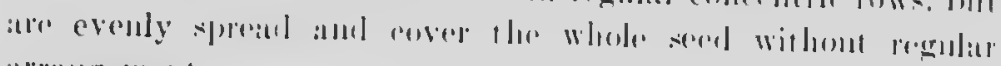
alraugenurnt.

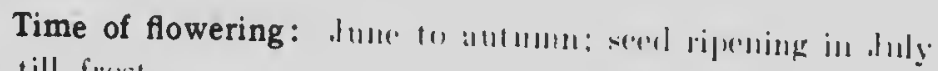
iull till frost.

Propagation: Iỵ sinds only:

Occurrence: Throughout the Inominion. Ahumlant in thr.

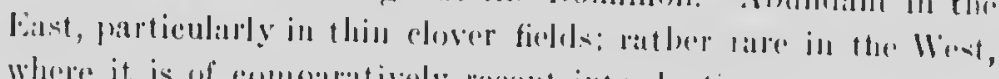

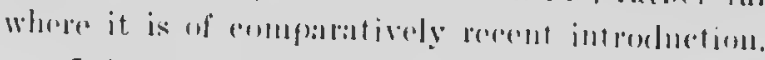

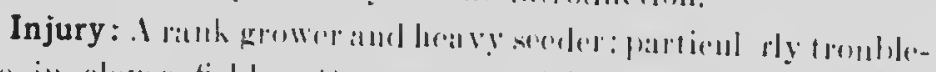

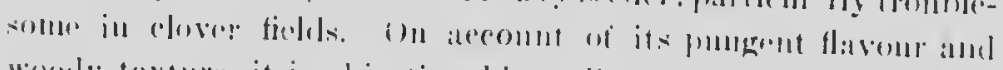

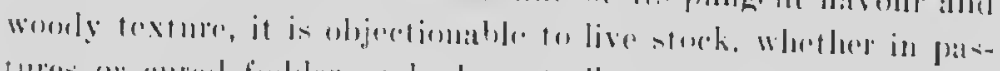

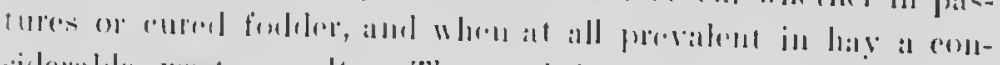

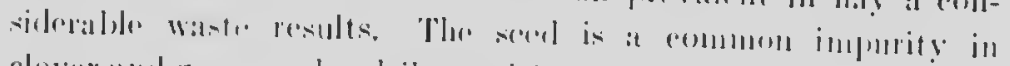

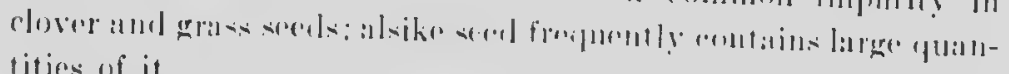
titims of it.

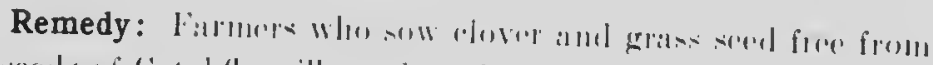

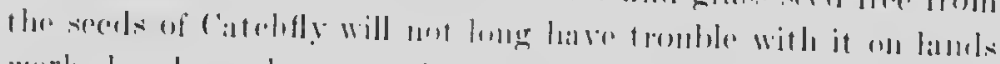

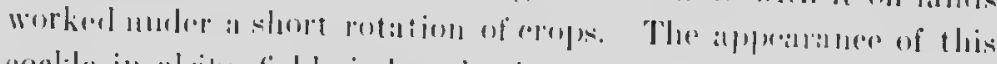

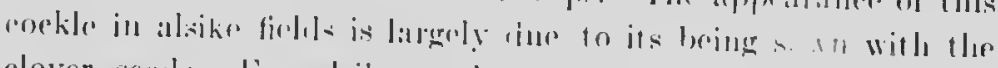

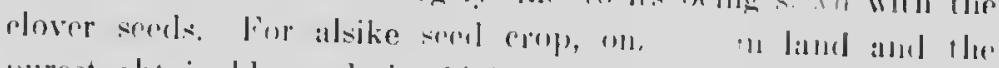

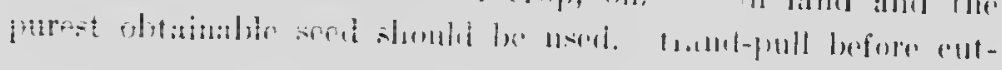




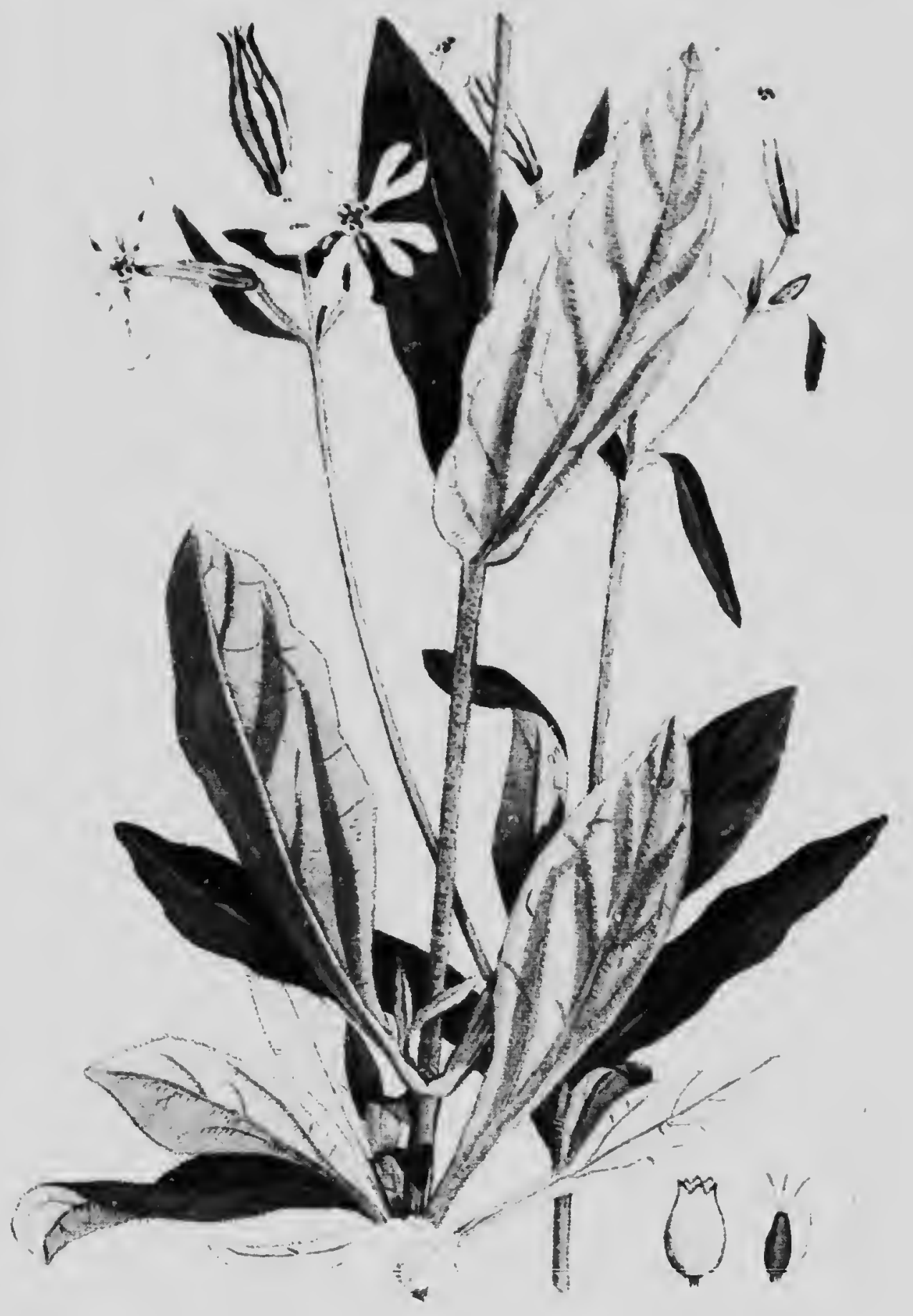

NIGH FLOWERINC CATCHFLY JE JTIC: COCMLE 

ting etover sored repops; the increased value of the secel will pay

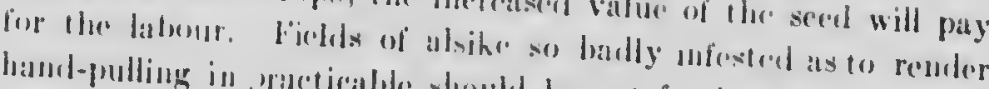

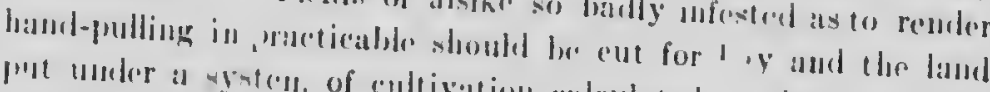

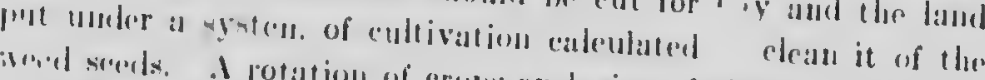

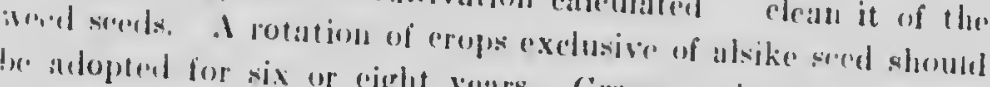

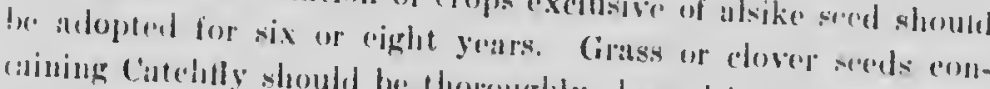

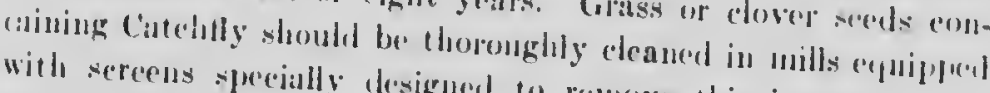
with sercens sprecially desigued lo remove llis implarity, atul

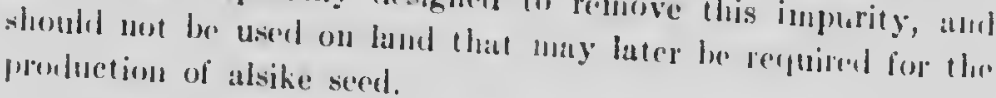

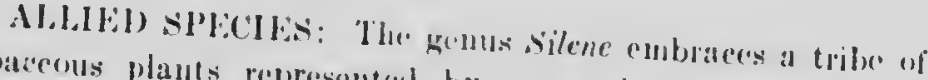
herbaceous plants represented by more than three hundred

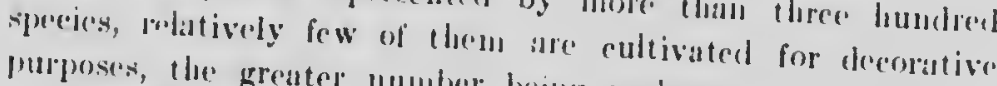
purposes, the greater unuber bring asedess wayside wreds.

Conical Catchfly (silene comice L.) is receasionally met in wonthern Ontario in fichls and waste phaces. It is a small plant, with small pink or purple flowers and a conc-shaped fruit cupsnle. 'lihe seed is about $2 / 3$ the size of that of Night-flowering

Sleepy Catchfly (wiiene antirrhina I probubly introduced with impoltod clover seed, is puite wiley distribnterl. It has a

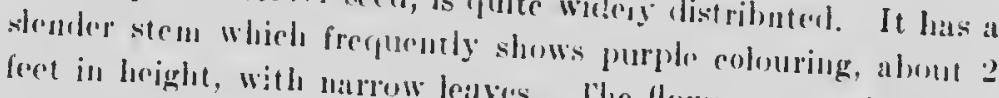

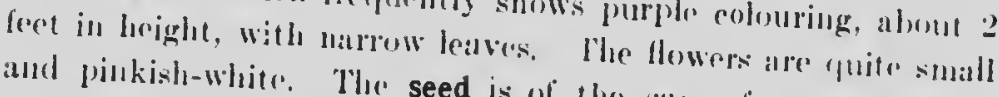
Night-flowering ('atchlly, about of the same form ats that of

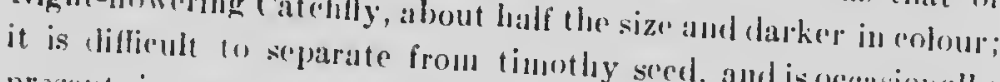

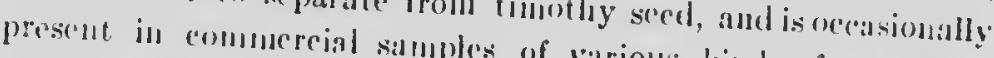
clover sords.

Garden Catchfly (Nilene Armeria I..) is frepurmtly found growing in fichls near old gardens from which it has escaped. It is a? annual, witl pink and white flowers, and sediom gives
sorious trouble.

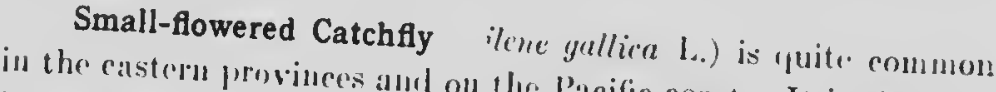
inches high, branched and ou the Pacific coast. It is about 15 similar to that of Stropy rests small and white. The seed is noticeably depresserl ong Catelity in size and colour and is 
BLADDER CAMPION (silene lutifolin (Hill.) Brittun d Ramlle).

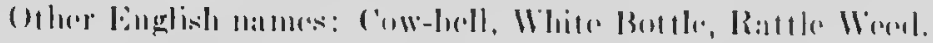

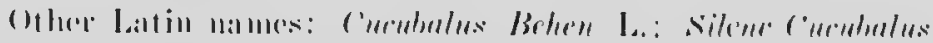

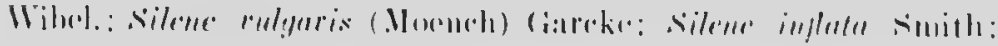

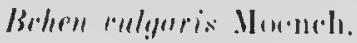

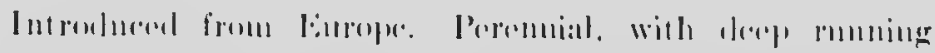

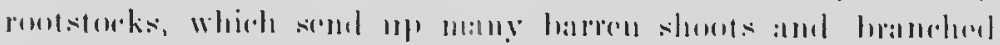

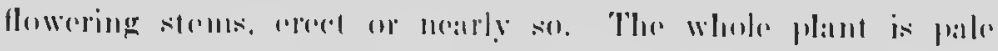

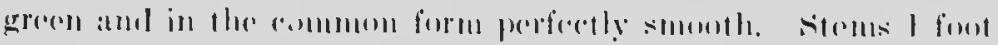

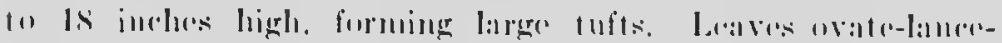

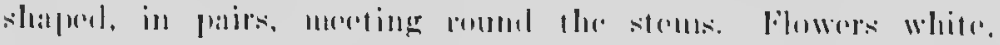

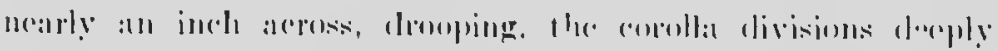

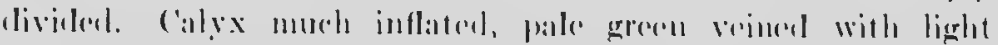

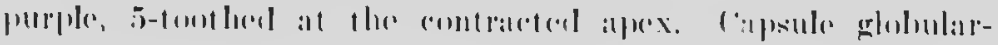

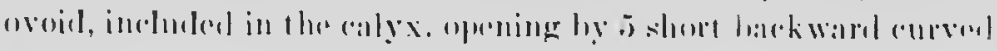
troth.

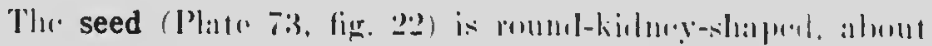

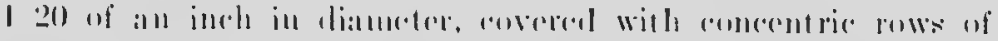

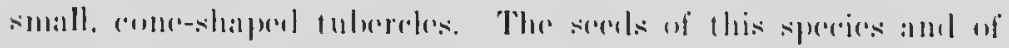

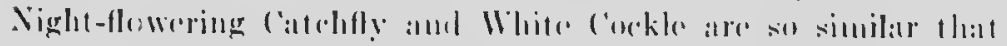

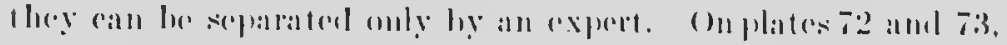

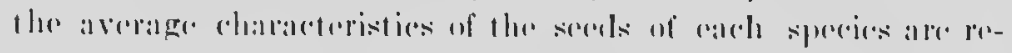

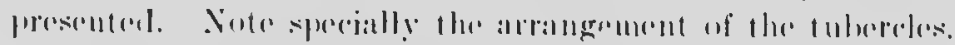

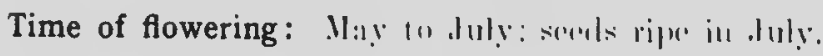

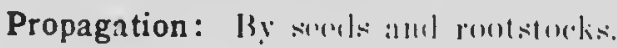

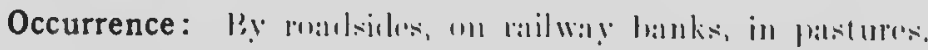

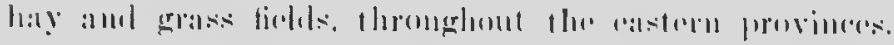

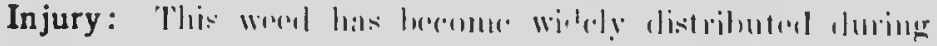

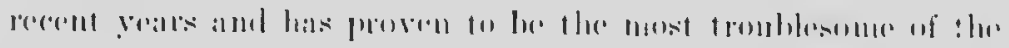

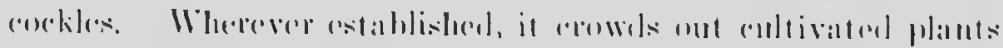

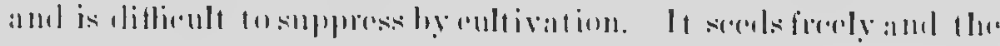

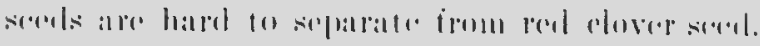




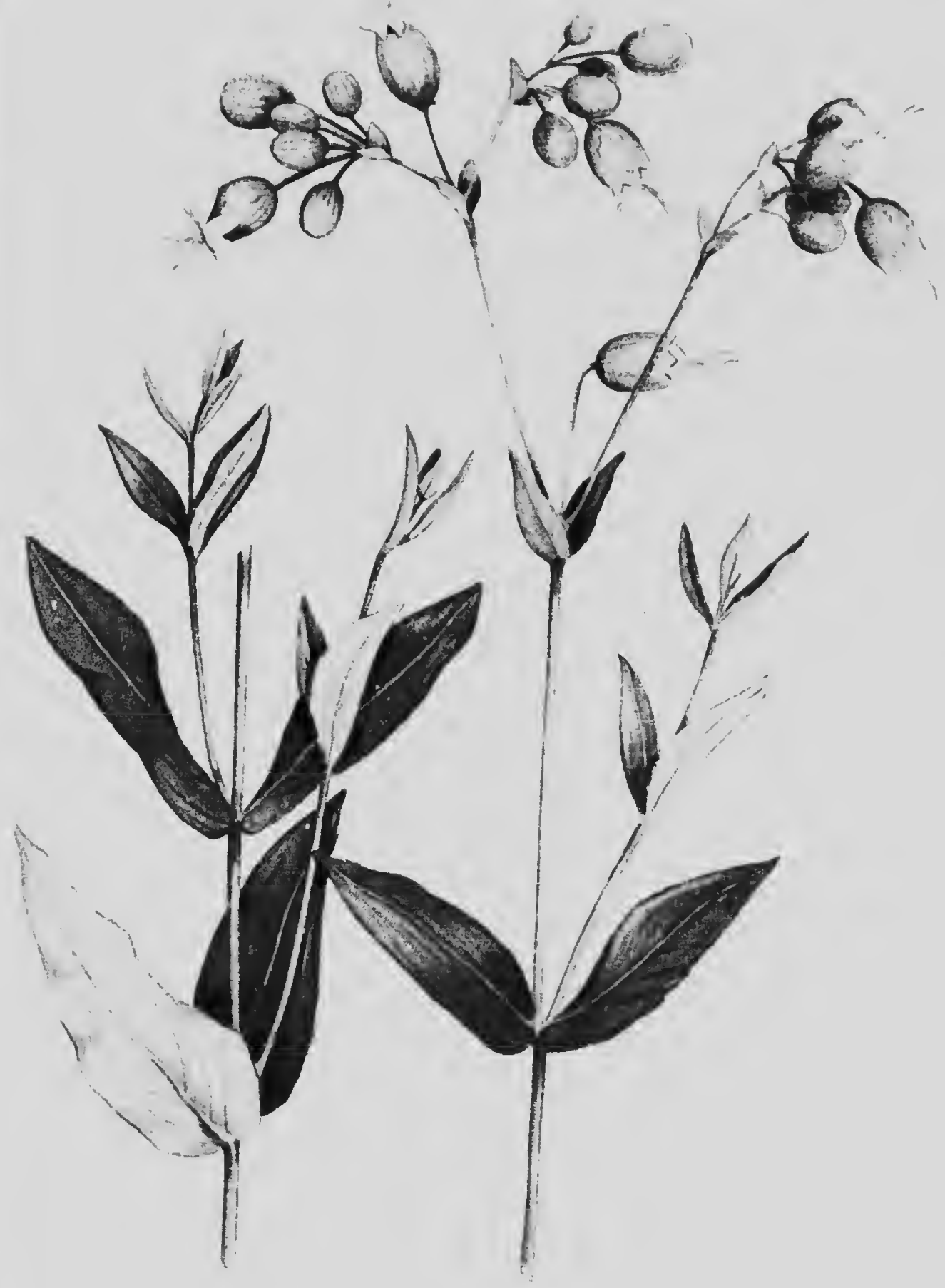




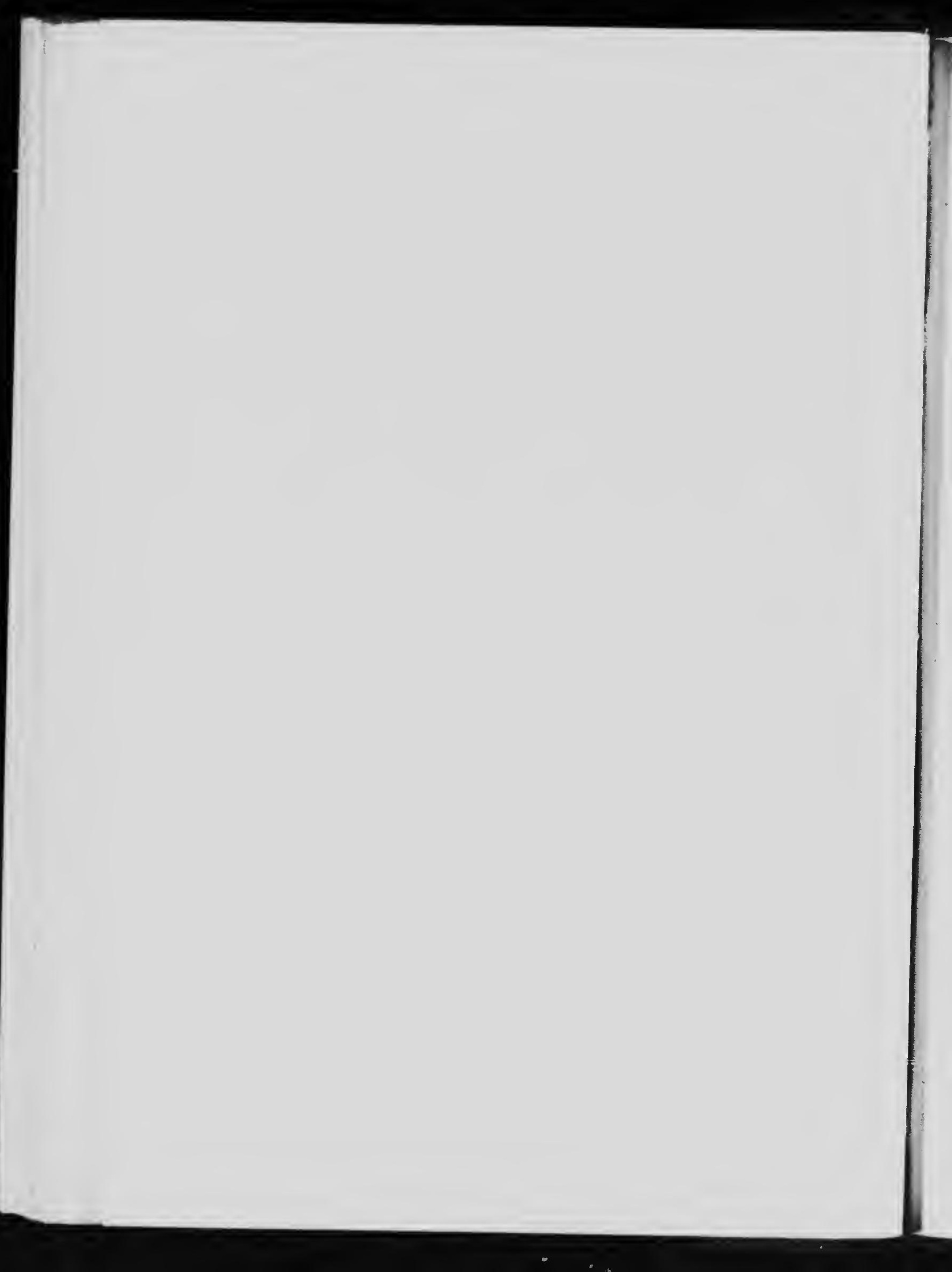




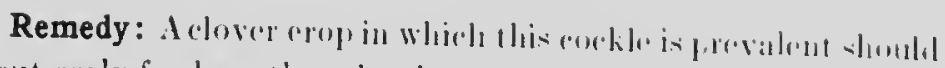

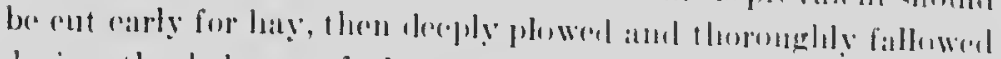

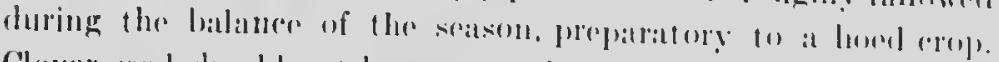

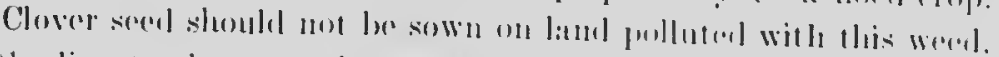

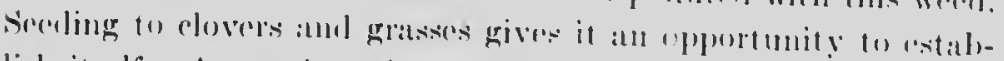

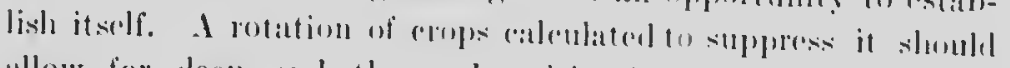

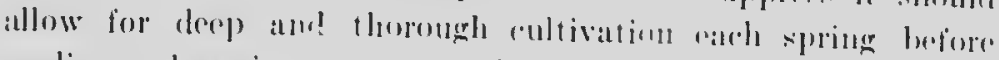

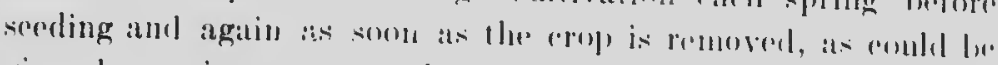

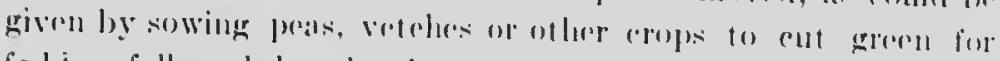

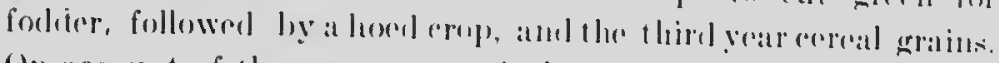
(1) aceount of the ocemeremese of the serel in commereial grass

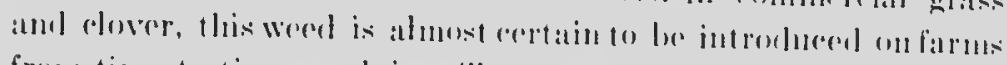

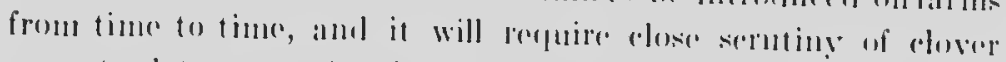

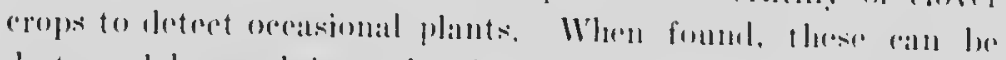

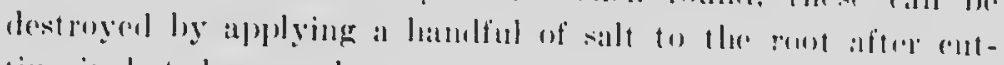
ling in hot liry woithor.

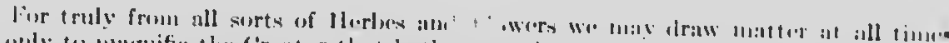

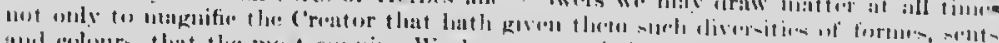

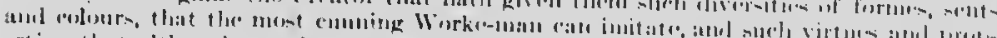

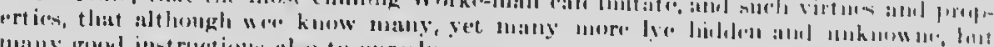

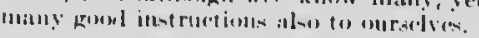

$$
\text { -l':arkius!n, Iri:!! }
$$

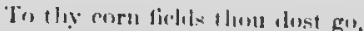

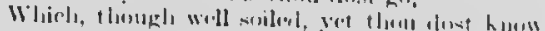

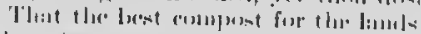

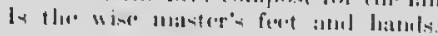

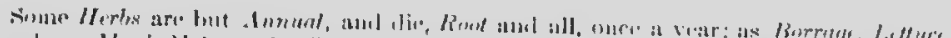

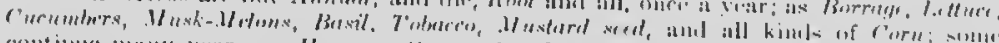

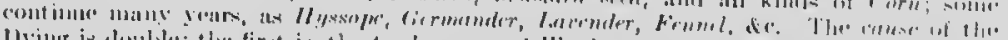

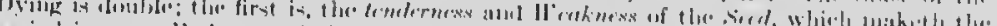

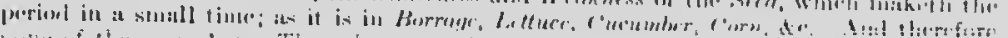

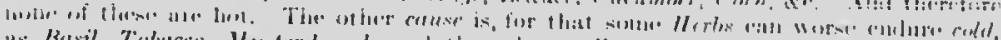

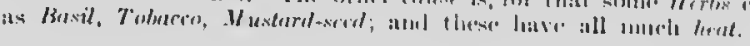




\section{COW COCKLE (Saponaria Vaccaria L..).}

Other Einglish names: Cowherb, China Cockle.

Uther Latin names: Vaccaria Vuccaria (L.) Britton; Vaccaria iulgaris Host.

Introduced from southern Europe. Annual. Stem simple, iranching above or much branched from the base, 1 to $2 \frac{1}{2}$ feet. The whole plant is smooth, succulent and of a grayish-green appearance, like the leaves of a cabbage. Leaves ovat, nceshaped, clasping the stem. Flowers pale rose-pink, $1 / 2$ inch across, in loose corymb-like cymes. Calyx ovate, 5-ribbed and much inflated, winged and angled in fruit. The smooth roundish fruit capsules contain about 20 seeds each.

The seed (Plate 73, fig. 23), is round, hard, dull black, about $1 / 12$ inch in diancter, and is often confounded with the secds of wild vetches. It can be distinguished fron vetch sceds of a similar size by its ininutely roughened surface, or by cutting it open after souking, when the germ, which lies in a circle around the seed just bencath the seed-coat, will be seen. It in no way resembles the inside of a vetch or pea, which, when the secl-coat is removed after soaking, can be easily separated into similar halves.

Time of flowering: July; secels ripe in August.

Propagation: By seeds only.

Occurrence: As a troublesonc weed, only in the Prairic Provinces.

Injury: A pestiferous weed in grain crops in the Prairie Provinces. The succulent plants rob the crop of moisture. Being a vigorous grower, the large branched top occupies much space and crowis out the grain. The secls are a common inpurity in comnercial wheat and are almost as objectionable to the miller and baker as are those of Purple Cockle. 



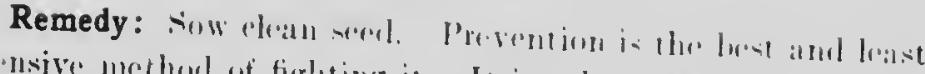
expensive methol of fighting it. It is a large slowy plant and

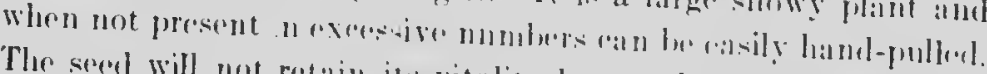
The sered will not retain its vitality long; whem land is sereled lo timothy or western ryegrass and left for a foll yorars, the supply of vital seresle in the soit will he greatly resluevel, if not entirely

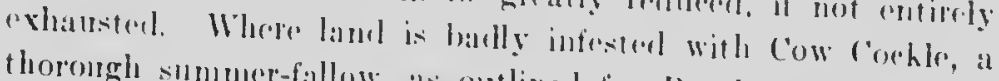
thorough summer-fallow, as outlined for Pourgle Cockle, is the most effertive methesl of exterminating it. IItrowing grain eropse just before the grain emerges from the groumd, and again when it is three inchess high, will kill any soreflling woreds.

ALIIEI) SPLCIK: Bouncing Bet (sommuriu officinalix L.) is a stowy plant about 2 foret in hright. Flowers light pink, in

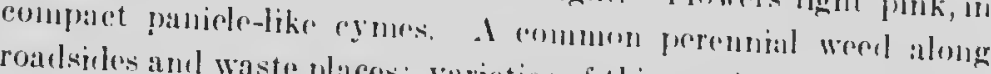
roadsules and waste plares: varioties of this spereves are collivaterl in gardens. Sometimes alled soapwort berallse the rente ran be uscel for washing instrat of soapl.

\section{THE PURSLANE FAMILY Portulucucerin.}

This suall family of plants comprises abont twenty speries. all low, fleshy herlse, with mostly alternate thiek loaves. The

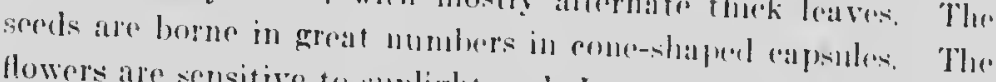
flowers are sensitive to sunlight and rlose at night or whe: wom-

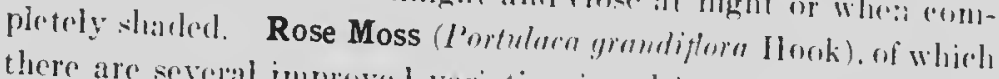

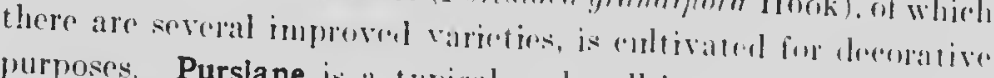
purposes. Purslane is a typical amd well-known representaltire

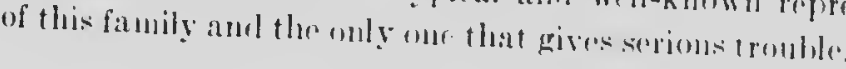

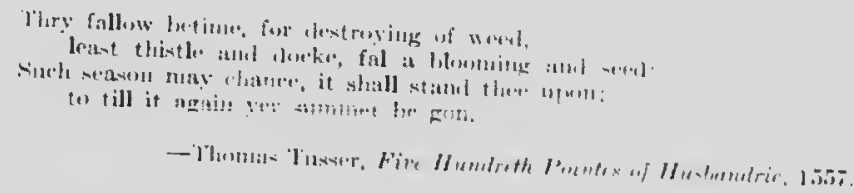




\section{PURSLANE (l'orlulua weruicul I..)}

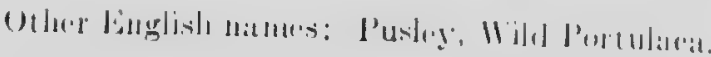

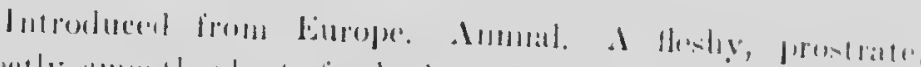

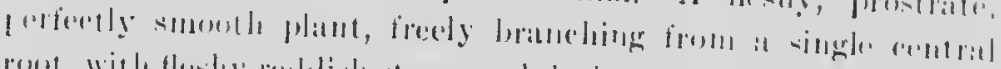

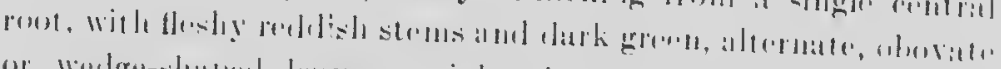

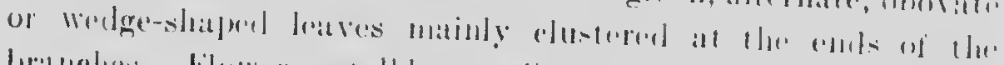

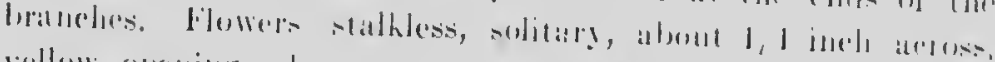

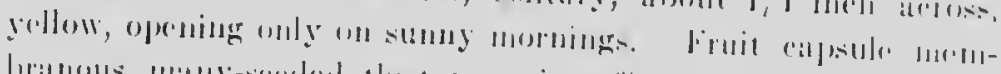

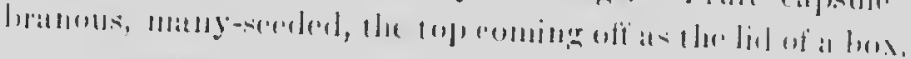

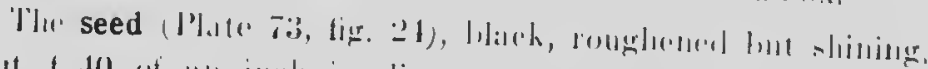

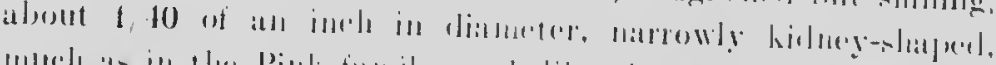

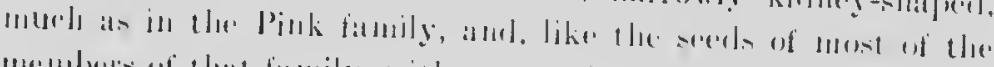

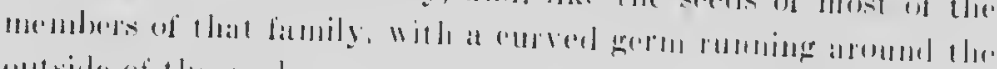
entsille of the sired.

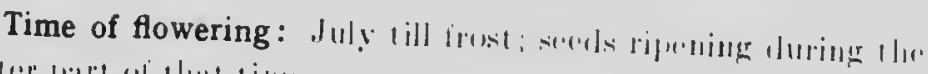

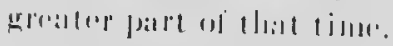

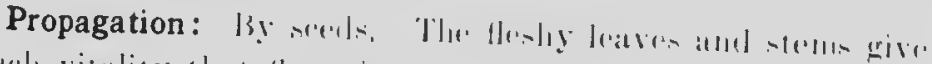

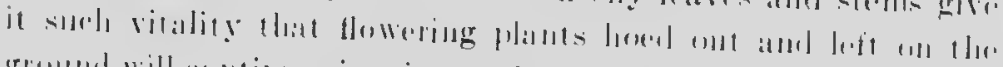

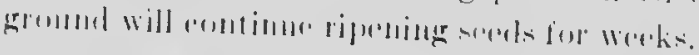

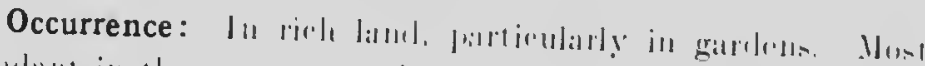

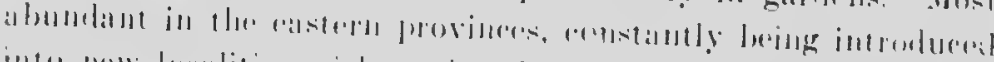

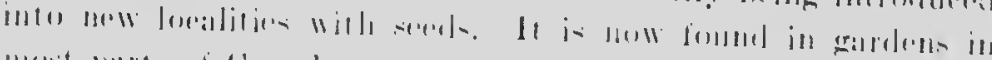

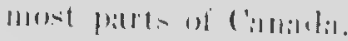

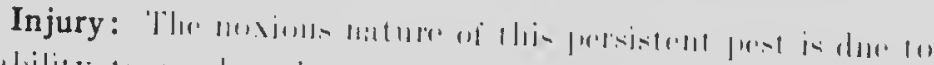

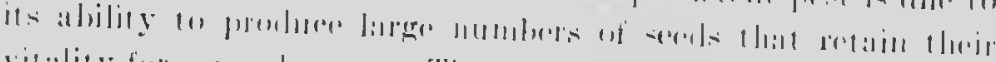

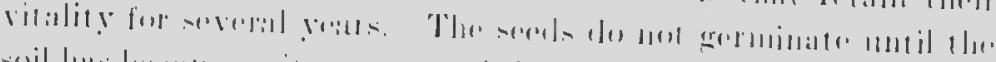

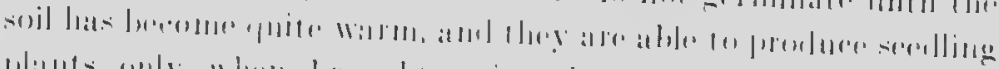

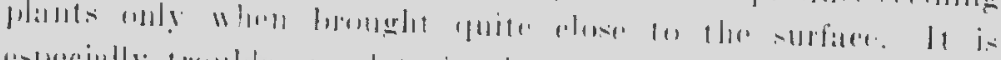

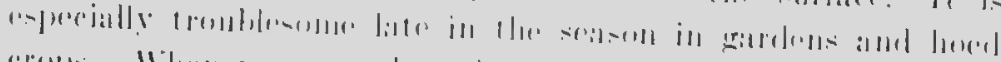

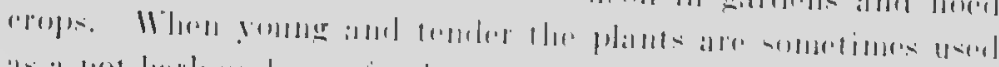

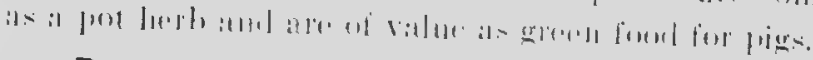

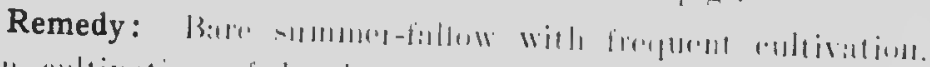

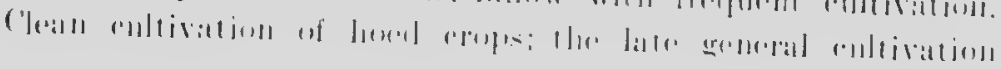




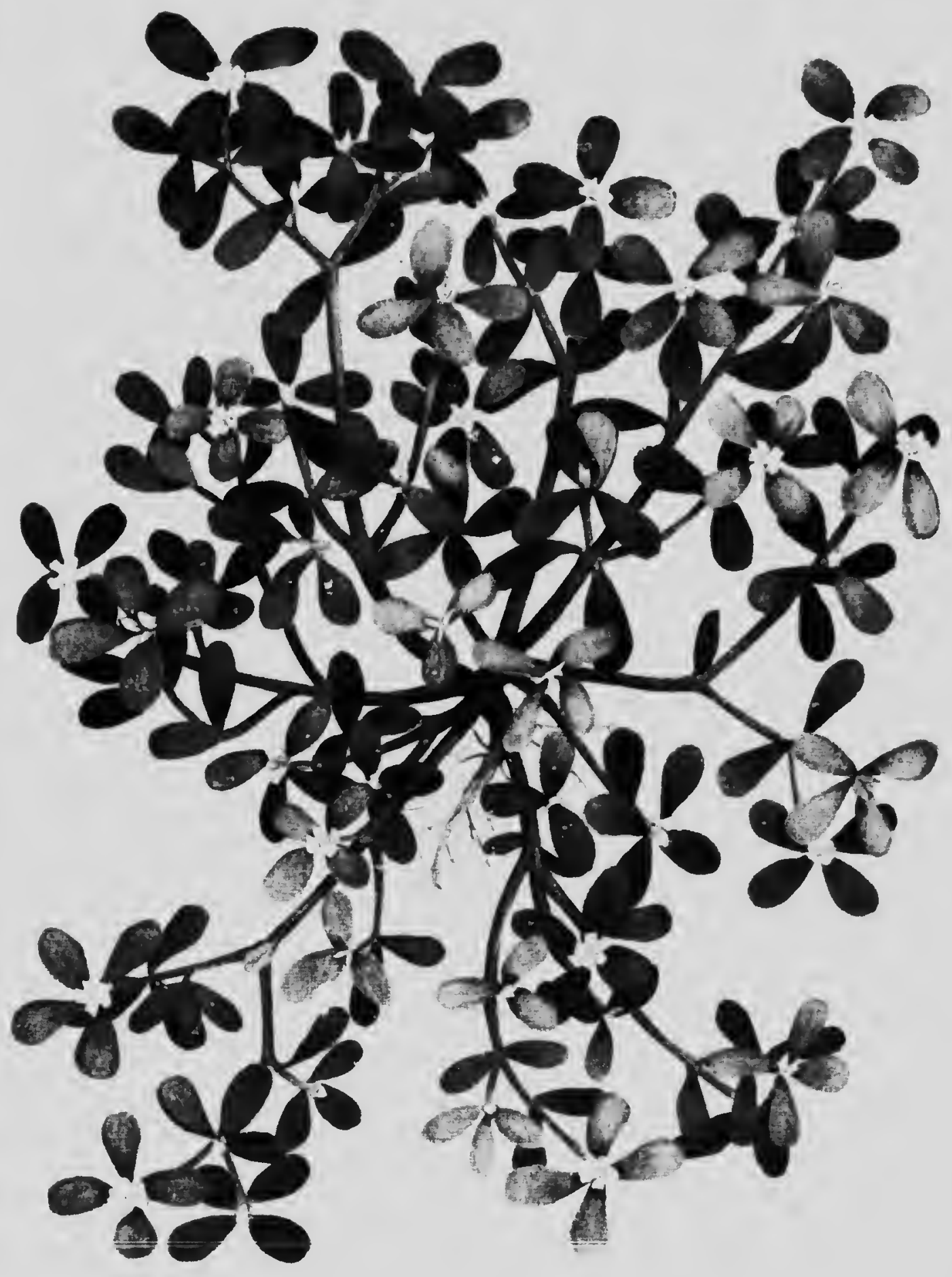



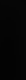


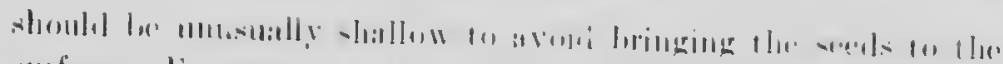

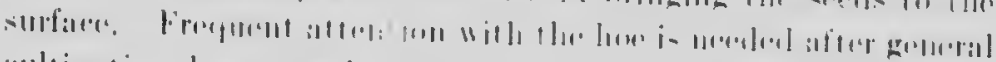

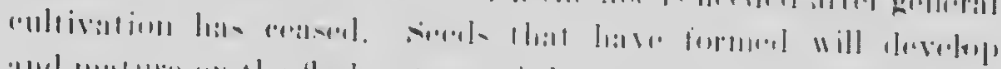

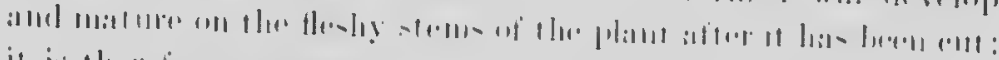

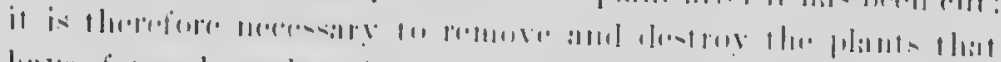

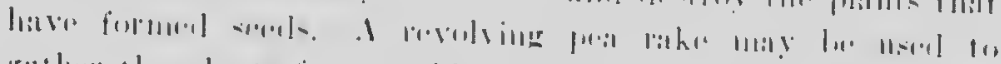

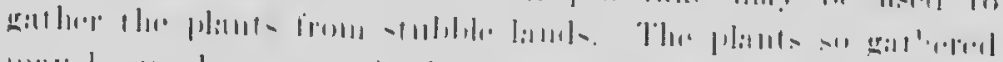

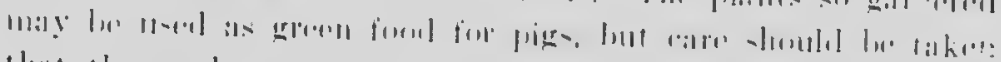

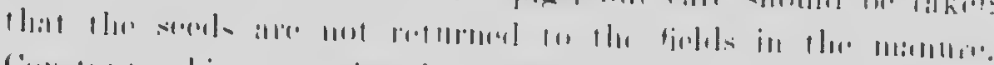

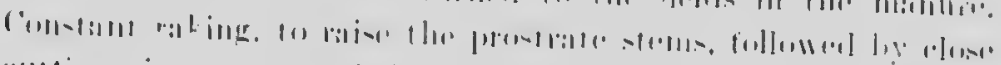

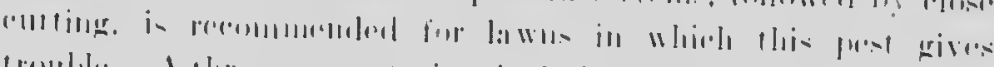

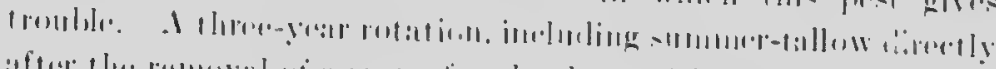

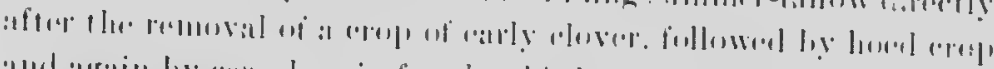

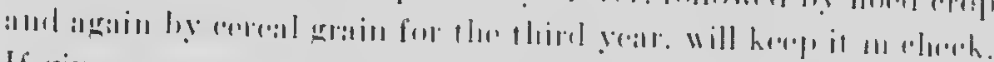

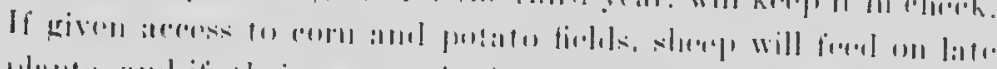

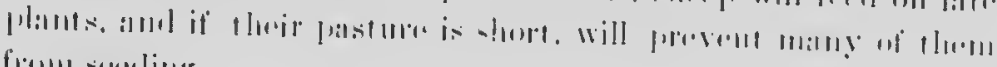
fivill sinlingr.

\section{THE BUTTERCUP FAMILY (Rmunumlncmi}

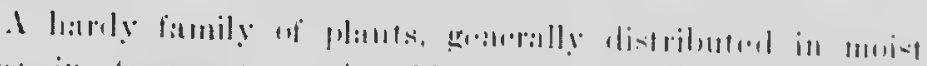

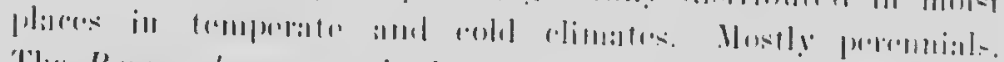

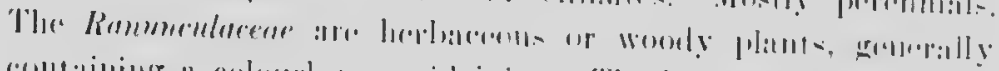

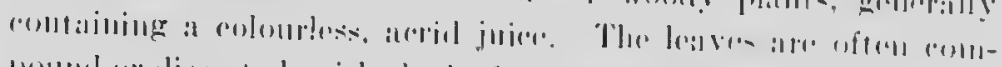

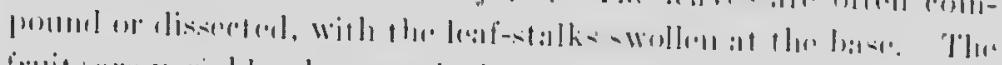

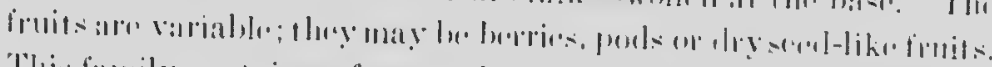

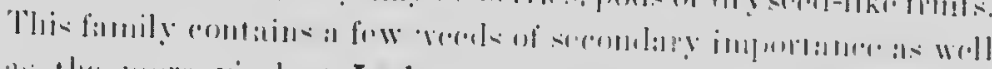

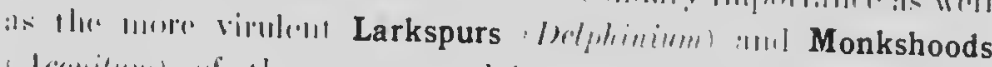

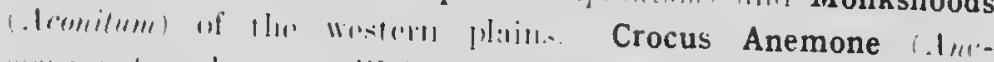

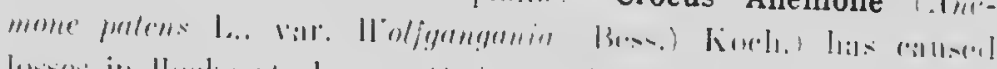

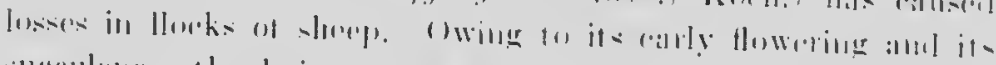

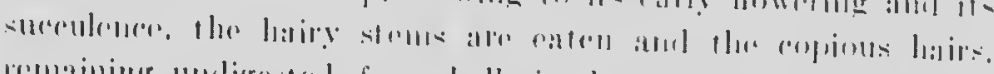

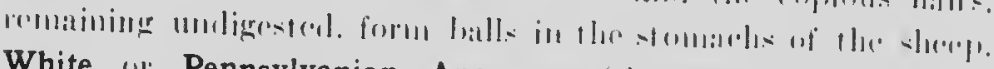

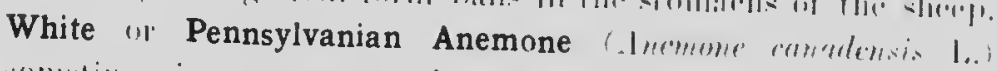

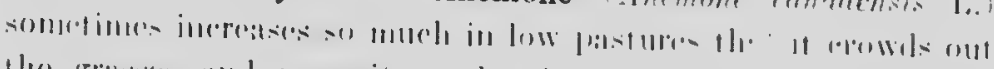

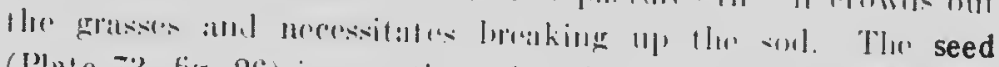

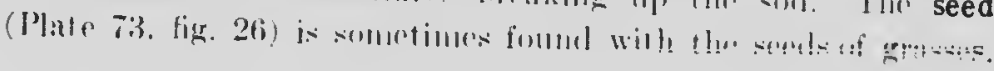


iti

F.IIU แH.HW

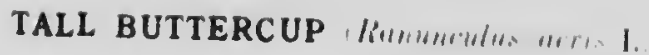

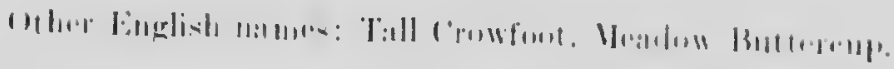

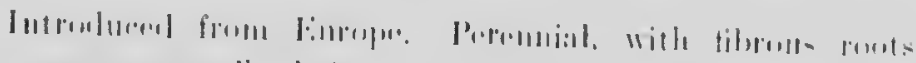

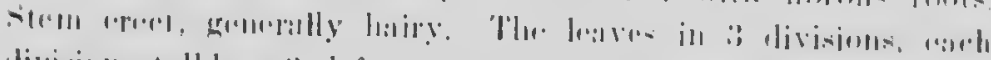

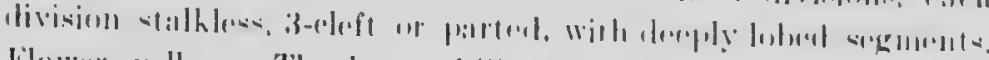

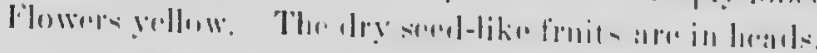

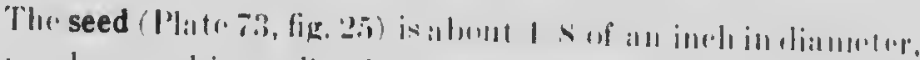

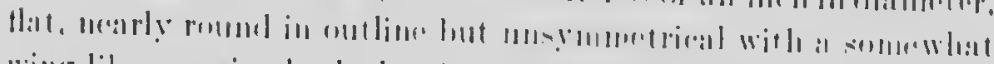

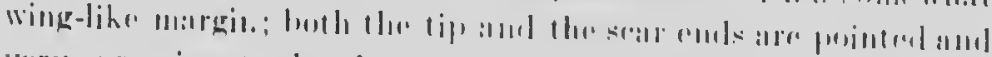

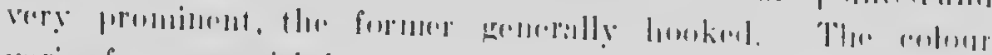

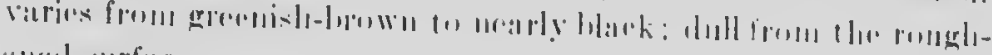
"uलnl surfilere.

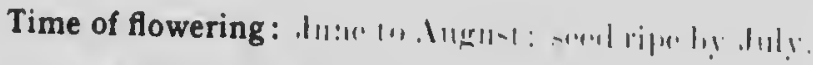

Propagation: Ily semls.

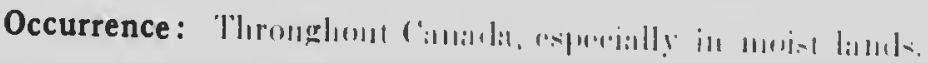

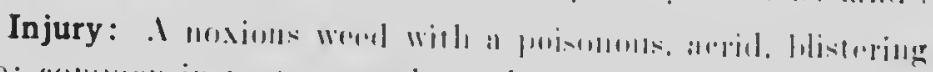

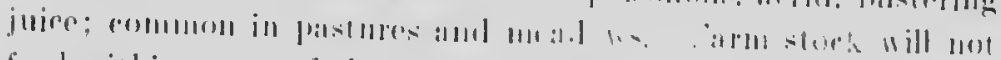

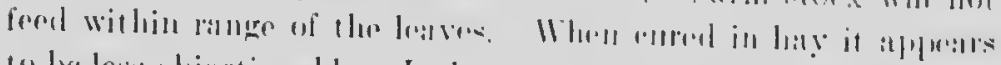

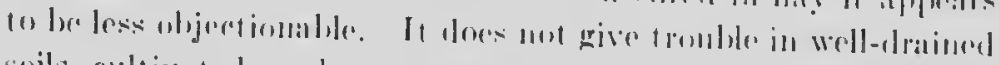

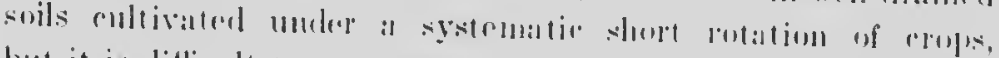

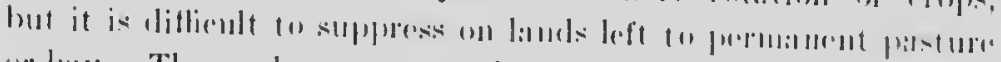

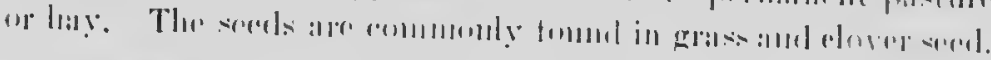

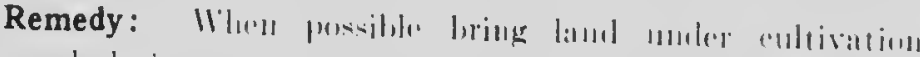

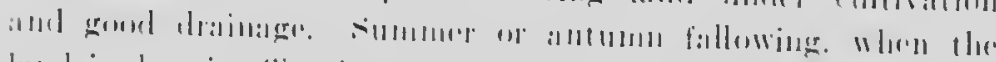

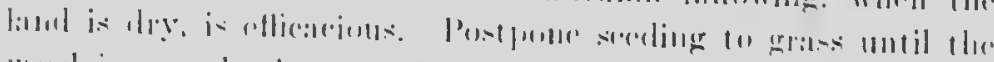

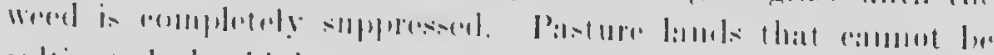

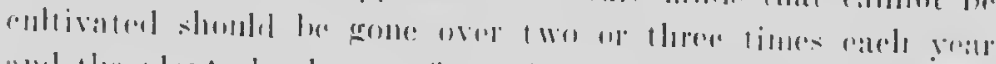

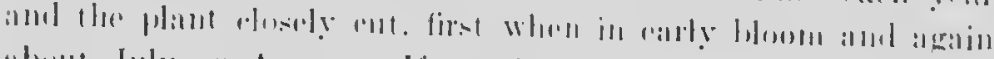

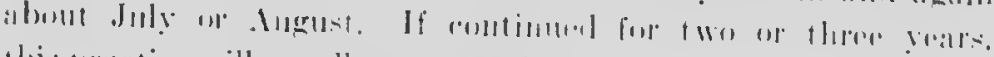

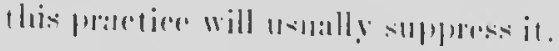

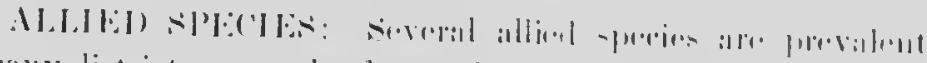

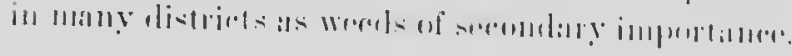




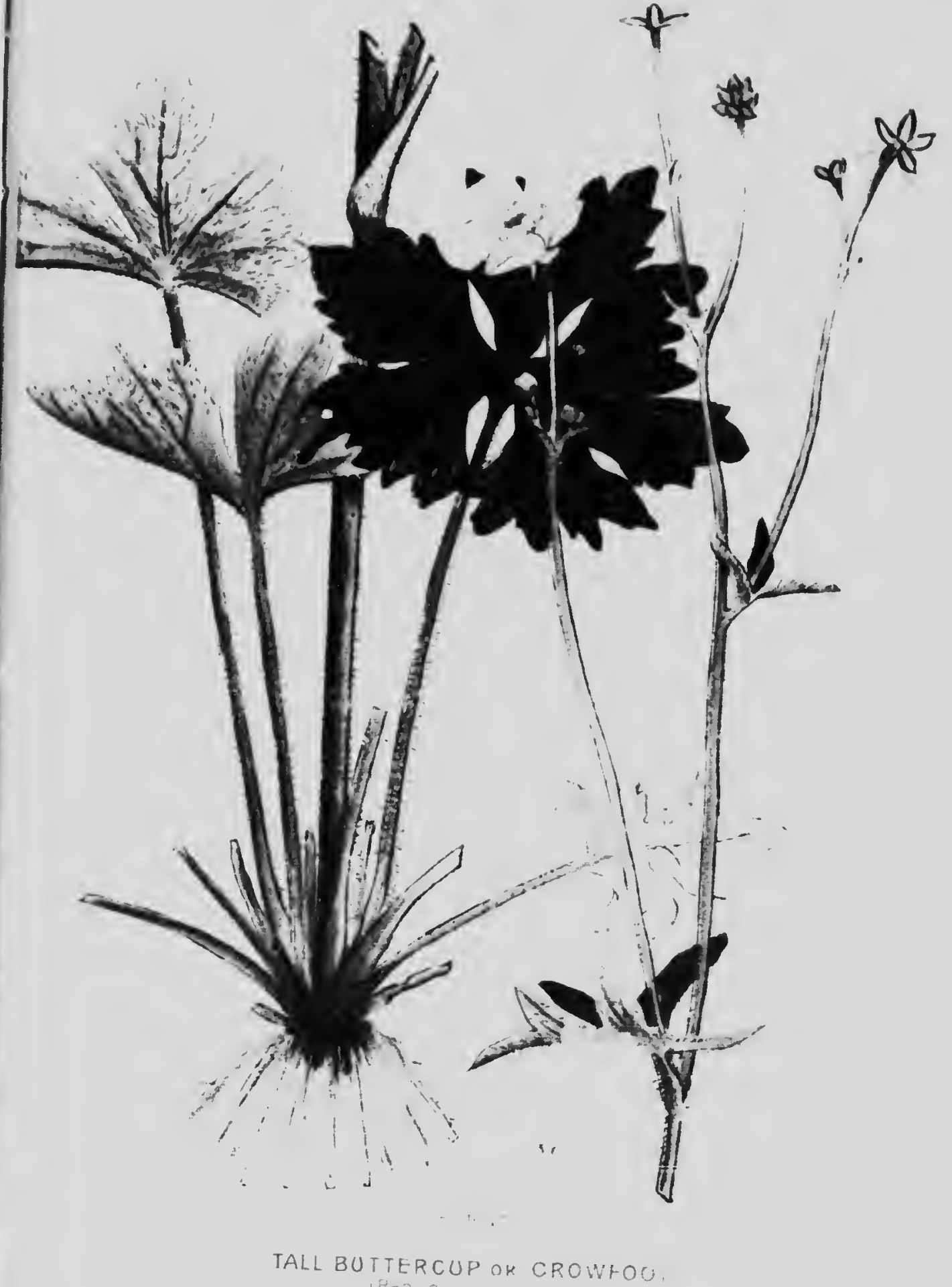




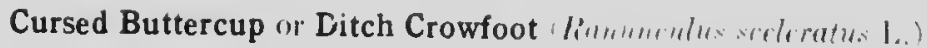

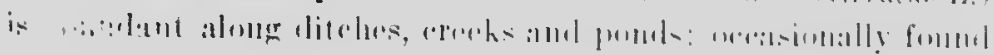

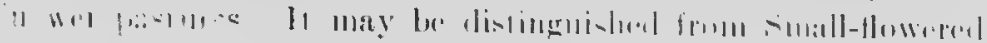

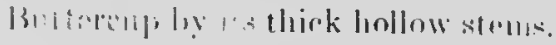

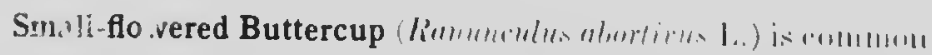

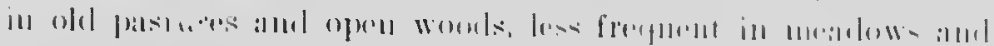

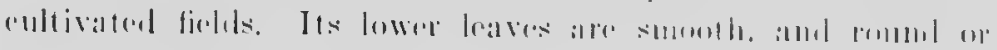
lidene-shajperl.

\section{THE FUMITORY FAMILY ドmmincu!}

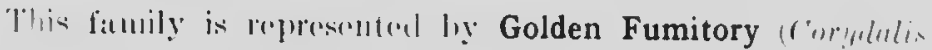

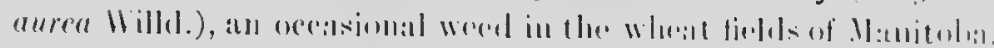

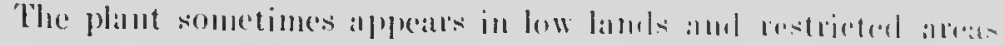

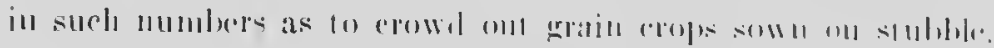

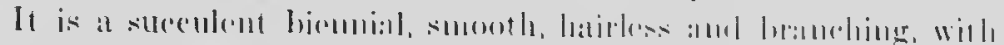

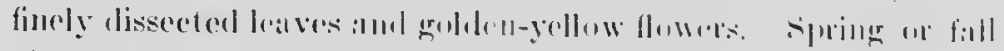

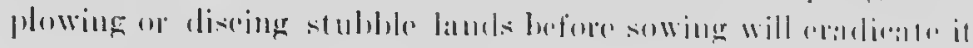

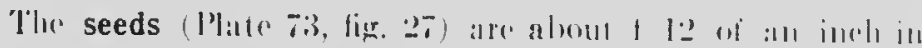

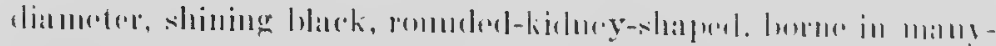

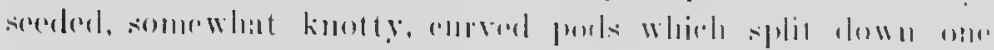

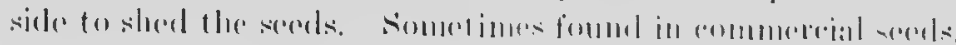

\section{THE MUSTARD FAMILY ('meifrm.}

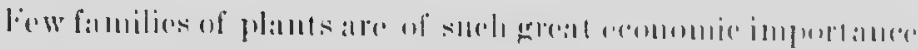

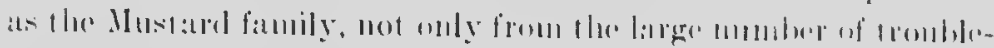

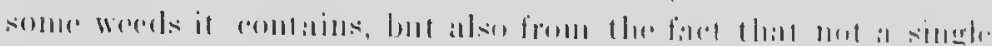

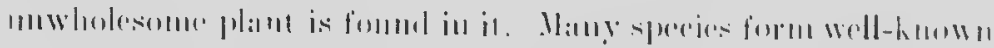

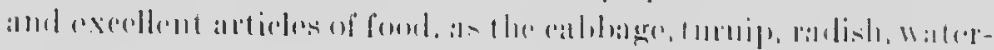

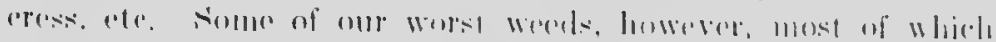

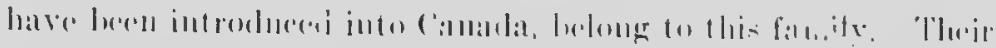

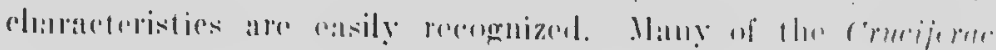
have in their mots. 
to julentify them. The leares amel stems of many bear small, star-shapend hatrs. The flowers anre regular, composed of four fror ralyx divisions and four free copolla divisions, atranged in two opposite pairs and forming a ross-shaped flower, from

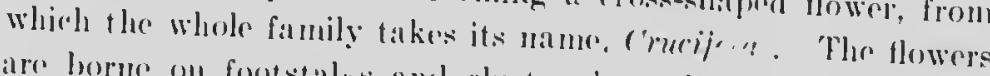

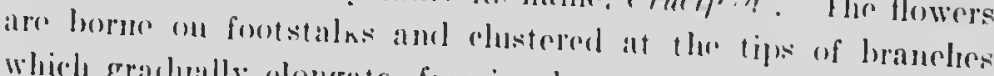
which granhally dongate, forming long, upright racemes, of ton with fully formed and even ripe poels holow, hefore the topmost flowers have opened. Whold ripe the seed pork, which are of varions shapme, tsublly colsist of two outside walls separated by at hin white partition, to the sidles of which the sorols are at tacherl.

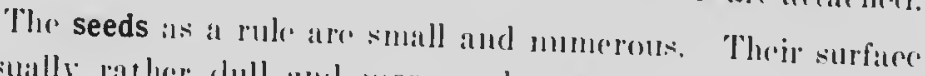
is listully ratlere dull and more or less gramulas. Many, whon

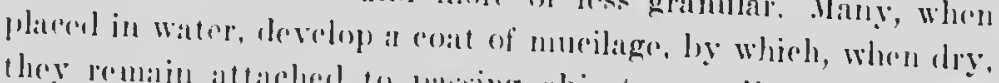
they benalu attached to passing objects or aldiarent surfaces. This is an important factor in their distribution. Tho puantity

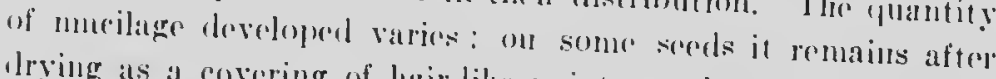
drying as a covering of hirir-like points or threads. The seded-

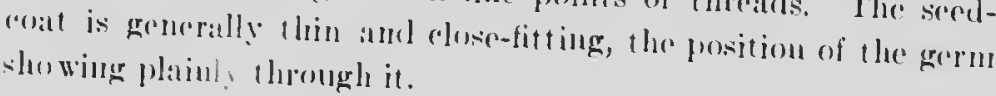

\section{WOOD WHITLOW GRASS (Irmba nemorosa L.).}

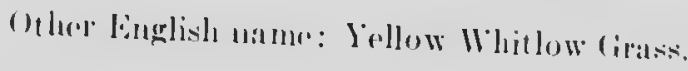

Siltive. Ammual and winter ammul. Slightly downy. Sitem

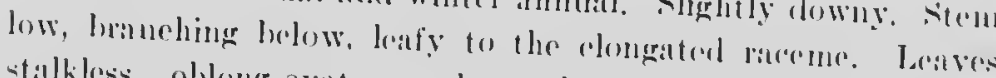

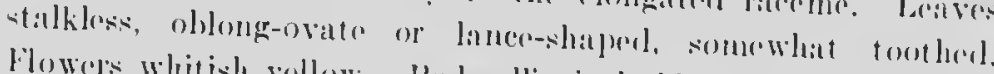

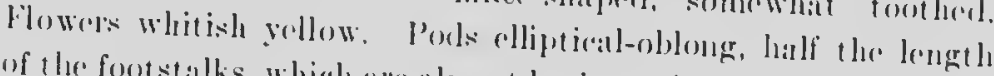
of the footstalks, whirle are almost lomizontal at maturity.

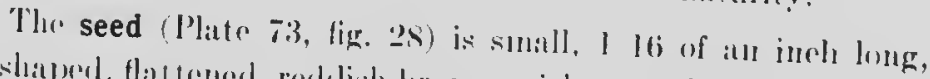

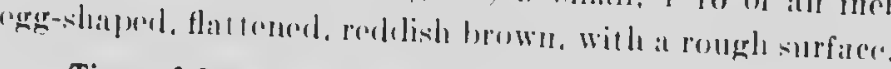

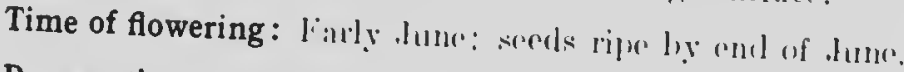

Propagation: $13 y \cdot$ sorels. 


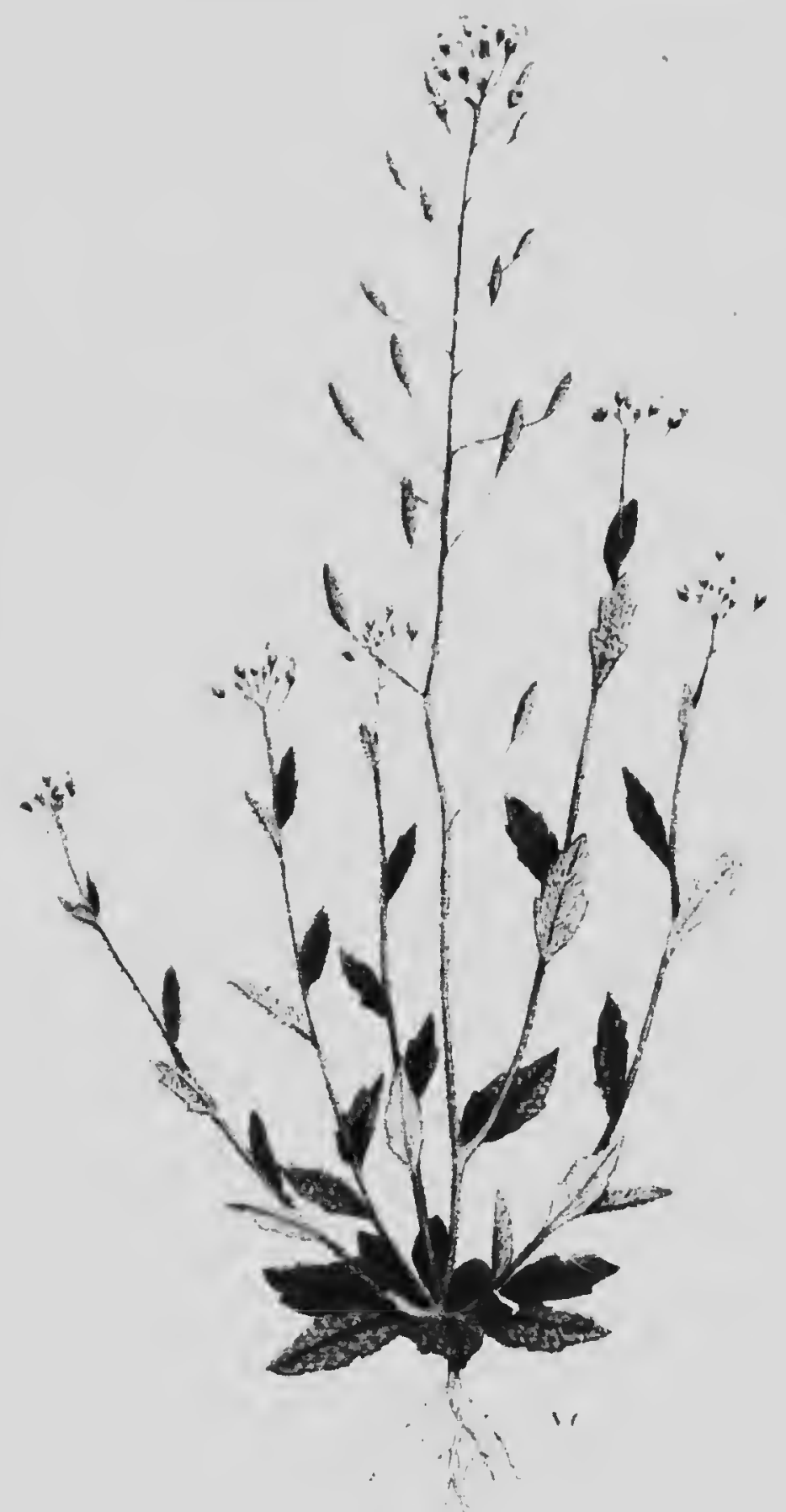

WOOD WHITLOW GRASS 
$\gamma$ 


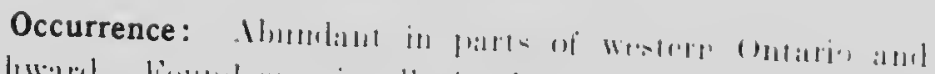

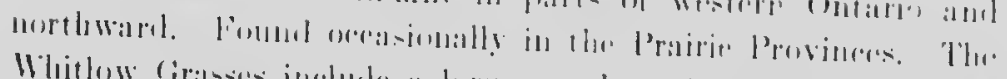

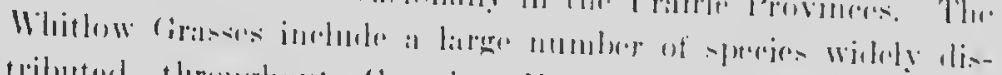

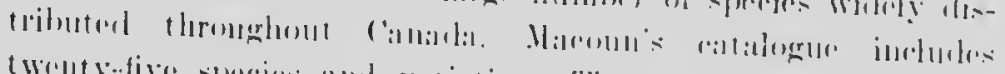

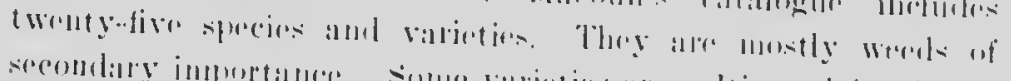

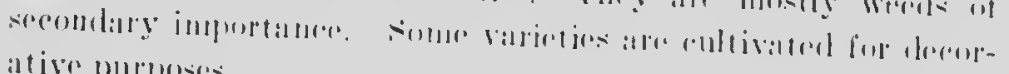
ation purposis.

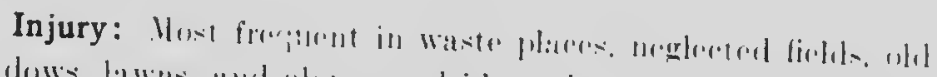

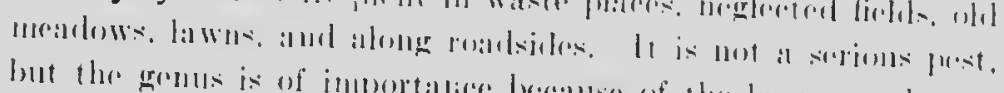

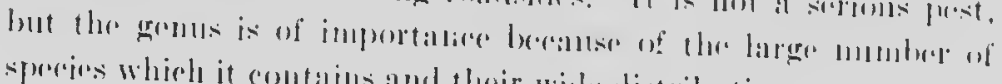
sprocios which it contalus and their whlle distributiont.

Remedy: The whithow grassese to mot long rontimur in

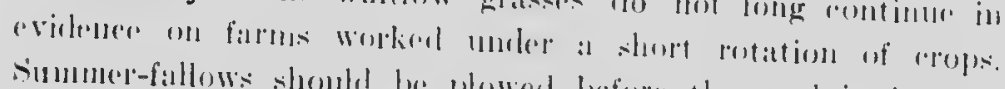
sommerefallows shombl he plowed hefore the sored is forment. Contimued raking and dose "utting will suppertes them on law

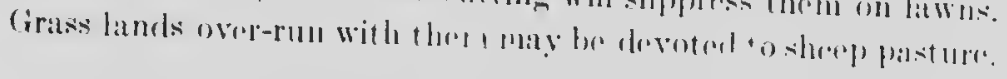

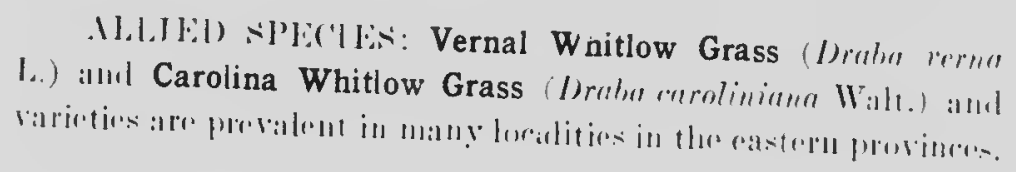

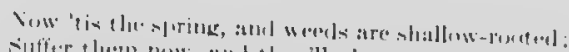

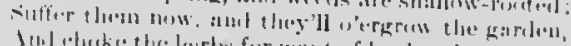

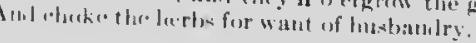

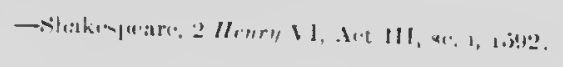

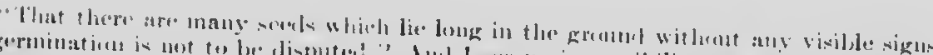

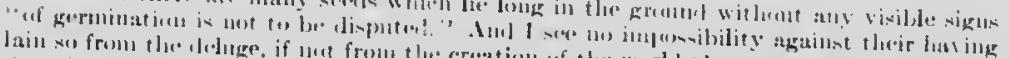

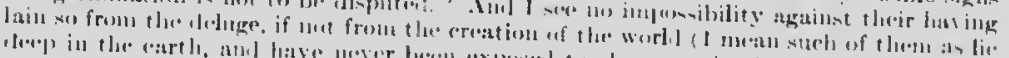

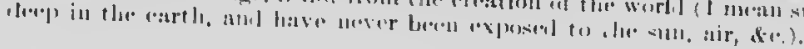

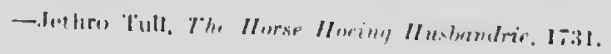




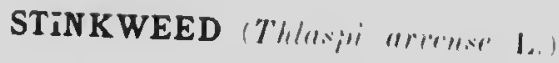
Ilustial.

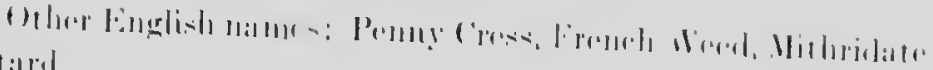

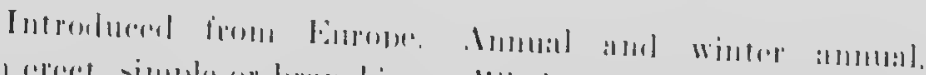

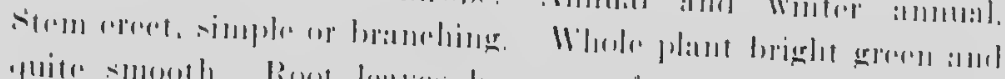

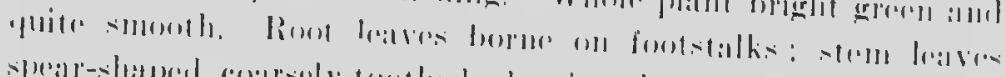

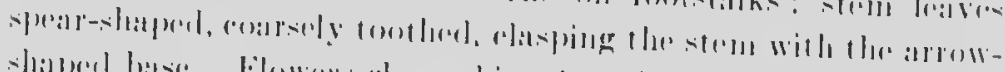

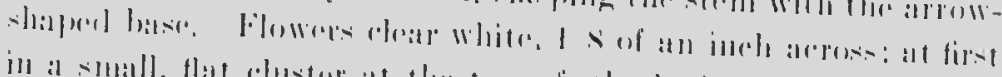

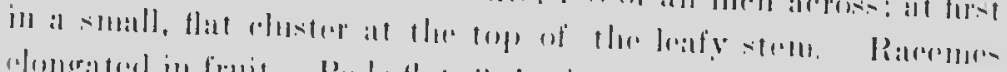

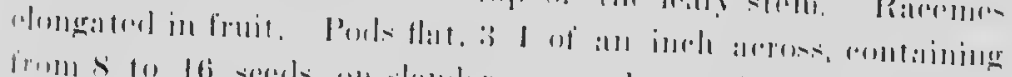

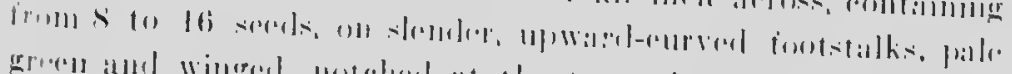

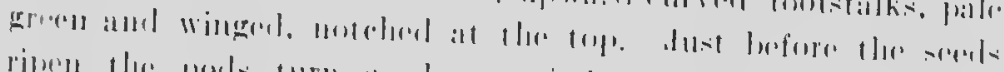

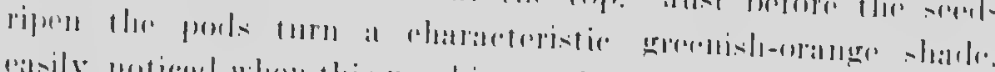

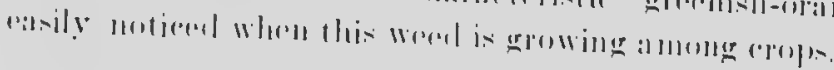

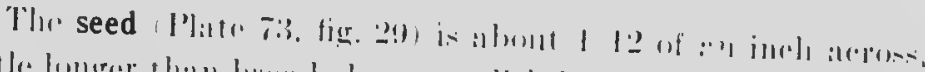

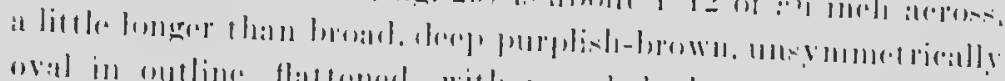

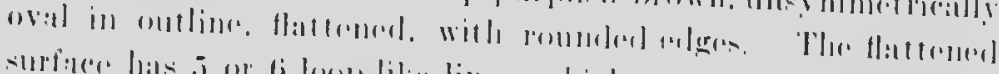

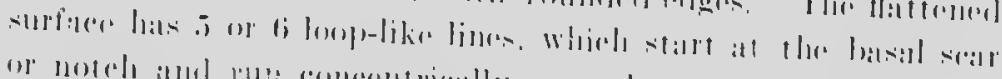

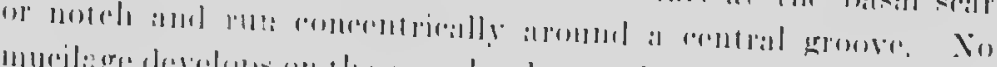

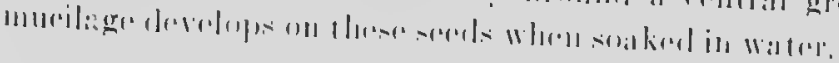

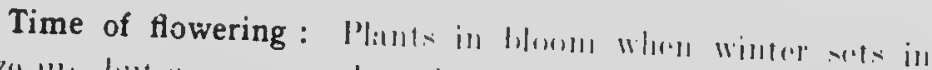

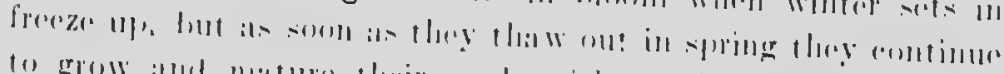

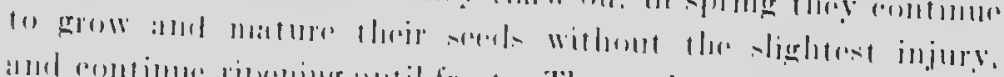

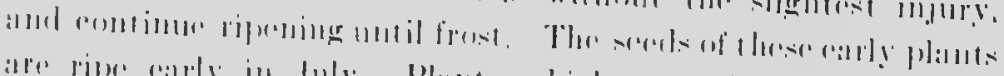

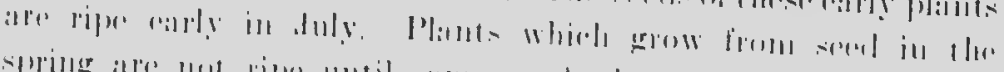

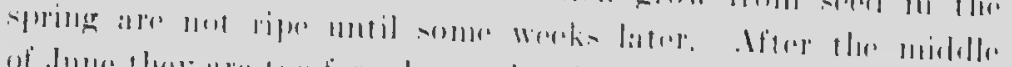

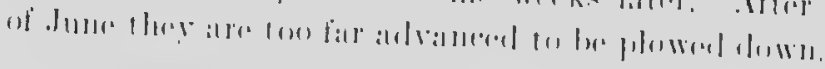

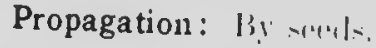

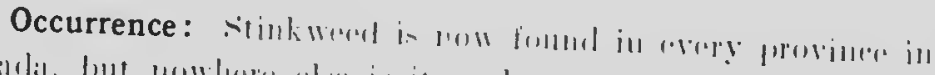

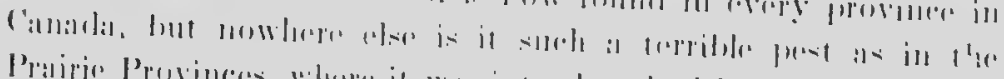

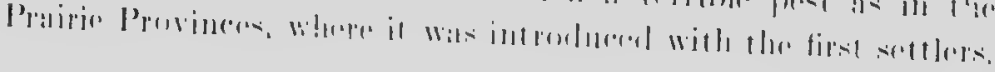




\section{sing}

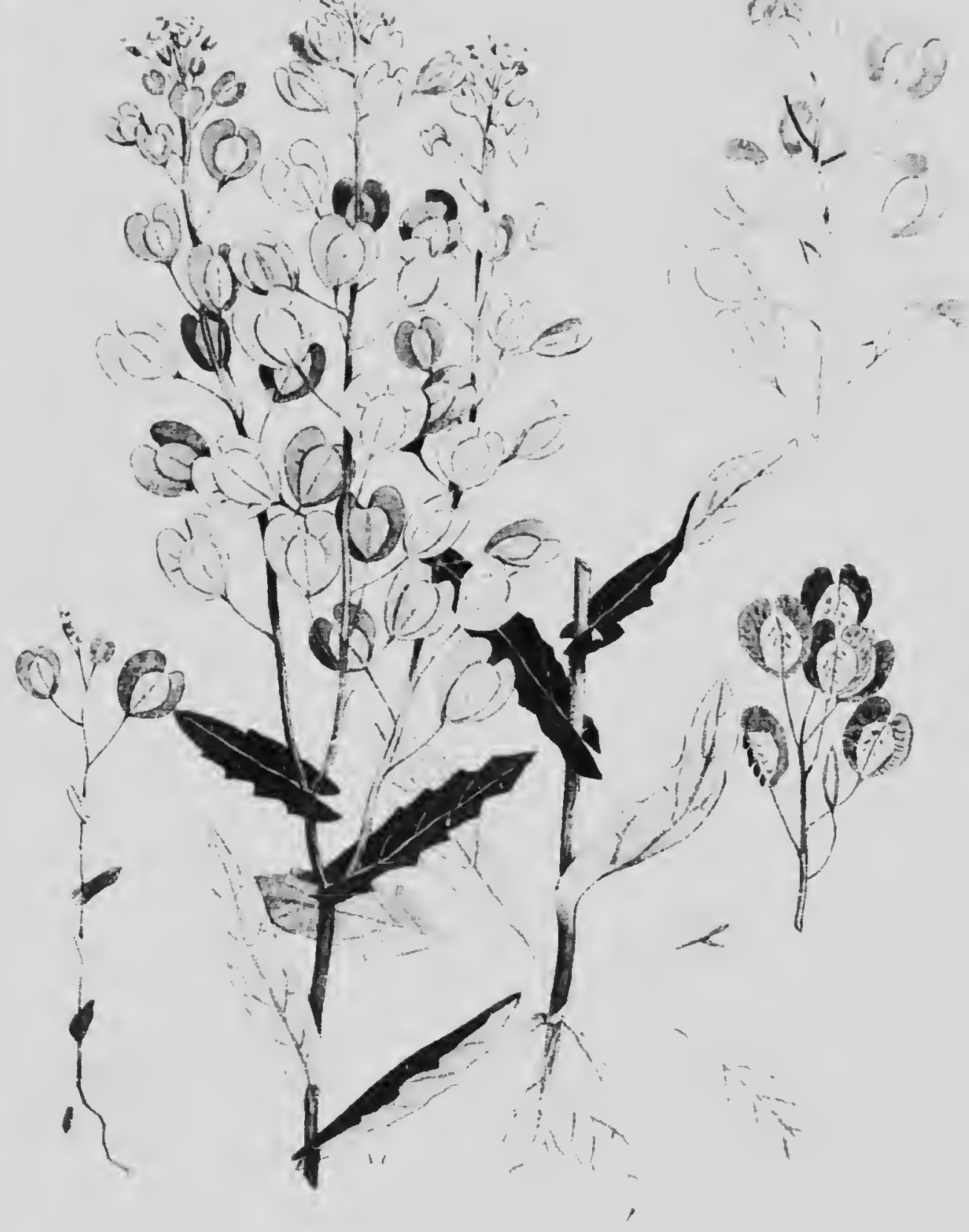

STINKWEED OR FIELD DENNYCRESS 



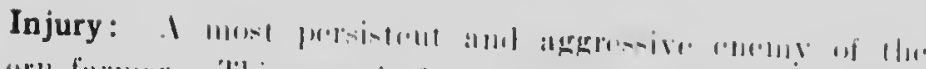

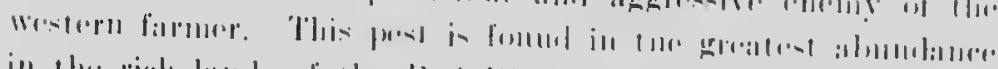

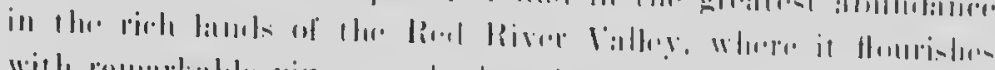

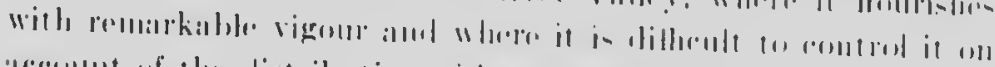

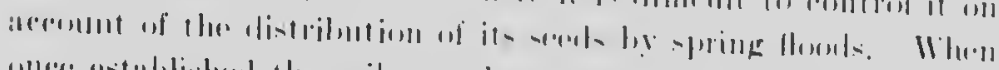

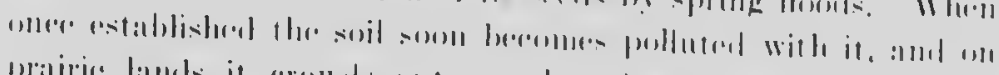

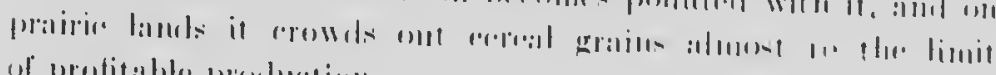
of protitahle pombretion.

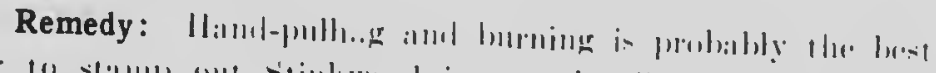

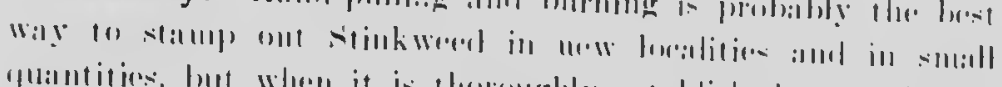

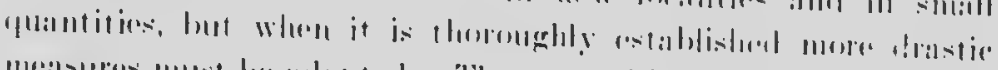

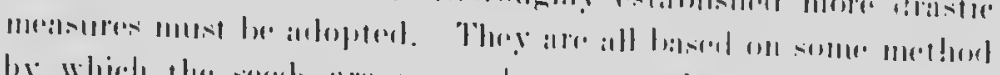

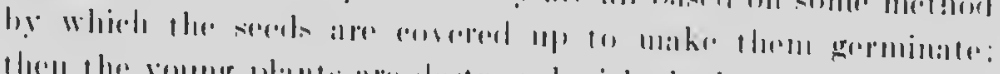

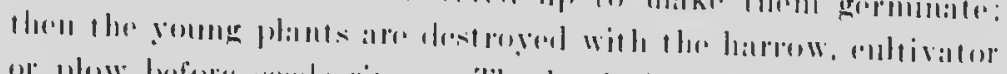

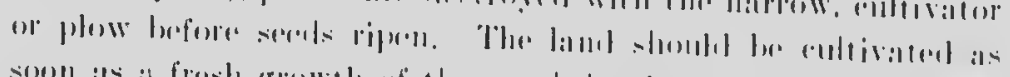

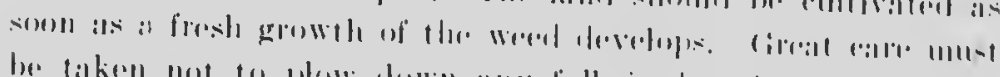

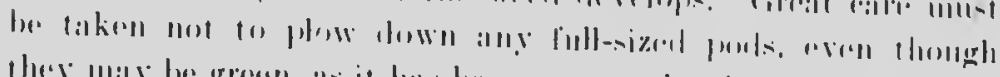

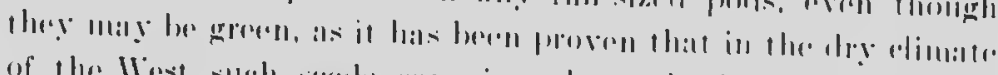

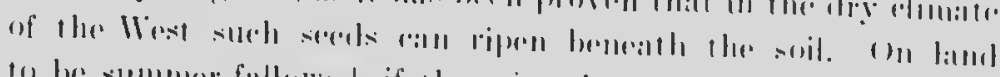

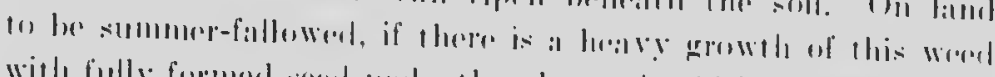

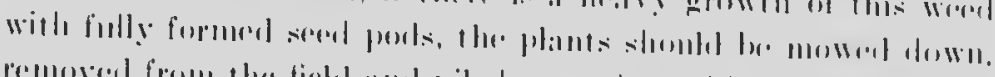

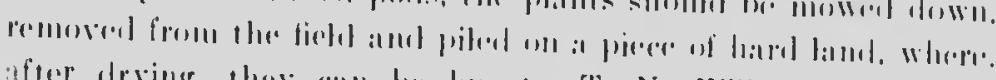

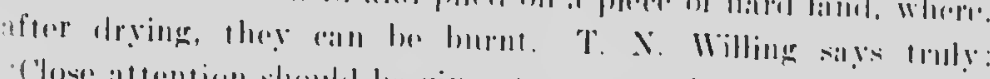

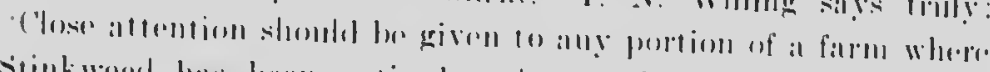

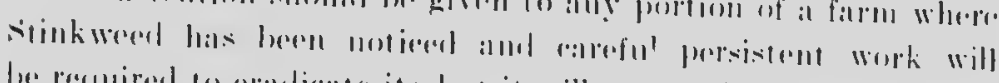

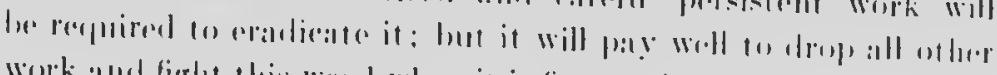
work alded fight this werel when it is first noticent."

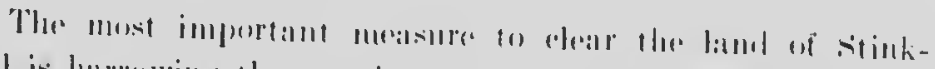

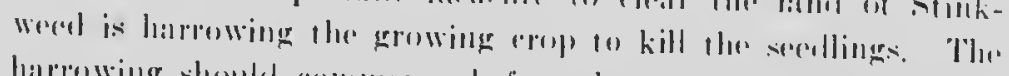

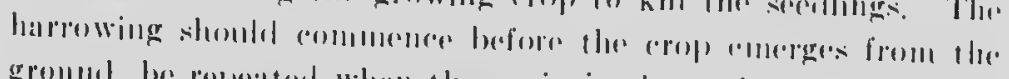
gromul. be reperated when the gralin is about three inclese high, and repeated again in bad rases when the grain is five or six

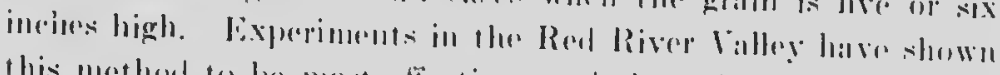

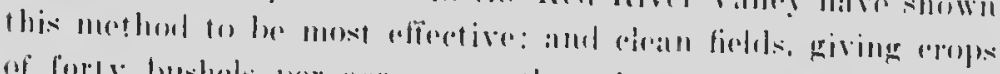

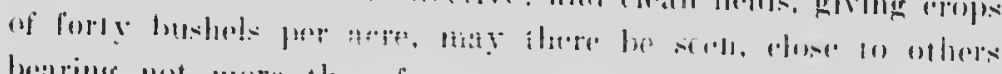

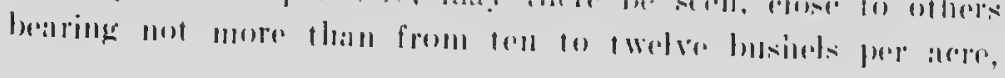


บ.

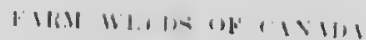

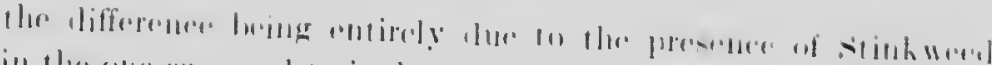

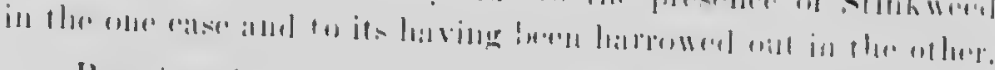

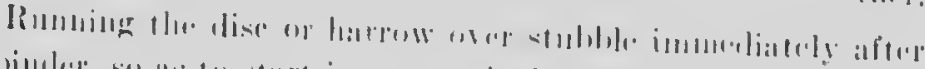

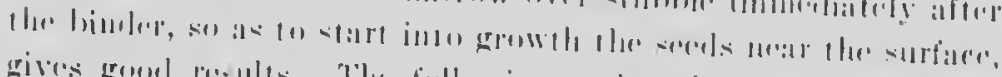

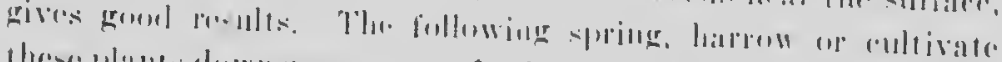

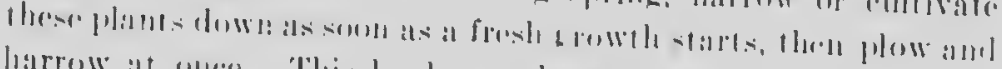

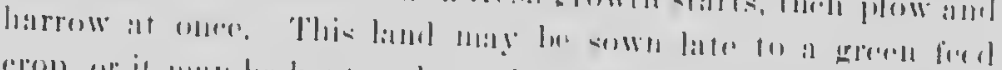

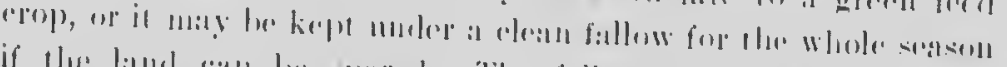

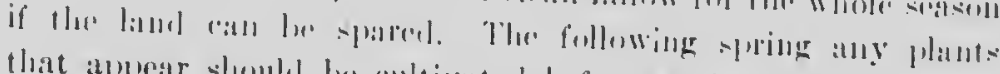

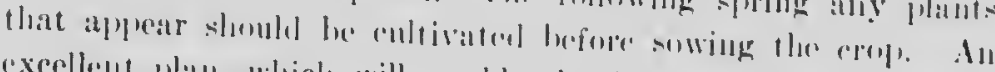

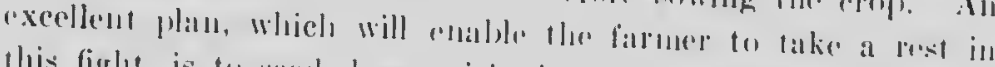

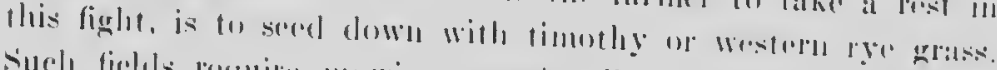

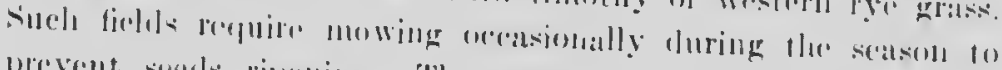

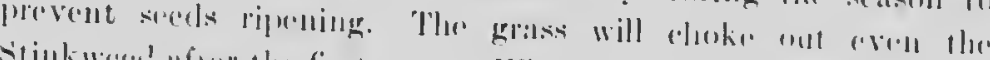

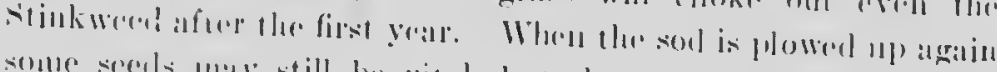

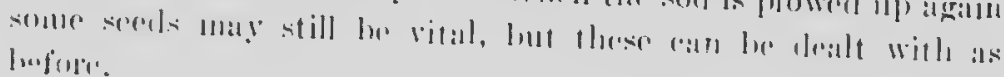

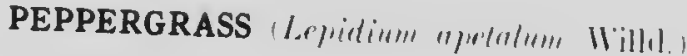

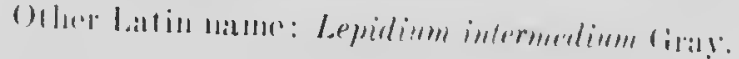

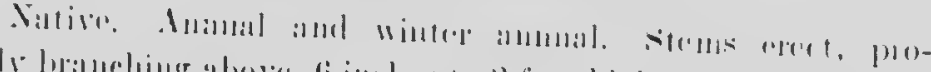

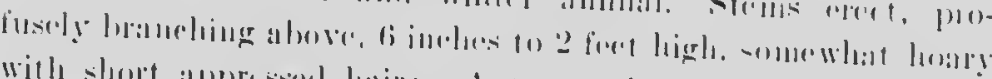

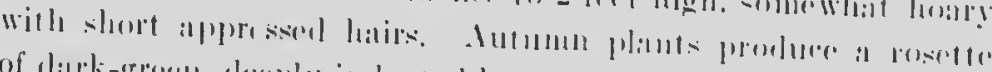

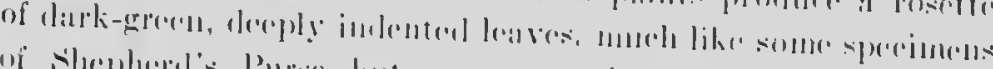

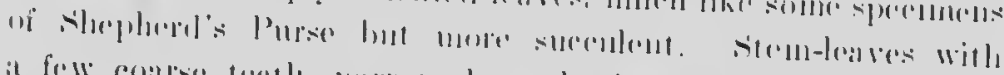

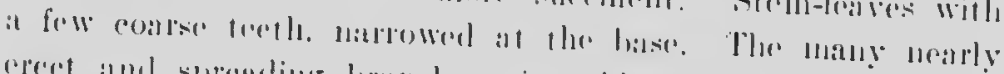

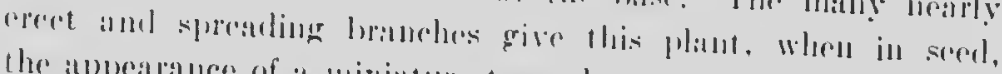

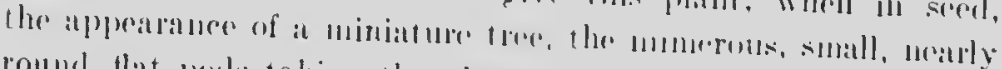

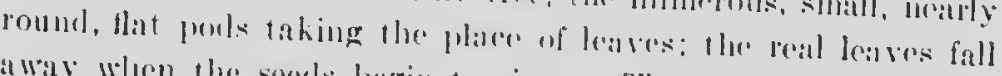
awa when the sorels begin to ripen. The flowers atre minute:

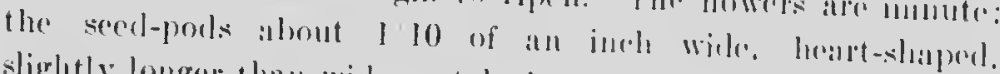

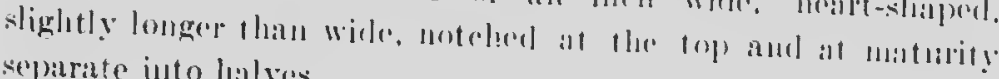
separate into halvos. 


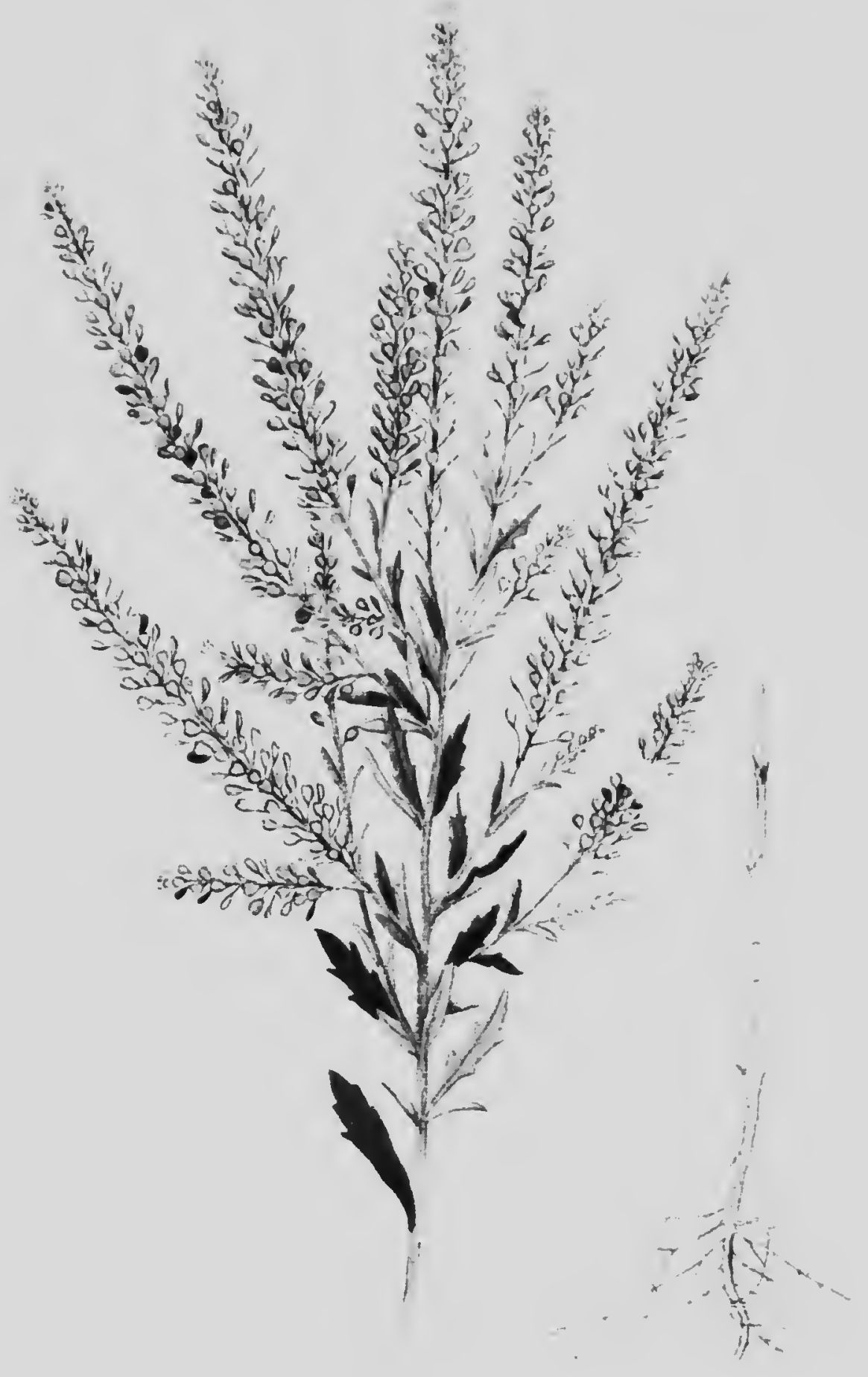




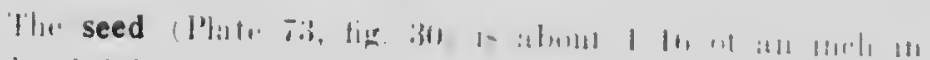

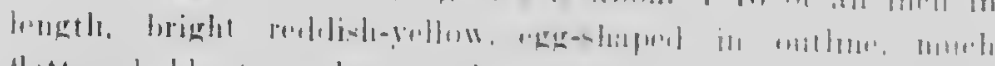

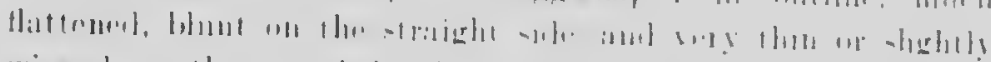

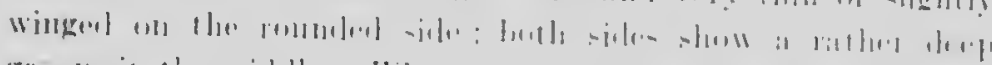

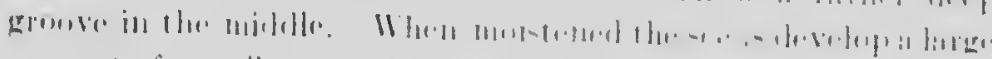

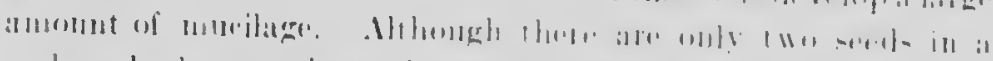

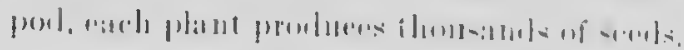

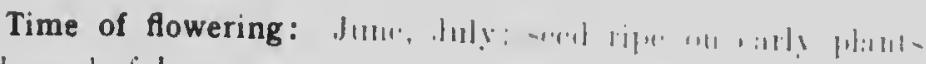
liy [he (1) of Jull.

Propagation: 13y, ard.

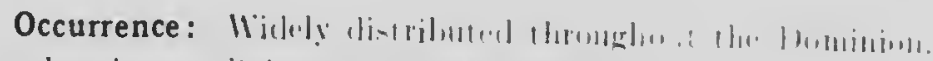

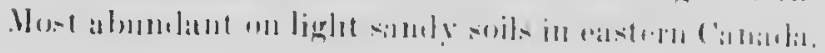

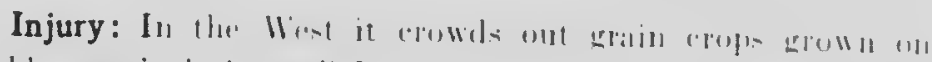
stubble, palticularly on light land amel in a wet -pring This in

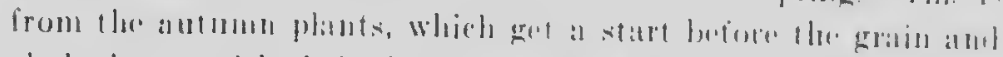

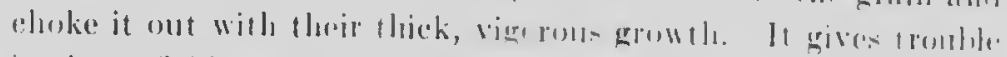

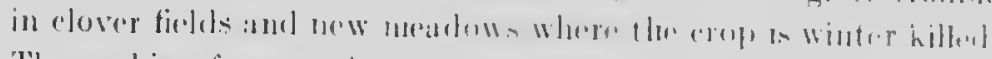

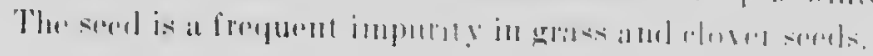

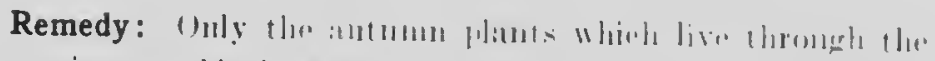

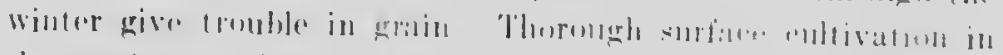

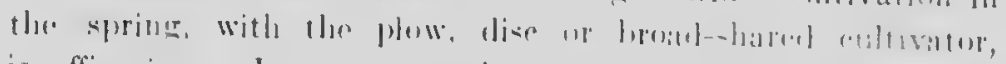

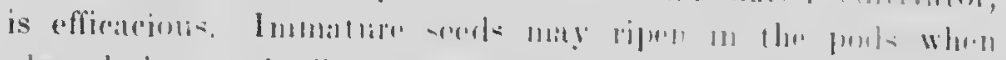

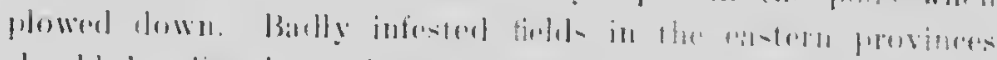

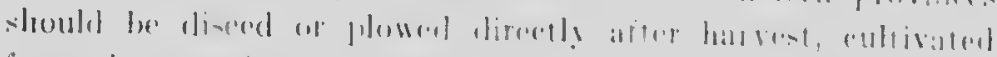

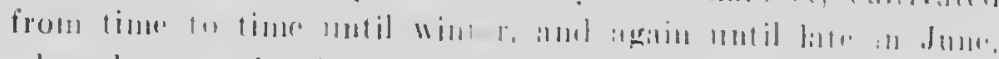

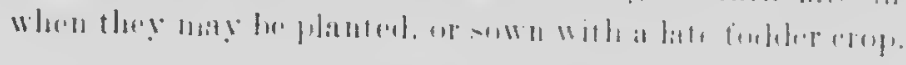

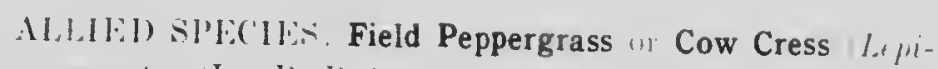

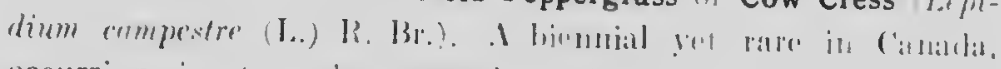

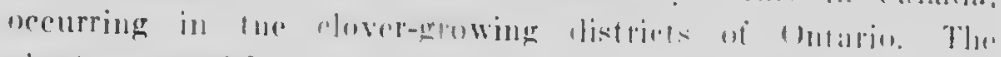

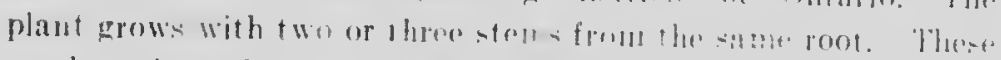

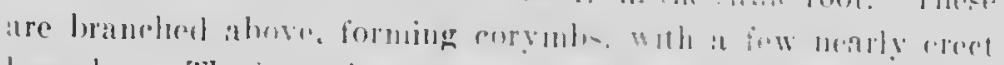

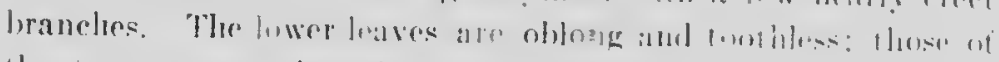

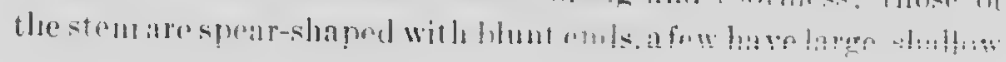


sit

FARM WHAS OF (OWIDS

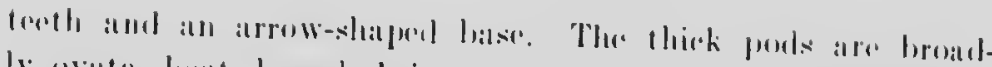

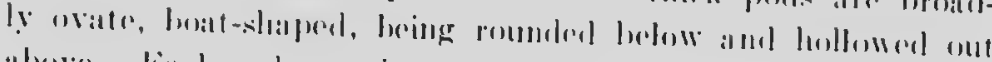

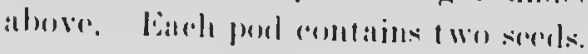

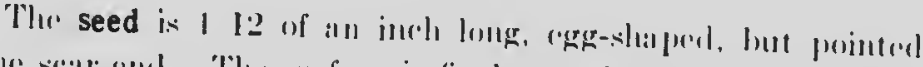

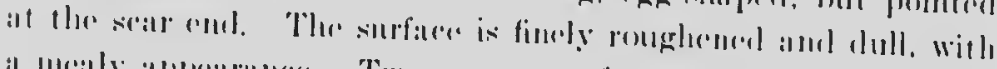

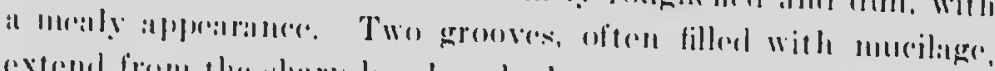

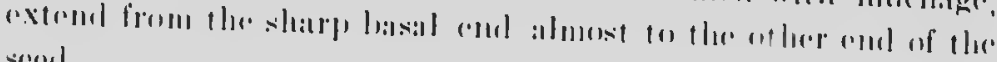
sionl.

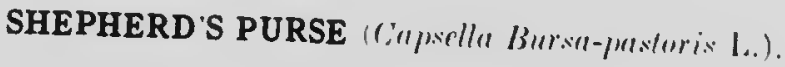
mestoris: 1.

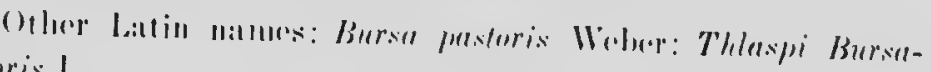

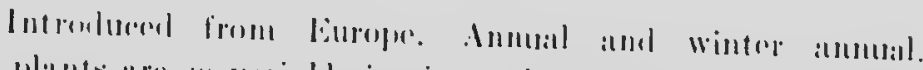

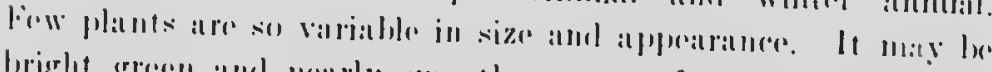

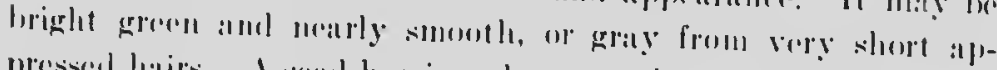

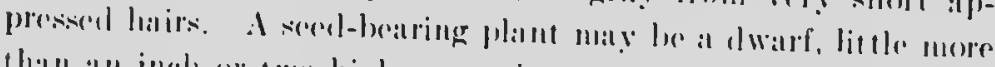

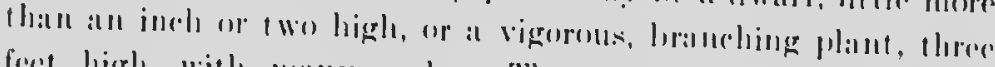

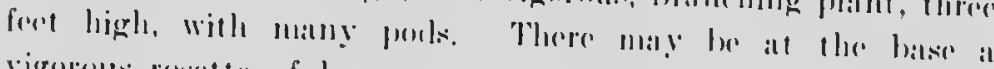

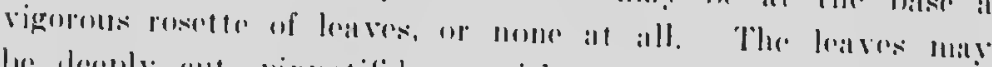

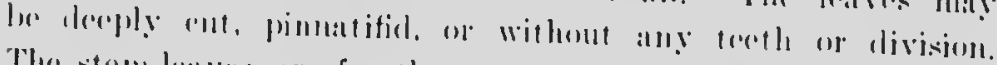

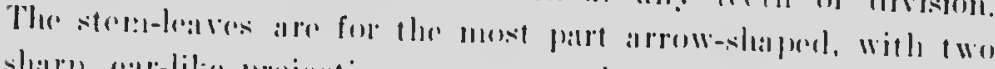

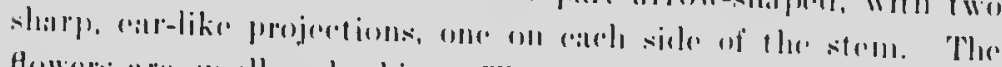

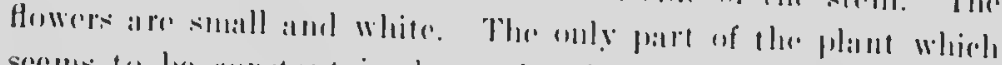

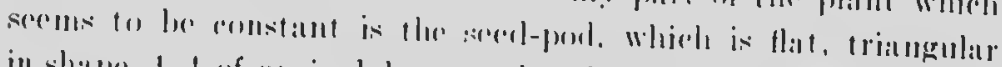

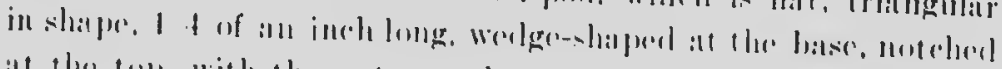

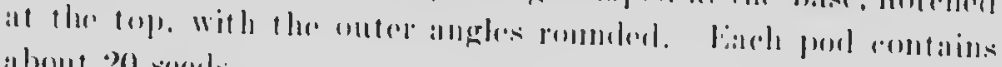
about 20 sisls.

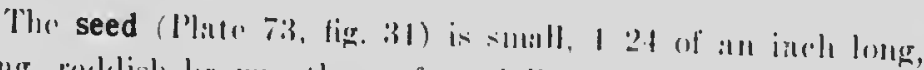

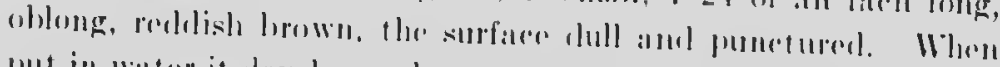

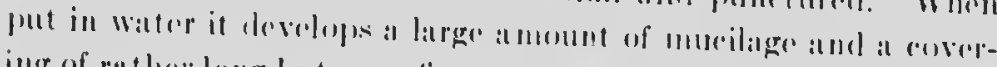
ing of rather long hut rereg finc, transpat rent hitirs. 


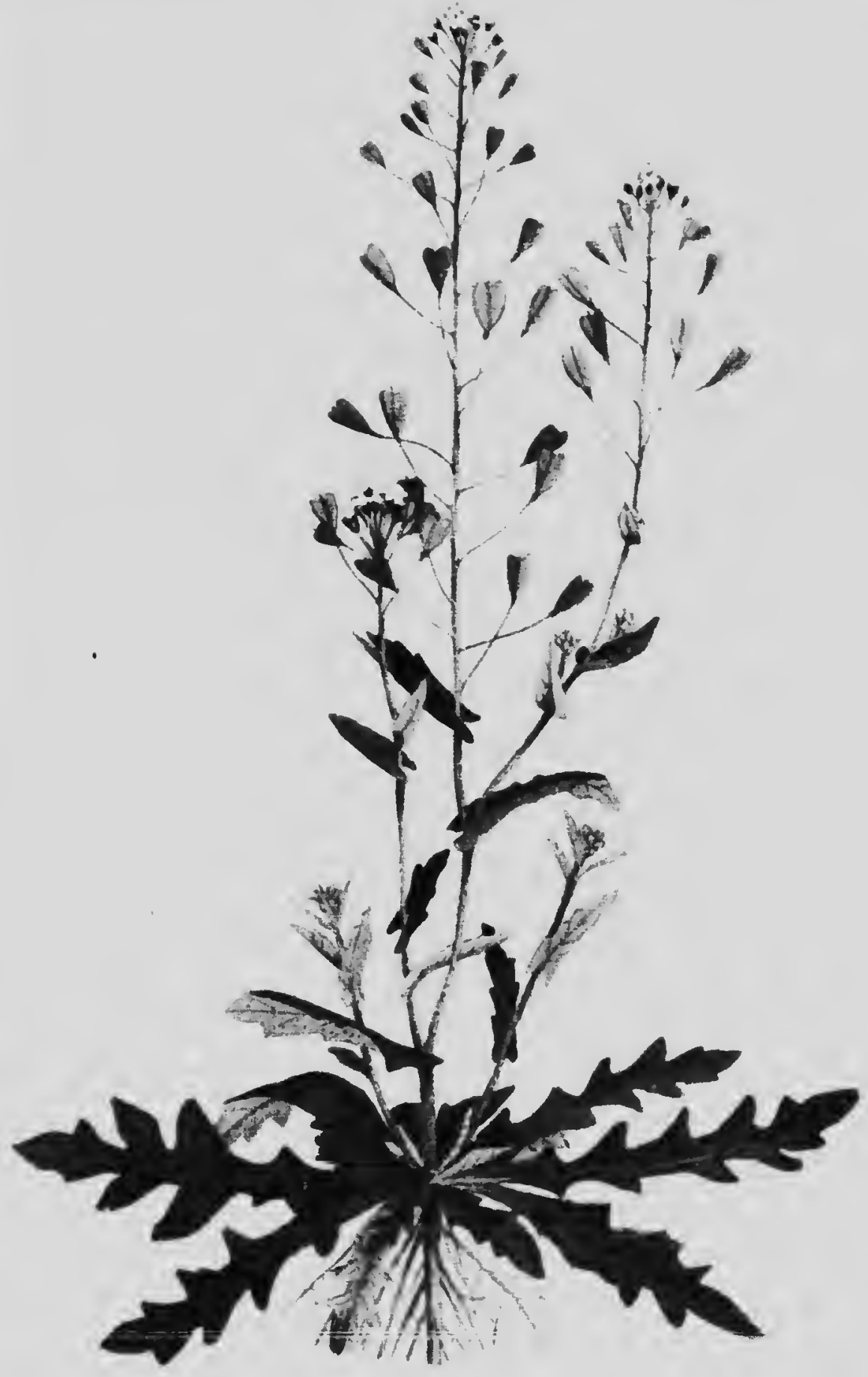




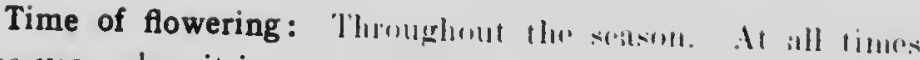

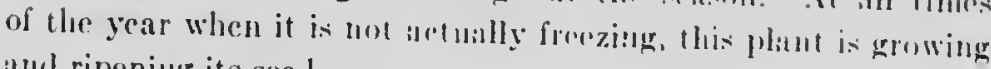
athel ripening its secels.

Propagation: 13y siecels.

Occurrence: Throughout ('alsitla, in ill sulls. The sirel is found in all small commonerial werecls.

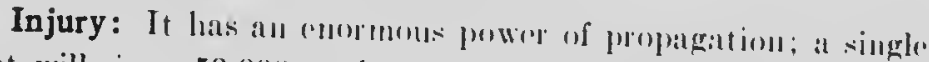
plant will ripen 50,000 serels. It will thrive in all kimls ol soil, is of a succulent mature iturl aboots much moisture. In mearlows

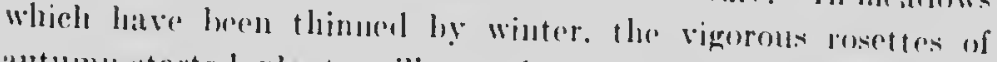

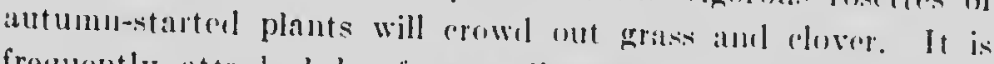

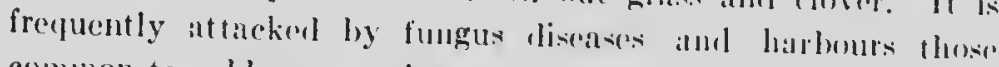

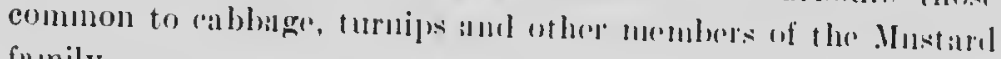
fanily.

Remedy: The same general treatmint ats giren for leppergrass. Waste places should be cleaterl ats fare as practicallale alle seceled to grats. It does not give serious trouble an lands

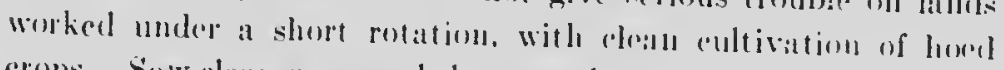

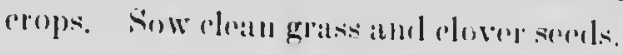

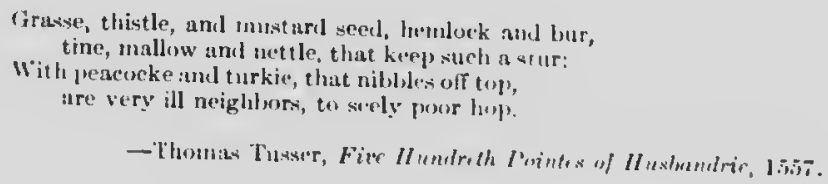

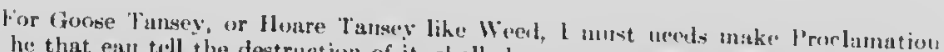
That he that ean tell the destruction of it, shall show a very aceptallus service; ami fur

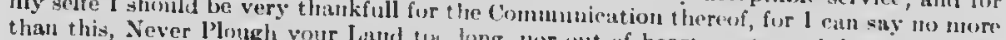

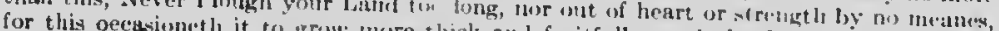

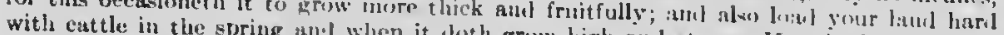

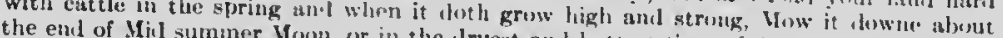
lier the better, and ot soyle it well with gotul l) proseribe none other, but in ail your llowings of experiesce hereil will holp une.

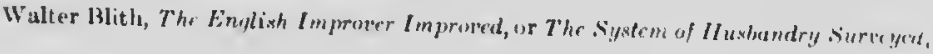


FALSE FLAX (Camelina :uliua (1..) ('rintz).

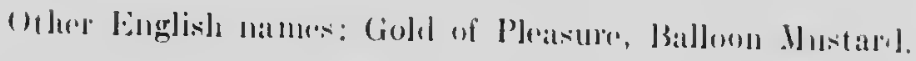

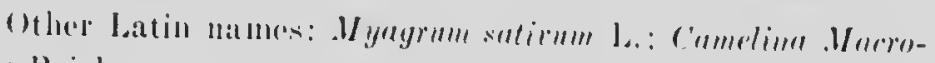
carpa Roiels.

Introdueed from Emrope. Ammual and wintor ammal, 2 to

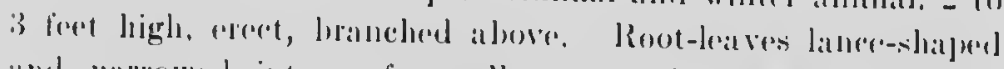

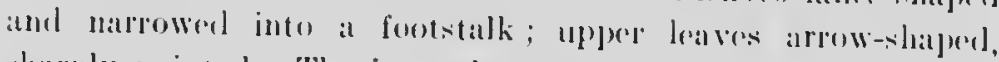
sharply pointerd. The lower leaves and the lewer grale of the stem downy with stal-shalperel hatirs. The upjere palt of the

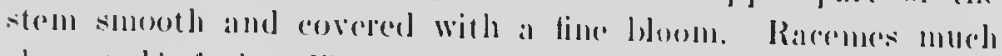
rlongated in fonit. Flowers mumeroms, smanll, 1, siof a n inch ateross.

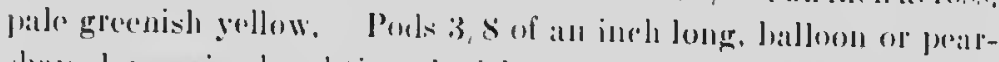

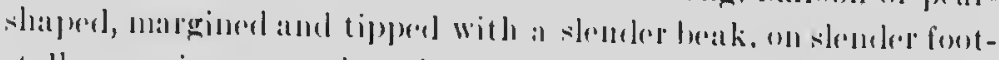
stalks, curving npwarel, calch eontaining about 1t serols.

The seed (Plate 73 , fig. 32 ) is valiable in size, almut 1, 12 of

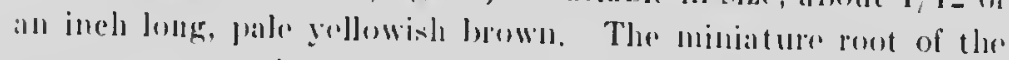

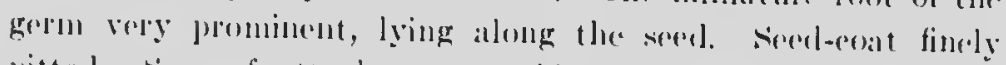
pitted. Sear of attachement a white perint in a netele at the

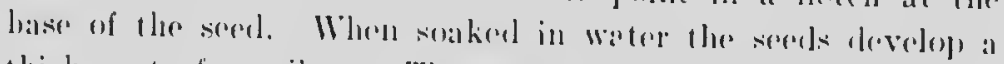

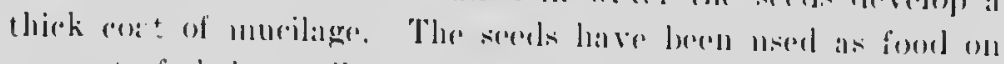

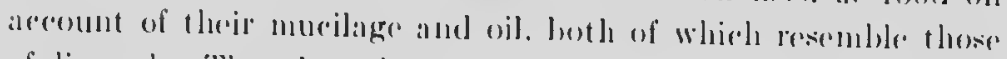
of linserel. The plant has lenen coltivated for these probluets in firmanty alml lianture.

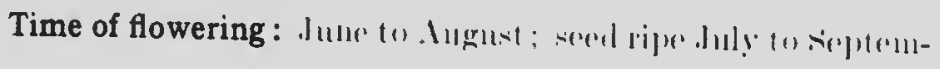
Inel',

Propagation: 13y screrls.

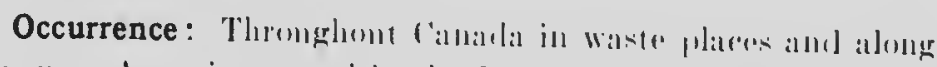

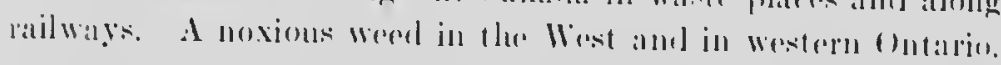

Injury: In westrern Callatla it is in revilenere in grain sown

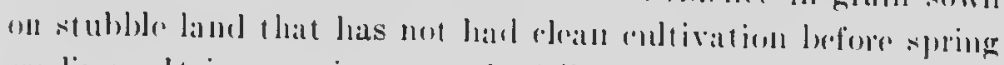

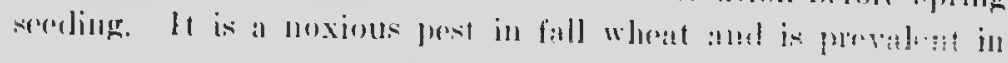




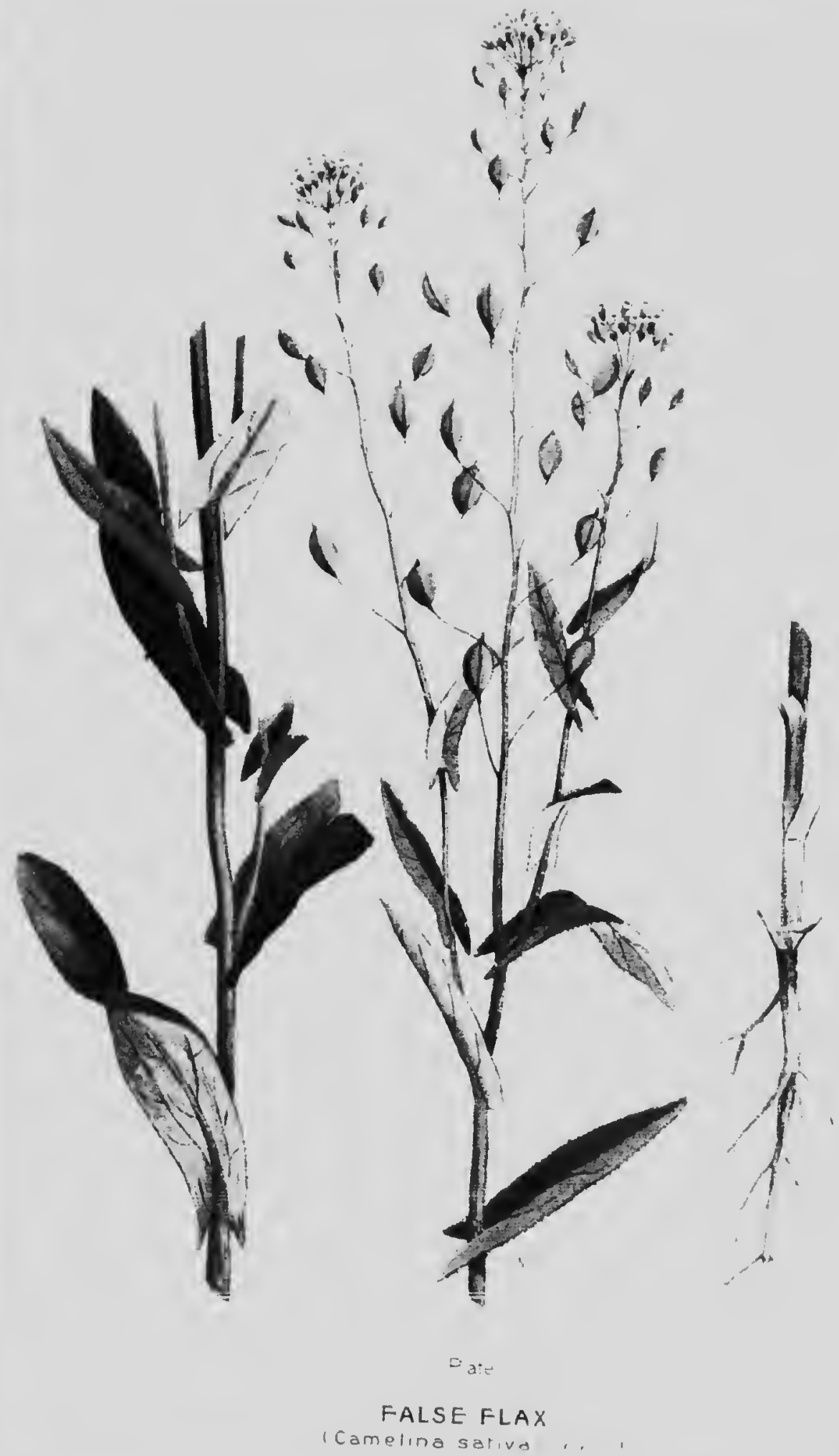




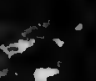

8 


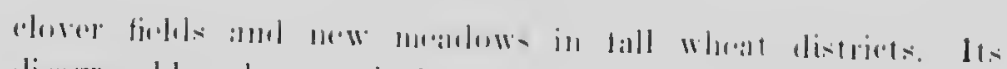

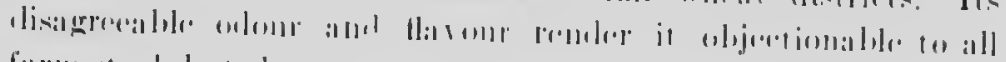

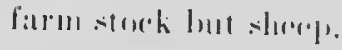

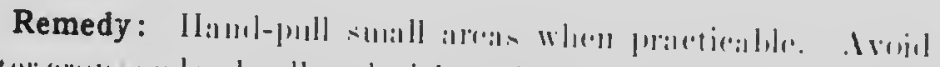

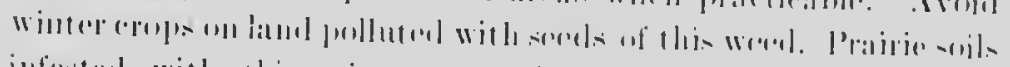

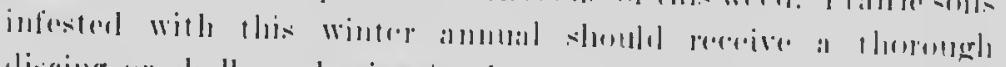

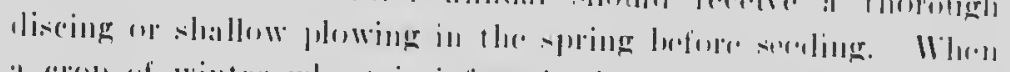

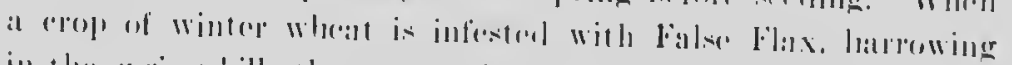

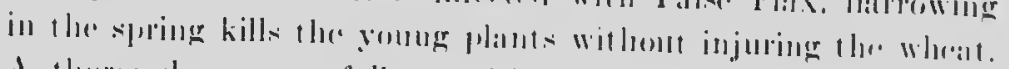

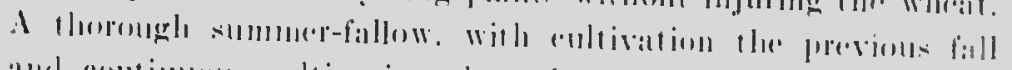

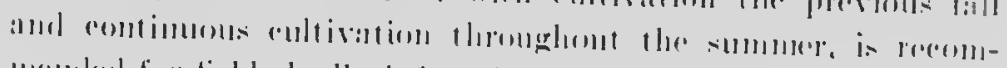

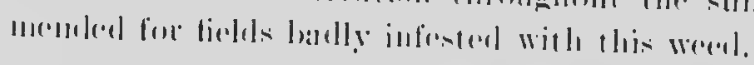

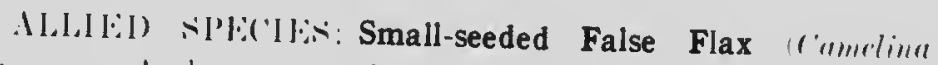

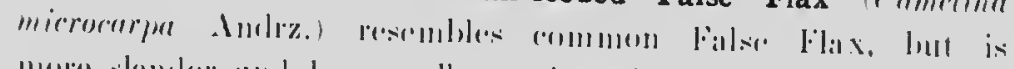

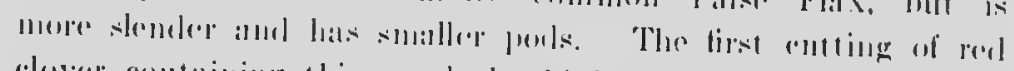

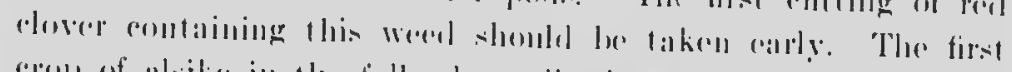

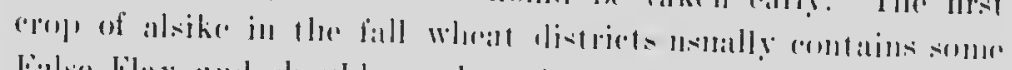

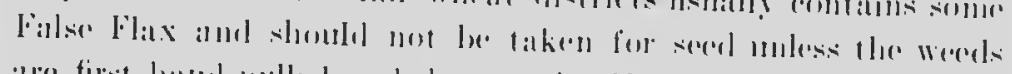

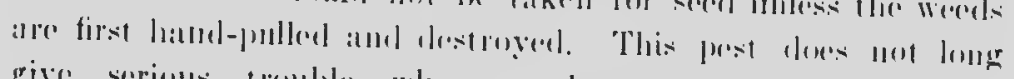

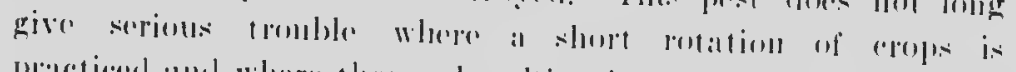

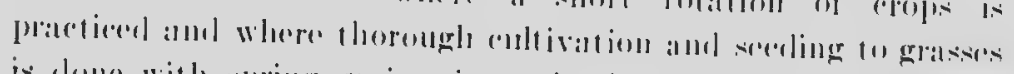
is done with spring grains instrill of fall whestl. The seeds

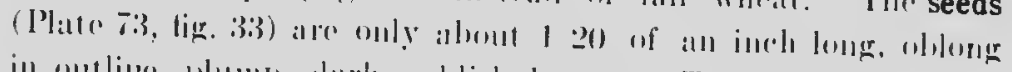

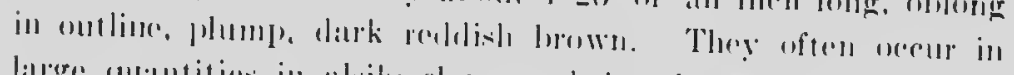

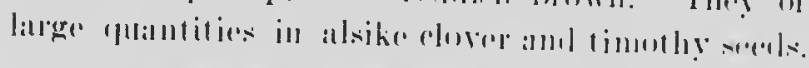

Round-seeded False Flax (Cumelinn dentotu Pors.) was

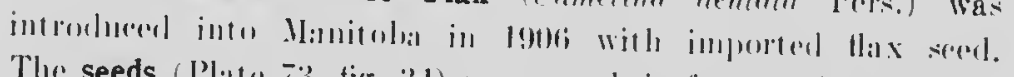

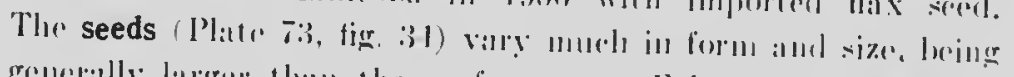

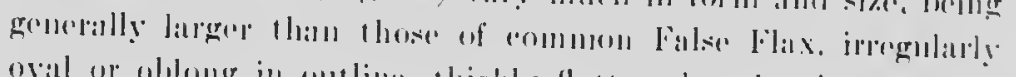

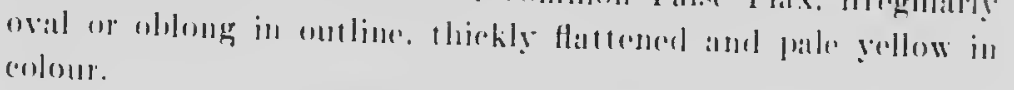

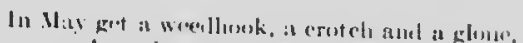

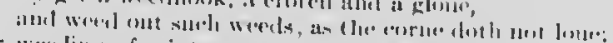

lior werelieg of wintrer corne, now it iv best,

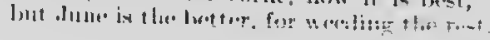

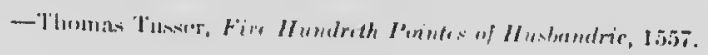


BALL MUSTARD (Neslin muirulatu (I.) Dess).

()ther Einglish nanmes: Vellow-Worel, Nestiat.

()ther batin nanne: M!yagrum paniculatmm l.

Introhheref from Europe into the Wrest about the same time

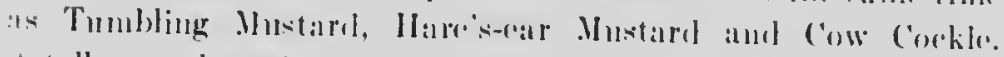

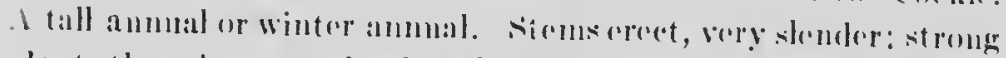
plants throwing out a few long branches. Whole plant yollowishgreen and covered with small, apperesserl, stall-shapped hairs. Lower leaves laner-shaperl, narrowed at the base; strm-leaves arrow-shaped relasping the stoul at the basc, blunt-pointed. Flowers small, l/s of an inch arross, orango-yellow; racomes very long.

The seed (Plate 73, fig. 335) is (melowerl in small, roumrl, one serelerl. shot-like pods, commonly ratled "serel." which are borme on slencler footstalks, ahomt i 2 of an inch in longth, staneling out from the strem in all directions. These porks, when mature and dry, are about 1, 12 of an inch in clianoter, romolish, greenish-brown, romghly net-reincel, somewhat like a small

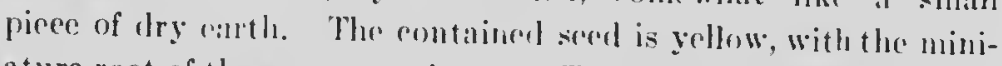
ature root of the germu prominent. The whole pods are genemilly found in grain, as they fon not open to discharge the soreds.

Time of flowering: Junn to .tugust ; somes ripe Julle to september.

Propagation: By somls.

Occurrence: Very provalent in northern Alberta: rapirlly becoming more abumlant in the other Pratie Proviness. ('on-

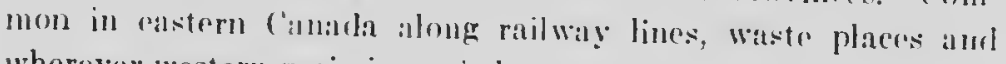
wherever western grain is earriol.

Injury: A noxions weed in the grain repos of Ilanitoha, saskatrhewan and Albertá. The wrinhled pork or bills contaning 
A

0

$0.10^{\circ}$

- $) 00$

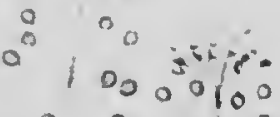

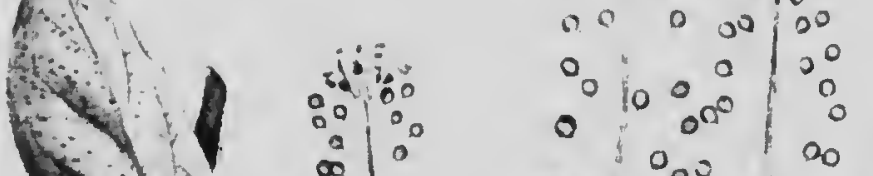

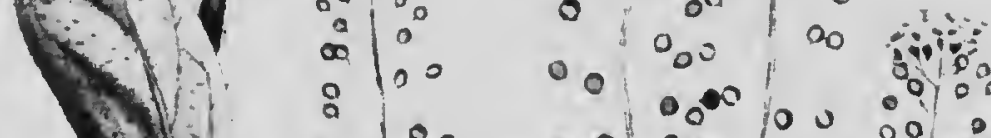
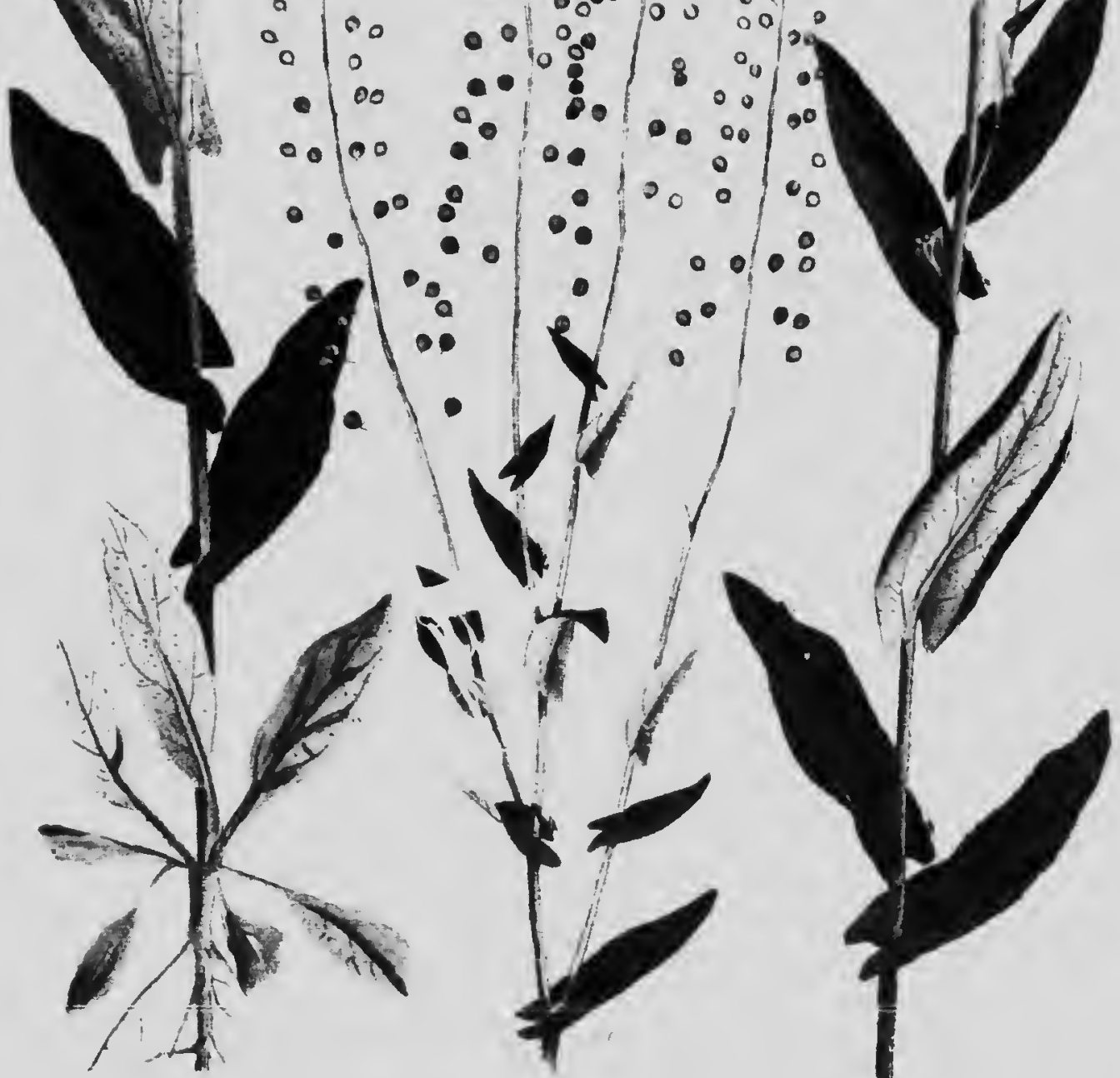

-

- 000 $\int_{1}^{0} 0,100$

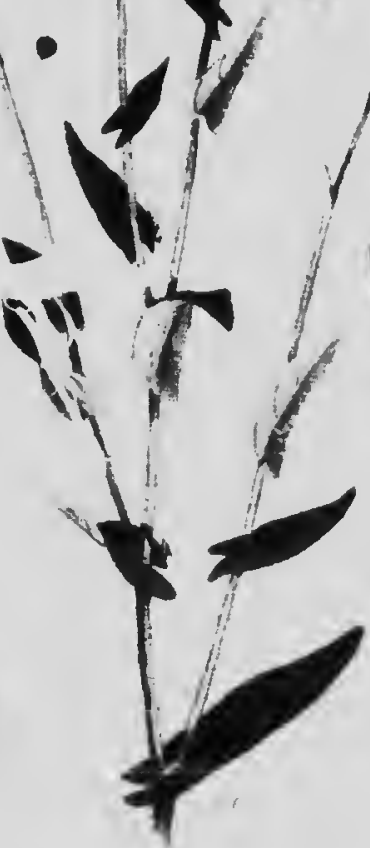

Fi:

BALL MUSTARD

Nesira paniculare 


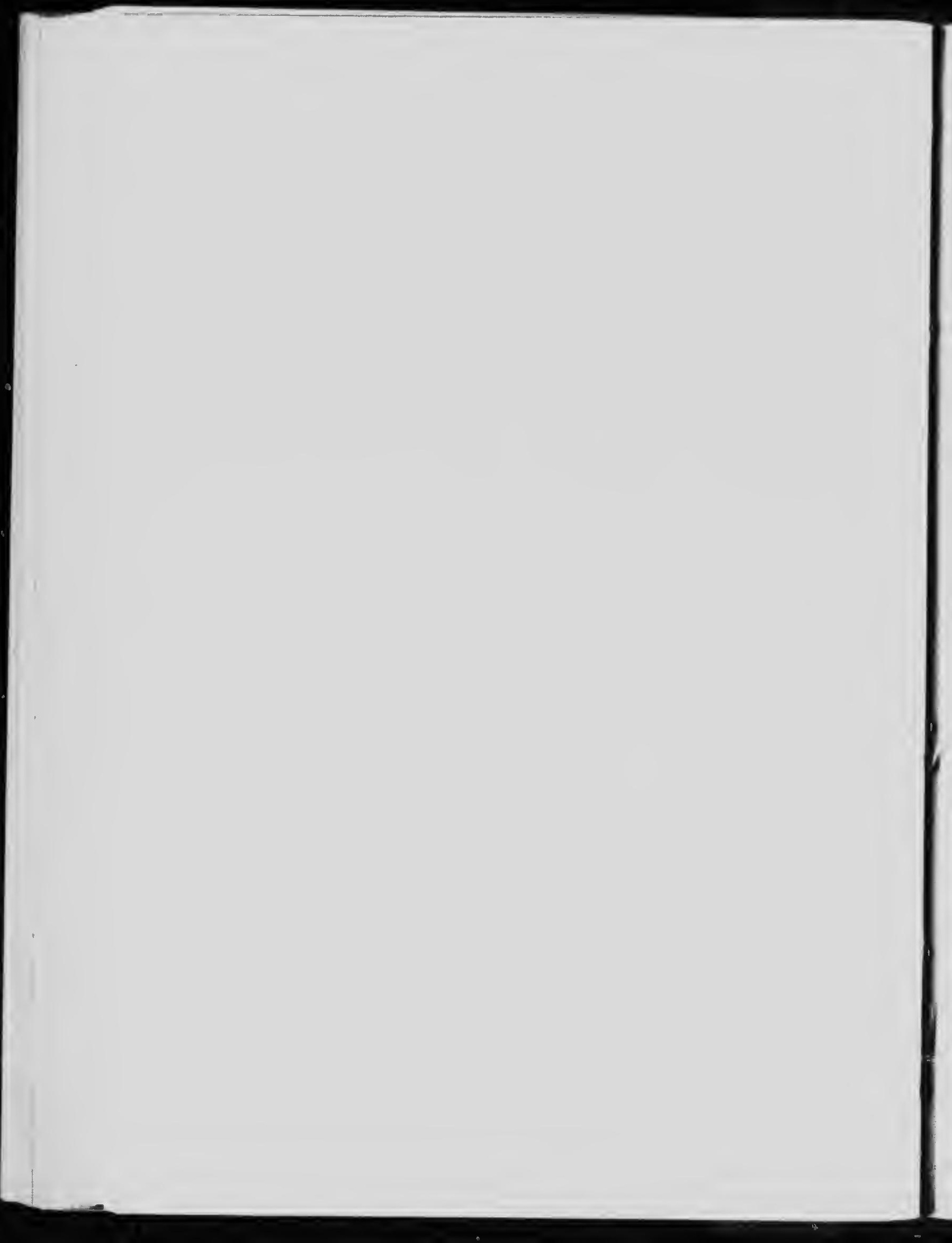




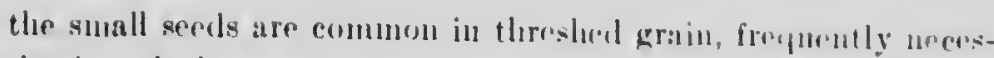
sitating dockage and recoleaning at points of inspertion and storage.

Remedy: Sow cloan semel. This wowel will mot lomg givo

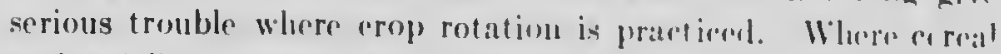
grains follow cereal gratus, plowing or discing in the fall and clean eultivation in the spring, with a tise or hrost-elaurel cultivator, is recommended. Harrow the arop before the plants emerge from the gromul, allel again when they alre flure inclies high, to destroy sondling weots. Bally infestod alloas shoulc. e smumer-fallowed: rlise and harrow rarly in the sprimg and plon arly in June. Soreding to grase for throw or four vears

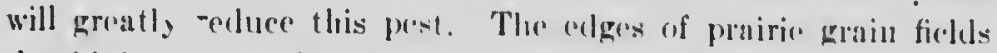
should be tr. emed with the mownr before these werels lave passed the flowering stager.

In some of the more mortherly distriets of the l'mirie Prowinces, where summor-fallowing is not rxpmlinent. growing grain for fodder gives an opportunity to clostl the land of this pest. Is with sumumer-fallow, begin with aliscing or early plowing immediately behind the binder in the fall. This shomlel be followed by cultivation with dise or hanrow rarly in the spring. The land should br plowed in June, thoroughly workerl up, and seeded with oats, barley or timothy. Bu surre to cut the crop bofore any of the mustard seeds mature.

Ball Mustard seeds aro nstrally prosent in wostom mats sold for serel in Ontario, Quebere and lle Maritime Proviners. Where chean seed can not be obtaimed, he fanning mill will climinate these serts by serening. Thr altermation of omps comnonly practiced in mixed farming will usually kecep this weed in cherek in eastern Camala. Sherp will ford on the yommg and temeler plants of this weet and of most others of the llustand fanily. 


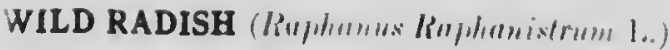

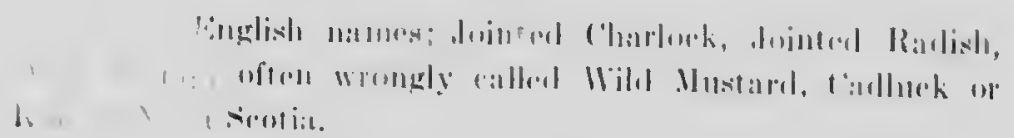

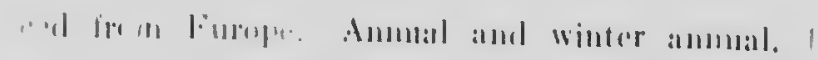

i.

'1

$1.1+1.111$

it it 11 silf

$11 i, 11, \ldots$

"ling a

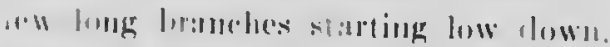

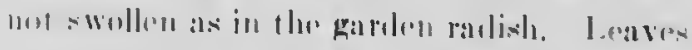
'inply lolect, amel, like the sterm, baring l'ler llowers aro fower amel larger than in

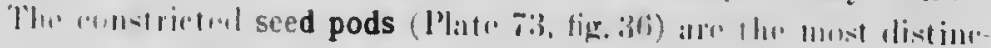

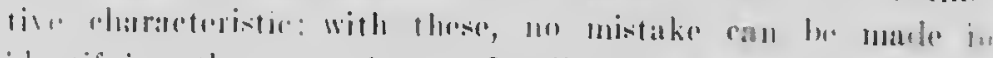

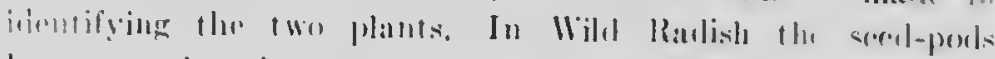

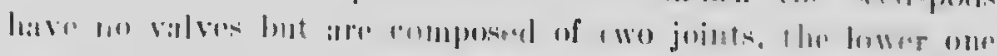

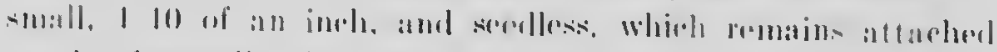

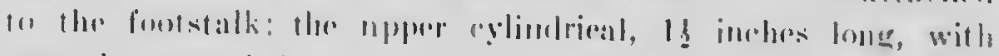

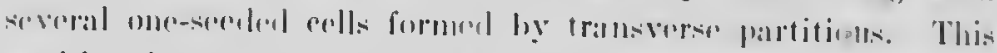

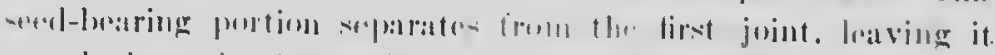

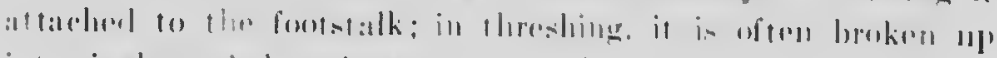
into single-sinterl swrtions.

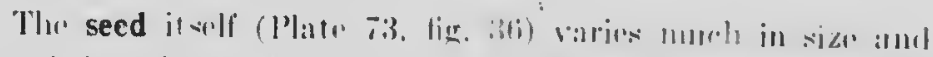

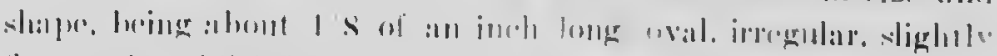

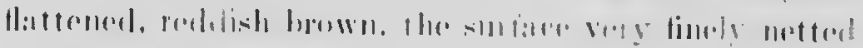

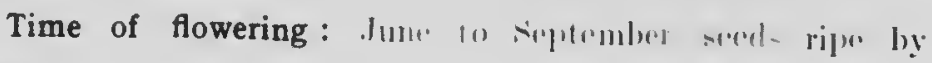
August.

Propagation: By sinels.

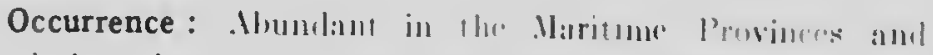

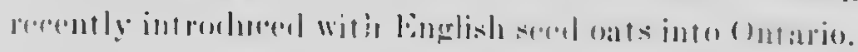

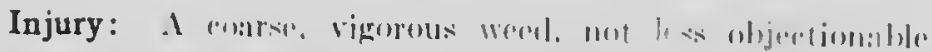

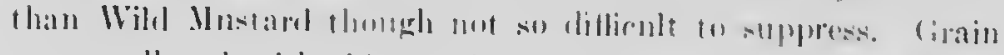

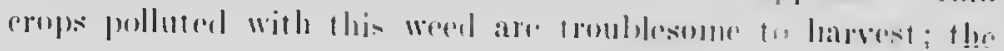




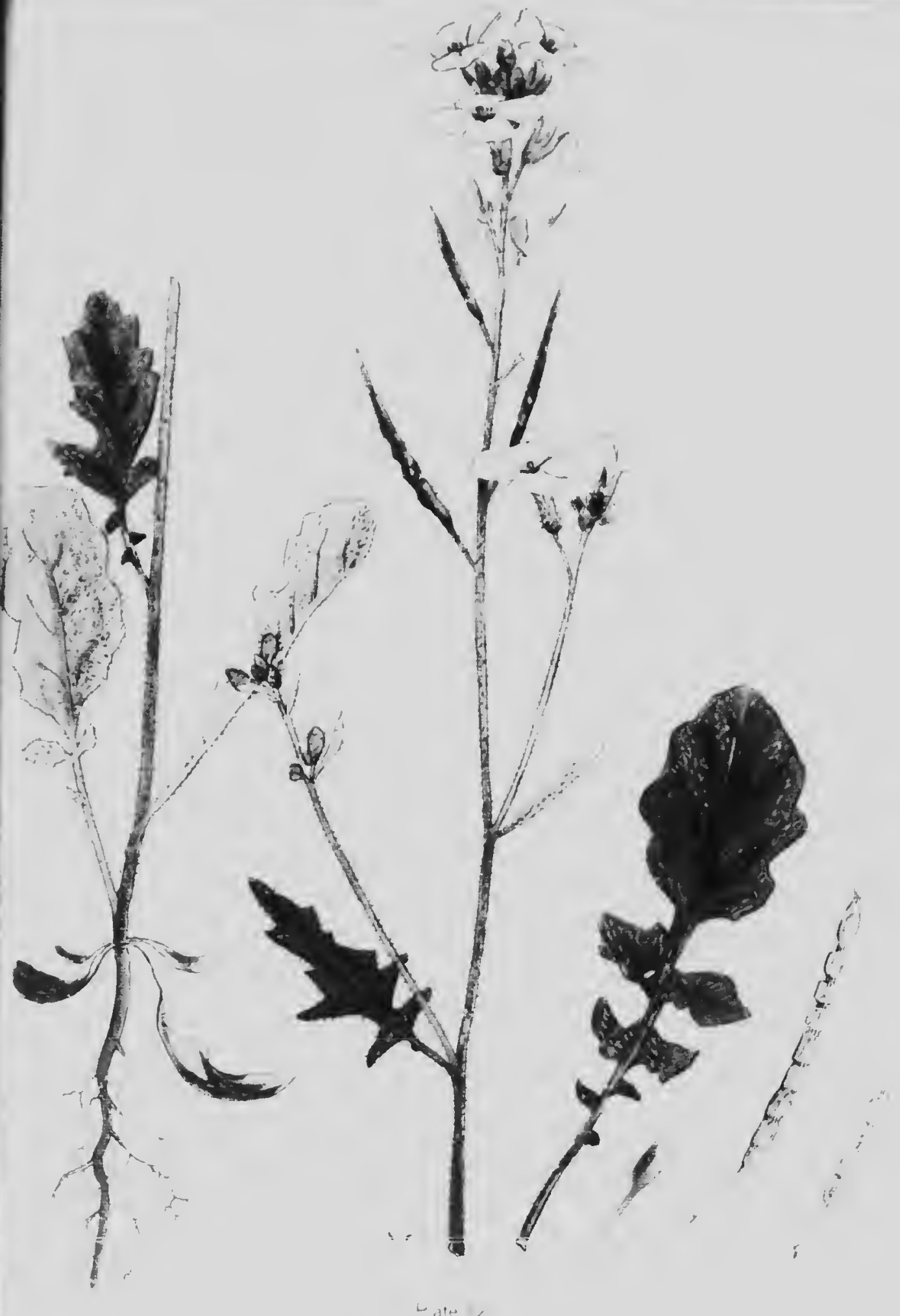

WILD RARISH OK JOINTED CHARIOCH 


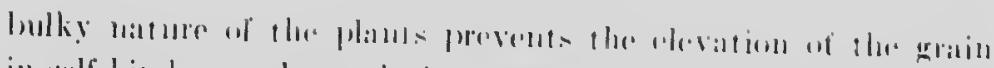

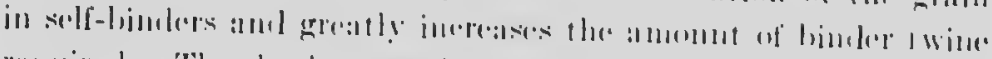

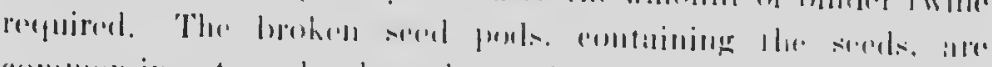

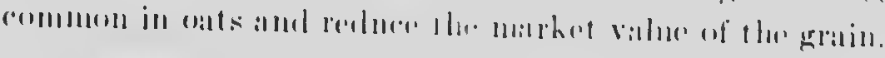

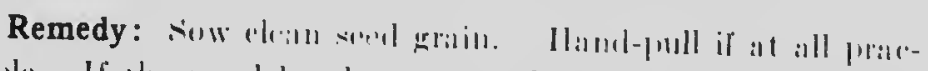

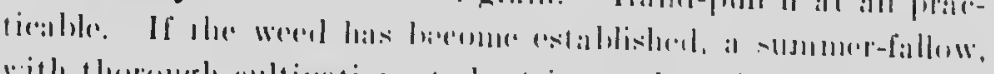

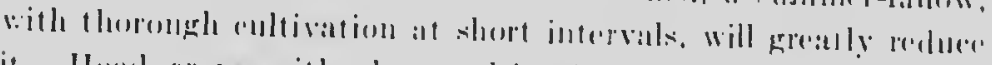

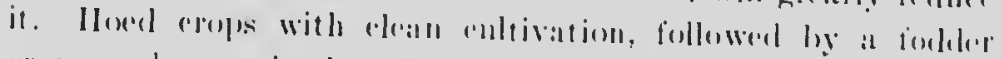

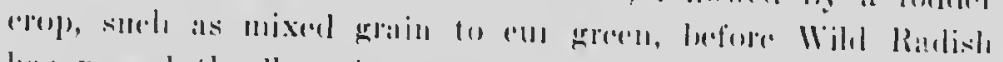

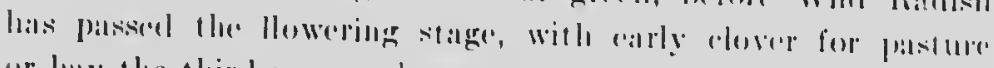
or laty the thirel year and a grass creple for haty the rourth pear,

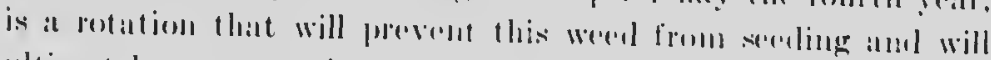

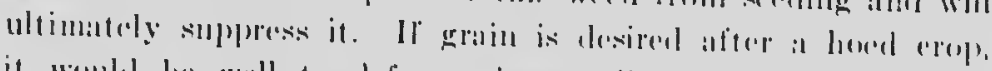

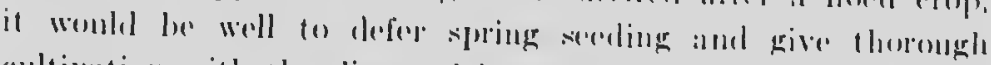

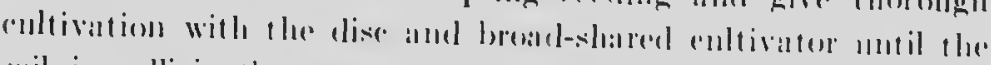

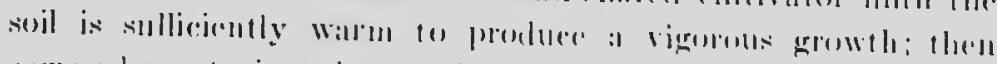

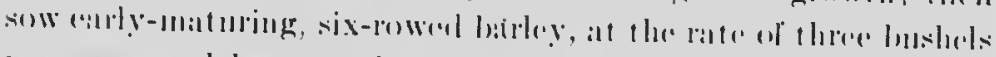

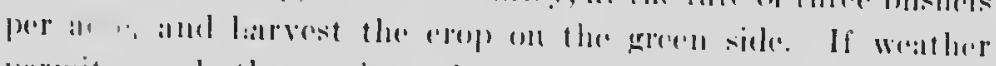

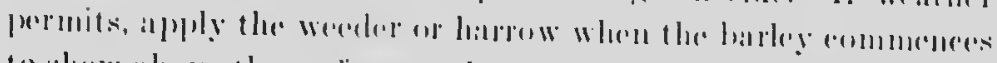

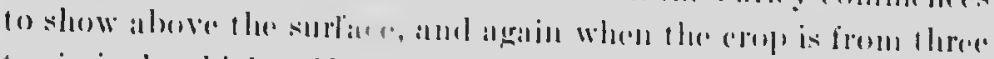

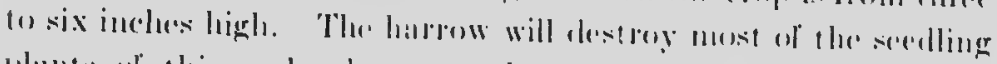

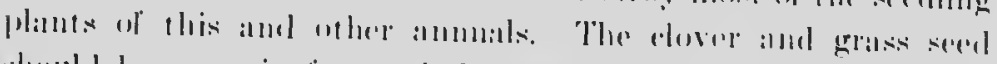
should be sown in forme of the hatrow at the last applieationt.

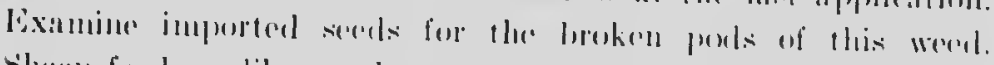

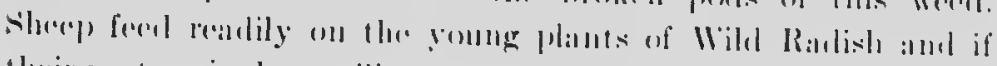

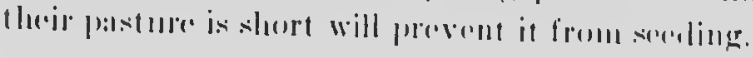

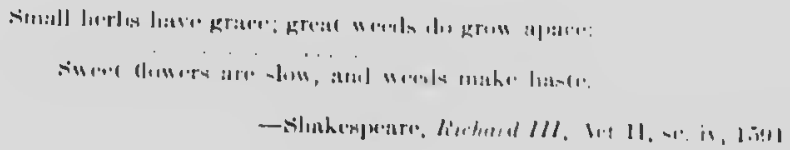

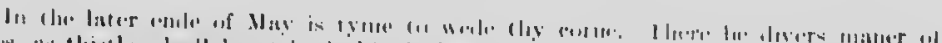

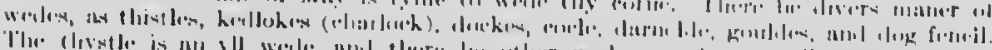

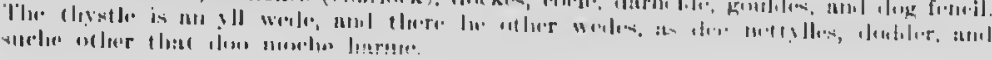




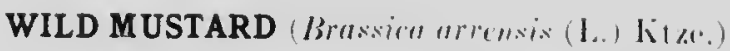

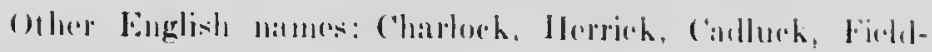
k:ale, (1)tario .llistaril.

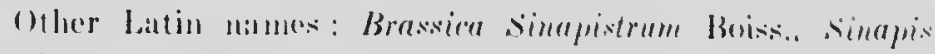
arcensis: I.

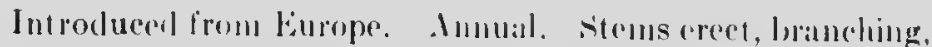
1 to 3 fort high, rough, with stiff, sollu,whtt downward directoel

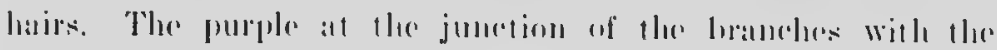

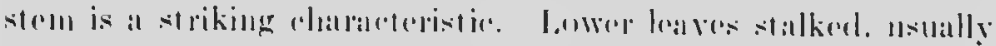

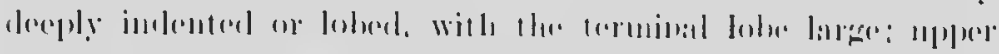

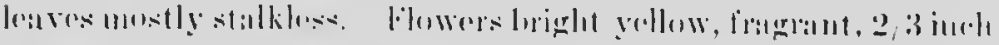

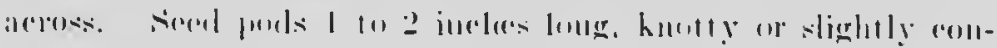

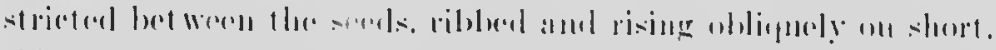

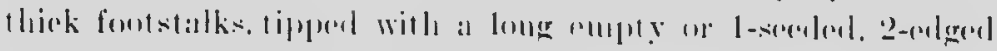

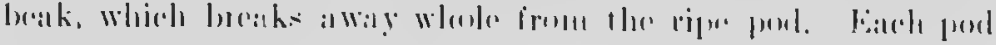

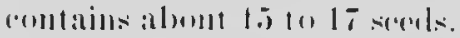

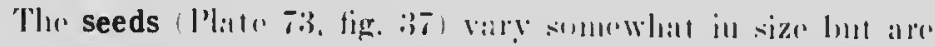

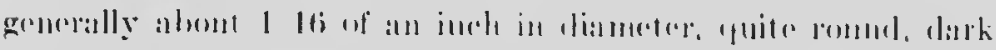

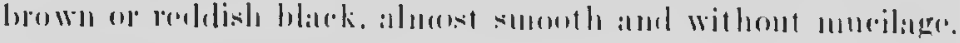

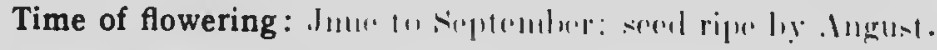

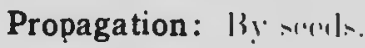

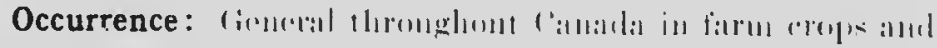
Nisstre plisurs.

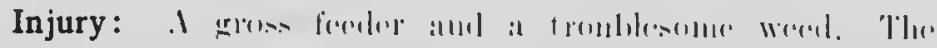

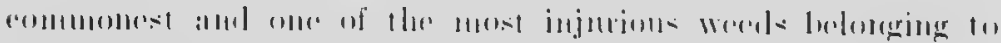

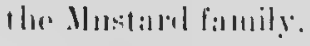

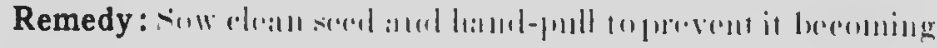

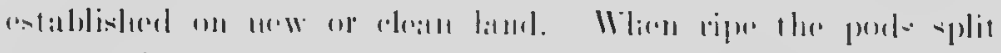

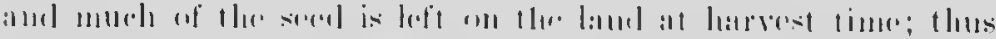

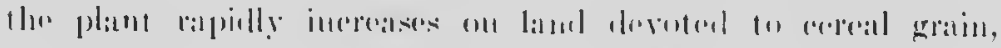

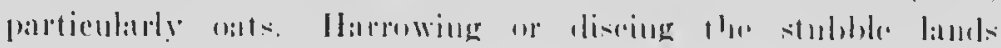




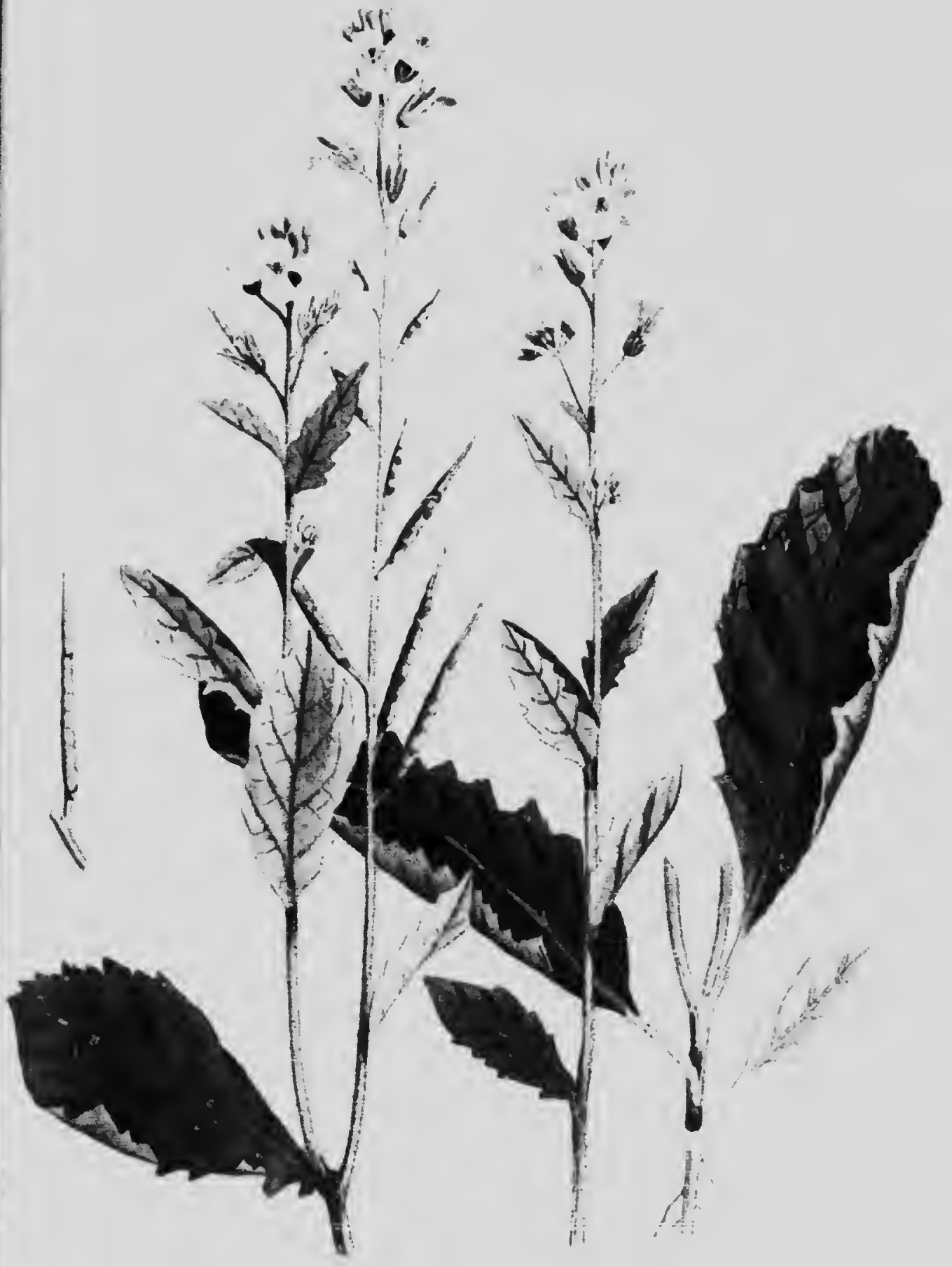




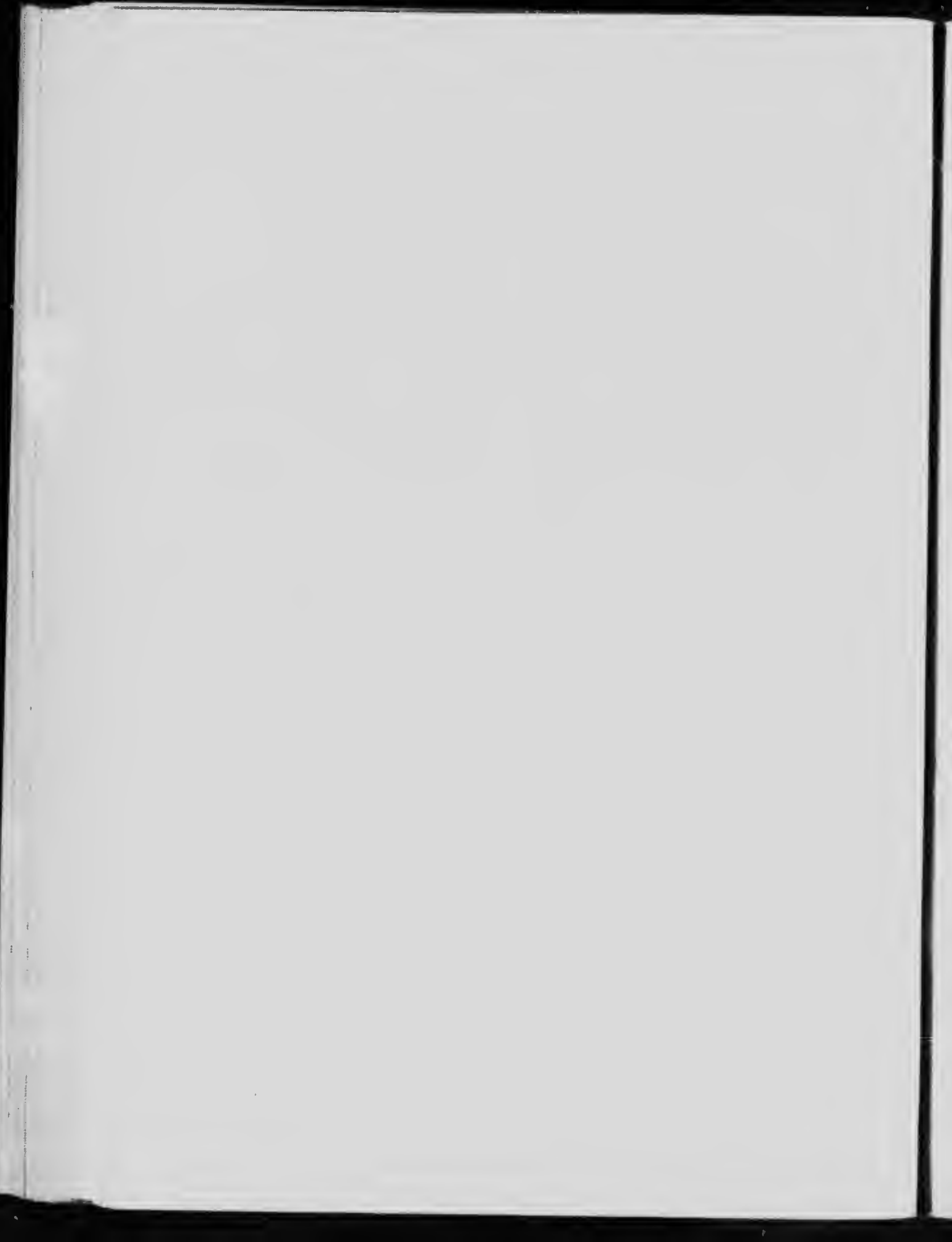




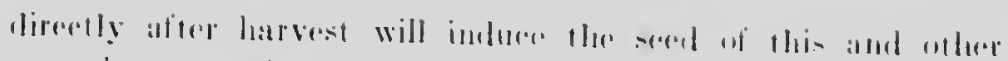

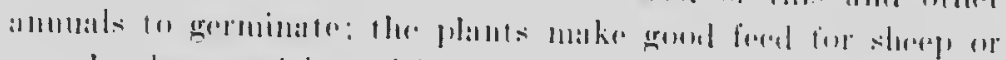

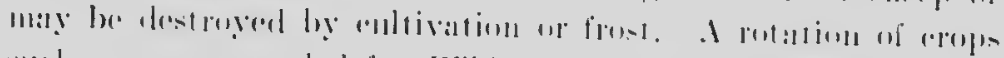

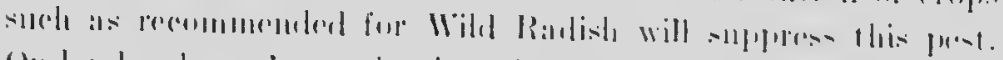

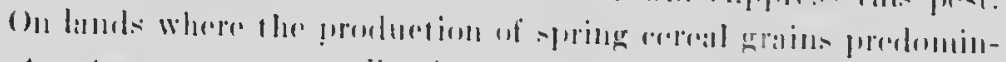

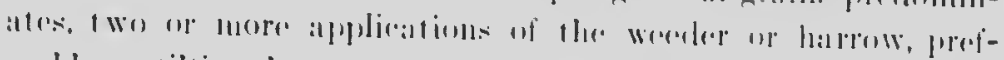

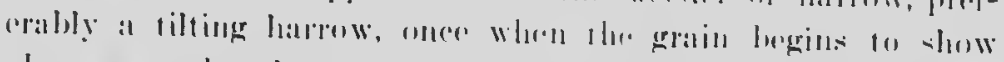

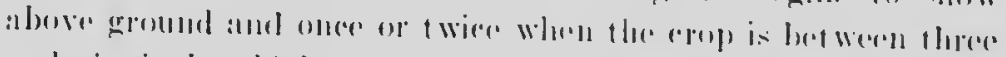

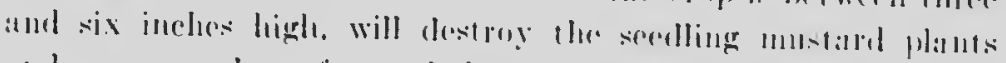

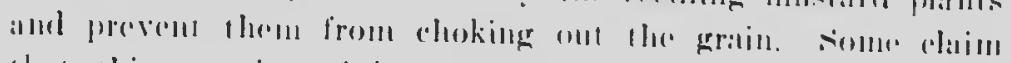

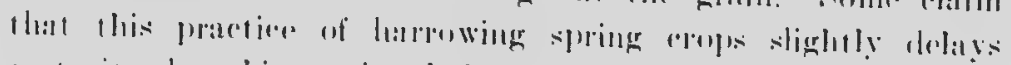

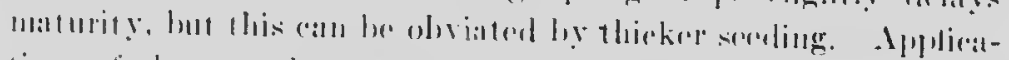

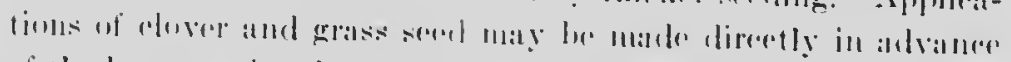

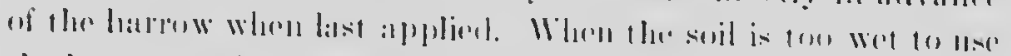

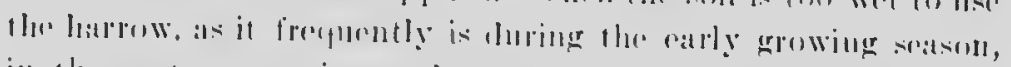

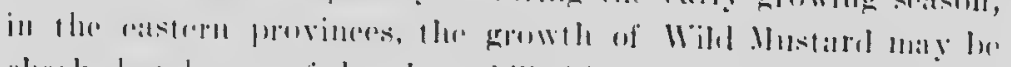

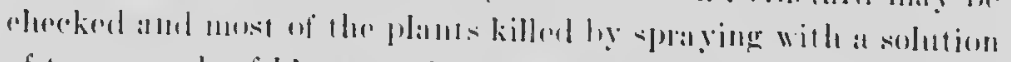

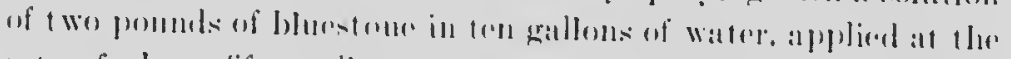

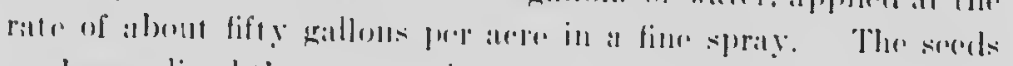

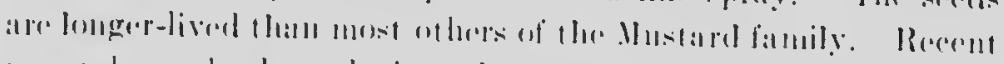

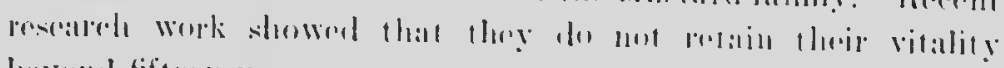

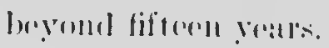

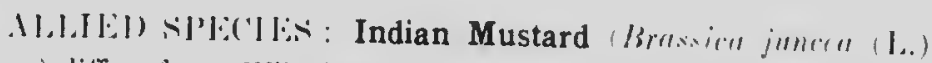

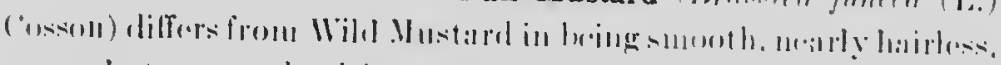

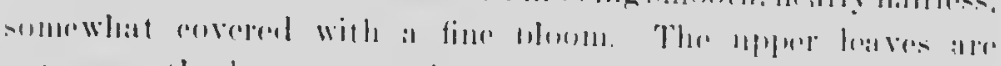

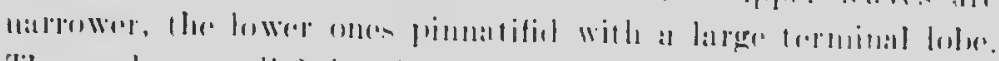

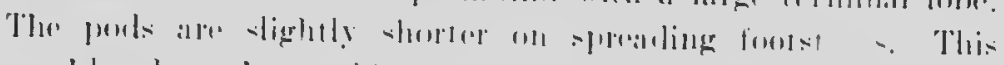

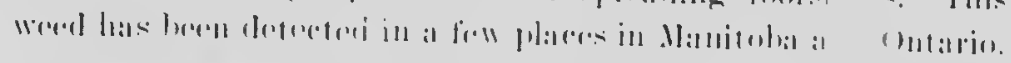

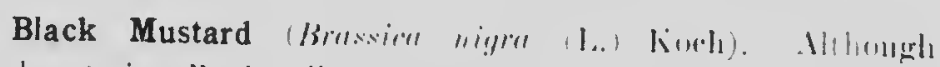

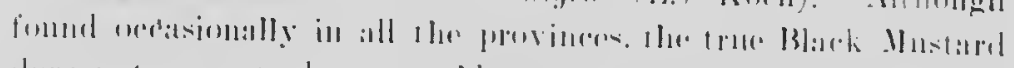

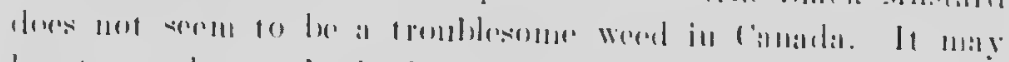

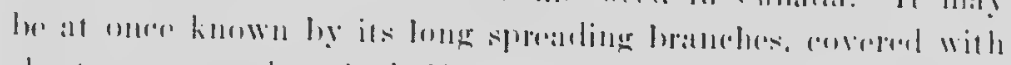

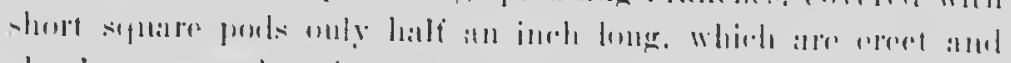

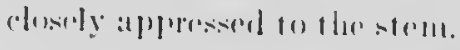

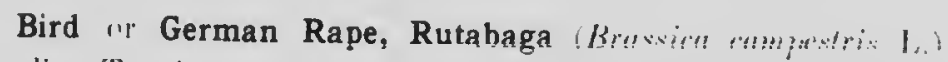

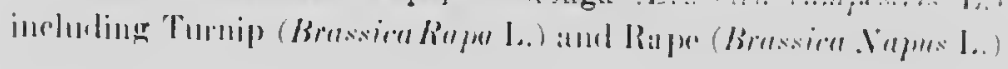




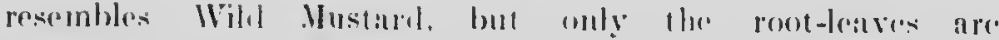

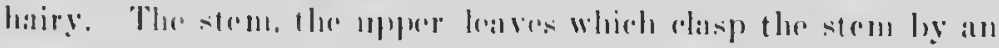

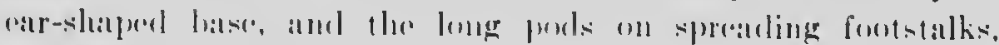

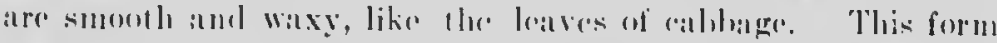
is abumelant in llanitoba and in some patrts of Queber and Ontario, Birel Ratpre. unlike Milal Musiand, ran not lor killed by spraying with bluestone solution. on siceount of its smooth leaves to whieh the solution will not stick.

Rocket or Rocket Salad (Eruca salira lam.) lıs reerntly been introrlueed into Ontario, probably with European alfalfa seerl. It is a hairy anmual, somewhat resembling Wild Mustard. The leaves are pinnatifild, with a latge trominal lobe. The

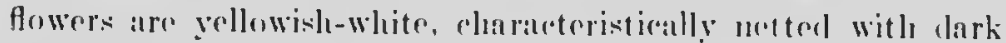

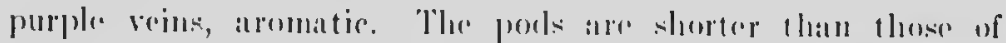

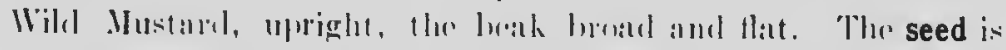

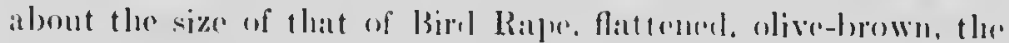
miniature root of the germ gemerally lightere in erolour. It is pungent and bitter, with a tlavour charaleteristice of ralish. The

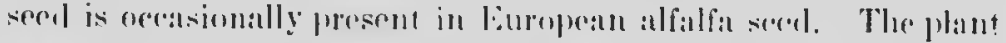

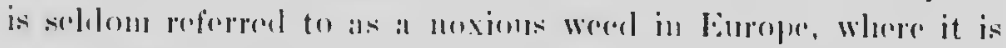
sometimes rultivalted ats a pot lierle. It should met be allowerl

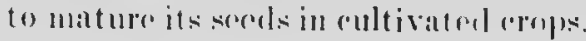

HARE'S-EAR MUSTARD ('omringin urimlelix (I.) l)umort.).

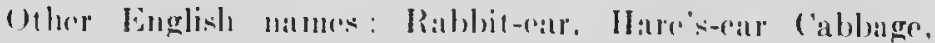
lilinkwerel.

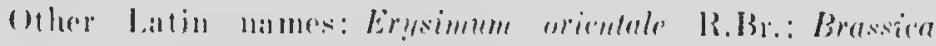

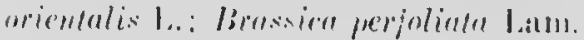

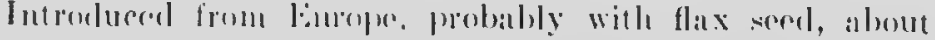

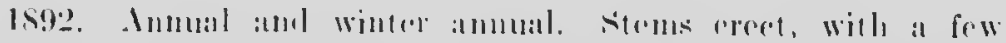
branches. I 10 I fore high. Whole plant preforetly smootle, and,

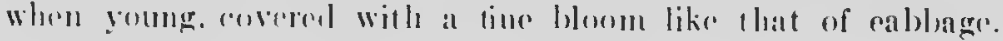

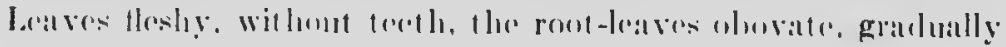




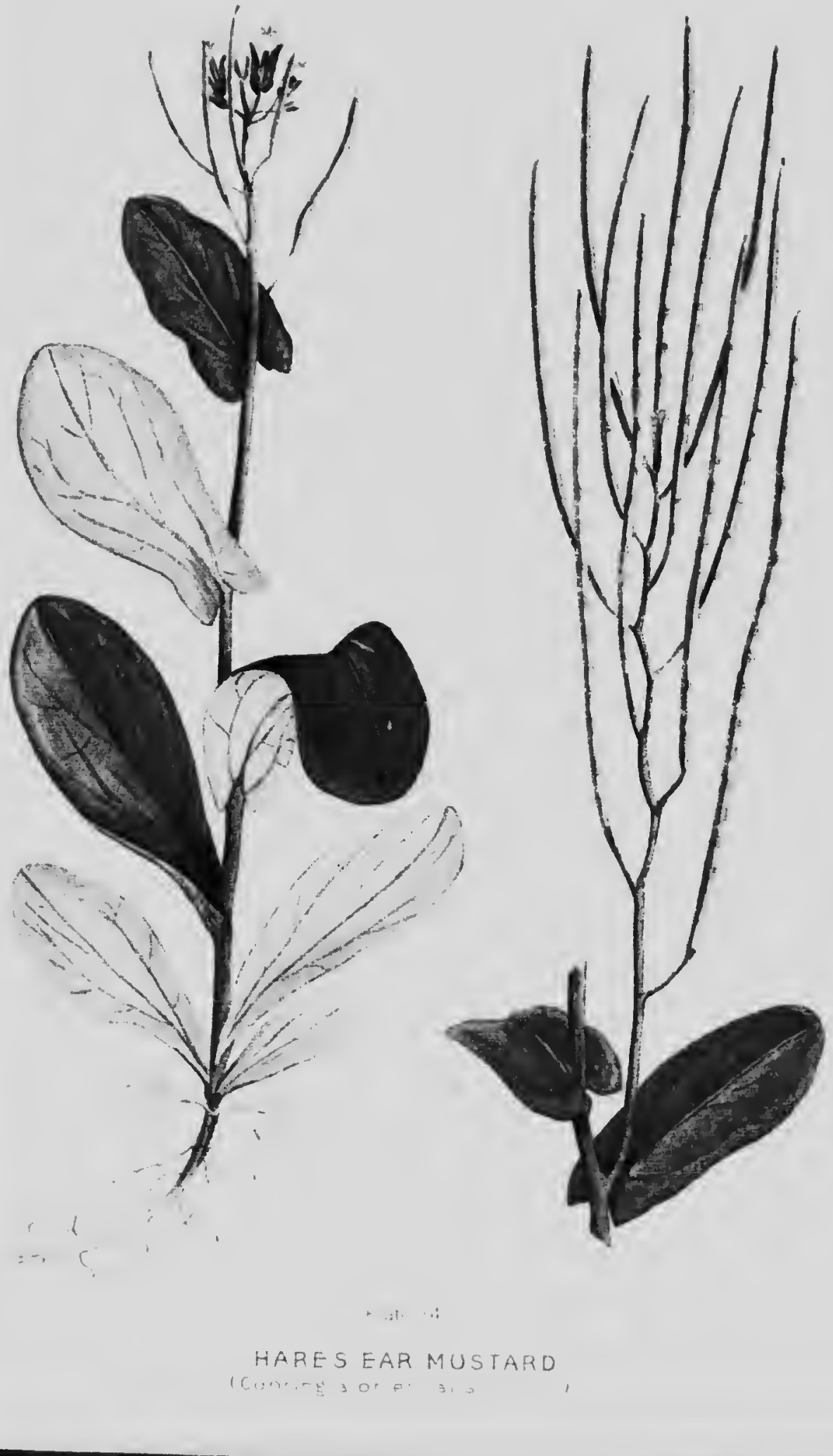


marrowed to the base; those ofl the stiff strme, which herentere

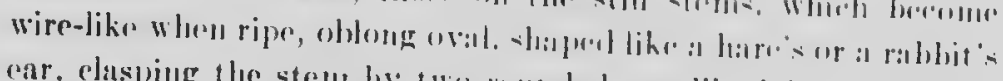

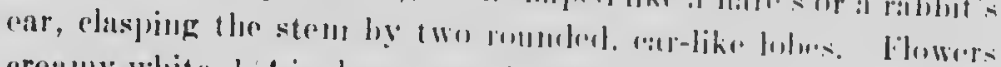

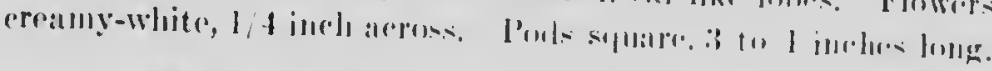

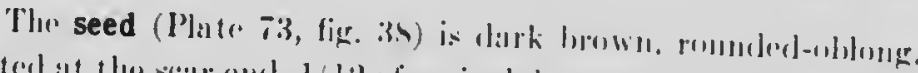

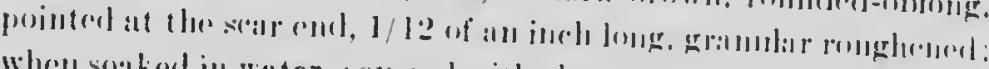

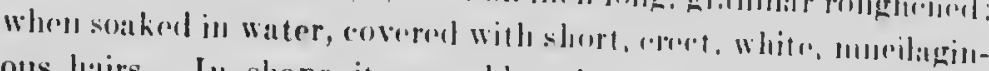

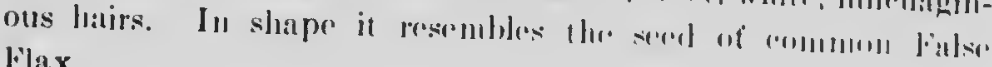
filax.

Time of flowering: lims of Jums: arols ripu dugnetSeptembrer.

Propagation: 13y sireds.

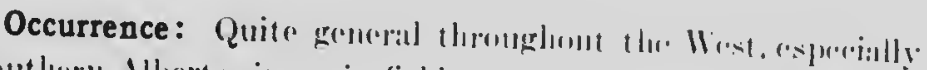

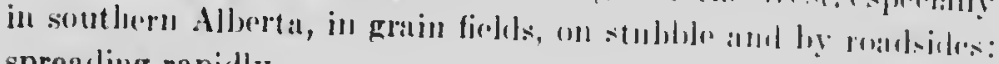
sprealing rapidly.

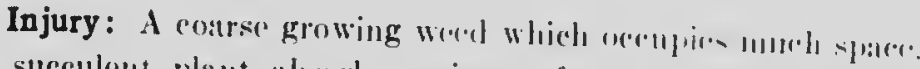
The suceulent plant absorles moisture from the oril and littl. grain ean grow where there is a patteb of it. The wiry strolls

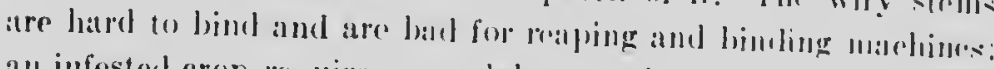
an infesterl erop repuires more labour to hathlle and horre twillo

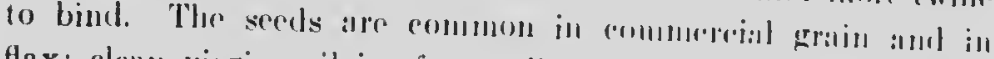

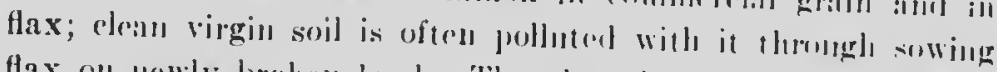

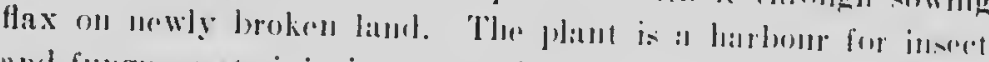

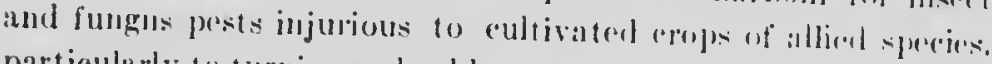
particularly to turnjes amd cabbage.

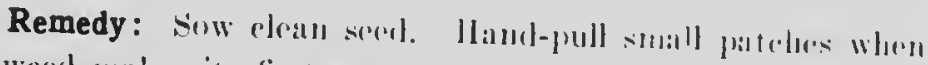

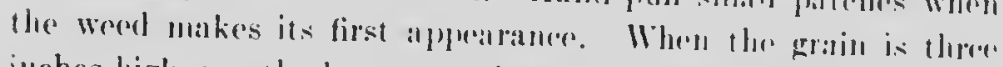
illehes hight, use the harrow to destrog the serolling werels. This praction. oumbines with discing immoliatoly after lastrest

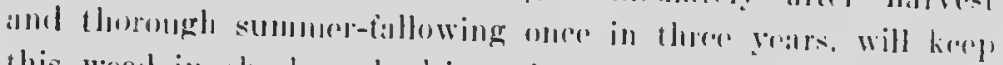

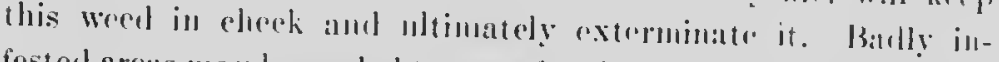

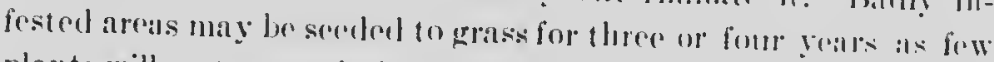

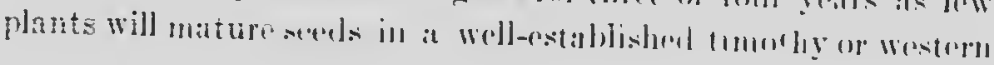




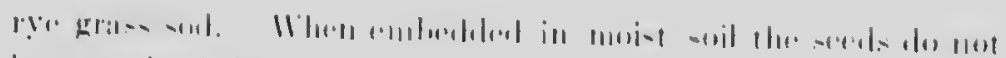
long rentain thrig vitality.

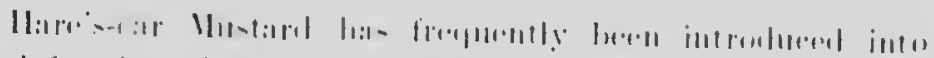

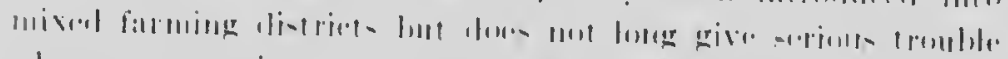
"lace - -

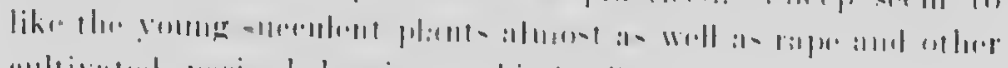

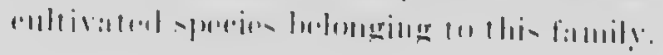

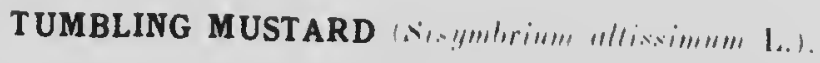

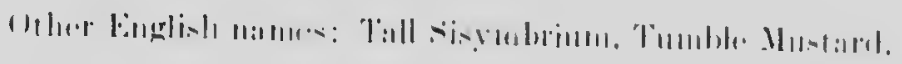

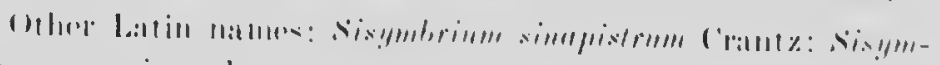

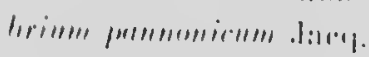

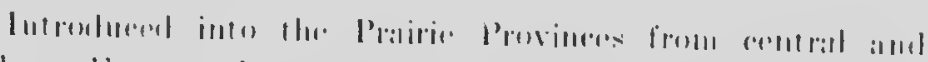

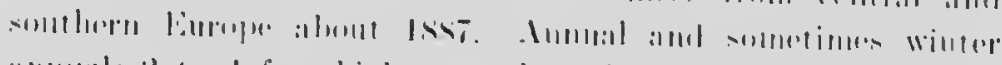

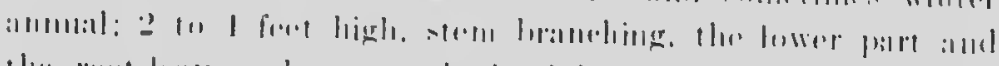

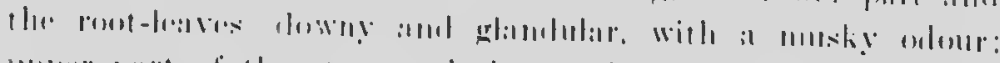

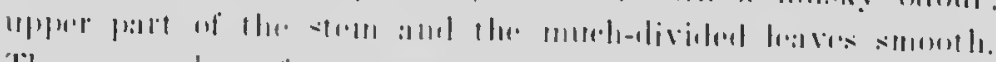

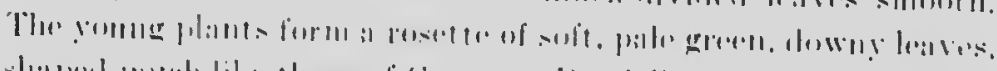

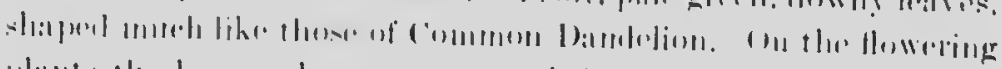

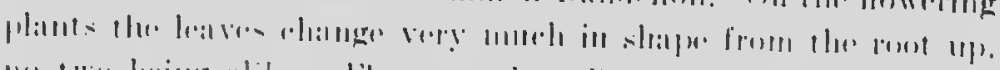

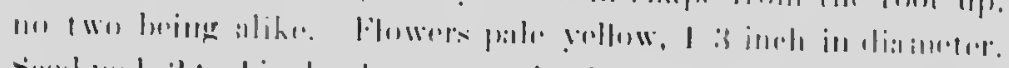

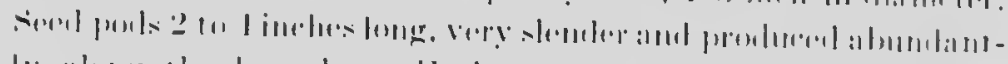

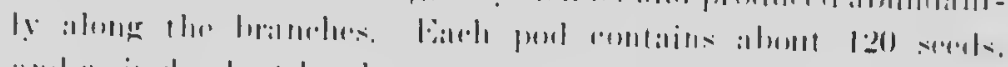

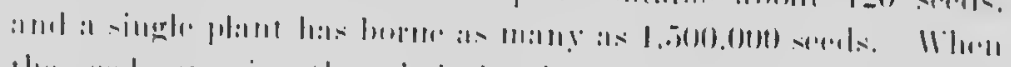

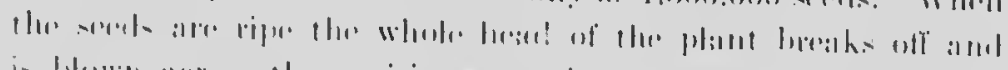

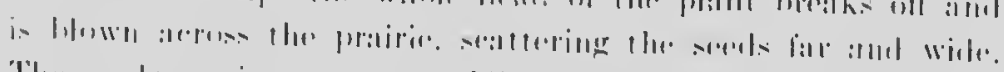

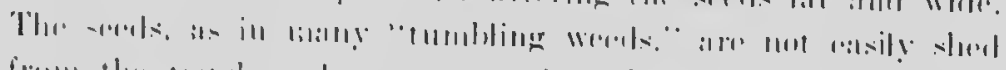

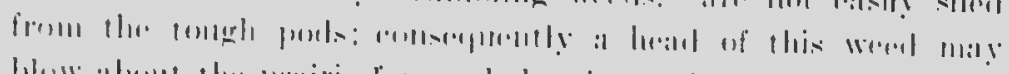

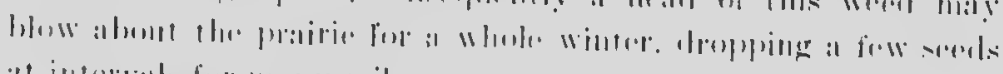

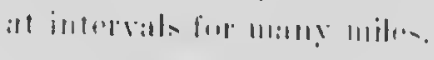

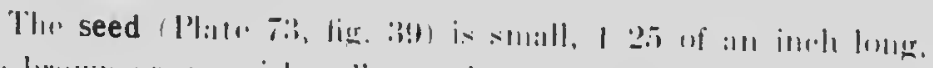

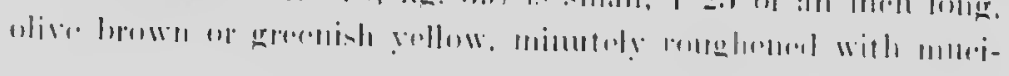




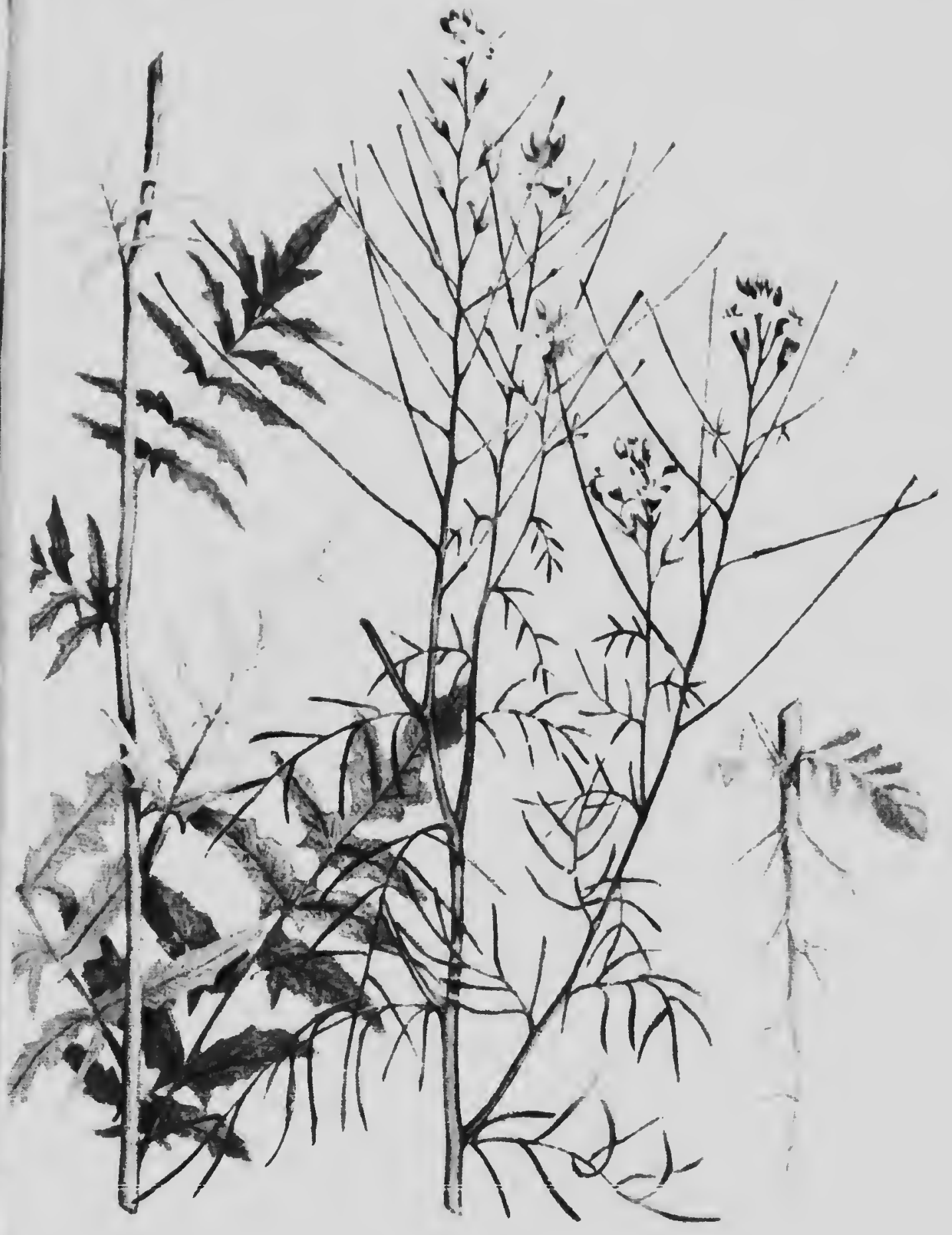




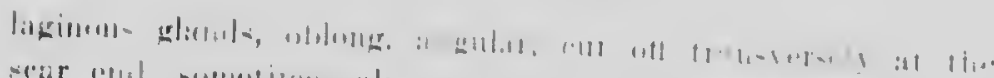

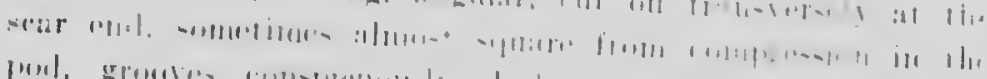

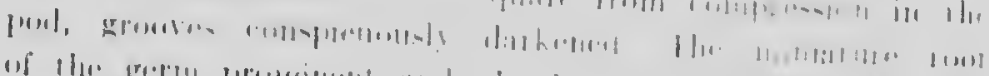

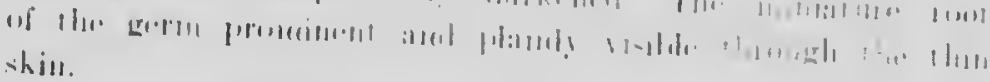

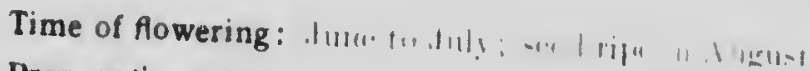

Propagation: |iy *inl.

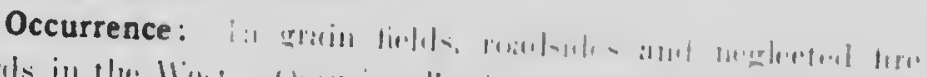

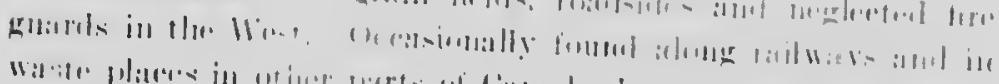

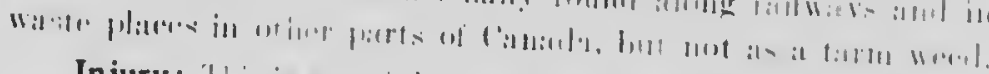

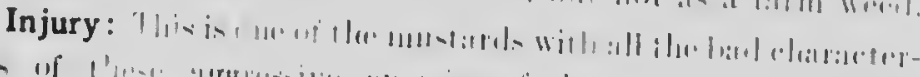

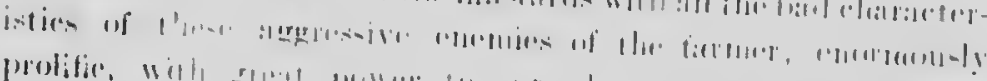

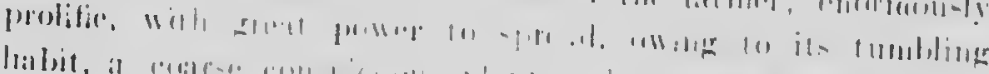

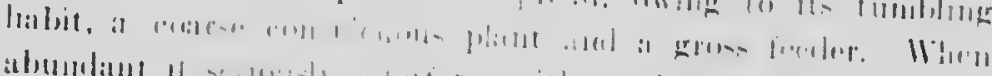

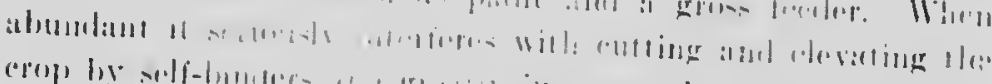
crop by a

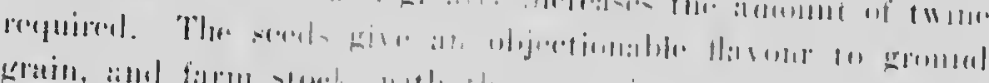

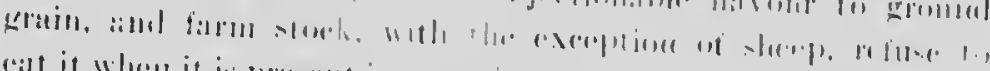

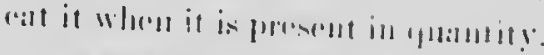

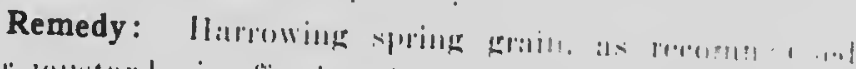

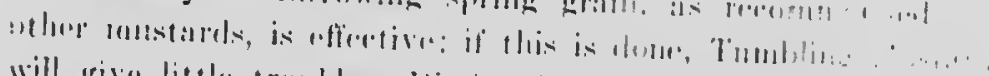

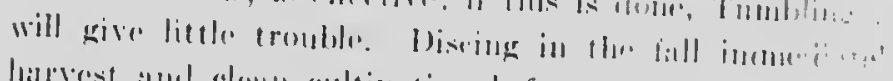

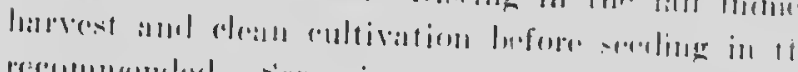

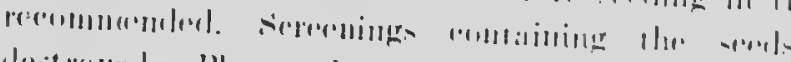

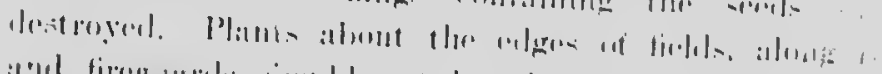

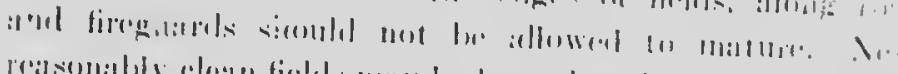

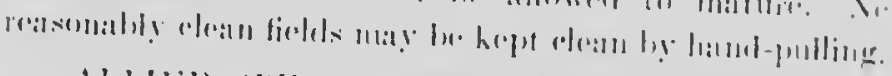

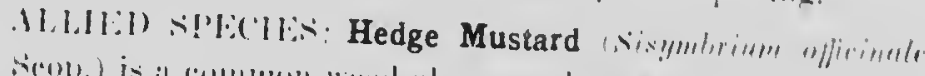

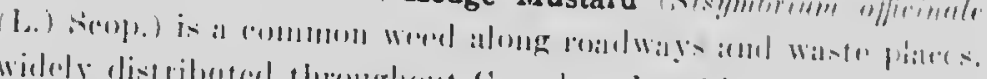

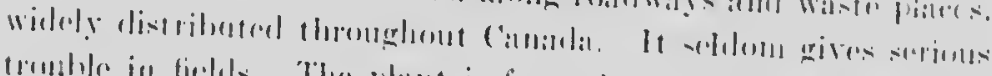

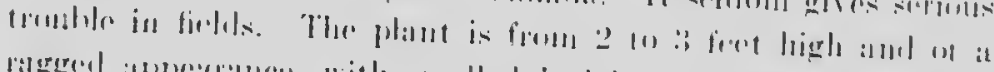

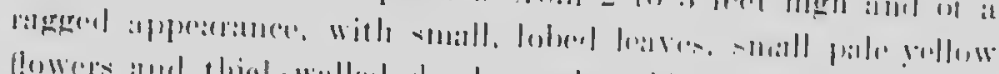

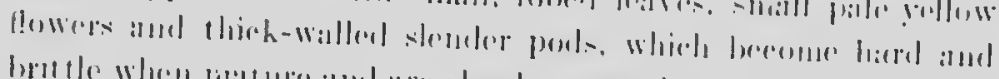

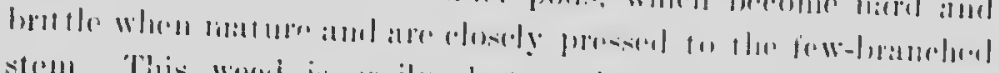

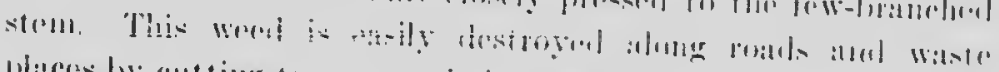

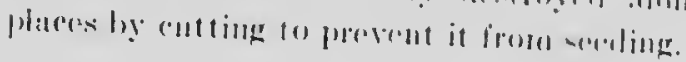




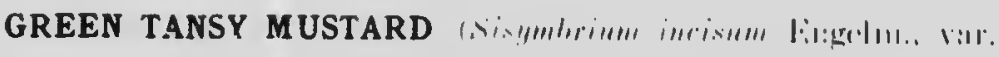
filipus lilisy

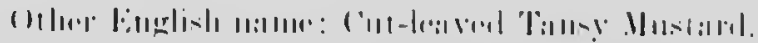

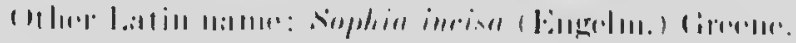

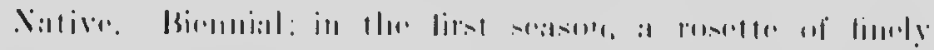

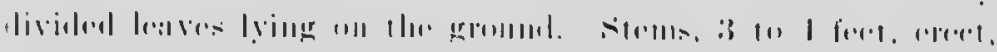

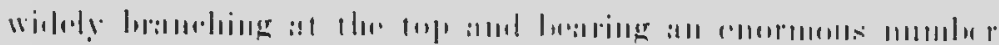

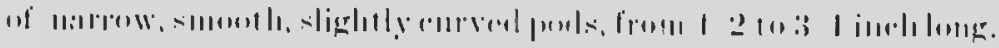

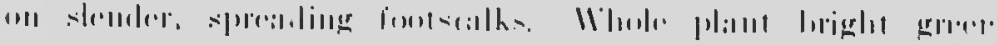

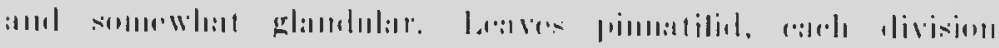

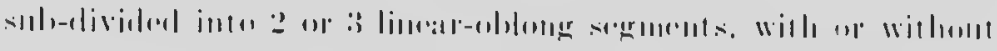

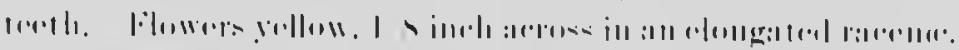

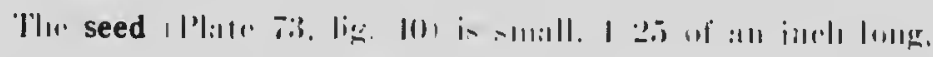

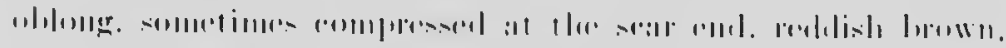

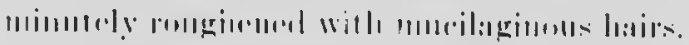

Time of flowering: .|uly: * *

Prepagation: $13 y-y, i r$.

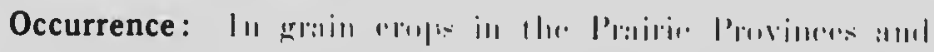

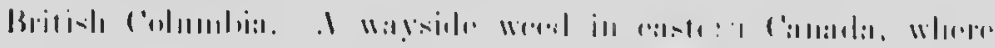

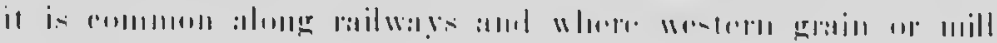
l, -

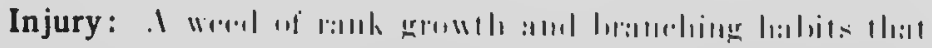

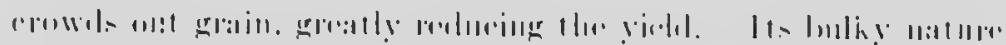

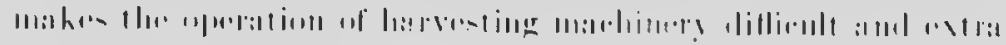
bimlan Inime menesiary.

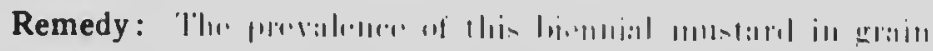

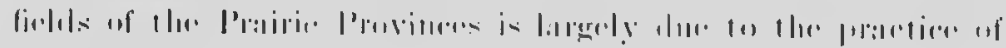

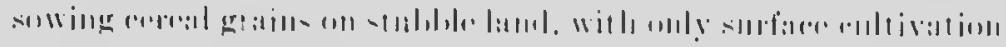

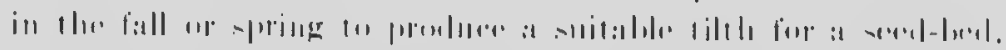

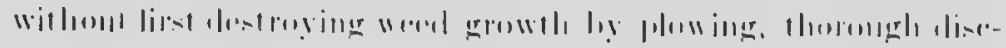

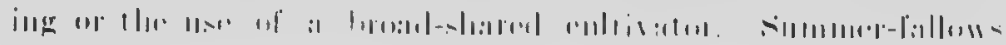





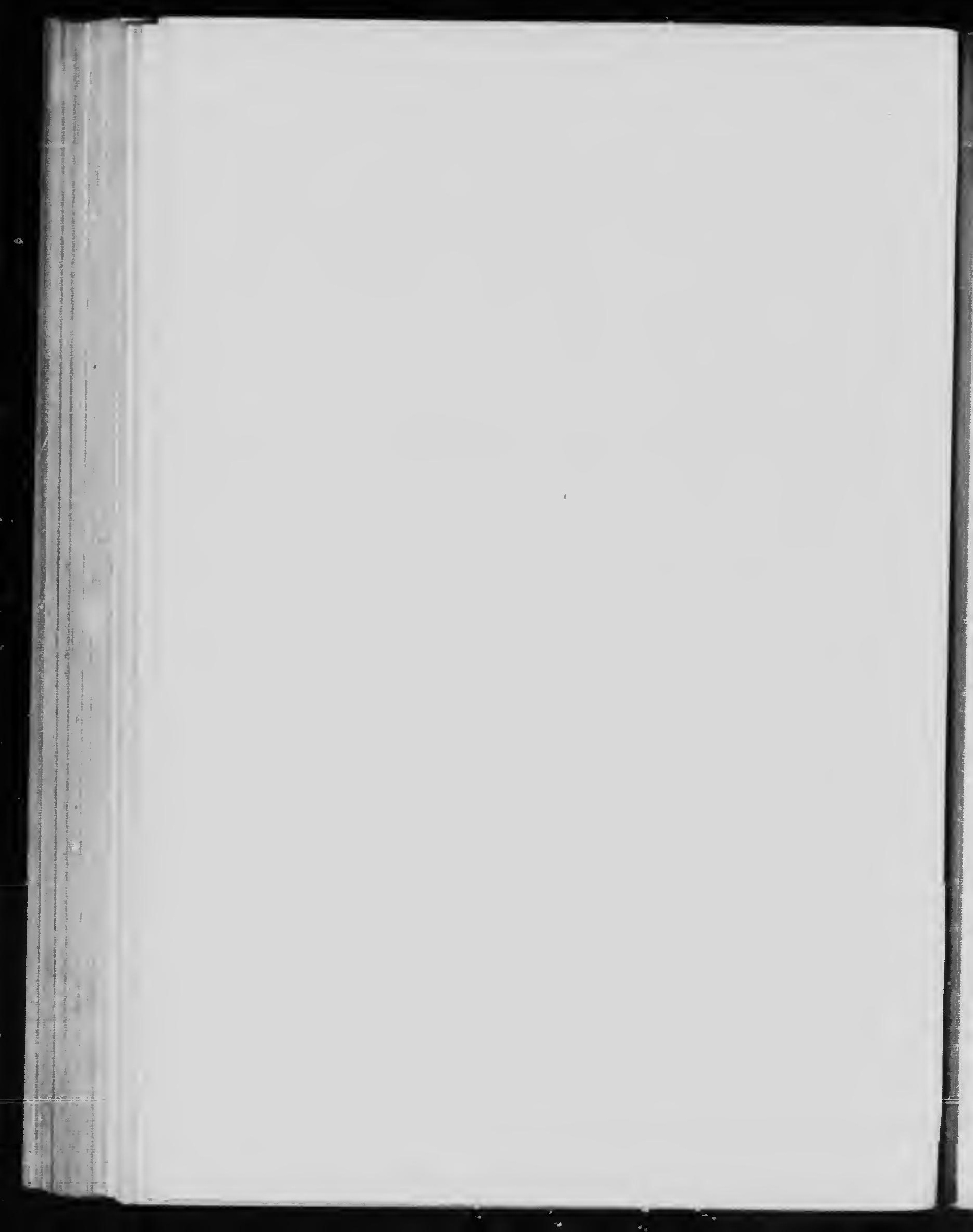




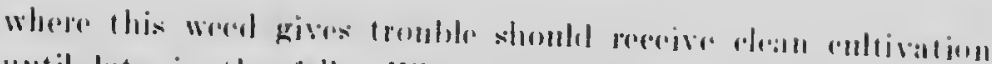

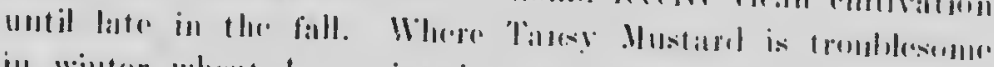

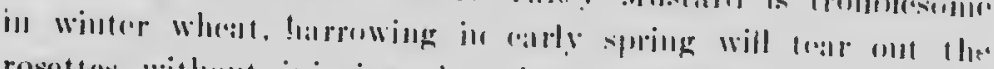

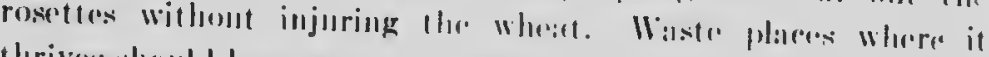

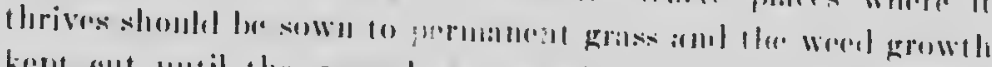

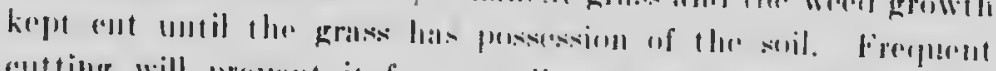
entting will prevent it frome sereling along roblwily and the borrlers of tiolus.

All.lil) SPl('Ilis: Gray ur Crowded Tansy Mustard

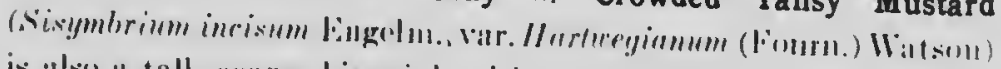

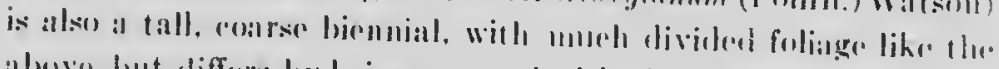

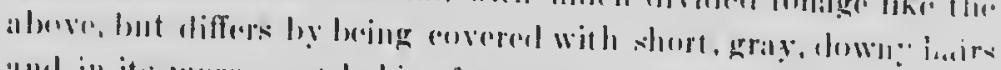

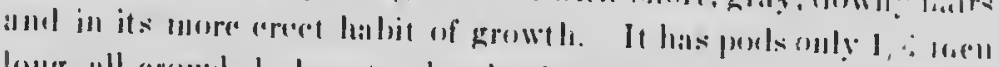

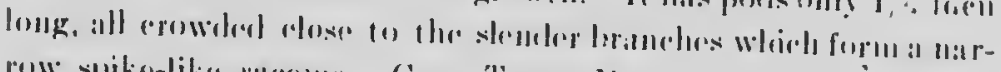

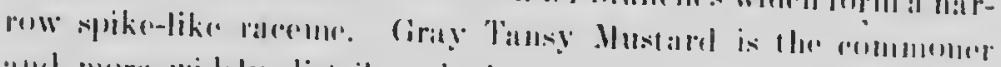

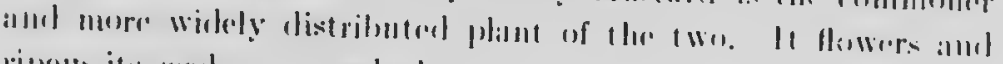
riprens its sereol solute wroks latser.

Thar seed (Plater it, lig. H) insomblane that of (irrent

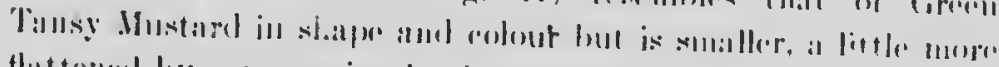

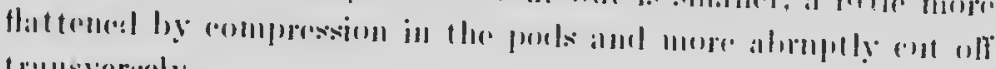
transisersoly:

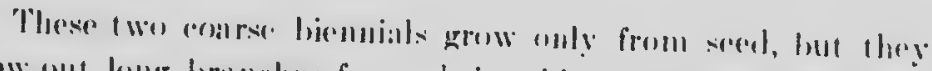
throw ent long branchese from there white tap lonts and dralw

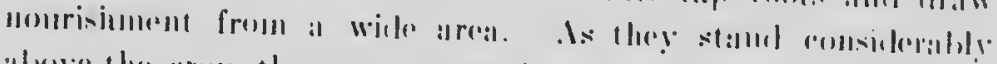

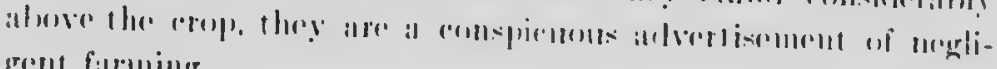
grolt farming.

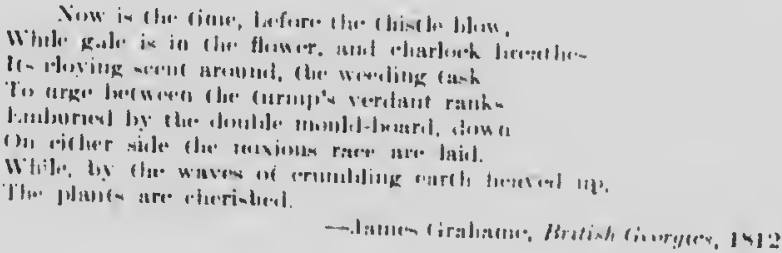




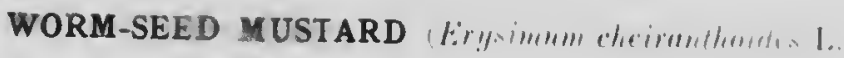

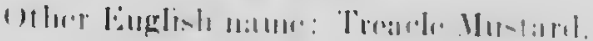

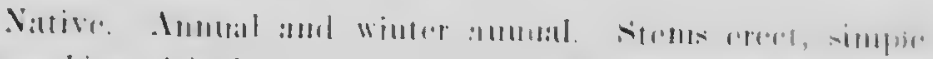

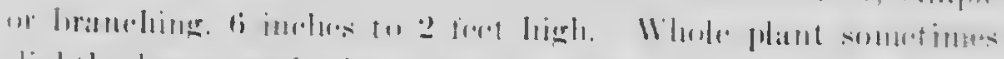

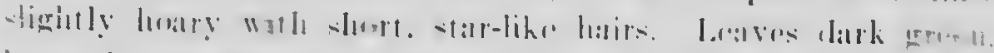

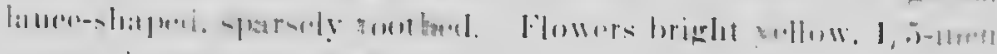

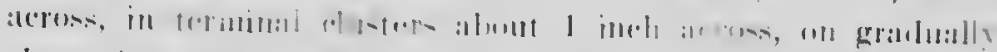

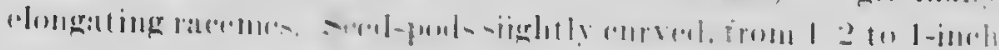

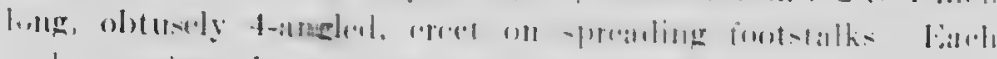

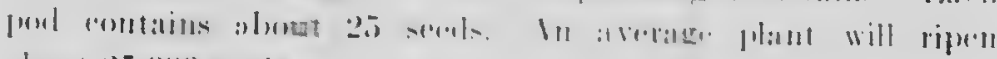

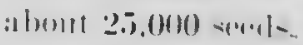

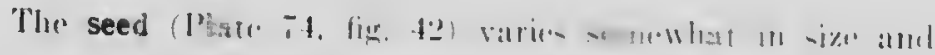

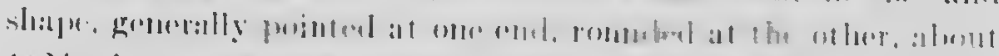

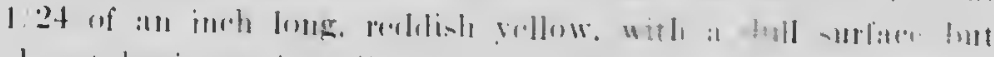

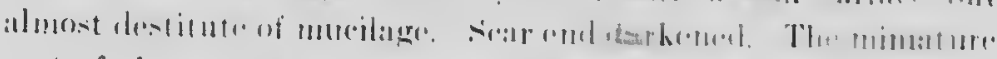

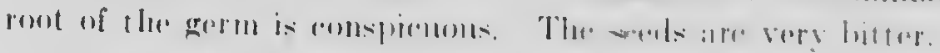

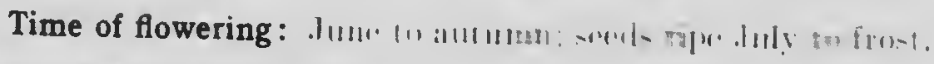

Propagation: 13y sirels.

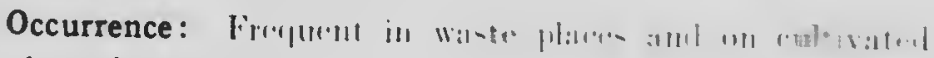

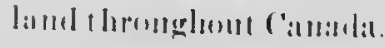

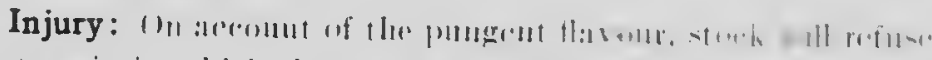

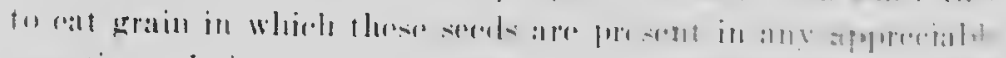

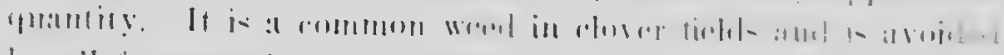

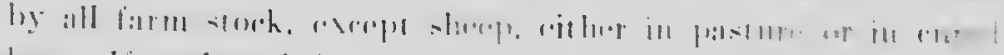

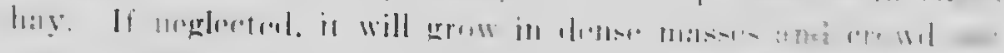

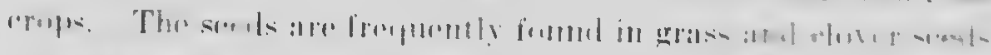

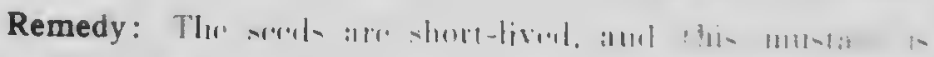

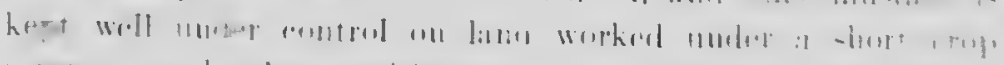

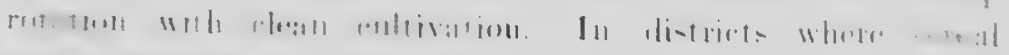

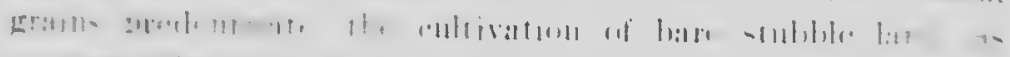

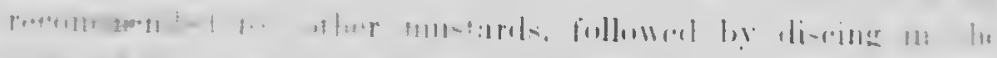

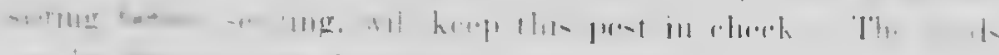

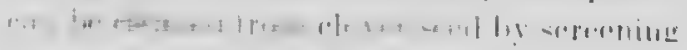




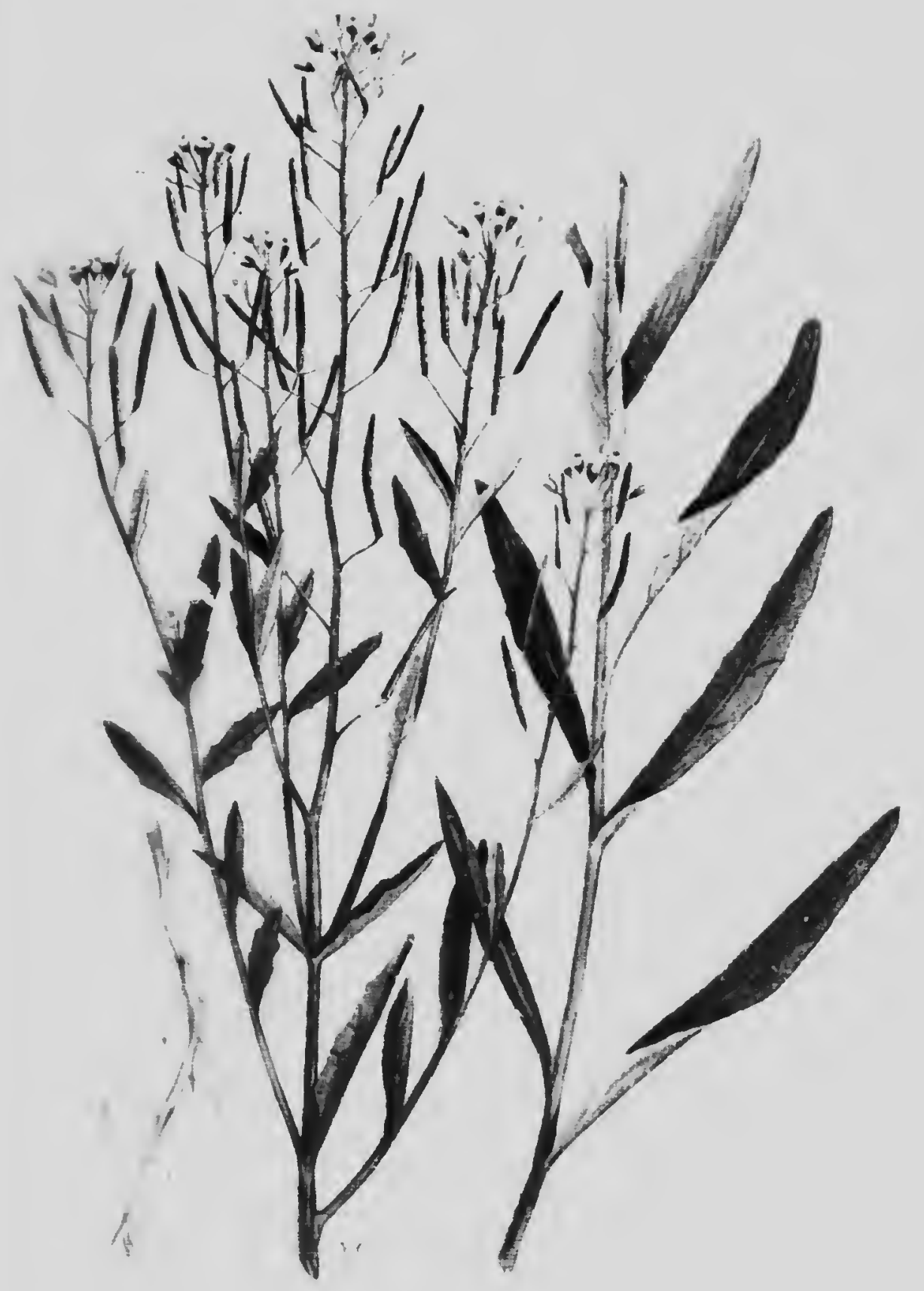




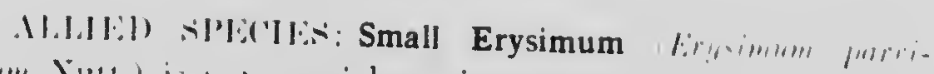

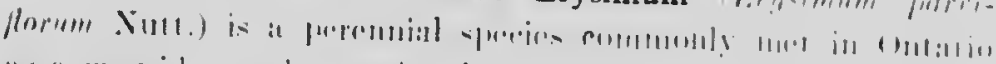

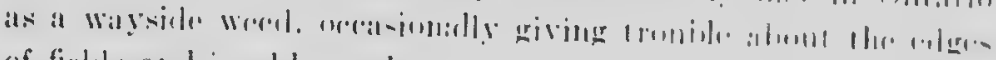

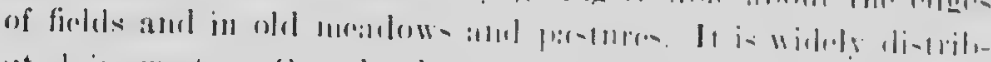

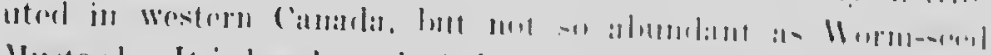

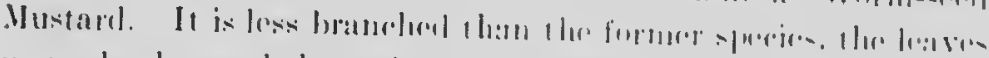

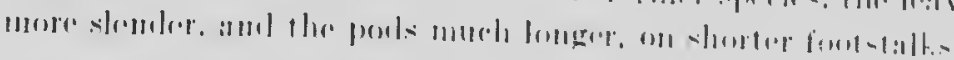

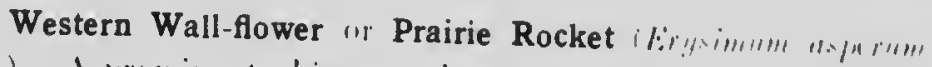

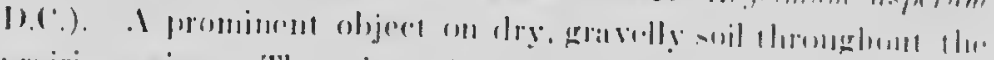

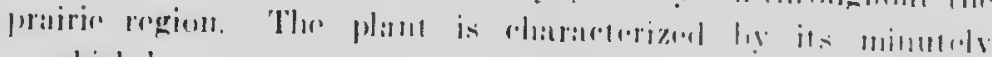

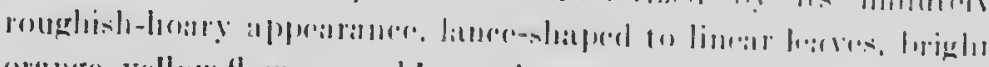

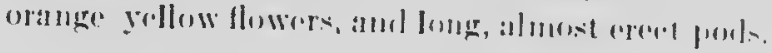

Yellow Rocket or Yellow Weed (Burlunen rulizurix R. IBr.),

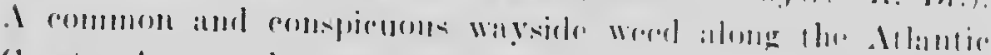

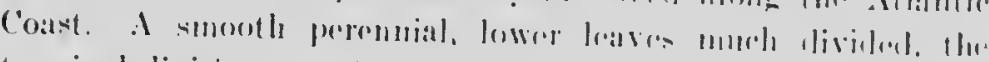

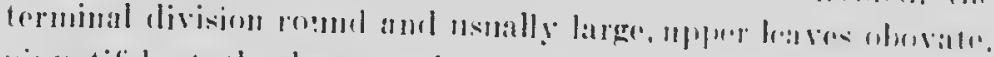

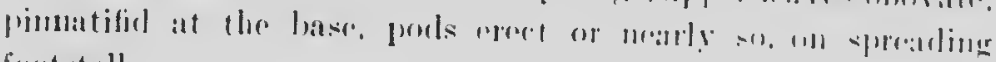
fortstalks.

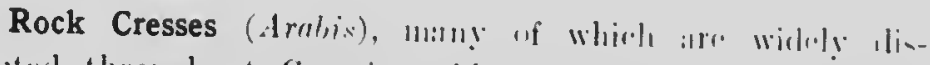

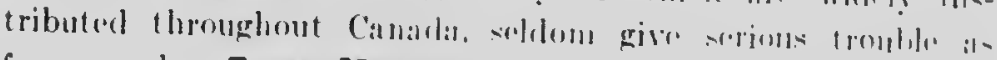

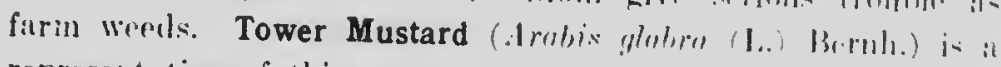
representative of this genns and is combromly - vent along rail-

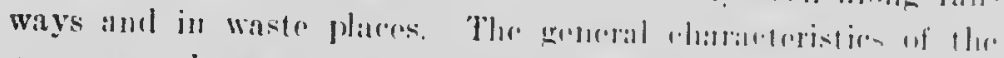

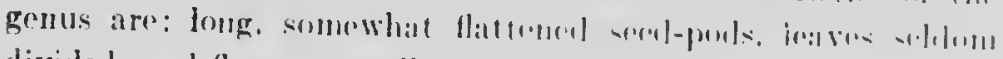

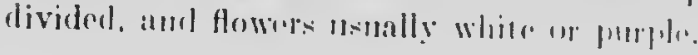

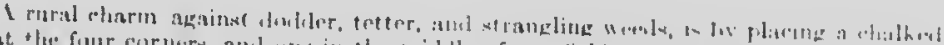

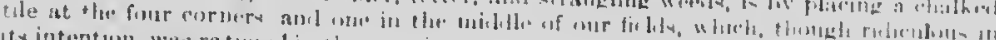
all partsof of the areat 


\section{THE CAPER FAMILY ('up)midmene".}

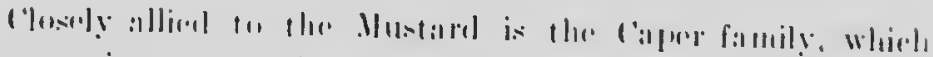

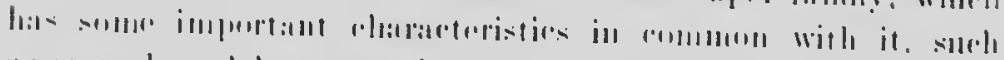

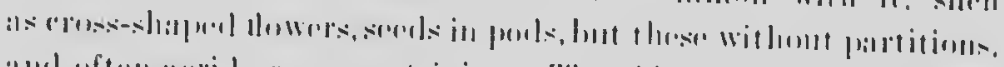

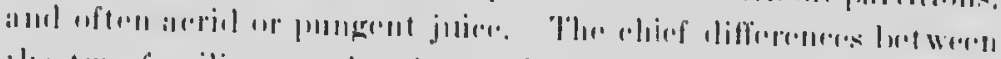

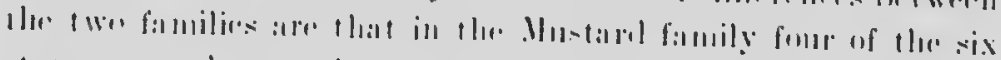

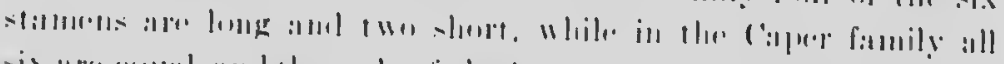

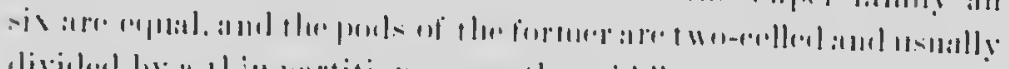

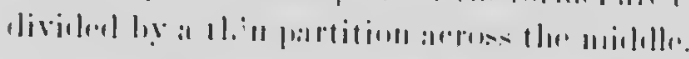

Spider-flower of Stinking Clover (1\%mme errululu l'ursh.)

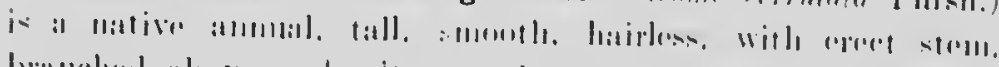

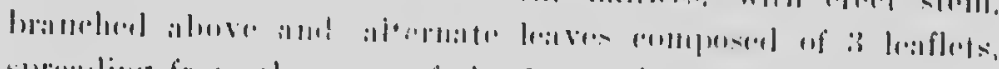

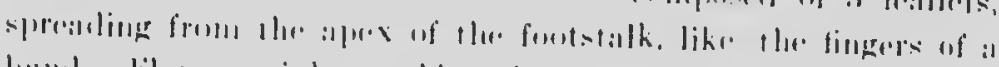

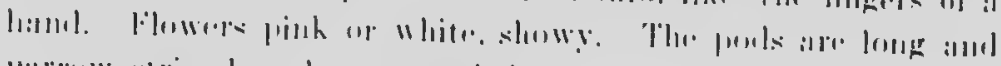

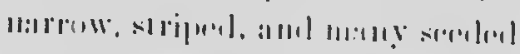

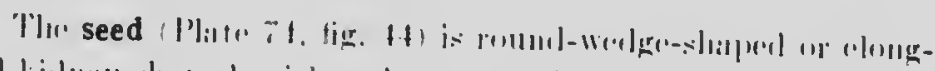

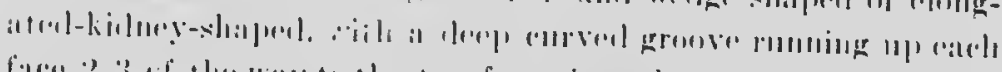

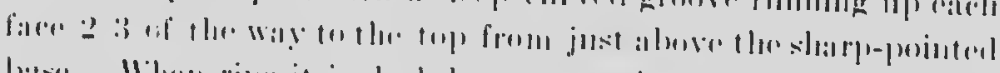

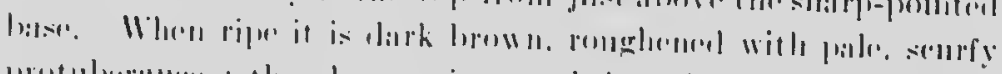

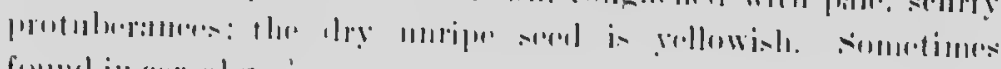

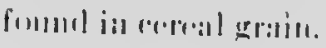

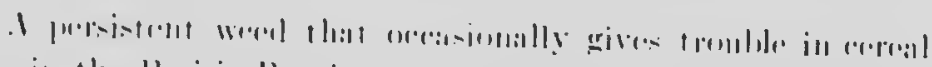

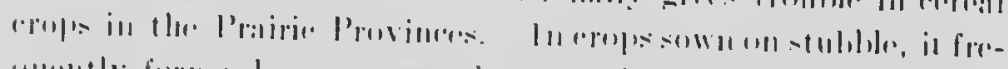

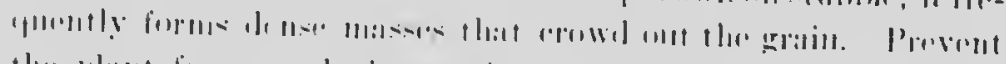

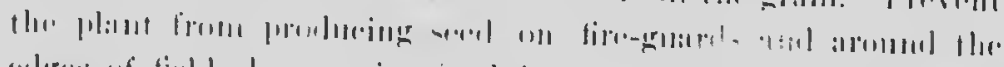

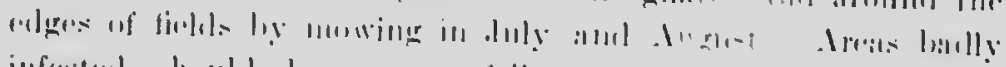

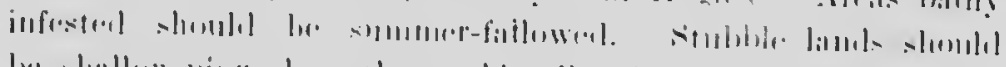

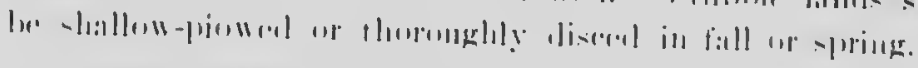

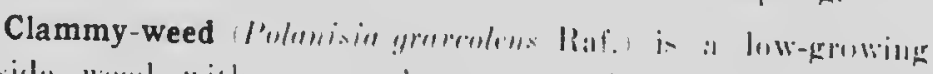

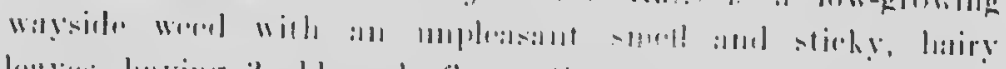

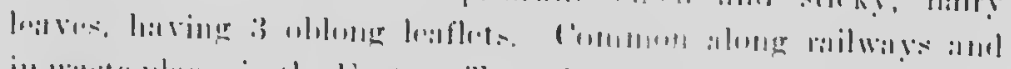

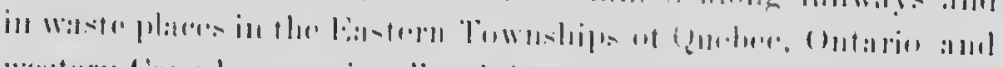

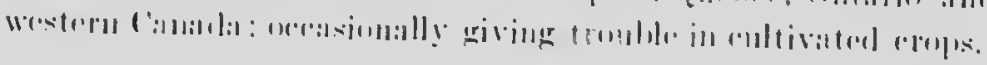




\section{THE ORPINE FAMILY / imsulucin,}

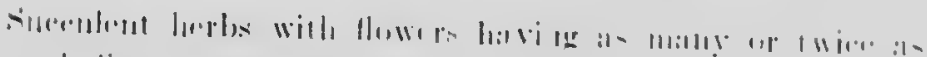

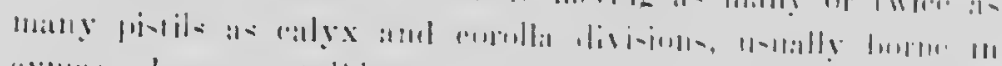

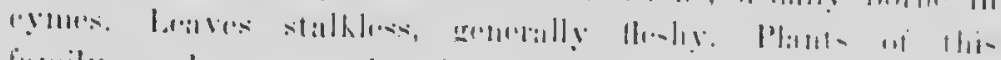

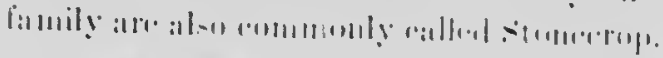

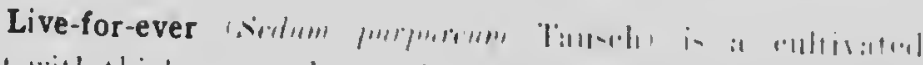

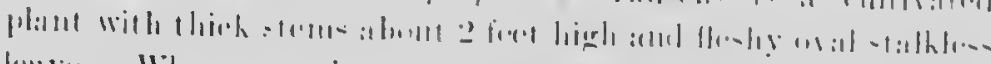

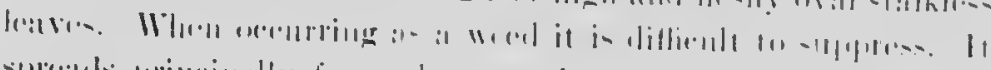

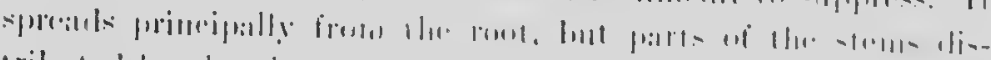

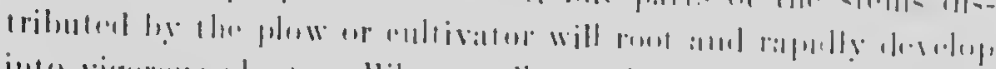

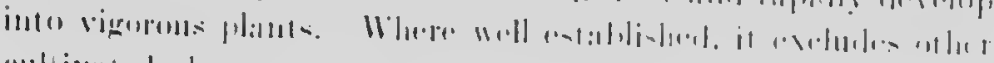

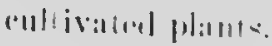

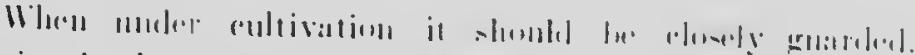

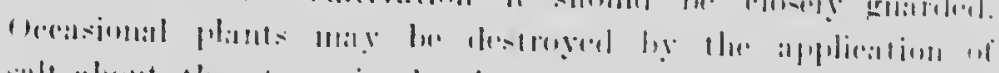

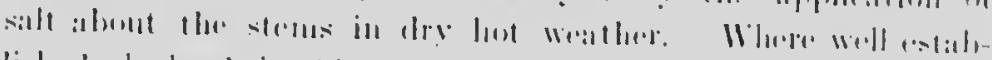

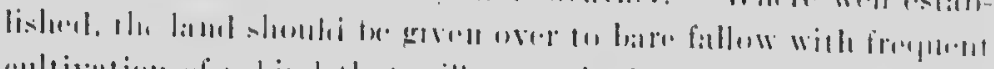

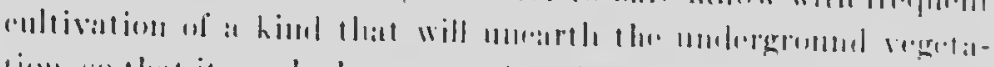

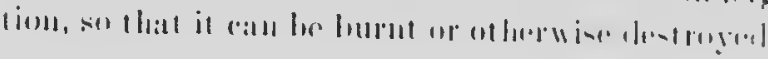

\section{THE ROSE FAMILY (lisucru,}

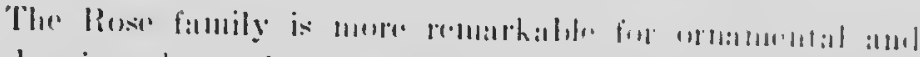

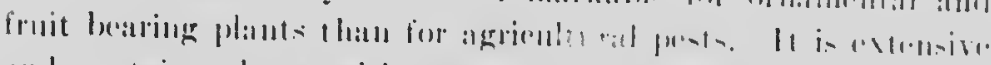

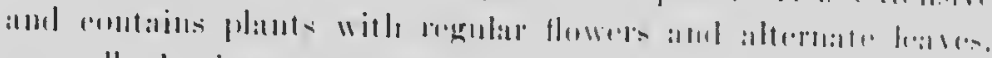

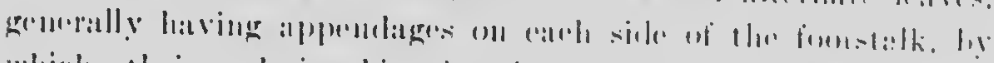

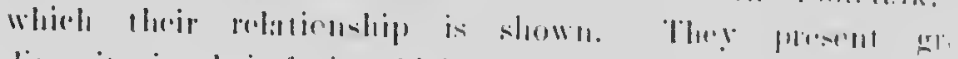

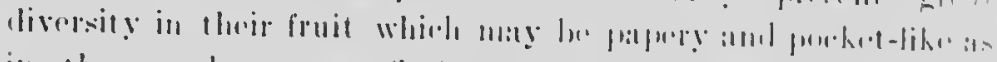

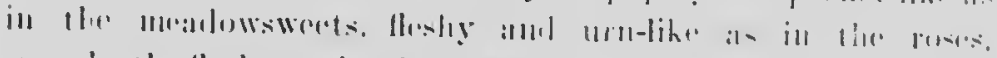

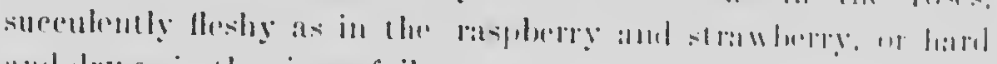
and illy as in the cinumufoils.

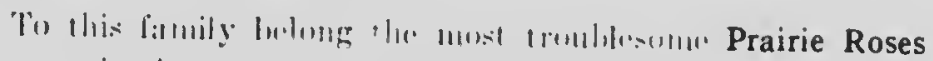

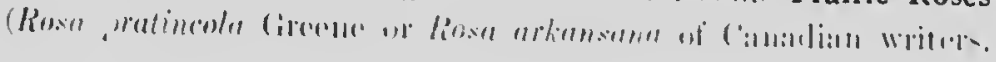


$\mid 111$

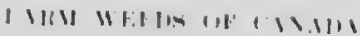

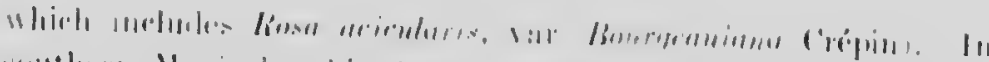

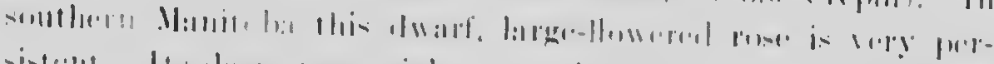

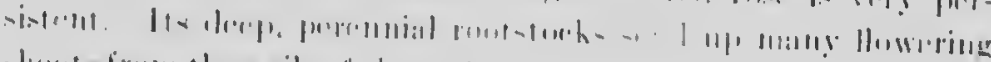

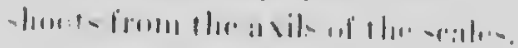

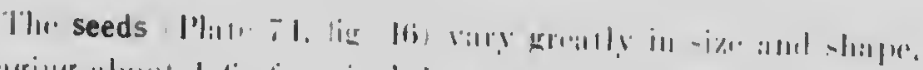

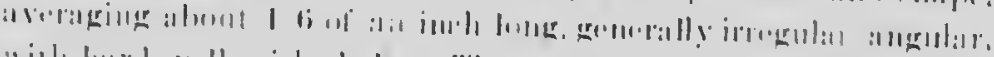

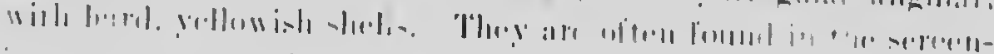

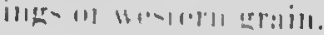

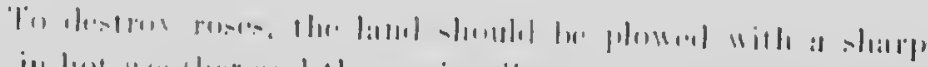

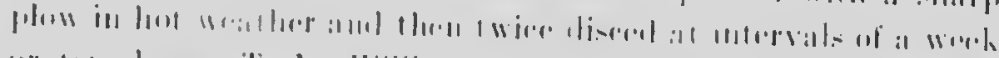

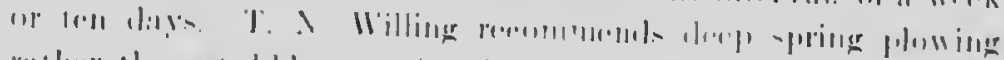

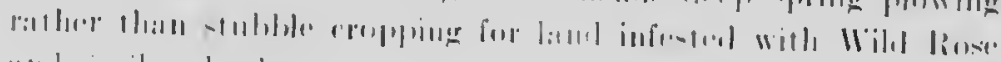

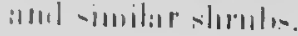

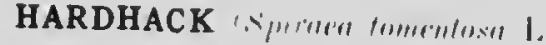

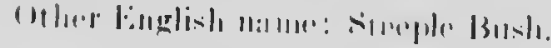

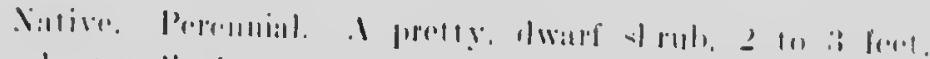

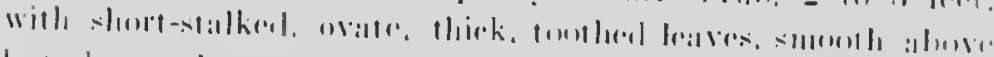

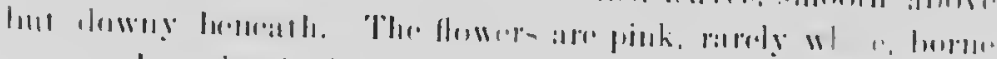

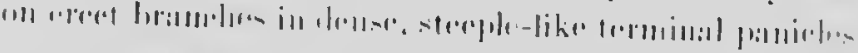

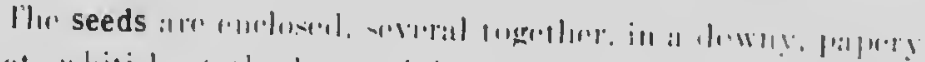

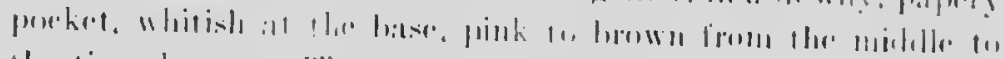

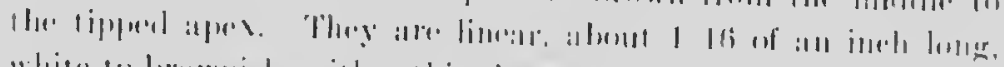

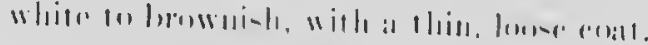

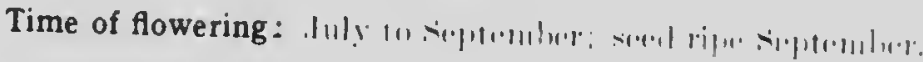

Propagation: |3! $\cdots \cdot \cdots \mid$.

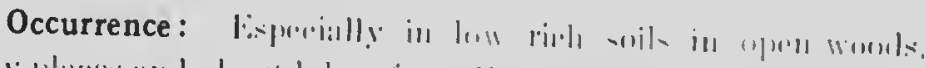

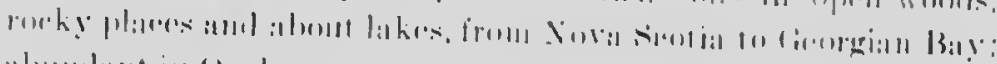

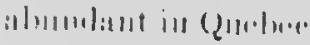

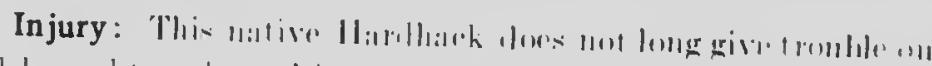

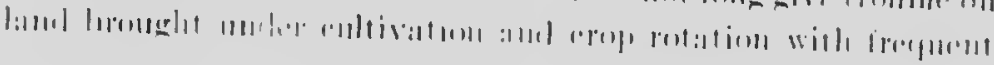




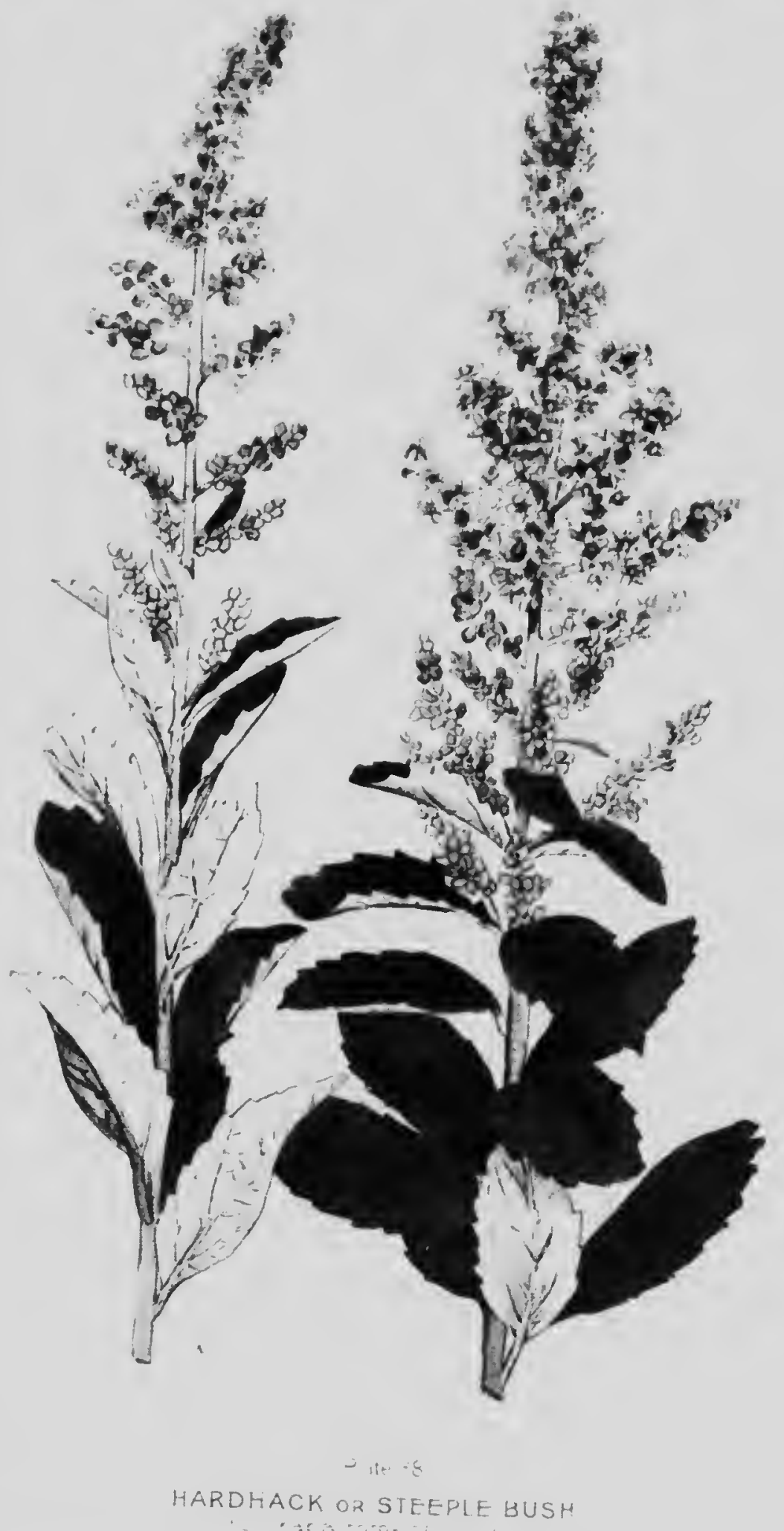




$$
-
$$


MICROCOPY RESOLUTION TEST CHART

IANSI and 150 TEST CHART No 2]
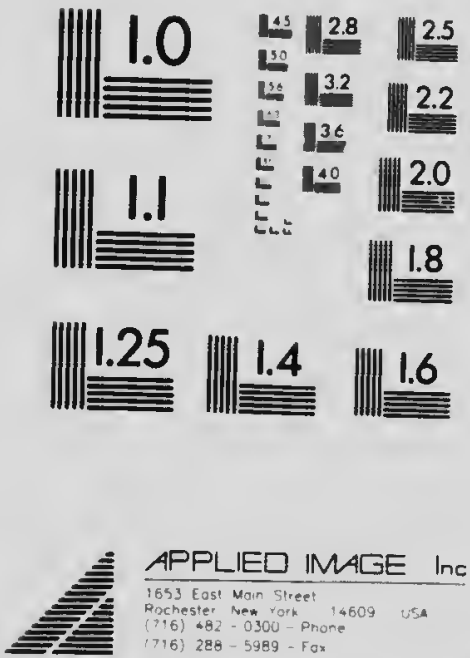


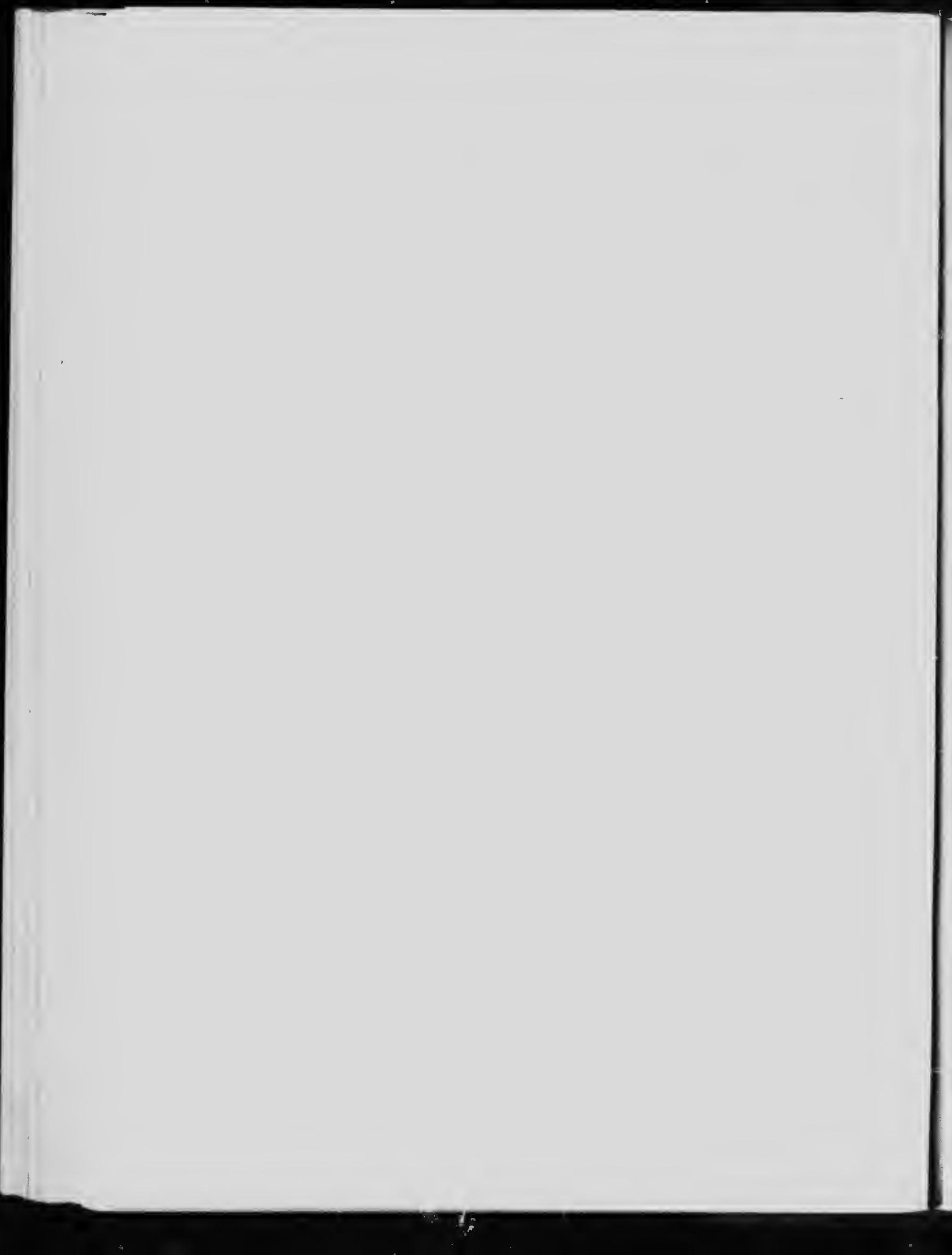




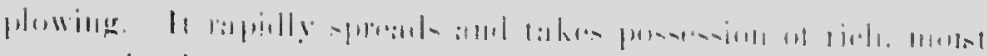

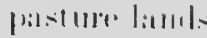

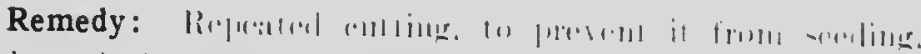

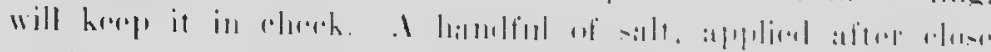

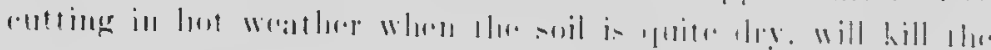

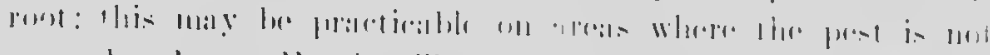

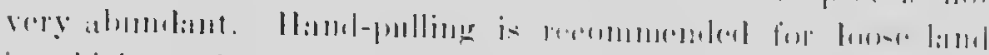

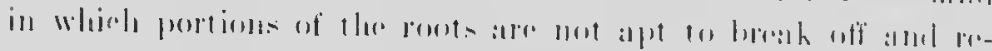

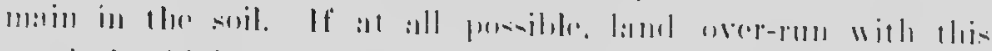

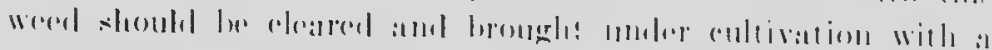

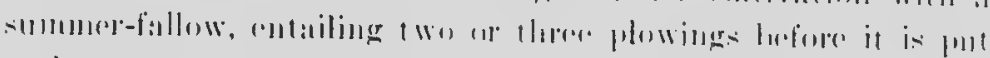

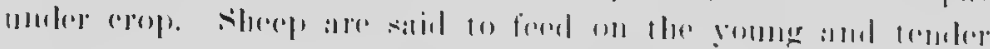

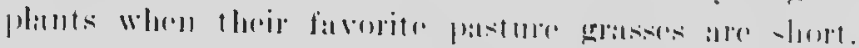

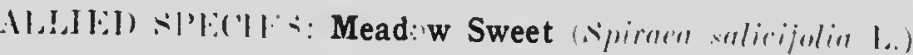

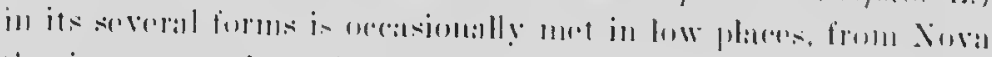

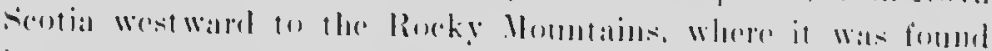

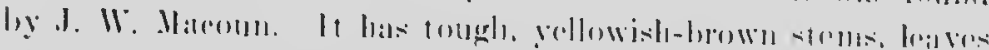

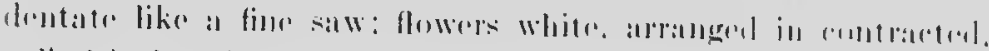

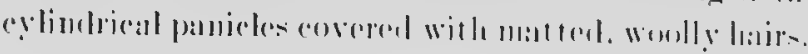

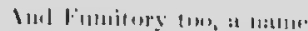

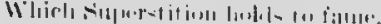

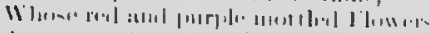

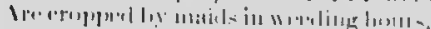

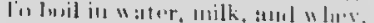

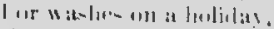

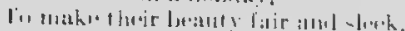

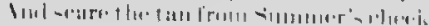

$1 \% 1: 1 \times, 11)$

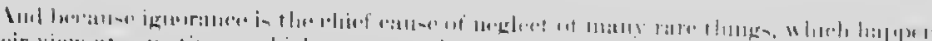

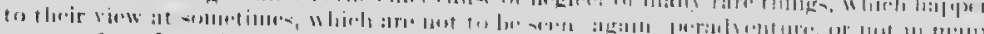

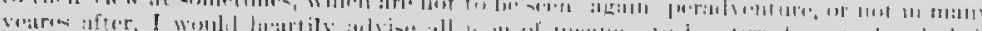

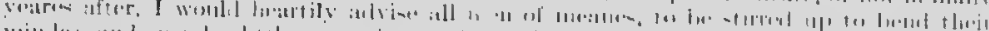

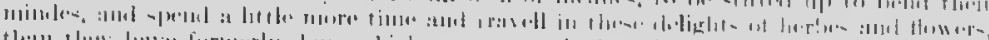

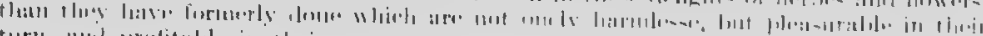
turu, aliil protitidslo in llacir lise. 


\section{UPRIGHT CINQUEFOIL (M"utertilla mon.puliensis 1..)}

()ther Euglish name: Rougl Cintundoil.

Other Iatin name: Potentille hirsuta Nichx.

Native. Anmual. Ereet, loranching, rough-hairy. The 3 leaflets of oach leaf are obovate: those of the top leaves, vhich are stalkless are toothed nearly the whole length. The mode of flowering is a leafy, rather chose ryme of yellow flowers. The seeds are grouped together on the receptacle, which is long. thin and dowily.

The seed (Plate 74, fig. 45) when lijee is leather-brown. dull, about 1/30 of an inch long, bluntly momma-shaped, with curved branching veins rmming longitudinally. Commonly found in timotly seed.

Time of flowering: June-.July; seeds ripe July to september.

Propagation: By seeds.

Occurrence: Widely distributed throughout C'anada.

Injury: A weed of seconclary importanee, eommon in olel mearlows and worn-out sandr soils.

Remedy: Repeated rlose rutting will keep it in eheek in waste plaers. It will not long give trouble on land worked under a short rotation of erops, inchuling elover and hoed crops oneer every four years. Good drainage and enrichment of the soil will stimulate a more vigorous growth of enltivated crops and ehoke out this wred.

AIIIED SPECIEs: The gonus Potentilln is widely listributed, eomprising many species olosely related to the Upright Cinquefoil, as Potentilla monspeliensis I.., rar. norregica (L.) Rydb., also eommonly ralled Jpright or Rongh ('incuefoil. It is distinguished by less hairyness and by somewhat more narowly oblong leaves. Both oceur in similar vtuations an vi about the same distributive range.

The seeds of the einquefoils are very similar and their identifieation is sometimes diffientt. They vary only slightly 


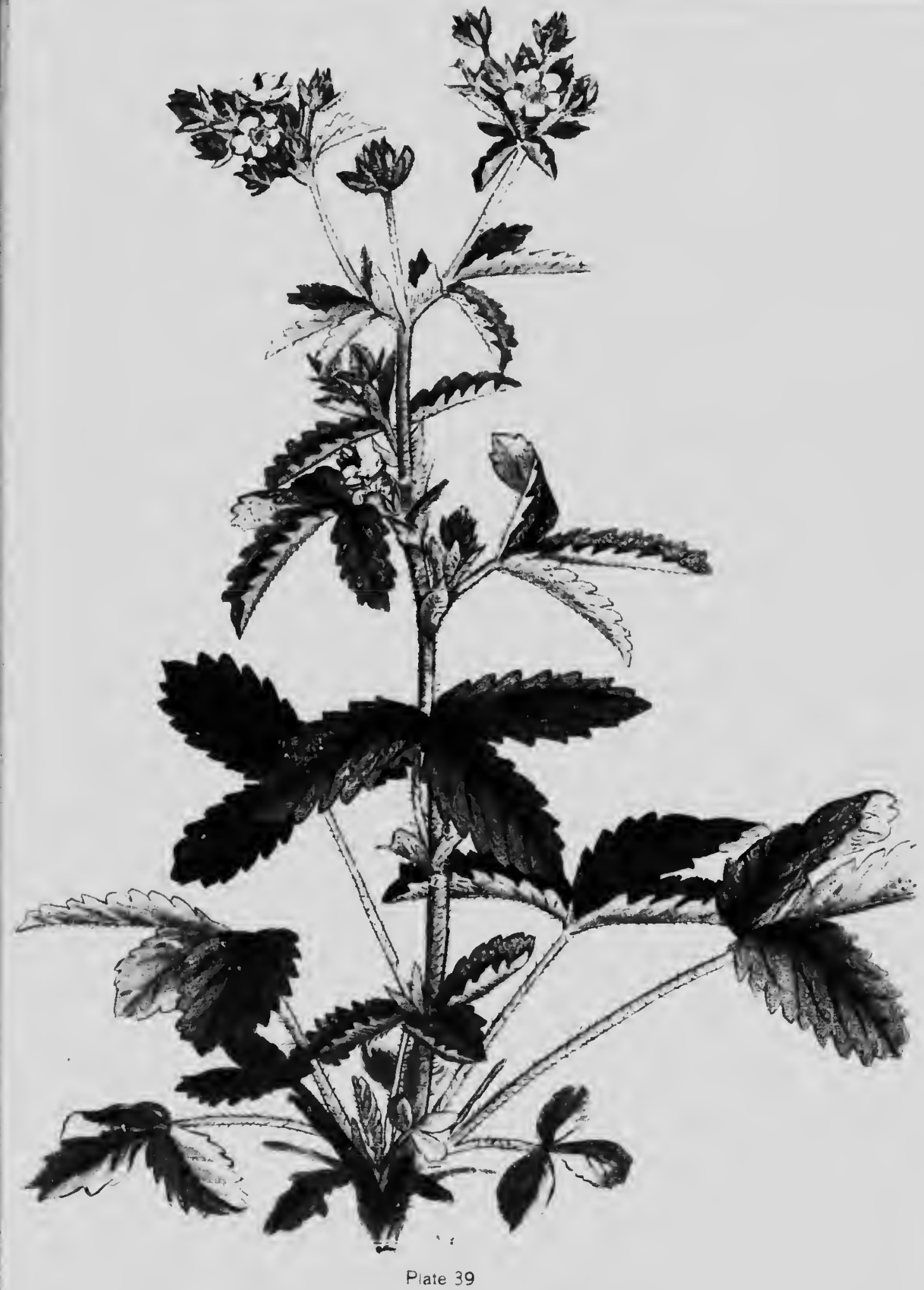

UPRIGHTOR ROUGH CINOUEFOIL 


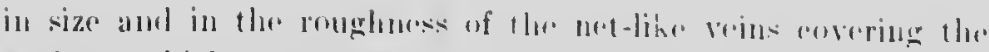

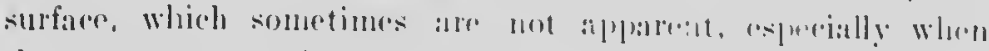
the sorels nare not enite ripe.

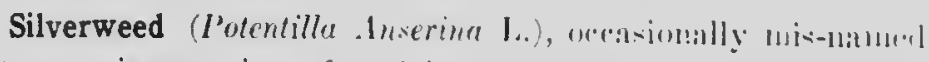

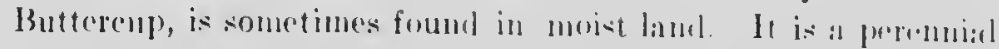
with slender, jointed runerers, which root and form new plant: at each joint like the strawlerry. The leates, silvery hatily beneath, alle fomposed of from :3 to lo large, oval. slatrply-tout lenl leaflets on each side of the stalk, with very stlatl ones betweren them. The long-stalkenl, gohlen-yellow flowers, neally an inch

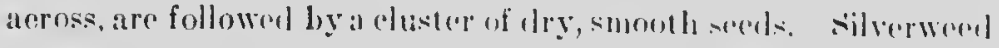
roots on the surfaer of the ground and is best routrollerl hy drainiug the land and plowing down the platnts.

\section{THE PEA FAMILY (Leyuminosme)}

This large and important fomily is woll represcutod in Canada and rontains many useful plants, surl a as inas, locals and elovers, as well as some poisonous sperims ats the Loco Weeds (Oxytropis) and Golden Bean (Thermo wis) of the western plains, and a sinall numbere of werels of secomblary importanee. All plants of the l'ea family colloes nitrogen from the air and render it a vailable for plant foul.

Every species of this fanily ean be recugnized ly one of two characteristics: either a butterfly-shitperl corolla, surb

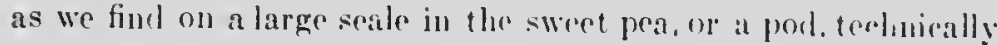
called a legume, for a fruit. like that of the salue plant or of the garden pea. By far the larger number of the plants have both eharacteristics.

Rabbit's-foot Clover (Trifolium artenic 1..) is at useless member of this family, not ecmmon in (anada and of little importanee.

The Sweet Clovers (.Melilotus alba Desr. and Velilotus officinalis (I.) Lam.), often complained of by farmers, are biennial wayside weeds which are casily subdued by preventing then from seeding, as each plant lives for two years only: 
III

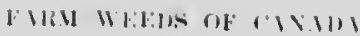

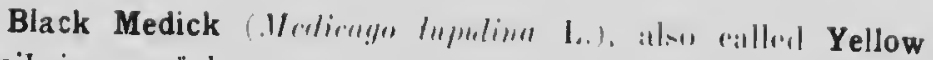

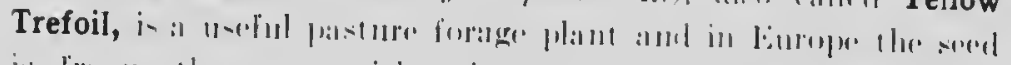

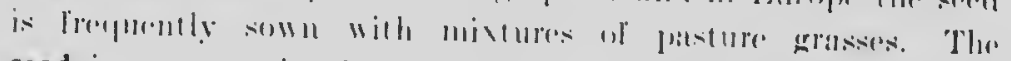
seed is anmmon) in clover serels. It is colmetimes mixnel with

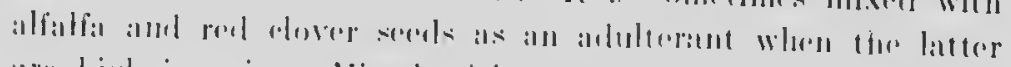

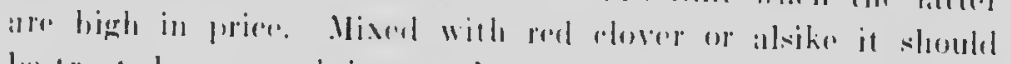

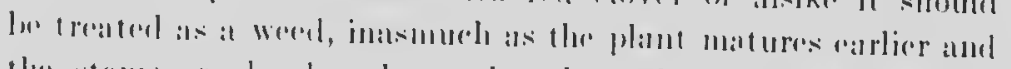

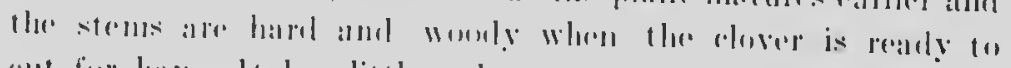

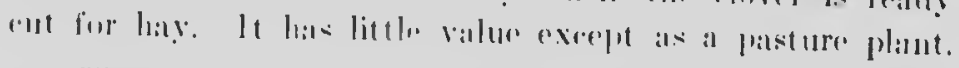

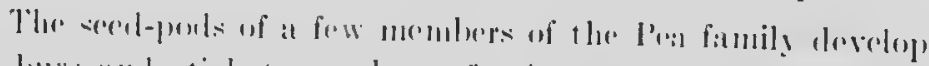

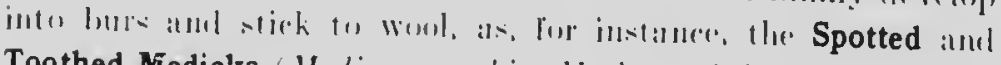

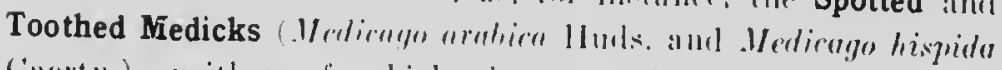

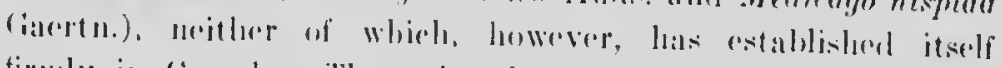

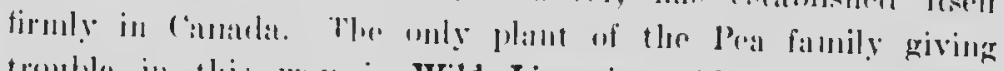
trouble in this way is Wild Liquorice cilycyrrlizn lepiduta

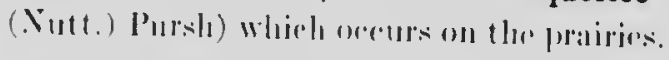

Loco Weed (1)rytropis Lamberti l'ursh.) diffors from the Milk Vetches (Astrugales) of the westorll plains in that

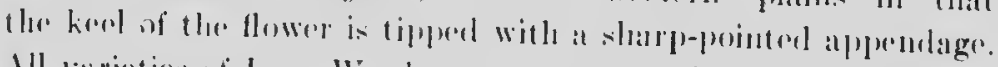

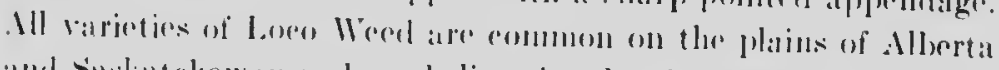
and saskatelewall andel are believerel to be the ranse of a preuliar mental disinereler among horses and eattle.

\section{WILD TARE (Virin unguwtijolin (1.) Roichatrl)}

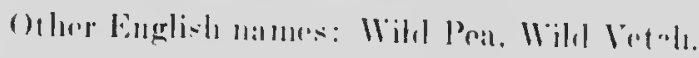

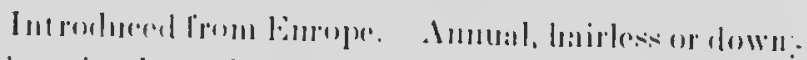

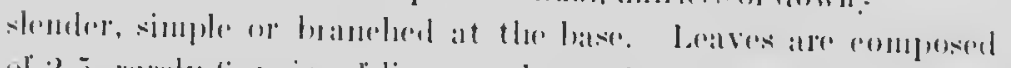

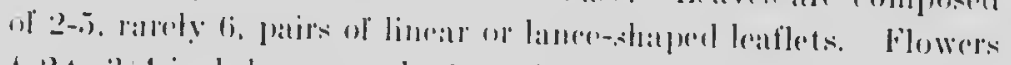

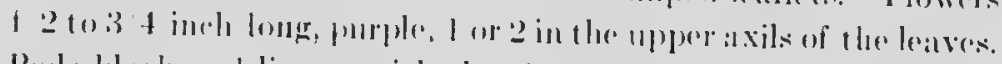

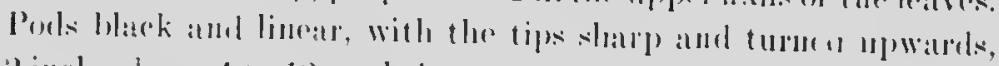
2 inclues long. 4 10 12-seredorl.

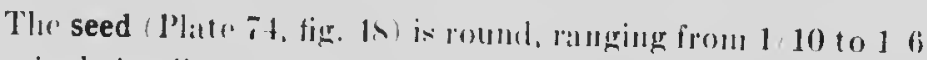

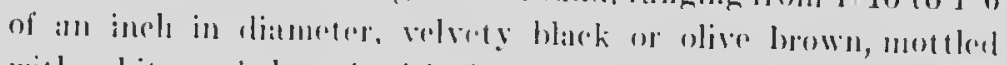
with white and dotted with fine blark spots: the whitish seat 


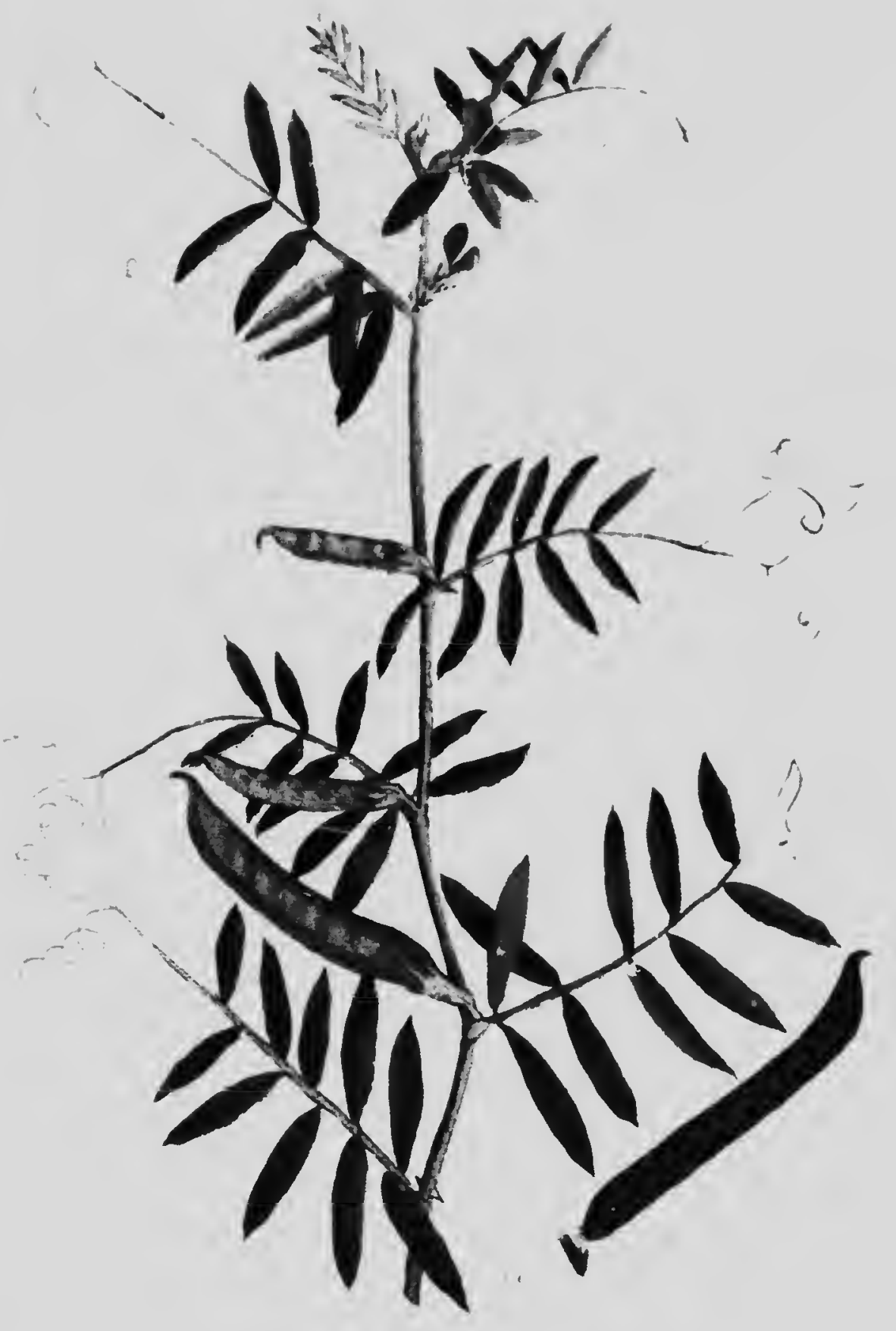

COMNON :FICH OR WILD IAP 


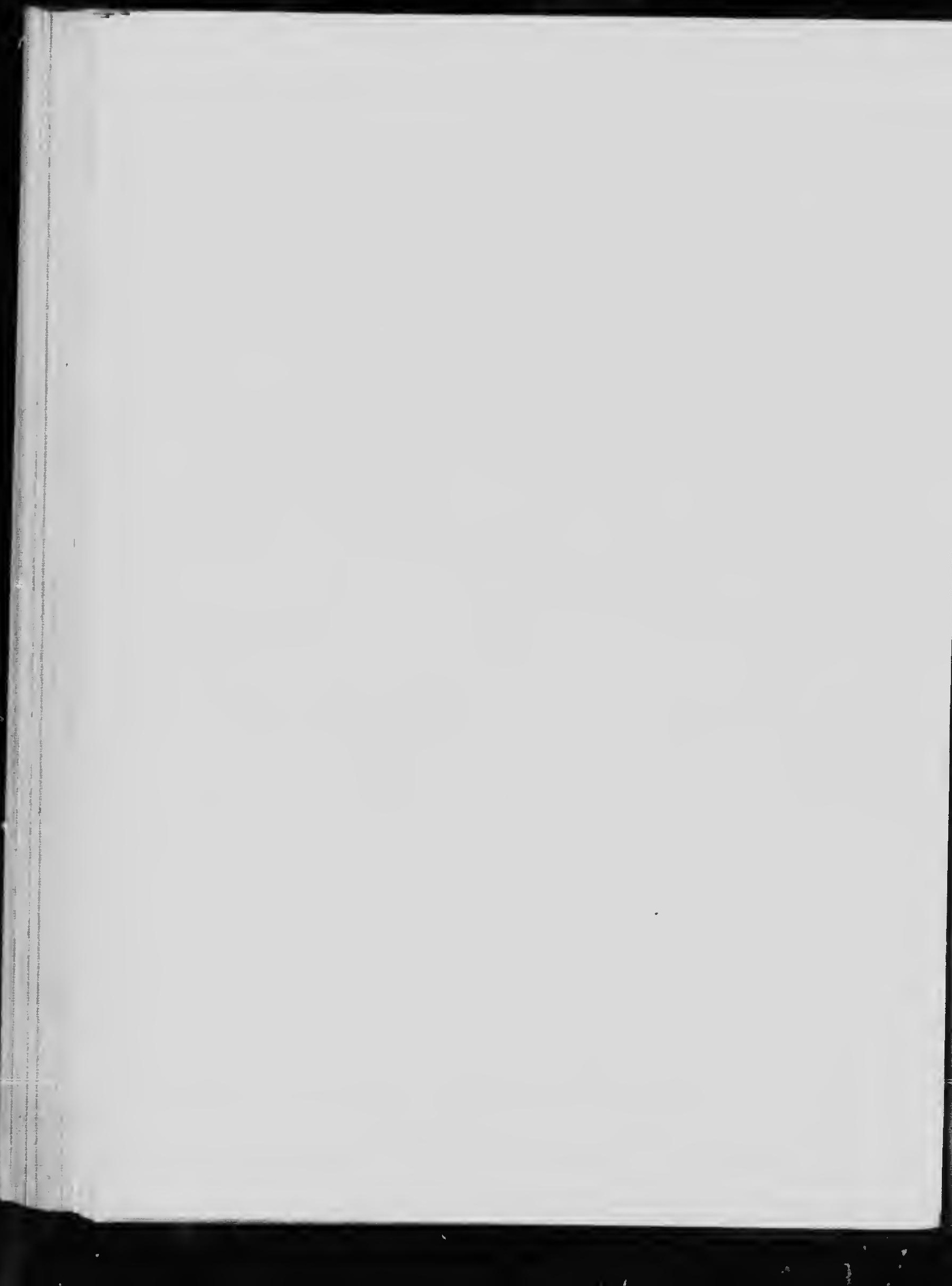


about $1 / 5$ of the rirennferenere of the sorel in length, thin, threastlike.

Time of flowering: Jum( t) August; :mels ripu hy dugust, Propagation: 13y sorids.

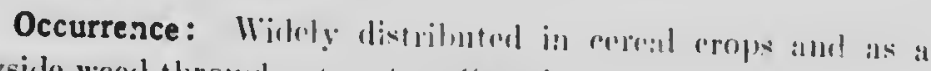
waysile wrent throughout rastern l'antala.

Injury: When present in quantity, Wild Tares materially. reduee the yiold of grain; they sometimes mat the erepl hy twining about the stens of $t f_{\text {e }}$ grain and make it more likety to loolge. It is often diflientt to operate solf-bincters in grain crops matted with this weed. The seeds are cxeeselingly (onnmon in grain and are esperially objectionable in oats required for milling.

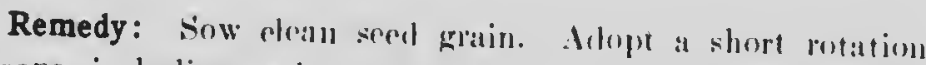
of crops, inchulling early matmoing harley rather than gats, on lands where this weed is fervalent. ('ultivate bare stubhle directly after harvest, 10 stimulate germination of serels, ant pasture off the rop so procluees. Barly infested folds maty be sereded to grass for there ur four years, but this will he foumd neessary only when a erop mation, to prevent it from soroling. can not be followerl.

\section{AI.LIFD SPLC'lEs: Cultivated Tare or Spring Vetch (I'irie} sative L.), so valuable for forleler and known lo solno farmors as Vetches or Fitches, sommohat resombles llihl Tare, hut

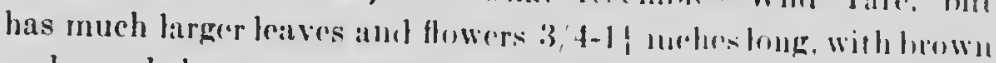
pork, and does not persist a. the land whin sown. The seed is nearly $1 / 4$ inch in diancter, generally platin hack, the threal-

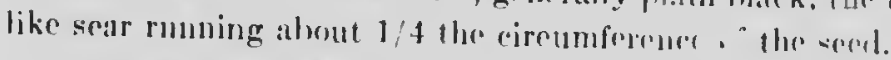

Purple Tufted Vetch (Vivir Cracen l..) is a persistent peremial rather difficult to get out of old mesalows, but it produess a large crop of rich folder which is mother benefiejal than of herwise in hay. The seed is simbilar to that of Will Tare hut the sear is mueh broader ant longer, abmut 13 in 1 '? he viremuferenee of the seert. 


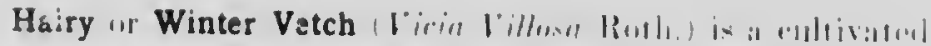

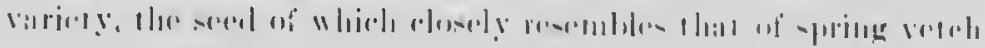

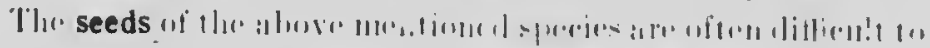

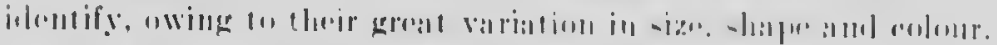

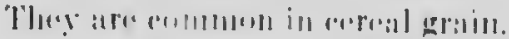

\section{THE SPURGE FAMILY Kuphentiarm!}

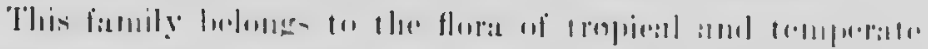

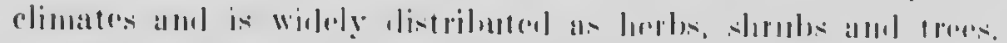

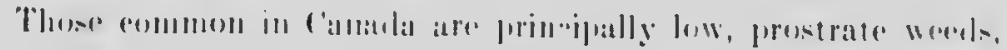

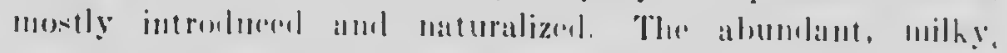

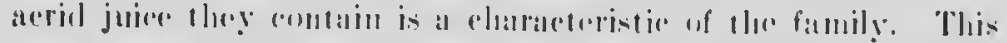

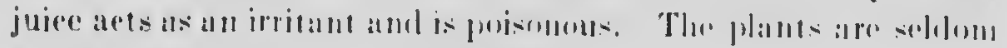

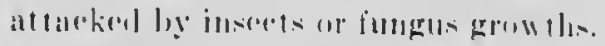

Wax-ball "1) Three-seeded Mercury (.lonlyplin rirmimina

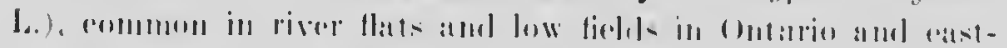

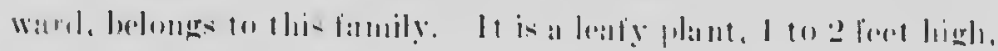

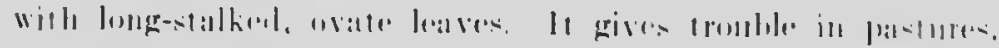

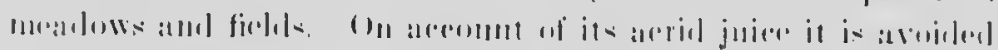

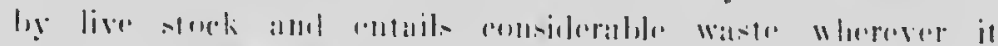

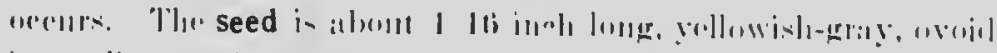

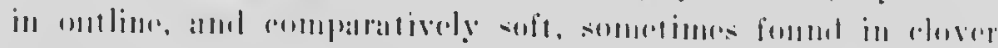

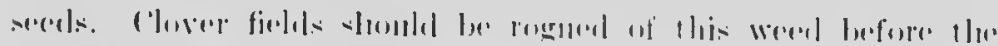

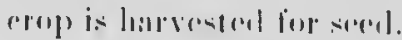

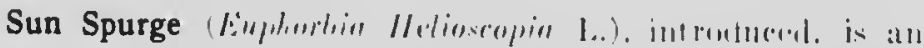

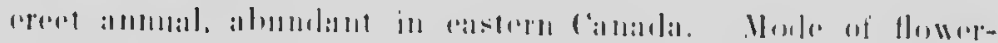

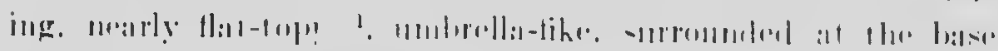

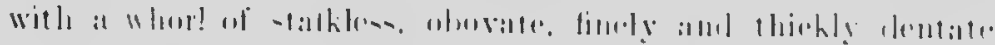

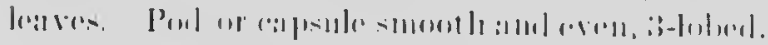

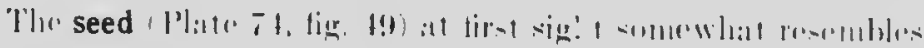

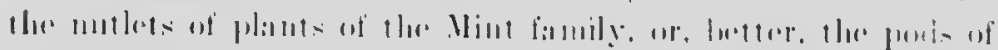

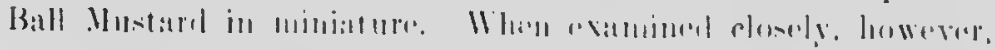

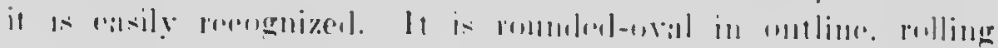

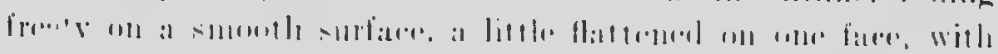

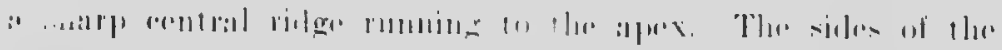

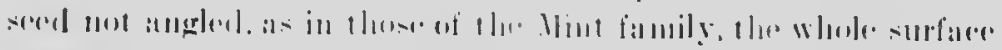

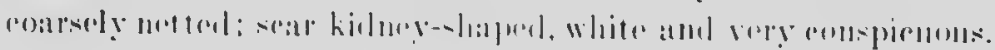




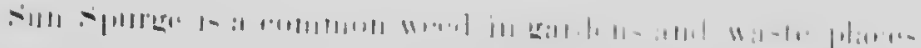

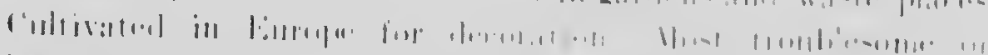

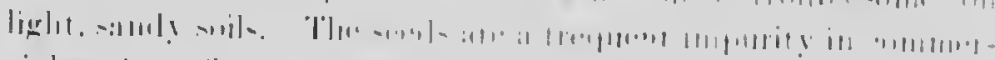

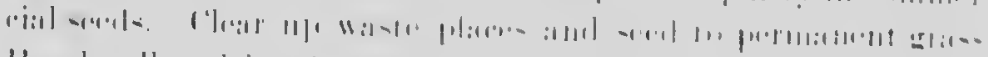

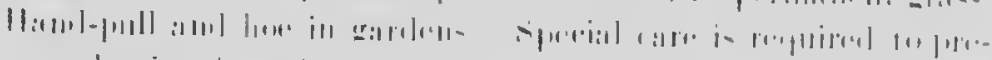

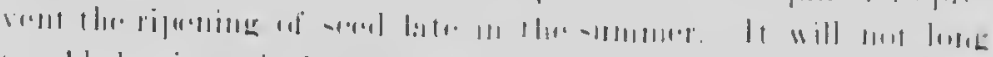

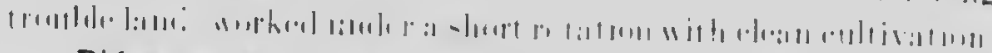

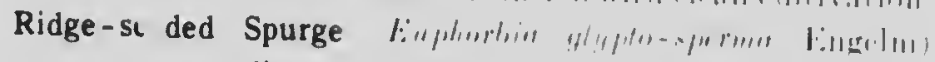

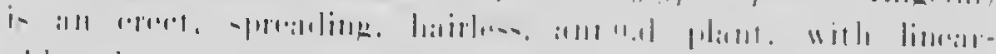

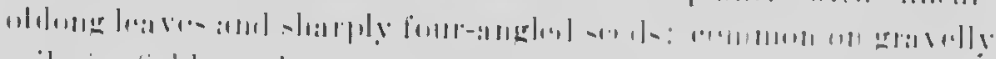

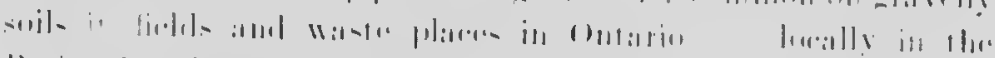

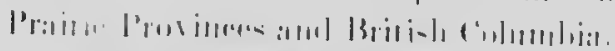

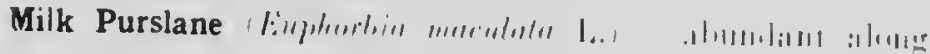

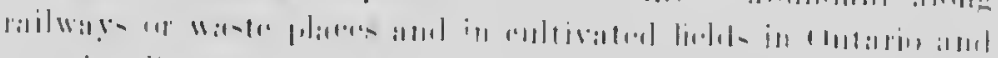

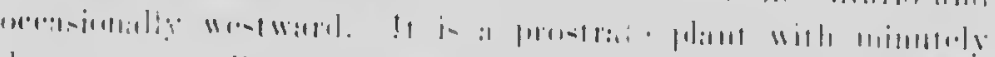

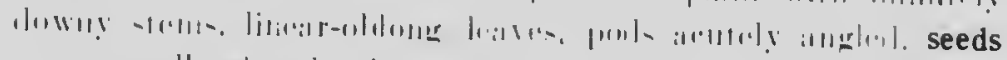

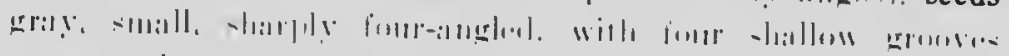

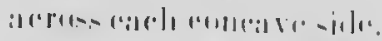

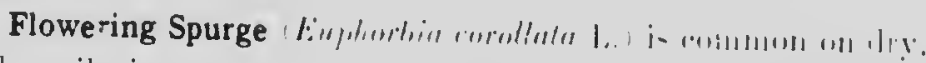

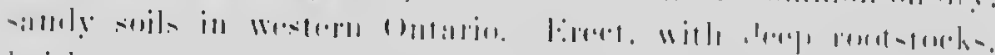
la

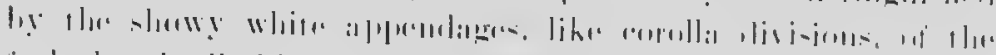

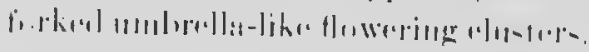

\section{THE MALLC TT FAMILY I/u!nu}

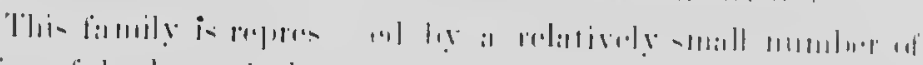

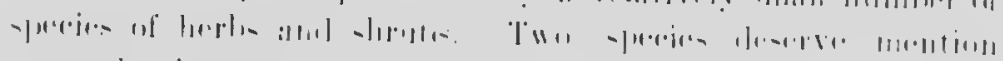
is $110 \cdot 1010$ -

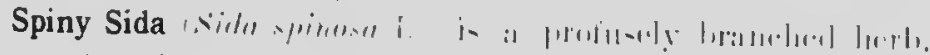

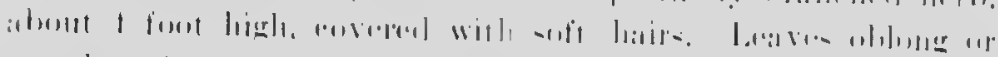

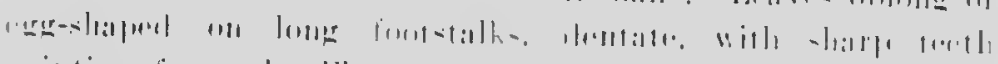

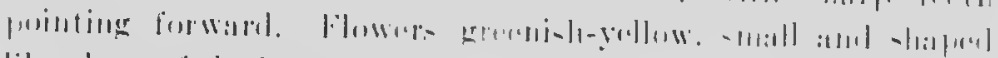

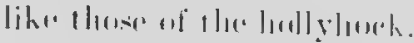

Round-leaved Mallow, Common Mallow (it Cheeses $\mid / 1,1 / \cdots$

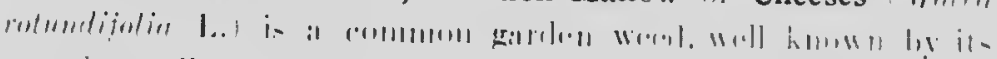

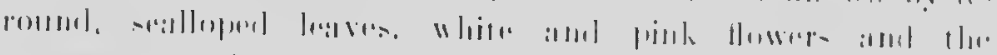

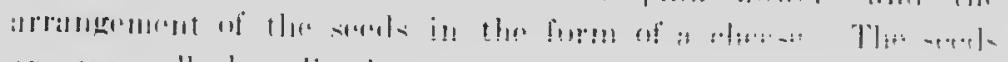

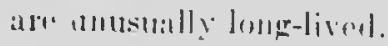




\section{THE ST. JOHN'S-WORT FAMILY (IIypericacrac).}

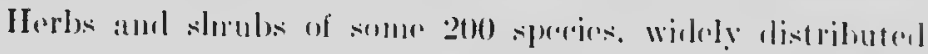

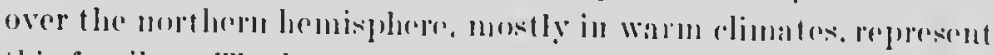

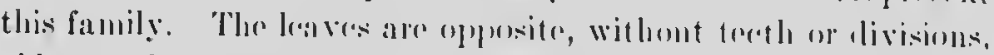

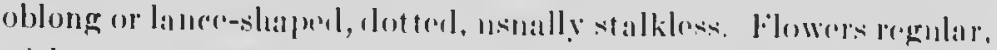
with many divisions, forminal, solitaly or dispmenl in singlo or

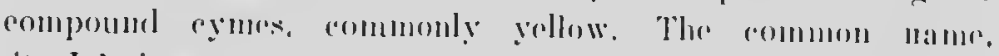
st. John's-wort, comes from the the of plants of that family in Europeras areoration onst. Joluts Day.

COMMON ST. JOHN'S-WORT (H!nericum perforalmm 1..)

Other English nanes: Amber, Prong-olohn, Rosin, Rose, Ilerb-Johı.

Introtueed from linopre. Peremnial by muners at the

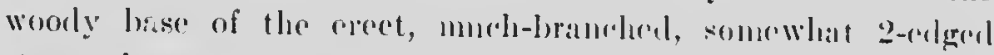
stem. Leaves opposite without taeth or divisionse colliptic or linear oblong, black-elotted along the margin like the ropollit divisions. Flowers dorep yollow, grompere into tomminal, lowse eymes.

The seeds (l'ate 7t, fig. 50) are borme in 3-celled, ovoid pork. They are abont 1,25 of an incle long, eylindrical, rommled at the remels, with a mimeste point. The surface is rongh, pirtorl, a little shiuy, dark brown to black in eolour.

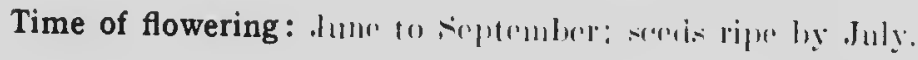

Propagation: By serels and rootstoreks.

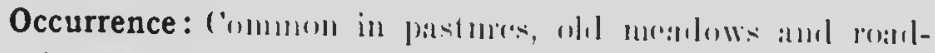

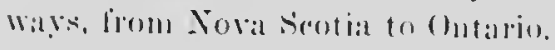

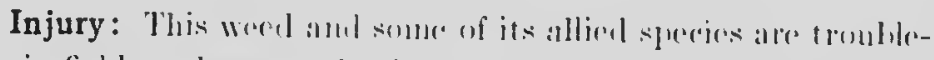
some in firluk and pastmro lamels.

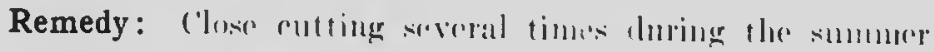
will roduer it in pastures. In spplimation of silt - at small 


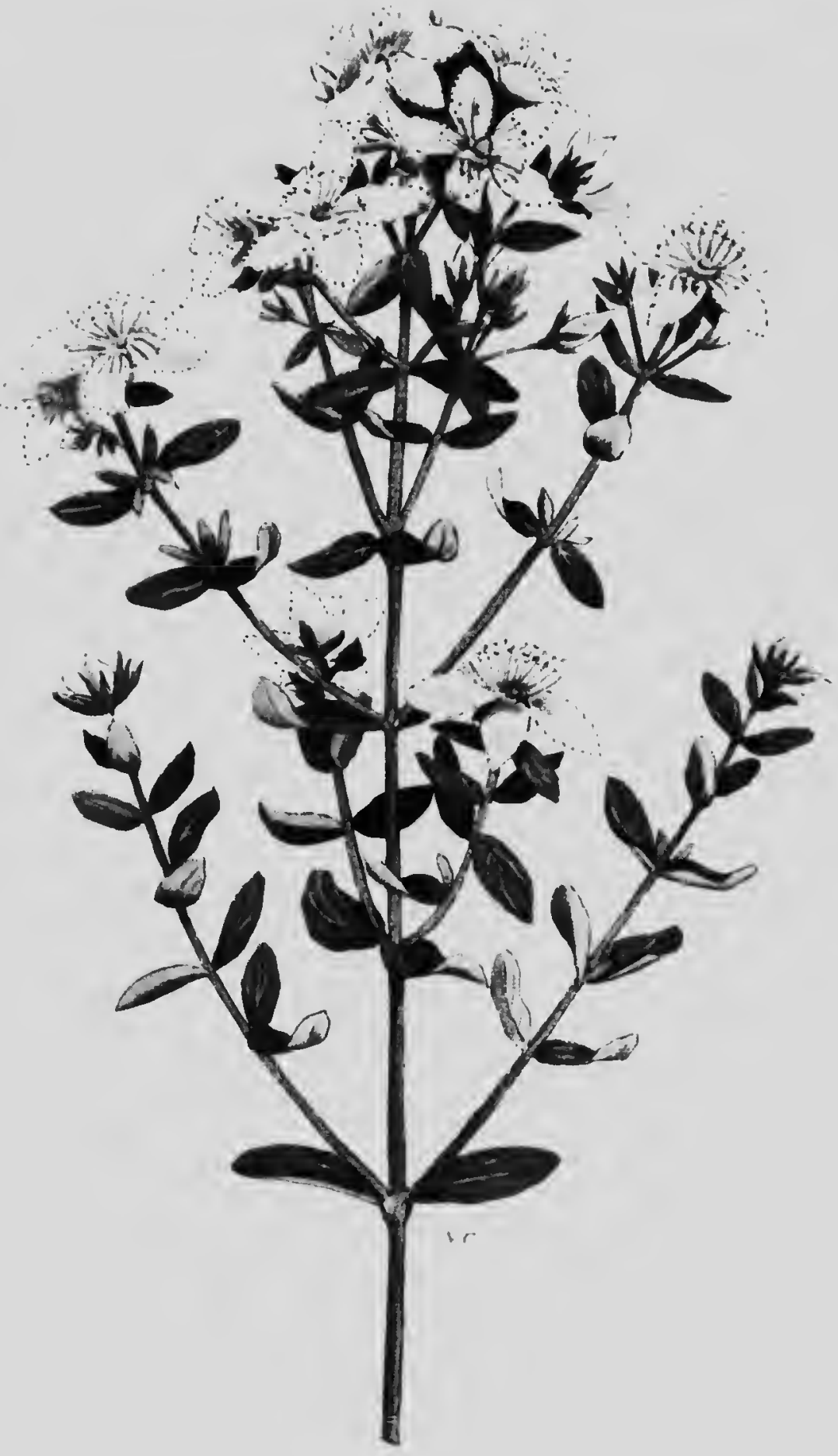

COMMON SI JOHNS-WORT 
handful to each plant after clese cutting in hos thy woatleer -

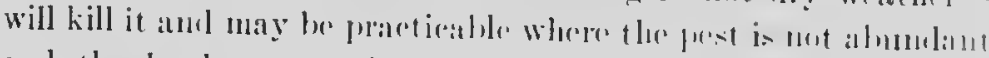

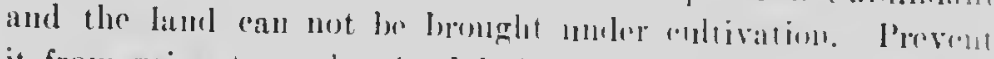

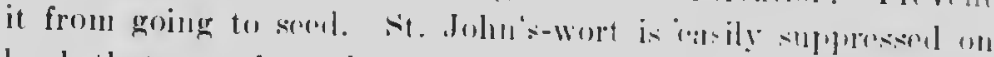
land that can bo roltivalted moler a systomatio potation of crops. Where it is establisluel, it would he wroll not lo serel to griss: until it is supprescorl.

AI.LIL1) SPEC1LA: Great St. John's-wort (il!nurimul A.-

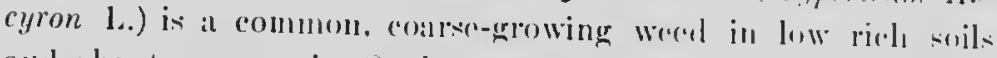
and about swamps in Quebore and Ontario, oreasionally arentring in old meaclows and fastures along river flats.

Spotted or Corymbed St. John's-wort (II! lperienm functutum, lam.), about 2 fort in leright, is almumlant in the Brmer peninsula of Lake 1luron, and furte gencral thromglont

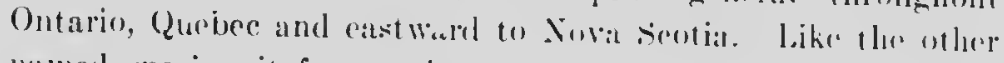

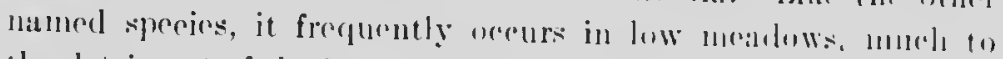
the detrimment of the hay.

Pale St. John's-wort (Iyperienm rllipticum llonk.), witlt it.

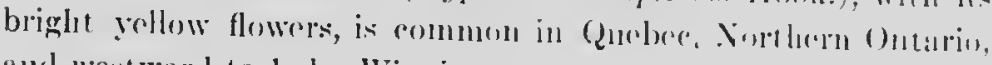
and west ward to latke Winnijeg.

\section{THE EVENING PRIMROSE FAMILY (O)nagracria').}

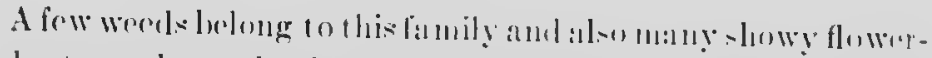

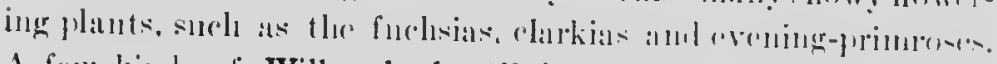
A fow kinds of Willow-herbs (Evilubinu), :lsol known :s Fire-

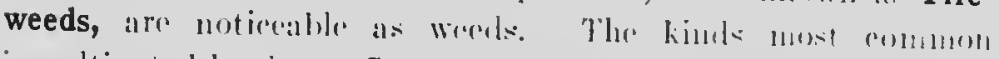

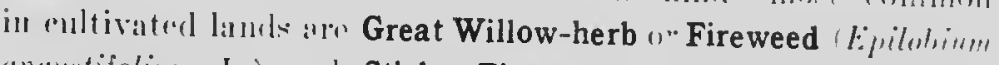
angustifolium I..) and Sticky Fireweed (I:prlolimm udenor(miun

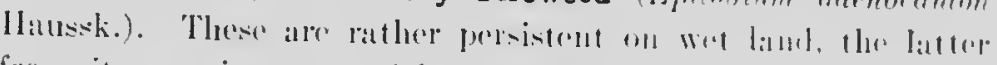

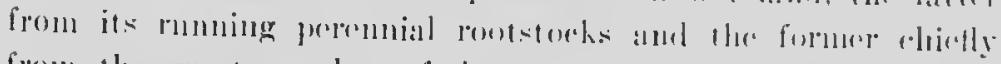

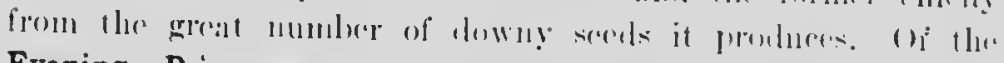

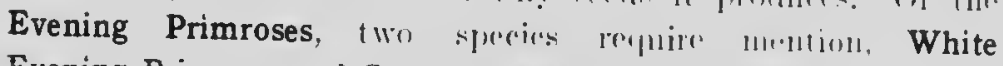
Evening Primrose and Common Evening Primrose. 


\section{WHITE EVENING PRIMROSE (Oenothera pollila l.indl.)}

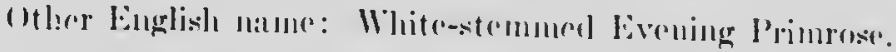

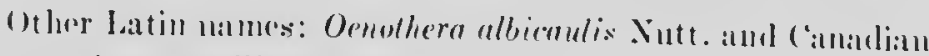
aluthors; Anogra pallida (1.imll.) Britton.

Native. Perennial. Roots white and fleshy, wille-sprealing amel throwing up flowering stems at intervals, thus forming large pateloses. Stroms mostly simple, shining white. spansely lowny aloove, erect or nearly so, about 3 feet high. I.raves from l to + inches long, narrow sul waved, somotincs pimatificl but usually without teeth or divisions in plants found in the

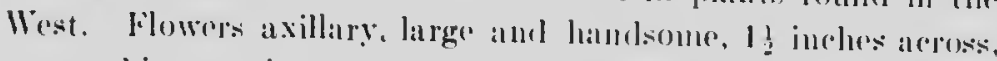
maxy-white, turning pinkish as they fatde. open in day time.

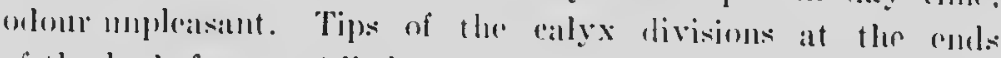
of the butk fore, as t little perints. ('apsules manew and curvel,

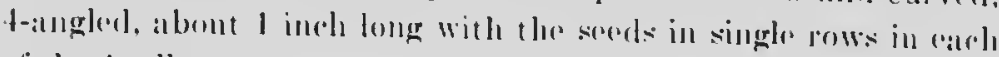
of the t enlls.

The seed (Plate 74 , fig. 5is) is alonut $1 / 16$ of all inci. long, normally spimdk-slatped but angular and somewhat twistol

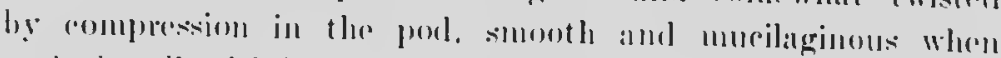

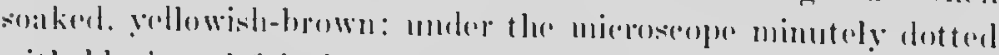
with blarek and fintly striate lengthwise.

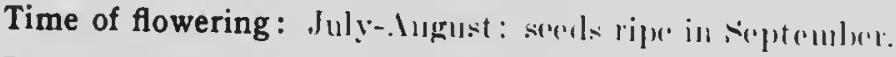

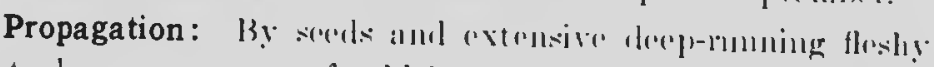

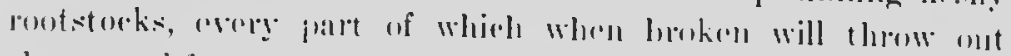
shoots andul formu num platuts.

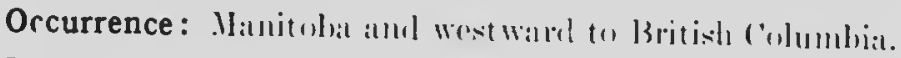

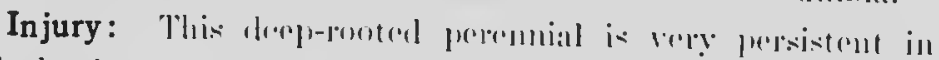
:andy laurl.

Remedy: Summer-fillow with tere or shallow phowing. areoreling to the nature of the soil, aftere the growtl hats becen mate ill summmer. ('ultivate in fall of in spring bofore sorerling (1) : a ('以). 


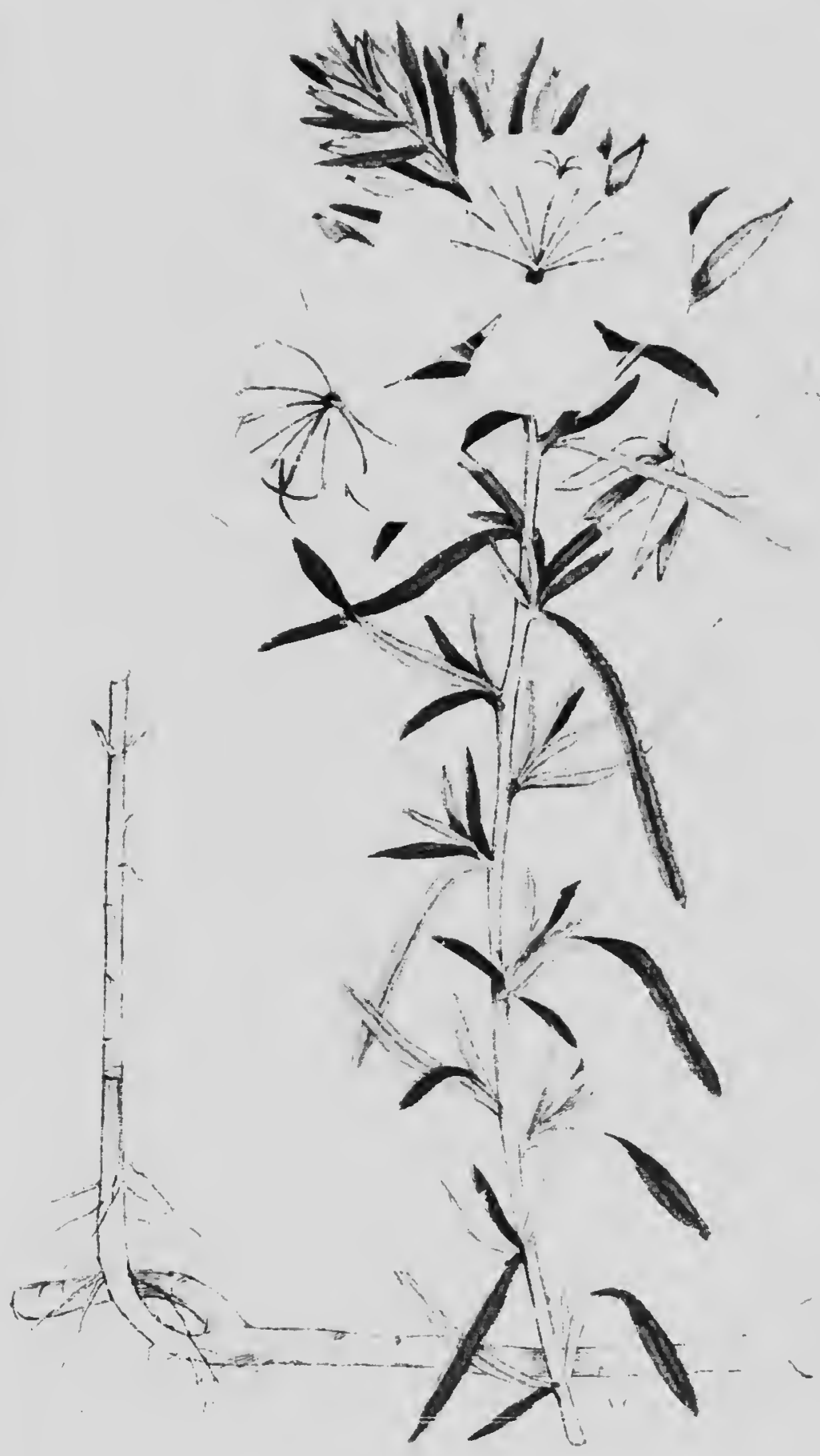

WHITE EVENING PRIMROSE 


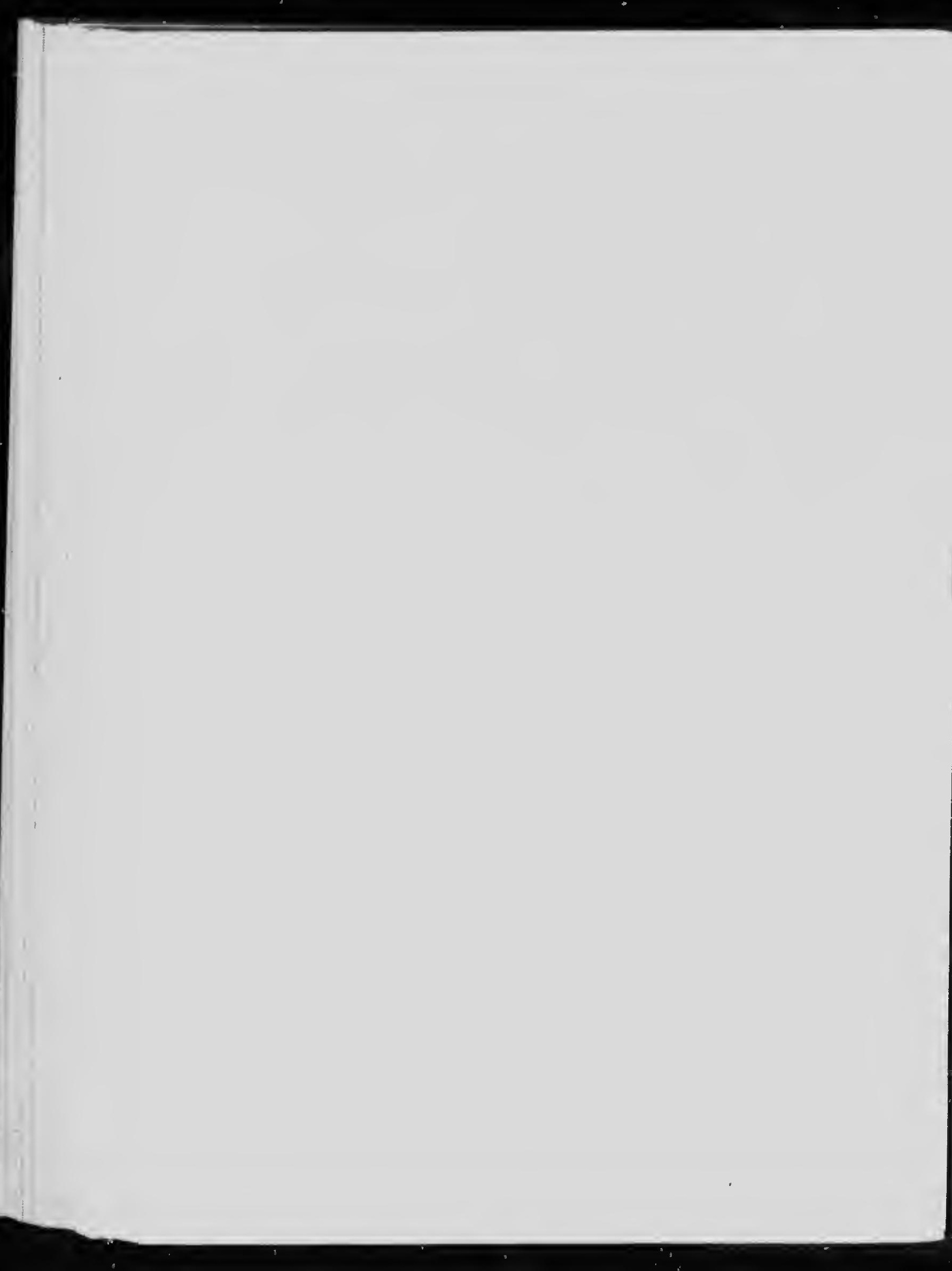




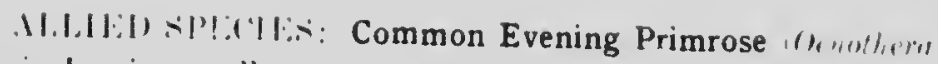

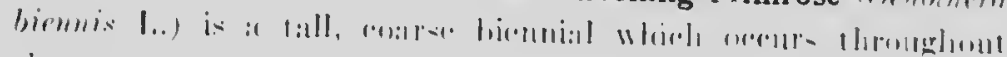

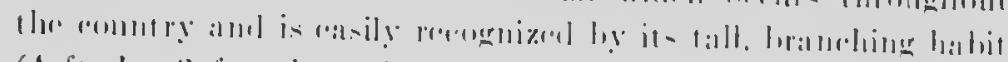

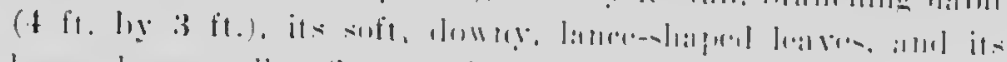

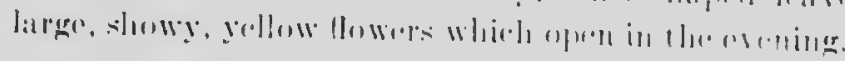

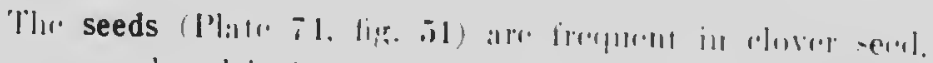

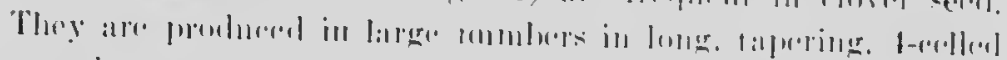

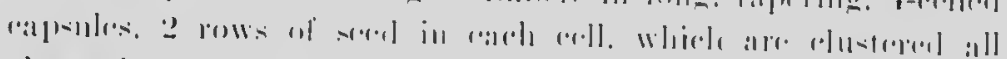

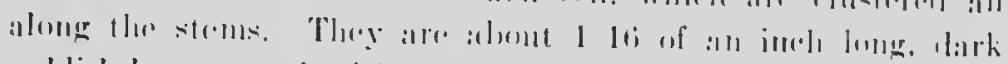

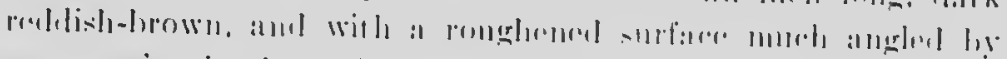
rompression in the prois.

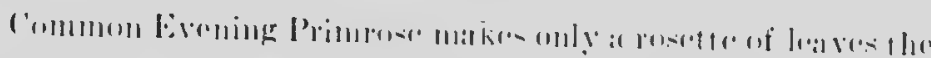

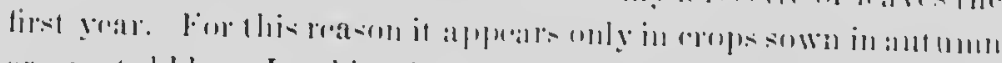

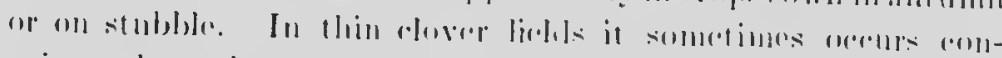

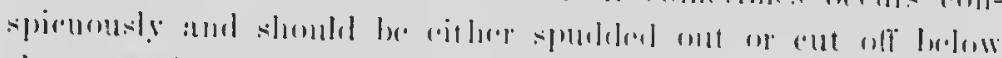

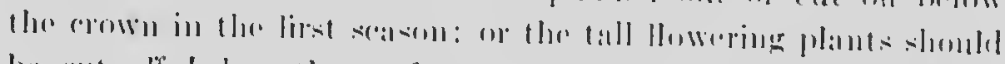

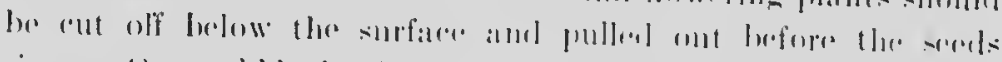

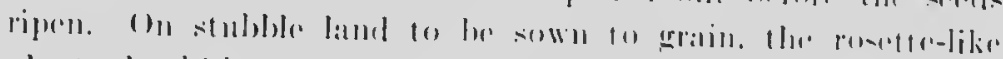

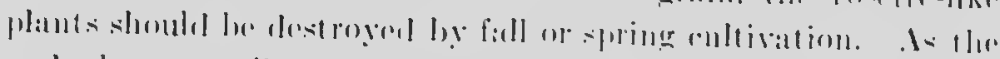

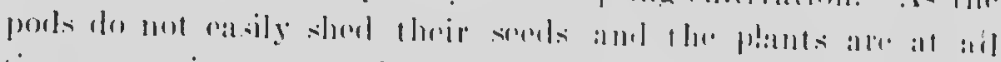

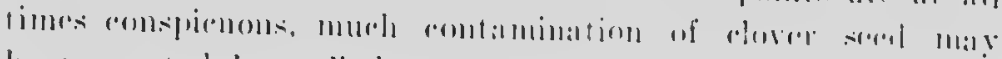

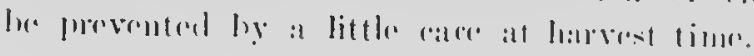

\section{THE PARSLEY FAMILY, Cimbellifent.}

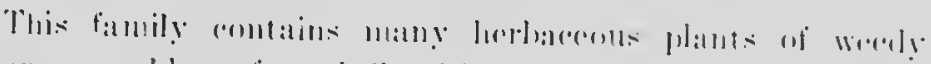

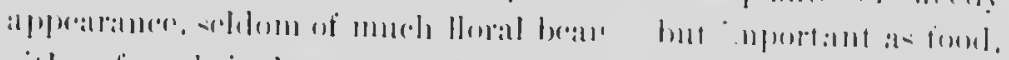

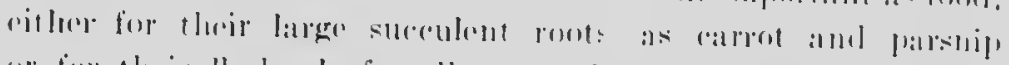

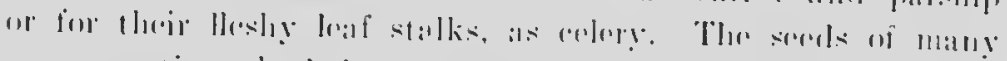

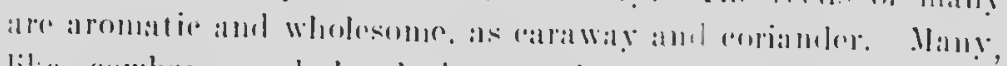

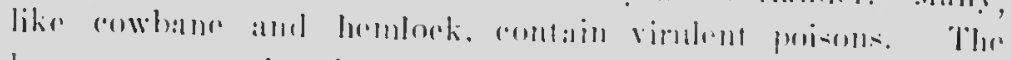

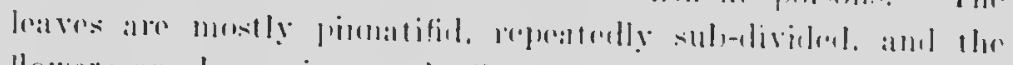

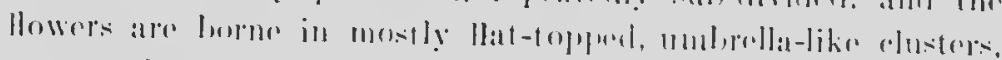

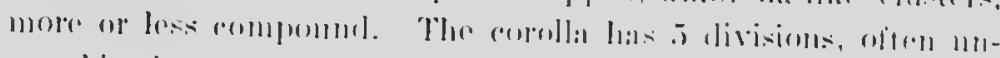
"rfual iu $-\mathrm{i} \%$. 


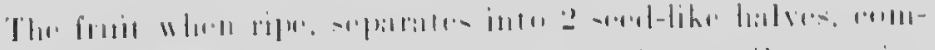

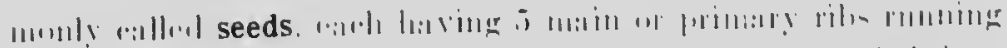

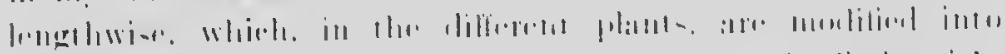

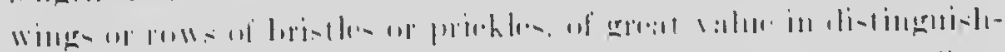

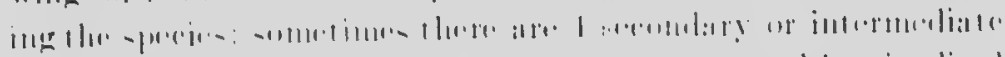

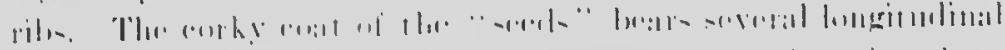

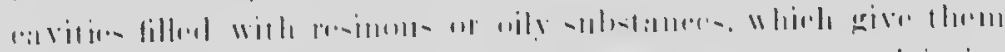

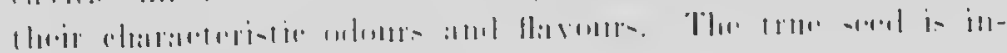

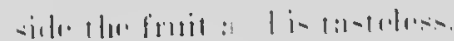

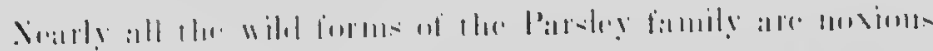

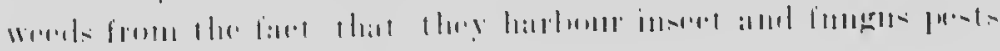

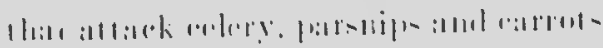

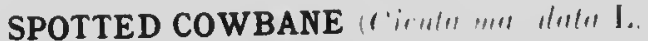

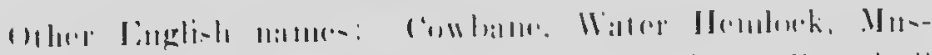

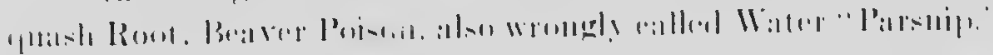

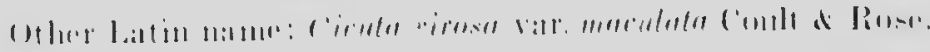

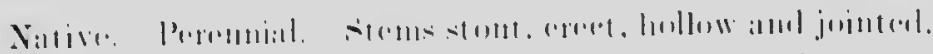

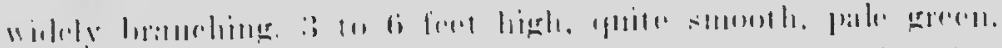

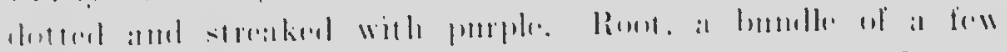

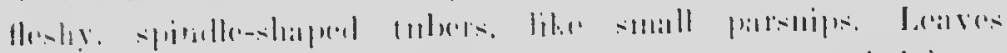

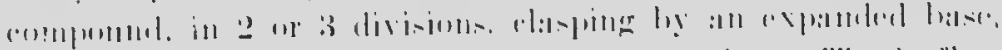

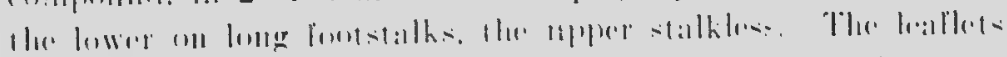

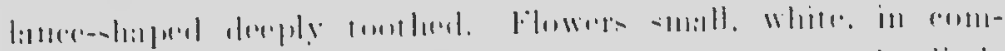

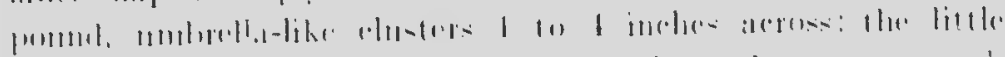

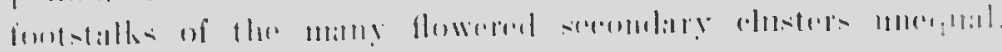

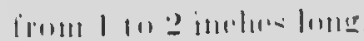

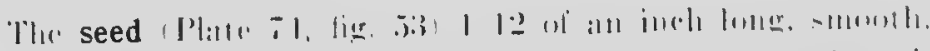

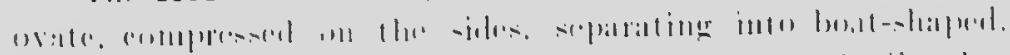

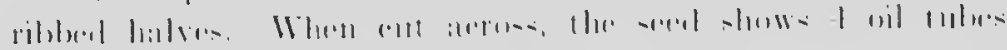
lw1 w

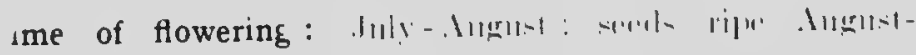
siptrmlurs.

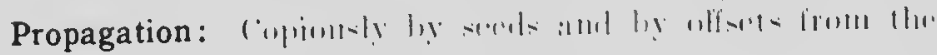

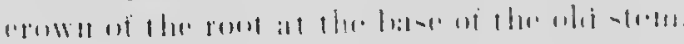




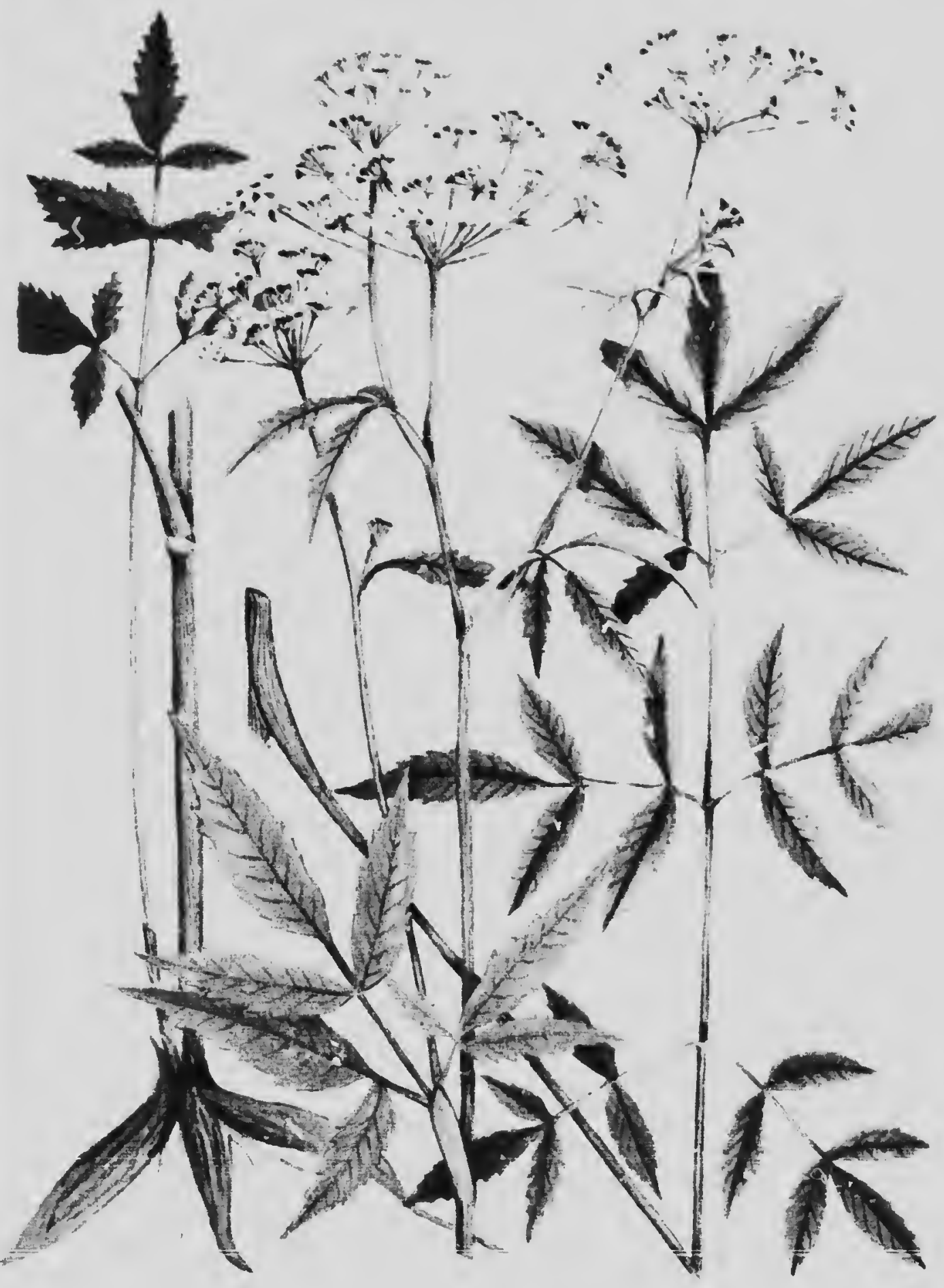




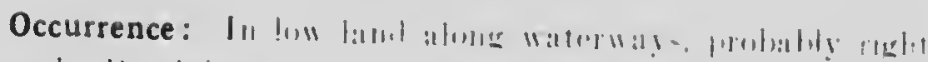
ateres Ihe Hentuinion.

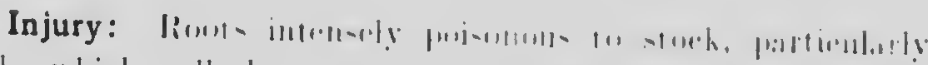

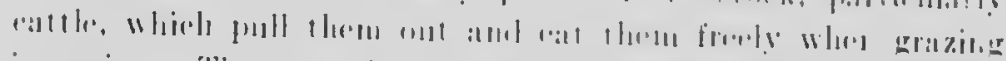

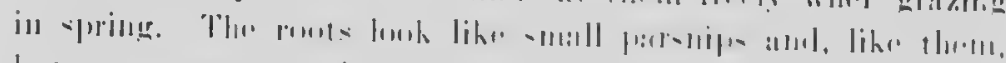

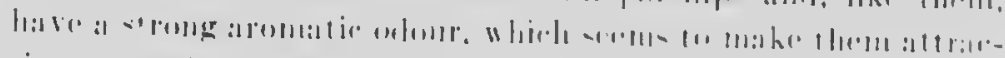

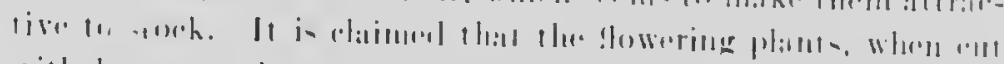

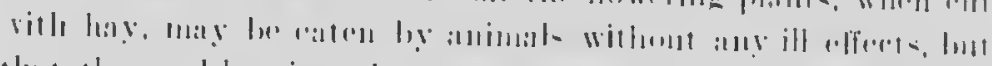

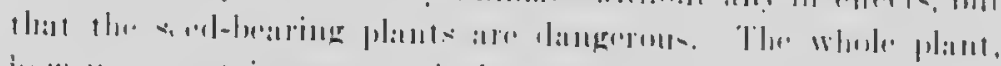

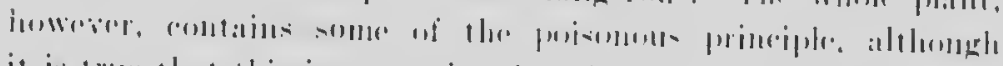

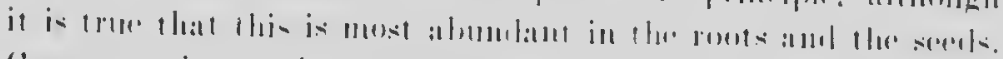

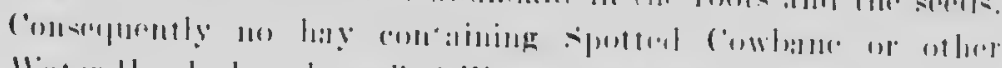

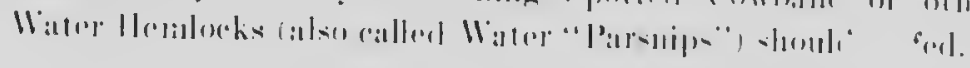

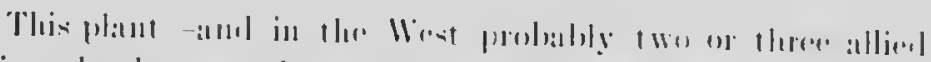

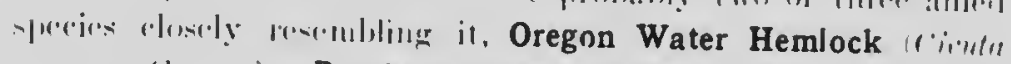
"ufrul: (irrinc). Purple-stemmed Water Hemlock "irml"

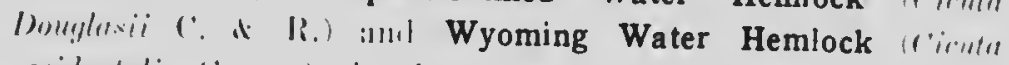

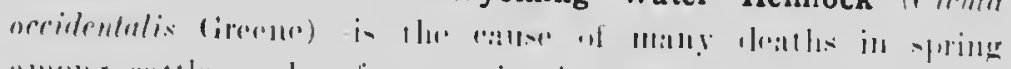

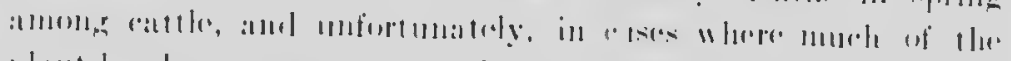

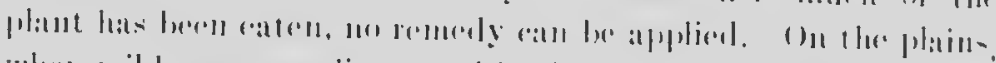

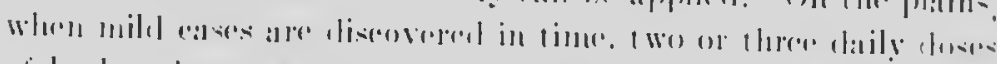

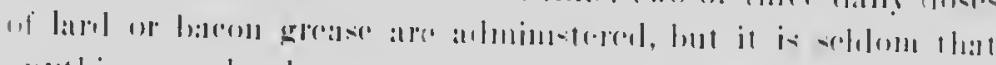

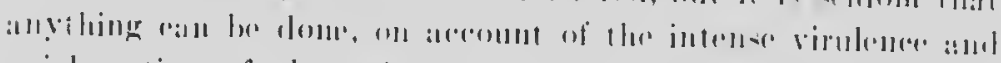

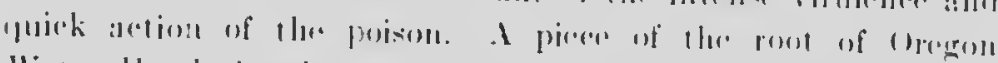

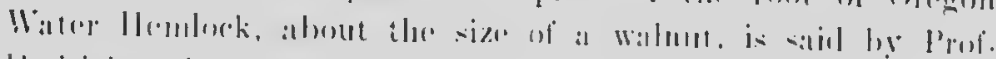

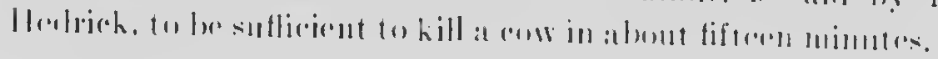

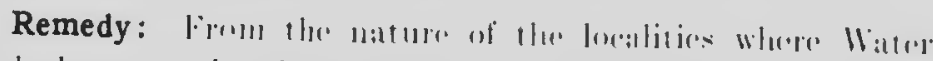

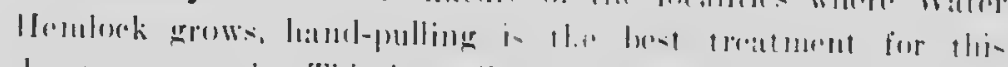

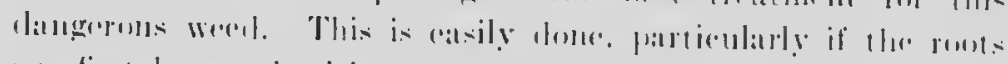

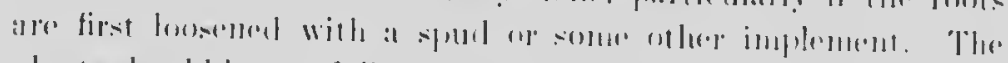

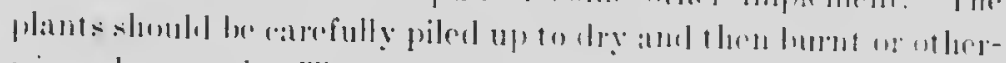

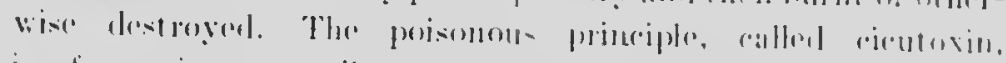

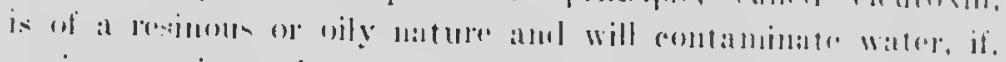

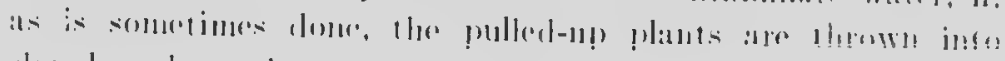

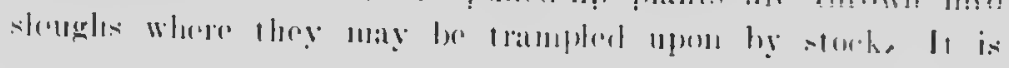




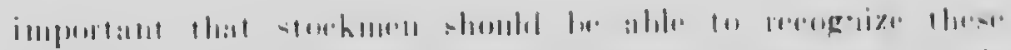

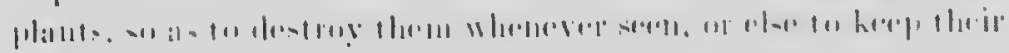

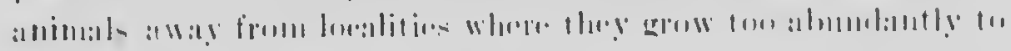
|x. pullenl unt hẹ haml.

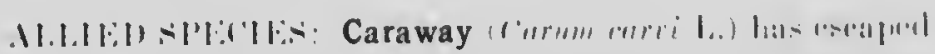

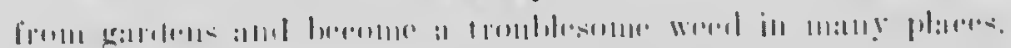

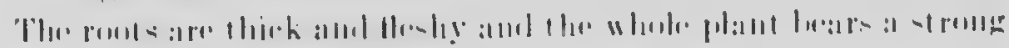

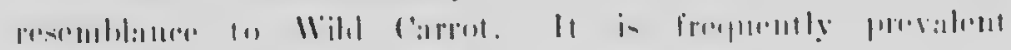

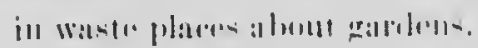

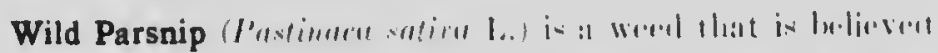

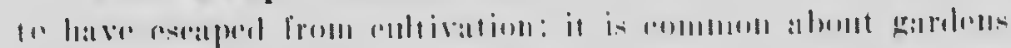

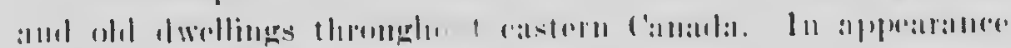

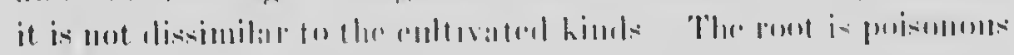

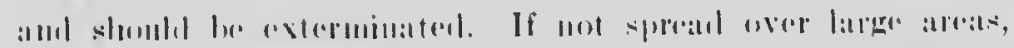

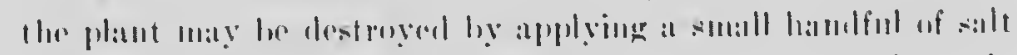

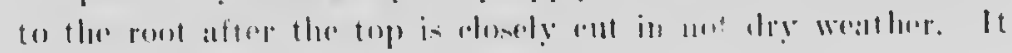

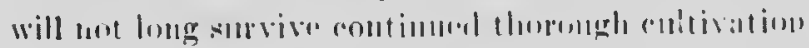

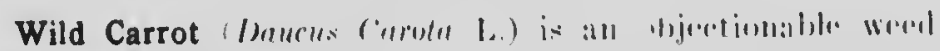

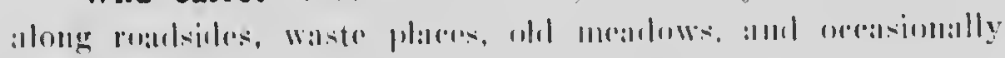

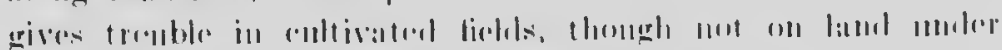

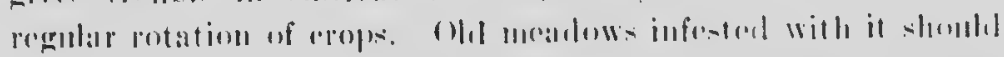

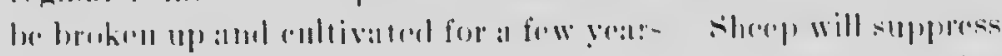

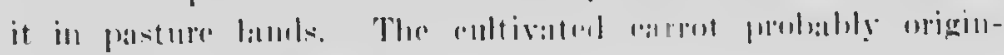
ated from this wihl plint.

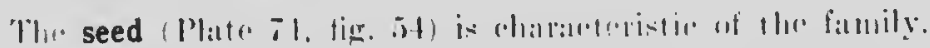

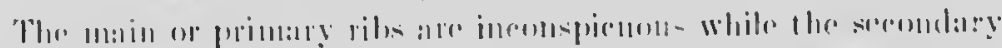

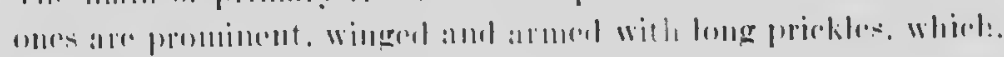

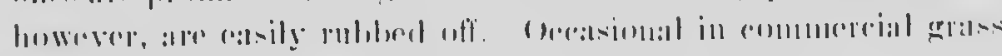

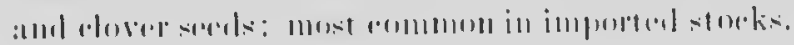

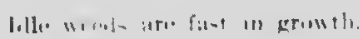

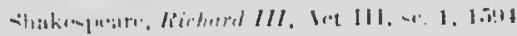




\section{THE MILKWEED FAMILY 1.1.er primlucen}

Milkweeds

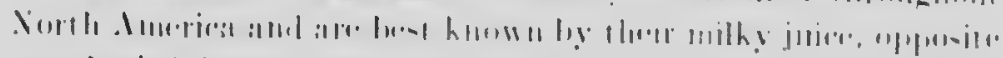

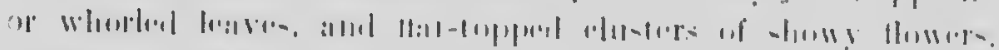

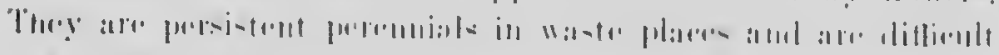

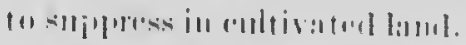

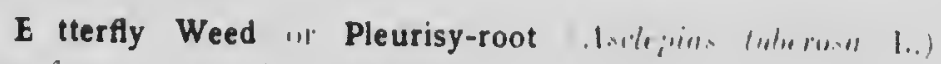

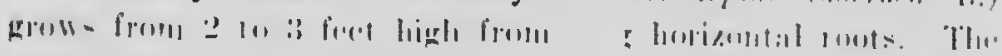

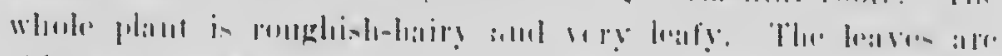

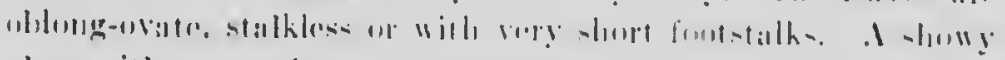

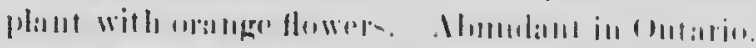

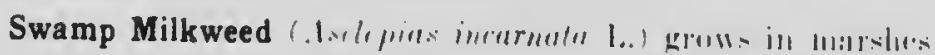

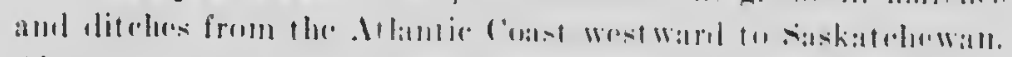

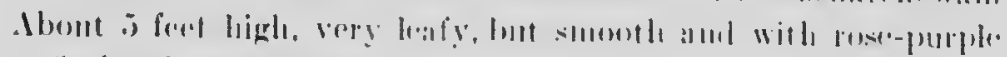
or flesti-rolourmel flowe?"

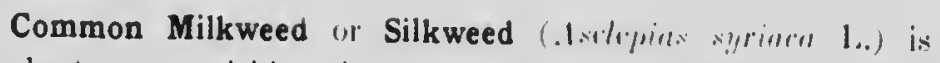

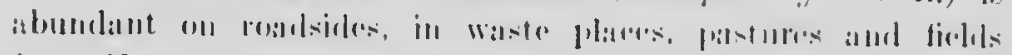

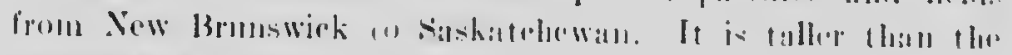

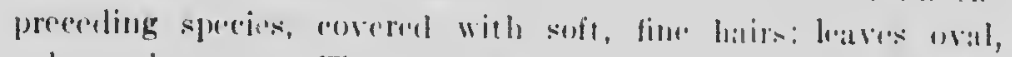

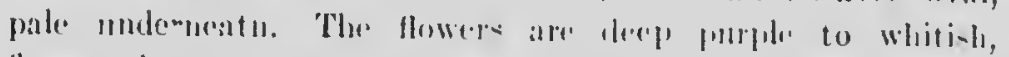

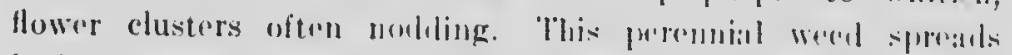

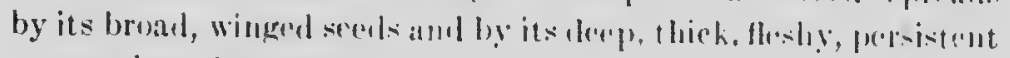

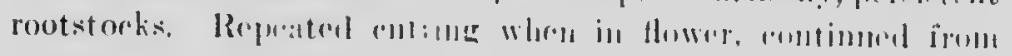

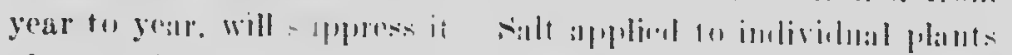

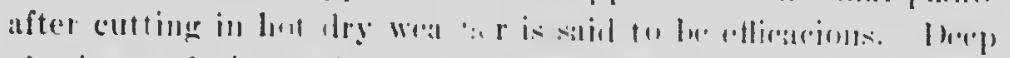

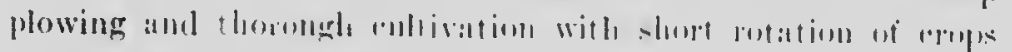

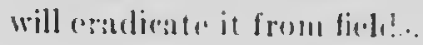

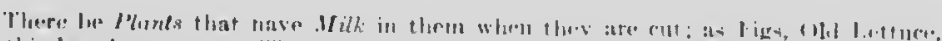

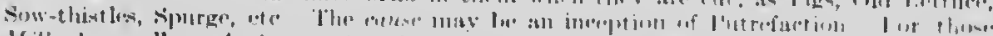

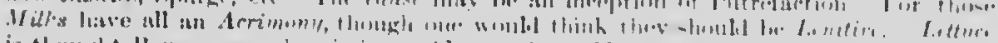

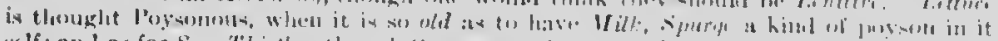

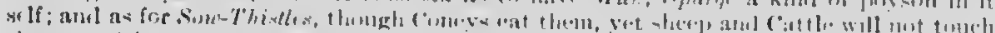

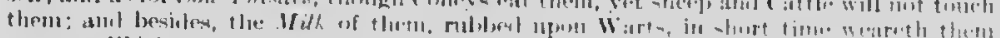

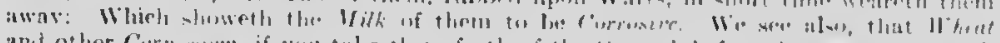

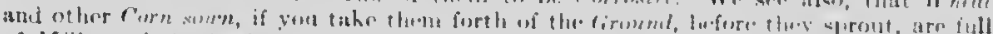

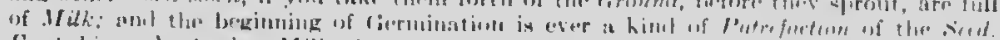

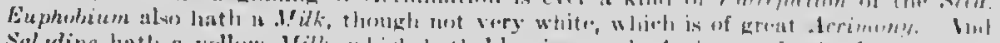

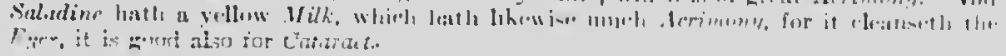




\section{THE MORNING GLORY CONVOLVULUS FAMILY ('mmolruluerar').}

Ther plants of this family posises chatrateloristies hy which

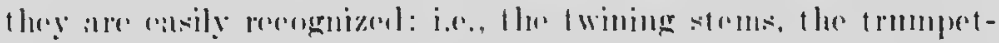
shaperl flowers, and the fruts which are spheriesl antilaginoms

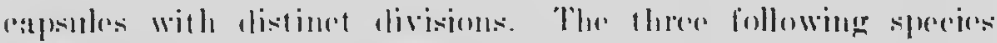

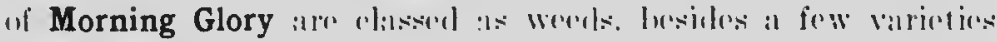
of Dodders Which are elosely alliod to them and mepesent

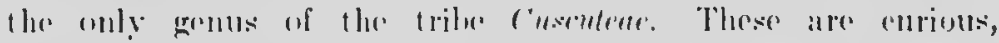

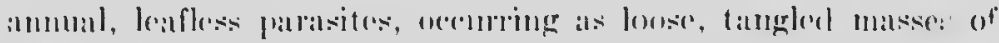

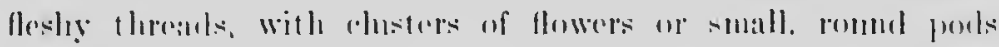

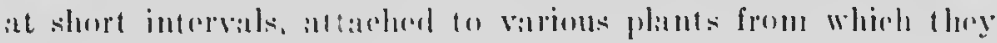
dr:il thrie nomrishmont.

\section{FIELD BINDWEED (c'mrolmulus urrmsis I.)}

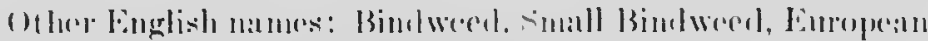

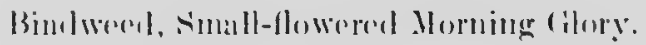

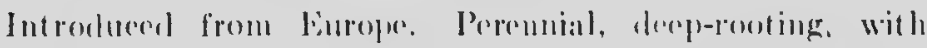

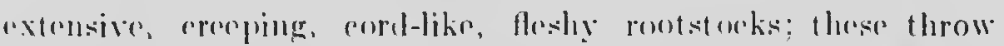

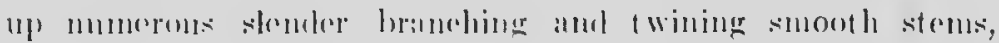
which form theck mats on the surfare of the land and twist

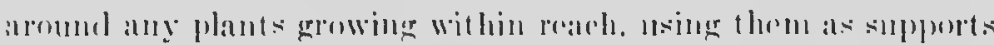

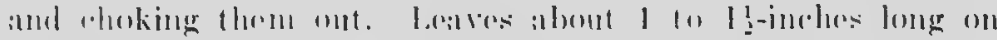

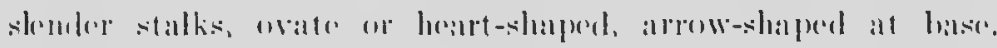

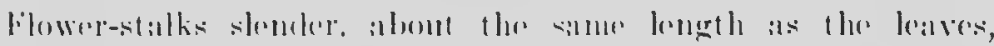

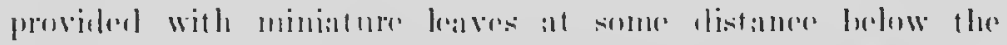
large, open, fummel-sh:phel, pink flowers, which : ore over an inch

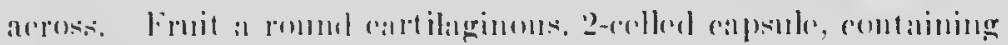
3101 somis.

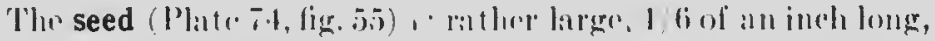

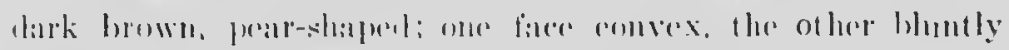

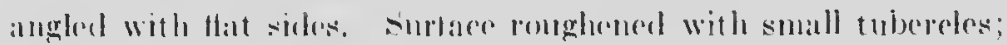



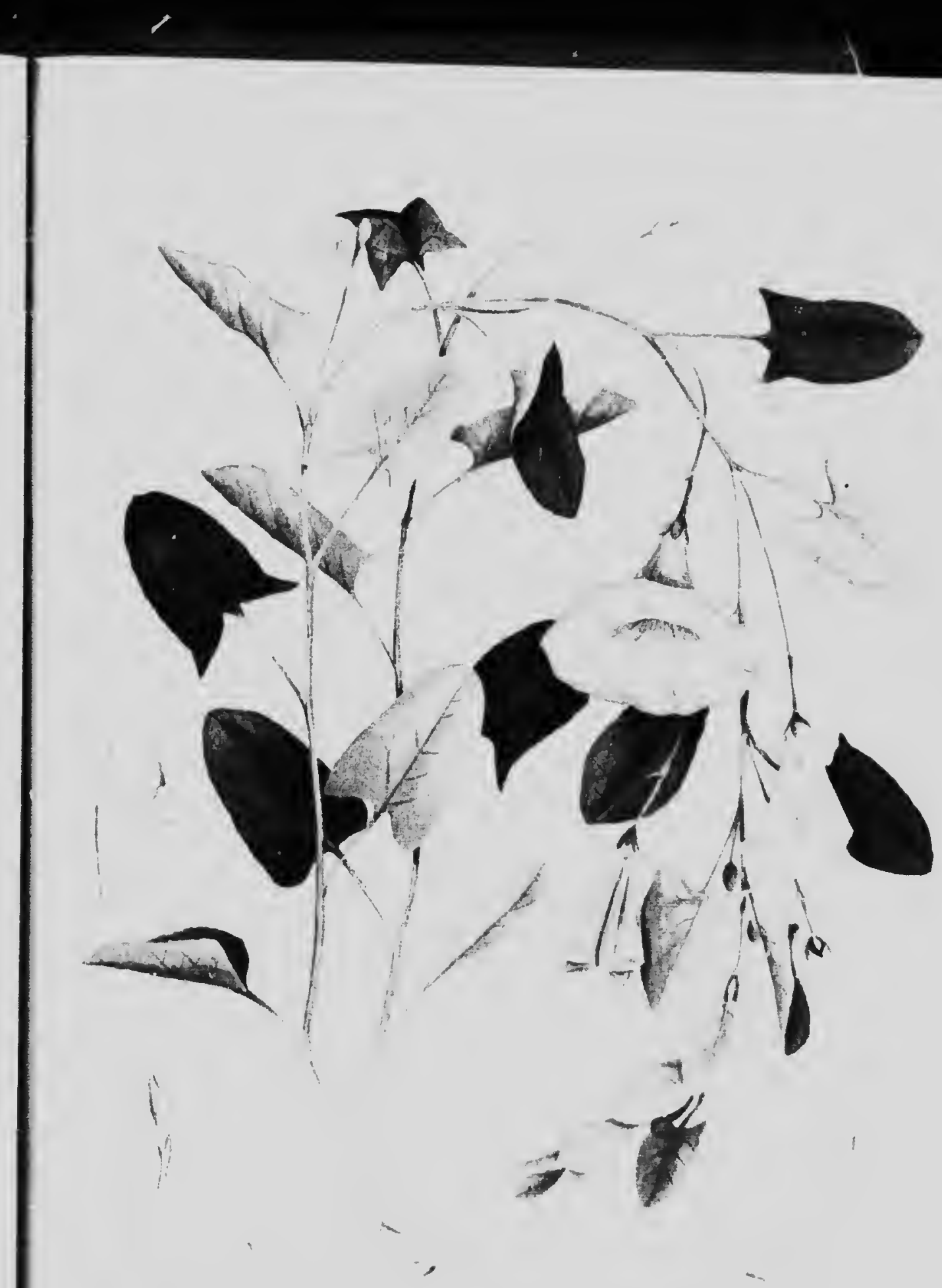


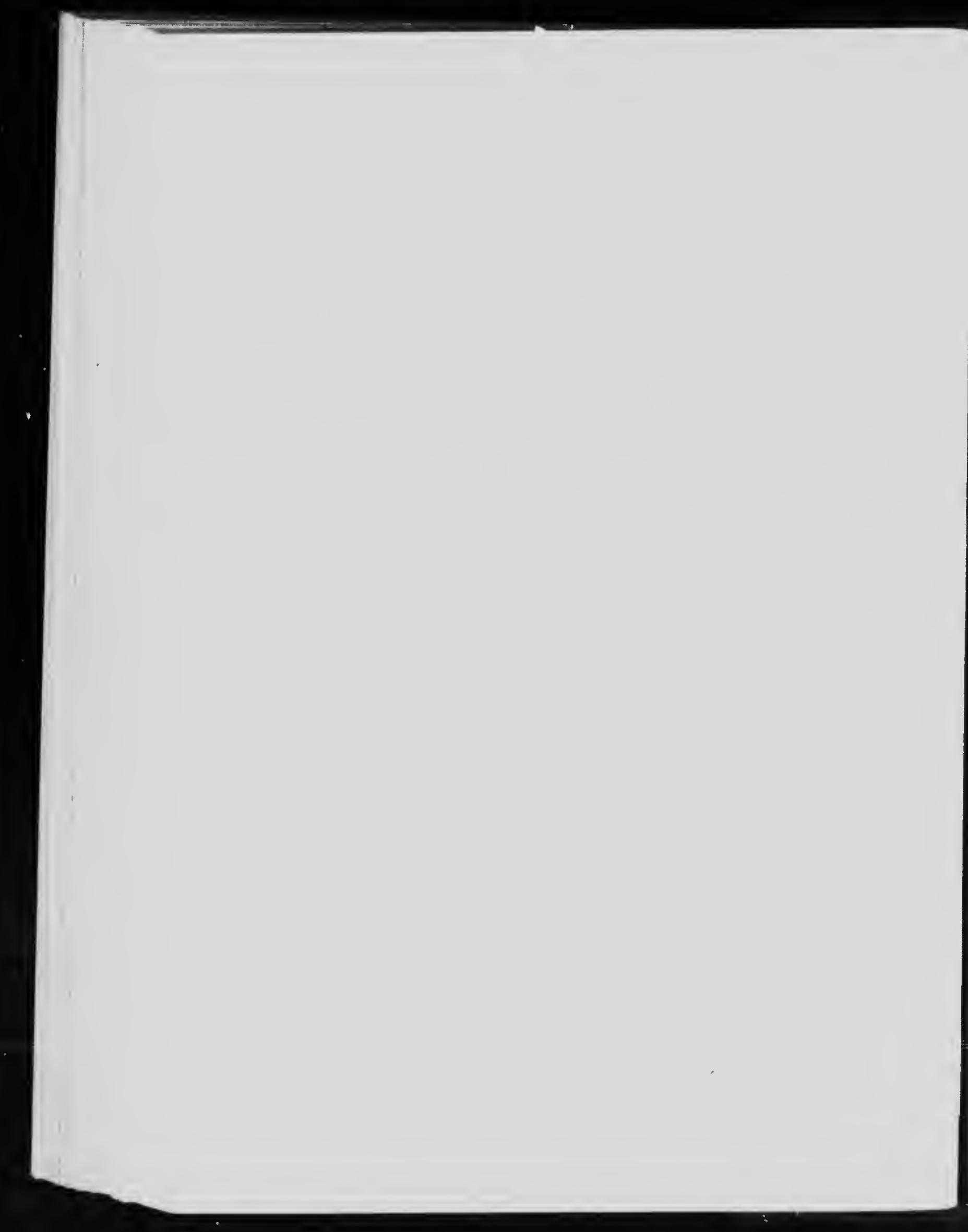




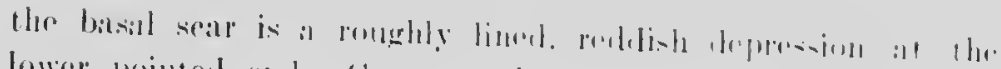

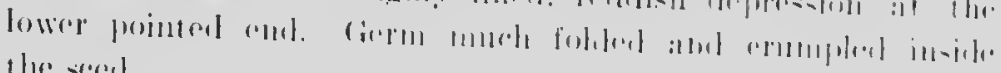
the serest.

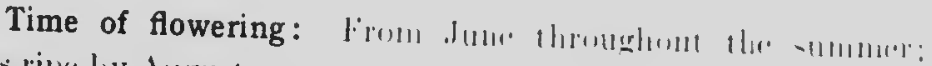
serels rijes hy Alleruit.

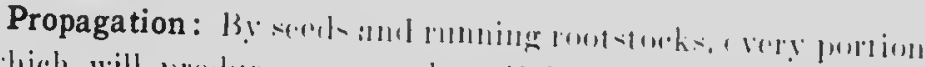

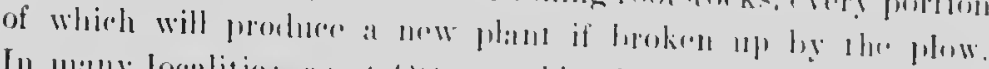

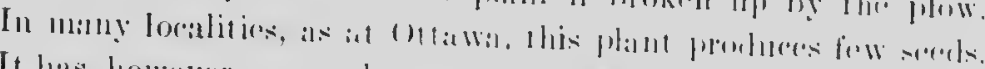
It has, howevere, overgwhere a toret persistellt habit of growth.

Occurrence: Althomerh wirlesplestl thromehomt the Inominion

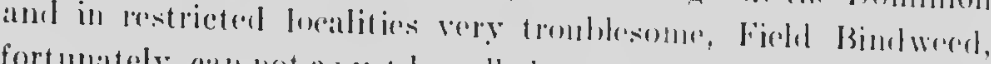

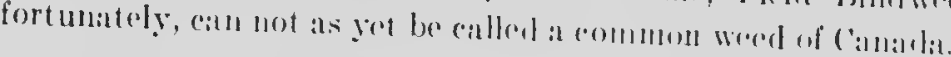

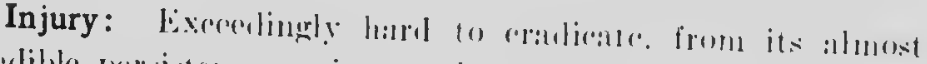

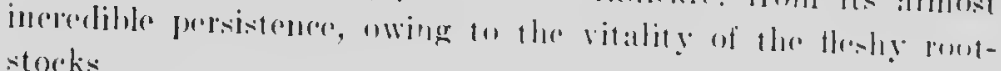
stoctis.

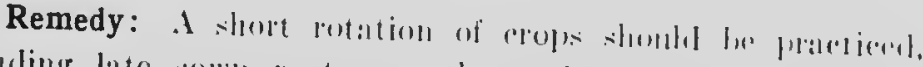

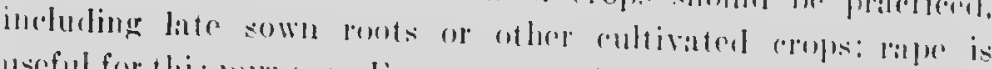

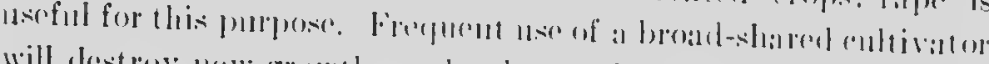

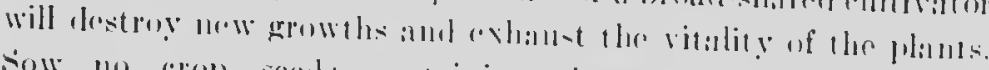

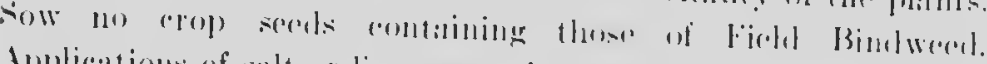

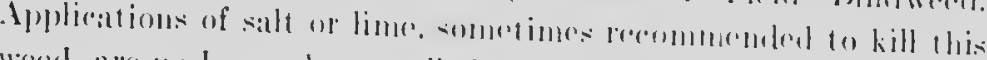

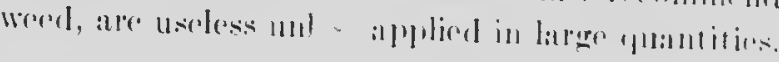

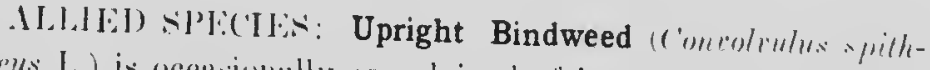

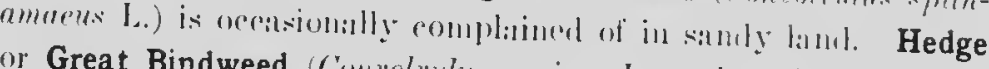

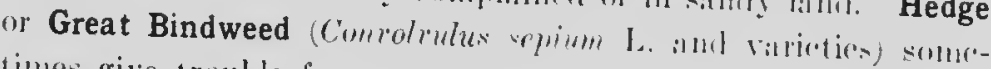

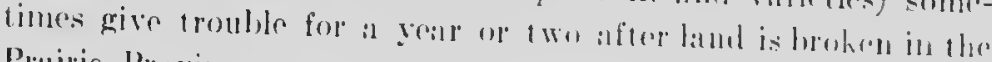
Prairir P'rovincres.

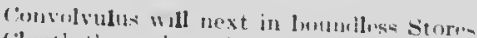

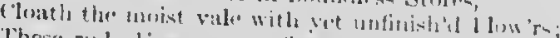

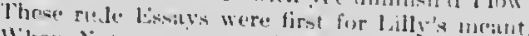

When Xiture on a tobluler work intetit.

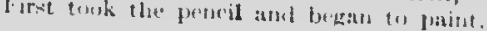




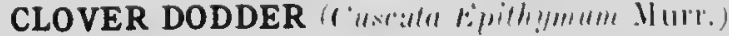

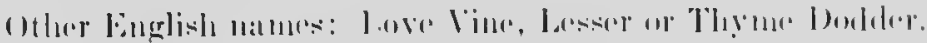

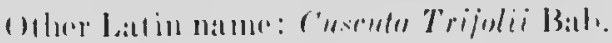

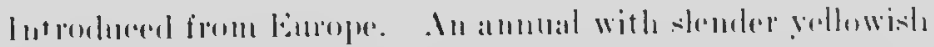

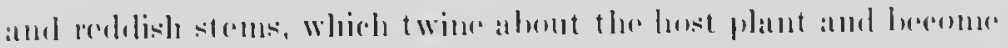

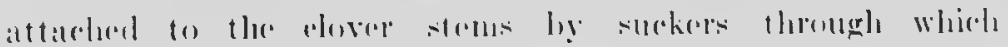

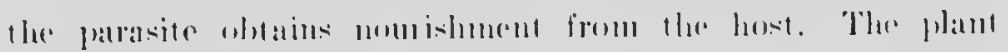

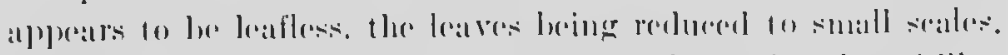
lowors whitish or pinkish, in elustress alome the threal-like, twinimus stems.

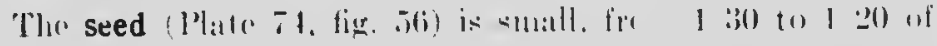

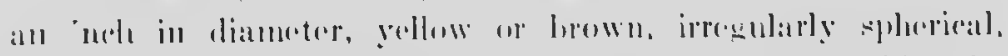

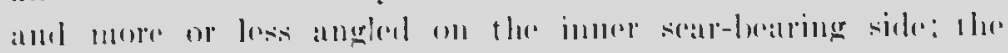

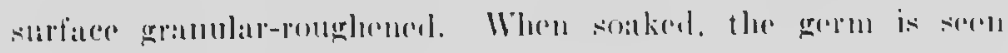
10 be spirally roilod, wormlike.

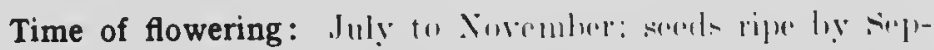
tomber, when ihey fall to the grouml amel greminste the following -] ) rillus.

Propagation: $13 y-1 \times 1.0$.

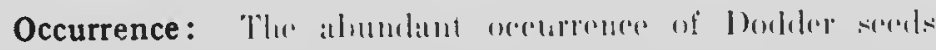

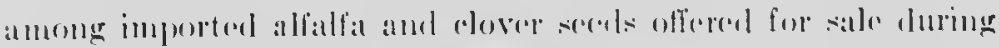

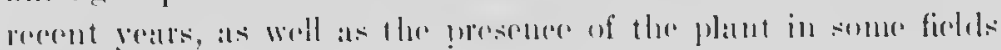

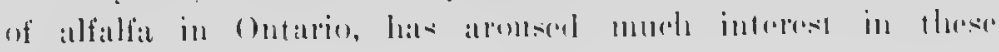
patrasitic plantis.

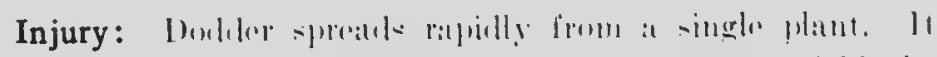

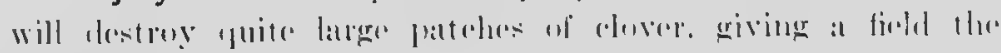

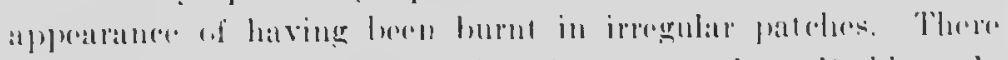

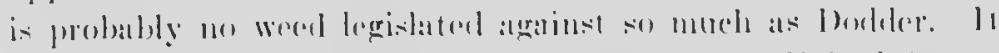

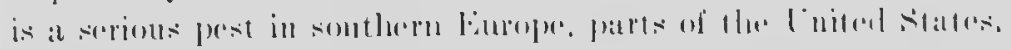

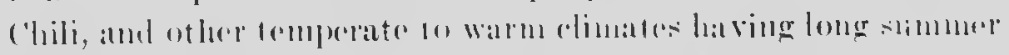

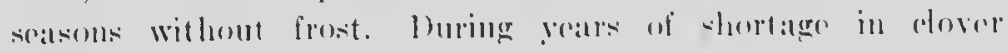

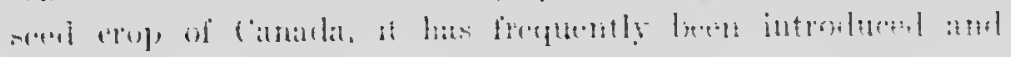




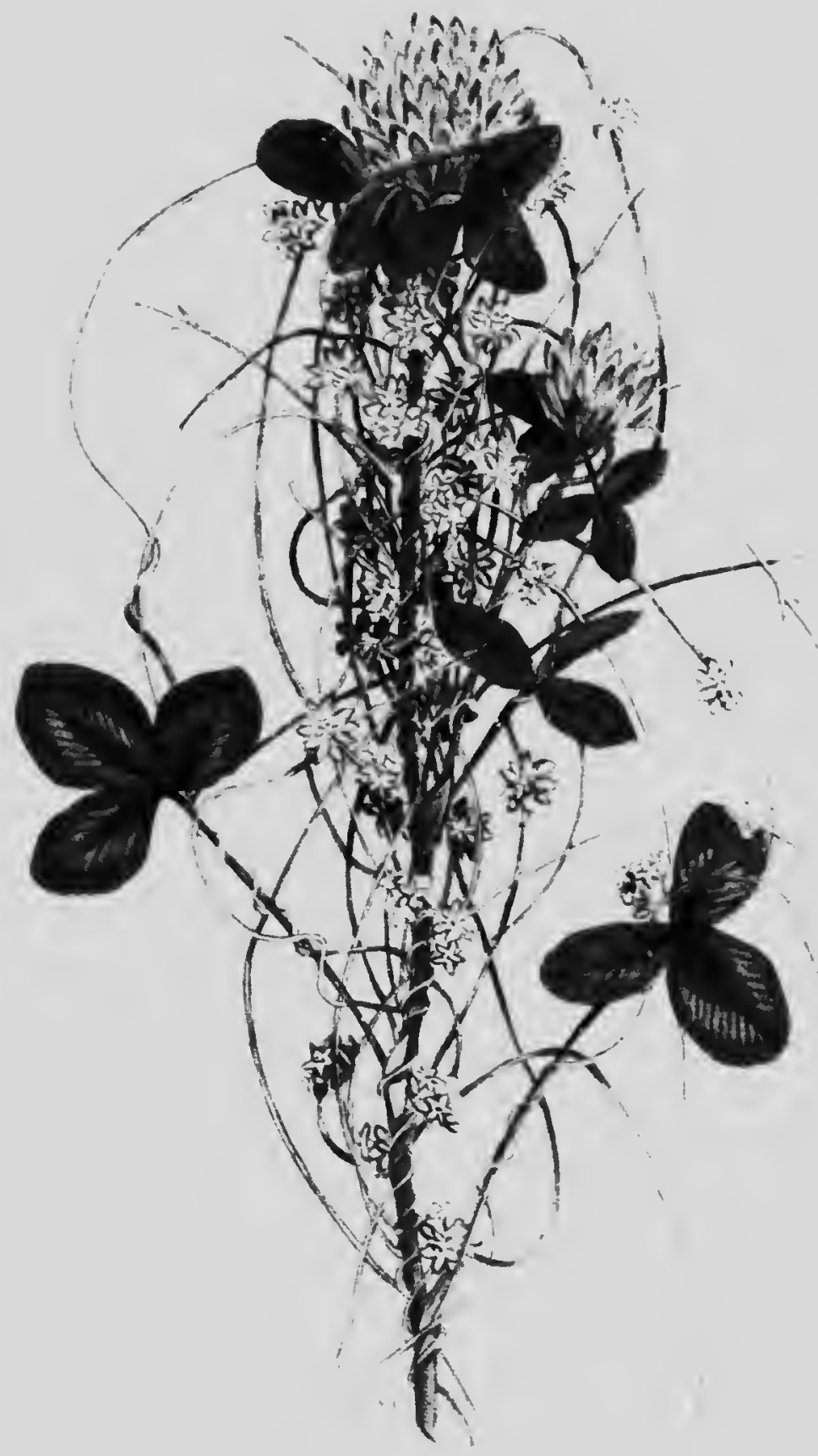


- . . . .

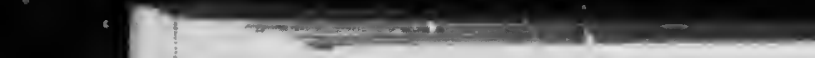




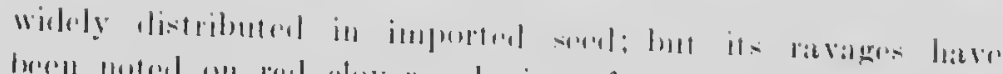

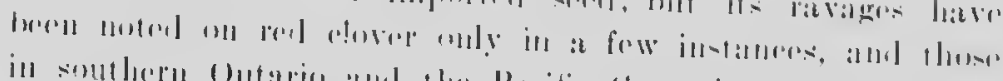

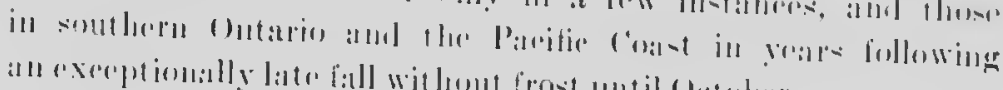

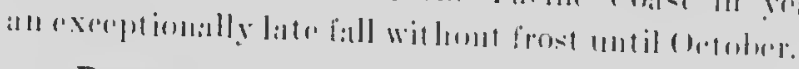

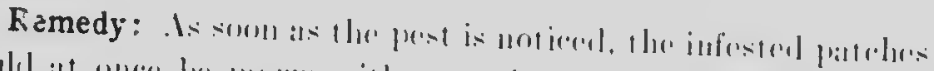

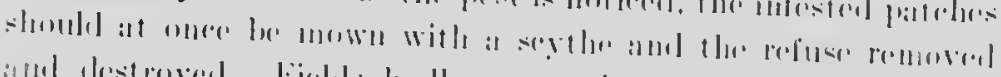

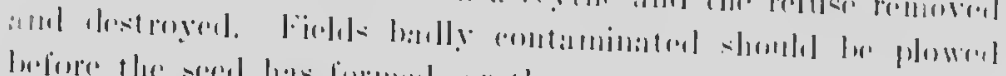

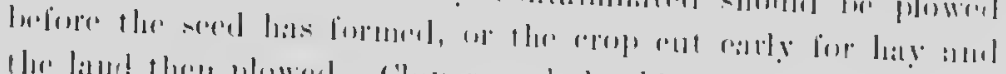

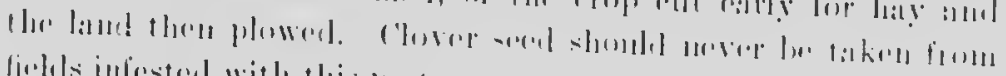
forhls infostond with this ferst.

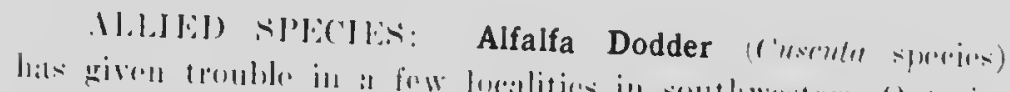

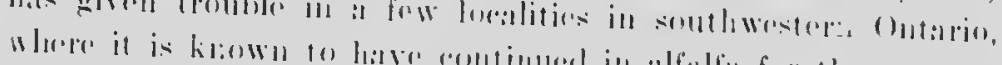

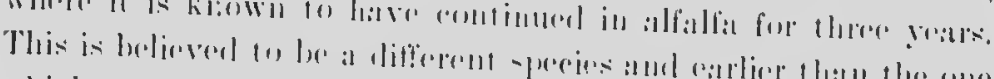

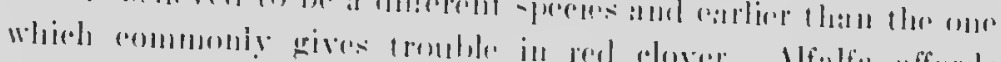

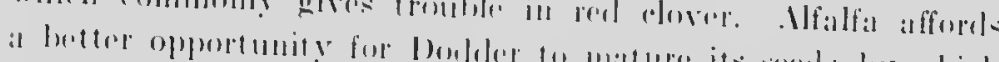

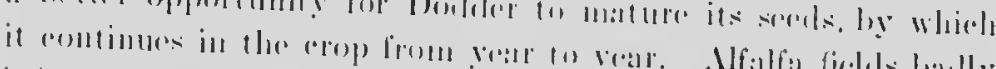

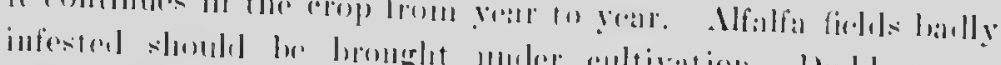

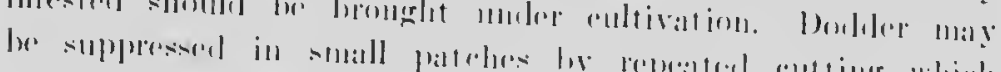
provernts it from somlingr.

\section{THE BORAGE FAMILY (Burminurent).}

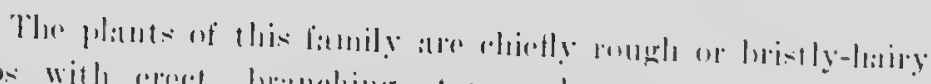

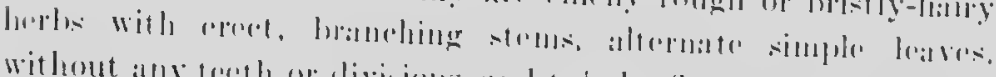

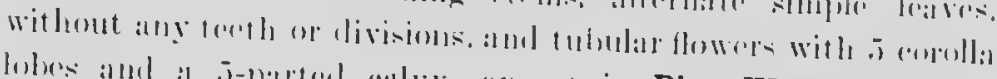

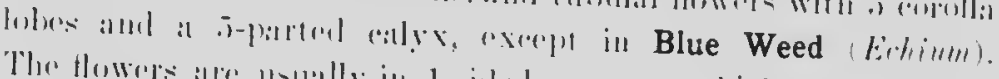
The flowres:

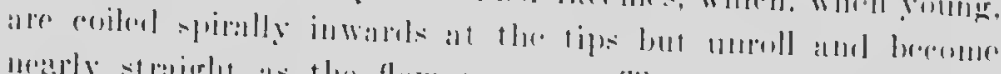

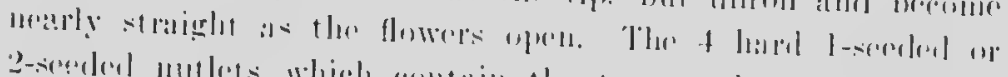

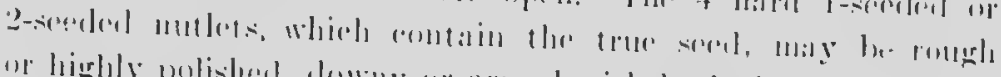

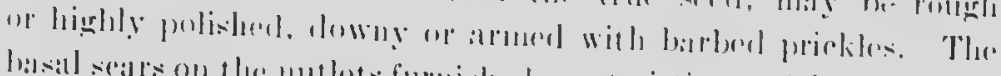

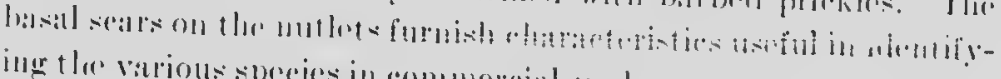

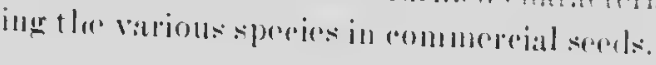




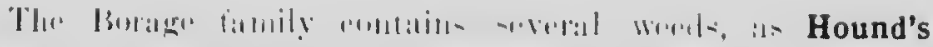

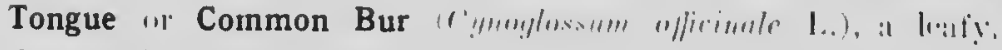

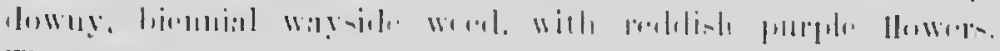

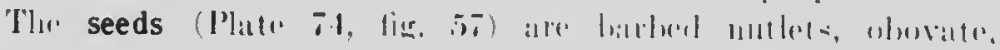

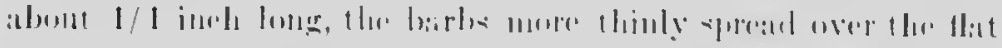

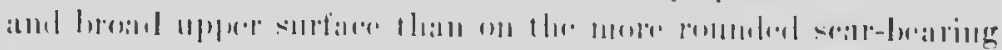

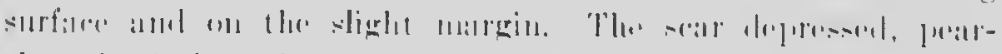

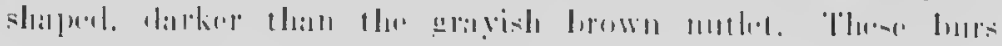

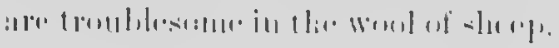

\section{BLUE BUR (I.n)mln" whinal" (iililwrt)}

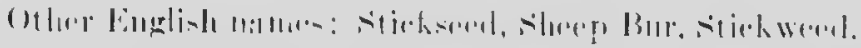

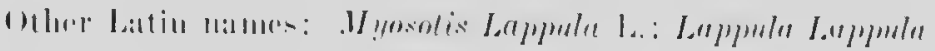

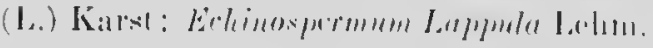

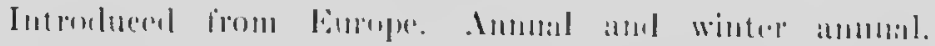

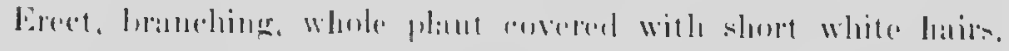

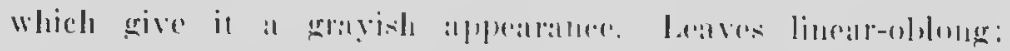

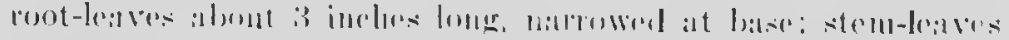

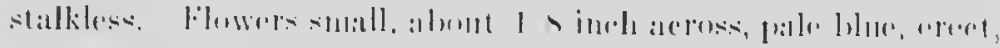

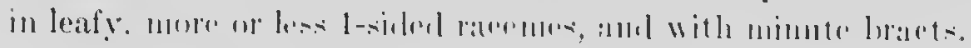

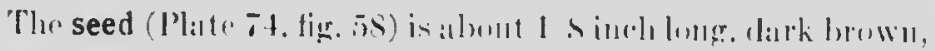

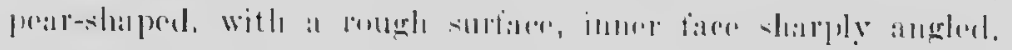

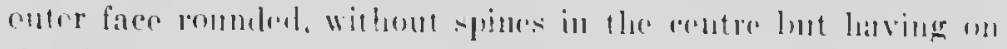
the sirles a double areries of long stiff spinese rach of whiel has at its apes a stale of 3 or 4 slatre borlss. This nutlet is

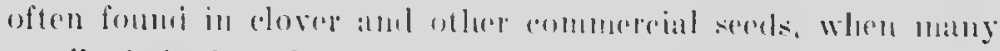

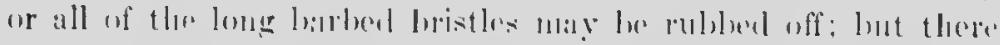

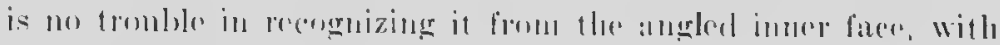

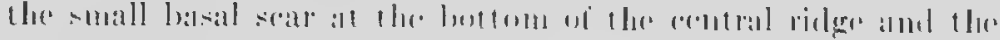

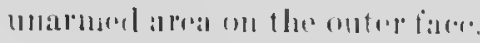

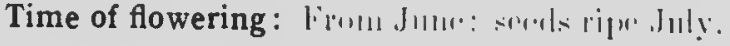

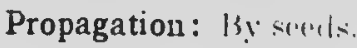




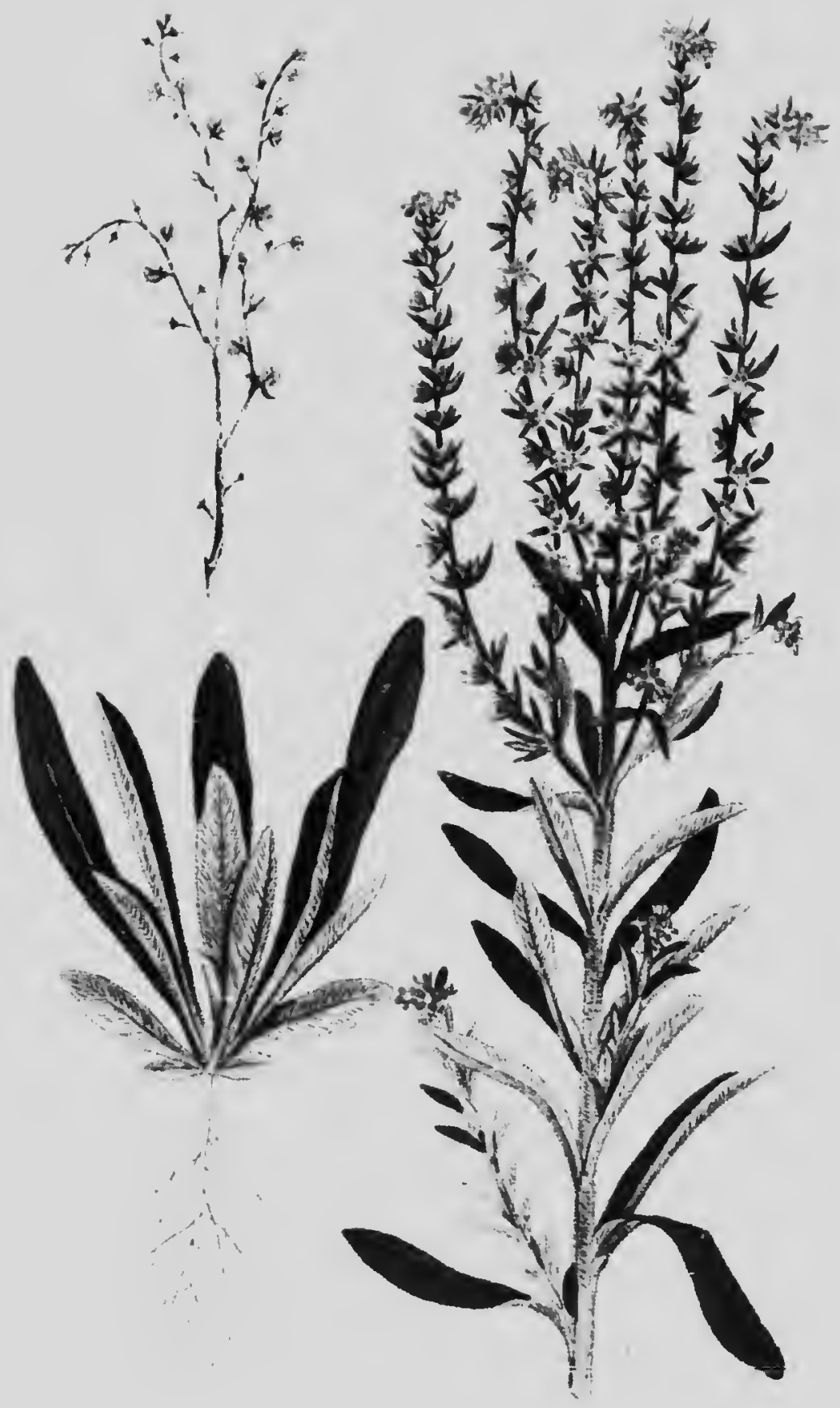

BLUE BUR OR STICKSEED 


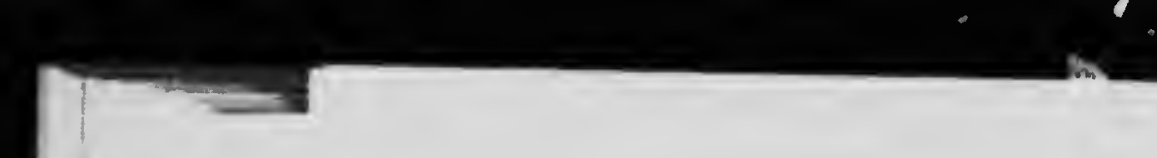

$\rightarrow$

' 


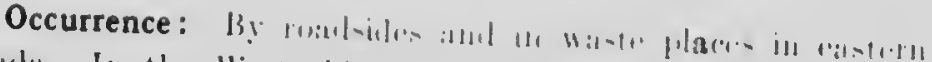

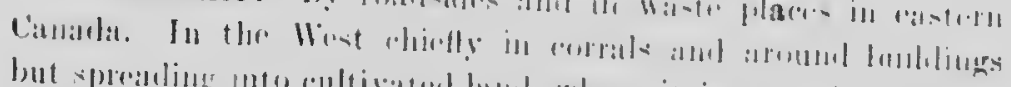

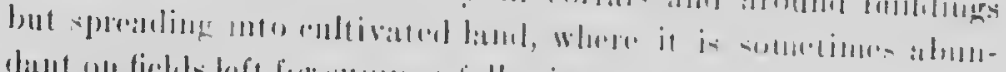

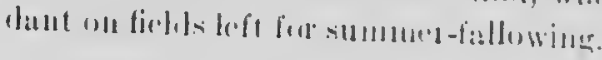

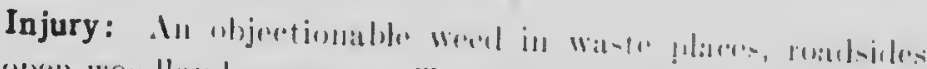

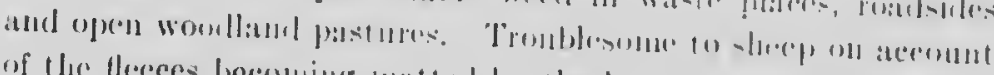

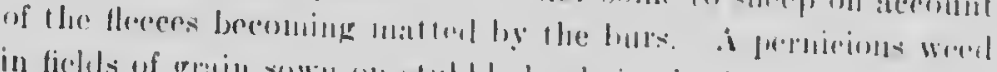

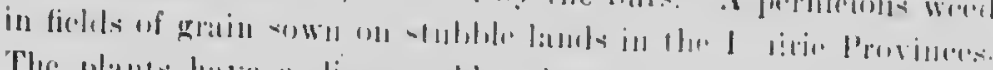

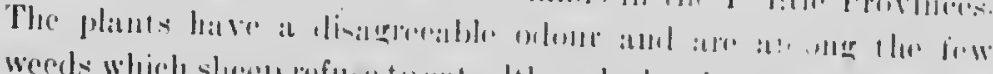

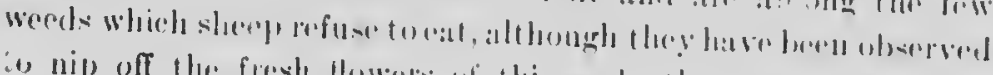
at nip off the forsh flowers of this atul where menteres of the statlu. fanily.

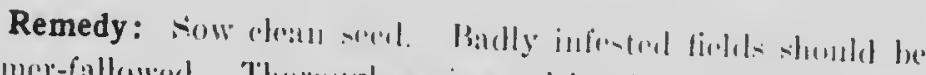

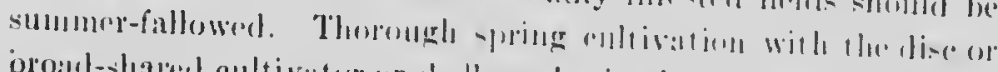

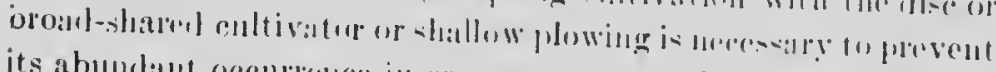

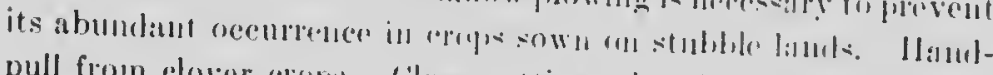

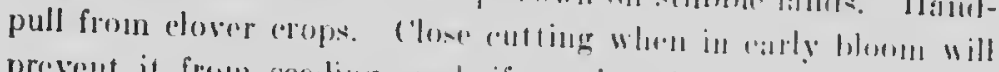

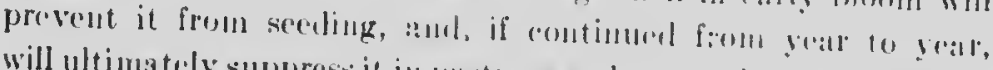

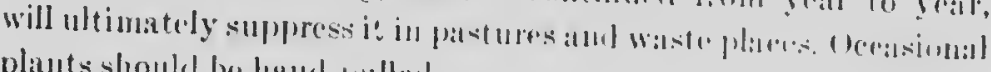
plauts should bre haudl-pulloul.

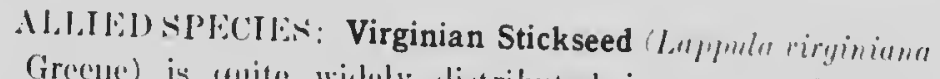

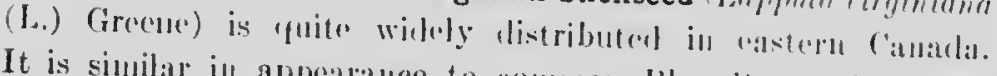

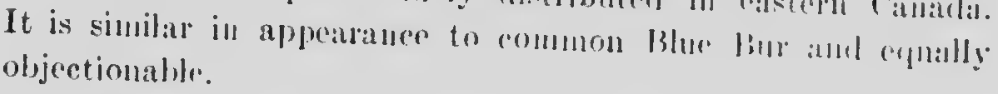

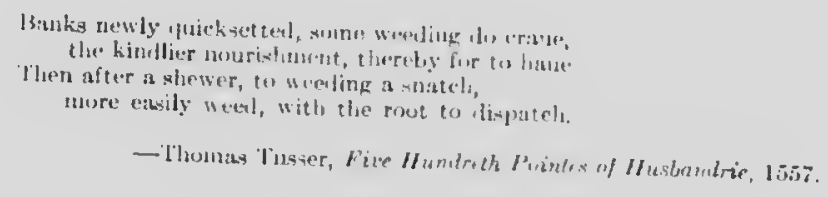

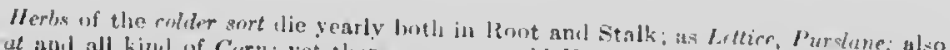

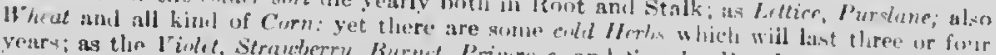

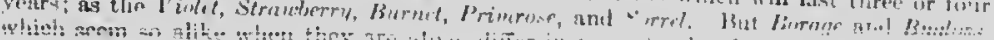
oge year, Bugloss will last, wore. 
BLUE WEED (lirlinm ml!nre l.) l).vil.

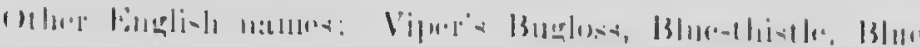

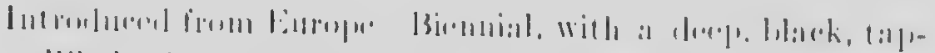

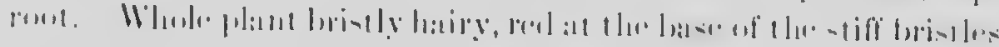

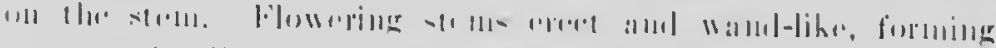

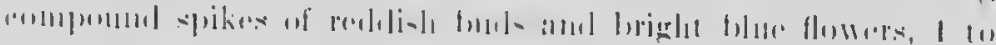

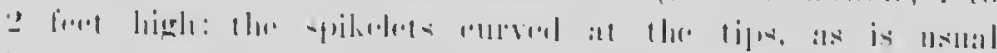

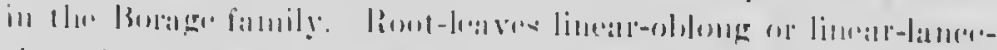

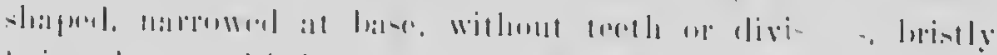

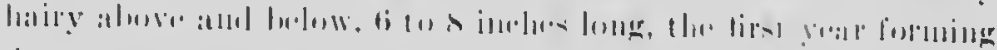

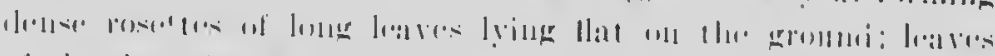

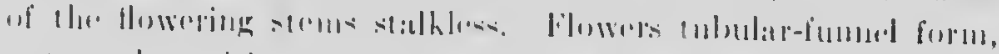

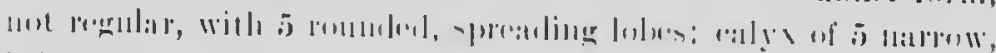
luristly divisions.

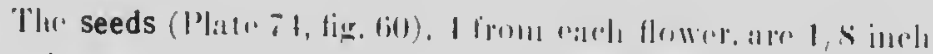

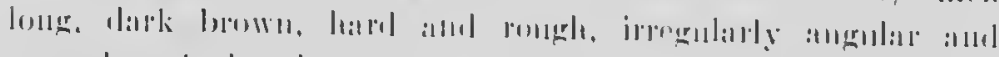

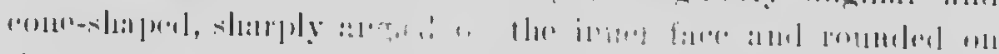

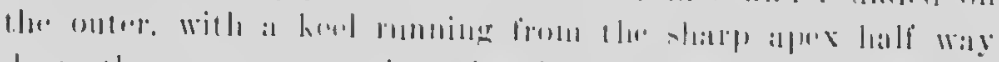

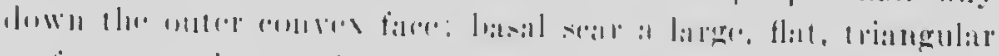

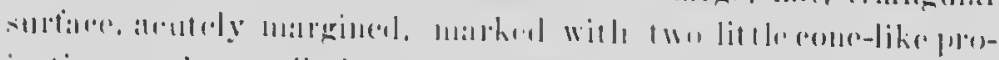

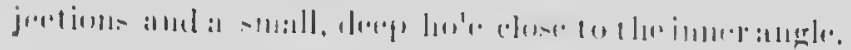

Time of flowering: duly $\{11$.

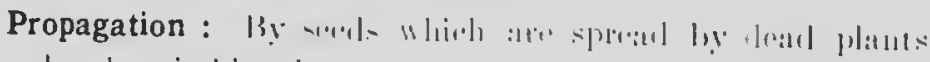

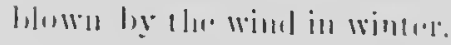

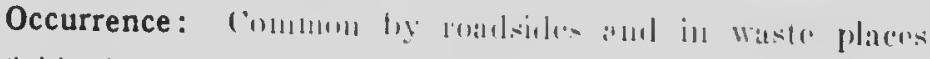

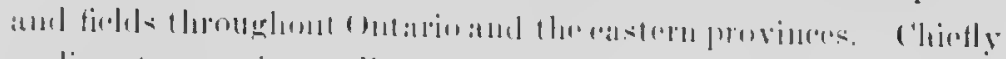

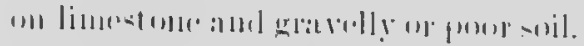

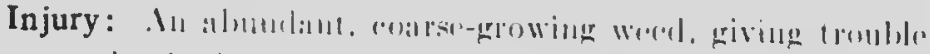

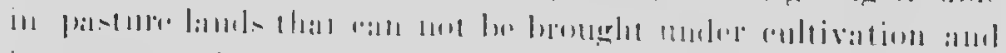

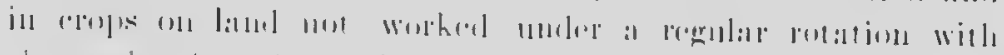

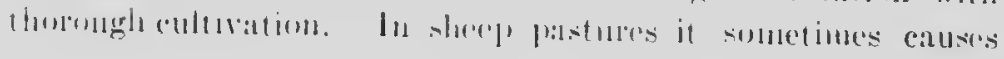




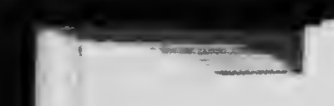




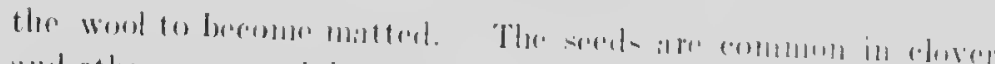
and other commererial soret.

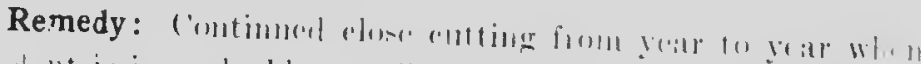

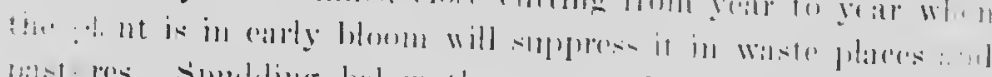

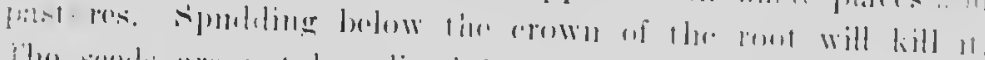

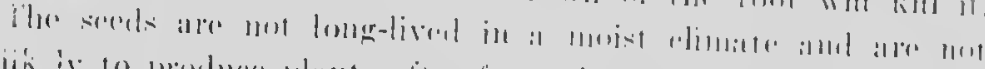
licis

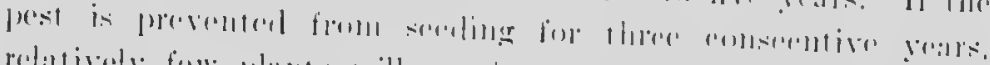

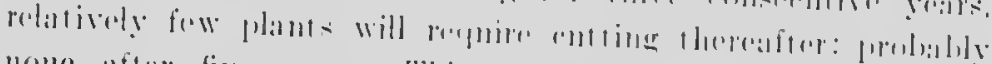

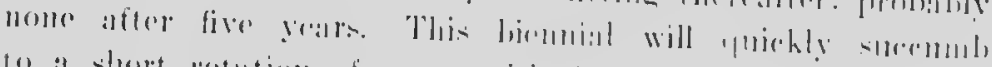

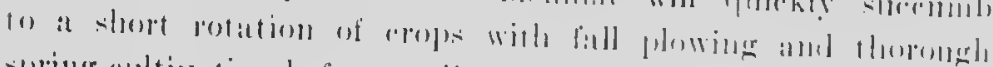
spring antication leceroresendine.

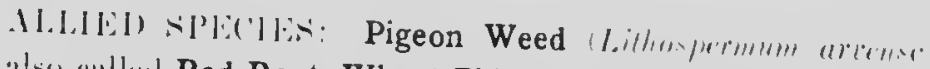
1..), ilso callud Red Root, Wheat Thief aml Field of Corn Grom-

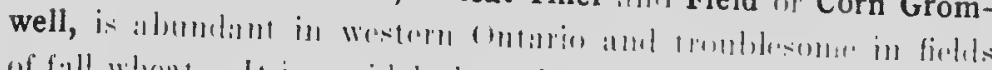

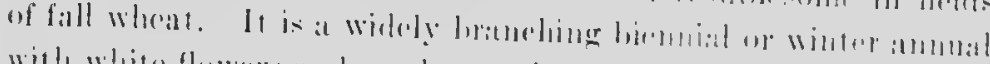

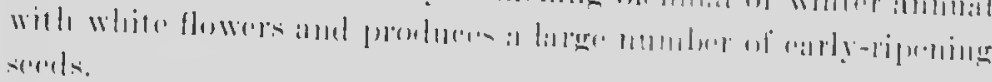

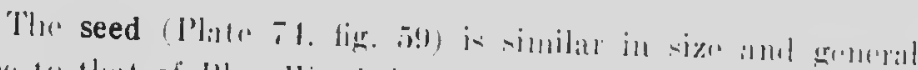

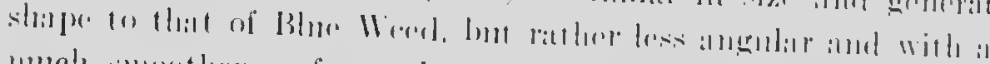

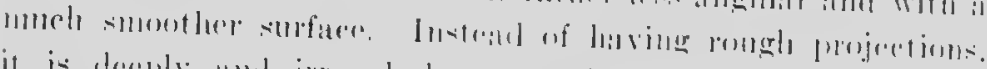

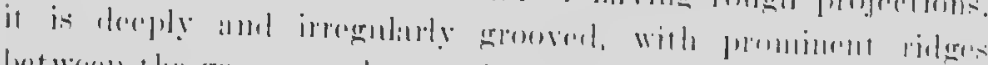

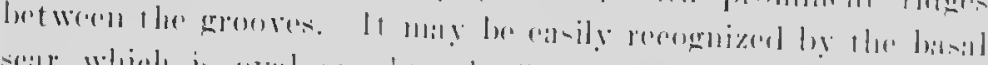

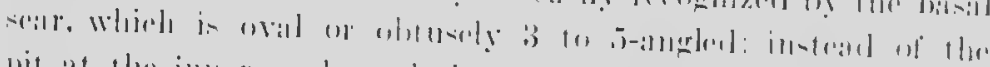

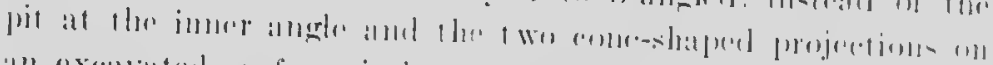

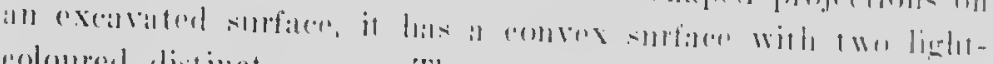

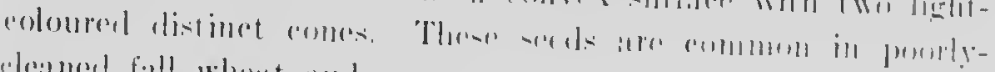
driturel fall wheit atml rye.

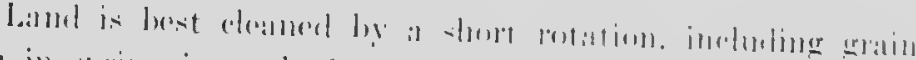

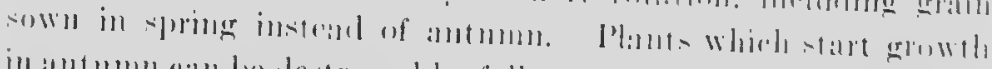

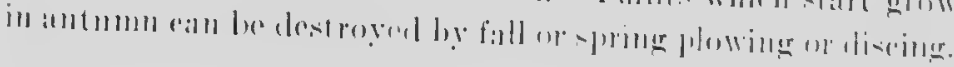

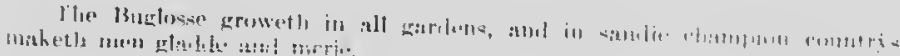




\section{THE VERVAIN FAMILY (Verbenacene).}

A family of mostly tropical plants, closely allind to the mints, represented in camalda $\because$ only in few woreds and many variecies of ornanental plants.

White Vervain (Verbena urticrefolia J.), frobibly introduerd but indigenous in eastern (amada and common alonge roadsides, waste places and pasture lands, from Sew Brunswick to Ontario. It grows from 3 to 5 feet higle, has white flowers in slemeler, branching clusters, and stalked, oral. areute loaves, coarscly dentinte with shatrp, forwarl-penting terelt.

Narrow-leaved Vervain (Frituna angustifolia Miclix.) is

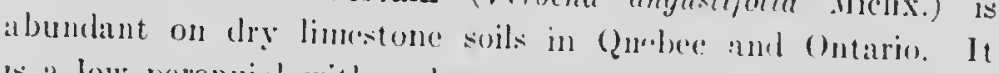
Is a low perennial with a deep rout : roughish, namowly lanerstraped leaves tapering at the base, stalliless: flewers in destse spikes, purple, and linger than those of Blur Vervin.

Blue Vervain (Verhena hastata l.) is the commonest weed of this family. Il is a tall plant, from 4 to 6 foet in rich, monist soil; stem t-angled and branched. Leaves stalked, lanee-shlaped. taper-pointed, with sharp, forwarl-pointing teeth. flowers violet blur, small, borne in a cluster of spikes at the summit.

The seed (Mate ois, fig. fil) is brown exept the large, whitish busal scar at the hottom of the immer face. The outor face is convex, irregularly ridged lengthwise and shaply angled ant the sides. The imere face solese to the matrin from a shapplyangled eentral ridge. This sond is ofton fomme in timotly and other gratsisingers.

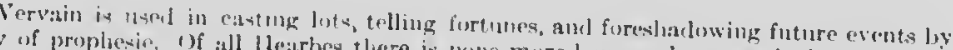

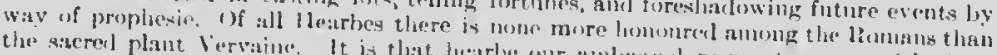

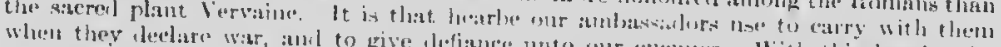

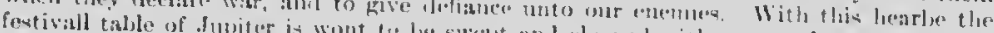

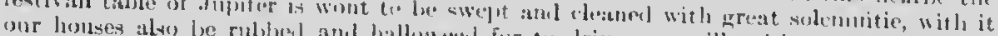

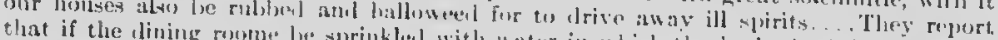
the guesta will be norriar. 


\section{THE MINT FAMILY (Lutriutu).}

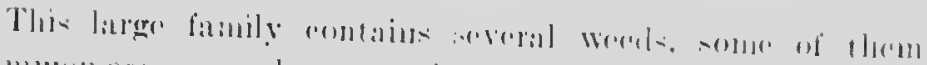

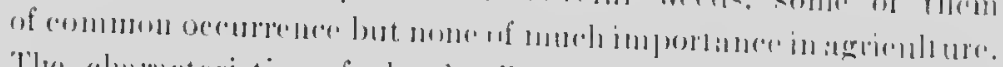

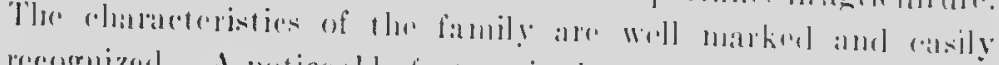

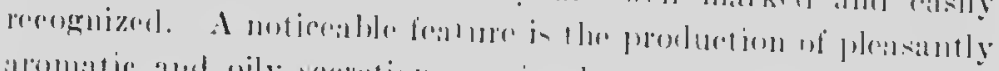

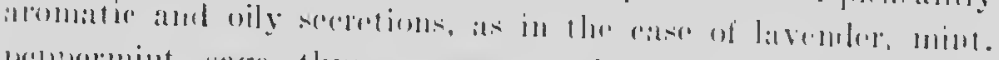

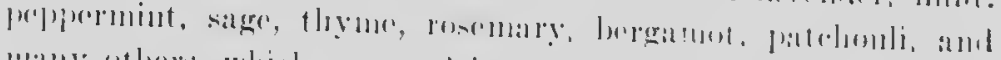

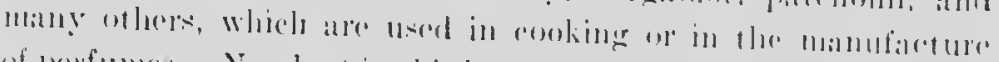

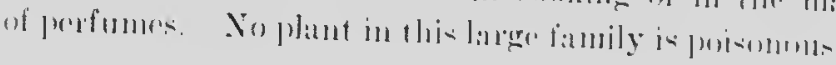

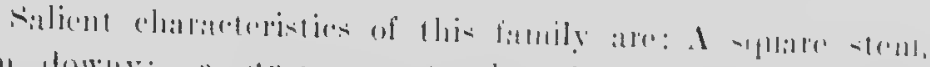

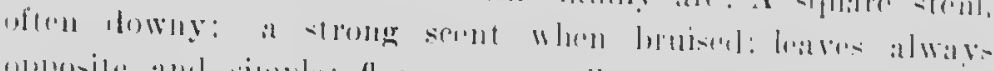

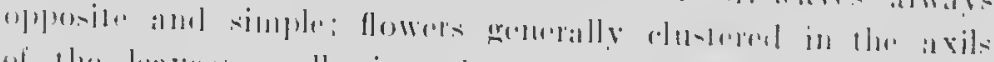

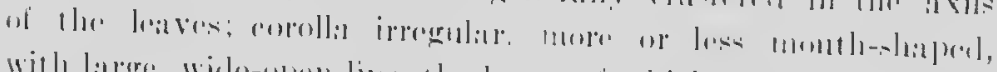

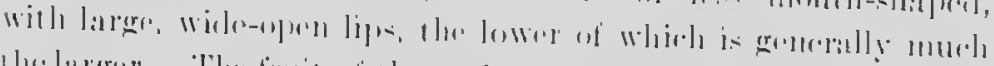

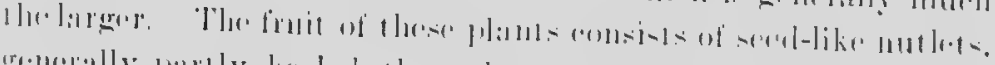

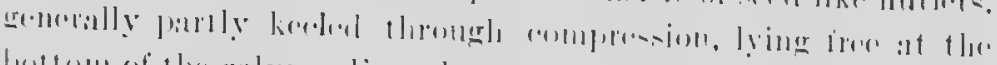

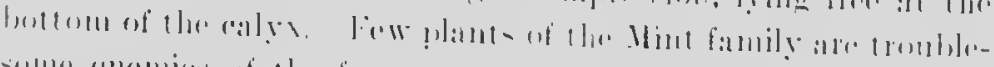
-

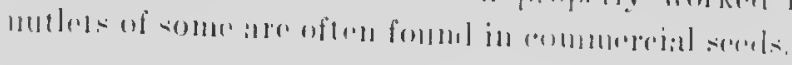

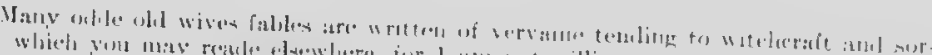

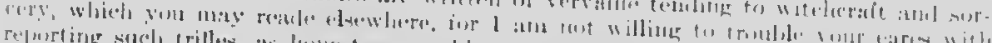

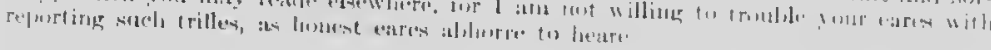

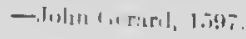

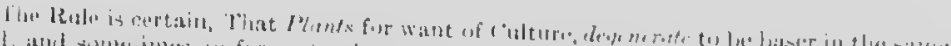

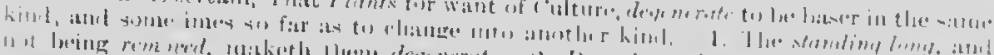

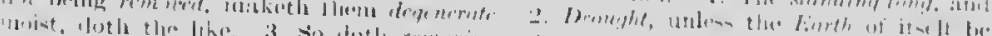

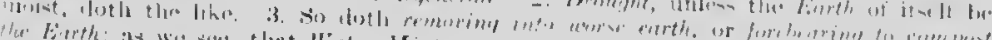

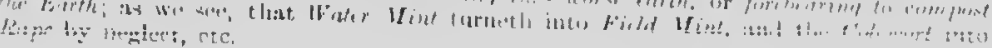




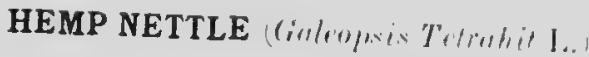

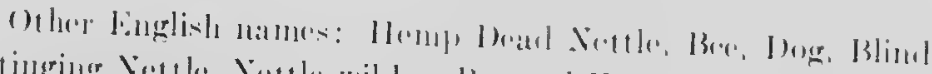

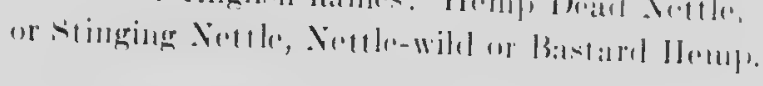

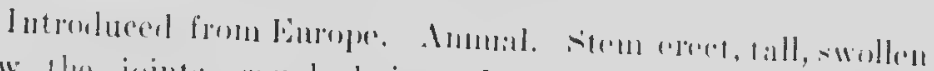

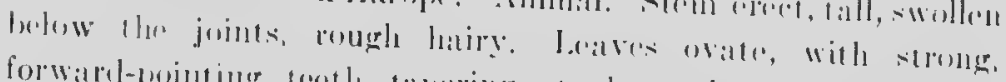

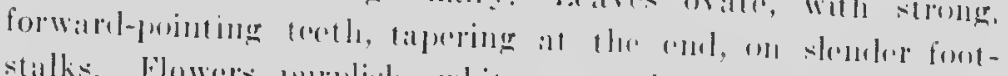

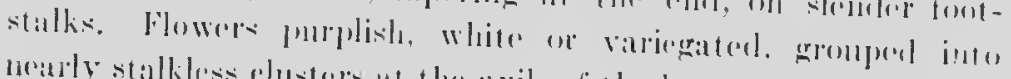

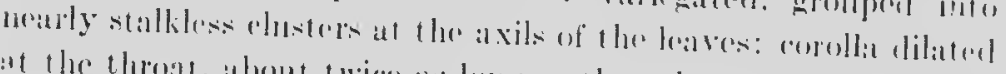
at the throste, about twier as longe as the ablyx: the geoth of the

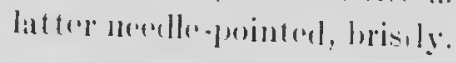

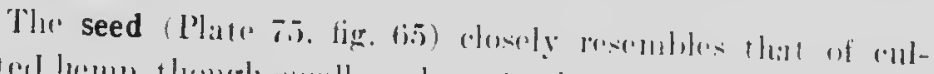

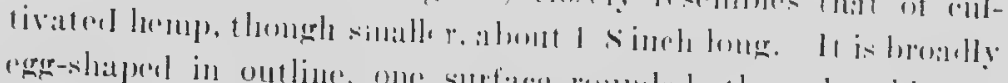

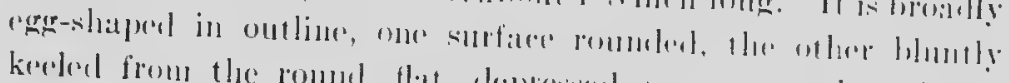

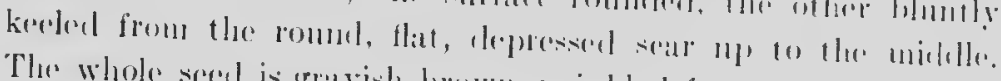

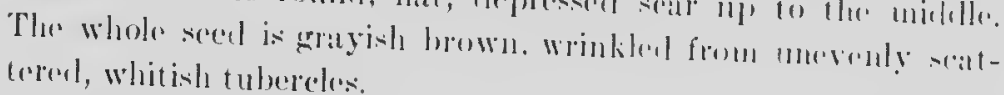

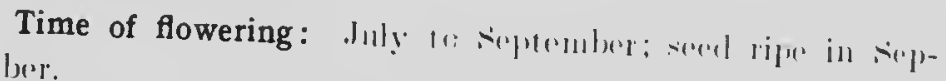
trinbrer.

Propagation: 13ỵ. sirecls.

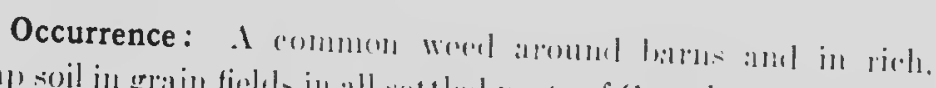

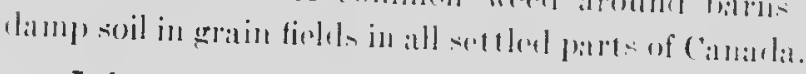

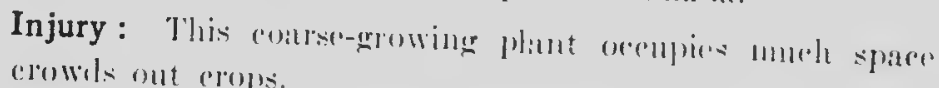

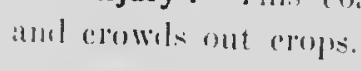

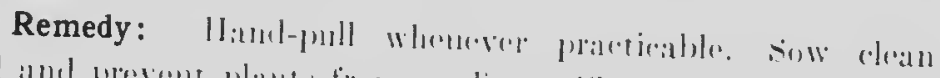

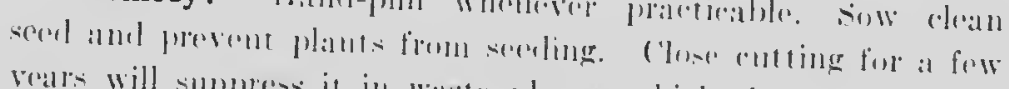

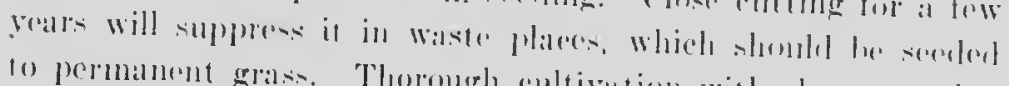

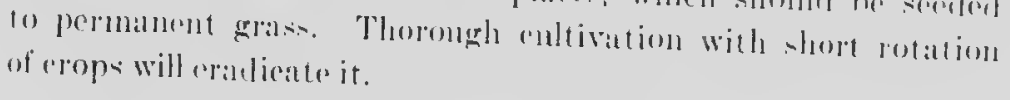

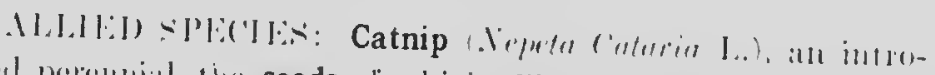

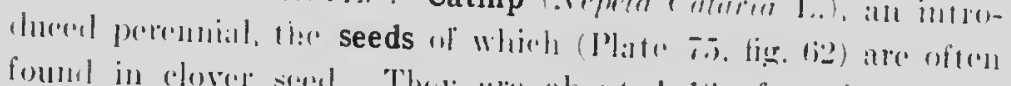

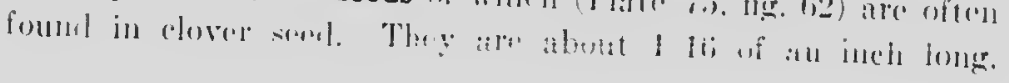




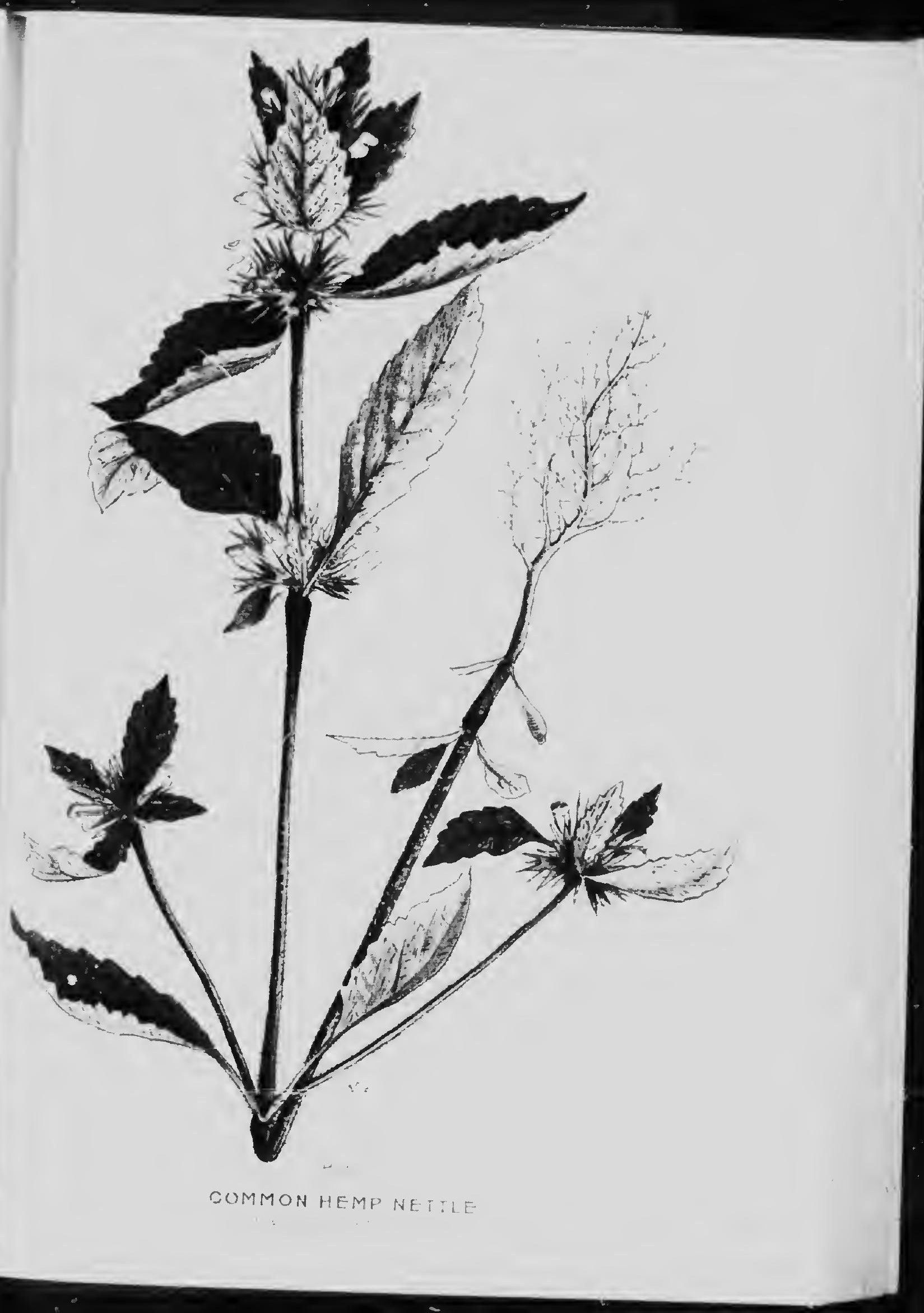




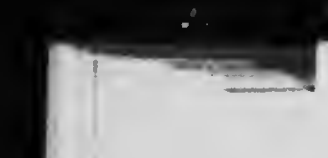

a

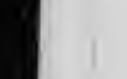




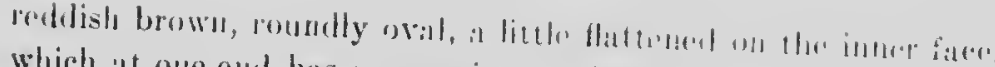

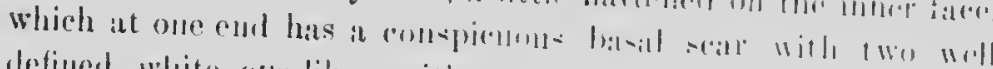

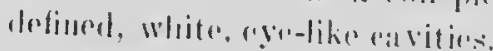

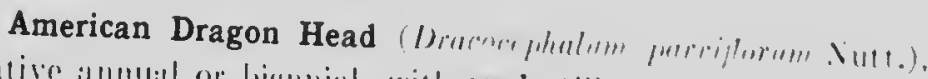

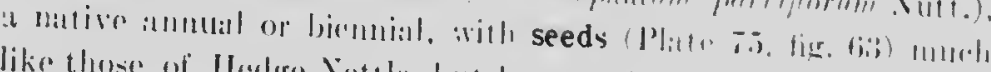

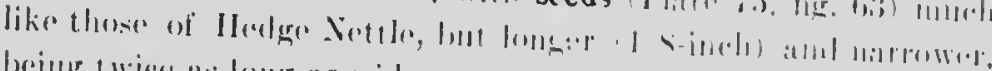

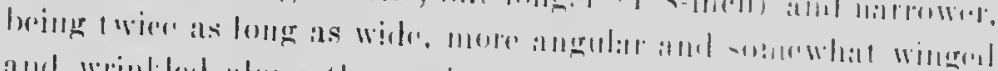

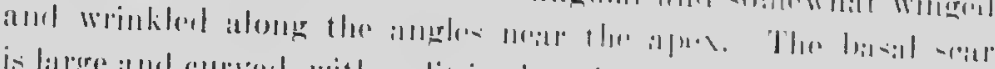

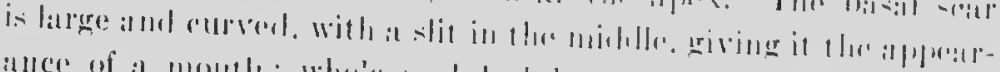

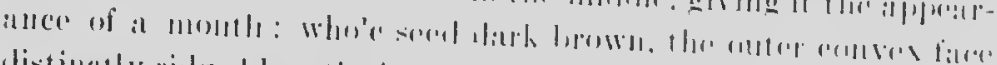

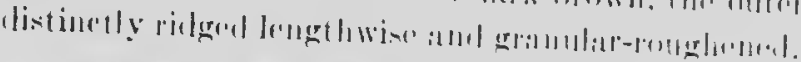

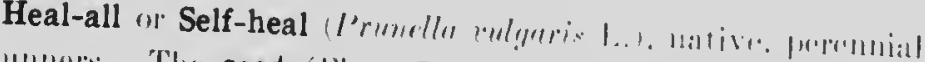

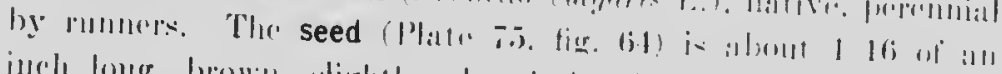

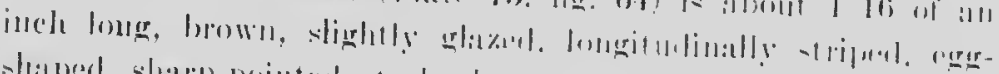

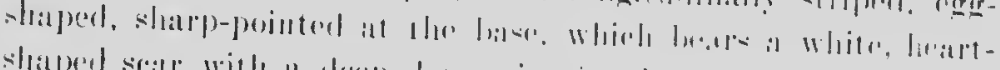

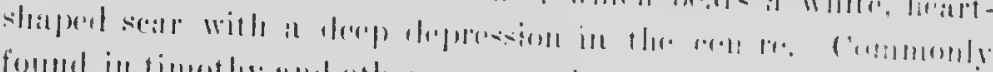

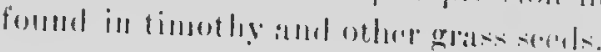

liverviliage that growe withmut J

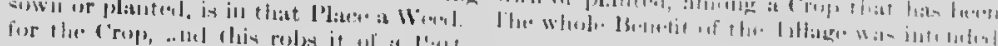

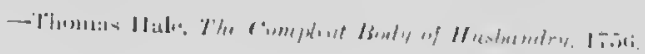

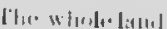

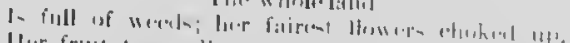

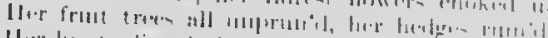

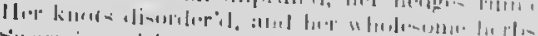

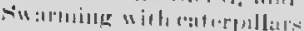

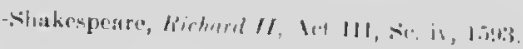

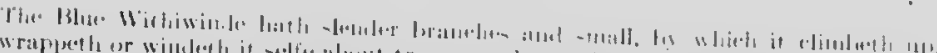

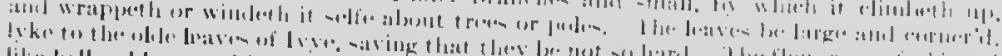

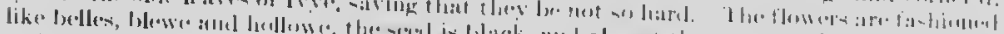
and lowktes, after tla..

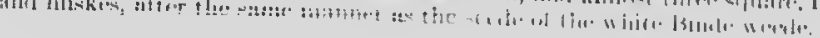




\section{HEDGE NETTLE (siluchys palustris L.)}

()ther Finglish names: Womndwort, lown's Wiomulwort,

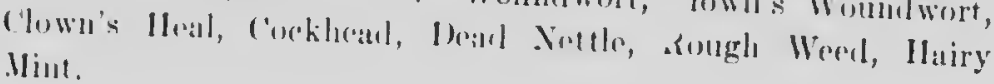

Sative. Peremual by at cober-like rootstork producing

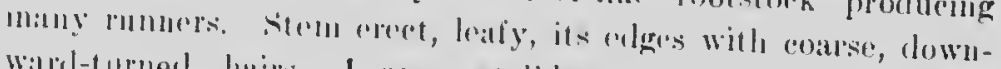
watrl-turned hairs. labess salkless, lamre-slaped, oblong, tapering at the apes, rounted at the base, with rounded teeth, hatiry Flowere pile rid or spefted, formol into a long, interrupterl spike of 6 to 10 flowered whorls at the axils of leaves: ralyx l'o the lrugtl of the corolla, hristly hatry, with spiny teeth.

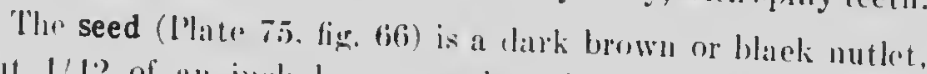
about 1/12 of all inch long, exce-shapenl, pointed at the base, which lears a small, shrunlion sear. The one sicle is sharply herelod from the sear up to $2 / 3$ the lougth of the seed. surfaee

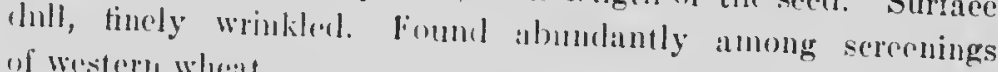
of western wheit.

Time of flowering: June to september; serels ripe lyg July.

Propagation: By serels alul rootsturks.

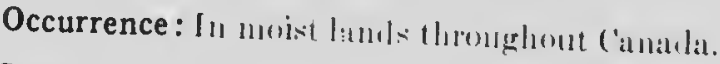

Injury: A secondary woed in castorn Canada and northern Alberta, giving trouble only in moist, low lands in gram fielels and mearlows.

Remedy: Good drainage, elean cultivation with short rotation of erops, will electi this weed and enable cultivated crops to smother it out.

lo put agloss upon their nractice, the physciatw eall an herb (which country neolle

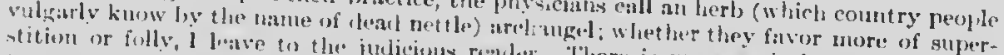

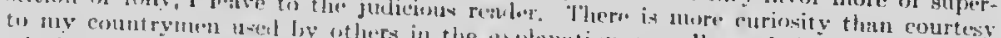

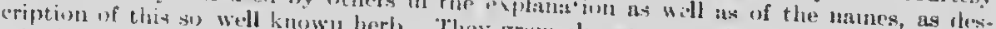

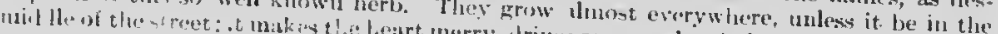




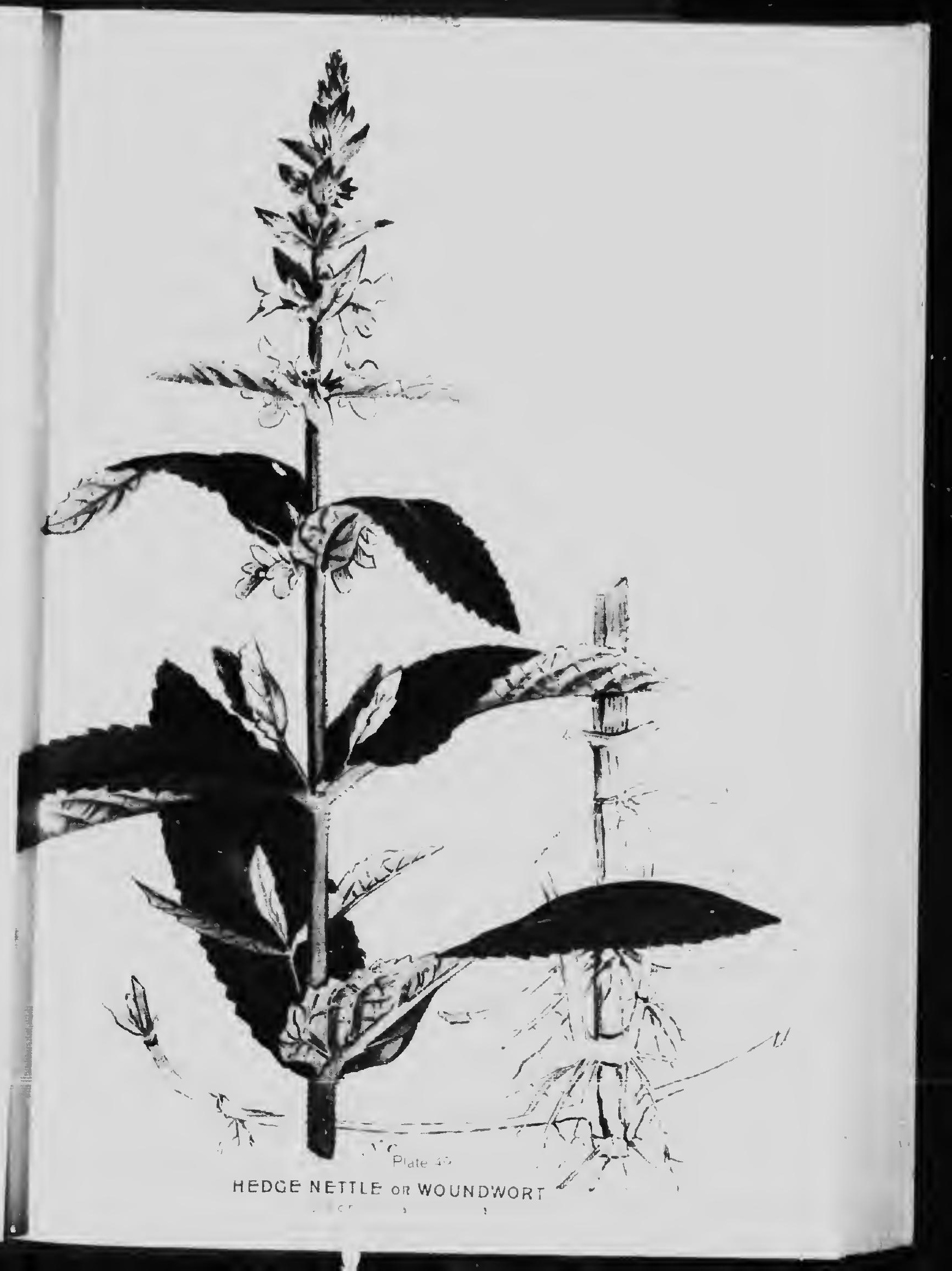


$=$ 


\section{THE FIGWORT FAMILY (simphulumen)}

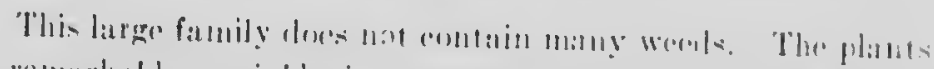

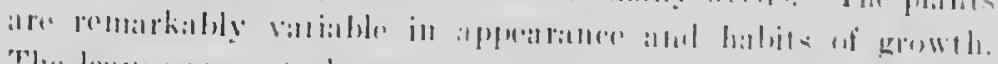

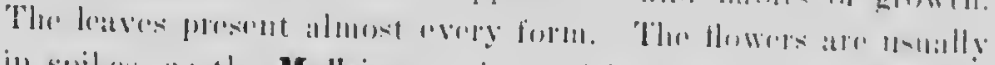

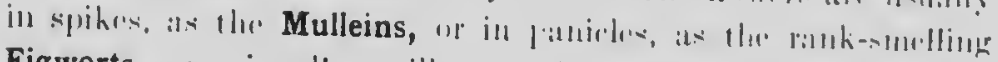

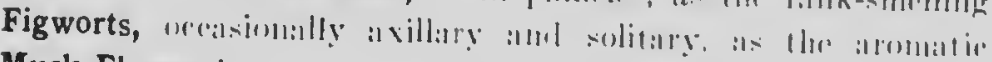

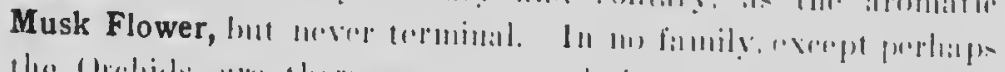

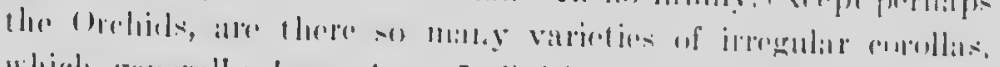

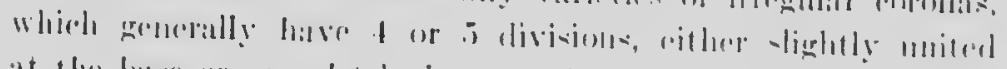

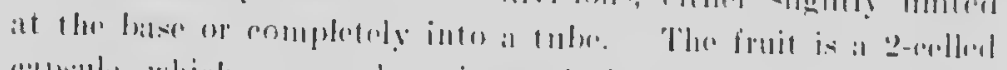

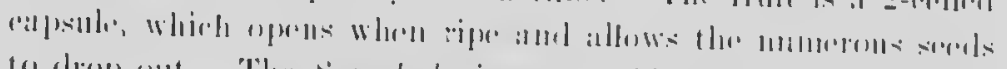

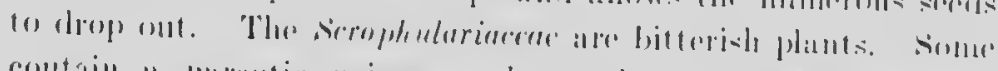

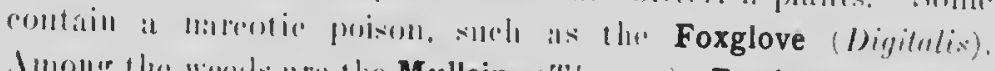

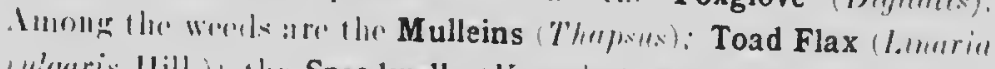

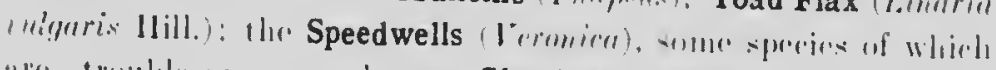

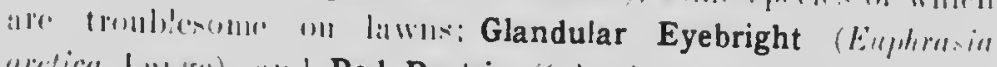

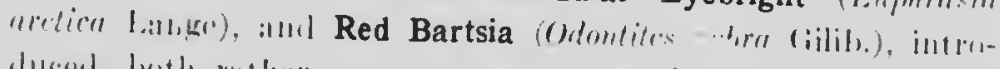

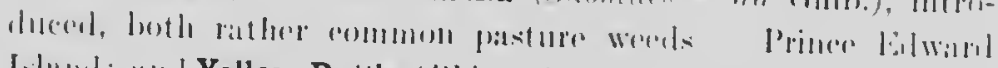

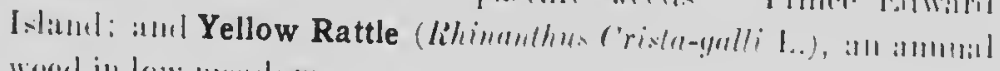
wererl in low mentows.

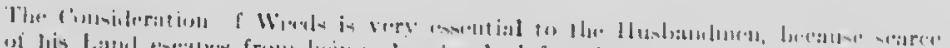

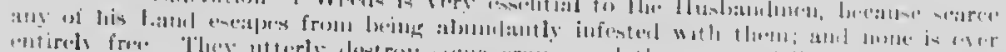

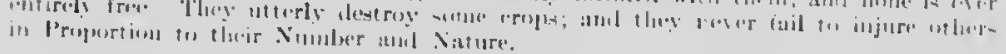

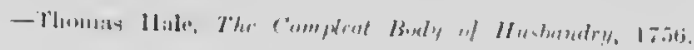

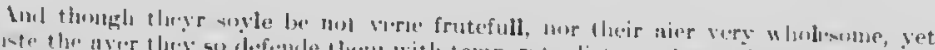

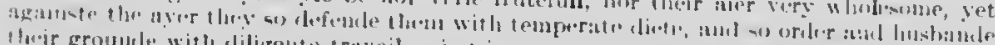

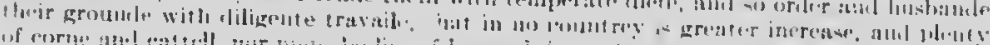

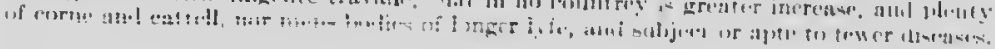


TOAD FLAX (lointrin I wlynris llill.)

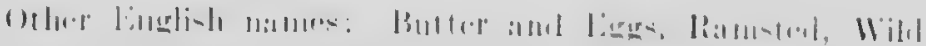

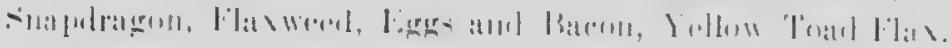

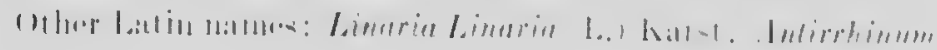
l.imurin I.

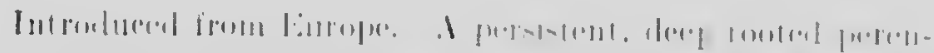

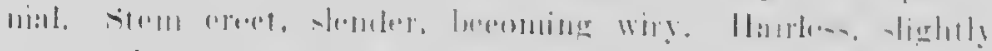

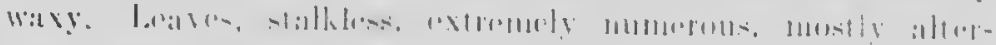

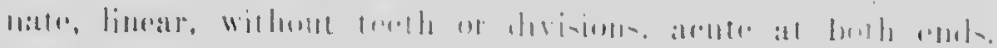

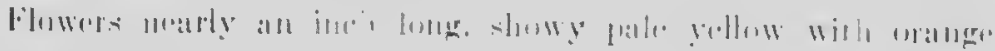

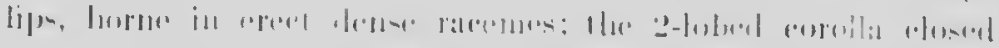

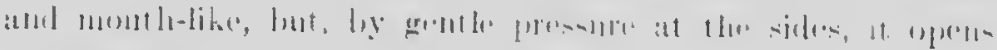

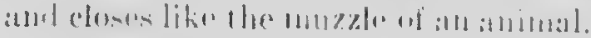

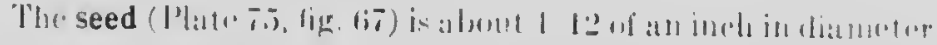

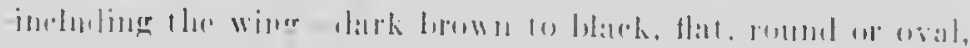

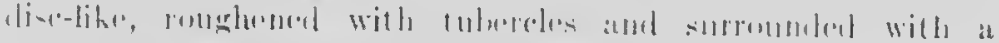

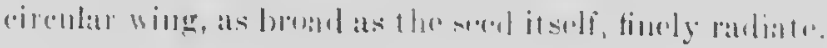

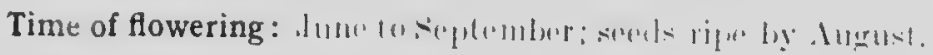

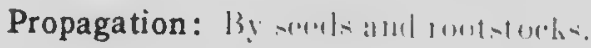

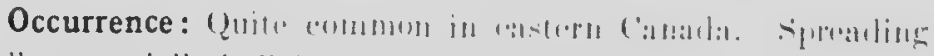

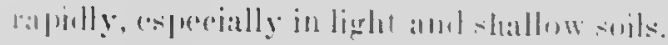

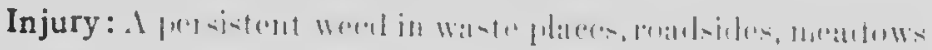
:[1, (ल)

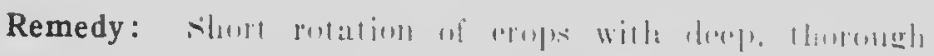
coltivation in spring and fill will suppress it. Ilamel-pulling

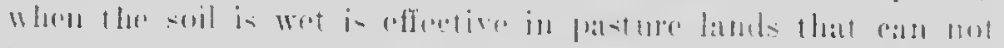

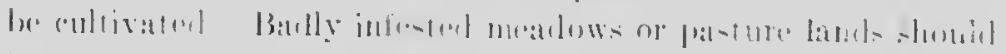

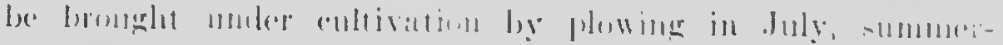

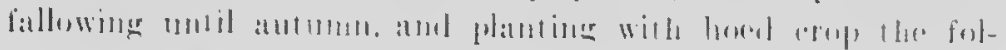

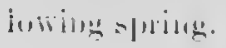




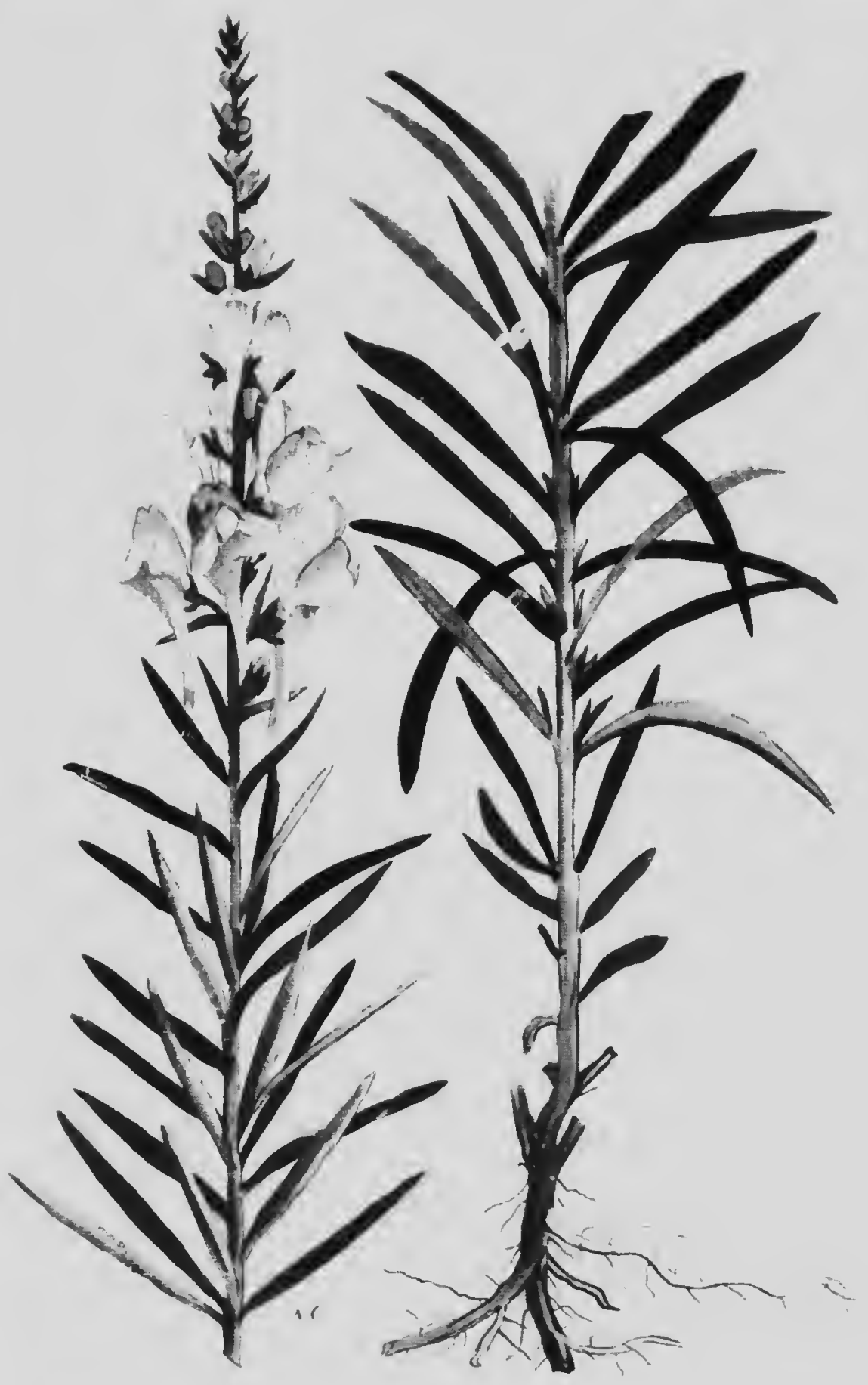




\section{THE RIBWORT W PLANTAIN FAMILY}

\section{(l'lamlunginacene')}

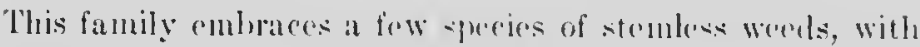

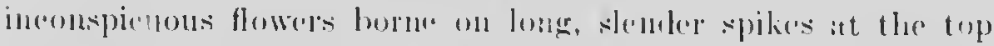
of leafless flowerstallis or "scapess." The linit is a cappsule, the upper part of which, when the serels ale ripe, lappos of like

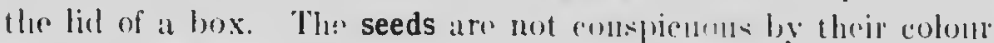
among gras serels, and on aceount of their -ize and shape they are diffientt to separate from them. This remers a knowlectge of the appearane of the conmonon kinds very inportant. The seeds of plantains mity le remphly separated into two groups, according to their shapke; in one divison, the secels are irregularly

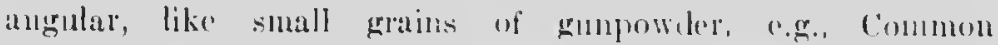
Pantain and Pale Phutain: in the othere, they are boat-

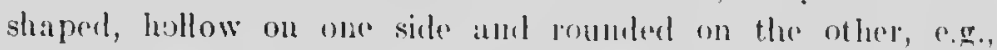
Narrow-leaved Plantain or Rib-grass aml Blacted Plan-

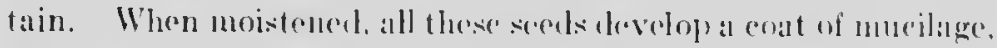
hy means of which their distribution is murh farilitalted.

\footnotetext{
The maiweed doth hurbe, and the thintle duth freat, the fitches pull rewawnel, both rie anl the wheqt:

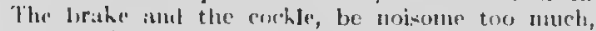
get like nute bothlle, no weerl there is such.

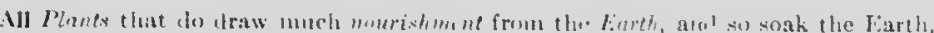

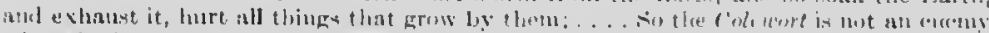

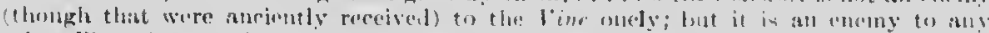

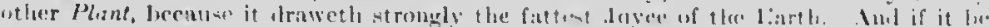

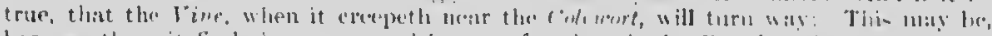

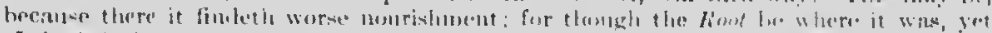

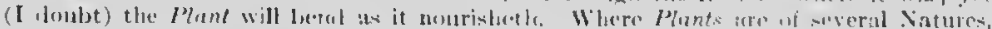

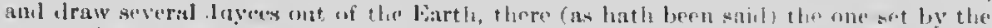

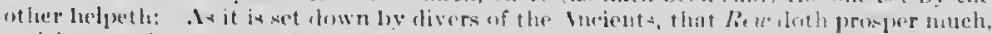

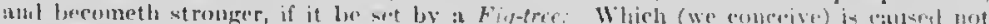

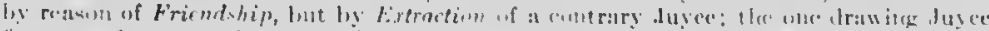

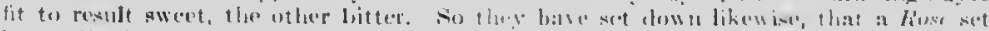

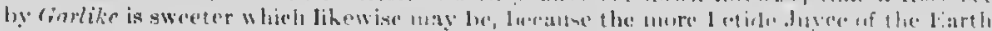

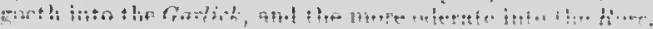




\section{COMMON PLANTAIN (I'!mingo mujor l..)}

Other English names: Broanl-louf Plantain, (ireater Plantain, Dooryarl P'lantin, Birolsonel Plantain.

Introduced and native. Peremnial. Rootstock short and thick, bearing many thick-xpreating roots atul a large tuft of dark green, oval, long-stalliod, conrsely-touthed, sprealing or up-

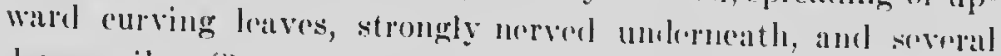
lense spikes (3 to 12 inches long) of inconspicuons flowere with purple stamens. Somel rapsules oval, diviling about tho midelle.

The seed (I'late 75, fig. (is) is about 1,20) of an inch long, errechish-brow!, variable in size ame slatpe aceoreling to the number in the eapsule (which varies from 8 to 16), rounderl on

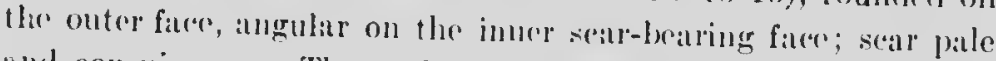
and conspieunos. The surfare of the soed is fincly netted with dark brown broken wavel lines, which ratiate from the scar.

Time of flowering: ILay, Ihroughout the stumber; sect ripe ly July.

Propagation: By secels.

Occurrence: Throughout the llominion, generally in rich, moist soil. In various forms, some of which may low listinct species, as indicatril by the differenore in halhit of growth and the degree of hatirymess.

Injury: A persistent, sucenlent we(e), nstually abundant in fields and gardens in low, rich soils and woll able to comperte with most cultivated reops or natural grassos. Lisperebilly' objectionable in litwns. Its seofls are common in grass ame elover sorels.

Remedy: Hood crops erery four years will keep this werel in check. Working witl a broat-shaterl rultivator, followed by a harrow, to trag the plants with their fiblous roots to the surface, is recomacndol for spring enlivation. Platain in 


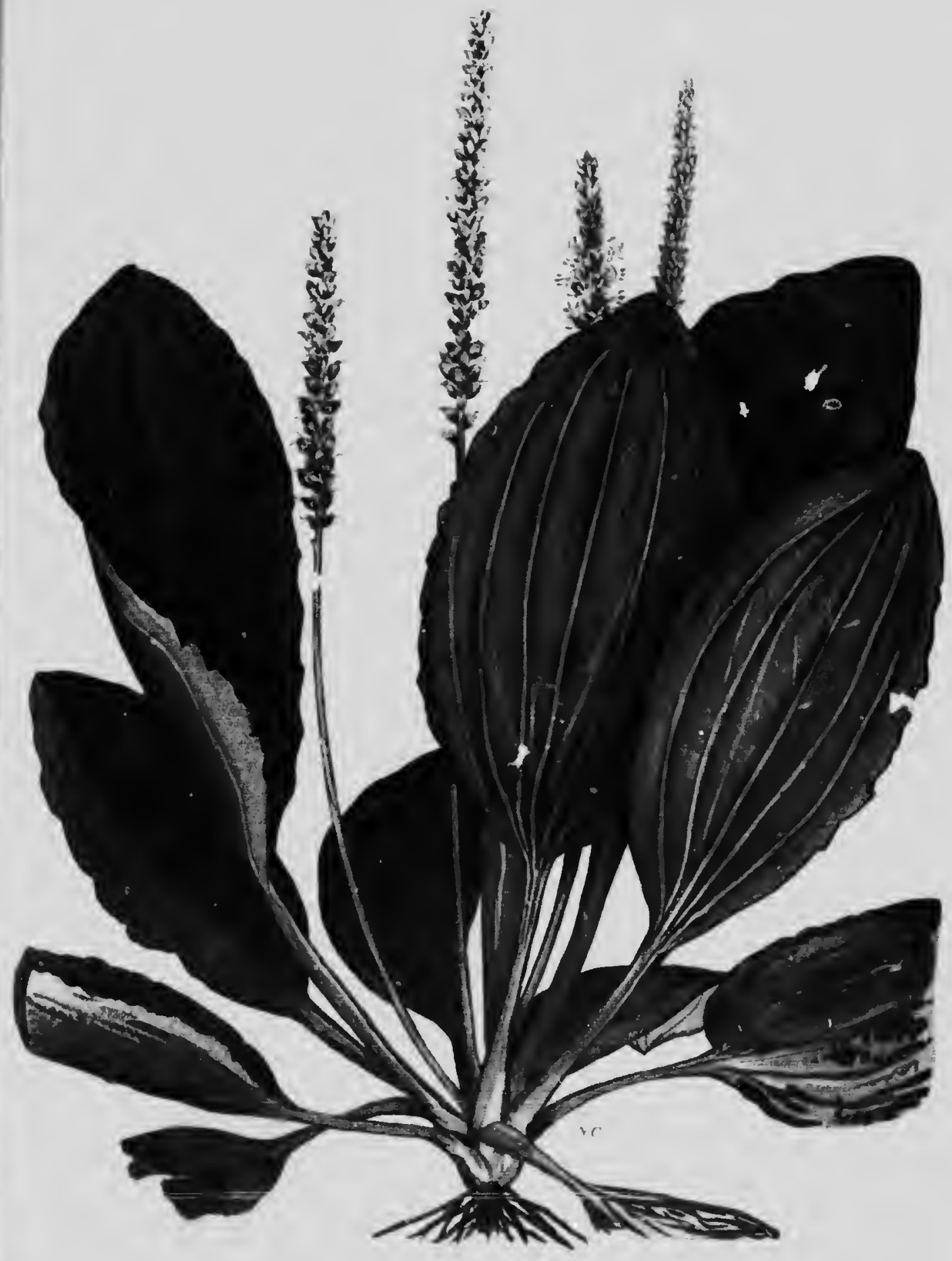

s

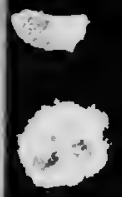

$3=$

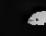

COMMON PLANTAIN

IPlantago mejom, 


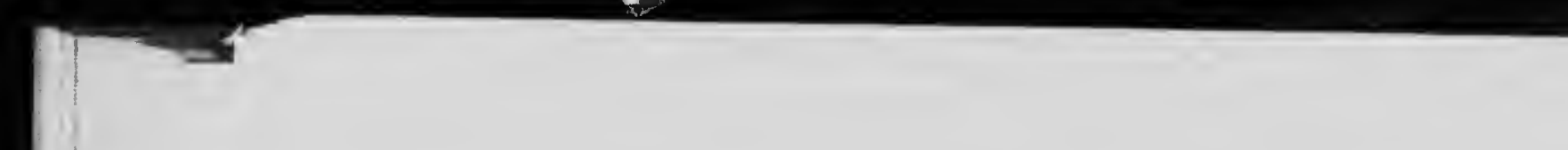




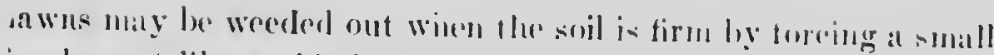
implement like a chisel, with a lalf-romel bladr latring a point

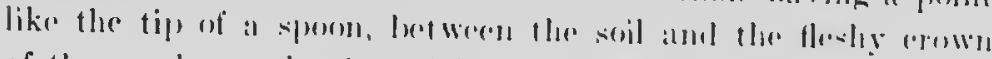

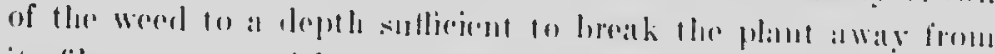
its filorous routs withoul disfiguring the turf. I ceaspounful of

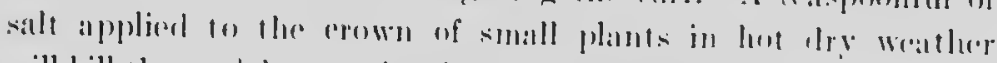
will kill them without soriously injuring thr grass.

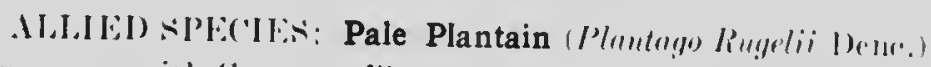
often orenurs wilh ('ommonn Plantain. It is a rathere larger plant with suore ereet, smooth leatres, of a paler of yollowish greon. the loaf-stalks purple al lloe latse. Tlare spikes are longer and

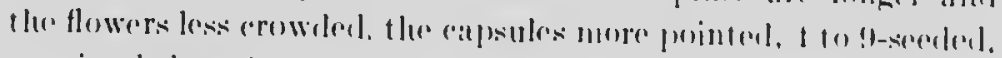
")

The seed (Plate 75, fige (69) is of the same angulall slalpe

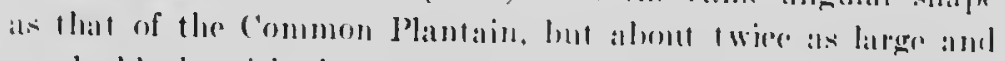

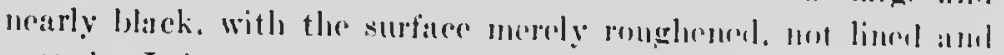
metted. It is common in timothy amel alsike seresl.

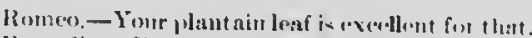

Benvolio. - lior what, I prity then?

Romeo,-lior vour brokell ahim.
}

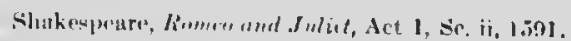

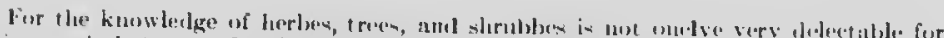

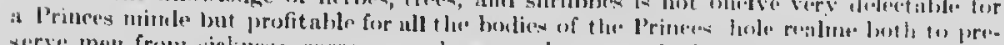

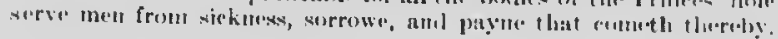

It is needless to go about to eanpute the value of the damage weete lo, sitre all

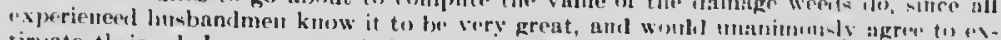

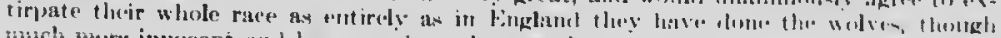

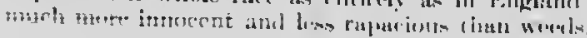




\section{RIBGRASS (Plaulngo lanccolata I..)}

()ther English names: Buckhorn, Einglisli Plantain, Ribwort.

Introdured from Euroure. Perennial or biemial. Rootstoek short. laves numerous, 2 to 12 inches long, narrowly lane-shaped and distinetly :3 to 5-riblorl, lairy, with tufts of brownish hair at the base. In the first yoar the leaves lie close to the ground, forming a dense rusctte: on old plants thry are erect. Flower stalks stiff, slender and grooved, 1 to 2 feet, much taller than the leaves. Flowor heads at first ovoid and rather showy by reason of their numerous yellow stamens, elongating with age and forming dense, eylindrical, black spikes of secel, from 1 to 4 inches long. Capsules oblong, obtuse, 2sereled, opening about the midhlle.

The seed (Plate 75 , fig. 70 ) is about $1 / 10$ inch long, eliestnut brown, minutely granular-roughened but highly polished, boatshaped with rounded ends, the outer face rounded with the edges folked inward around a deep, longitudinal groove, in the eentre of which lies the dark-eoloured scar which sometimes has a pale ring of dried mueilage around it.

Time of flowering: Throughout the summer; seed ripe by July.

Propagation: By scels.

Occurrence: Throughout Canada; most abundant in elover crops.

Injury: In Europe, Ribgrass is consilerel a valuable forage plant for some soils; its seed is an article of commerce and largely used in mixtures for pasture lands. In Canada it is an injurious weed in elover and meallows for hay or seel crop. The seeds are very common in red clover seed.

Remedy: Sow elean seed. In common with other species of plantain, this weerl is easily suppressed by hoed erop and short rotation. It is prevalent almost exelusively in elover 


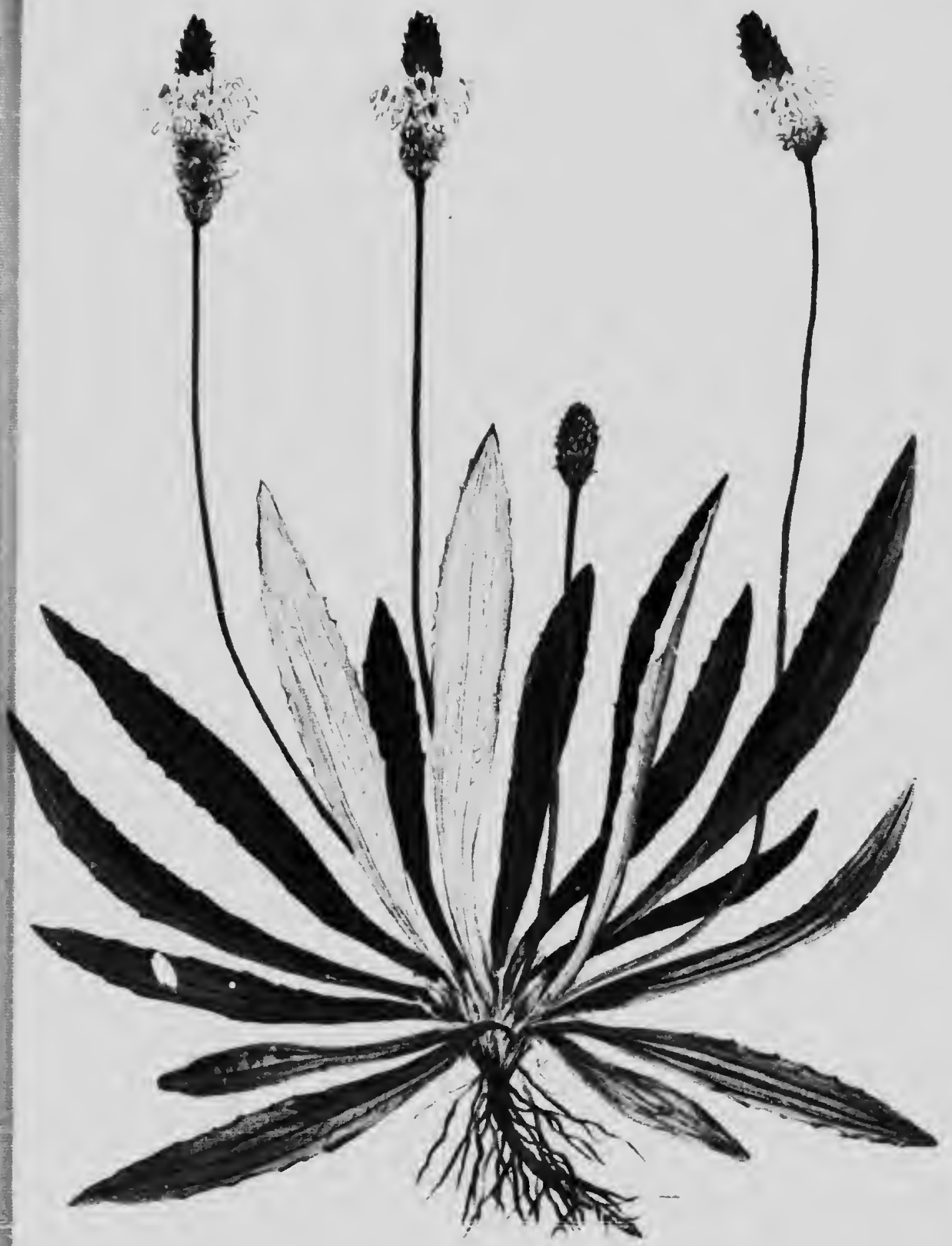

BUCKHORN. RIB GRASS OR ENGLISH PLANTAIN

(Dlantago ianceolara , 


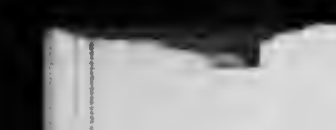


ropes, in which it inereanes rubilly hy the distritution of $i t=$

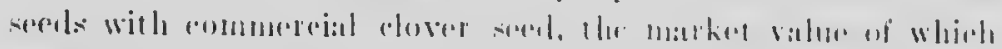

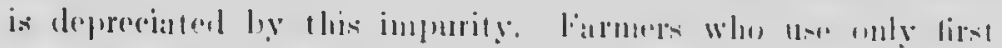

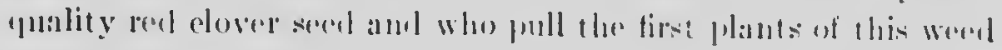

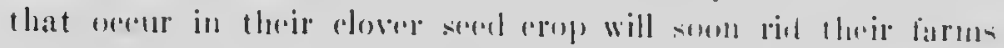

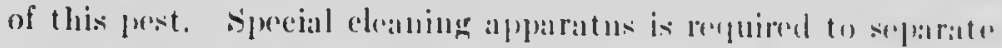

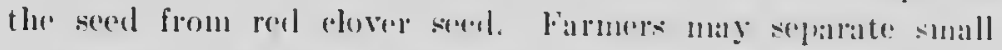

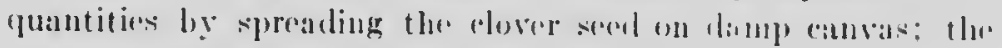

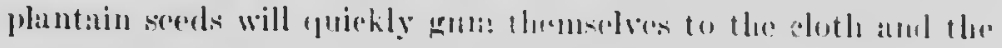

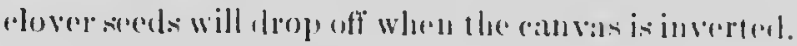

MILIEI) SI'LCIEs: Hoary Plantain (Plantago medin l..). This plant is much less frepuently seren than Rihgrass lut it has the sane wide range, as the serel is distributed with grass seed. It is derp-rooted and more diffiente to aradieate from law ws than the othere species here mentioned. lonses orate, thickly covered with white hairs, slobt-stalhed and always lying alose

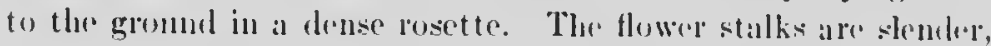
abont 1 fout high. Flower heak showg ly reasm of their purple and white stamens, at first oval, cradually elengating to cylindrieal spikes 1 to 3 incless hong. Flowers pleasuntly fragrant. (apsules olslong, 22 to 03 -sinderl.

The seed (Plate 75, fig. 72) is of the bont-kaped class, about the same size as that of Ribgrass but thinner and flatter, often somewhat twisted, with the edges not so roumlly turned in around the groove which bears the sent. It shows an indistinet, shallow gros". "rotriotion aeross the outer face just ledow the middle, id dissting the part of the soed which fitted into the top of the c: pisule.

Hoary Plantin is intermediate in appeatunce between Common Plantain and Ribgrass, and its seeds ane intermediate between those of Ribgrass and of Brieted Plantain.

Bracted Plantain (Plantago aristala llichx.). A westorn annual which is rather rare in Canmla, ahthough its seeds are not uneommon in grass and elover seeds. The whole plant is lowny; leaves narrow, lincar, grass-like; flower stalk: erect, 


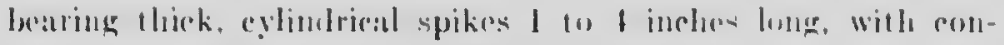

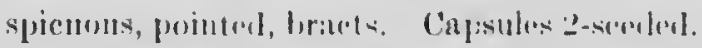

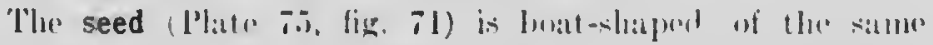

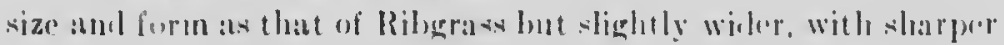

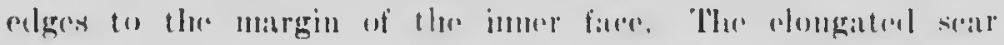
consists of 2 small, shathow pits lying close together in the cent re

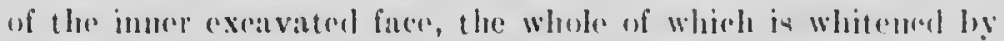
at coat of driol mucilage. The romuled outer fater has a distimet shallow groove crossing it just bolow the millthe. This grouse amel the two pits of the seat are the best characteriotions for listinguishing this serel.

\section{TEE MADDER or BEDSTRAW FAMILY (Rubincene).}

This is a large family which shows great variations in habits

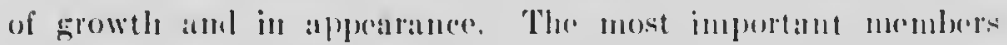
are tropical, such as the coffee. The plants are herbareens or wooly, with opposite or whorled leaves, flowers bearing both stamous amel pistile and various fruits.

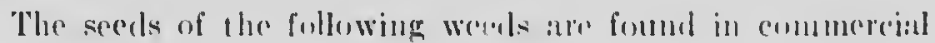
sirenls:-

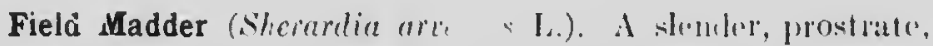

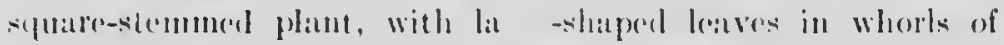
4-6, and small pink or blue fle. is. The seed is ash-gray from

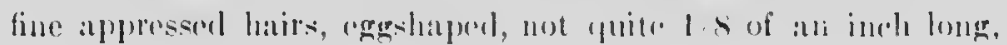

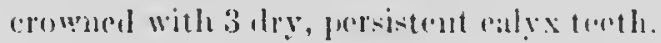

Northern Bedstraw (Gialuim boreale l.), the nurt eomumon of the bedstraws or cleavers. A nation promial, with sifuare ster, linear, lane-shaped leaves in whorls of 1 , and coupanet panicles of hright white flowers.

Thr seed (Plate 75, figr. 73 ) is a gond represutation of the secel of the genus Galium, only it is much smather than some 


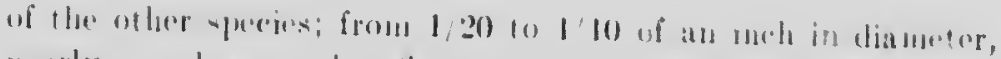
mearly roume, somewhat flattemed on the shle bestring the sear.

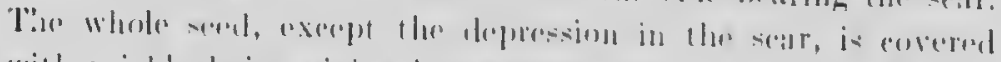

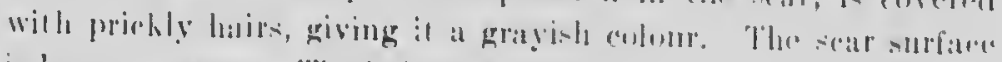
is brown, rugeses. 'llhe hatirs are sometimes brohen whi by lhreshing atul chaning the serol.

\section{THE SUNFLOWER FAMILY (C'mposilue).}

This, the largest fanily of flowering plants, inclneles ten to twelve thousand specios and is represcutrel in all parts of the mble hy ecomomice, medicinal and ornamental plants, mul by ses. " prosonesus and werel peats. Tlac characteristies of the fams, are well mathed. The roots and reotstoeks contains a chemical principle, inulia, which is poisonous and gives to many plants their medicinal properties. The flowers of all are compensite; that is, romposed of many small flowers or florets

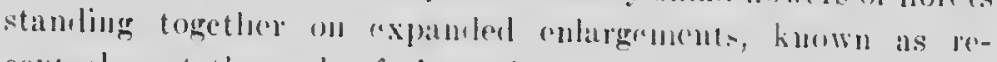
ecplacles, at the ends of the stallis. Inelividually. these flower heals, or collections of many florets, have the alpuarance of simple flowers amb an popularty so spoken of als, for instance, the flower of a sunflowere, a dasisy or a damdelion, while in reality

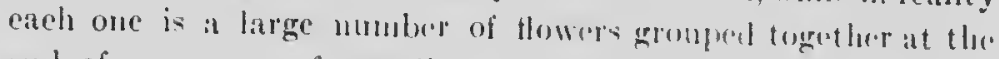
cond of a common foutstalk, and what appears to be al caty is a clustor of small brats. I striking chanacteristic of this

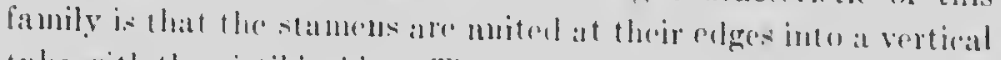
tabe with the pintil inside. The ealyx of the florets, where present,

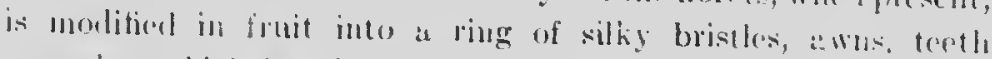
or sealce, which is callod the papluns. The florets of crmposite flowers are of two kinds, both of whieh may somerimes he seen in the same flower lacal, ats in Common sunflower. The marginal or ray flowers are stap-shaped, and the smaller entue or disce flowers are tubular. When the flower heal has ray flowers, either throughout or round the edge, it is ternuel radiate: 


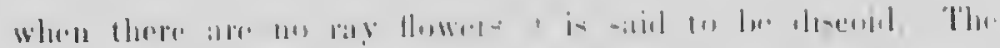

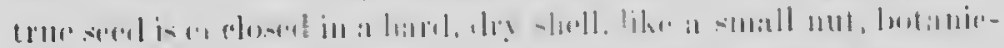

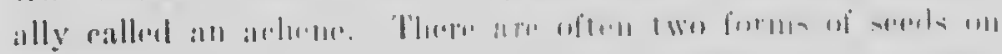

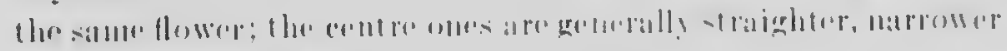

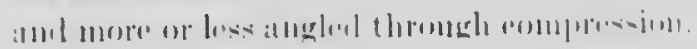

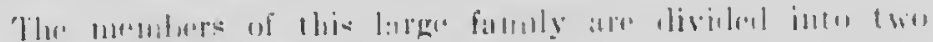

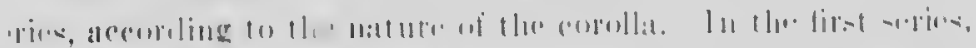

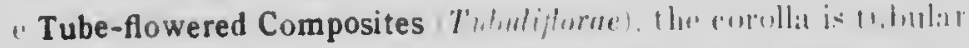

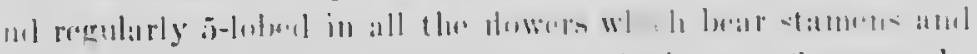

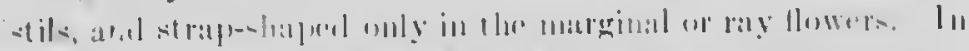

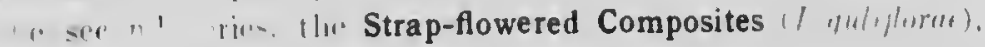

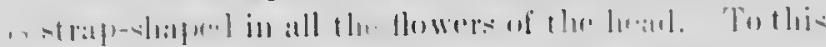

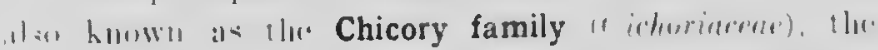

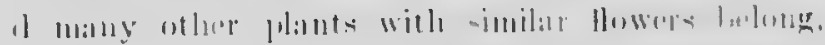

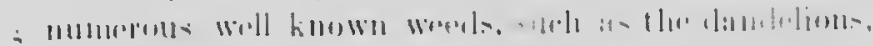

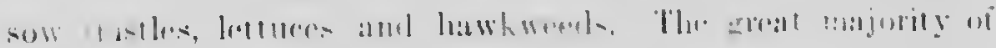

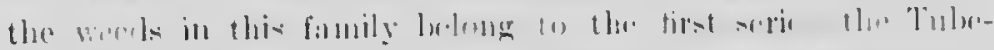

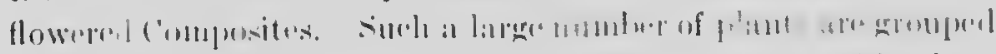

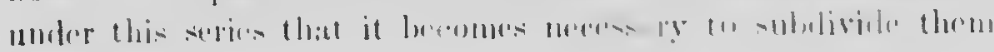
intu trilus.

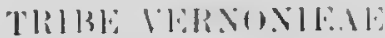

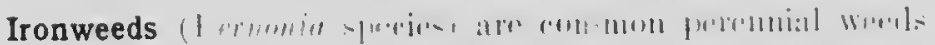

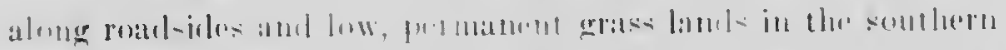

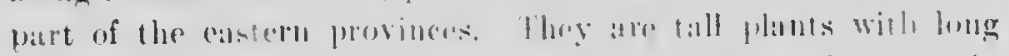
leaves and rentepurple flowers hasals. Tlus maty be hept in

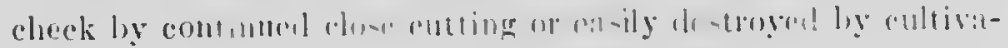

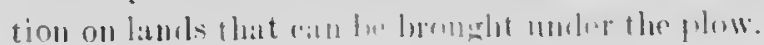

\section{THIHI: ELPALUIH II:}

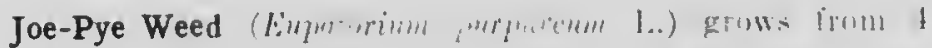
to $S$ foret high, withont hathe?

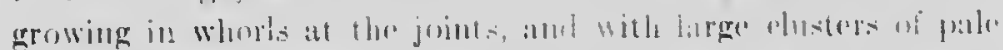
pink to whitish flowers. ('ommon in low mealum and patsle as

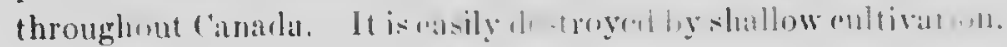




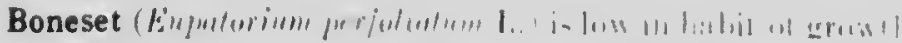

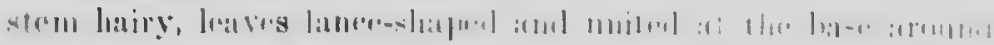

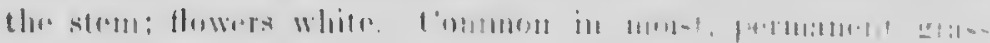

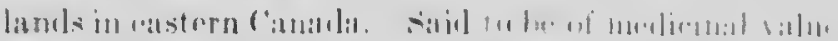

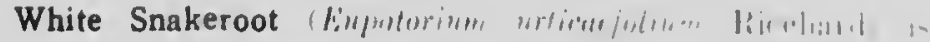

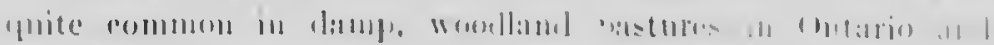

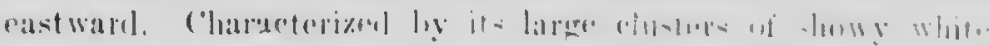

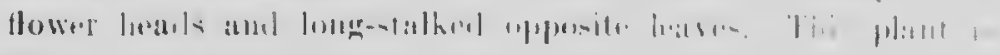

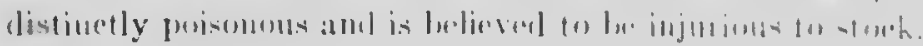

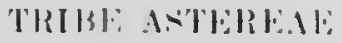

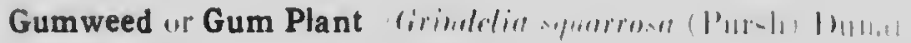

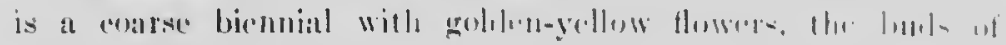

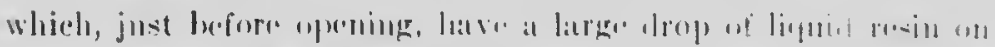

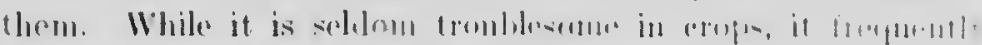

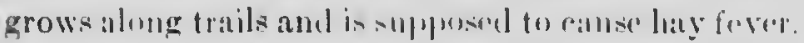

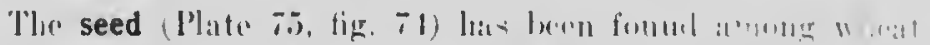

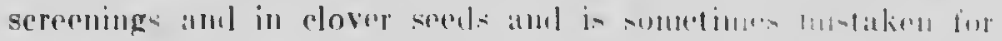

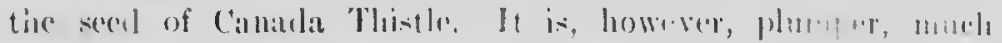

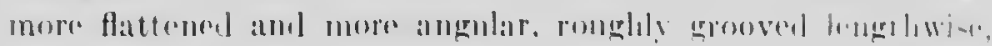
fisler and duller in colour.

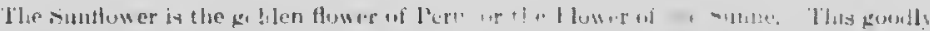

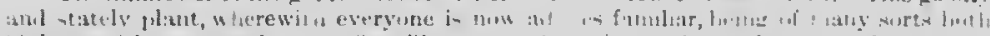

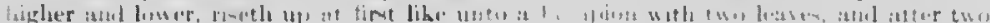

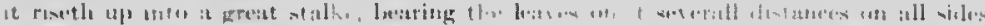

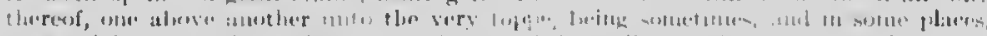

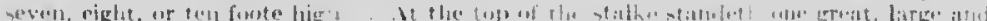

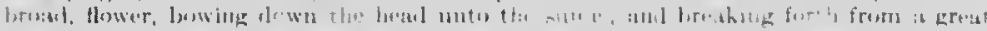

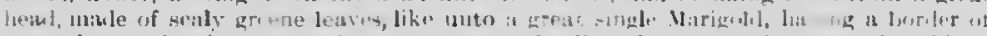

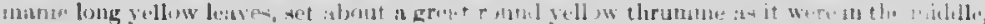

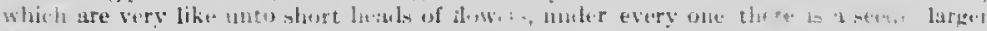

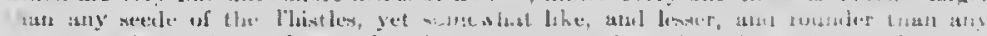

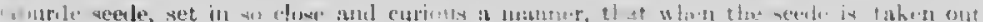

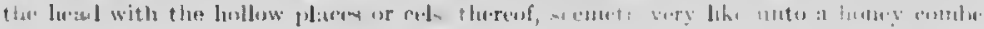

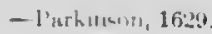


NARROW-LEAVED GOLDENROD (Solidago graminifolia (I.) Salisb.).

Other Linglish names: Bushy or Fragrant Goldenrod, Yellow Weed.

Other Iatin names: Euthamia graninifolia (L.) Nutt., Chrysocoma graminifolia I., Solidago lanceolata L.

Native. Perennial by running rootstocks. Stems ereet, branching above into eymes, 2 to 3 feet high, almost sinooth. Leaves numerous, linear-lanee-shaped, 1 to 5 inches long, the edges rough-lairy. Separate heals of flowers a is it $1 / 4$ ineh aeross, bright golden-yellow, in clense, flat-topped elusters.

The seed (Plate 75, fig. 75) is small, white, about $1 / 12$ of an inch long, ovate-oblong, nearly eylindrieal, slightly tapering, many ribbed, downy. The pappus is white, eonsisting of a single row of rough bristles, about twice the length of the seed.

Time of flowering: July to September; seeds ripe in September.

Propagation: By seels blown by the wind and by long rumning rootstoeks forming new plants at the tips, which, if left undisturbed, soon form large patehes.

Occurrence: In low land throughout the Dominion.

Injury: This and many other speeies of the goldenrods are objectionable: in meadows on clamp soils, as marsh lands and river bottons, that are not well suited for general eultivation and rotation of erops. These weels are unpalatable to stoek and their presenec in hav entails muel waste.

Remedy: To prevent them from sprealing, oceasional weels in the mealow nay be destroyed by the applieation of a handful of salt after eutting. Bally infested land that is wet until late in the spring should be shallow-plowed and thoroughly eultivated as soon as the hay erop is removed. These perenuial pests ean 


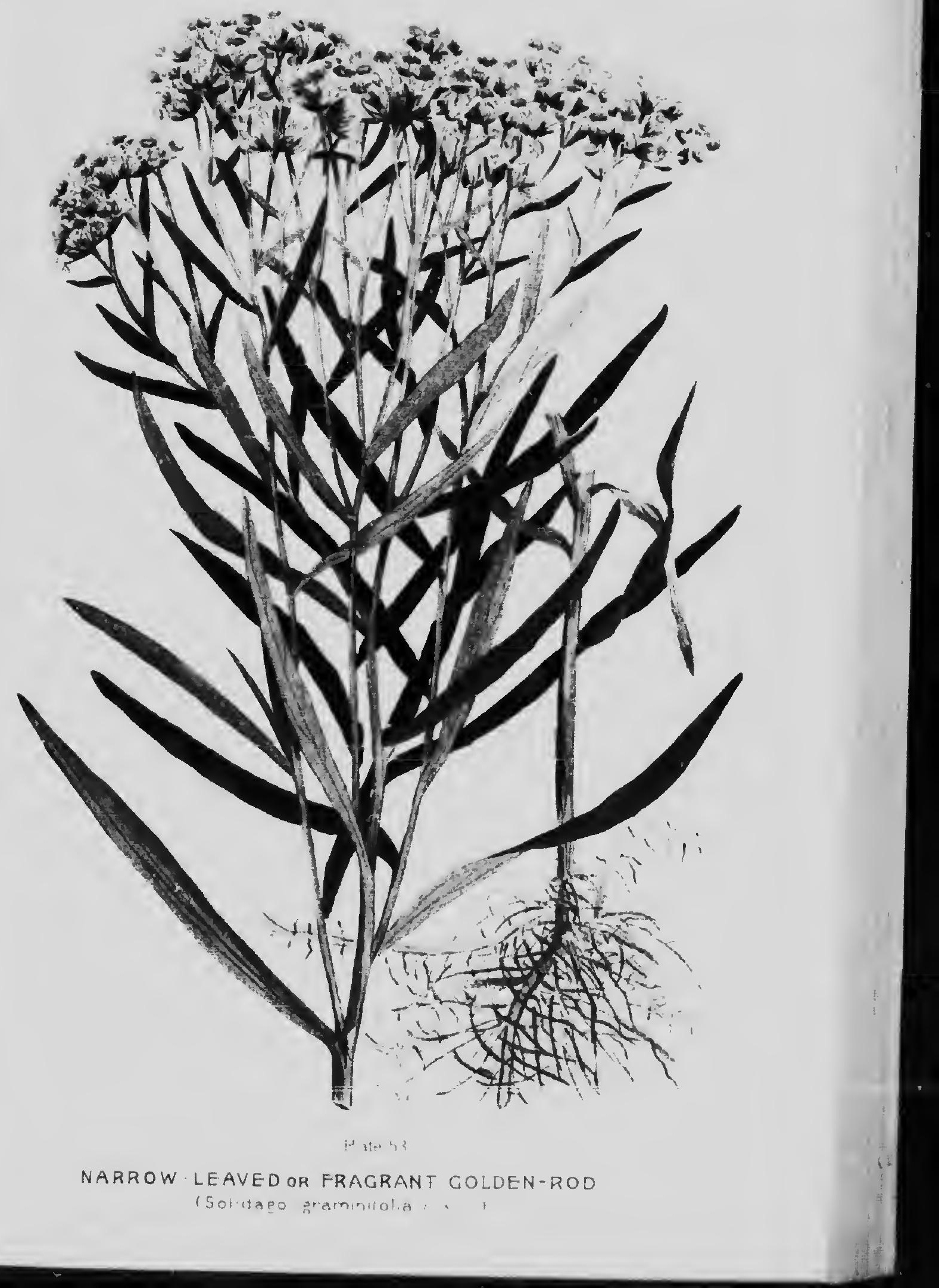


be suppressed by repeated cultivation between the midrlle of July and the middle of sieptember, when the land inay be seeded to winter rye with a liberal application of thornughly elean griss seed.

AlIILD SPECIES: Several otler goldenrols are rather troublesome free-growing perennials; anong them are:

Tall Hairy Goldenrod (Solidago rugosa Mill.), with long hairs, crowded leaves and a broad, pyranidal panicle.

Tall or Canada Goldenrod (Solidugo canadensis L.) and varicties, with a slender stem, hairless at the base, and thin, narrow-lance-shaped leaves.

Smooth Goldenrod (Solidago serotina Ait.), with slout, smooth steins, leaves smooth on both sides.

All these showy, autumn-flowering plants are wayside and grass-land weeds and de not give trouble on fields under regular cultivation.

The true Asters, of which about 70 species are native to our country, very seldom become aggressive weets.

As for the Sow-Thistle, the chief and ondy Annoyance of all Thistles (as for other Thistles I searce know how to rauk them opinion of most men are, that they are most certain symptons of grum land as usually. they are; so are Nettles, IIemlueks, Malliwes, etc.), anl y.t 1 hat rather they were ail

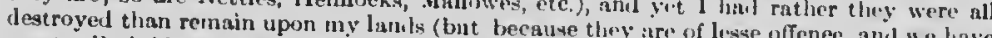
greater Prejuilees than these, lle let them passe); but fur tho sow-lingtle it in of an great offence that it destroys all the grase it covers, which is many times in fout round, and also so easie to be destroyed that I shall puts, wheh is many times in fout round, and or trouble, or trouble, but onely to take a litule l'alille statfe, is a Walhing-viffe, and give wach one a chop at the loot as hasseth by them, which will be rather a Rrereation to an active inn, than a Burthen, and thus every clay a feu as they grow in bignesse, will in a few rlays destroy them all; ()r else a Shephearal, or liepuer uf the (irouml. as he walks among his Cattell may easily keep them muler, aa he gues abont his duih husinese; 13at since heive found out a more eertain way wheh will olestroy them at one spulding up, whicl

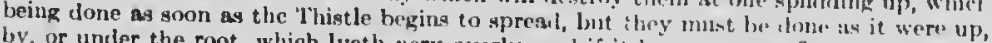
$b y$, or under the root, which lyeth very overly, and if it be not rit at fime chop, it may

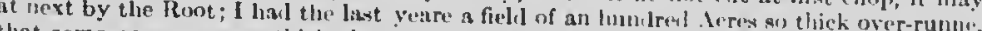

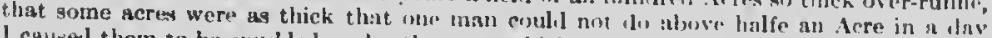

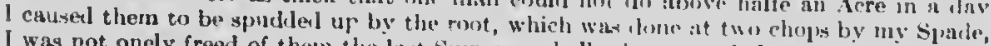

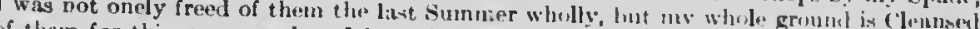

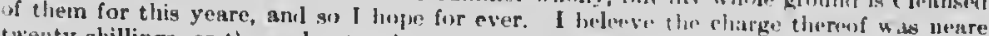
twenty shillings, or there alowt. A more certaine way I know not.

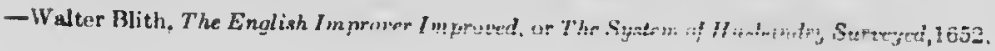




\section{COMMON FLEABANE (Erigeron ranaden.is: 1..)}

Other Euglish nauns: IIorseweed, Firmerd, Butterweed, Prideweed, Blood-staunch, Coris, Colt ₹- or Matre's-tail, Bitterweed.

Uther Latin nanı: Leptilon Canaden.e (I..) Britton.

Native. Annual. Sometimes very tall and much branched, with want-like strms; generally hristly hairy. Jeares without teeth or divisions, linear, the basal oness dentate. The numerous, small, white hower heals form a panicle.

The seed closcly resembles those of the goldenrouls and is practically indistinguishable from them and from sone varieties of asters. It is yellowish, fhattenerl, 2-nerverl, often slightly eurved. Uctuber.

Time of flowering: July tu Octuber; seres ripe August to

Propagation: By seeds married with the wind. Sirel-producing plants are of all sizes, up to 6 or 7 fere ligh. An average plant produces about 120,000 secels.

Occurrence: General in ficlls and waste places. A native of North America, exeept the extreme noill. Spreal from America to E rope and common in South Amerien. It is most aburdant in moist grounds and pastures, but is found in meadow land and even cultivated fields.

Injury: Its seeds are found in poorly eloaned grass seed. An objectionable word in meadows.

Remedy: Any methor of eultivation which prevents it going to seed is effective. A short rotation with clover and a hee erop or a barc fallow will misily kill it. Waste places should be watehed and the weeds eut before they develop seed.

ALLIEI) SPLCIES: Daisy Fleabane (Fingeron annuus (L.) Psrs.) has coarsely-toothed liaves. 


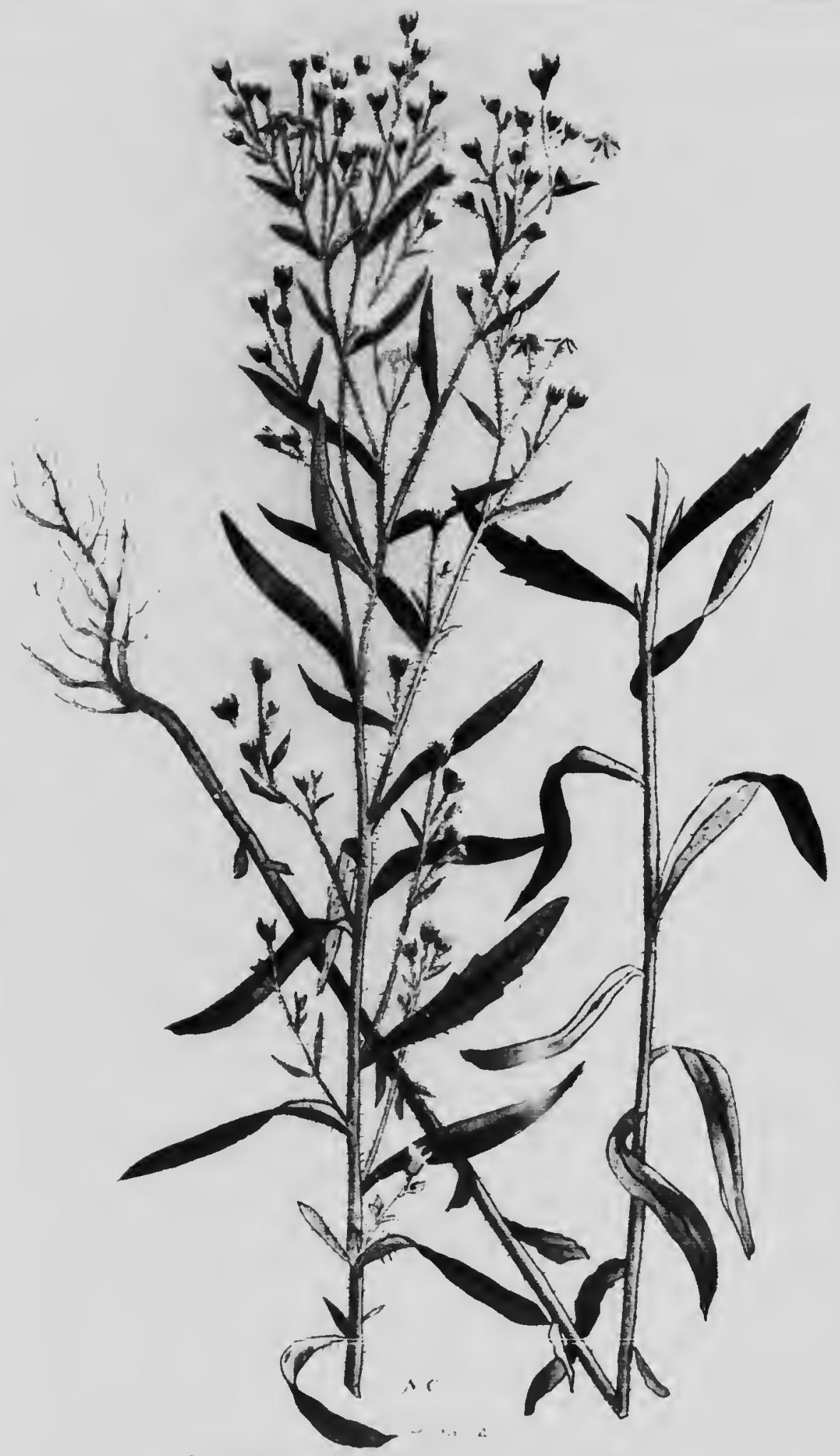

CANADA FLEABANE OR HORSE: WEED 


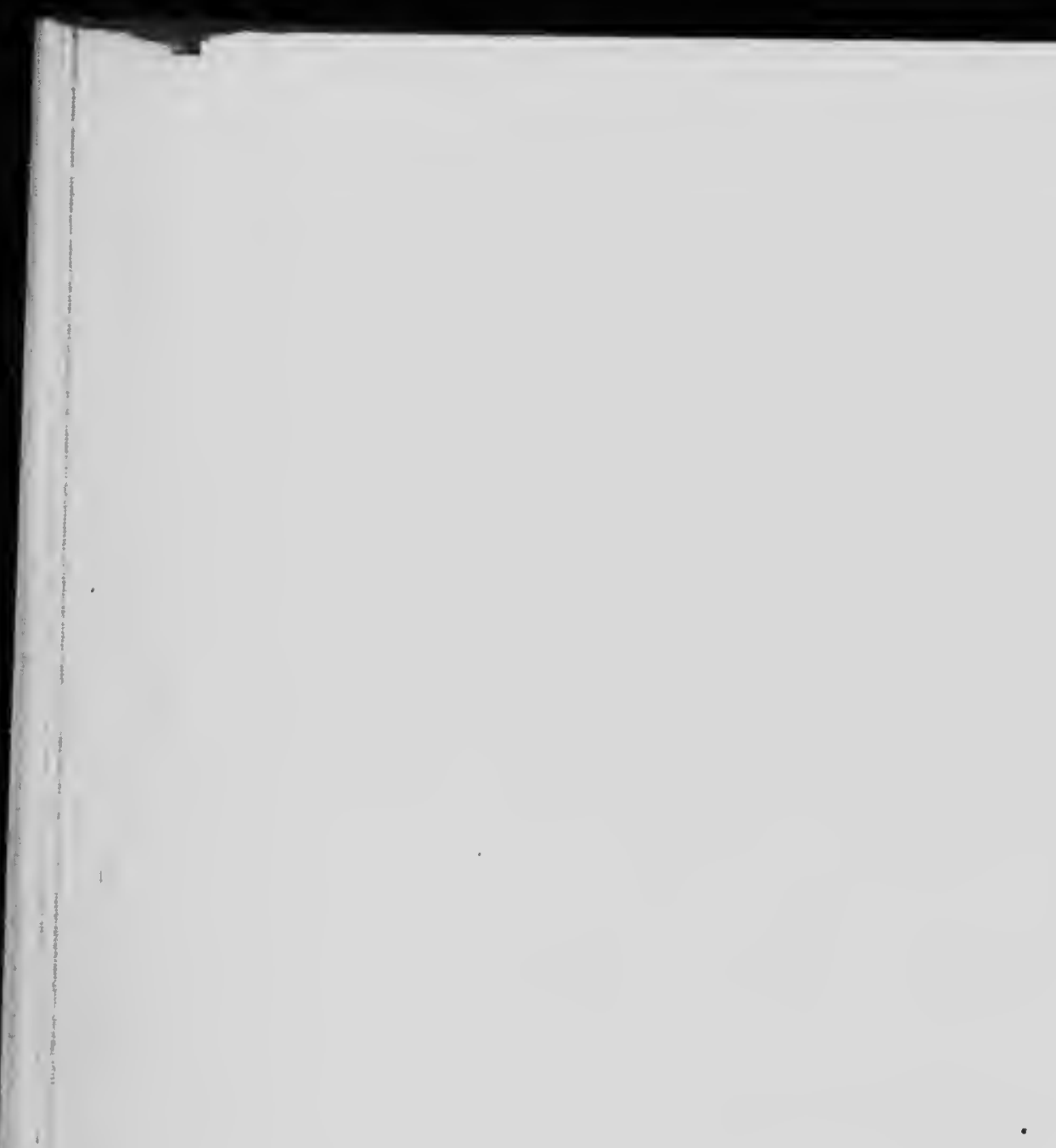


Rough Daisy Fleabane (Erigernn ramo:ns (Walt.) B.s.l'.) has louves, without teetl or divisions.

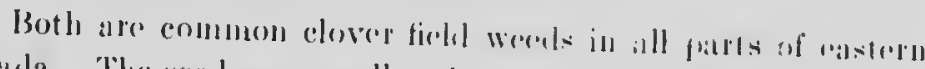

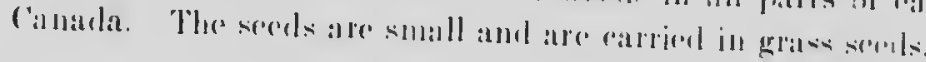

\section{TRIBE: INCLFAE"}

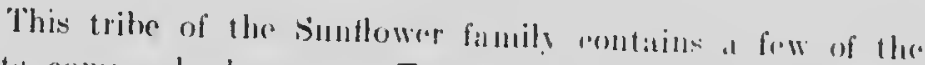
plants commonly kuown at Everlastings, whicl: alre wroels of secondary importanee. Such arr thre True Everlastings, or

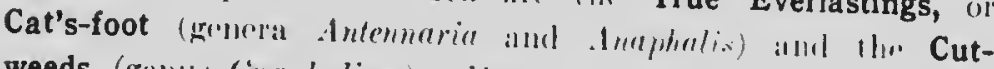

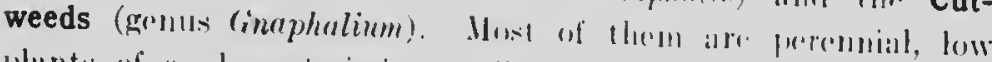

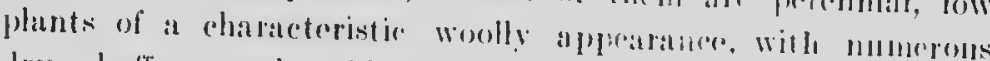

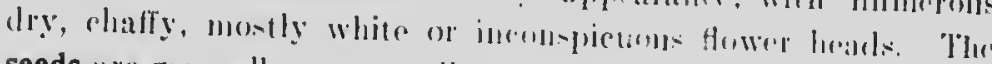
seeds are gemerally very small.

Elecampane (Ihula I/elenium L.), also rallo, Horsehead, is at stout peremnial with it thek, mucilaginous ront; intronhered

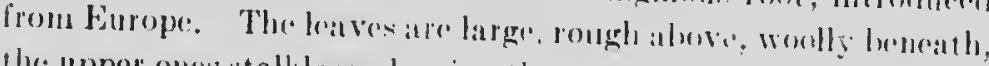
thr. npper ones stalkless, chasping the stem.

The flower hoals are yollowish, with many lays. The seed is about $1 / 5$ of an inch long, olive bown, t-allghal, with al heng, spreacling pippus.

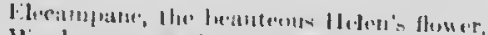

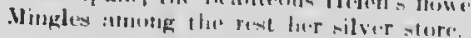

$$
\text { - R:upin, I(iก) }
$$

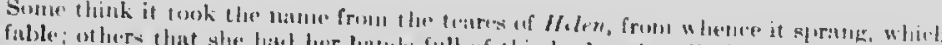

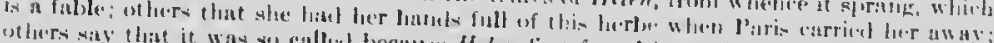

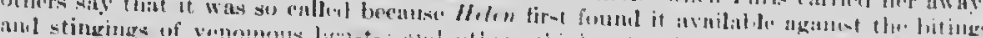

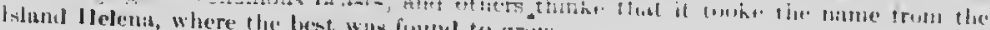


TRIBF: HEIIANTIIEAE

\section{POVERTY WEED (Ira axillaris Pursh.)}

Other English nanıe: Sull-flowered Warsh-elder.

Native. Perennial. Whole plant with a rank odour. Stems herbaceous, branching, nearly erect, from tough, woody, extensive ruotstocks, 6 to 12 inches high, very leafy. Iseaves thick, obovate to linear-oblong, without teeth or divisions, rough-hairy; the lower ones opposite, the upper alternate. Flower heads drooping, solitary, on short footstalks, fron: the axils of the upper leaves, $1 / 6$ of an inch across, ineonspieuous.

The seed (Plate 75 , fig. 77 ) is 1/8 of an inch long; colour variable, olive-green, yollowish-brown to almost black; surface mealy and dull; pear-shinped, slightly flattencel, sometimes keeled on the sisle and a little curved towarl the base. There are seldom more than one or two scerls in anch flower hearl, and many heads have noure.

Time of flowering: June to August; seeds ripe July to September.

Propagation: Mainly by the extensive underground stems, which send up many flowering, leafy shoots.

Occurrence: In groin frolds and pastures from Manituba to the interior of British (olumbia, thriving in all soils but occurring generally on land where there is some alkeli. The sced of Poverty Wred seldom oecurs in grain or grass secels.

Injury: $A$ persistent permuial, forming large patelirs. Exlanstive of moisture. thus starving clops and rendering the laud hard to work.

Remedy: This is a diflicult i . 'my to dislodge when well establishad on the rich suils of the $\|$ It requires well directed, persistent effort, with sharp implen, is. Plowing for sumnerfallow shoult be clean and decp, followel by frequent cultivation with a broad-shared cultivator. 


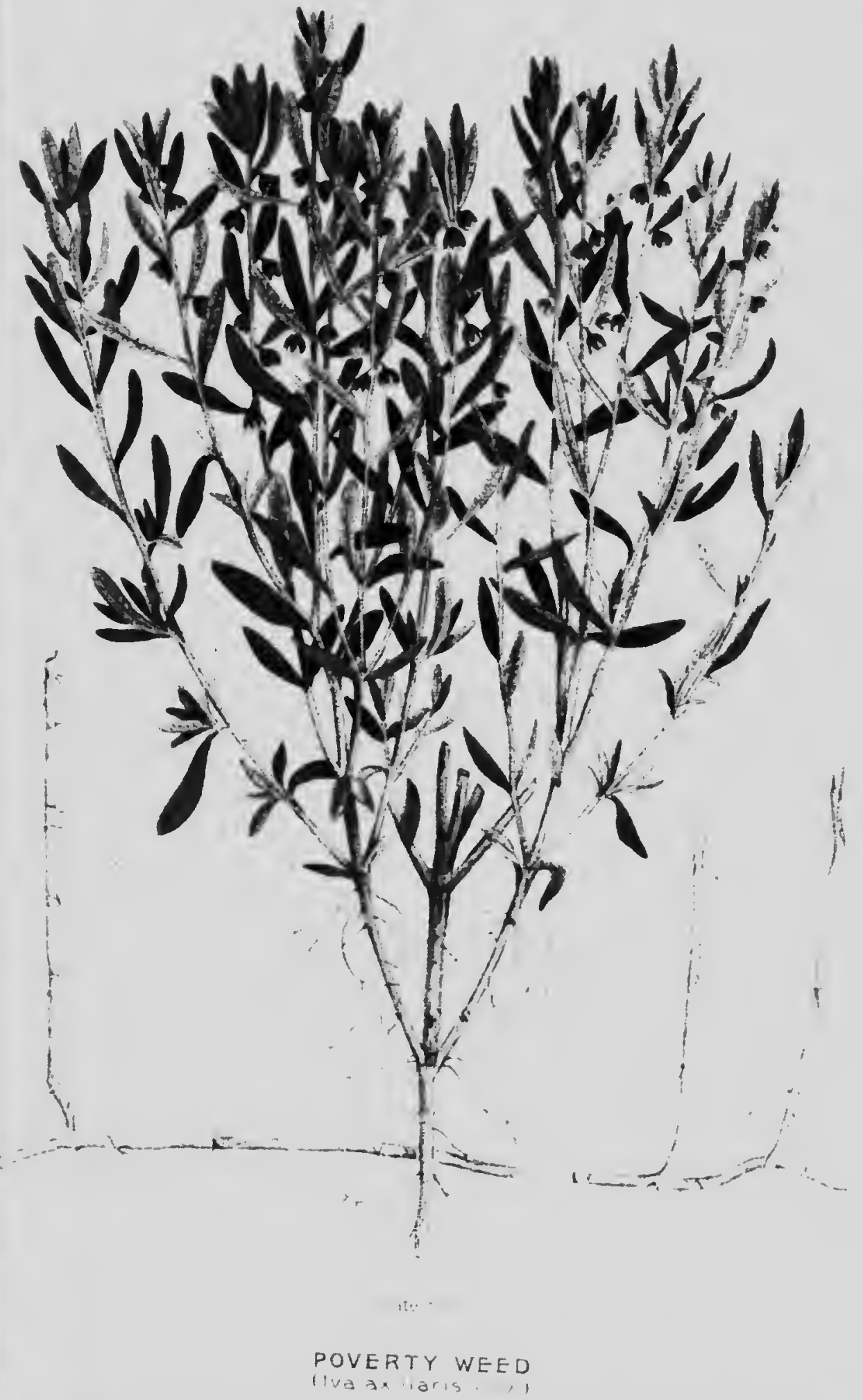




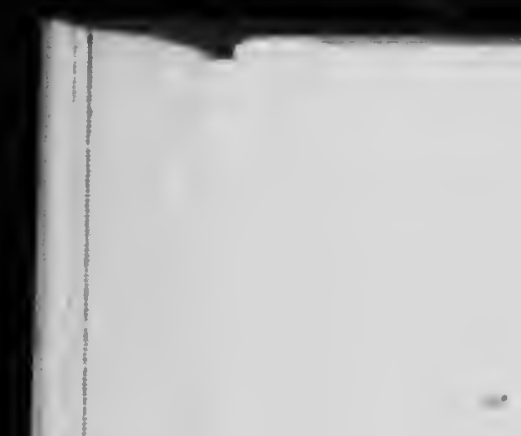


ALLIED SPECIES: False Ragweed (Im xanthifolin Nutt.),

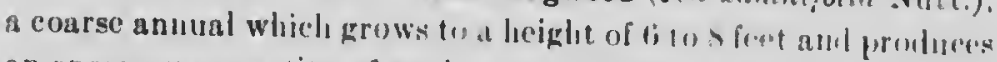
an cnormous quantity of sorel. Bhefore flowering if las a remartable superficial resemblnure to Grent Ragwerel, having tlar

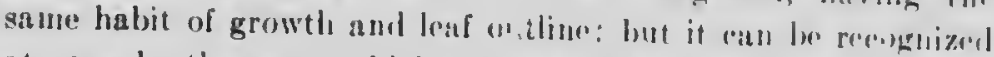
at once by the strom, which is purfertly smonth, while in Cireist

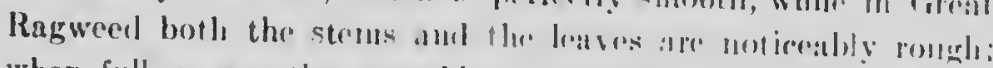

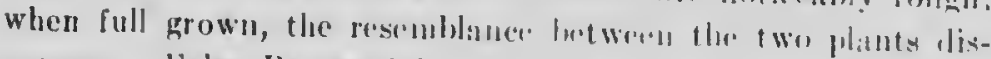

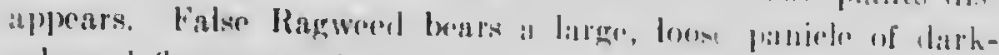
coloured flowers at the top of the steme, while direat Ragwered lats a long, rat-tail-like spitie of male flowers at tle tip of ralle branch.

The seed (Plate 75, fig. 76 ) is of the samm general shitje as that of Poverty Weerl, hut is only 1,10 of at incli lomg, more

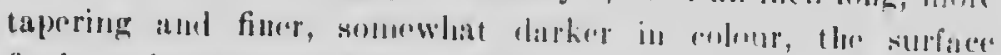

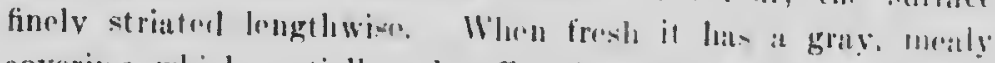
covering, which partially ruhs off and gives it a mottloil alperarance. It is ocassionally fumbl anmong grain, grass and alfalfa secd of western production.

False Ragweed is quite common in parte of the llost,

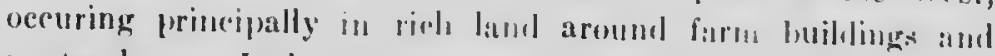
waste places. It does mor oflen give troulde in cultivatgel fiedds.

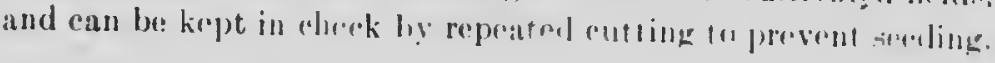

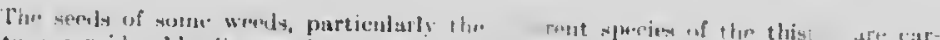

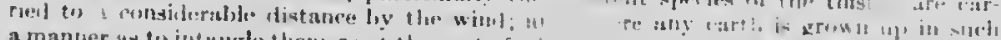

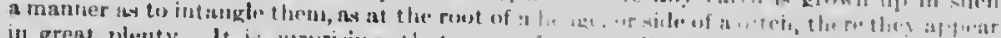

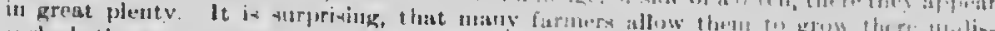

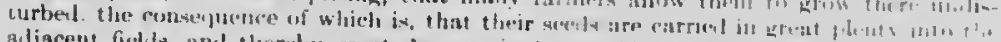

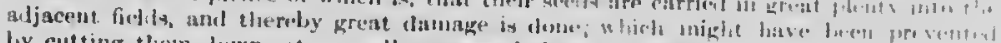

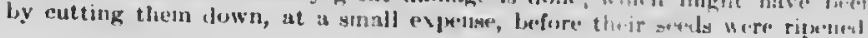

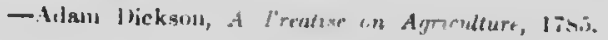




\section{GREAT RAGWEED (Ambrosin trifidu l..)}

Other Linglish hanes: "lall Ragwered, Crownwerd, Kingwerd, Bitterwered.

Native. Anmal. A tall, eoarobranding planc, 4 to 8 fort high, with rough strms aml loaves. loblves palo green, opposite, on long, margined footstalks, viarialule in slatpe, on young plants decply inlented but searcely lolued; as the stems grow, 3 or evell 5-folued loaves are prouluend, but on matuy plants leaves may lo found withont lobes. The male and female flowers arr borne in clifferent heats on the samr plant; the male in long, slemeler spikes at the cmels of the branches, and tl:. fomale 2 or 3 together, stalkless, in the axils of the leaves at the base of the spikes. Male tlowrers $1 / 4$ inch across, culp-shuperl, nodling; stamens yellow and conspicums. fomale flowers inconspicuous; pistils stemiler and purplish.

Tlue seed (Plale 75 , fig. 78 ) is aloout $1 / 1$ inch !ong, brown, urn-shapel, tipped with a tapering beak and bearing arouml the base of this, about $1 / 3$ from the top. 6 or 8 blunt spines, like tie points of a crown, which are the enels of more or less distinet rilss. This crown-lilic appearance of the top of the seed lias suggested the names Kingwerel and Crowuwerl, sometimes userl by millers.

Time of flowering: July, sreil ripe hy the heginning of August.

Propagation: By seeds, which are distributed in grain ani carricel by watel. Illeat from some distriets of the Wrest often

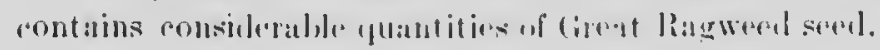

Occurrence: Ontario and oreasional in otlar ractern prorinces. Aburdant in the rioh Rod River lalley in llanitula ant axending wostwat mostly along the railways. 


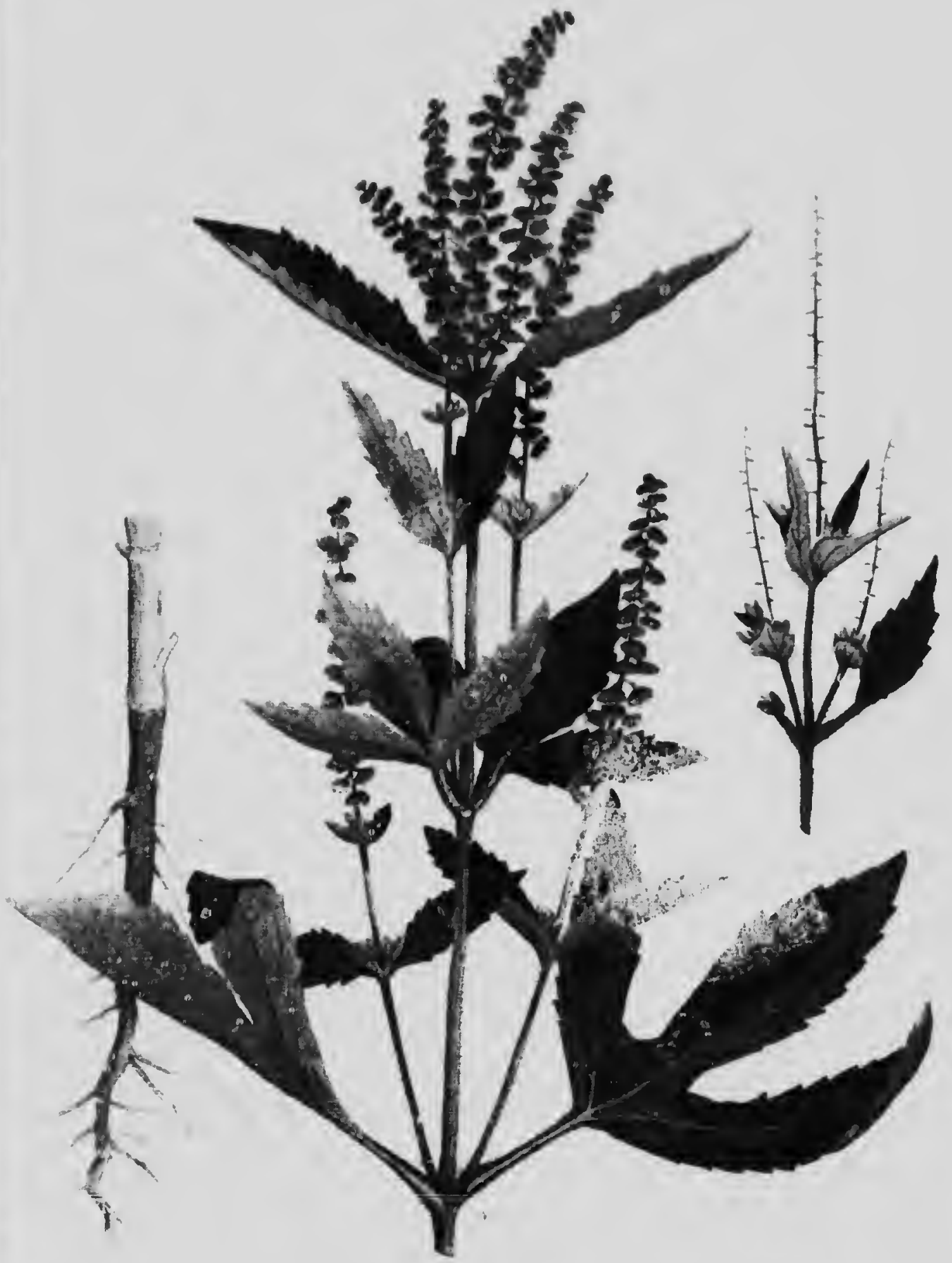




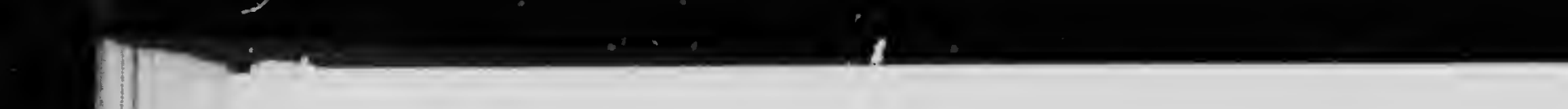

7 
Injury: This coarse annual crowls and starves grain growing near it, but the elief loss to farmers is due to the diflionly millers experienee in separating the serel from grain, owirg to its similarity to wheat in size and wright. The spines evtrh ill the meshes of the scronss and give trubblo in cleaning.

Remedy: This is ore of the frow werels in Manitola for which hand-pulling is pricticable. As a rulde, the plants arr

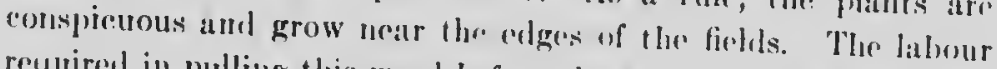
repuired in pulling this weed before the serel is ripe is more than repaid by the increasenl value of the grain harvestonl. Special attention should be given to fielels along streams that are liable to be flooded. A mowing machine shonuld he nsed alound the erlges of infested fietls lefore the sered is ripm.

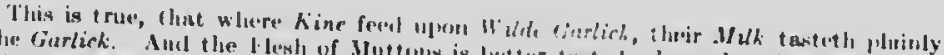

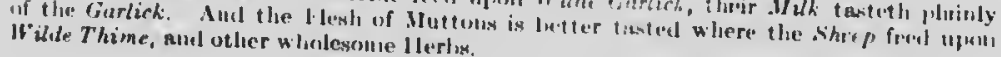
- Harcil, A alutal Mlatiry, Jize.

Most subject i. tho fattest guil to weets.

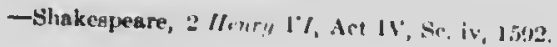

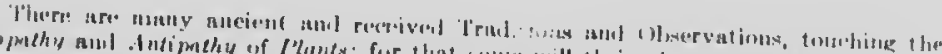

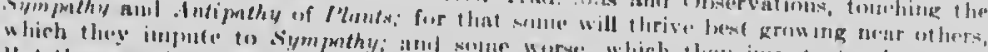

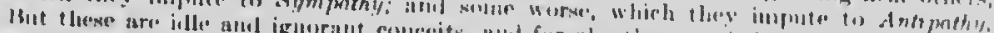

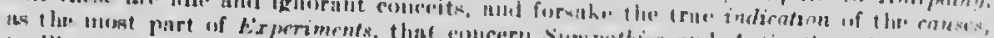

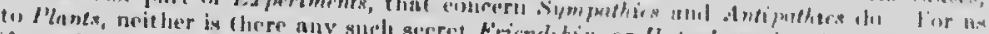

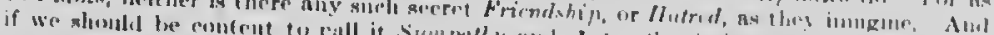

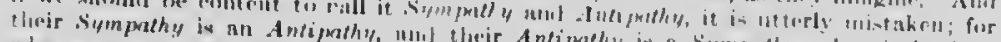

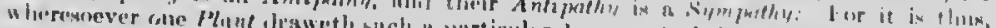

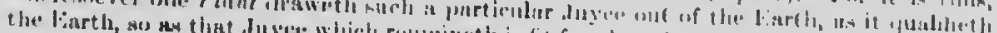

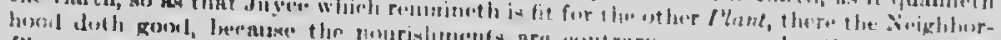

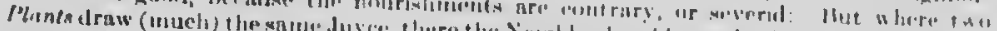
the ot her. 
COMMON RAGWEED ( Imlrosin mitemivifolin 1..)

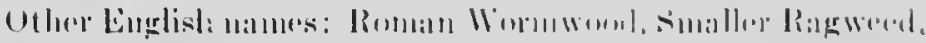
llogwored.

Native. Ammat. A roalse, himmehing plant with hairy

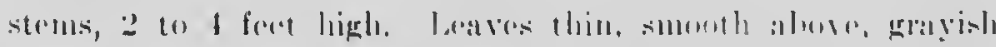

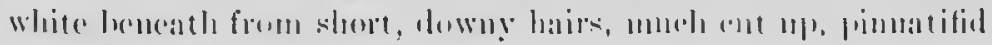

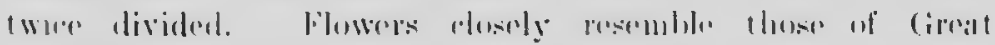

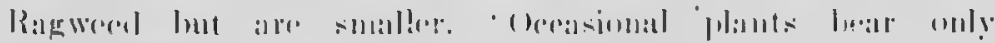
lemille floweris.

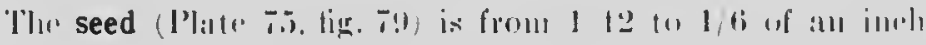

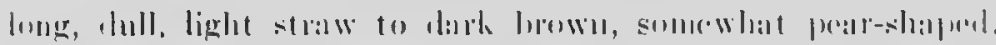
the alex long and tapering to a shatp) peint. The surface i-

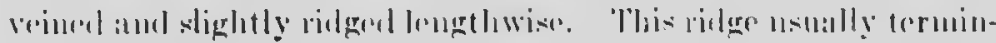

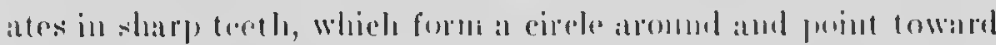
the apex. The se terth valy in mumber, size aml regulatrity and

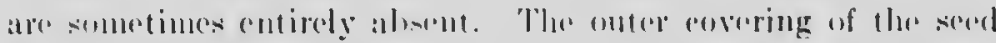

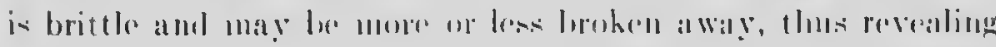

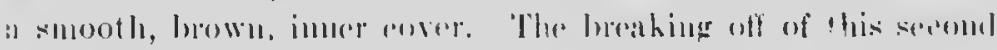

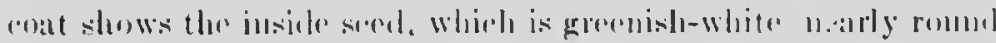

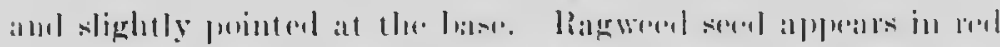

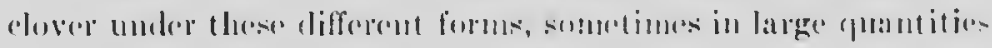

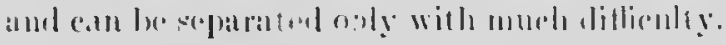

Time of flowering: July: :

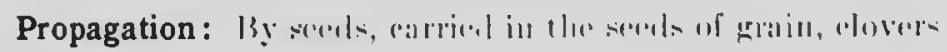
allol glasssos.

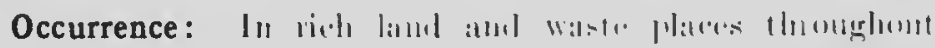

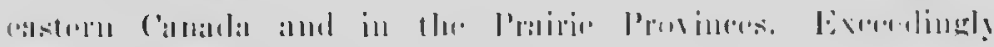

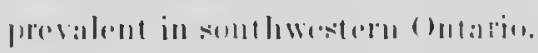

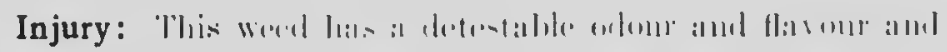

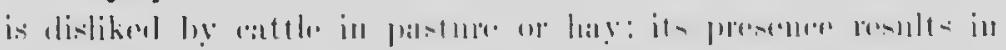

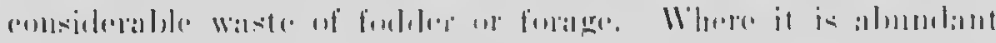

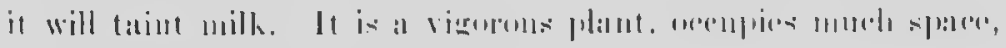

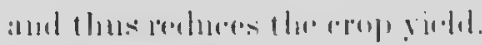

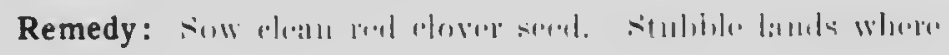

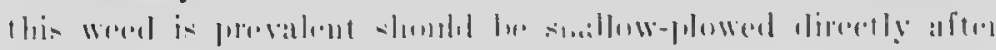




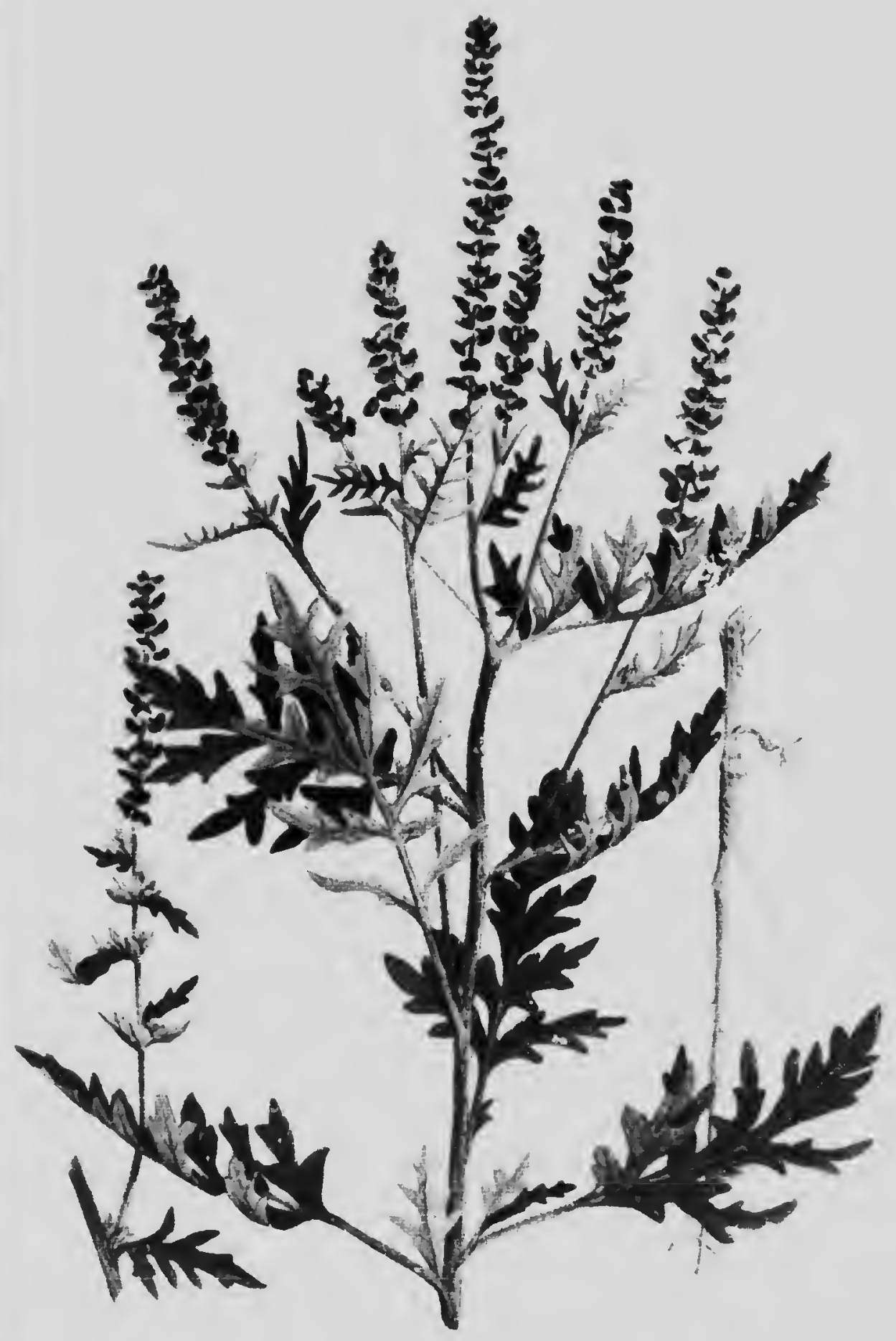




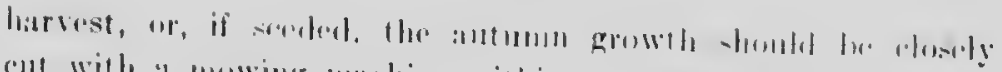

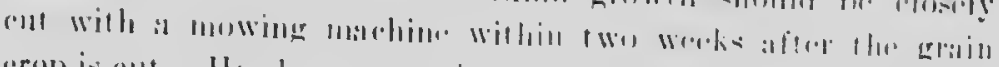

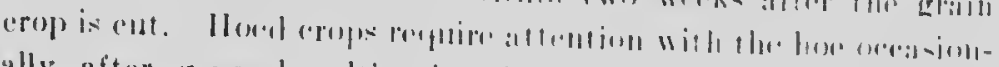

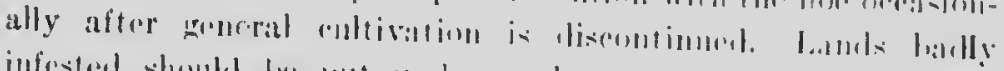

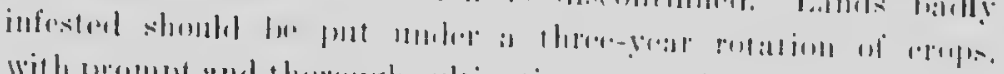

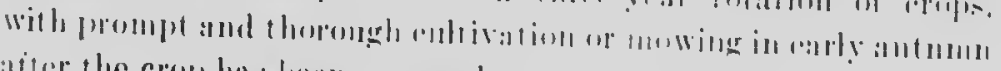
atrer the croph has beren removert.

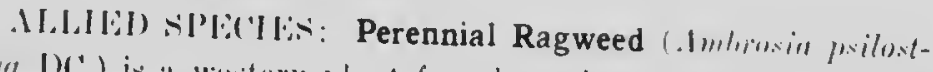

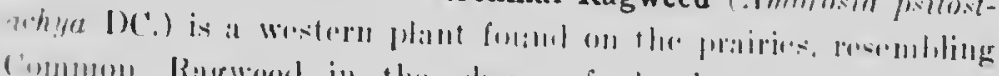

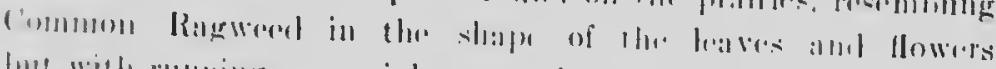

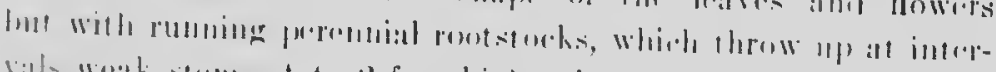

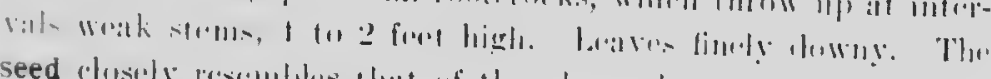

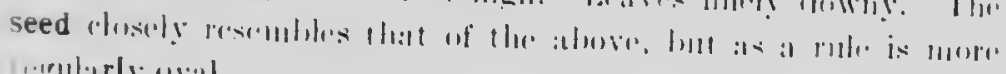
1.'guliarly wral.

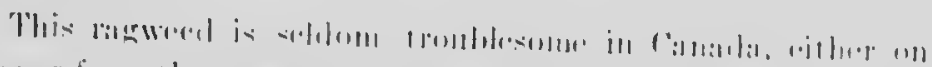

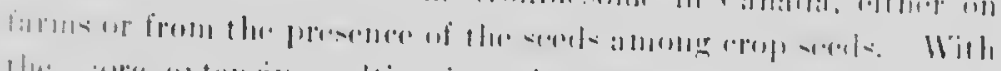

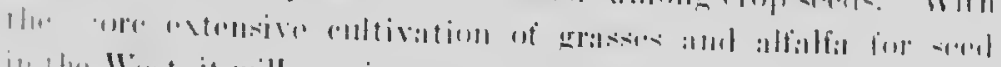

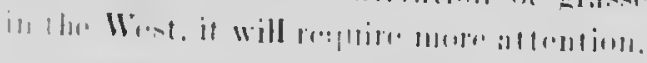

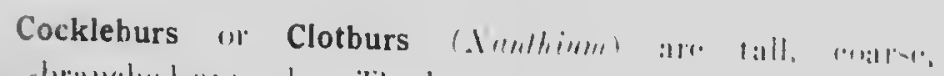

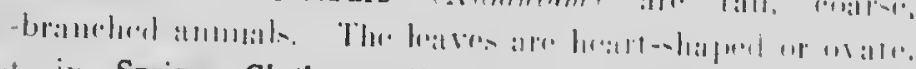

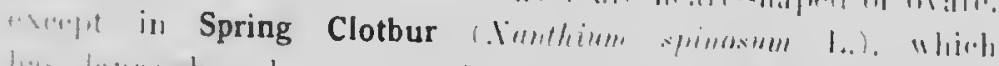

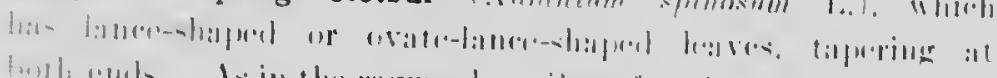

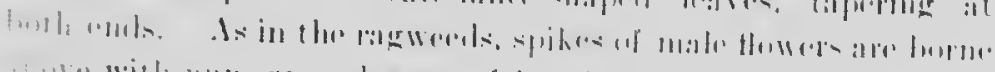

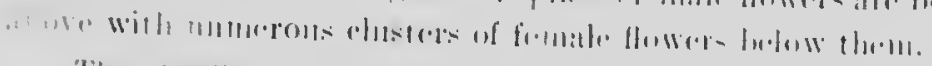

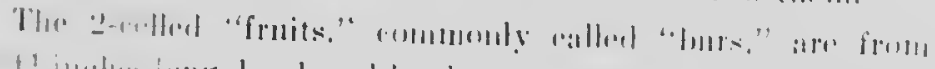

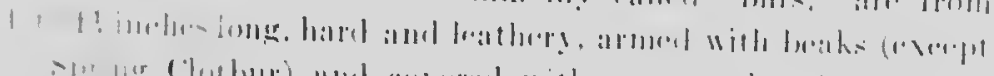

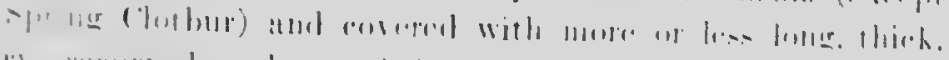

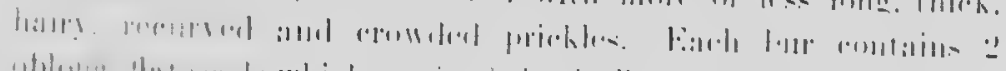

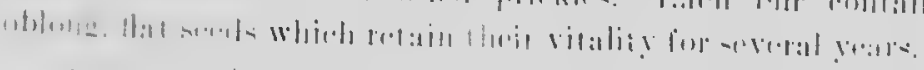

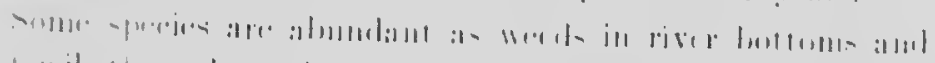

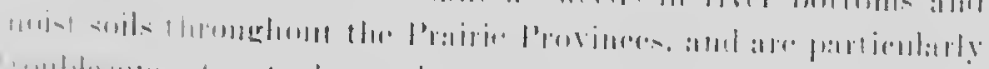

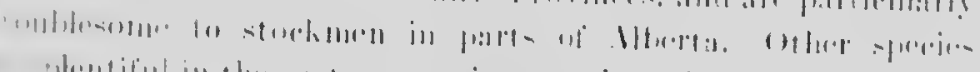

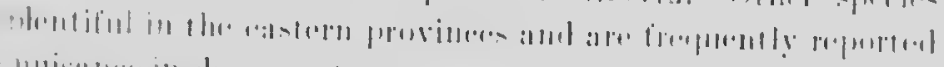

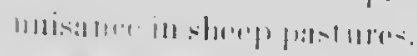

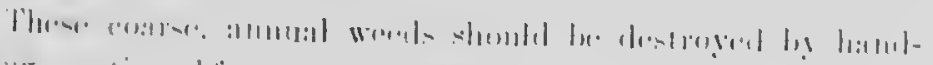

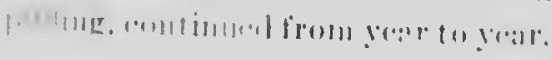




\section{CONE FLOWER (Rudberlina hirta I..)}

Other linglish names: Blalek-eyol sinsan, Yollow lanisy, ()range Daisy, Nigger IIraul, (iollen Jurusialem; sometimes miscalled Ox-('y. Inis.

Native. Biemnial. Course, romgh, hairy thronghont. Stem simple, sonetimes brancherl bolow. lonsures llick, withont loeth or divisions, the mpluer ones oblong-lance-shaped, stalklese, the lower ones brobiler at the tope, lapering towards the base, on footstalks. The molu of flowering is by showy, terminal, usually solitary heats, frlaring golden-1)range, about the size of those of (3x-ryo Daisy. Rays 10 10 20, much longer than the hairy scaly bracts aromul the thwer heall. The alatk brown rentre, with it: ehally sesles hairy at the top, is high, come-shapeol,

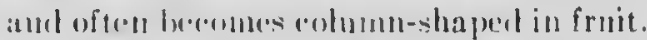

The seed (Plate 75, lig. $6(1)$ is : 1 butt 1, 12 of an inch long,

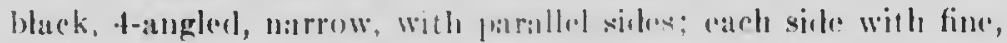
parallel homgitulinat lines. Flu (up) of the senel is flat and bears Iแ1 рімирuк.

Time of flowering: dum (1) August: sont riph by dugust.

Propagation: $13 y$ serests.

Occurrence: In prairie and pasture lambs, ohl meatows and oceasionally in altivater liolds. Alument in Quebec, where it has doubtless bern interhluered from westorn cinata.

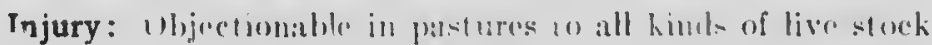

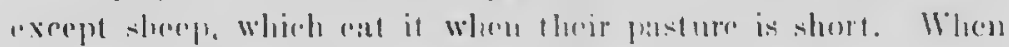

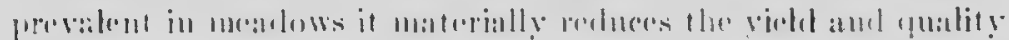

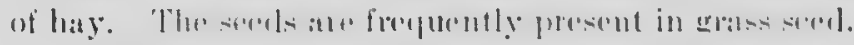

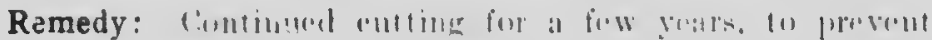

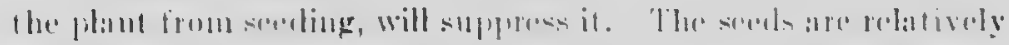

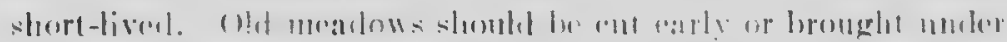

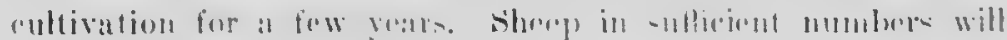
-uppress this woml in pasture lants.

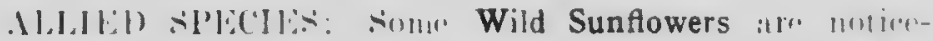
able werkts in the Prairir l'rovinere. In Manitubit Black- 


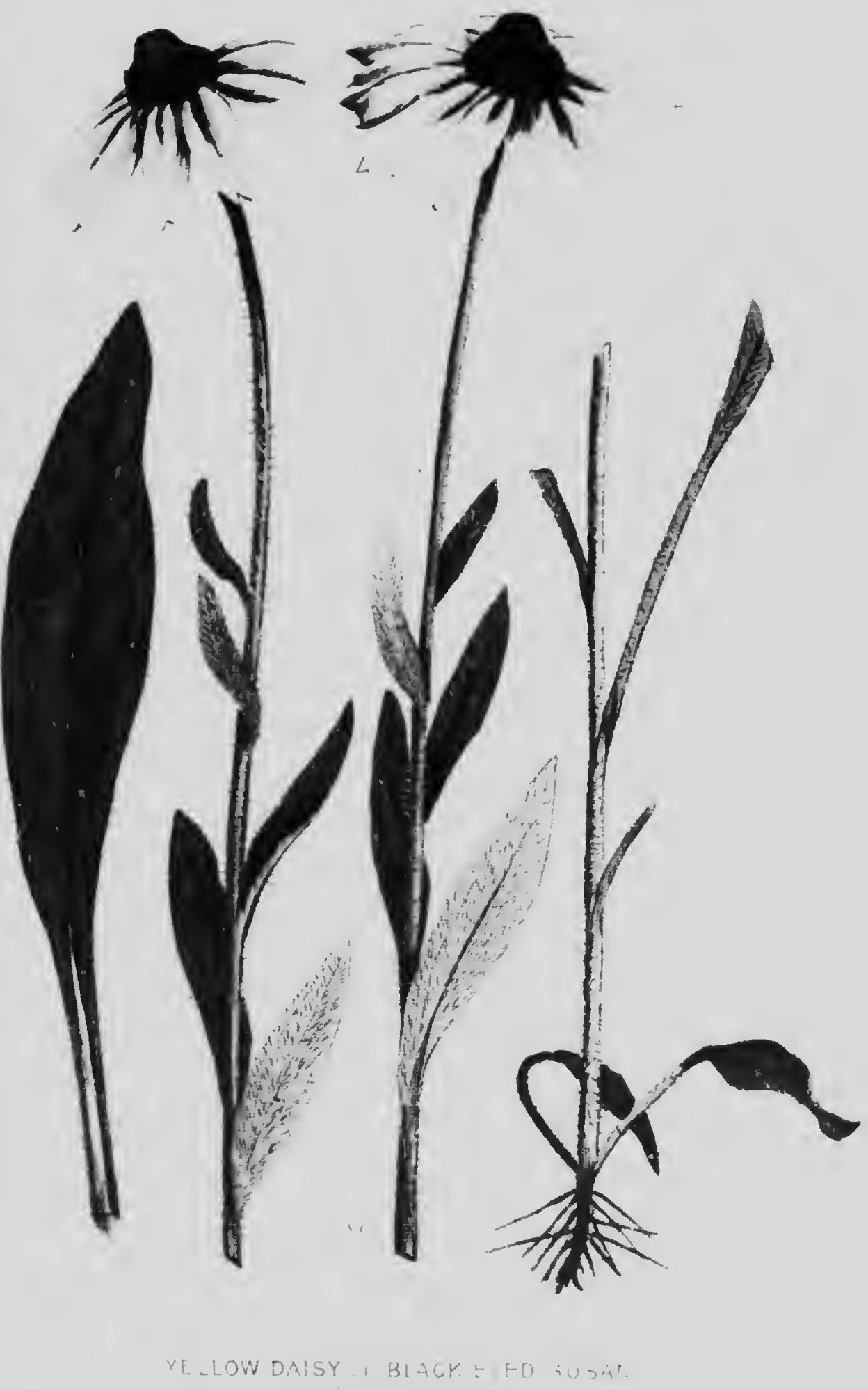




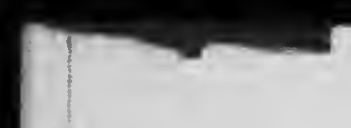




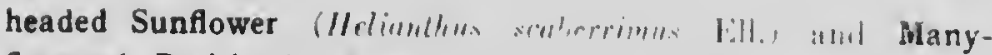

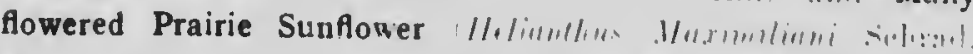

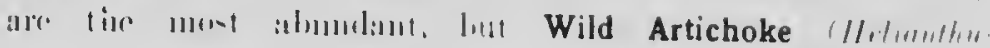

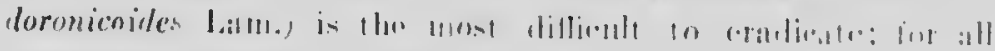

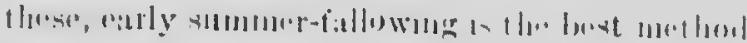

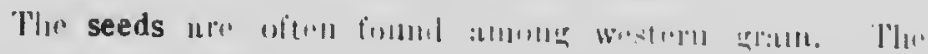

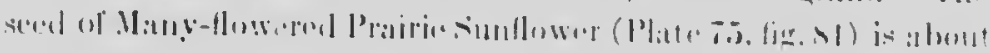

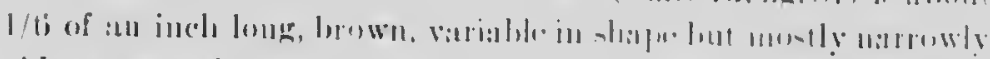

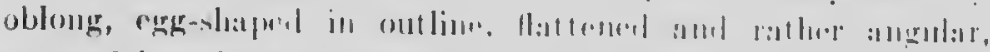

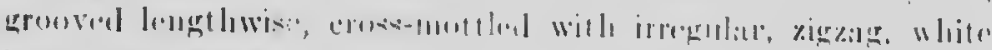

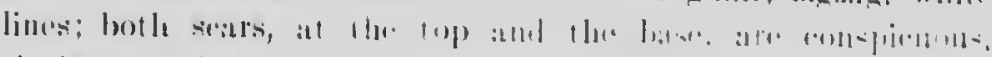
tho lattere ratlere oblipur.

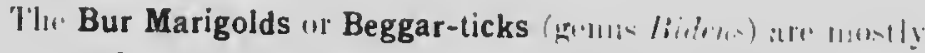

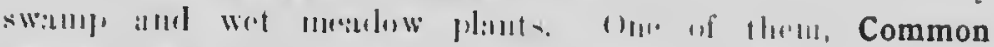

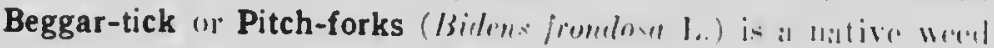

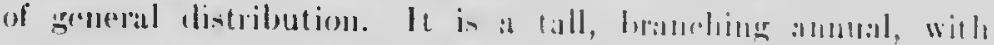

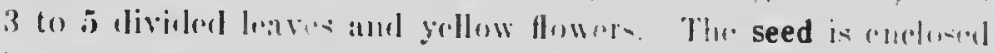

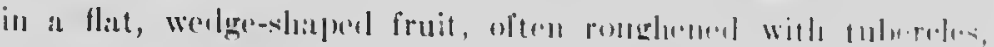
olive brown, alout $1 / 1$ to $1 / 3$ of an imeh hog, provildel with

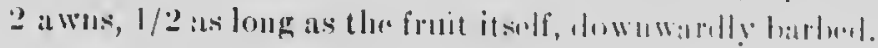

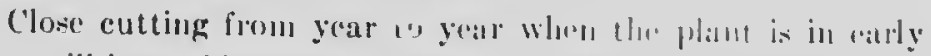
bloom will krep this weet in relock ly prerenting the protuetion of sered.

\section{'TRIBE HLI E.OIEAE}

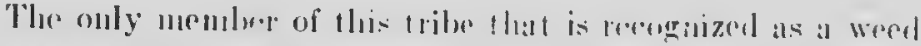
is Sneezeweed. False Sunflower or Yellow Star $(1,1, \ldots \ldots$

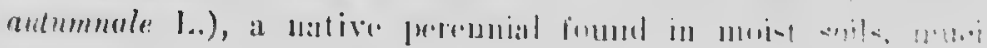

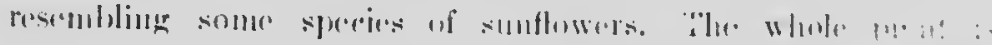

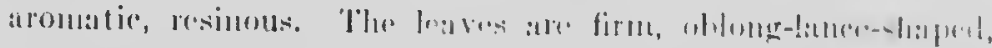

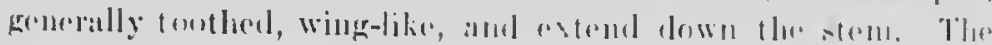

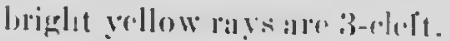

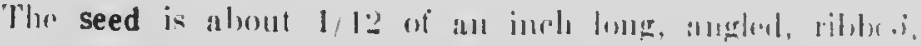

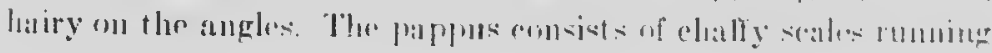
into leristles. 


\section{TRIBL ANTHFWIDEAE}

\section{STINKING MAYWEED (Anthemis Cotula 1..)} Frincl.

Other linglish names: Mayweed, log's Chamomile, Dog

()ther latin namie: .Mamia ('otula I)(:

Introrlued from linrope. Aunual or winter anmual. Dult green, slightly hairy or hairless, with an acrid taste and a strong, fetid odour. Stems 12 10 18 inches high, much branched from the root up. leaves fiucly dissectud, twiee or thrice pinnatifid. Flower heads numerusus, white, yollow-ryoul, daisy-like, only about 1 inch in dianeter, supportod hy slender, naked footstalks, forming a flat top bunch. Towarl maturity the rays turn abruptly downward.

The seed (Plute 76, fig. 8.3) is snıall, about $1 / 16$ of an inch loug, ovate-oblong or oblong, cut off stright at the upper end, with a small knob in the eentre, the smaller and abruptly pointed. The surface roughenel with tubreles arranged more or less syımetrically in abont 10 longitudinal rows; sometines, however, the surface is nearly smooth.

Time of flowering: Sunner to autumu; seed ripe by July and young plants sometimes abundant in Septrmber.

Propagation: Hy sicels.

Occurrence: A common werd in old settlements, around lunildings, along roads and in wast plares, from the Atantic Coast to Manitoba, where it is rare as yot and found only along railways but is rapidly appearing in uew districts.

Injury: An objectionable pest in fields and gardens; most abundant where crops have killed out in wet plares. The seed is a coumon impunity in grass and elover sects. The dust from Maywed, ragweel and others of this fanily, produced in threshing grain, is irritatiug if not poisonous. 


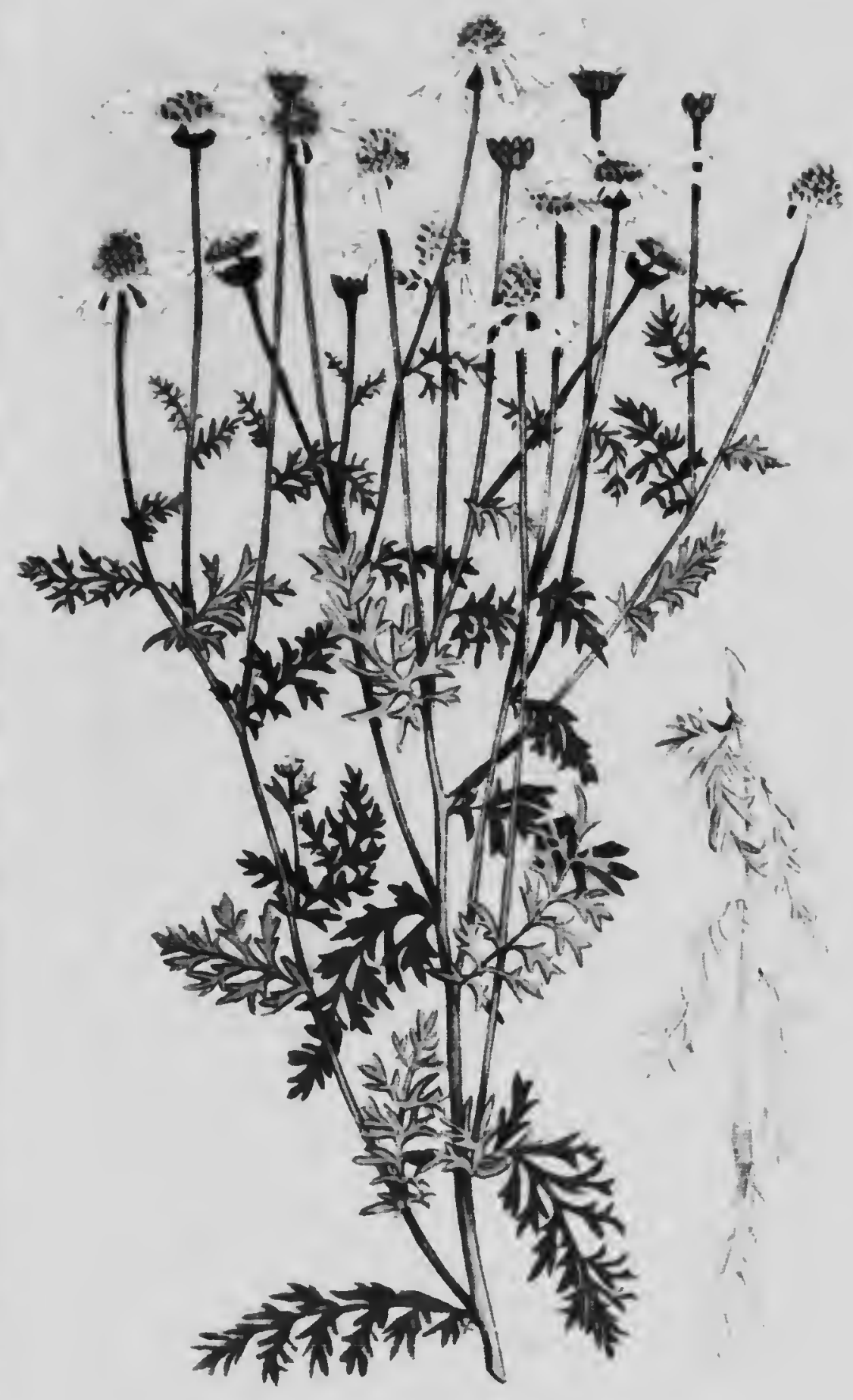




$$
\rightarrow
$$




\section{MICROCOPY RESOLUTION TEST CHART}

(ANSI and ISO TEST CHART No 2)
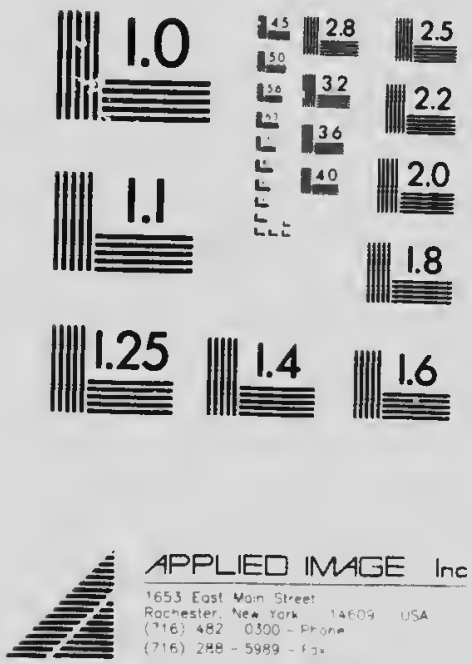


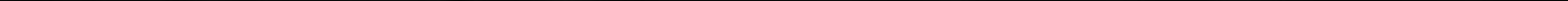


Remedy: Sow clean grass and rlower secels. Wo unt allow the plant to mature. Clean up waste plares about farmyarts and seed to permanent grass that will talse fall possession of the soil to the exelusion of this and ot her wereis. The glant is u<ually prevalent in garlens fertilized with minure from city stables. The seeds are not long-lived and the vitality of many would be destroyed by piling the manure and allowing it to forment for a few inonths.

AJIJED SPLCIES: In the Maritime Provinees Scentless Mayweed or Chamomile (.Matricaria inorlora I..) is commonly found growing with the above. The two plants resemble rald other, but seentless llayweed is a nucle handsomer plant, witl. flowers nearly 2 inches across and foliage of a dark, rich green. It lacks the unpleasant orlour.

The seed is entirely different, being about $1 / 10$ of an inch long, square, somewhat flattened, dark brown except tle margined top and tle 4 very prominent, wing-like ribs, present in some seeds, which are generally mueh paler.

Yarrow or Milfoil (Achillea Millcjolium L.) is a well known plant by waysides and in meadows throughout the Dominion. A native form in the West oceurs high up on the mountains as well as on the prairies. The ereet stems, 6 to 18 inches high, bear flat-topped elusters of white flower heads and fincly-divided, fern-like leaves.

The seed (Plate 76, fig. $\$ 2$ ) is aboul 1/16 of al inch long, gray with a white margin, flat and thin, oblong-wedge-shaped. It is similar to the seed of Ox-eye Daisy, lut flat, smooth and ribless. Often found among seeds of the sualler grass.

Who soweth his Barley too soon, or in lisin,

Of thats and of Thistles shall after complain.

I speak not of May weed, of Cockle and such,

That noieth the Barley so often and much. 
OX-EYE DAISY (Chry.unthemum Leucanthemum L..var. pirnatifidum l.eeo( \& lamotte)

Other English names: White 'Jaisy, White Werl.

Other Latin naine: Leuearthemum vulgare Ialn.

Introdueed from Europe. Perennial, shallow-rooted. Stems numercus, simple or little branched, 1 to 3 feet high. Basal leaves are more or less pinnatificl or coarsely and irregularly toothed; middle and upper stem-leaves narrowly oblong or somevilat lanee-shaped, conspicuously pinnatifid at the base. Flower heads solitary on long, naked footstalks, very handsone, $1 \frac{1}{2}$ to 2 inehes aeross; rays 20 to 30 , pure white, spreatling, 2 to 3 -toothed at the apex; centre flowers yellow.

The seed (Plate 76 , fig. 84 ) is $1 / 12$ of an inch long, elubshaped or elongate-ovate, usually eurved, almost straight on one side and eonvex on the other, the knob-like sear at the top prominent; 10 well-clefined white riclges run the whole length of the seed, meeting at both ends; between these ridges the surface of the seed is black, minutely totted with white; no pappus. A single plant produres íroln 5,000 to 8,000 seeds.

Time of flowering: Junc; seets ripe in July.

Propagation: By short offsets from the wooly rootstock, and more abundantly by seeds.

Occurrence: Enormously mbundant in old pastures, in meaduws and by roadsides from the Atlantie Coast to the borders of Manitoba and occasional along the railways to the Pacific Coast.

Injury: A vigorous, persistent weed in old mearlows, where it soon ehokes out the grass. It frequently gives trouble in lawns. The seed is eommon in timothy and other grass seets.

Remedy: Sow elean seed. Sllatlow plowing of sod in August, with thorough eultivation from time to time until frost, will 


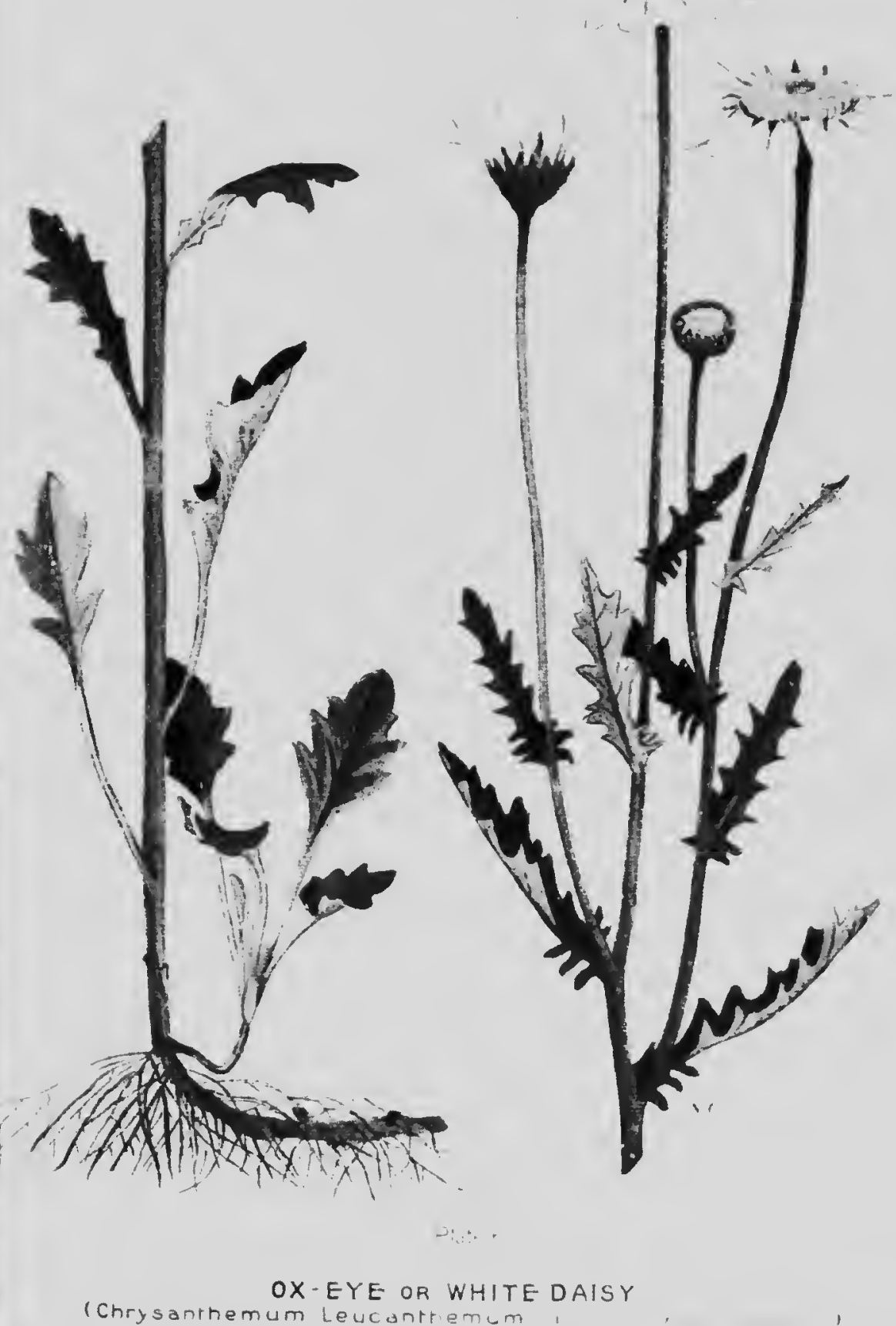$$
-40
$$

ck, in

ers ific 


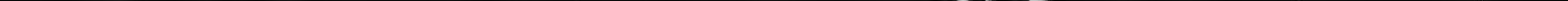




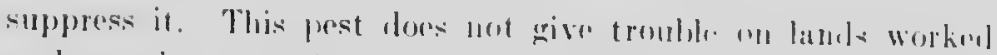

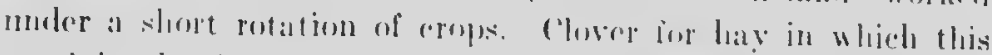

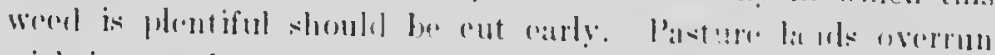

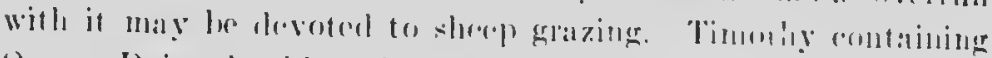

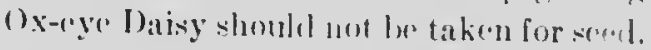

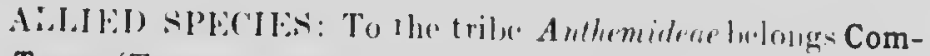
mon Tansy (Tanacetume culyure l., which is yuite difficront from Commor Ragwort, although the two plants sirem to be confuserel in the Naritime P'roviness, Tansy hats almost rayless flowers;

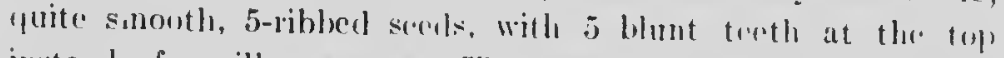
instead of a silky pappus. The plant is fleasantly aromatio insteal of rankly fotid, a characteristic which in Nova sicotia has gainesl for Common Raywort the name of stimking Willie.

On the western plains there are many species of Wormwoods (Artemisia) whinli are spolin of collectively as Sage Brushes. Two of thrse. Pasture Sage (.Iremixia ludoriciund Nutt.) and the so-ealled Sweet Sage or Lnsser Pasture Sage (.I rlemivia jrigilla Villd.) sometiunes infest home pastures, where the grass hats hern eaten elose, necessitating brouling up the sol]. The best knwwn of the wormwoods is False Tansy (Arteminin biennis IVilht.), a bionnial which occurs in all patrts of c'analia, Althongh wasily

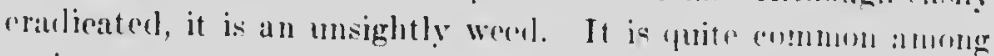

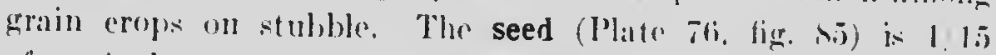
of an inch long, dark brown, egg-shaped, wrinklod longhthwise.

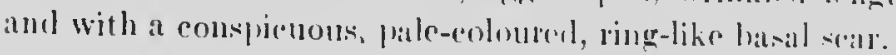

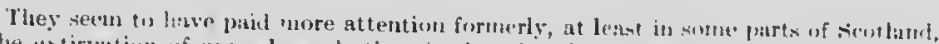

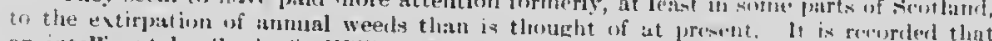

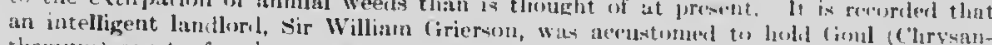

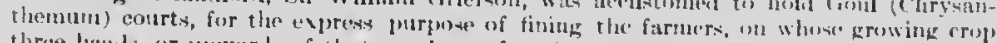

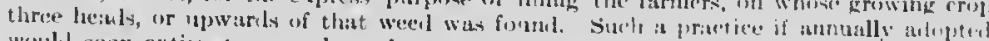
woul.l soon extirpate annual wceds.
} 
TRIBE: SHATECIONEAE:

\section{COMMON RAGWORT (ivenerin Incubatn I..)}

()har English manure: Stinking Willie, Hantghlan, Tansy Ragwort, staggerwort, st. James'-wort.

Introduced from lupope. Pereminal from few shallow, short, thick rootstocks. Cuder cultivation many plants, after flowering the second year, dir without making any offists. Whole plant ahmost haijless or with tufts of woully hairs at the base of the leares and flower heads and straggling hairs over the whole surfare. Stem stiff, ereet, grouvel, 2 to 3 fret; much brancherl above. Root-leaves 6 to 8 inches long, staltied; stontleaves stalkless, rmbracing the stem; all leares dart green, deeply twice pinnatifid, the segments croweted anel overlapping, crisperl and wavel. Flower heats golden-yellow and very showy: :3/t inch across; numerous, ereet, arrangerl in flat-topporl, dronse, compound corymbs.

The seeds (1'late 76 , fig. 56 ) are about $1 / 12$ of an inel long, ereamy white, oblong, excavatrel at :ne top, with a small central point, deeply grooved along the rides; those of the center almost straight, wore or less an, r. , short bristles; those of the ray-flowers smeoth, me : and broater; pappus white.

Time of flowering: July till N. ....ser; serd ripe by August.

Propagation: By seeds and by a fow off sots from the base of the stemt.

Occurrence: Abundant in Pictou and Antigonish comties in Nora Scotia and in parts of P'rince Edward Island; also reported from Quobec and the township of Puslinch in Ontario. It louts as though Ragwort hath been imported into Nova seotia from Scotland and into Prince Felward Island from Irolant, where it is known under the same name, Baughlan, as it bears in its new home. 


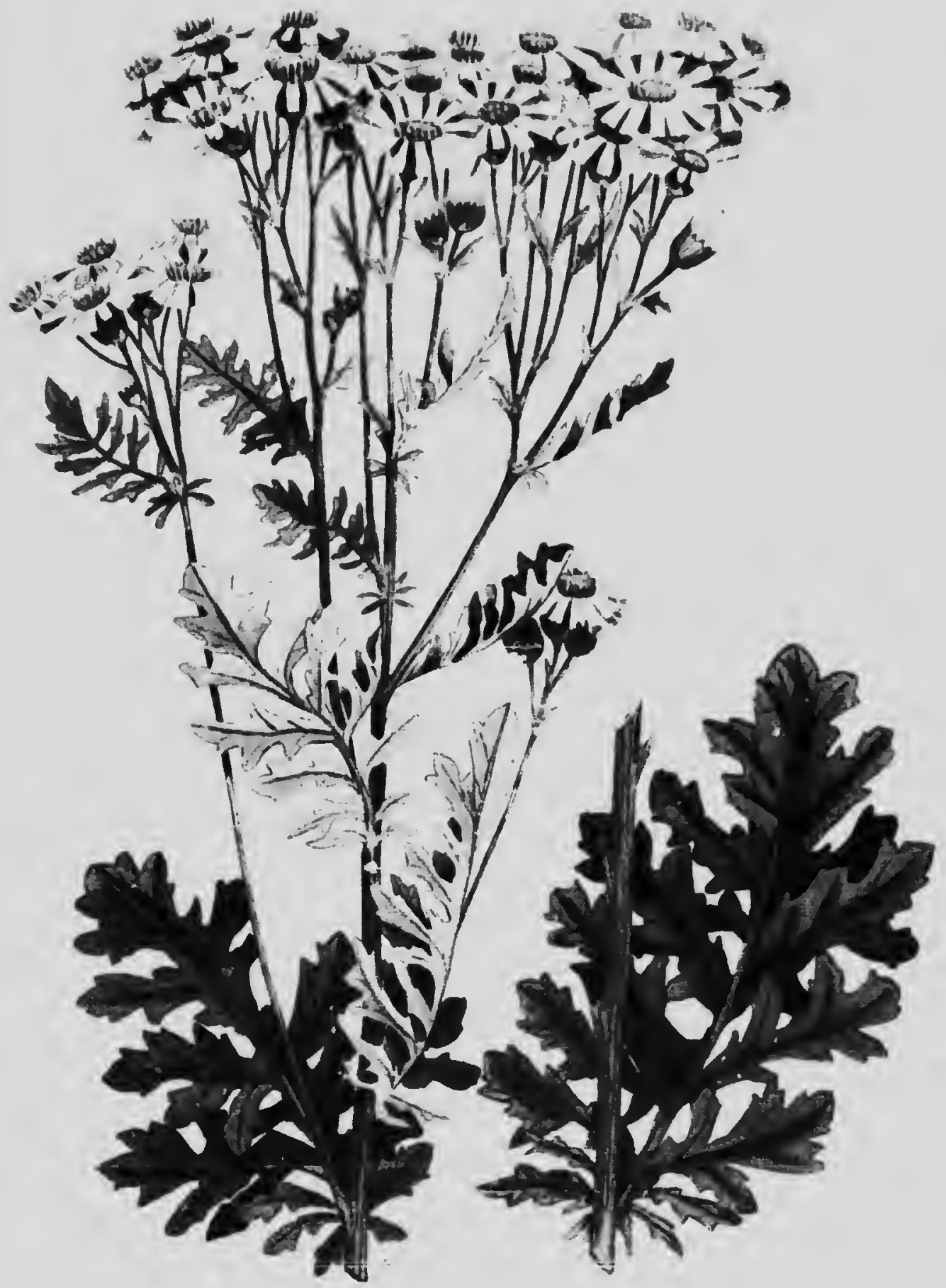




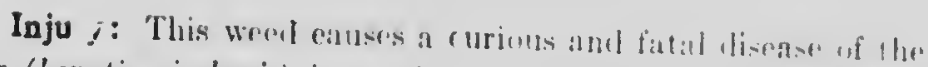
liver (hepatic cirrhoric) in caltle. For many yours it wats ms-

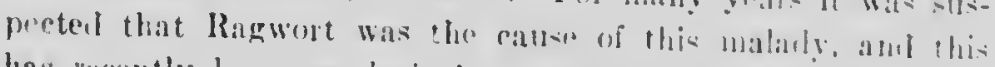

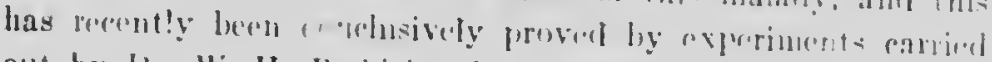
out by IJ. W. II. Pethick, of Antigunish, mulur the dirertion of the Doninion Veterinary birretor General, br, J. (i. R Itherford. The disease, previonsly stepposed to he eomtingums. has been removed from the list beale with muler the duimal lomtagious Diseases Act.

Remedy: Fvery coffort should be male to ranlicate this coarse, conspicuous and dangerous plant, now that there is proof of its nature. It does not incrmase extensively from the root and there is good evidener that where it is mowed systemutirally it soon disappears. In pastures aul mealows revery plant should be grubbed out before the seeds form. Ragwort is not reallily eaten by eattle when green: the first attention should therefore be given to eleaning meatows, becaus it is caten by all kinds of stock when mixed with hay. A short rotation of crops wemlel at onee exterminate it. Sheep can eat this werel with connparative impunity and it dies out when closely eatenoff. Systematic and combined effort should be make by muncian anthorities to have it destroyed along roadsides.

ALJ.IED SPLCILS: Common Groundsel (seme in mitgri l.)

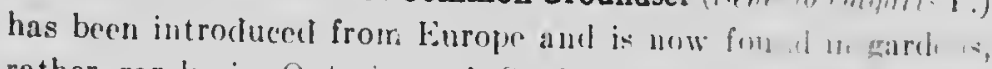
rather rerely in Cotario anel Quebec an!l the l'l '"l $\mathrm{P}$, inees tet abundantly in lhe Maritime Provinee al , Pacifie Coast. It is a small, branehing plant, 6 to,, tw in ? " bearing many tassel-like rayless fouers. The seed and narow, spindle-shaped, the upper anl hlunt ath:t enlarged by the white apical seur; surface fincly riege! wise, and covered with slort white bristles, difinring from the seed of the similar Stinking Groundsel (Senerio) I.) which oecurs in the Maritime I'rovinces with conts. Groundsel. Stinking Groundse. is riseid-hairy, its flower lifut bear marginal ray-florets, and the seed is rather loug, entire without bristles. 
Fireweed (Erechtiles hieracilolia (I.) Raf.) is a tull ranksmolling numul, with general habits of growth like some varieties oi gi oundisel. Thr brunched steni is sueculont and charucteristicully strinte. 'The flower heads are numerous, small, whitish and conspicuously swollen at the hase before opening.

The seed is small, linear-oblong, tnpering at the end and be-aring a thick pappus of fine, soft, white hairs.

The common nane, Fireweed, comes from the fact that this weed often occurs on land that has been swept by fire.

\section{TRIBE CYNAREAE}

\section{LESSER BURDOCK (Arctium minus Beruh.)}

Other English naines: Bardane, Comınon Burdock, Clotbur.

Other Latin nanes: Lappa minor DC., Arctium Lappa I.., var. minus Gray.

Introluced from Europe. Biennial, from a deep, thick, taproot. Root-leaves Inrge, heart-shaped, downy beneath, somewhat resembling tl.ose of rhubarb, footstalks hollow. Flowering stein much branched, from 3 to 6 feet high. Flowers purple, flower heads numerous, $3 / 4$ inch aeross, in clusters at the tips of the branches and in the axils of the upper leaves, ovalglobuiar; the scaly bracts surrounding the flower-heads ending with hooks, by which the seed-bearing heads become burs and are distributed by adhering to passing animals.

The seed (Plate 76, fig. 87 ) is about $1 / 4$ of an inch long, pale brown with rlark, transverse, zigzag, depressed marks, oblongovoid, cut off abruptly at each end, flattened, with about 5 longitudinal rilges generally somewhat curved; apieal scar eircular with a central point; pappus, when present, consisting of several rows of short bristles, upwardly barbed. 


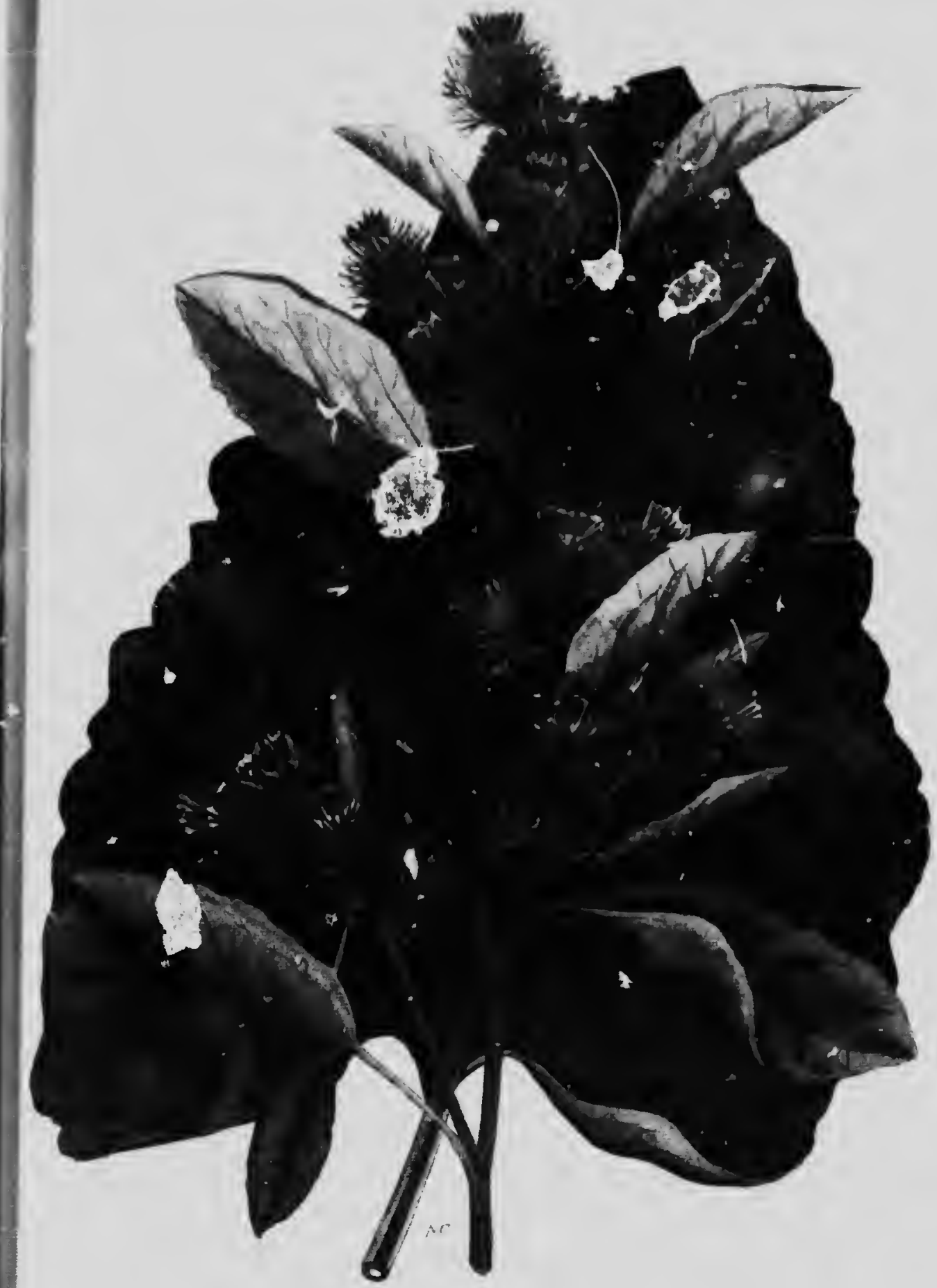

COMMON BURDOCK

(A-Criun minus": ) 


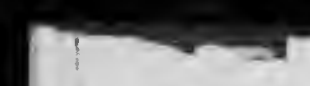


Time of flowering: July-August: seerl ripe hy sinptember.

Propagation: $13 y$ serels.

Occurrence: Rich land in the older settled provinees: comnon by roadsides, in waste places and orrhards in sod.

Injury: An unsighty weol about farmyards, Naste places wut in orchards. It is esperially objectionablo in pastures where sherp are kept. It sclelom gives trouble in ficlels under clean cultivation.

Remedy: Cut below the crown or spunl out when the ground is wet and soft, either the first vear or hefore the seeds are ripe the second. A handful of salt applied aftur eutting in hot dry weather will kill the plant. Waste places shonlel be seceled to grass and the weeds kipt out until the grass has become firmly establisherl.

ALIIED SPECIES: Great Burdock (Arctium Lappa L.), not as common as loesser Burlonk, is a larger, enarser plant, with much larger, green flower leearls, $1 \frac{1}{4}$ iuch aleross, with hooked scales and more sprearling and lougur leaf stalks.

For out of the old firlules. as men stitlie,

Cometh al the nuew rorme fro yore to yer.

And out of olit buokes, in kisin! foithe

Cometh al this new science that nien lere.

$$
\rightarrow \text { Chaucer. 7\%e dasembly of Fule, 13世1 }
$$

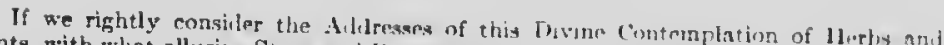
Plants, with what alluring Stepy aul laces the Stuly of them direds $l^{\circ}$ s to an anduiration

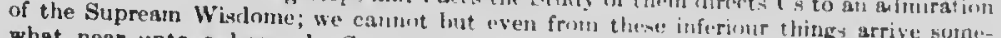
what near unto a heavenly Contontment.
} 
CANADA THISTLE ("irsium arrense (I..) Scop.)

Othor Finglish names: Crerping Thistle, soft lield Thistle.

(Other Latin names: Cardums ariensis (I.) Robs.: ('nicus uriensis: IIoff $m$.

Introlued from Europe. Peremial with deep running routstorks. Stems orect, 2 to + foet high, marked with finc lomgitulinal lines. Leaves variable in shape, deeply pinnatifil, wavel and erested, very prickly, in some plants much less so than in others, somm what lowny, particulaly beneath. Flowere heals numerous, in a large loose coryub at the top of the stems. Flowers variable in colour, ranging from pale purple through shades of pink to white. Some plants bear male Howers omly, which form no serels, other phants frmale flowers only, which produce many serels; the flower heads of male plants are nearly globe-shaped, 1 inch arress, those of the fomale plants only about half as large, oblong, with short florets. Isarge patehes may be found bearing only male flowers, showing that all the plants originated from a single seed.

The seed (Plate 76 , fig. S9) is 1 \& of an inch long, light hrown, clongated oblong, smooth, somewhat fattened and curred, more or loss bluntly angled, marked with faint longitudinal lines: the top is nealy round. flat, and has a narrow rim with a small cone-shaped point in the eentre: pappus copious, white. The pappus oasily loreaks off ly threshing ambl hamdling and in absent when the serel is foumbl in commereial grain and serels.

Time of flowering: Inur to . Iugust: serel ripe hy July:

propagation: By serels and extensive rootstoeks, which sond ny both leafy barren shoots and floweroug stems. This well kuown post. which, although called Canala Thistle in Sorth America, is really the Fiblh or ('reepling Thistle of lingland, has beren introlueed into almost all the british eolonies and has

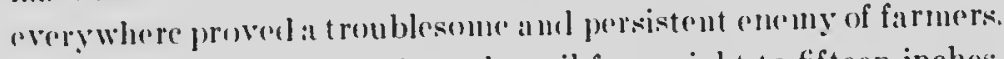
The rootstoreks run down into the soil from eight to fiftern inches,

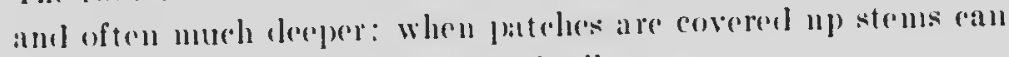
he thrown up through many fort of soil. 


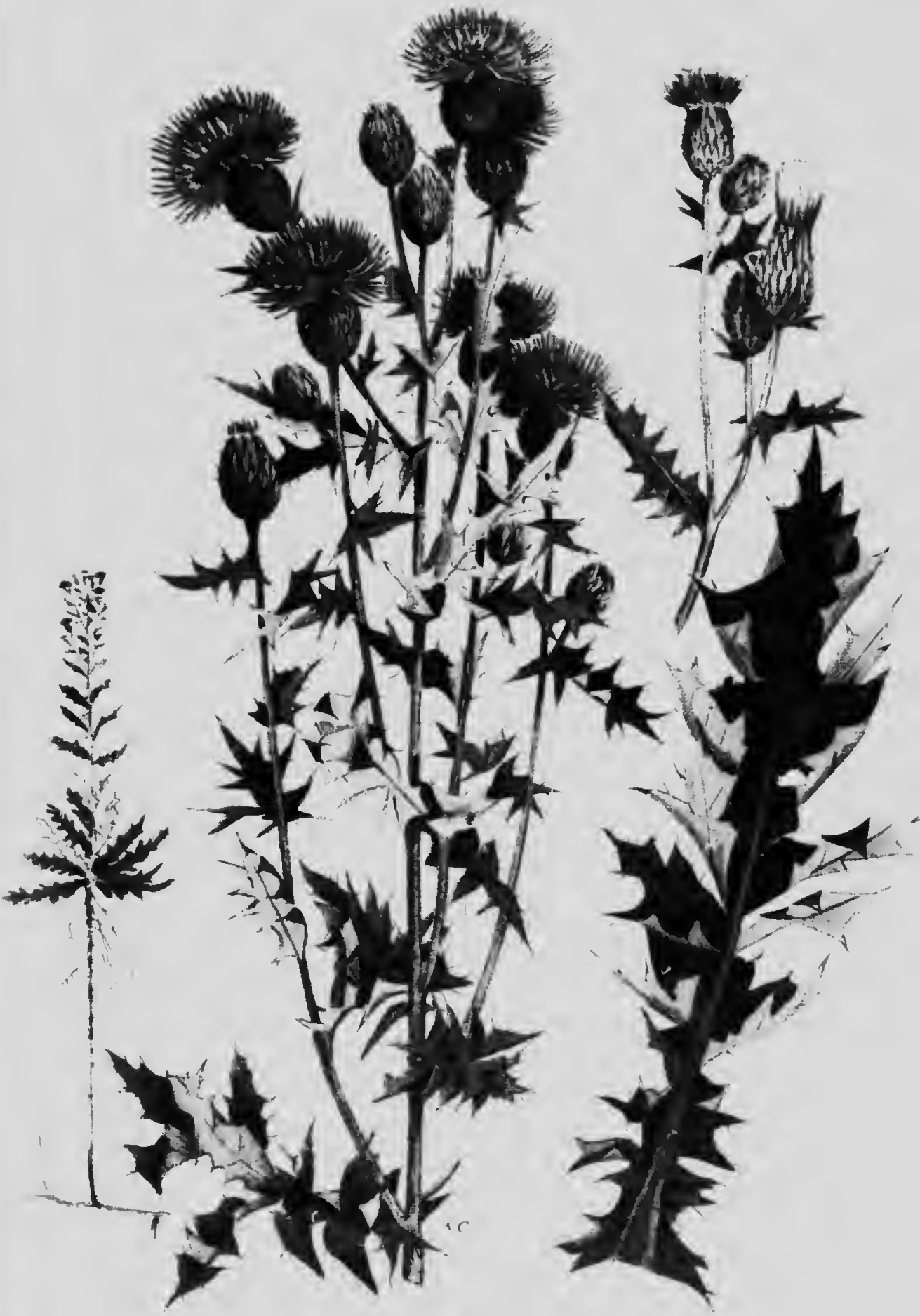




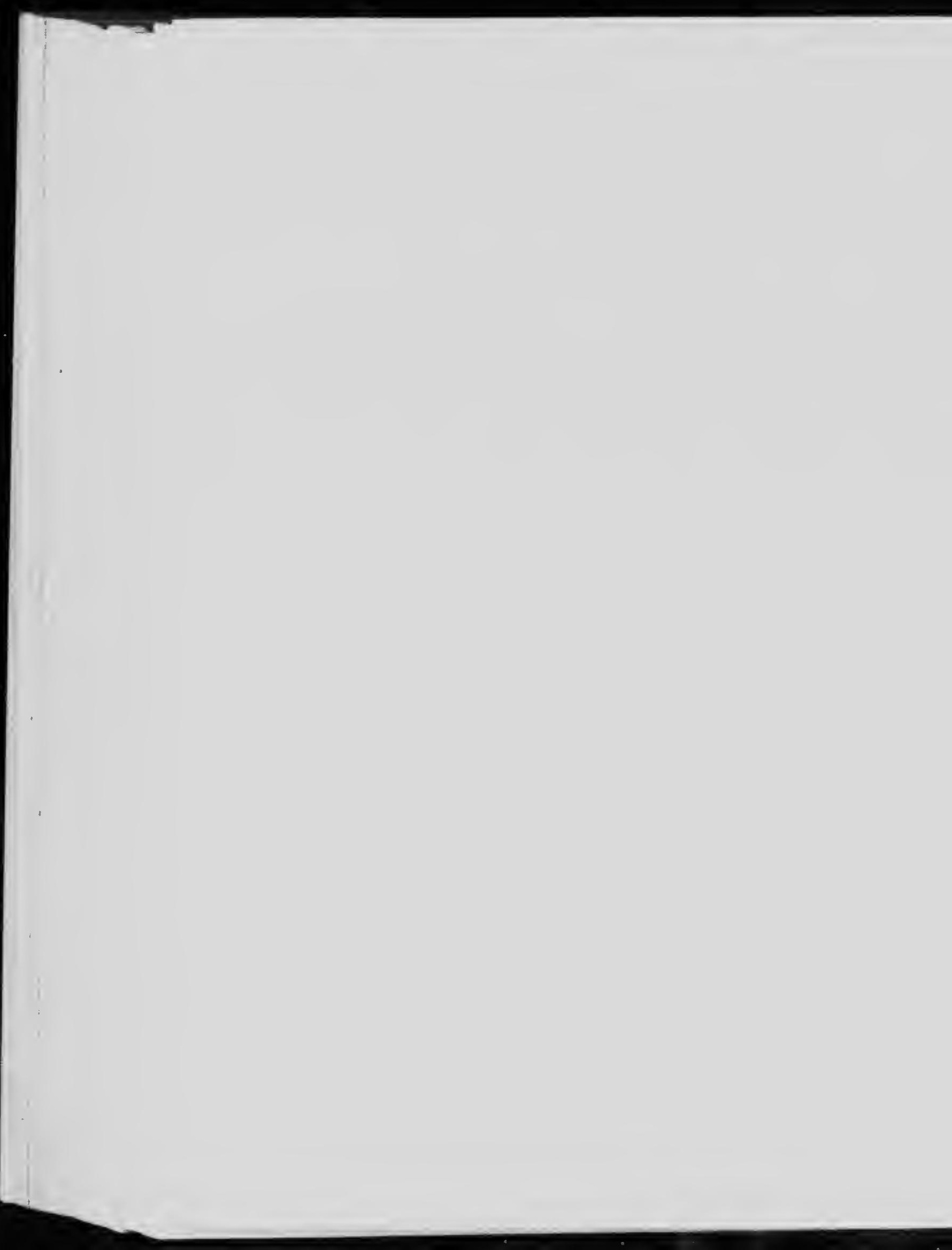




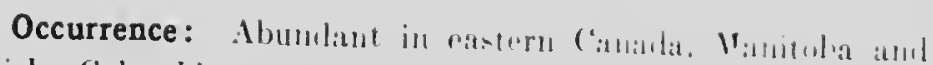

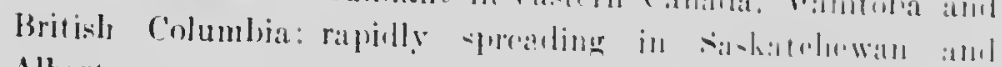
Alberta.

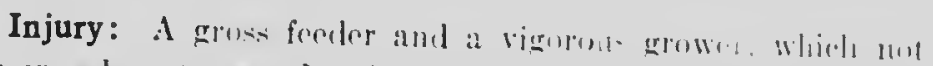

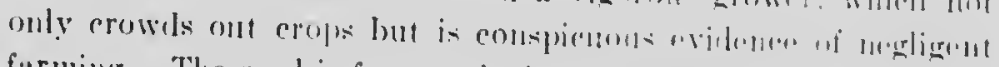

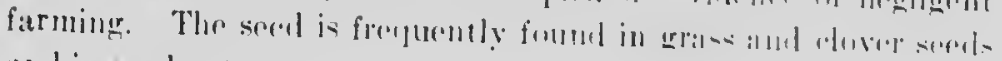
and in sered oats.

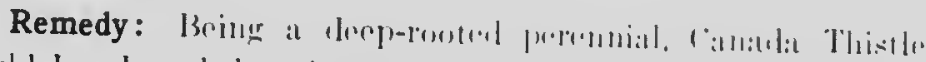

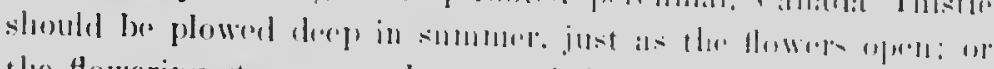

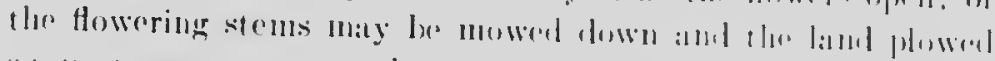

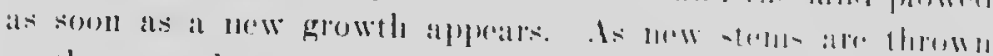

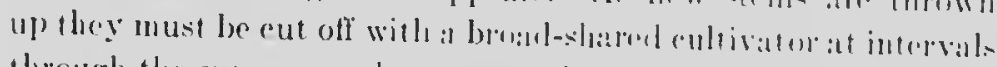

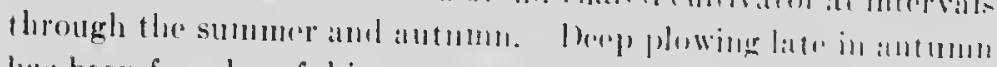
hat: bern found useful in suppresing thistles in llanitulat.

The chief safeguard agaimst ('andulat Thislle aml all similal'

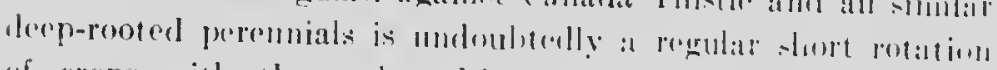

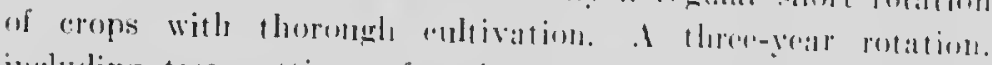

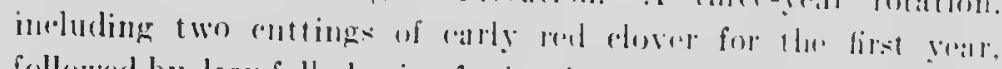

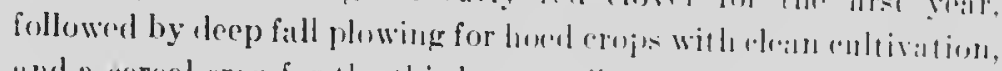

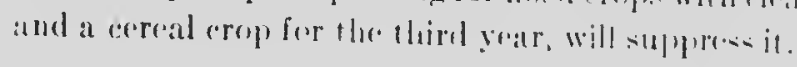

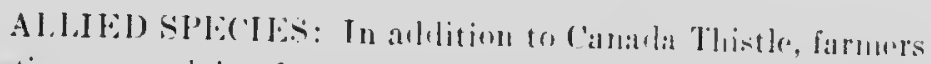

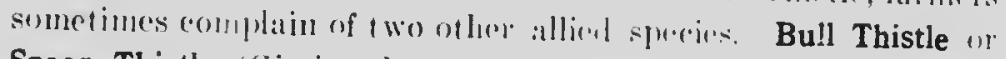
Spear Thistl (Cirsium lameolutum (1.) Hill.) is a large. (onatlser

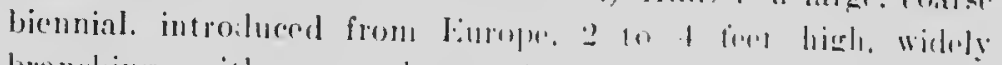

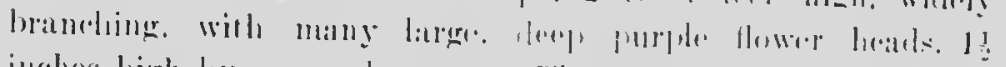

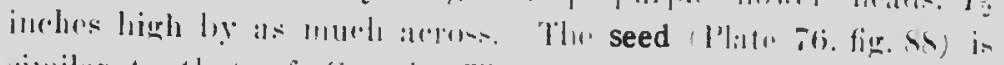

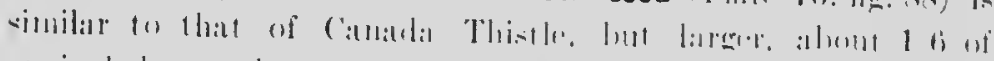

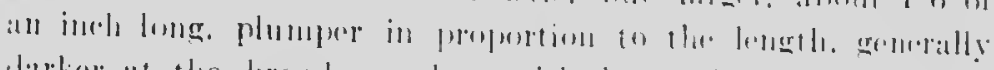

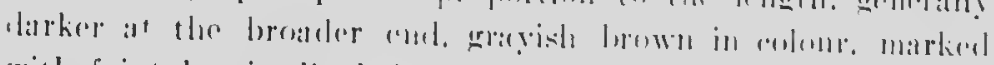

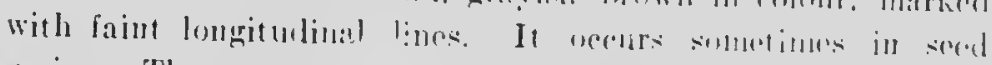

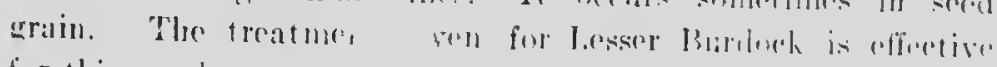
fur this aropl.

Prairie Thistle or Western Bull Thistle ririum indulatum

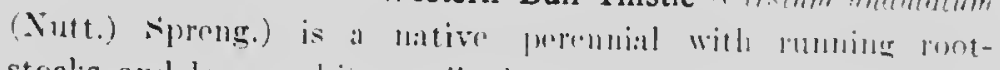

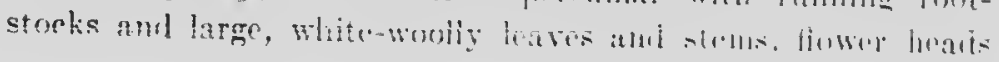




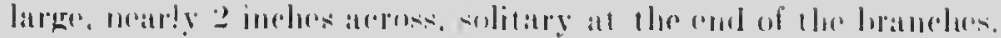

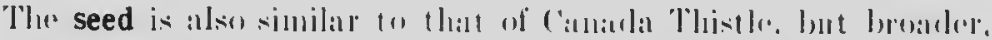

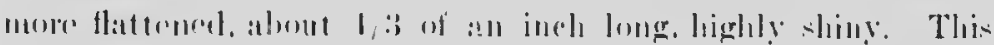

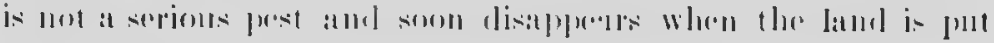
mater aropt.

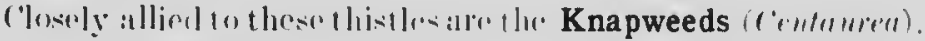

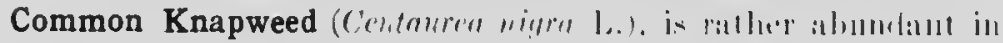

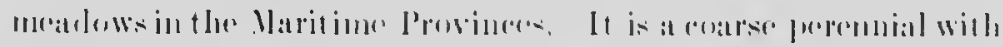

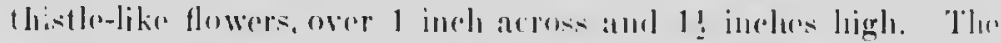

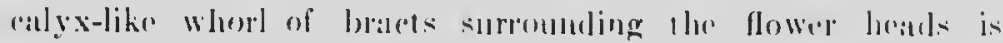

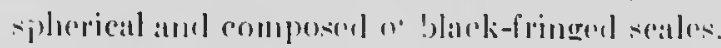

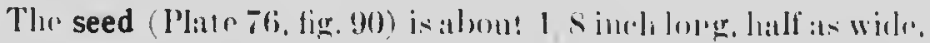
latpring to the base, slightly angulal, sollowhat flatlonorl and the datk, shiming graty surfaler strijmel lon:glhwise with pate

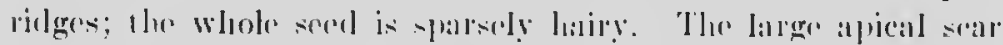

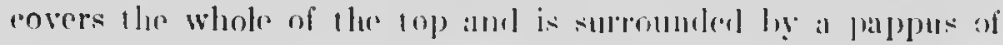

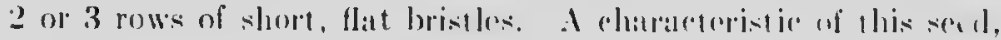

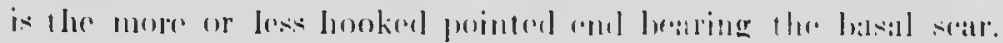

\section{TPIIBI: ('IO'HORIEAL:}

\section{CHICORY (rirhorium Int!lows L.)}

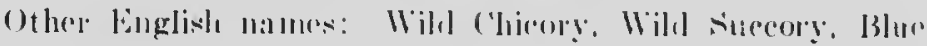
sailors.

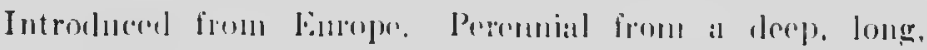

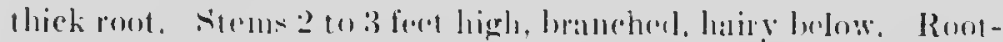

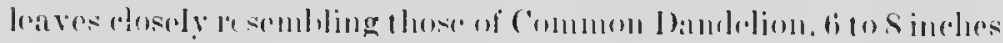

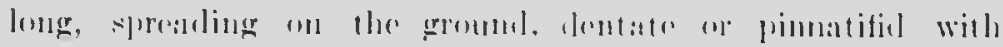

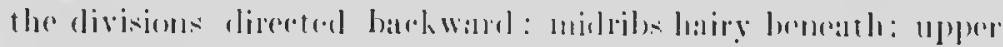

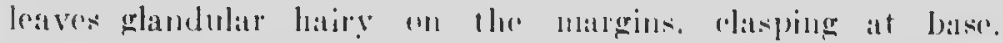

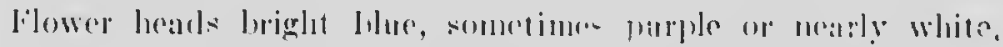

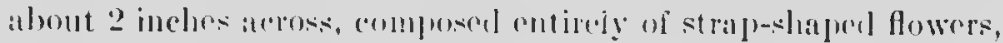

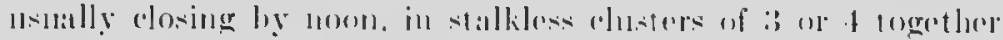

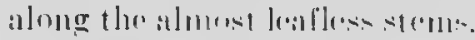

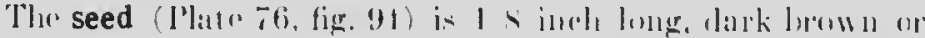

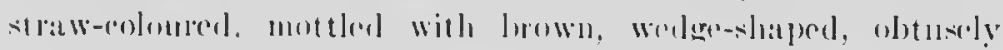




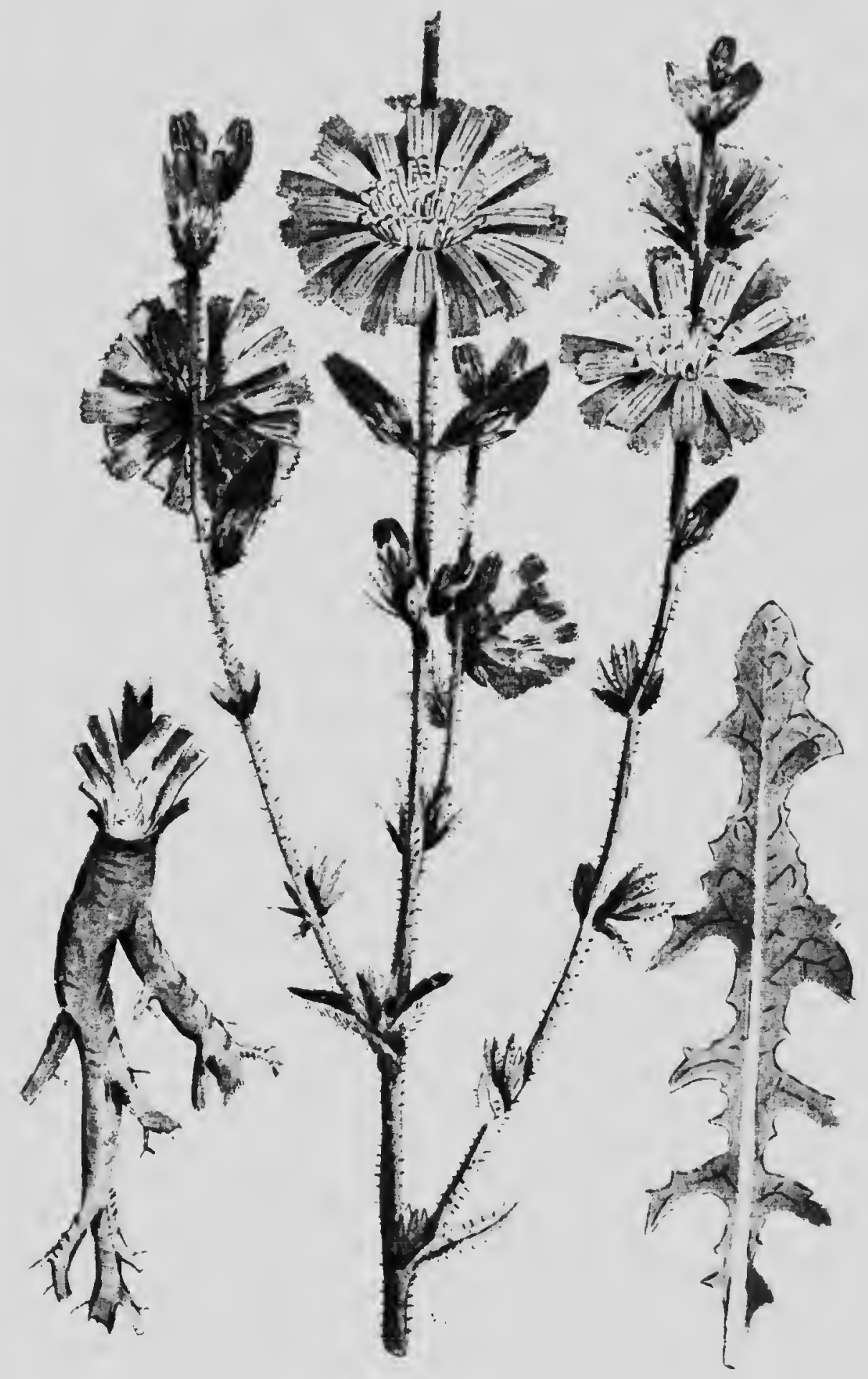


$y$

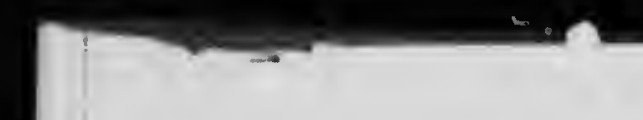




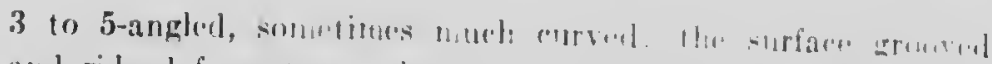

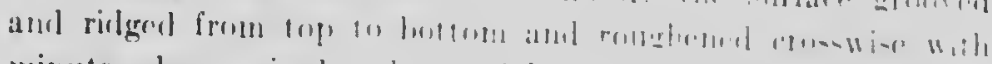

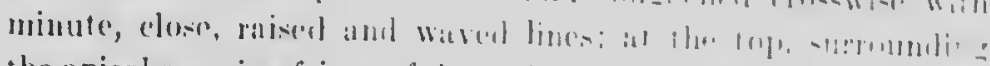

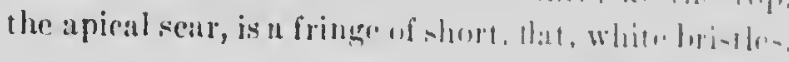

Time of flowering: July in frum wods ripe anty th Aıgust.

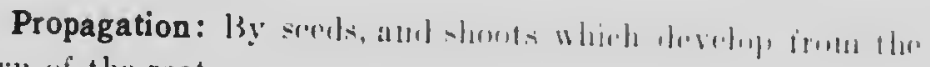
crowu of the roots.

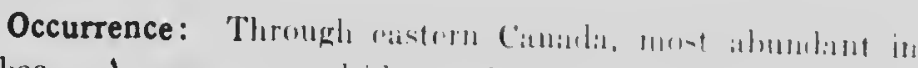

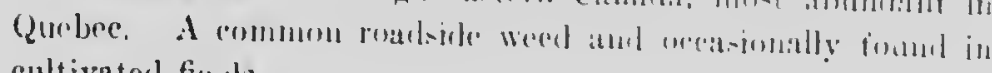
cultivated ficuls.

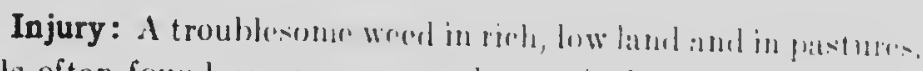

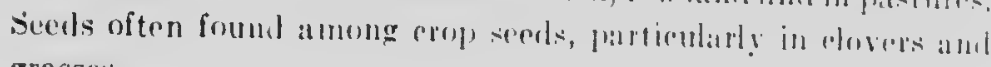
grasses.

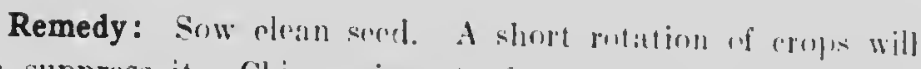

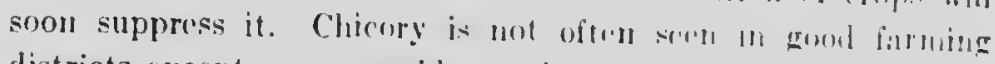

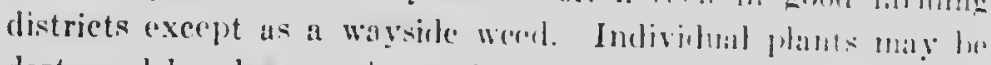
destroyed hy close eutting and :iplying salt to the root in hort, dry weathi'r.

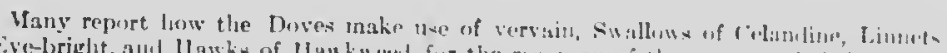

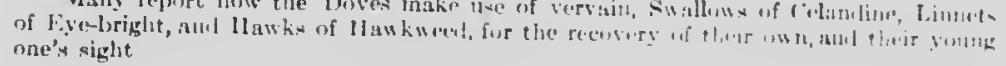

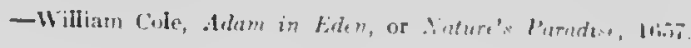

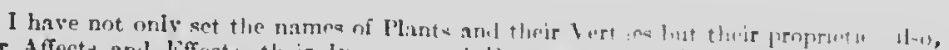

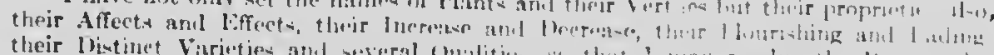

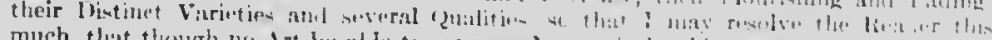

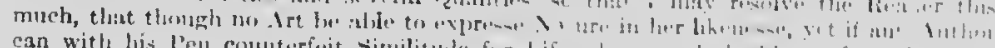

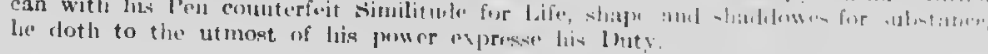


liv

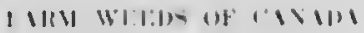

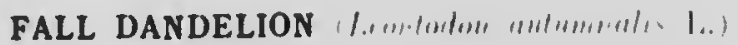

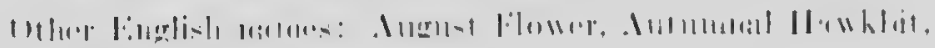

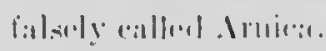

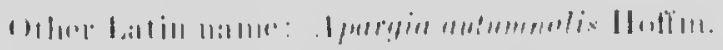

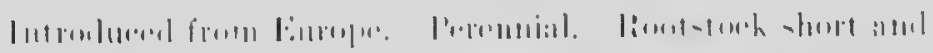

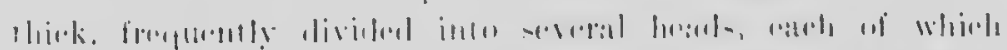

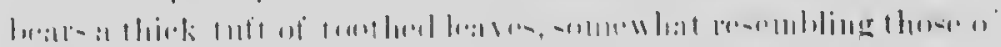
(

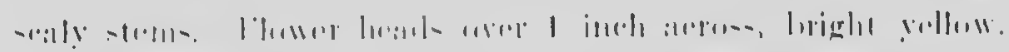

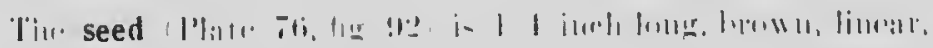

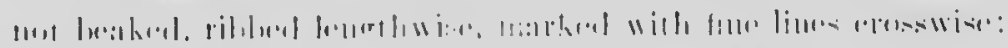

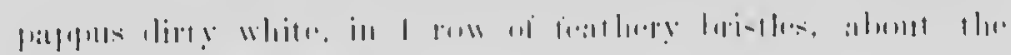

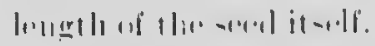

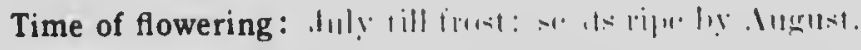

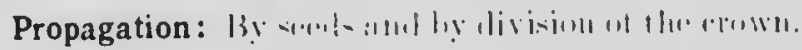

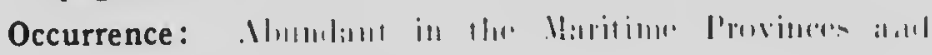

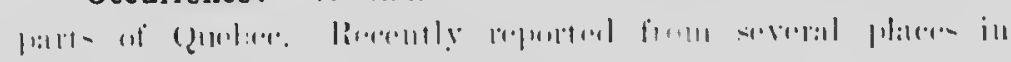

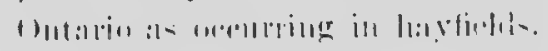

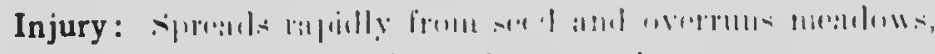

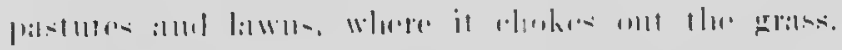

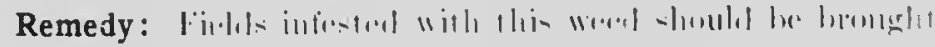

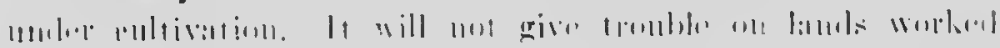

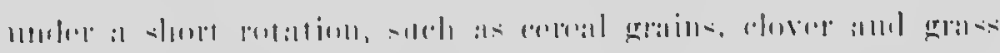

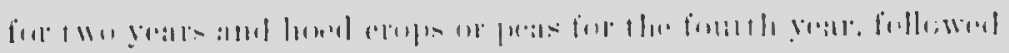

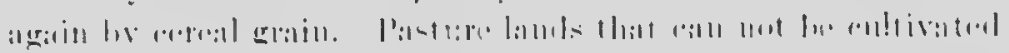

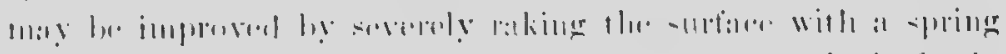

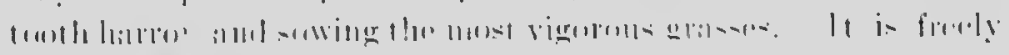

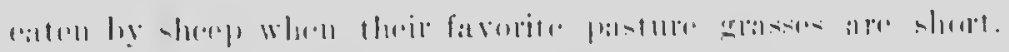

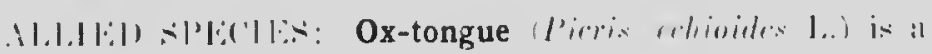

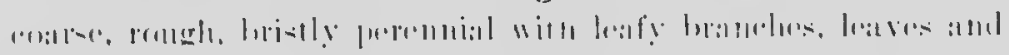

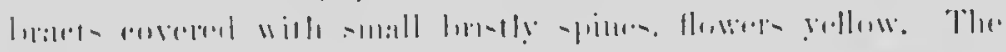

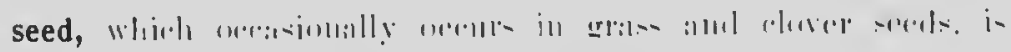

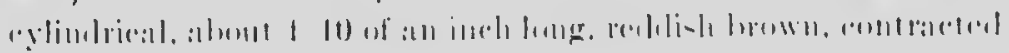

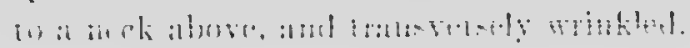




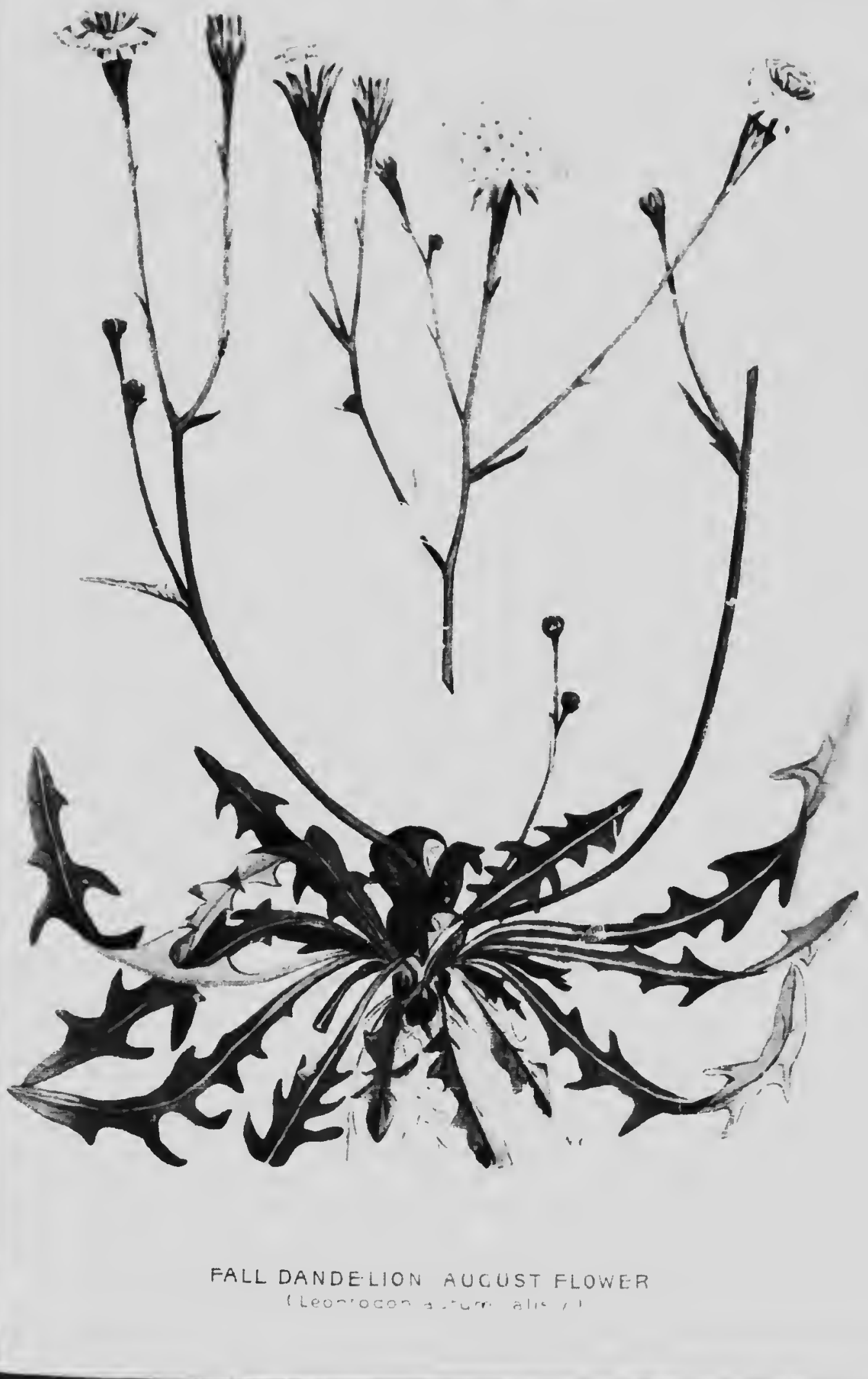




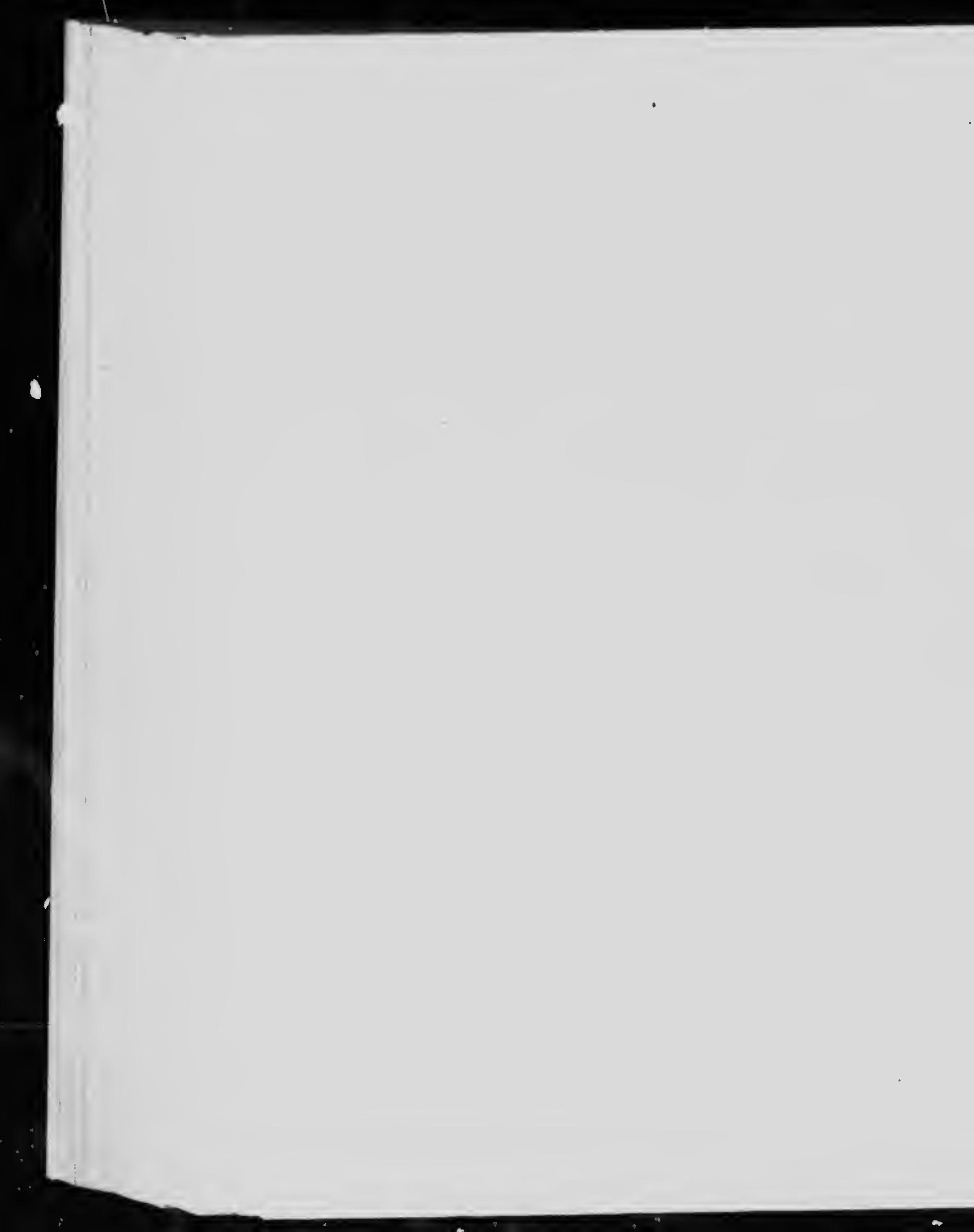


Salsify (Trayoponom purrifolum 1.) and Yellow Soat's Beard

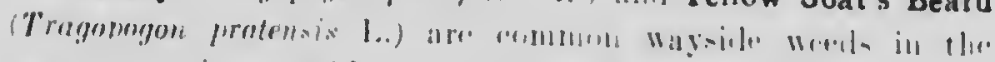

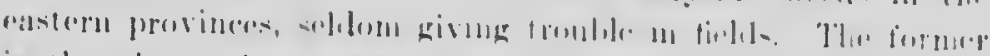

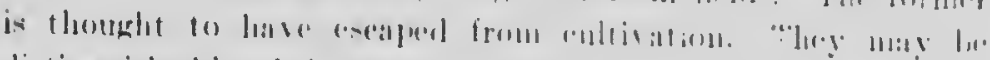

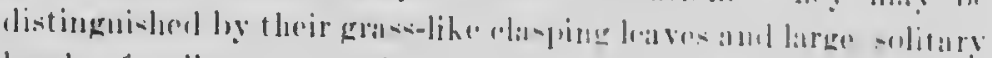

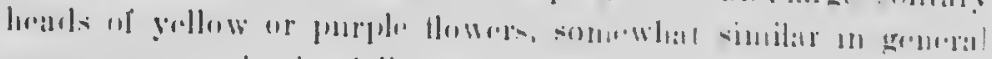

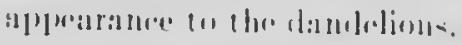

Comn Dandelion (Tarasuenm "fficinale Winler) is a

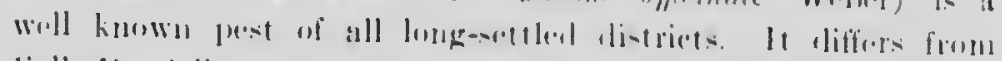

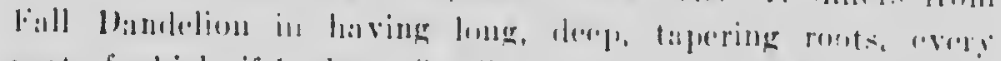
part of which, if bohen oth, will throw ont laskes and form now

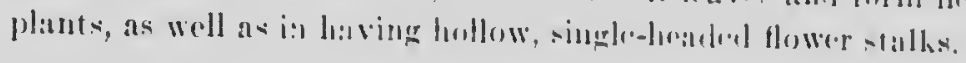

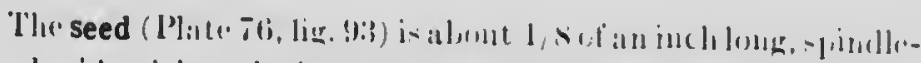

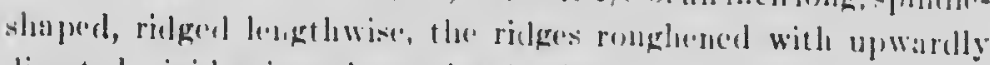
directed, riginl spine derereasing in size from the top to the hisise of the secel, where they apjear as mintute tubercles. Tla top

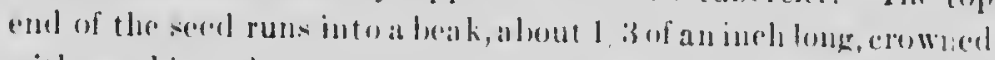

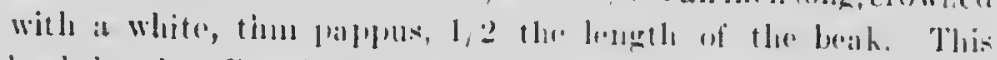

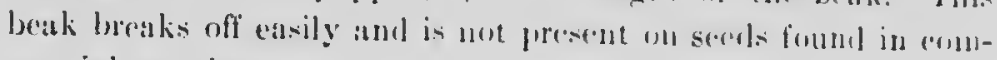
morcial samples.

Red-seeded Dandelion (Taruxucum erythrospermum Andiz.) occors with the preceding aud dilfors form it morely leg having

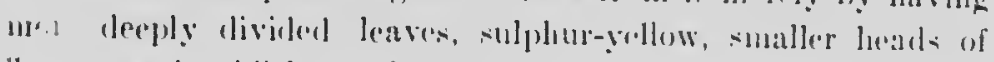
llowers, and redelish-purple serels.

It is important to provent daudelions from sereling in lands aljoerent to lawns. Though cutailing murle labeur, the most satisfactory way to dral with them. When deeply rooted in lawns, is to loosen the soil with a diggerug fork and pull them up. The use of the fork may nut be ureessary in some wet and soft soils. The applieation of keresene to the crowu of the platut.

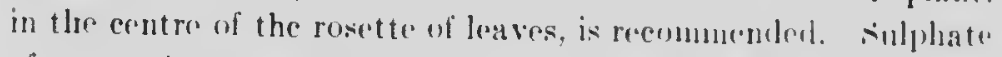
of ammonia or sulphlate of irem in exerse is also recommentlenl. A small tablesponoful of walt applion! in the moming at a lins day, when the soil is ruito dry, will kill them. 
PERENNIAL SOW THISTIE ( ‘゙m

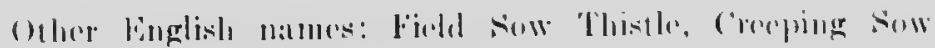

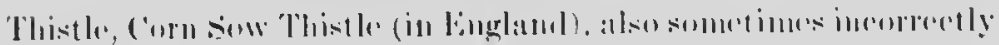

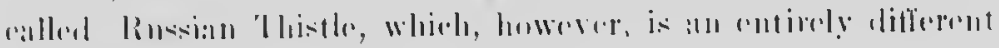

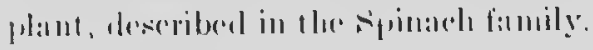

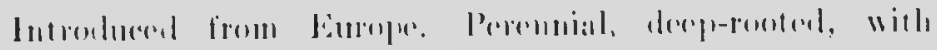

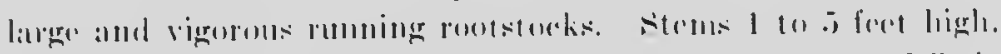

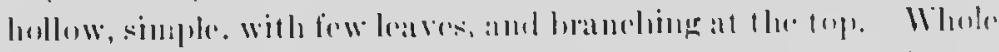

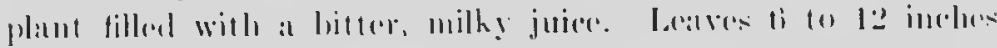

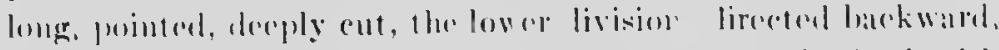

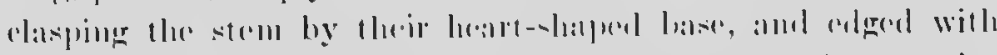

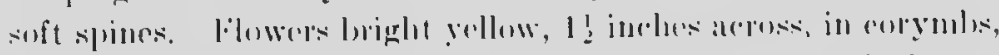
rlesing in strong sunlight: the thower stalk and the scouly hatets

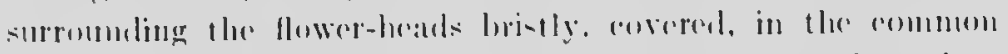

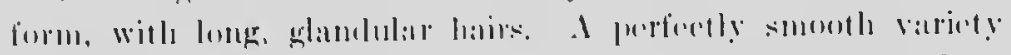

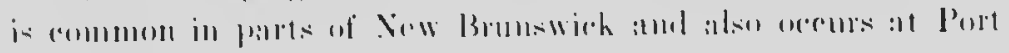

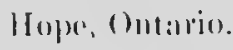

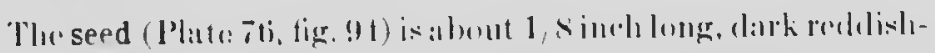

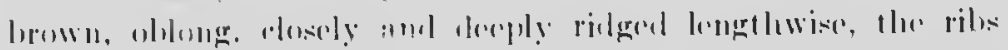

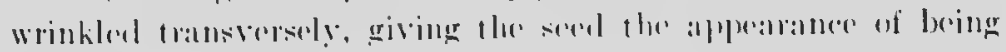

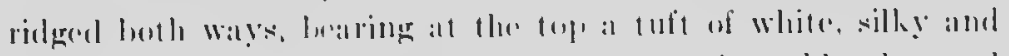

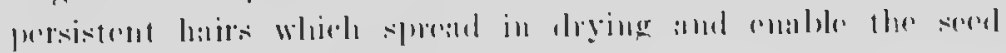
10 he atoried long distances hey the wiml.

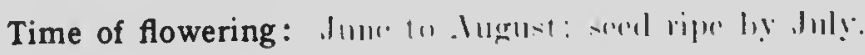

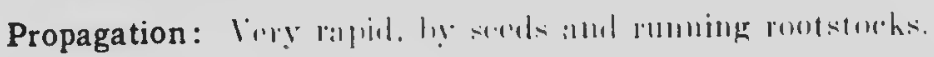

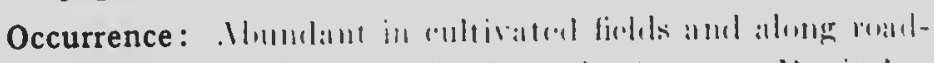

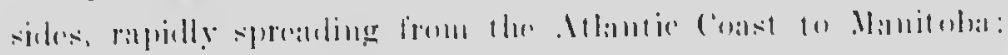

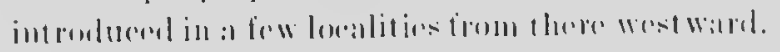

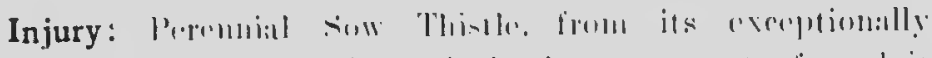

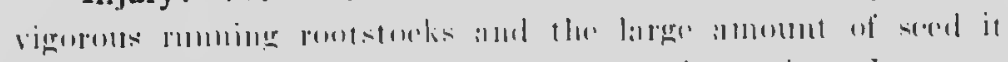

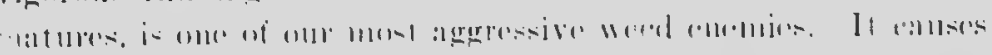

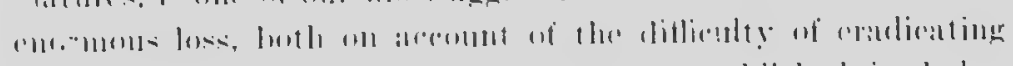

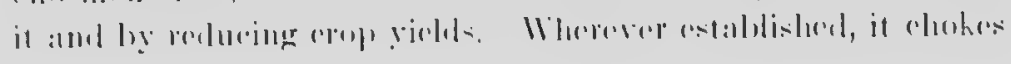




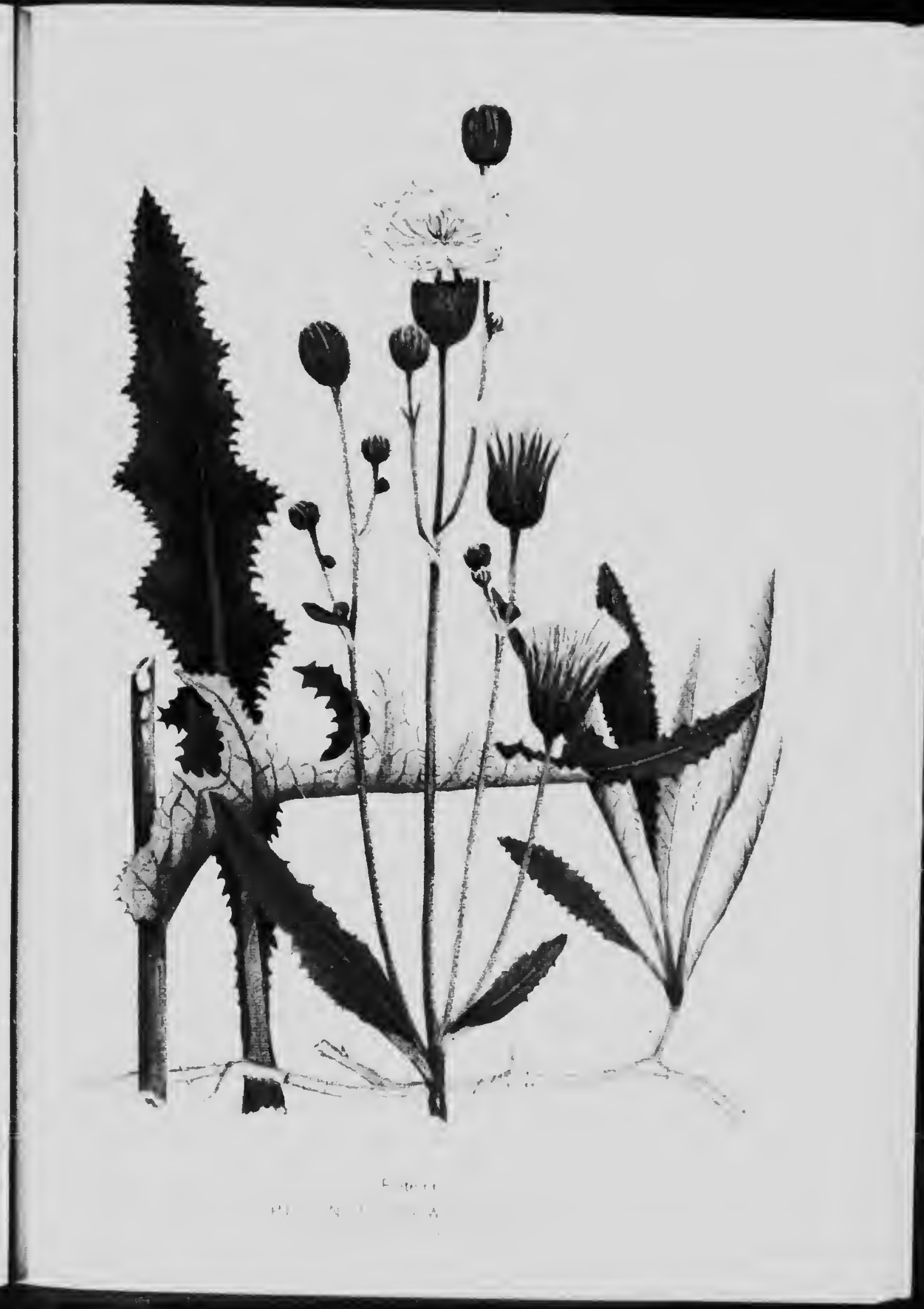




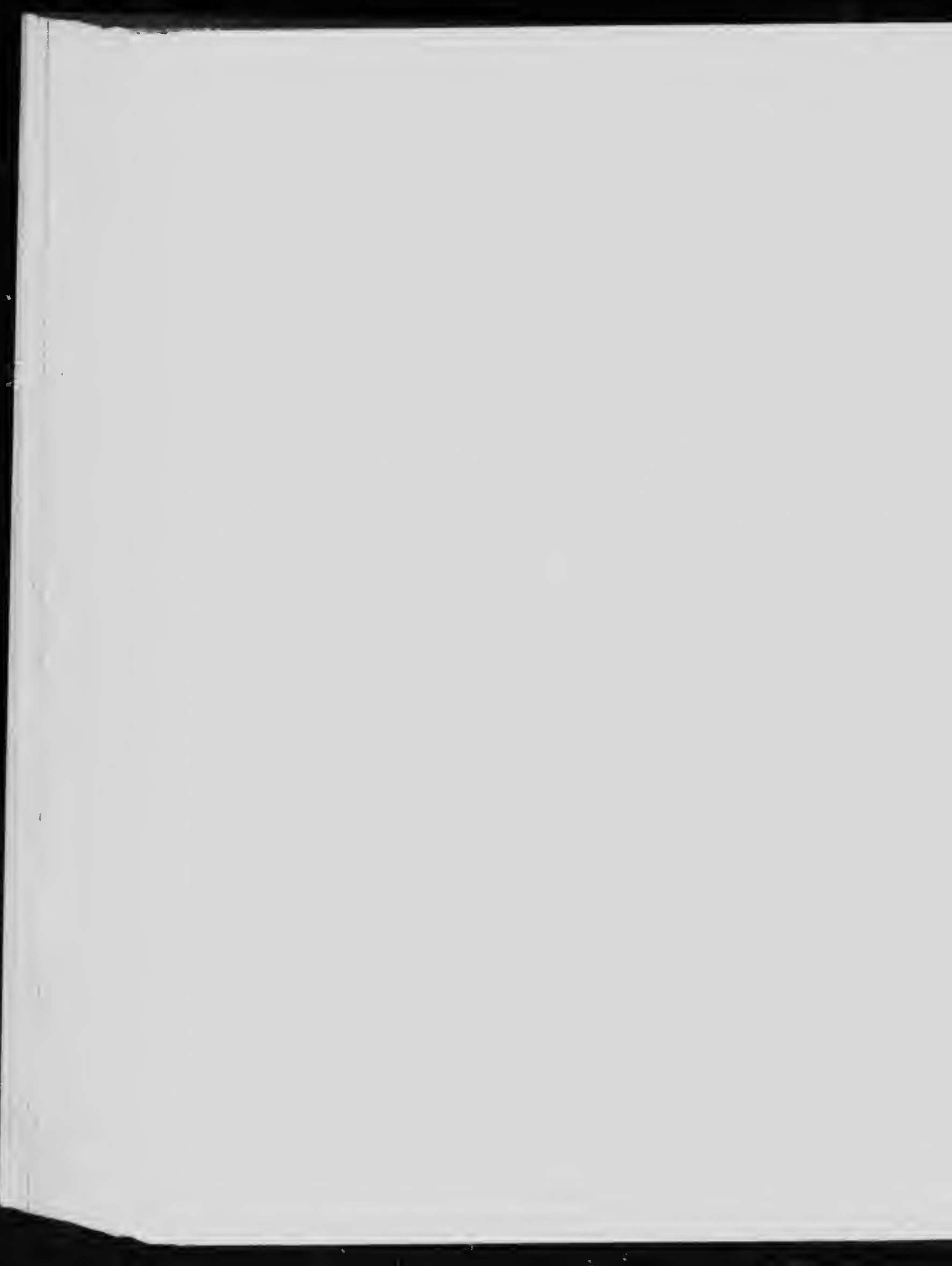




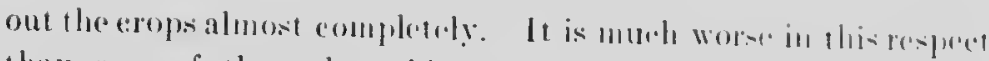

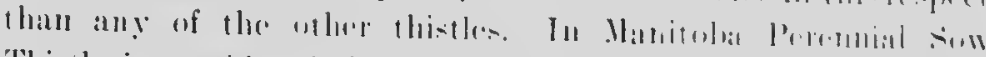

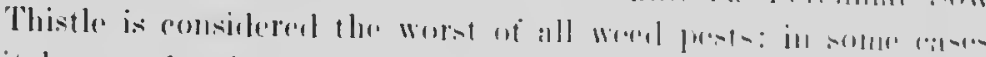

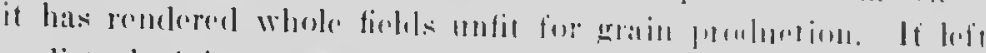

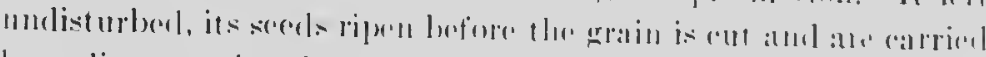

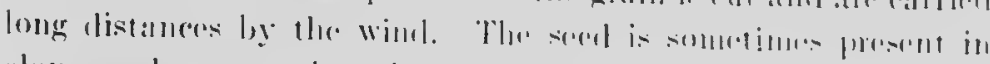

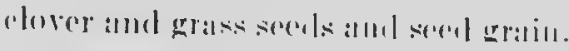

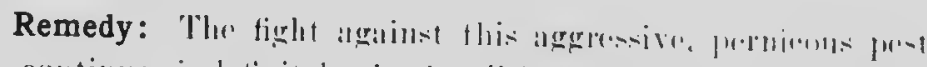

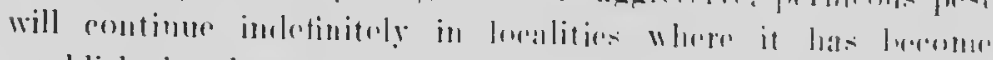

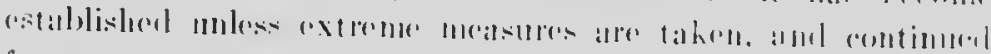

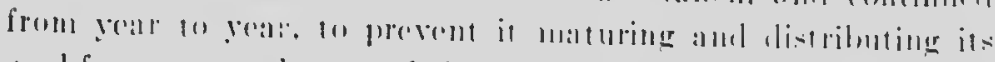

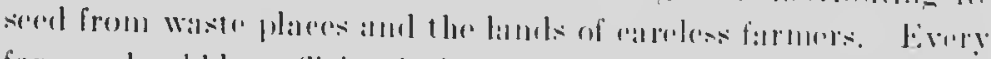

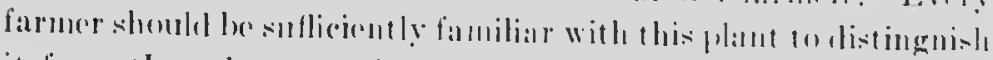

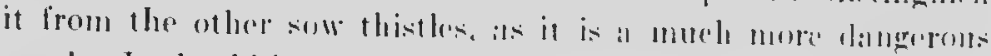

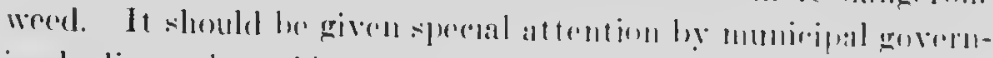
ing bodies and werel insperentors.

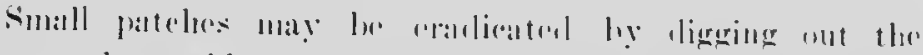

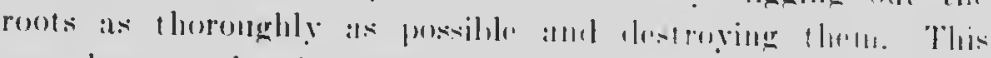

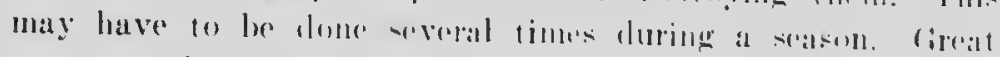

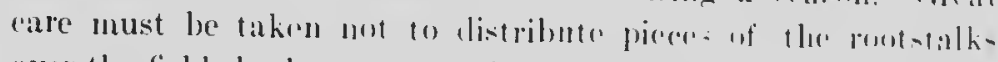

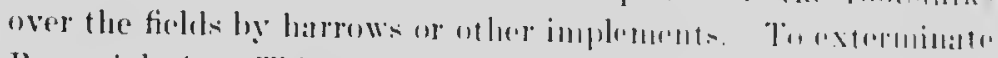

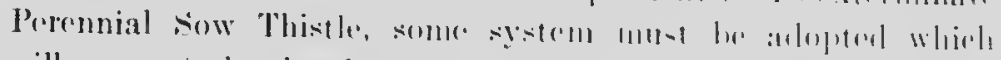

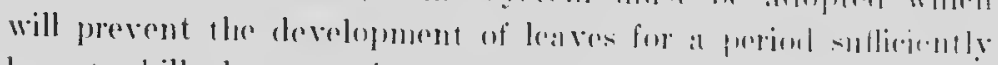

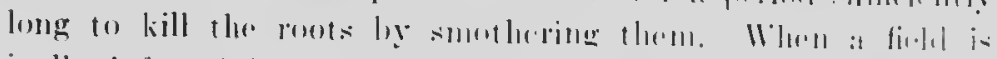

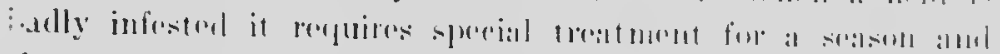

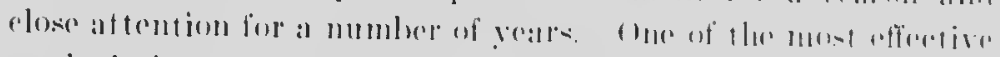

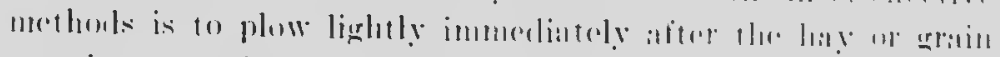

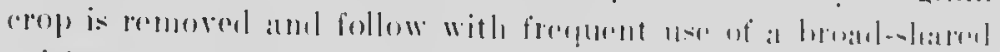

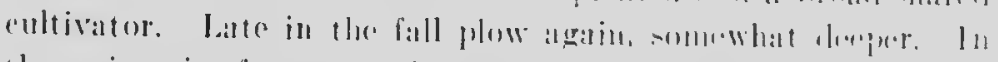

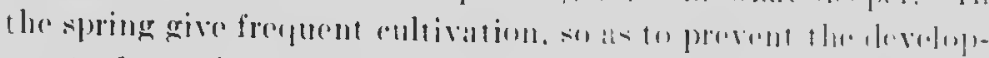

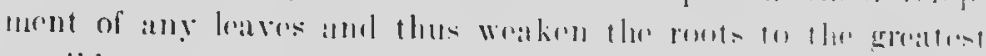

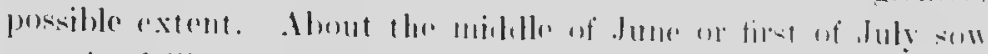

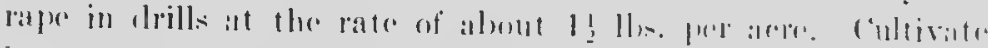
between tho drills as

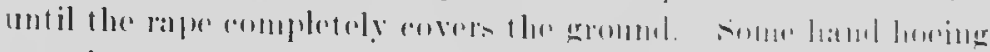

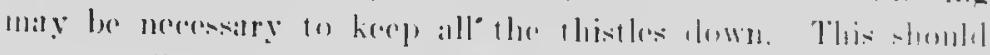

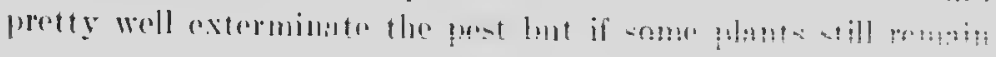


when the rape is cut or pastured off, the ficld may be fall plowed and put into hoed crop the next season, when special attention can be given to any small patches that may appear. Buckwheat is sometimes used insteat of rape for a smothering erop.

In the Prairic Proviness Premennial sow Thistle can be combatted inost effectively by a bare smmmer-fallow, which shoukl be plowed early and cultivated throughout the scason as often as is necessary to kerp down : lll loaf growtl. When a field is badly infesterl it may be necessary to plow again in the fall, give thorough surface eultivation until late the following spring, and sow will oats or barley to be cut green for feed. 'Too nuch emphasis can unt br placel on thorough cultivation, tor if this is not given a simmor-fallow will merely enable the pest to get a stron: $\because$ hold.

\section{ANNUAL SOW THISTLE (Sonchu. oleraceu: I..)}

Other English names: IFare's Lettuer, Colewort or Thistle Milkweed, Milk Thistle, Milky Tassel, Swinics, Connon Sow Thistle.

Introduced from Europe. Amuual, roots fibrous. Stem nearly simple, 1 to 4 feet ligh. L.eaves deeply cut and toothed with soft spiny teeth; the basal ones pinnatificl, trrminated by a large lobe, elasping the stem by their heart-shaped base, cncting in sharp points. The flower is pale yellow, ahou, $1 / 2$ to 1 inch in diameter. The sealy biacts surromeling the flower-hearls are downy only when young, later becoming hairless.

The seed (Plate 76 , fig. 95) is somewhat similar to that of Perennial Sow Thistle but a little shorter, flattened, pointed at the lassal eirl. The longitulinal ridges are wider apart, much finer, and the whole surface of the seed, the ridges as well as the interspares, is fincly wrinkled transwersely. Iappus falls off rasily.

Time of flowering: May to Oetober; seeds ripe by July.

Propagation: By seeds, which are distributed by the wint. 


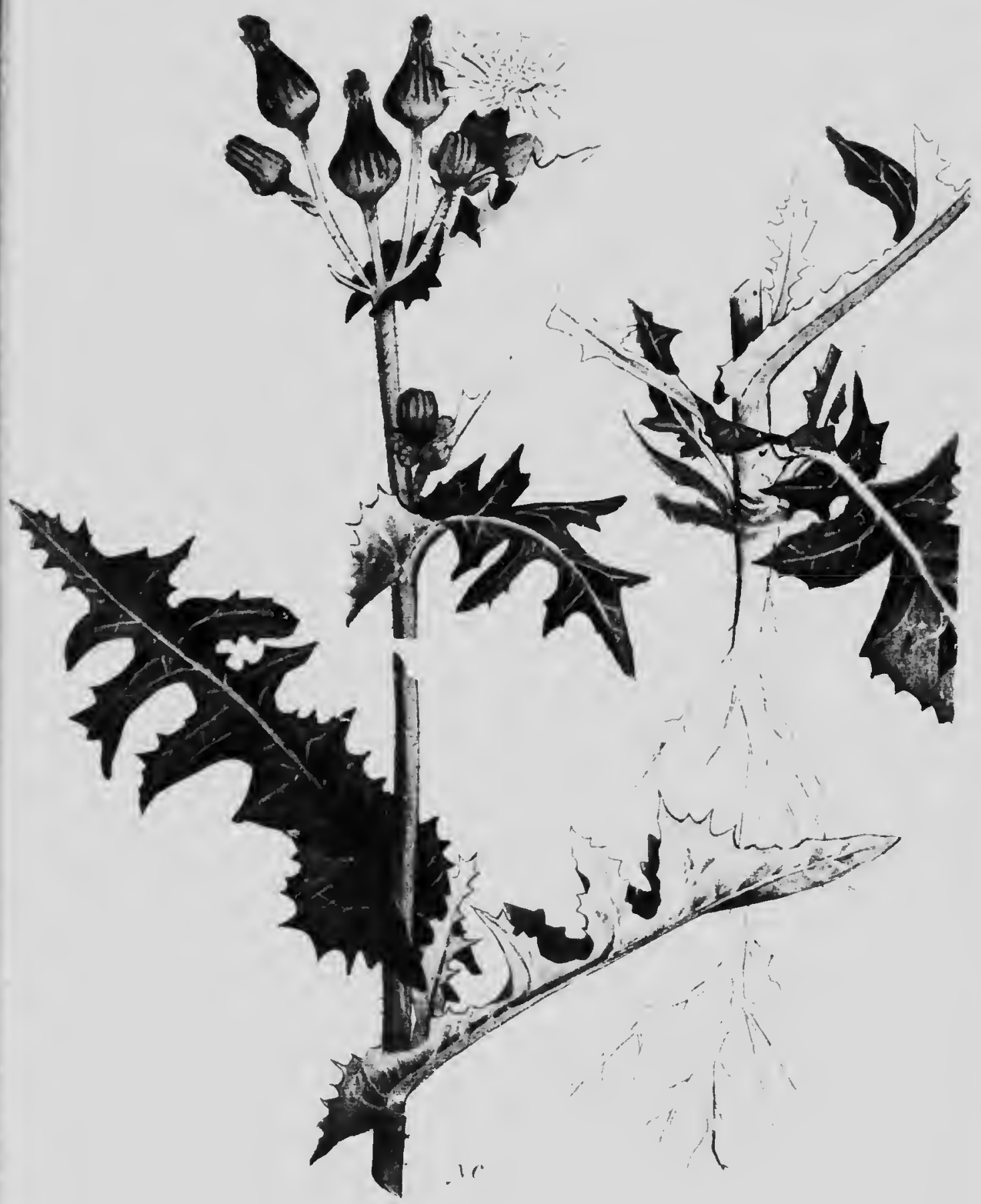


,

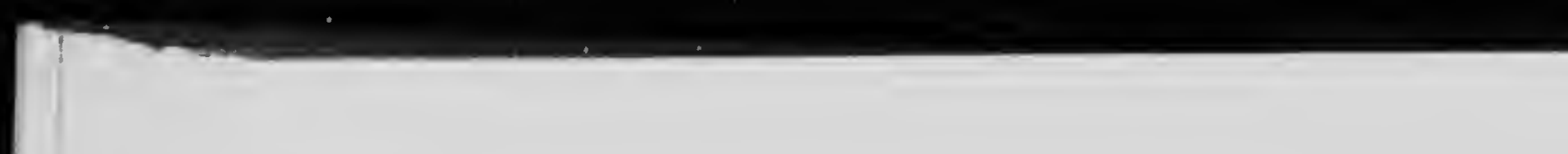




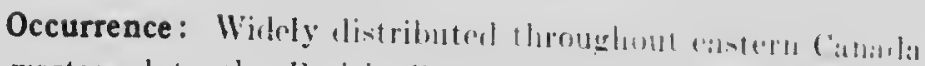

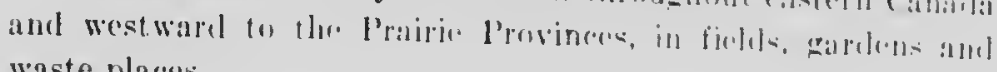
waste place's.

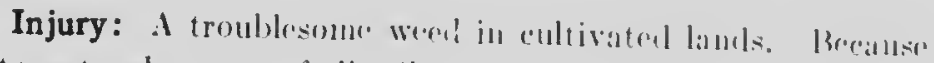
of its matural means of clinflihution, it is diftirult to supproses.

Remedy: Prevent it from sompling in waste places ly cleaning

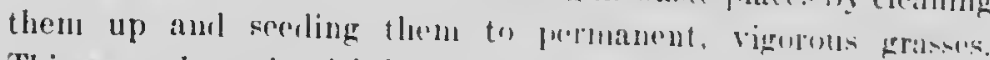
This anmual werd, with its relatively small, pale yollow flowers.

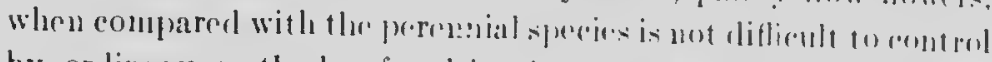
by ordinaly methorls of coltivation and altermation of elonse Sheep, if in sufficiont mumbers, will prevent sow thistles from sending in pasture lanrls.

AlIIED SPFCILs: Spiny-leaved or Prickly ! w Thistle

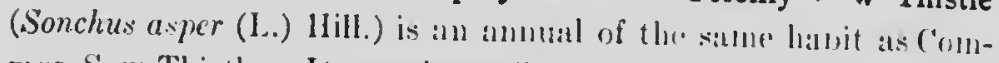
mon Sow Thistle. It may be ciscily irlentifienl ly its more prickly nature and less deeply eut leaves, the lanes appendages of which, insteal of spreacling, are appressed to the stem atul rounded.

The seed (Plate 76, fig. 96) is similar to that of the precoling speeies in size and shape: distinctly :3-nerverl on rach side, with nerves and interspares quite smonth. Pappus not persiatent.

Uncultivated lands, that arr often a hroeling ground for sow thistles and other weeds, conld be nathlo lese datherous by

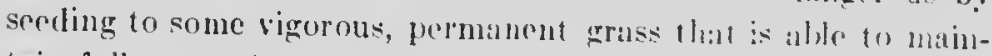
tain full possession of the soil.

The thistle proves a great annoyance to some lamils by killing the grasis curn, ote. although it be a sure token of the strength of the laml. The way (1) chestron then is to cut them up by the roots luefore feeting time: the mbantage you will receive will answer your expense and more.

-John Worlidge, The .Wystiry of Husbandry Disenered and laid open. IwWI. 
PRICKLY LETTUCE (I.netuen scariola l., vitr, integrata Gren. diodr.)

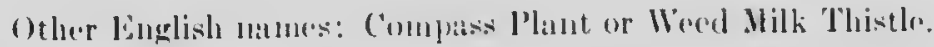

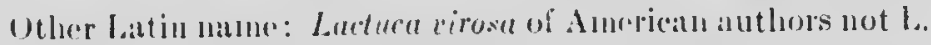

Introlumel from linnpre. Anumal, opeasionally a winter atumual. A routser, tall-stemmerl plant, areraging 3 to 5 feet in loright. In British Columbia plants s freet high lave beren found. The leaves are oblong-liance-shisped mangined with spines and priekly on the mirlrib lenenth, only the lowre ones more or less pinnatifiel, stalkless, with ear-like loless at thu hase. The leaves of thestem are wisterl at the (lisping base so as to stand vertieally with the elge to the sun, instein of horizontaly, as in the case of the leares of most plants. This pereuliarity has griven rise to a eommon name of this lettuer, the compass l'ant. The flower heads are pale yollow, less than 12 inch across, on a large, wicle-sprealing panirle, only a low open at a time.

The seed (Plate-76, fig. 97) is about 1/S inchlong, tark greenishgray, similar to that of the hack-seceled rarieties of the garelen lettuee, usually a little smaller, and. like them, froadly lanceshaperl amel somewhat movel, flattenerl, margined and bearing 5 to 7 nalrow rirlges down each face: whole surface roughened with fine wrinkles, and short, white histles un the rifges near thre apes. The beak wolens at the apex and is as long as the seerl, very stenelere and oftru twistrel: mappus white. Both beak and pappus casily hoken off by handing the socol.

Time of flowering: July-August; serels rije by August.

Propagation: I3y seeds, which ate carriol long distances by the wind.

Occurrence: Willely distributrel in waste plares from Nova Seotia to the l'airie Provineses and reporterl from parts of British Columbin: sometintes riving trouble in fiolsk. The seed is frequently found amoug crop seeds. 


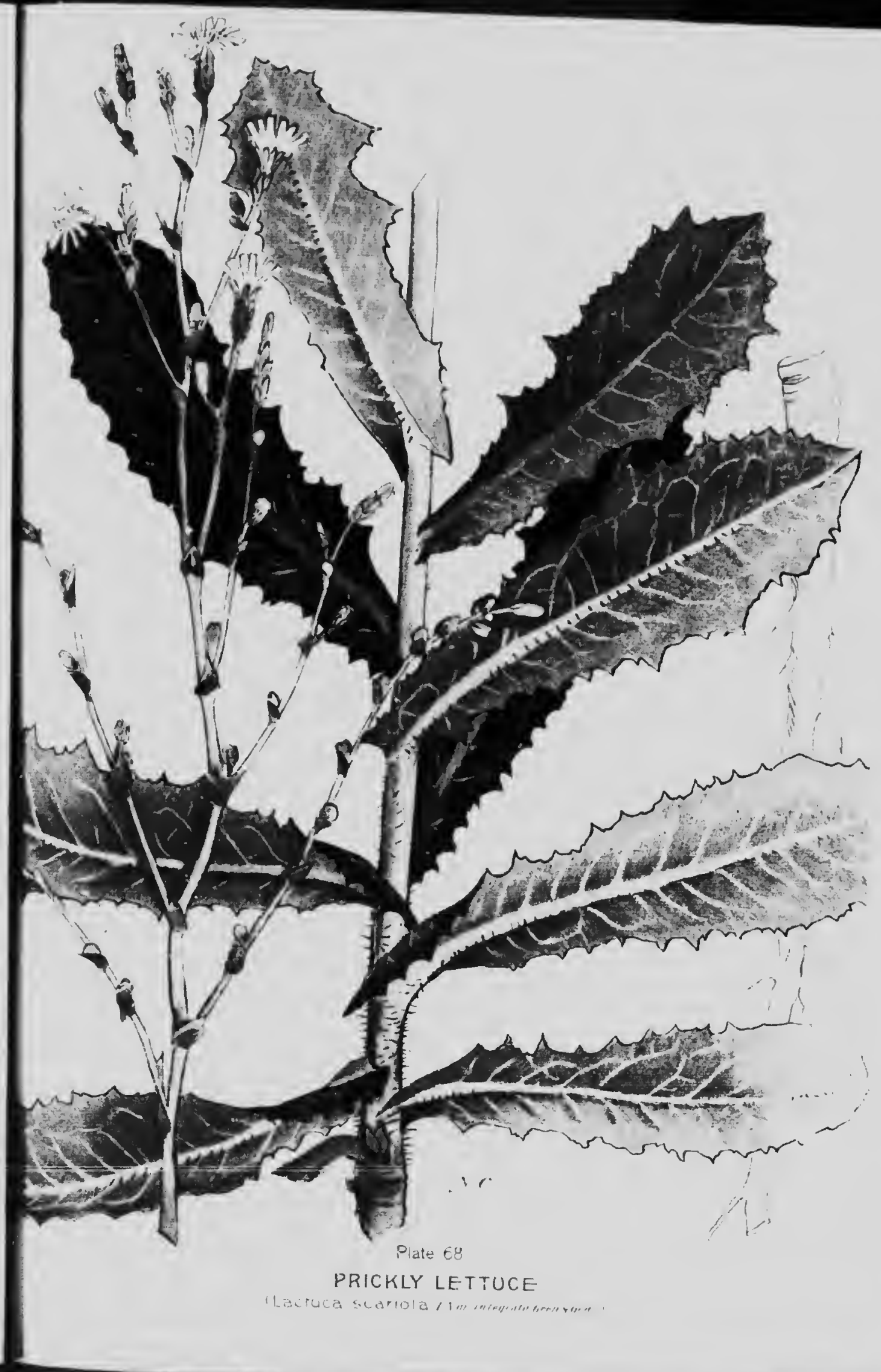




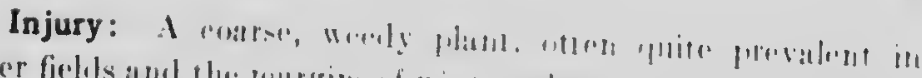

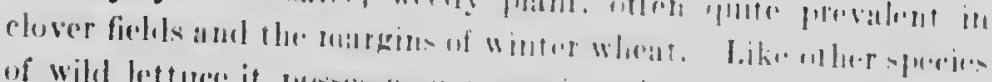

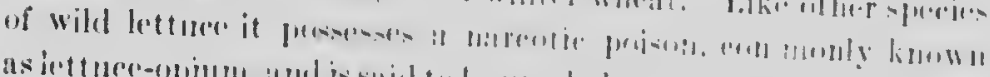

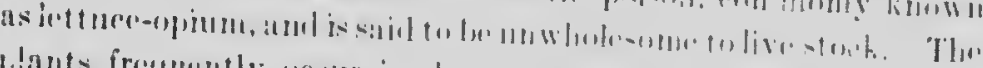

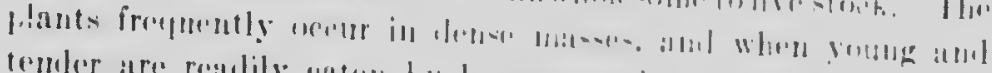

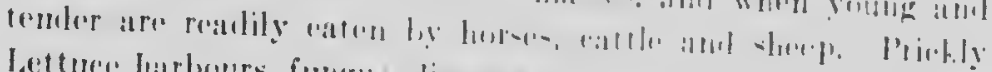

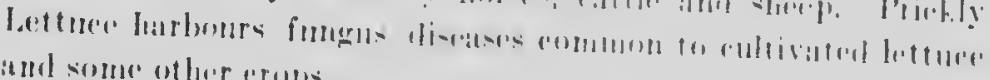
and somo otluer erope.

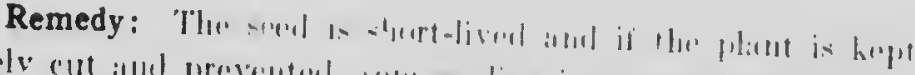

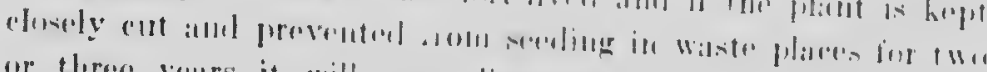

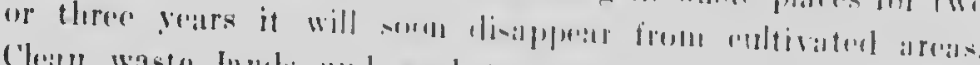

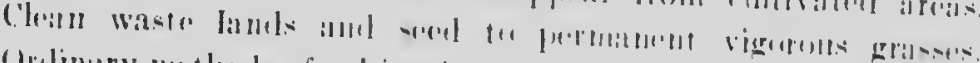

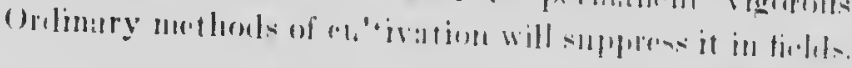

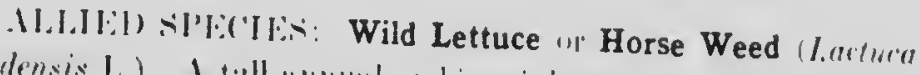

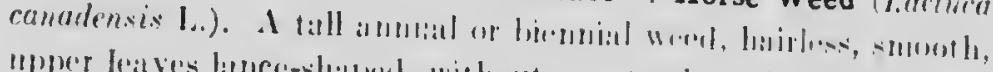

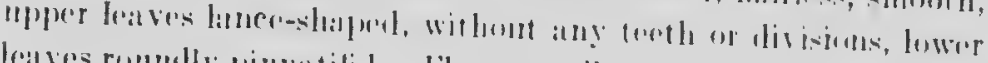

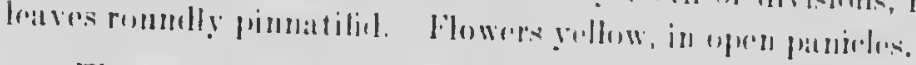

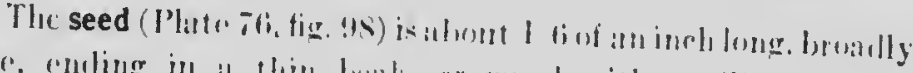

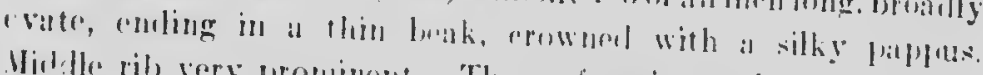

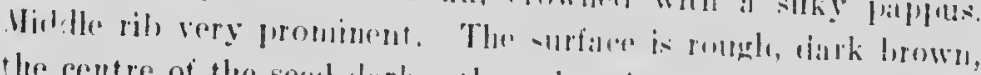

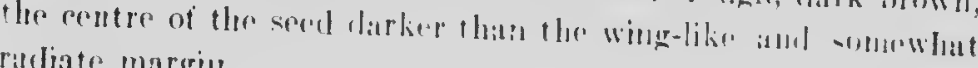
rinliate margint.

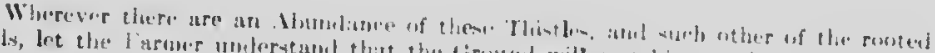

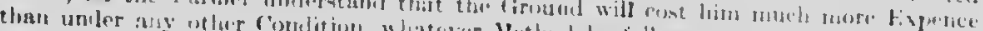

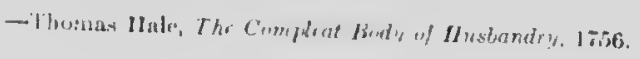

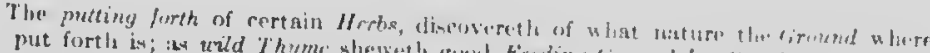

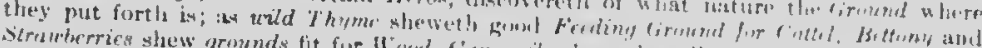

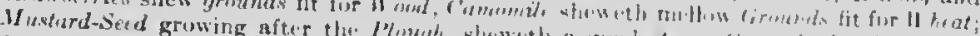

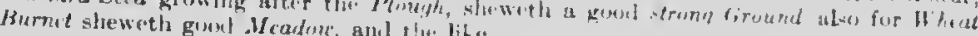


176

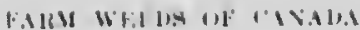

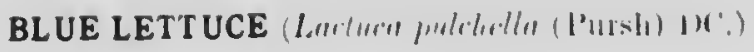

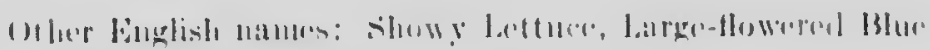
lanture.

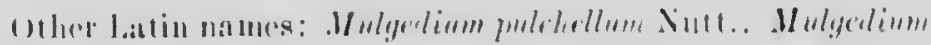

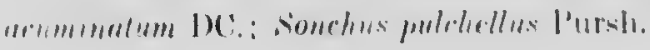

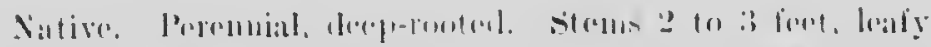

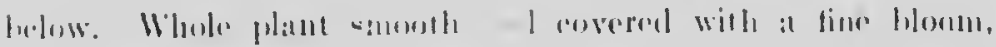

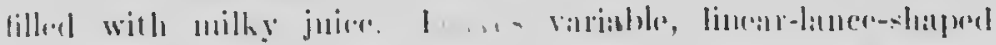

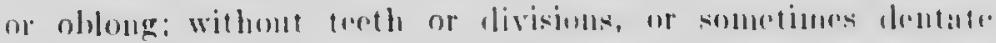

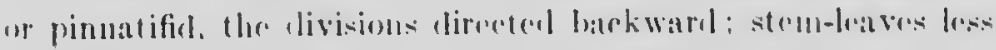
dividerl and stalkless. The llower homb are nearly I inch

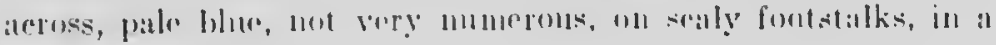
uarrow panicle.

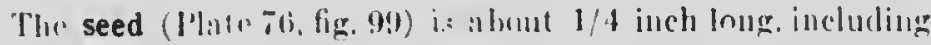

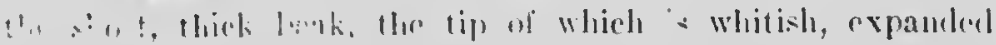

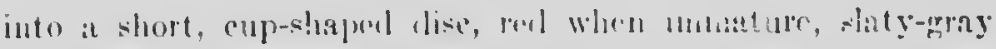

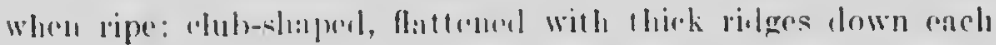

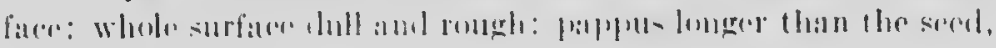
pure whito amb silky.

Time of flowering: Jump-July: : July.

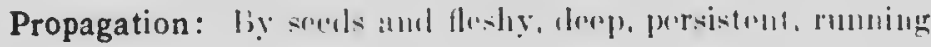
roolstoctis.

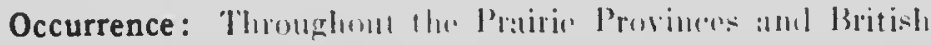

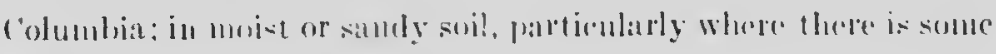
alk:ıli.

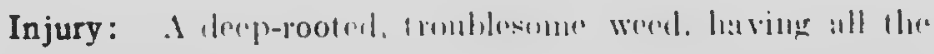

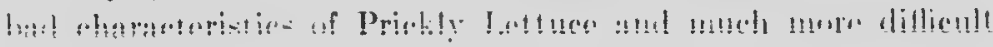
to stlppless. 


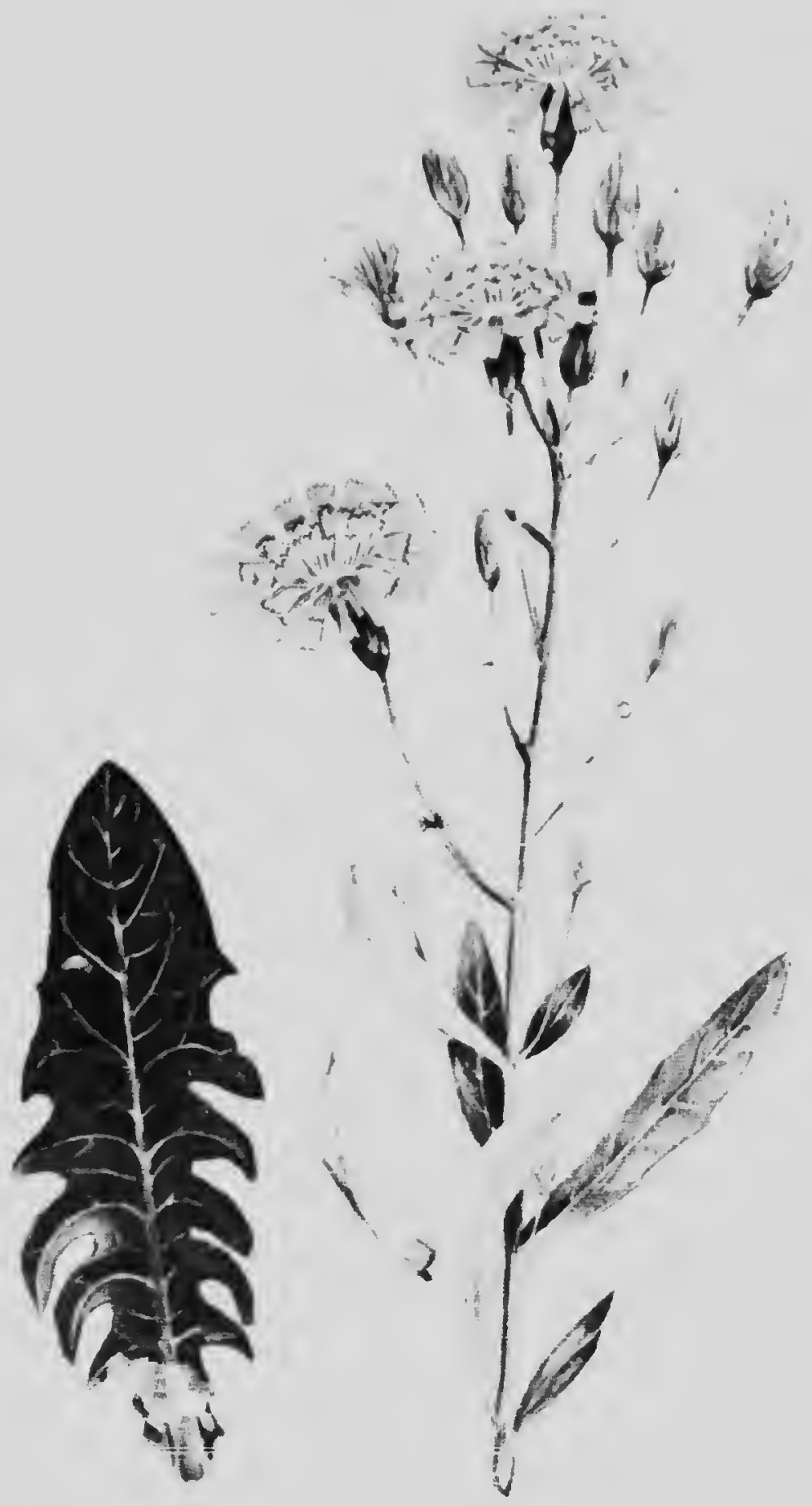




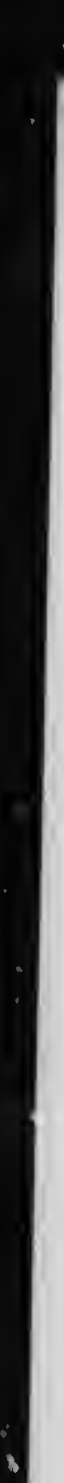




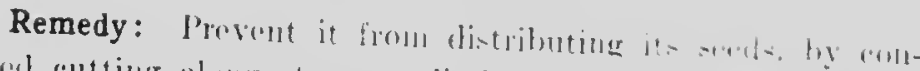

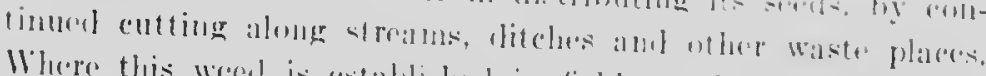

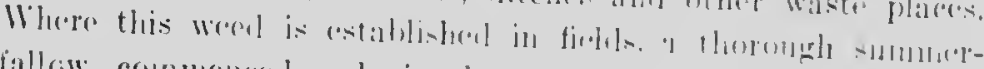

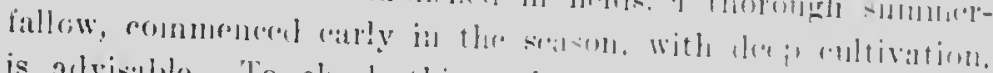

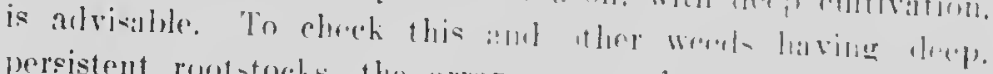

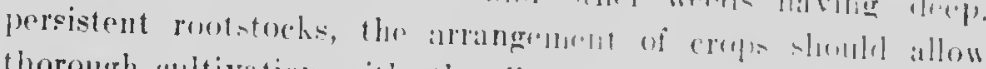

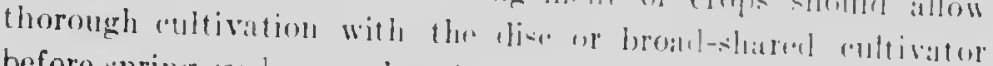
before spring seeslung. and again in thre autumn.

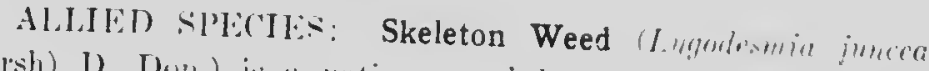

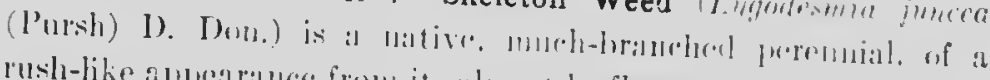

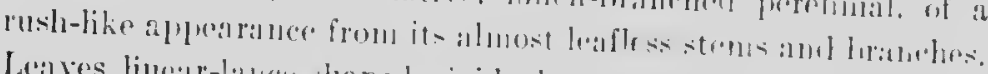

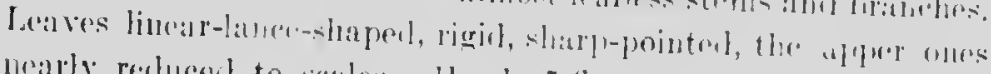

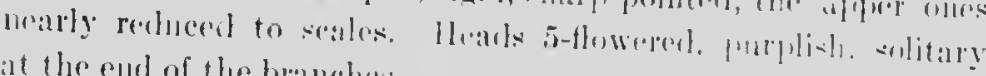
at the end of the branches.

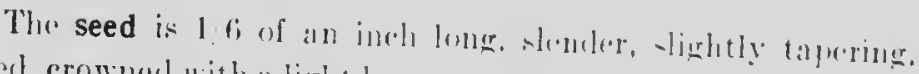

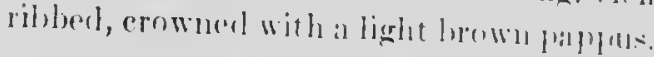

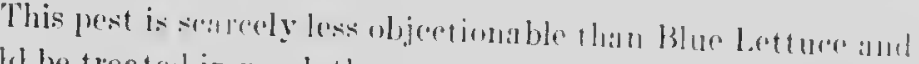
shoukl be treaterl in much the same way. It je morr. confimed to, local, relatively moist ar('is.

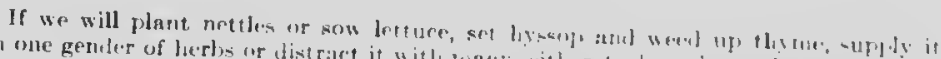

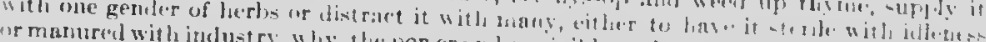

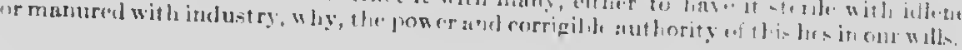

$$
\text { -Shakes:1:1re, thelle, 1, iii, 1+0). }
$$

Who weeting slacketh,

food husbandry lacheth.

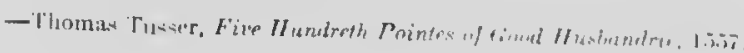

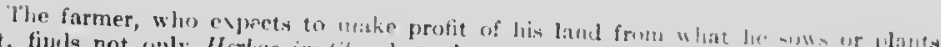

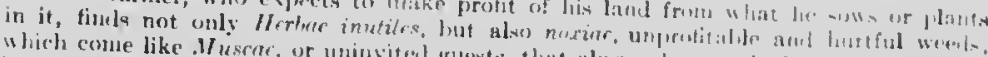

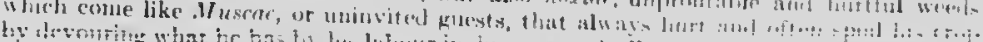

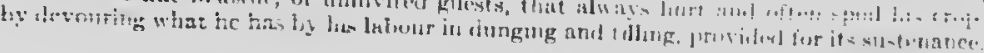$$
\text { -Jethro Tull, The Horse II wing Hushundily, ITiBI. }
$$ 
ORANGE HAWKWEED (Hierncium aure lacum I..)

Uther English nanes: levil's Paint-l,rusl, P'aint-brush.

Intreluend from Europe. Perenniat, low-growing, throwing out many areping branchus close to the gromel. Filled with bitter, milky $: l^{\prime}$. Whale plant vely hairy. Flowering stems 1 to 2 feret, elect and simple, almost leafless, clotherl with stellate fown, lalack ghaml-tipledel hairs and long white latirs from black tubereles, bearing at lhe top) a corymb of about a dozen hamlsome flower heads mearly 1 inch across. The tiery orange-perl of the flowers is rery strikmg. Leares long, rounded at the top, grablually narrowing towarls the base or lanee-shaped, blunt-pointed, 3 to 8 inches long, tufted, many lying clown tlat.

The seed (Plate 76 , fig. 100) is from $1 / 16$ to $1 / 12$ of an inch loug; purplish-black, unripe seed deep red; linear-oblong, eut off square at the top, pointed at the hase, strongly 10-ribbed lengthwise, the tops of the ribs forming a star-like rim around the base of the dusky white pappus, which is not persistent.

Time of flowering: Junce; seeds ripe by July.

Propagation: 13y secels and ereeping stems.

Occurrence: Abundant and troublesome in '" uplanel pastures of the kastern Townslips of Quebee and places in New Brunswick and Prince belward Island. Reper. asionally from Untario and all the easteru provinees.

Injury: A rigorous grower which spreals rapilly by its rumcers and matures malny secels, by mowns of which it soon overems land that can not be plowel, the abundant and useless foliage dieplateing grass and ruining meatows and pastures.

Remedy: Although a vigorous giower, all the roots are close to the surface of the grouncl. In land used for crops, plowing down followed by surface eultivation will kill it. Infested meadows and pastures must be broken up and put under a short rotation of cropss. For mountain pastures and uplands where plowing is not practicalble, small patelos may be kept from spreating by applying salt in lot alry weather, at the rate 


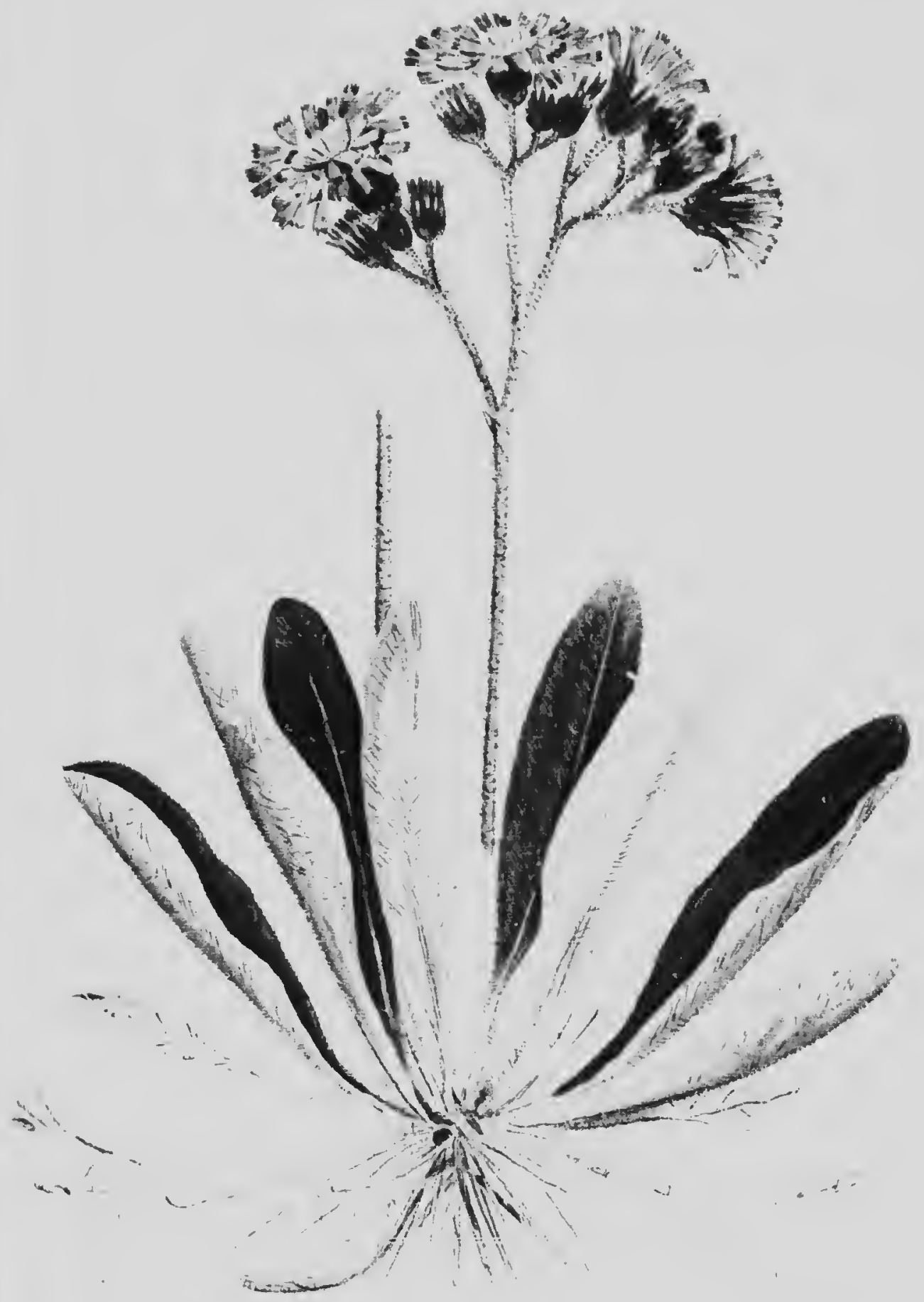


of 18 to 20 pounels to the spuare rot. lnfesed roeky pastures may be improved by sowing vigorous graseses that are butter at lete to choke nut hawk were thath the finer native specedes.

AIIIEI) SPliCIEs: Mouse-ear Hawkweed (ITieracium Piloselln I.) has bern introduced into Jince Lilwarl Island ant has taken almost entire possesien of some fields and ('x. tensive areas along the matrinles. It is atn eren worse peest than the species mentioneel athere, as it prenluees long, ruming. leafy stems on the surfice of the gromnl. from which tufts of root: and sid. shoots grow at short intervals, the lattrer being densely alothed with elustrrs of leaves, which are mooth atwowe, exerpe for some inconspicums long whit" bristles, and covered beneath with a thick fole rif star-khapenl hairs. The finwer hoals are solitary, on slemler stalks, julle yollow, wer an inclu across and sweetly seentell. The seed is a little longer than that of Orange Hawkworl.

Aceorling to Dr. D. L. Britton (Florat of the Sorthern States and Canala, 1901), the Prince Edwarl Istitul Molse-riar Hawkwedi the variety Peleteriunm. IH.r., of Hicrucium I'iloselln. The typieal form of the species is found oceasientally in the other

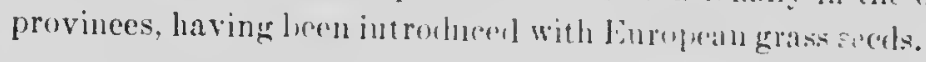

Branching Hawkweed (Hieracilem cladenthum Arpt-Tuure, US.) is a persistent perconial weruring in hay meatlows and pastures in parts of (Qunber and in many plares in . New Brmsewiek, Nova seotia and Pline lifwatl Istand. It is a pernicions

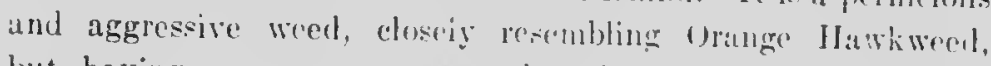
but having more numerous amel rather smallor, pale yellow flowers, narrow and longer leares, and, in strong planta, tall, flowering stems, solnetimes 3 feet ligh, bearing a large, irregular eluster of flower lieals. The lowest branehes start betow the mildle of the stem, a $t$ are much clemgatol and raise thei elusters almost as high as those of the upper branches. i weak plants, such as grow in hay ficlels, this banching habit is less conspicucus and the form nore nearly resembles that of Orange Hawkweed. 
KING DEVIL (Ilieracium praenlum Gochuat var. decipiens lioch.)

Introlueed from Europe. Perennial, with the general characteristies of the hawkweeds. It bears fow leaves, nearly all at the base, and numerous stender, leafy branches runnitug on the surface of the ground. The whole plant is sparsely hairy and lightly eoverm] with a fine bloom. Basal leaves narrow, the long flowrer stalk bristly hairy, supporting a sprealling corymb of yellow fluwers.

The seed is sinilar to that of the other varieties of hawkwerels, a little smaller, black.

Propagation: By rumers and seeds which are distributed by the wintl.

Occurrence: In the eastern provinees, abundant in southwesteru New Brunswick, where it is a pest in pasture lands and old meatlows.

Injury: I pernicious weal in pastures. Iike the other hawkweeds, it i. aroided by stoch on aceount of its pungent flivour and hairy natur". When present in any quantity, it entails much waste of forage or forlder.

Remedy: Grass lands infosted with King [novil should be brought under cultivation and a short rotation of erops. It clows not long give serious trouble in ficlds under a rotation of (rops that repuires frequent plowing. In meky pastures this pest may be treated the same as Orange Iawkweel.

Jlost of our hawkweels are of relatively recent introduction and many varieties have not get been cxactly beated and lescribed. 'Their identity may oceasionally prove dilficult, as there seem to be variations in the chartieters of some varieties.

The seeds of the different varieties are practically inclistinguishable. They sometiuns oecur in grass secels and are a langerous impurity. The method of eratication is the same for all and consists mainly of a short rotation, with seciing down to elover and grass at short iıtervals. 


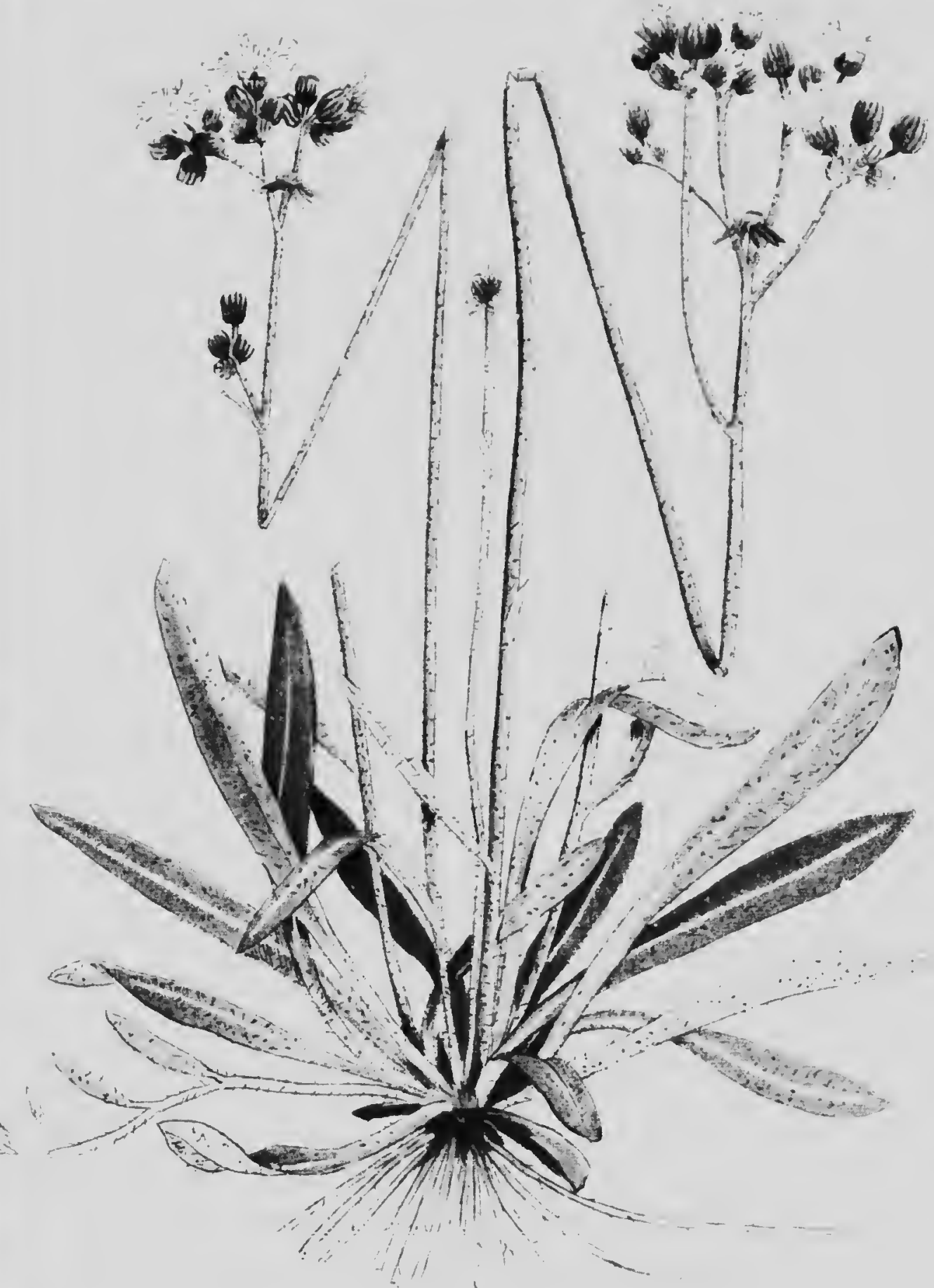




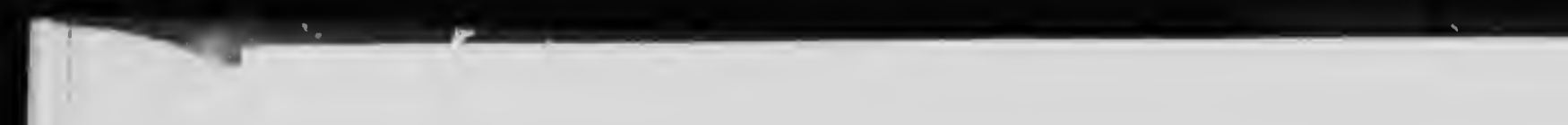



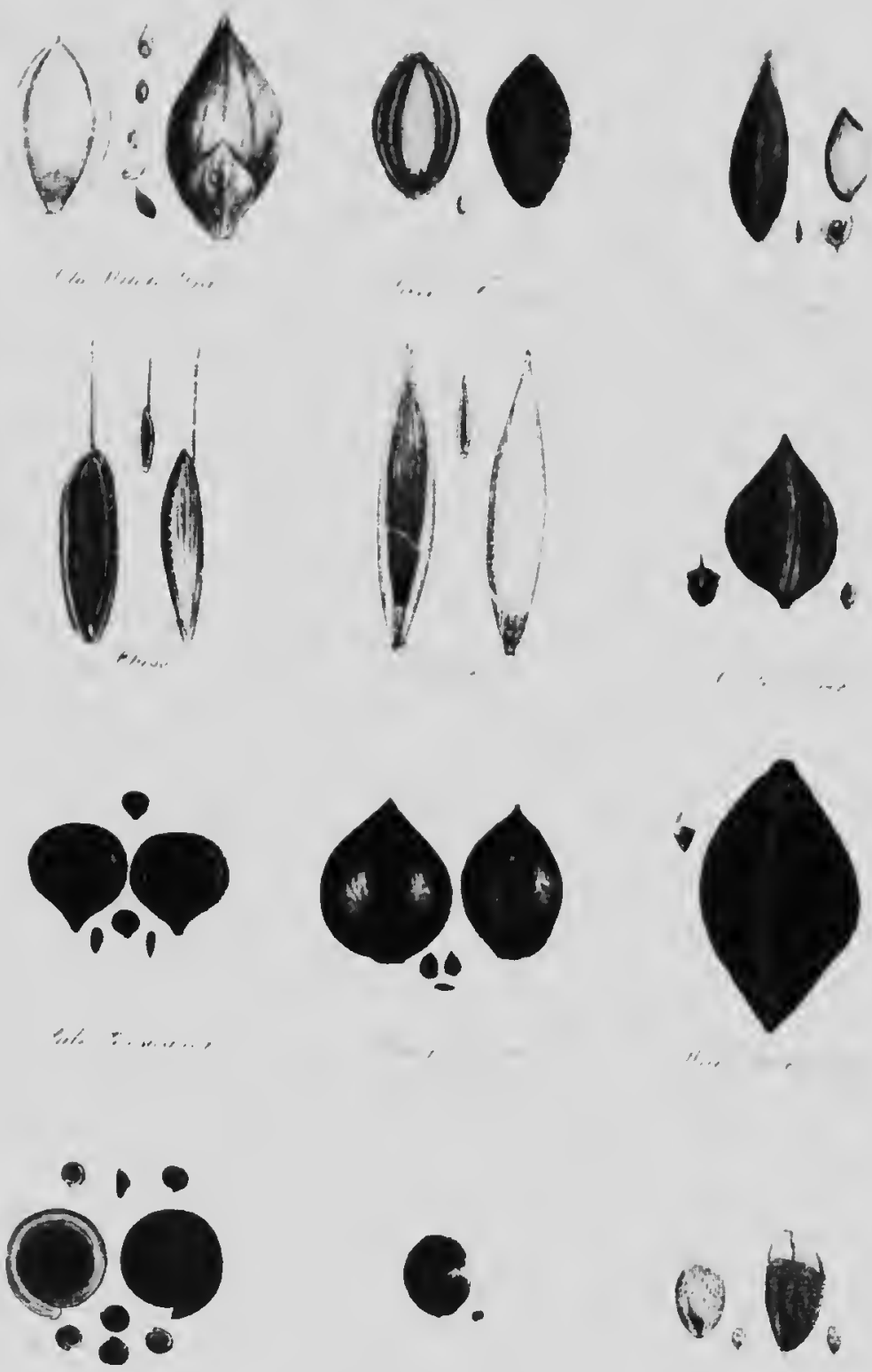

$\therefore$

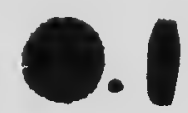

$\bullet .1$
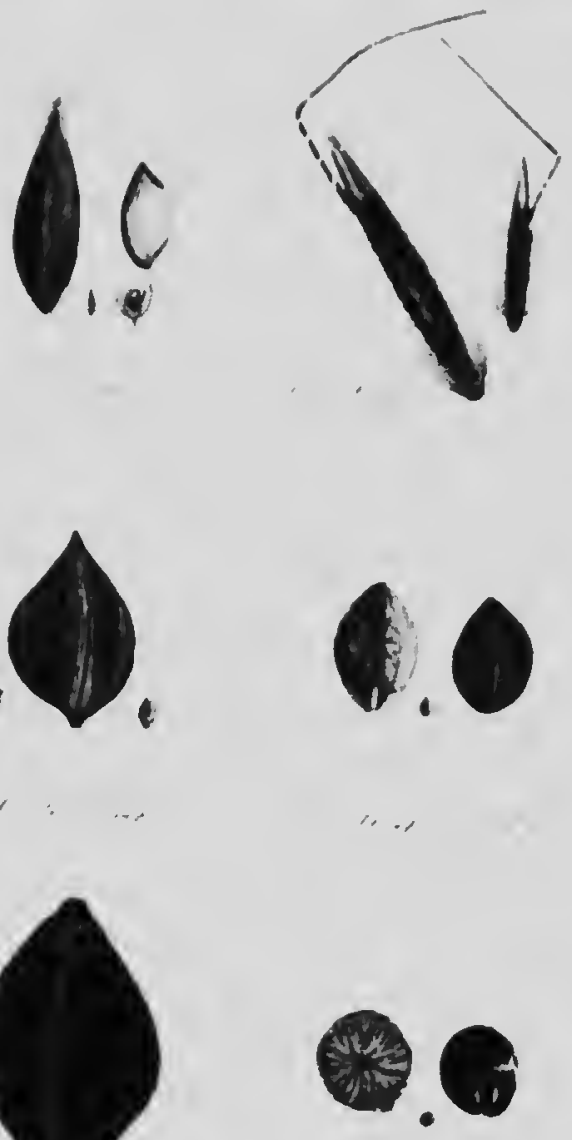
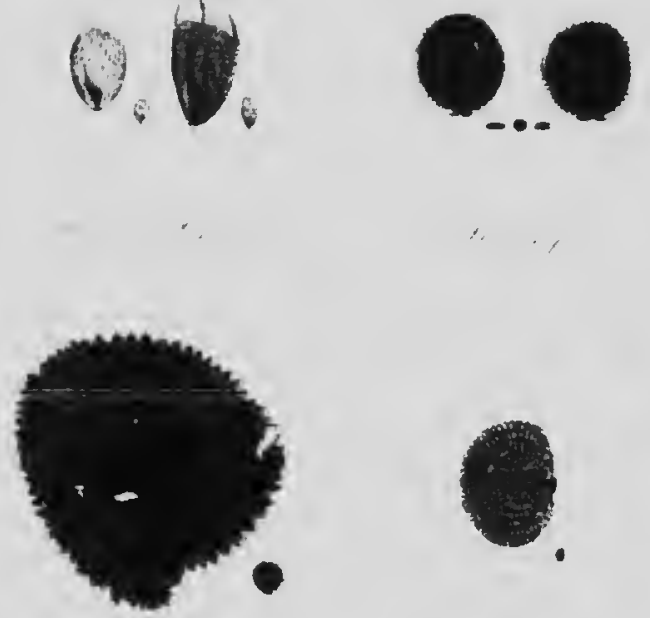


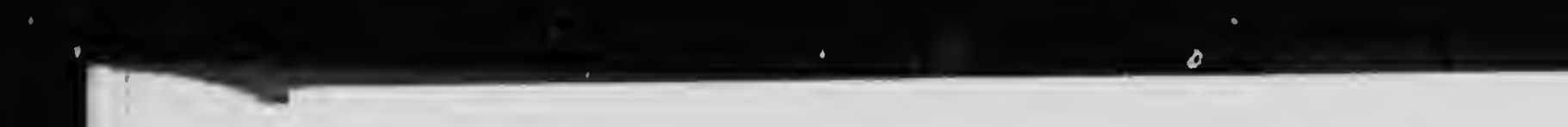



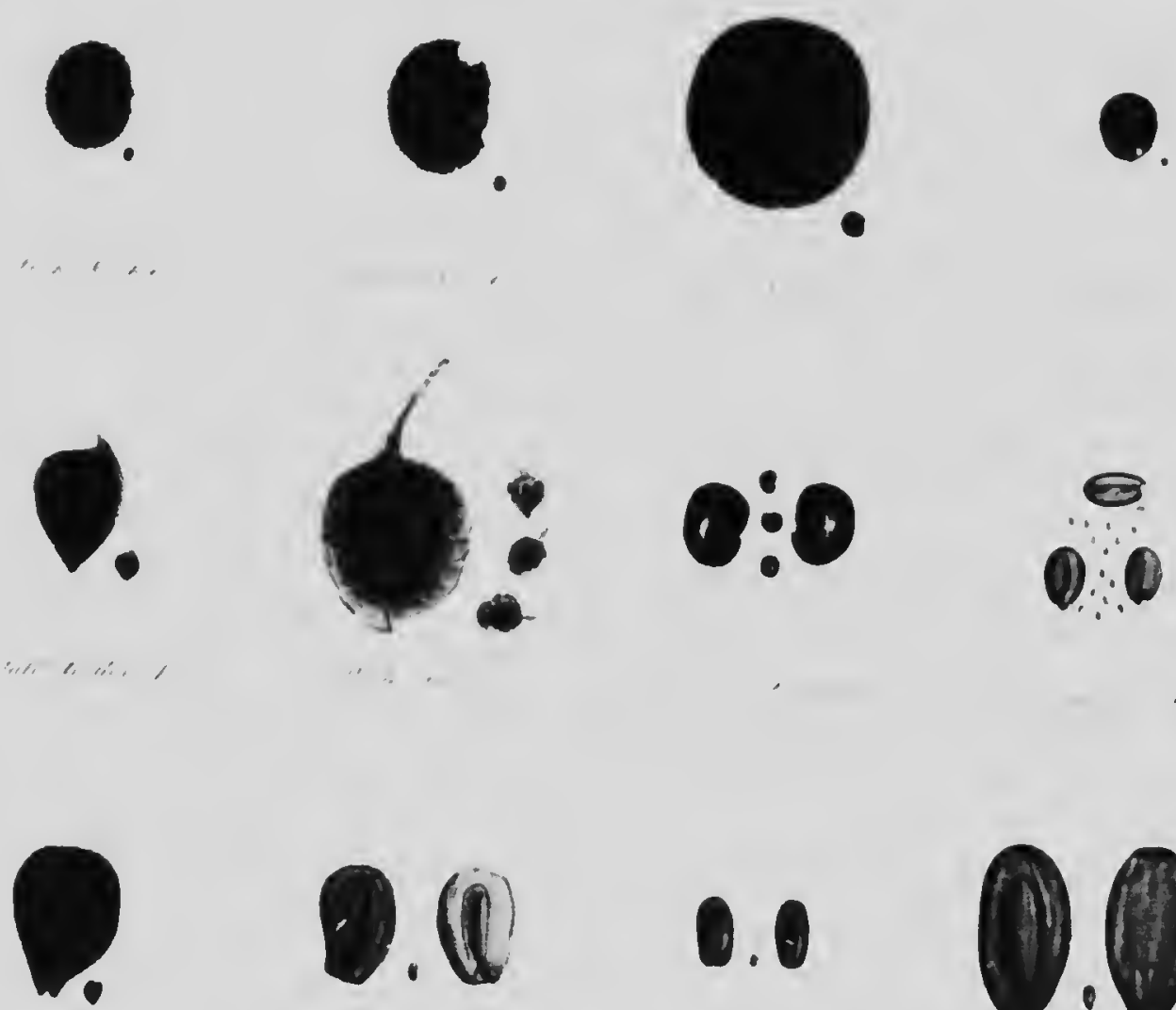

0.0
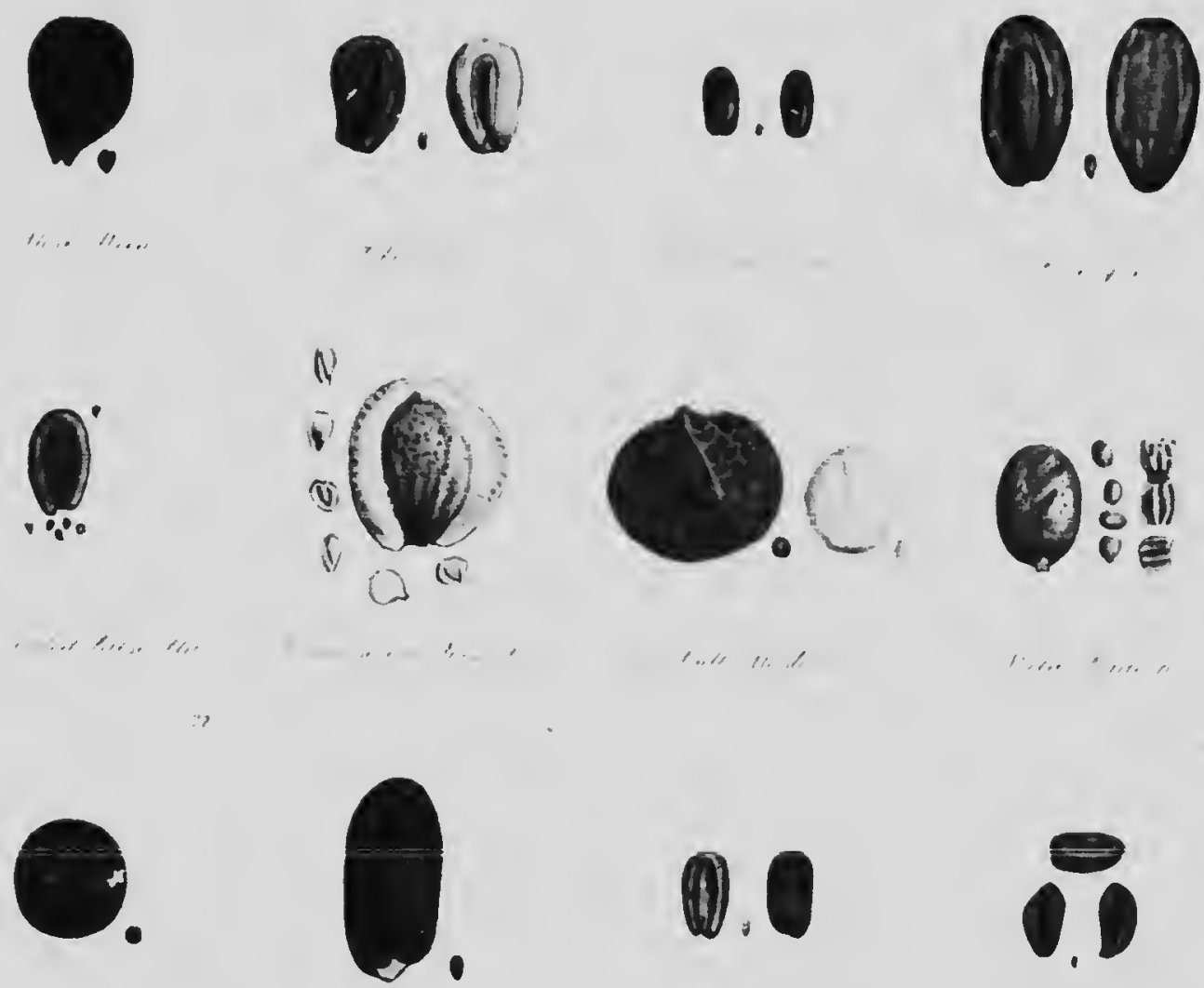

0.0

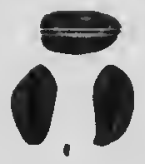




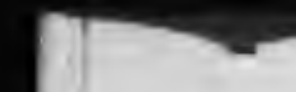


(3)
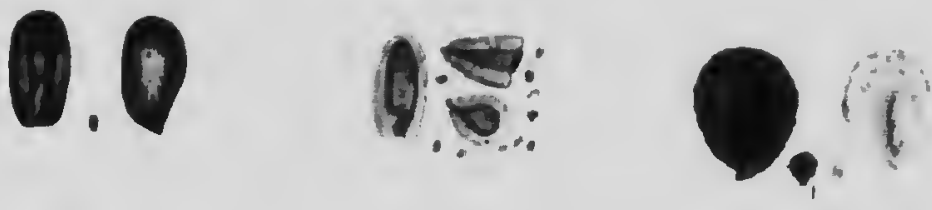

(1),
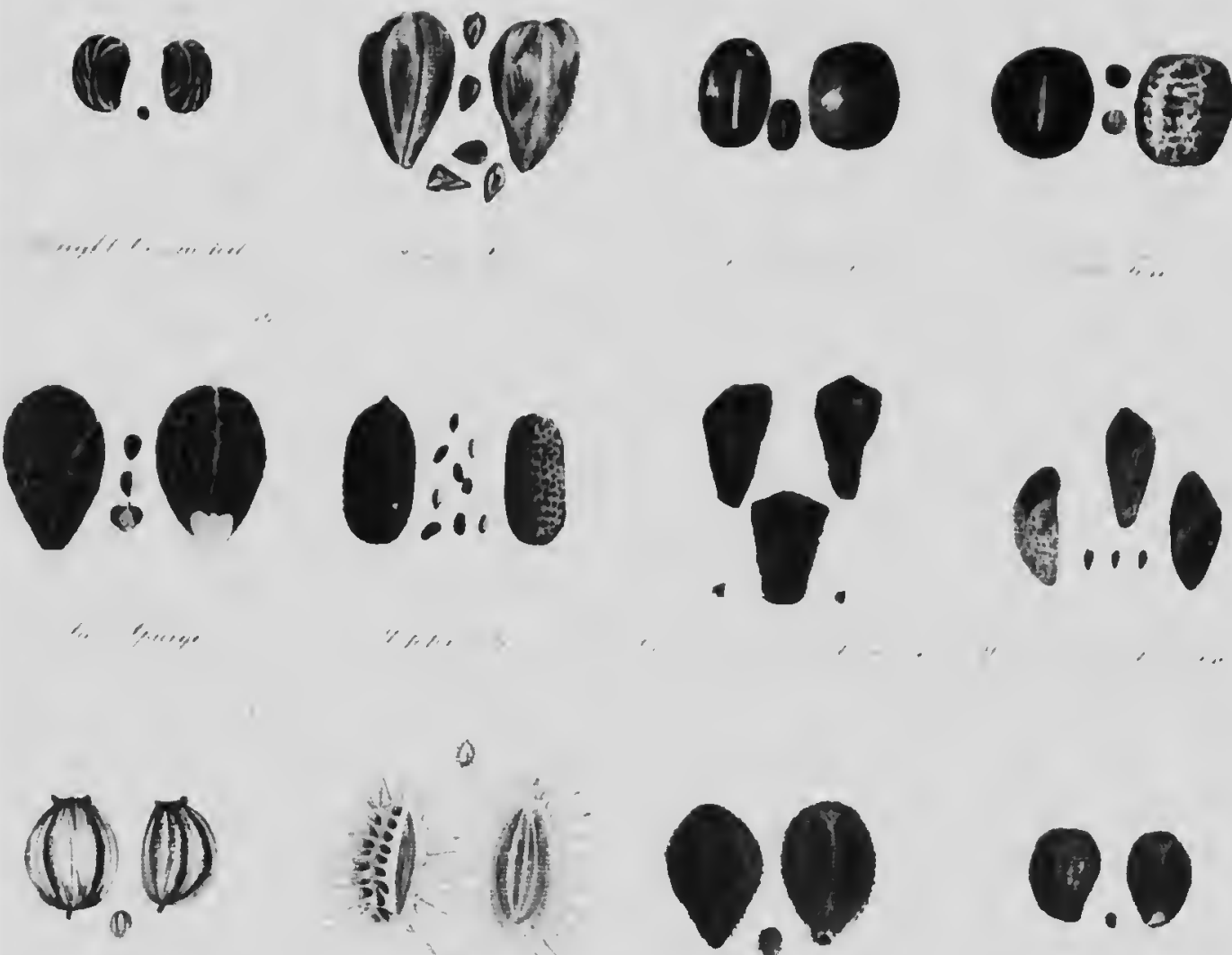

1
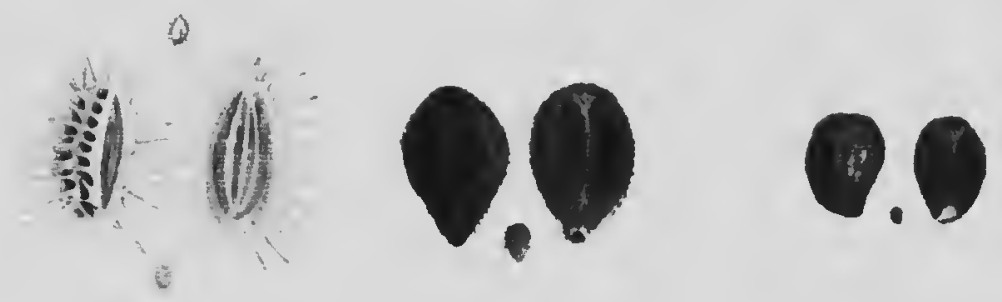

6
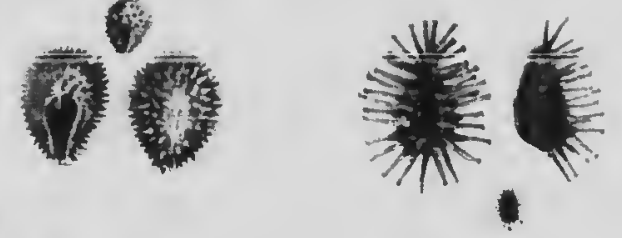

4 :

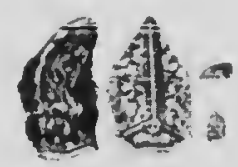


$\checkmark$ rar 

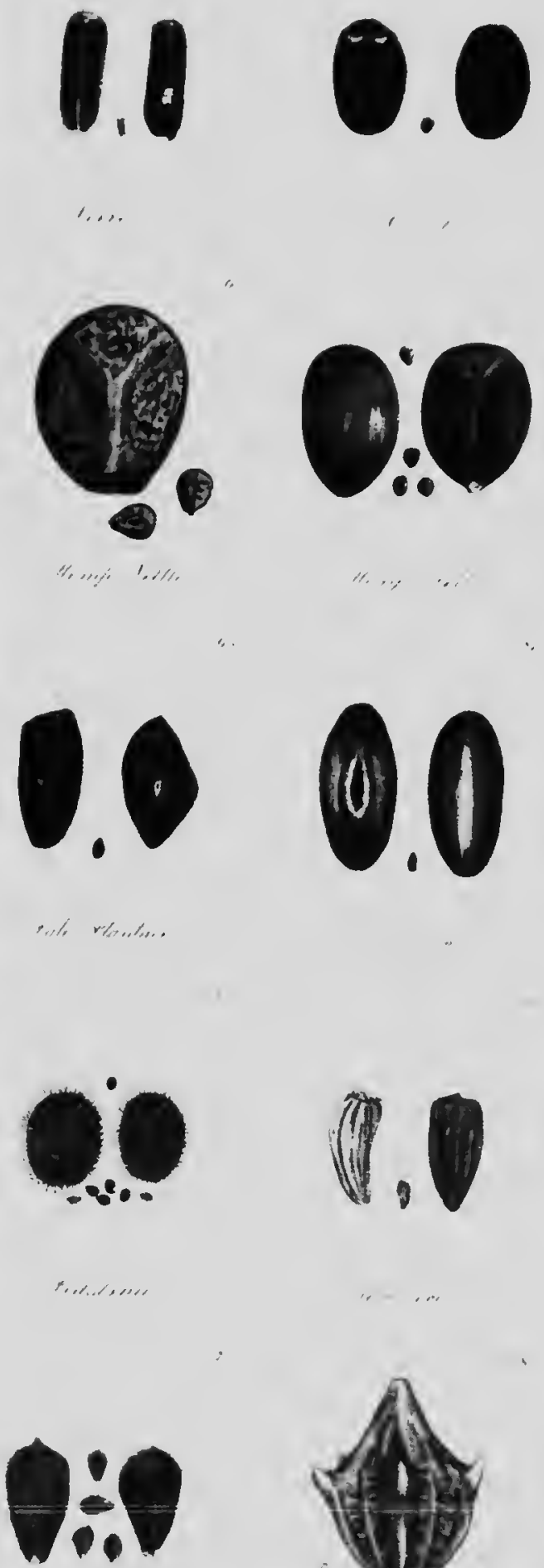
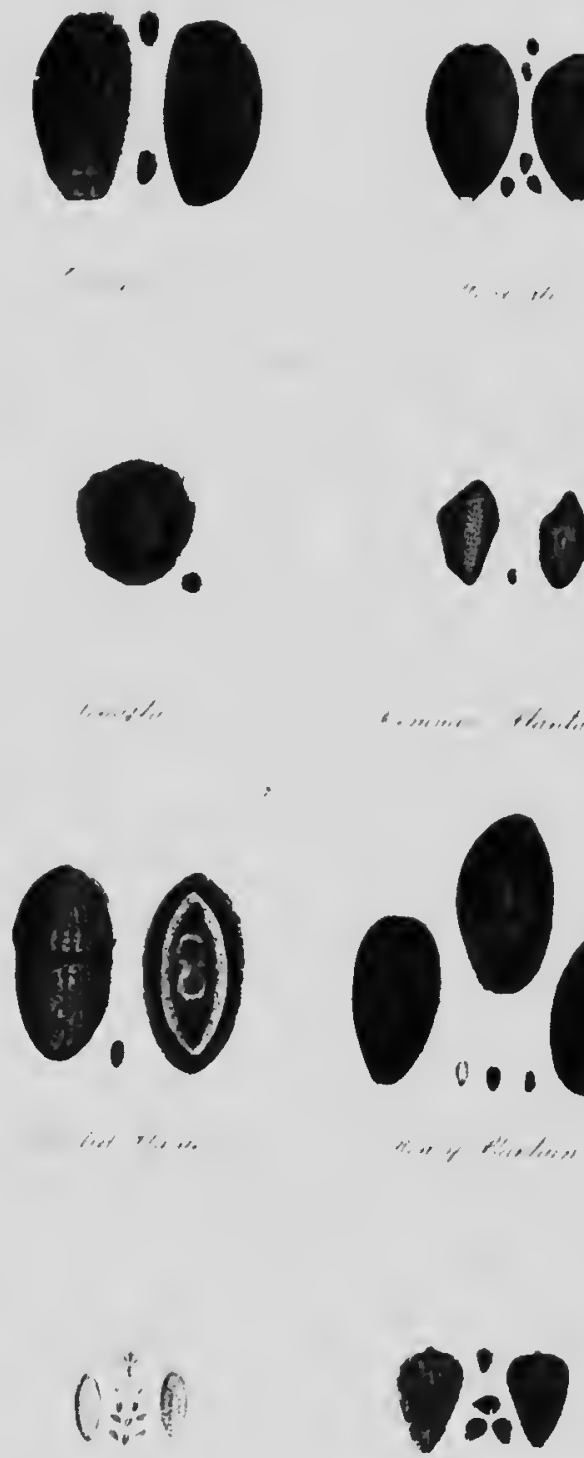

i, $1 .$.
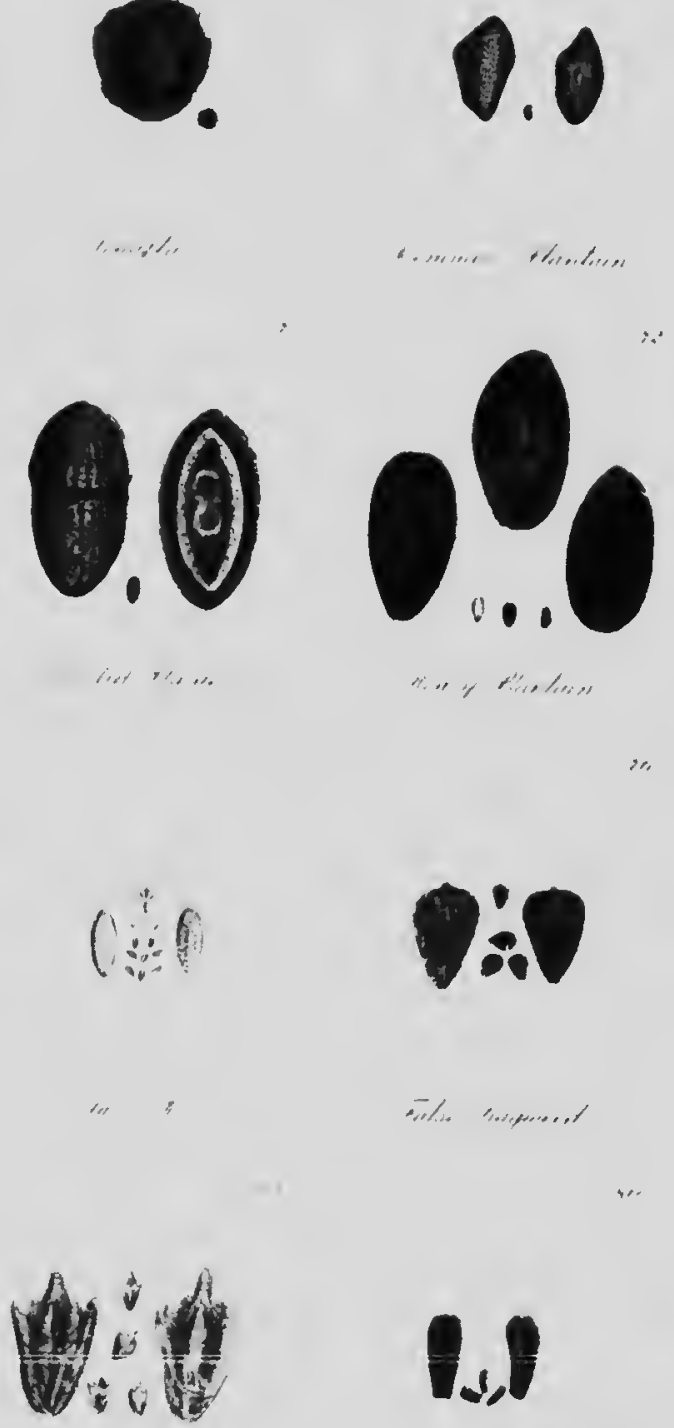

I.) 


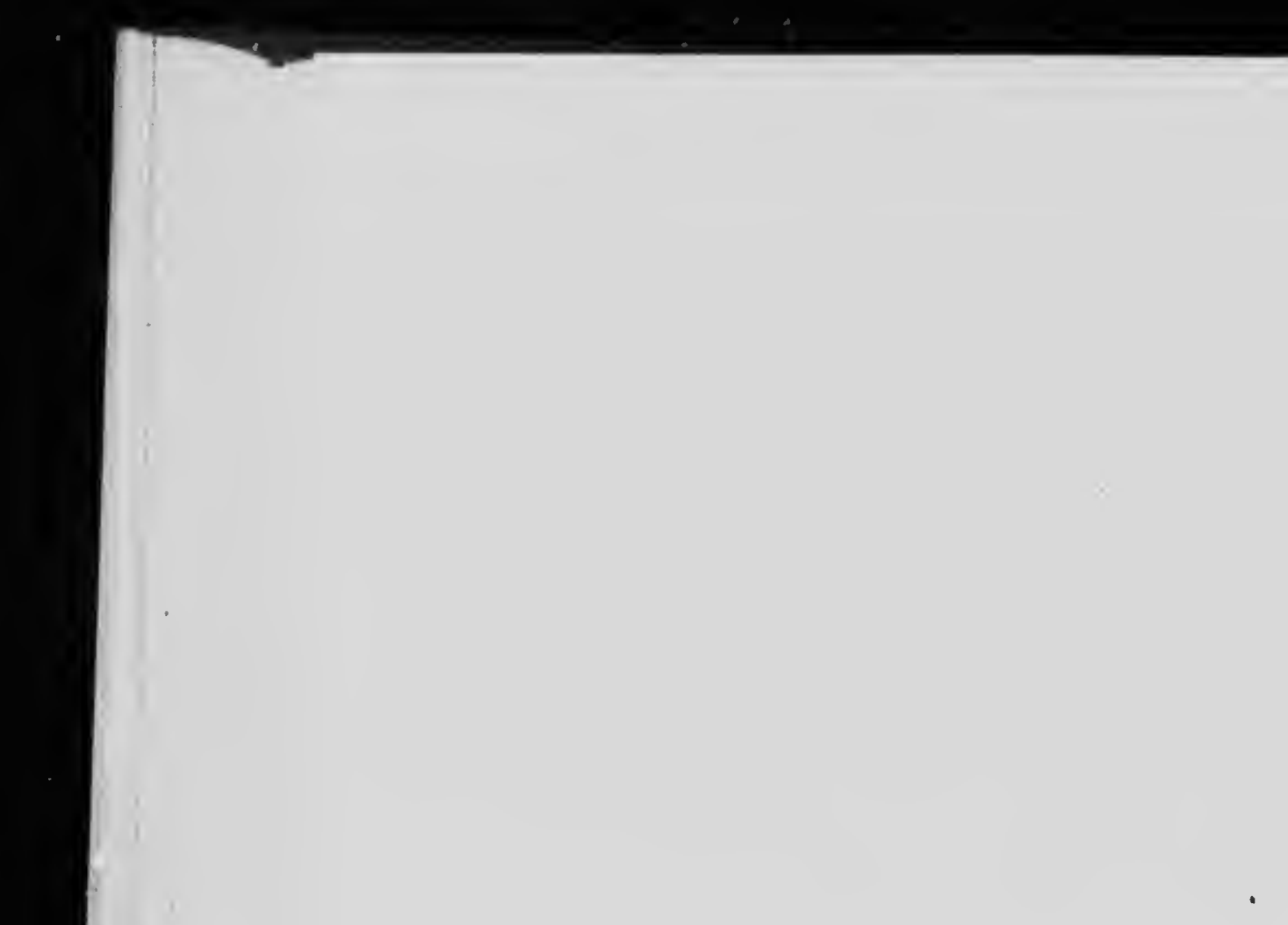



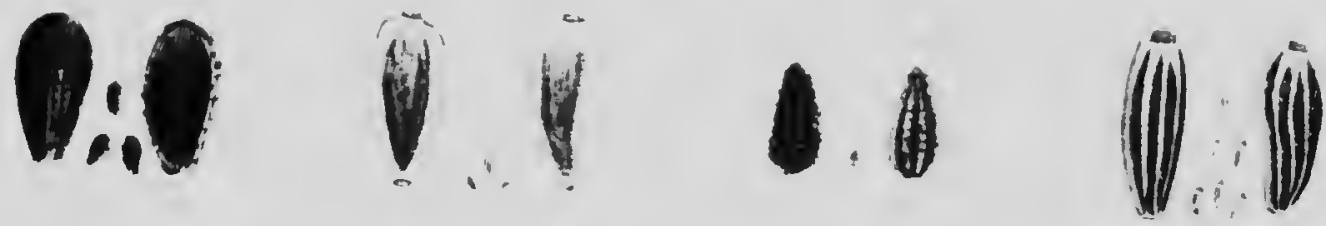

Mlter ente...
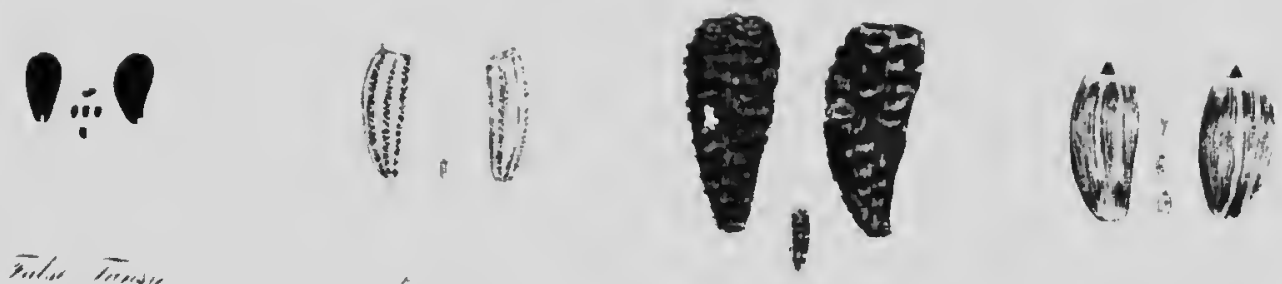

Finles inowy
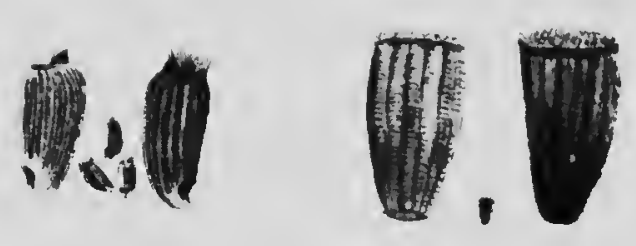

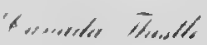
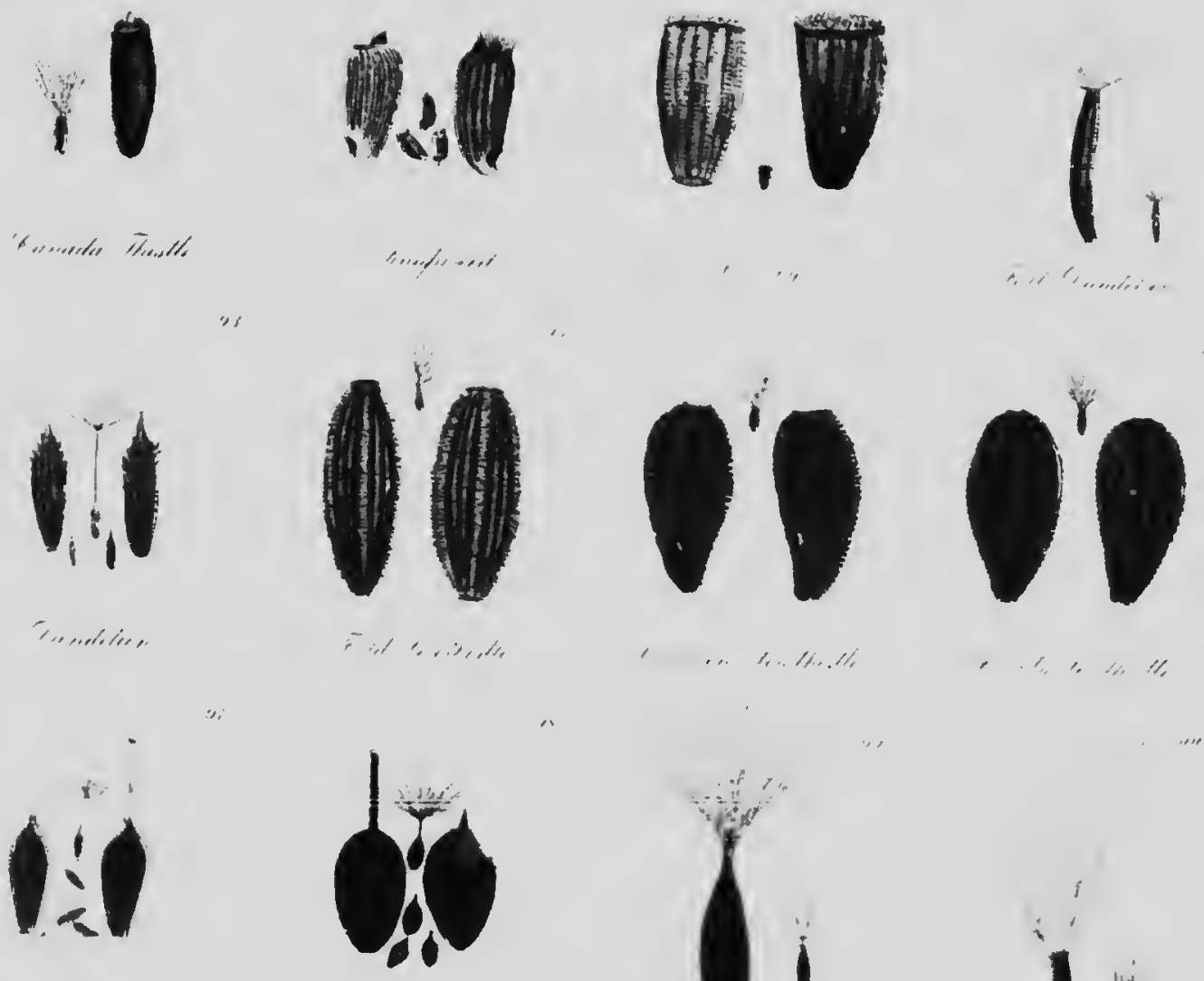

vinhly, d.11me.
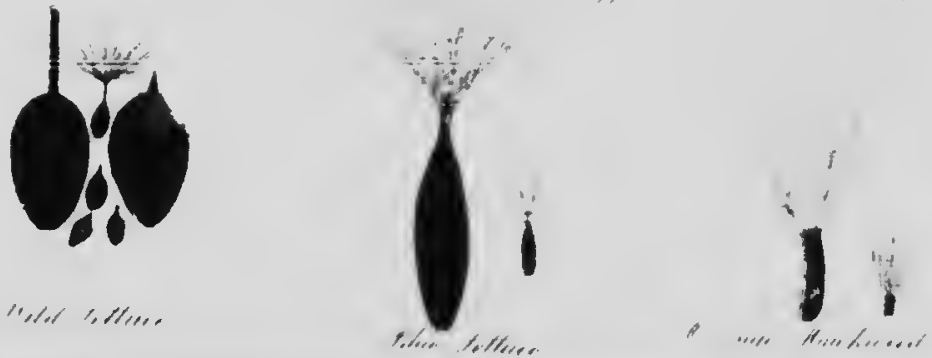


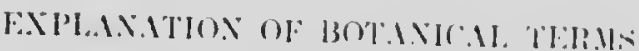

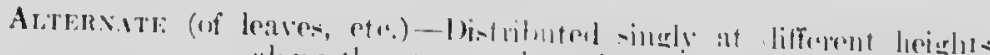
Anirat- Sere pinge 11.

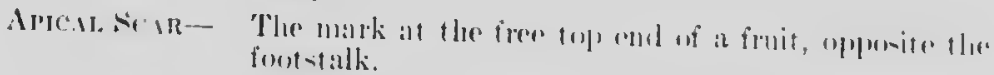

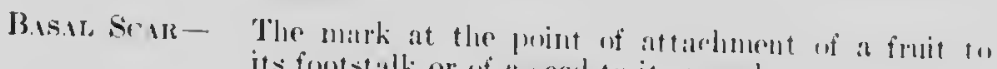

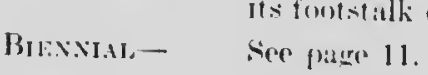

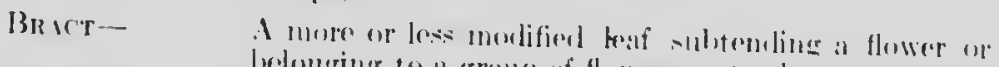

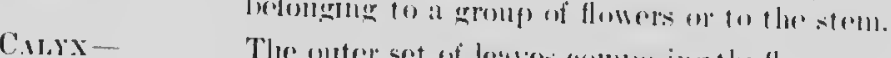

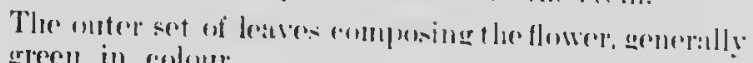

CALET:Li:totir.

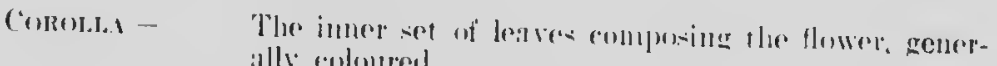
ally colomered.

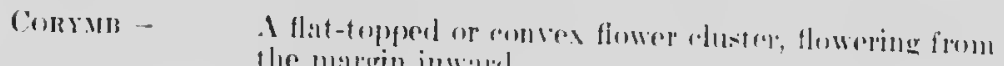
the matrein inw:url.

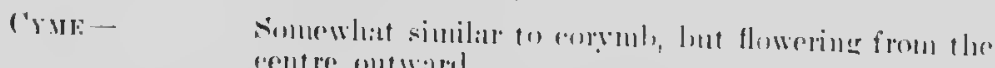
rentro ontwaril.
\end{abstract}

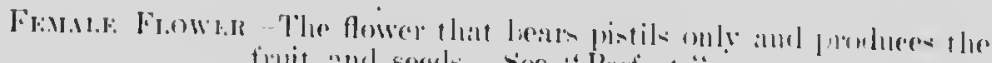

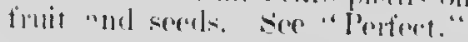

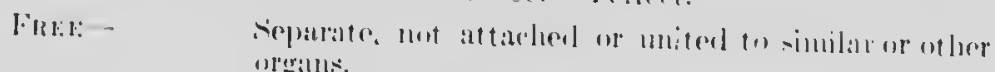

Fistitore?t11:

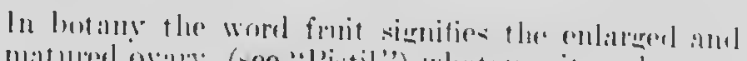

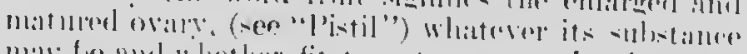

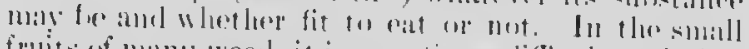

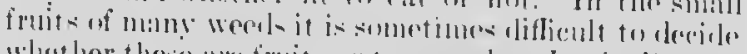

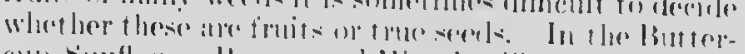

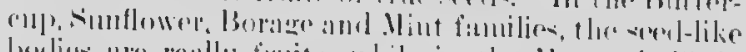

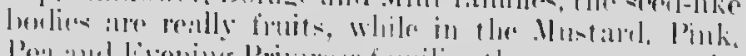

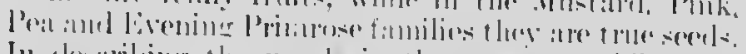

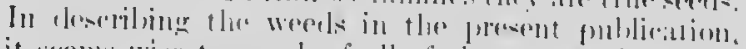

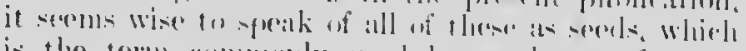

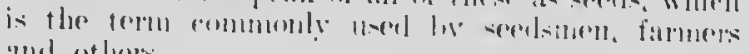
and ofleres.

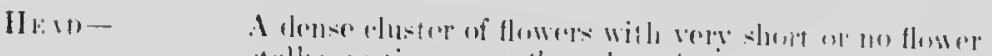

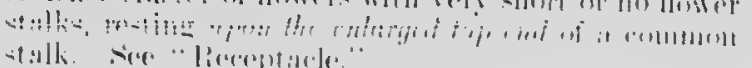


II I.t: Fow timin the pollen. Nere "l'rerfuet."

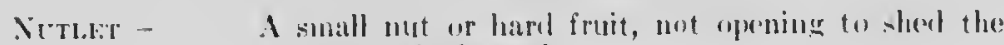
containel single soed.

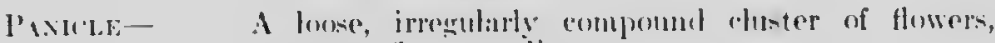
lurne on flowrer stallis.

l'merts- See pare 141, moder simflowor finmily.

Prizinia- See page 11.

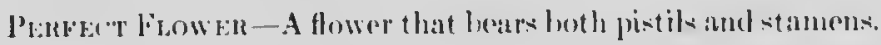

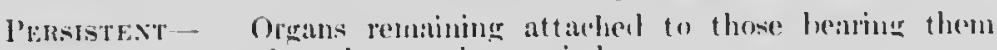
aftor the errowing periont.

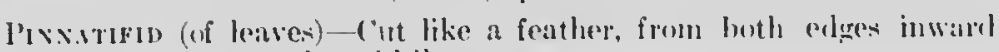
to the nivilrib.

I's'rtr.-

The fomale oranan of the flower, ansisting of the omer!? which rentains the serel, the stigma, a soft viscill part of the pistil which roreives the pollen grains. and the dyle which stlplurts the stigma.

low- Any dry fruit, opening hy valses, slits, ete., to sherl the contained serels.

Racruf- - A ehuster of flowers borne upon footstallis of an erpual and noticealib length, along a comment stalk.

RERPTACB- The enlareret top) end of a flower stalk or of the foutstalli of a flower heal. See pauge $1+1$ under siunflower family.

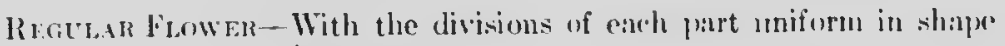
and st ructure.

Roorstork- A repeping stem helow the surfare of the gromel.

Sit. I. ESier page 23, nuder "The seerl."

SI:L:Dsiee linit.

s.m.

'The make oreran of the flowel', compesect of the anther, which hohls the fertilizing pollen gratins, and the support called the filament.

SIRE:An elongated fluwer rhtster, with the flowers stalkless or nearly so alon! a remmunn stalk.

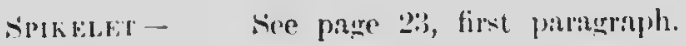

Tifren - Sime pagre 22, uncler cirass family.

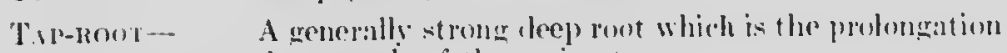
diwnw:alds of the main stem.

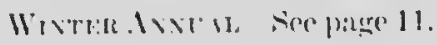




\section{INDEX.}

\begin{tabular}{|c|c|c|c|c|c|}
\hline & I'I Irt: & Patir. & & l’ & l'sibr: \\
\hline 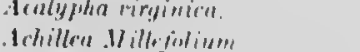 & & 1111 & Irtemenen & & $1 . i_{1}$ \\
\hline 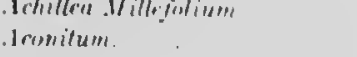 & & 1:i & hembr & & $1 . i^{\prime}$ \\
\hline 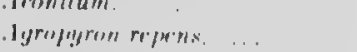 & & $\therefore i$ & inumlu & & $1,: 1$ \\
\hline 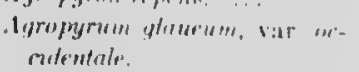 & ti & $: 31$ & 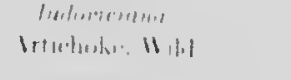 & & $\begin{array}{l}1 . i 1 \\
1.1 .5\end{array}$ \\
\hline Igrostemonie. . . & & 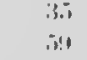 & 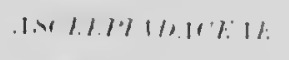 & & II! \\
\hline Githayo.......... & $1 ! 1$ & til & 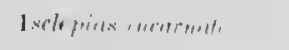 & & 1101 \\
\hline Alsine modict... & IV & 1,2 & s!rroune & & 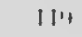 \\
\hline 1 lainear. & & .11 & tulteris, & & $\| 11$ \\
\hline A.MARAXTUACKAY: & & in: & Istrentes & & 11.1 \\
\hline Amaranth, Girenn. & & $\therefore$ & $1-1+12$ & & 11.7 \\
\hline Low ...... . . & & is & 1strumplirs. & & IIIM \\
\hline Kainbow . . . . . & . & $i i$ & .1 trupler & & int \\
\hline Spreading ....... & . & is & 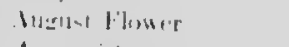 & (ii,i) & Itis \\
\hline Amaranthus rmulutus. ., & & $i t$ & 1 enne folluer. & i) & $\therefore$ \\
\hline blitoides. ...... . & & in & var. glolurenter & $\therefore$ & $\therefore$ \\
\hline graccizans. & . & $\therefore$ & ghobor and & $\therefore$ & $\therefore$ \\
\hline hylridus..... & & $\pi$ & Iricularies. & & 11 \\
\hline $\begin{array}{l}\text { retroflexus. . } \\
\text { tricolor...... }\end{array}$ & I1i & isi & 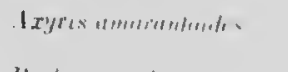 & 11 & $\therefore$ \\
\hline Ainber. . . . . . . . . & 11 & $11:$ & Binstarente molenets. & & 1111 \\
\hline 1 mbrosia urtemisiaginar. & i7 & $1 . i 2$ & B:t101:athe... & li:- & $11 \% 2$ \\
\hline pwilostachyn & & $1.3 ; 3$ & B:arb, Hih] & ? & $3+i$ \\
\hline Irifuk. . . . & .86 & l.j11 & Batrt-ia, lavi & & 1:3:3 \\
\hline Anaphalis... & & 117 & 13,111:bli:t11 & iil & $\mid(n, t)$ \\
\hline Anemone Crocus. . & & $\pi$ & Bratul, Cindsull & & 111. \\
\hline Pennsylvaniant. . . & & $\therefore$ & |beaver l'rifindul & $4 ;$ & $11 ;$ \\
\hline White.... . . . & & $\therefore$ & 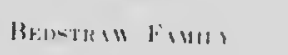 & & 1111 \\
\hline Anemone cunulfnsis. . . . & & 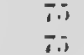 & 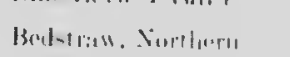 & & 1111 \\
\hline 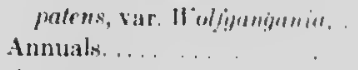 & & 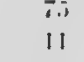 & 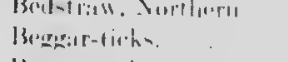 & & I.i.i \\
\hline & 12 & 111 & Bowgr:tr-t|rh, Cimmututh & & lisi \\
\hline Antennuria. & & 117 & Behen rulynirs & $\because 2$ & $i 1$ \\
\hline Anlu'mix rotula. & 当 & liti & Birlens . . & & $1 . .5$ \\
\hline Anthomidout. & & 1., & $\begin{array}{l}\text { lomelosa. } \\
\text { Biomotals. }\end{array}$ & & $\begin{array}{c}\text { lini } \\
11\end{array}$ \\
\hline Intirshinum l.ınurin. & (i) & I:3! & Bimuluned. . & 11 & $1: 31$ \\
\hline I pargia autummalis... & (iii) & l11. & Mi:r.k. . & $1:$ & 11. I \\
\hline Arulsis. . . . . . & & $\| 111$ & 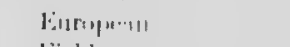 & 11 & $1: 211$ \\
\hline glabra. ....... & & 101 & 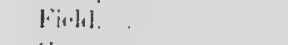 & 11 & 1311 \\
\hline Arctium lapm. & & $11 i: 3$ & r:pratt..... & & $1: 1$ \\
\hline Lappa, var, minus & b:2 & 1 (ii- & HInleme. & & $1: 1$ \\
\hline minus........ & ii: & lit:- & mm: & 11 & $1: 21$ \\
\hline Imira inimatluerii & iiii & Inis & I frighit... & & $1: 2 !$ \\
\hline
\end{tabular}




\begin{tabular}{|c|c|c|c|}
\hline Pl.atr: & Page & Plate & Page \\
\hline Bitterweed, (Fleabane) . ... 54 & 146 & Camelina dentata. . . . . . . . . & 87 \\
\hline “ (Great Ragweed). 56 & 150 & mactocarpa. ........... 30 & 86 \\
\hline Black-eyed Suann. . . . . . . 58 & 154 & microcarpa. ............ & 87 \\
\hline Blond-staunch. . . . . . . . 54 & 146 & sativa. ............ 30 & 86 \\
\hline l3lue Devil. . . . . . . . . 47 & 126 & Campion, Bladder. ....... 22 & 70 \\
\hline Blue Sailors. . . . . . . . . . 64 & 166 & Red. . . . . . . . . . . . & 67 \\
\hline Blue-thistle. . . . . . . . . 47 & 126 & White. . . . . . . . . . 20 & 66 \\
\hline Blue Weed. . . . . . . . . . 17 & 123,126 & Caper Fayily. . . . . . . . & 102 \\
\hline Bonewet. . . . . . . . . . . . . . & 143 & & \\
\hline Bornge Family........... & 123 & Capsella Bursa-pastoris. .... . 29 & 84 \\
\hline BORAGIV.iCEAE...... & 123 & Caraway. . . . . . . . . . . & 118 \\
\hline Bouncing Bet. . .......... . . & 73 & Carex trichocarpa, var. arinlala .. & 39 \\
\hline Brassica arvensts. . . . . . . 33 & 92 & Cardurs arvensis. . . . . . . 63 & 164 \\
\hline campestris.............. & 93 & Carrot, Wild. ............. & 118 \\
\hline juncea. . . . . . . . . . . & 93 & Carum Carri. ............. & 118 \\
\hline Napus. . . . . . . . . . . . & 93 & CARYOPHYLLACEAE. . . & 59 \\
\hline nigra $\ldots \ldots \ldots \ldots \ldots \ldots \ldots$ & 93 & Catchfly, Conical... & \\
\hline orientalis............ 34 & 94 & Garden $\ldots \ldots \ldots \ldots \ldots \ldots$ & $\begin{array}{l}69 \\
69\end{array}$ \\
\hline perfoliala. . . . . . . . . . . . 34 & 94 & Night-flowering. ........ 21 & 69 \\
\hline Rapa. ............... & 93 & Sleepy. .................. . & 68 \\
\hline Sinapistrum. . . . . . . 33 & 92 & 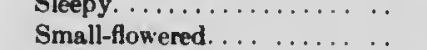 & 69 \\
\hline Bromus hordeaceus . . . . . . . . & 31 & 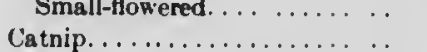 & 69 \\
\hline secalinus. . . . . . . . . 4 & 30 & $\begin{array}{l}\text { Catnip. .................. . } \\
\text { Cat's-foot. . }\end{array}$ & 130 \\
\hline tectorum. . . . . . . . . . . . & 31 & Cat'y-foot. . $\ldots \ldots \ldots \ldots \ldots \ldots$ & 147 \\
\hline Buckhorn. . . . . . . . . . 52 & 138 & $\begin{array}{l}\text { Celosia. .............. } \\
\text { Centaurea. . . . . . . . . . . }\end{array}$ & 56 \\
\hline Btckwheat FaMLLY. . . . . . & 40 & 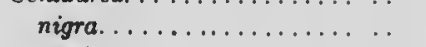 & 166 \\
\hline Buckwheat, Wild......... 12 & 48 & Cerastium. . . . . . . . . . . . . & 63 \\
\hline Bugloss, Viper's. . . . . . . . . 47 & 126 & ariense................. & 63 \\
\hline Bur, Blue. . . . . . . . . 46 & 124 & vulgatum. . . . . . . . . & 63 \\
\hline Common. ............. & 124 & Chaetochloa viridis. ........ 1 & 24 \\
\hline Sheep. ... . . . . . . . . . 46 & 124 & Chamaeraphis viridis....... 1 & 24 \\
\hline Burdock, Common. . . . . . . 62 & 162 & Chamomile............ & 157 \\
\hline Great. . ............. & 163 & Dog's. . . . . . . . . . . 59 & 156 \\
\hline Iesser. . . . . . . . . . . . 62 & 162 & Charlock ........... 33 & 92 \\
\hline Bursa-pastoris. . . . . . . . . 29 & 84 & Jointed. . . . . . . . . . 32 & 90 \\
\hline Butter and Eggs. . . . . . 50 & 134 & Cheat. ............... 4 & 30 \\
\hline Buttercup Fasily. . . . . . . & 75 & 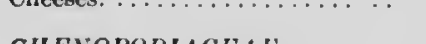 & 111 \\
\hline Buttercup, Cursed. ........ . . & 77 & CIIE.VOPODIACEAE' . . & 50 \\
\hline Meadow. . . . . . . . . . 25 & 76 & Chenoporium............. & 50 \\
\hline Small-flowered............ & 77 & album............. 13 & 50 \\
\hline Tall. . . . . . . . . . . 25 & 76 & hybridum.............. & 52 \\
\hline Butterfly Weed. . . . . . . . . & 119 & Chess.............. 4 & 30 \\
\hline Butterweed. ........... 54 & 146 & $\begin{array}{l}\text { Slender. } \ldots \ldots \ldots \ldots \ldots \ldots \ldots \\
\text { Soft } \ldots \ldots \ldots \ldots \ldots \ldots \ldots\end{array}$ & $\begin{array}{l}31 \\
31\end{array}$ \\
\hline Cabbage, Hare's-ear. . . & 94 & Chickweed.............. 18 & 62 \\
\hline Cactus, Russian. . . . . . . . . 15 & 54 & Common. ........... 18 & 62 \\
\hline Cadiluck. ... . . . . . . . 33 & 92 & Common Howie-car. . . . . . . & 8.3 \\
\hline “ (misnained). . . . . . 32 & 90 & Field, Mouse-ear. . . . . . . . . & 63 \\
\hline
\end{tabular}




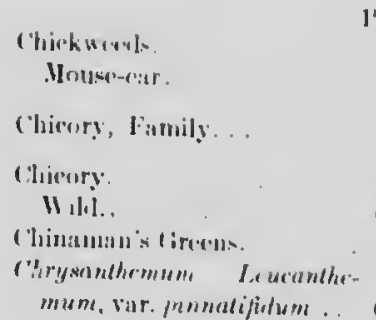

Chrysuroma yraminifolia. .... is

Cichoricae.

Cichoriaceae.

Cichorium Intybus... . . . . til

(iruta Donglasii..

maculata. ...

orrilentalis.

myans.

virusa, var. mandata. ... 4:

('incpuffoil, lkough

livight. .

Cirsium arvense.

lonceolatum. .

undulatumi...

Clammy-weel. .

Claviceps. .

mirpurora

rleome serrulato.

Clotluars....

Clothinr.

Sipring. ...

Clover, 1R:ublut s-finit

Stinking ..........

('Iovers, siuret

rIown's Heal.

Cnims arrensis.

('ockliearl. .............. (i)

C'ockleburs.

Circkle, Chin:ı. ... . . . . . 2.

Com..... . . ...... 11

low. . . . . . . . . . . :

Furple.............. I!

Siticky................ It

White....... ,... 20

Cockles...........

Cockscumbs.

Colewort. ..............

Colt's-tail. . . . . . . . . . . ;

Compass Hant. .
11.11" J'ME

$$
\text { iit }
$$

ti.i

$11:$

(i) lliti

(i) 1titi

iti

1 1.5

114

litij

4.1

Ititi

$11 \%$

3110

117

117

11 ;

liti;

111,

Ifit

Iti,j

16.5

10:2

39

38

$10: 2$

1.3

Iii.

15.3

$10 \div$

10:

$11 \%$

13.1

liti

1:3:"

15.5

7.)

(i)

7.2

i.j

fis

iti

5 ?

inti

17.

$14 i$

171
(") /II.)/T.।

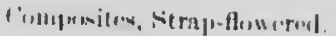

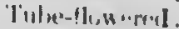

lime jlimir. .

Cimringin orentulix.

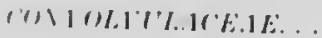

I'I.AIt: I'Wir:

111

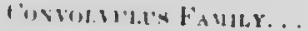

foncolvulus arienxis

$$
\text { se rium. }
$$

spithormaens. . .

tirris.... .

forylolis aurea.

('i) bituc.

siupterd.

('nw-luell.

(i) wlicrlı.

112

$11:$

1ij)

34

129

130

CR.1SSULACH.1F

Crens, Cow....

C'rowfout, Ditel.

1inll. .

(row uwregt.

CRUCIFEKIE:

("ucubalus brelen.

... 22 70

('usculu. ...... 12:3

limilhynum... ....... 4.7 122

Trifolii... ......45 45

('uscutere............. . 120

Cintwreds . . . . . . . . $\quad 147$

f 'ynureac.

("ynoglossum offiriunle.

(")IRARHE:

('yperus diandrus...

exmilentus.

1)ilisy, (1)x-rye

(j)

1) $x-c y \cdot$ (1)ishatued)

1)rajuge..

58 1.51

Ilite.

ifllow.

54

(i)

.89

1)andelim, (oummon.

Irall.

Red-sieded

I'arnul, Bear. '4..?. . . .

(omasor
162

1.58

\section{1:2)}

121

121

$11 i$

77

116

lii

i11

$7:$

$10: 3$

8.3

77

1,50

77

(7)

3

20

i2

21

151

158

169

i.j $\quad 168$

10i!

i $\quad 32$

\section{5}

1

1


ISfi

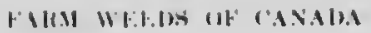

\begin{tabular}{|c|c|c|c|c|}
\hline $\mathbf{P} \mathbf{1}$ & l'arik: & & '1.41t: & l'wr: \\
\hline P’uisoll & 32 & EUIHORBI.1\%H.1\%: & . & III) \\
\hline Whitr. . . . & 32 & Eiuphorisia corollatu. & & 111 \\
\hline Daurus C'arota. . . & 118 & plyptasmerma. .. & & 111 \\
\hline Delphinium. ..... & $7 i$ & Ircliosenpia & & 110 \\
\hline Inigitalis. . $\ldots \ldots \ldots \ldots$ & $13: 3$ & morulnen. . & & 111 \\
\hline Wuck, Bitter. ......... & $4: 3$ & linphrawse arrtirs ... . & & 1:3:3 \\
\hline 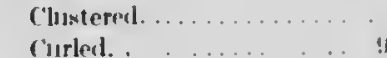 & $\begin{array}{r}4: 3 \\
13,4: 3\end{array}$ & Enthumin graminifulin. & .j3 & 111 \\
\hline Sullr . . . . . . . . . & 4 & 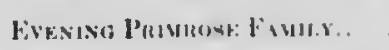 & . & $11: 3$ \\
\hline Vrincel. ........ $\ldots \ldots \ldots$ & $4: 3$ & Evening Primmer, ('umnmo. & & 115 \\
\hline Yellow... .... & $1:$ & White. . . . . . . . . & $4: 3$ & 114 \\
\hline Dueks... . ..... . . . . & 40 & Whito-mtrollmorl. . . & 42 & 111 \\
\hline Bodiler, Mlfalfa. .. . . . . & 123 & Everlastings. . . . . & r & 147 \\
\hline ('lover. . . . . & $12: 2$ & True............. . & $\cdots$ & $1^{1 \cdot}$ \\
\hline Inser. . . . . . 4. & $\begin{array}{ll}12: 2 \\
1 \cdot 2 !\end{array}$ & Bxplanation of Botaniral & & \\
\hline 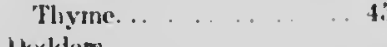 & $1: 2$ & Terma $\quad \ldots \quad \ldots \quad \ldots$ & . & 181 \\
\hline Iholders. . . . . . . . . . & $1: 20$ & Fyebright, (ilandul:ar . . . . . & . & $1: 3: 3$ \\
\hline lhog Fennel. . . . . . . . . & $154 j$ & & & \\
\hline 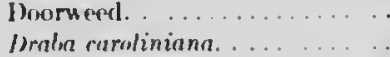 & $\begin{array}{l}1.17 \\
7 ! 1\end{array}$ & Filse Flax...... $\ldots \ldots \ldots$ & 30 & $\mathbf{v i j}$ \\
\hline $\begin{array}{l}\text { Dralua ruroliniana. .... . . } \\
\text { nemorosa. ......... }\end{array}$ & $\begin{array}{l}7 ! 1 \\
78\end{array}$ & Round-seerlod... ....... & . & 87 \\
\hline 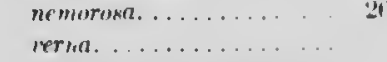 & $\begin{array}{l}78 \\
7 !\end{array}$ & Snall-keeded........... . & . & 87 \\
\hline $\begin{array}{l}\text { Ireria. } \\
\text { Isracorephalum parinflomint. }\end{array}$ & $1: 31$ & Farm Implements to Dest roy & & \\
\hline $\begin{array}{l}\text { Iracosephnlum parifflomim. . } \\
\text { Dragonhead. Ameriean. ... }\end{array}$ & 131 & Weeds.... & $\therefore$ & 19 \\
\hline 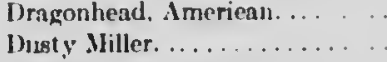 & 167 & Fat-hen........... & 13 & 50 \\
\hline Druminond's Pink. .. . . . . . & ii7 & Figwont Fami.y. ...... & - & $1: 33$ \\
\hline Echinonparmun Lapprela. . . to to & 121 & Figworts. . . . . . . . & & $1: 3$ \\
\hline$\ldots \ldots \ldots \ldots \ldots \ldots$ & $1: 3$ & Firewred. ............... & & 162 \\
\hline tulgare. ............. t & $1: 3$ & " (Common Flealane) j & 51 & 146 \\
\hline Fggen and Bareon......... if & 134 & “ ((irc:at Willow-herb) & . & $11: 3$ \\
\hline Elee:mupane. . . . . . . & 147 & Stieky. . . . . . . . . . & . & $11: 3$ \\
\hline Emilotrium. $\quad \ldots \ldots \ldots$ & $11: 3$ & Fireweeds $\ldots \ldots \ldots \ldots \ldots$ & . & $11: 3$ \\
\hline$\ldots \ldots \ldots$ & 113 & Fitches. . . . . . . . . . . & . & $10 ! 1$ \\
\hline anmustijo. . ....... & $11: 3$ & Flarweerl. . . . . . . . . . & 0 & 134 \\
\hline rirechtites, ..urifoliu... . & 162 & Fleabane, (ommuma........ & \$1 & 146 \\
\hline Ergot ou Couch, liyo aurl & & 1): 1sу. . . . . . . . . . & . & 146 \\
\hline Timothy. . . . . . . . & 38 & Kough Daisy. . . . . . . & . & 147 \\
\hline Erigeron annuus. .......... & 149 & $\therefore$ oxglove. ............. & . & $13: 3$ \\
\hline cat.uterus.z......... & 146 & Foxtail, Green. . . . . . . . & 1 & 24 \\
\hline ramasris. .............. & 147 & Yellow. ............... & .. & 25 \\
\hline Eruca sativa. . . . . . . . . . & 91 & Foxt:all (misnamed) . . . . . & 7 & 36 \\
\hline Frysimuin, Subll... & 101 & Fronch Weed. . ....... & 27 & 80 \\
\hline lirysimum asperum. . . & 101 & & & \\
\hline cheirantheriles . . . . . . . & 100 & FI:VARIACLALE. . & & 77 \\
\hline 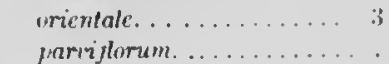 & $\begin{array}{r}9.4 \\
101\end{array}$ & Fushtuky Fasm.y. . . . . & . & 77 \\
\hline Euputorifue.......... & 142 & Fumitory, fislden. .... & . & 77 \\
\hline Euputerium pofolintum. & $14: 3$ & $\begin{array}{l}\text { Galeopsis Tetrahit. . . . . . } \\
\text { (ialingale. . . . . . } \ldots \ldots \ldots\end{array}$ & 48 & $\begin{array}{r}130 \\
3 ! !\end{array}$ \\
\hline Tis & 142 & Iatium. ... & . & 140 \\
\hline urtiraefolium. ........... & $14: 3$ & Galium boreale. . . . . . . . . & . & 140 \\
\hline
\end{tabular}


riencral I'riuciplen.

l'inte l'uit:

lilyeymhizu lipudolu. ....

Cinaphalium.

Giont's Beitrd, Yicllon ..

(ioll of P'leawure. .

(ivlteurod, Buslig

Cunsula. ...

Fragrnut . . . . . . . . 5 :

Nart.su-leaved. . . . . . is

simouth.

Tall. . .

Tull Ilairy.

Giulden Jerusaleu... .

GoOnetoot Family.

Giusefoot, M:tple-leaved

II lite. .... .

GRANINHAL...

Gans Family,

Giruss, Blue Juint. .

Bottle. . . . . .

Cousls. . . . .

" (mistaried).

15

III

117

Ifi,

iil

.i.3

.

i3i

Holy...............

Old-witch............

Purtc. ..... . . . . . . .

Pigern. . . . . . . . . . . . I

Poisou rye .........

l'overty.

Quack.

(mishamed)......

Serutel. ...........

Seneca. .... ....

Skunk............. 7

skumk-tail. ........... ;

Squirrel-tail. . . . . . . . . 7

sweet.............. "

Tickle. . .........

'Twiteh...............

Vauilla..............

Vernal. . . . . . . . . . . . .

Westem Couch

Whitlow, Carulin: . . . . . .

Wood ...........2 20

Vicllow ...........20 20

Grindelia squarrosu. . . . .....

Gromucll, Corm.

Field.

Stinking. (ium Plant.

1 інпик

Haine l'anis:

.

Itardhack.

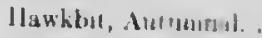

llankwecol, Brabciatus

Mouse-eir.

Orange...

Ile:Il-all.

Meliantheas.

II, lumthus aloroniconde

.Harbmilani.

sculs rrimus. ...

Hele niene.

Jelenum autumnak.

Ilemluck, II ater. . . . . . . 4. 4is

Origuu........

l'urplesslesumed

II yorning......

Heup, Biastird. . . . . . . . is

Ilerh-John. ...... .... \&

Herrick. .... . ........ 333

IItracium aurantiacum. ... 70

cladanthum. . . .......

179

vas. l'eleteriunum...... . 179

pracaltum vis. decipiens. II Iso

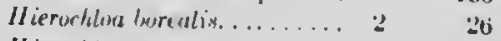

Mierochlue enlorata. . . . . . 2 2

IIogweed. ............ is 1,3

Hokus mloratus. . . . . . . . 2 26

Yordeum jubatum. ..... . ,

llorselead..... . . . . . . . . 147

llumeweerl. ... ... ... is 116

llorse lWeel . . ........ . 175

llound's Tomgre. . . . . . . . I:I

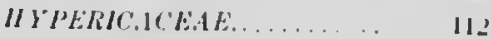

IIypericum Alscyron. . . . . . II:3

elipticum........ . 11.3

jerfurulum......... I1 11:3

prunctatum............ . 113

Indian Ilay.. ........ \& :

Inula Jelenium. . . . . . . . 147

Inuleae....... . . . . $\quad 147$

1 monweeds........... 11:2

Ita arillaris. . . . . . . . i.) $1+8$

penthifutist. its

Ivray. ........... ; . 32

Ixuphorus rirwis. ....... 1 ,-I 
IST

Jax-1ye II InI.

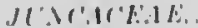

Jitncus tonuis

liake, litelut

" mi-flitment: .,

king ldent .

longuran!

Klinkwiel. .

houpwerds...

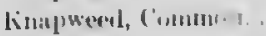

linut need. .....

linetwe erls. . .

I.ABL.1T.1E..

l.atuca cremulurwix pulitullat. . . sectroulu, vats. infoyntul virosa. .

Lancly's Thumb...

l.anulis (Quitrters.

latpla moluer.

l.riplude erhimatir.

l. "Ipplizes.

mirymulutu

Larkepurs:

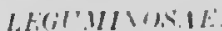

lecutluden culummolex.

I.1 jutatim apelulum.

ramilestre.

intermedium. .

let platon r'anuelensis

l.e.1114e, Blue. 1. arge-llowered

1.are's

I'richly

-miul

IVilu

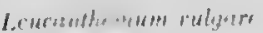

l.igulegt the

Linariu lomeria

Talyares.

Liqueurien, II ilil.

Lihosperstess ariento

live-for-ver.

locull II ext

loco 11 ends

I.elium armense.

temulentum.

love-lies-bleeding.

Love Vine. . .

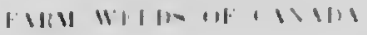

P'ith: Pant

$1+2$

(11)

l.yolonim, lesentisus

l.ychmix allut

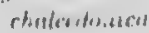

coronurin

dimsta. .

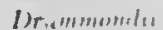

Flersinurul

cisthesente.

respertant

l. nesenlesmin jumat

P'Mr. L'ver

(2) tits

(4)

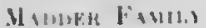

maliter final.

JaLIOW PAMIIY

$1: 4 !$

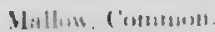

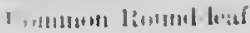

$1 / 1 / .1^{\prime} .11^{\prime} l: 1 \%$

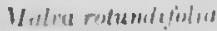

Mare's-tait.

ix

Marigulil, 1sur.

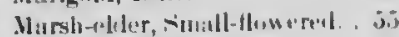

1.21

121

llarules' inle

Vatring a inembers

123

117

Maymerel

seculless. .

stinking. .

ini

lest

Menluw siscet.

28

4.

Mediram arulicas

$$
\text { htspilita.. }
$$

lit adime.

Vedick, Black. .

simetted.

'I'unthed.

Molustrium medelifurum.

1. delus ulhut.

uncunatis. .

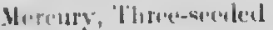

Hılluil.

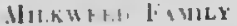

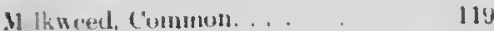

- wiml. 119

lhistle. . . . ti: 17:

Milhutath ...

Milky । s.l. .. . . . . . . .

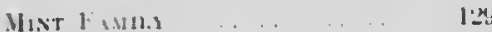

10

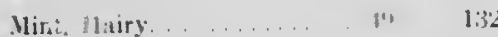

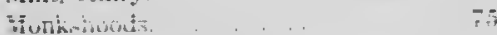

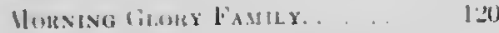

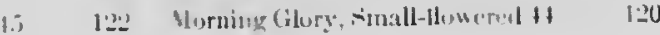




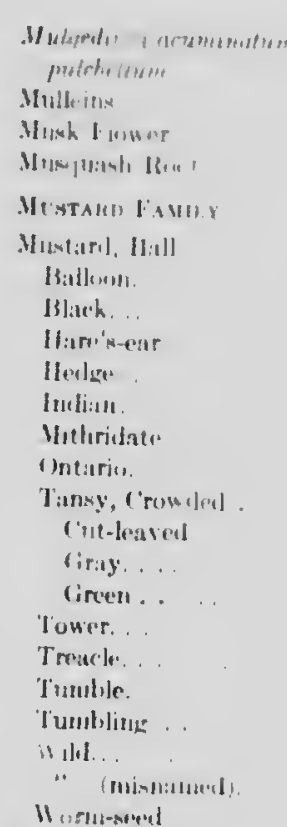

\begin{tabular}{|c|c|c|}
\hline |'い, & $1+\ldots, 1$ & \\
\hline $11^{\prime}$ & 17. & 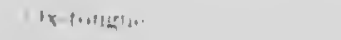 \\
\hline$B, 1$ & 17. & srotruene \\
\hline & $\begin{array}{l}1: 3 \\
13 i\end{array}$ & lomelumi. \\
\hline 1: & 16 & 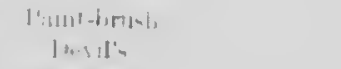 \\
\hline & $\because$ & $1, \ldots .$. \\
\hline .11 & M & ipeller. \\
\hline in & vii & irule \\
\hline & 11,3 & 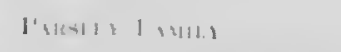 \\
\hline 34 & 41 & 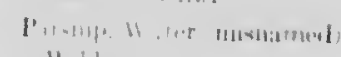 \\
\hline & 11 & $11 \% 1$ \\
\hline$\therefore 7$ & all & 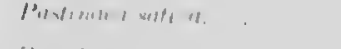 \\
\hline i:3 & "! & ['] I +1149 \\
\hline & ' $1 ! 1$ & ]'.1. 111$] .1$ \\
\hline iti & !x & l'intuy lirime \\
\hline & ! & I'onitalu: II \\
\hline $3 i$ & !h & 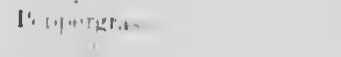 \\
\hline & 101 & I' $\quad$ is \\
\hline .37 & $\begin{array}{l}\text { lun }) \\
\vdots n\end{array}$ & Tis \\
\hline$\therefore ;$ & $\begin{array}{l}\text { : } \\
: n\end{array}$ & I'trat \\
\hline $\begin{array}{l}\text { ii } \\
\therefore\end{array}$ & thi & lhwndensent \\
\hline$\therefore$ & $1+41$ & ril:1: dri.ır \\
\hline it & $\|(x)$ & {$[: a 1$} \\
\hline 31 & 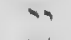 & l'ir nprimes. \\
\hline in & wit & Peeren , hinsilex \\
\hline $\mathrm{lit}$ & $1-1$ & 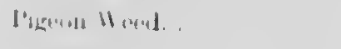 \\
\hline & 1:in & 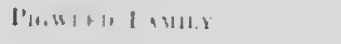 \\
\hline$\$ 1$ & 4 & I'ie \\
\hline$\therefore$ & W & I Irinil \\
\hline is & $1: 30$ & 1. ats \\
\hline th & I:31 & li:maitn \\
\hline 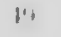 & $13:$ & 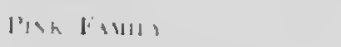 \\
\hline N & $\begin{array}{l}1.31) \\
1: 3,\end{array}$ & l'ul h-turks. . \\
\hline 11 & $\begin{array}{l}1: 32 \\
1.90\end{array}$ & 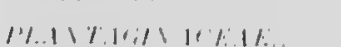 \\
\hline in & $\begin{array}{l}1.30 \\
1: i 19\end{array}$ & 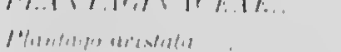 \\
\hline 心 & $1: 311$ & 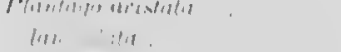 \\
\hline Is & I.311 & $m e_{2}$ \\
\hline in & 1 in & "enu" \\
\hline & ' & linulu \\
\hline
\end{tabular}

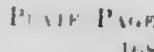

Itiv

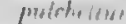

Mhisk I Inwar

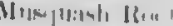

Mestele linuly

Latitipil, 11:1

liaringear

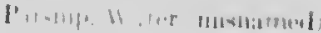

$111 \%$

iil 17

il 17x

25

$\therefore$

121

Jyalyrum panichdatu." sotivum.

Myoutix taplomela.

Arintu émirat.

Nessia.

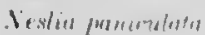

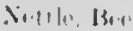

silmal.

I teirl].

I)

Iterler:

Henli?

$$
\text { i) (lind }
$$

Alinginz

Nette-mut

Nigger [1 rit.

Nisigrum

1)its, 11 ild

Citsutites retirat.

Jenothera alliculel

tiemnis

fullisla..

Oi.lehter i

h HPINe Famir.

31
$12 \quad 113$
$11 \quad 113$
111
$11: 3$
103

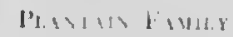

116

118

114

167

III [iा

$27 \quad x$

11 11:

is is

8.3

11

11 it;

$11 \quad 17$

17

$11 \quad 47$

17 (n)

Itiv

1.7

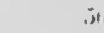

1:3 is

16) it

16 in

11 is

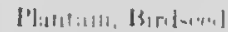

$$
\text { [Briveled }
$$

Brold-1+af.

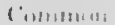

[homersitre]

l.tiglests.

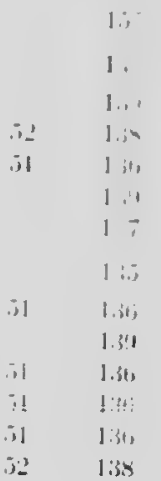




$$
\begin{aligned}
& \text { Ciniater. } \\
& \text { lloary. } \\
& \text { liale. }
\end{aligned}
$$

I'leurisy-rent

Polanisin yraroblens.

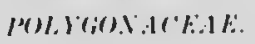

Polygmun . .

arienlars.

fomrolinulus. .

licmathijolicm.

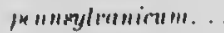

Persicaria.

l'ortulara yrandiflamo. .

oleracru. ........ .

lortuliu'st, Will....

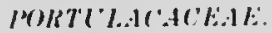

l'ucentilla.

A usurinu ........

lirsulu......

monspeliensis. .

var. noriegiea

poverty IV ind. . .

Prislewimel. ...

I'runella melgari:

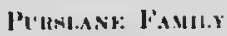

l'urstitue'. .

Mlilk. ...

luisling . .

Raluhit-rar. . . .

Kudislı, Juintınl

IVilkl...

Ranged Roulins.

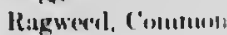

fralso.

inut. .

Jeremulial.

sinaller.

Titll.

Ragw urt, ( Tillisy. .

|Ramistonl

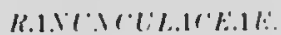

Ranumenluse nhontirus.

acris. .

scthonlus. .

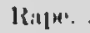

Biial.

(incrutail.

Ruphanus Ruphunistrum. . . :32

Rattlo Wierl...

I.

l'vie:

$131 ;$

$13 !+$

$1: 37$

119

1112

10

10

$+1,+7$

$.11,+8$

47

47

11. 16

73

7.1

74

$7 i 3$

liv:

$10 i$

34

is

$x^{2}$

isis

iv

13

31

$\because 1$

31

$3: 2$

32

i7

(1)

inti

it

iti

(i)

(i)

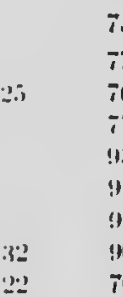

ltrul lenut.

Ihiunuthus ('rista-yulli

Rilugriass. .

Rluwout linulu.

lithwort.

linek l'rrensiss.

lewekel..

Pricirir...

Sislaul. ... .

Villuw.....

Roses arimbluris, vitr. Bunr-

genuiana. .

arkminstulu,...

prulineolu. .

RUS.10\%:1\%...

Rosr: FaMII.

Plotr: l'vit

R.we (it Johns-wort)

Renicen, l'ruirio.

Rone Ilosis... . $7: 3$

Romin.... . 41 11:2

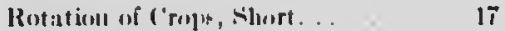

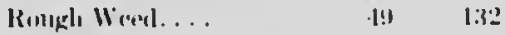

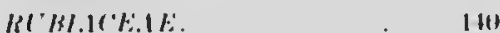

Ruellectiu hirlu.... is 15

Rumrx.... . It!

Aretesan . . . . . .

Irrtowilla... . . . 111 H

ronglouncratus. . . . . . .

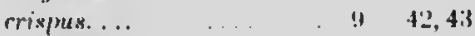

ohuxifolius. . ...

rmosus. . . . . . . .

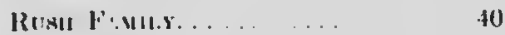

Rush, slomiler. .

Rutalsitut. . .... 1 is

Sitge Bruslies. . . . . . . .

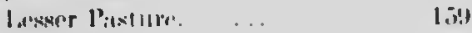

liasture. . 1.5!

fiwert...

Silsify _ . . $16 !$

Sulsula.... . . il

inesola linti, var. tenuifulin. 15 is

vir. Trugus lis it

Trutus. . 1, is is

simlunal. 17 . 17

Susmurit. . . 54

offirinulix.....

Vinscrurin..... . . 2:3 7.3

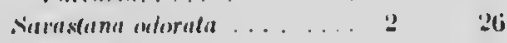

Secirlet lightıing.. . . . . . . 67 


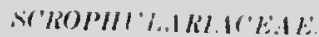

sintels.

SFmer, Fauा.x.

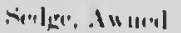

Nidum purpurtum

sienliug lo lirass.

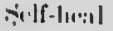

sineciunu,

Simeriol forwheres.

piverestex.

inlyuris.

sirfuriu glensian rmilis...

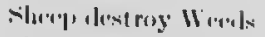

Slenpleeral's Plurse.

sheraldiu urrensis.

vidle spinusit.

vilf ueter. . . .

silene'..

untirrhimu

Armerin..

imuiru.

riecululus.

!mllisa. . .

influtu. .

lintijulin....

nocfiflora. ...

praterusix. .

ruluarix.

silk wrevl. .

rilk werels.

Nilverweenl. ...

Silupris urmensis.

Pisymbritum, Till. .

Sisymbrium allisximum"

incisum, var. Ifarfurgmumum

offiriuale. . vil r. plifis.s.

panumiram

simupestrum

Stirlelon IVirel.

inlitranarel

Sillarerticulas.

silakernot, Whil,

'Mlip|lragen, II il]

Silurgewered. . .

inlidenu remule usis.s.

yrrommonslice

lesncrolatie.

rugmenrm. ... listr. I'net

$13: 4$

i) .it

:31

in

Itis

is

$1: 3 \mid$

lialt

iil |ili

|ivil

|iil

iis

1

2

2

1

III

in!

bit?

(ii)

1,11

(ii)!

…

li!!

$\because 2 \quad 7$

2.:

$\because 1$

-11

$\because:$

119

$11 ! !$

(11)

$333 \quad 112$

3.7

3,3

:iti

a

iii

ii (Hi

175

110

(1). 11

14.1

1:31

I.isis

I 1.1

11.4

is:

iil sortint

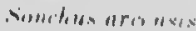

II.N/n't

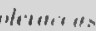

julchillux

suphour arelast

Sirrel. I*inll

(i.lliling)

lia.el

-/14\%”.

cillir-zrrims

-jonelurells

sien ryulu irr.ensix

- prialer-llewer

-iven limis

- irily siila.

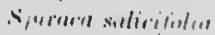

$$
\text { tomertensot. }
$$

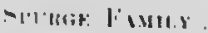

-jurge, flowerime

Riilur-getolin! .

intn.

- Currry...

(i)ris.

it. Jil IIIen'-wolt

si Jolls s-wour finu,

it dollis-wort, fimamum

linrytulnel

linill...

l':alo"

- initial

viarlys pulustio.

Siagre.rwort.

$-(1 \cdot 0) \mid)_{1} \cdot 1311=11$.

vifellarin srements

$$
\text { medres . }
$$

-1110 hNind

sichured.

$$
\text { Virmuialu }
$$

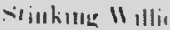

-lumhwiril

milleliworl, Riram leisul

$$
\text { I.e.ina.r }
$$

cilevenrs, $11,111$.

- mannar linlloming

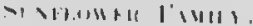

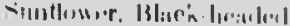

I:Alsi"

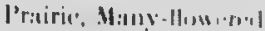

I'ill. line linir

14.7

liti |Tा|

$17: 3$

(i) 17:

(ii) 17,

3ii is

III I

I.)

IIt

III II

IIt II

$1::$

17 in

111:

iH

I11

III:

if 1111

I II)

III

| | |

II)

17 (ii)

17 (i)

(i) $1(i)$

- 112

11 11:

$11: 3$

$11 ; 3$

$11: 3$

I 1:1

4!) 1:1!

iil lliat

:35 11)

. 1i:

Is

(1) 1:1

Iij 1:1

$1: 1.5$

(i) lial

$\because 7 \quad$ VI

i.i.

ii.'

(i) liti

1.7

| |1

|,il

1.i,

$1, i, i$

1.iI 


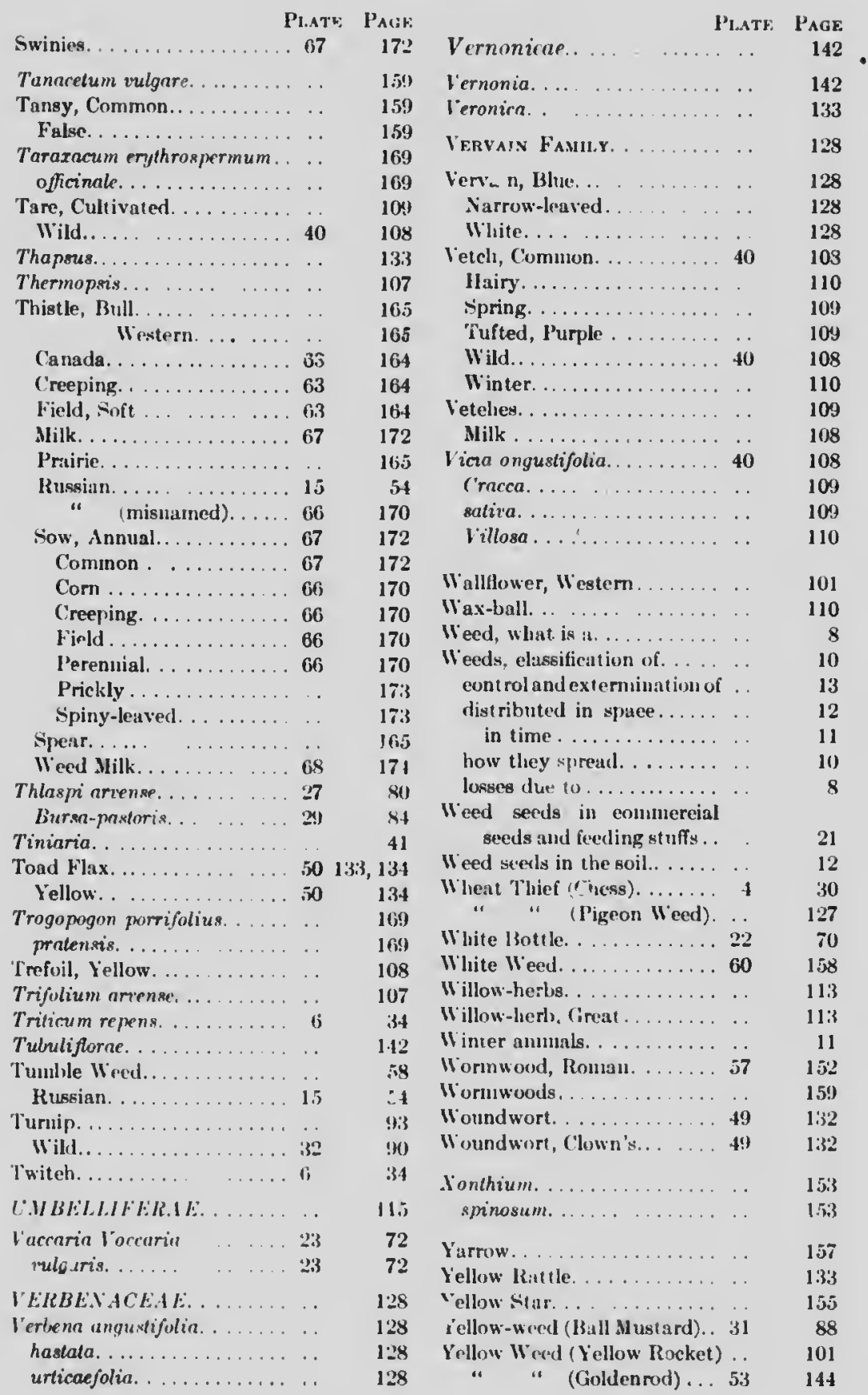




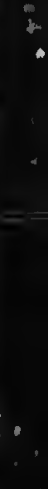




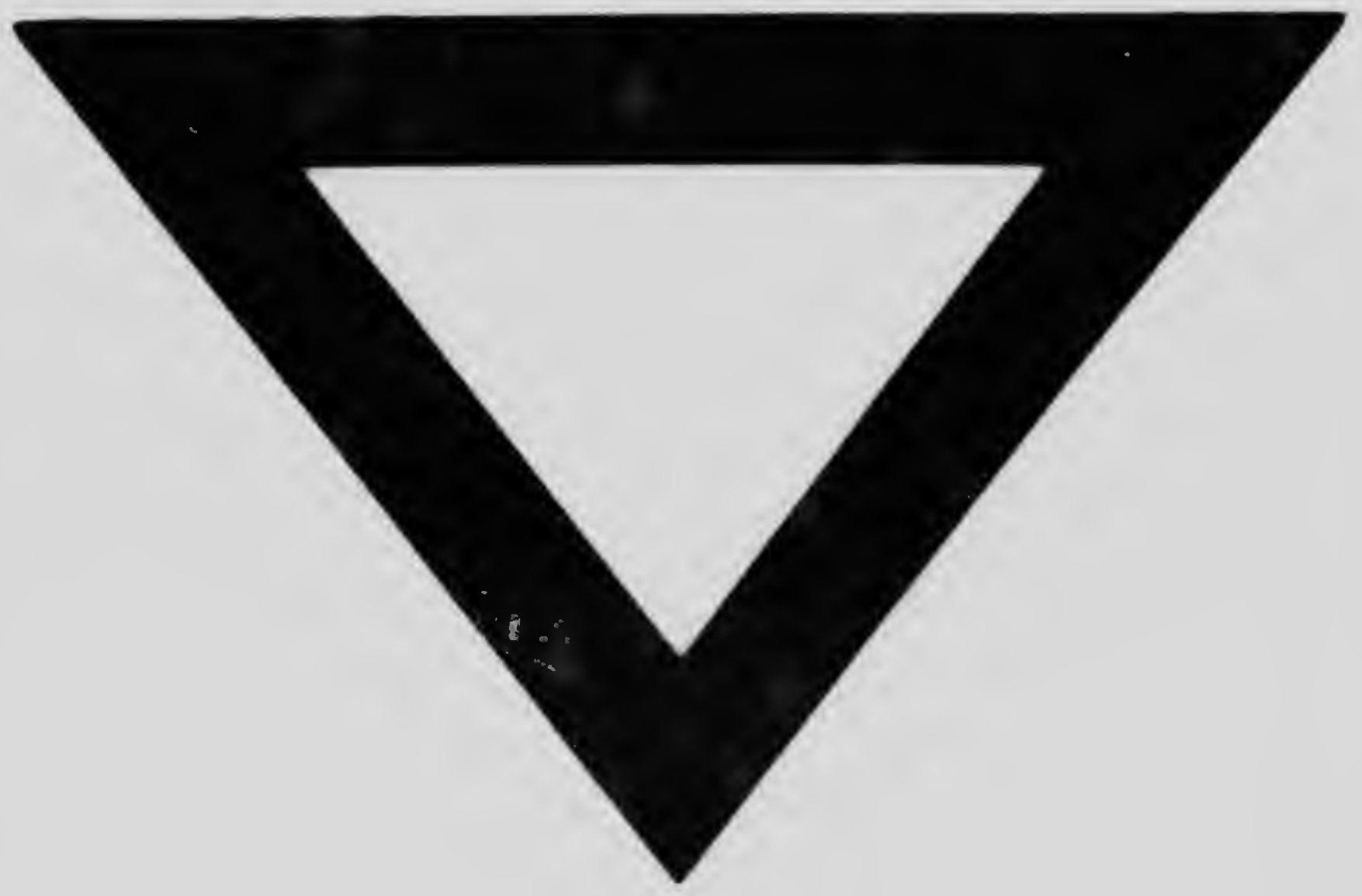

